PEDRO DARAHEM MAFUD

\title{
RACIONALIDADE ECONÔMICA E ASPECTOS JURÍDICOS DOS DERIVATIVOS: UMA ANÁLISE JURISPRUDENCIAL
}

\author{
Mestrado em Direito \\ Orientador: Professor Doutor José Alexandre \\ TAVARES GUERREIRO
}

FACULDADE DE DIREITO DA UNIVERSIDADE DE SÃO PAULO SÃO PAULO

2014 


\title{
PEDRO DARAHEM MAFUD
}

\section{RACIONALIDADE ECONÔMICA E ASPECTOS JURÍDICOS DOS DERIVATIVOS: UMA ANÁLISE JURISPRUDENCIAL}

\begin{abstract}
Dissertação apresentada à Banca Examinadora, no âmbito do Programa de Pós-Graduação da Faculdade de Direito da Universidade de São Paulo, como exigência parcial para a obtenção do título de mestre em Direito, sob orientação do Professor Doutor José Alexandre Tavares Guerreiro.
\end{abstract}

\section{FACULDADE DE DIREITO DA UNIVERSIDADE DE SÃO PAULO SÃO PAULO \\ 2014}


Banca Examinadora

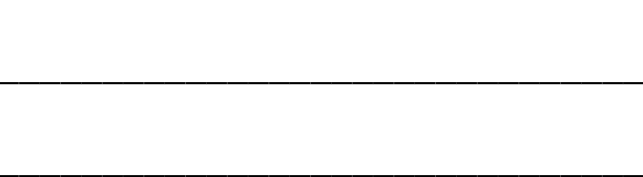




\section{AGRADECIMENTOS}

Em primeiro lugar, agradeço aos meus pais, Leonel e Wania, por tudo, mas especialmente por terem eleito a educação de seus quatro filhos como prioridade absoluta em suas vidas. Agradeço também aos meus irmãos, Leonel, Marina e Mario, pela nossa eterna união.

Agradeço ao Professor José Alexandre Tavares Guerreiro pela orientação desta dissertação e pelos ensinamentos constantes em sala de aula e fora dela. O Professor Guerreiro é uma das mentes mais geniais e uma das almas mais generosas que já conheci. Sempre disposto a ajudar, com sua impressionante biblioteca disponível a todos, o Professor Guerreiro leva a sério e enobrece o ofício de ensinar, dividir conhecimentos, estimular a reflexão e, sobretudo, inovar. Conviver com este ícone do Direito brasileiro é o maior privilégio que qualquer aluno poderia ter!

Ao Professor Francisco Satiro de Souza Junior, agradeço pelo pioneirismo e pela qualidade com que traz os assuntos de mercado de capitais à Faculdade de Direito. Muitas das ideias deste trabalho são frutos da sedimentação de conhecimentos obtidos em suas aulas da graduação e do mestrado (sobretudo os cursos de valores mobiliários, ministrados em parceria com o Professor Guerreiro, em 2011).

Agradeço à Professora Rachel Sztajn e ao Professor Otavio Yazbek pelos comentários e sugestões feitos em banca de qualificação. Ao Otavio, um dos maiores responsáveis pelo salto da qualidade do mercado de capitais brasileiro nos últimos 5 anos, sou especialmente grato pela disponibilidade e pela interlocução de altíssimo nível.

Aos amigos do Machado, Meyer, Sendacz e Opice Advogados, Dr. Moshe Sendacz, Mauro Finatti, Artur Andrezo, Adriana Pallis, Katia Ichiba e Luiz Felipe Costa, sou eternamente agradecido por terem-me apresentado o Direito Empresarial.

Aos amigos do Banco Votorantim, Dr. Marcus Olyntho de Camargo Arruda (i.m.), Marta Knecht, José Salvini, Daniela Sanchez Andrei, Livia Visnevski, Viviani Bacchmi, Rudmila Cruz, Marcella Urada, Francisco Horta, Diego Brandão, Eduardo Pachi, Carolina Uip, Juliana Mitico, Alberto Serafim, Milena Pina, Raphael Passarelli, Alethea Santos e Patricia Ferrari, muito obrigado pela convivência sadia, pela ajuda em conciliar os créditos do mestrado com as atividades profissionais e pela contribuição que cada um, com materiais, ideias e discussões, deu a este trabalho. 
Aos amigos do Banco Itaú BBA, Gilberto Frussa, Sergio Goldstein, Leandro Telles, Glaucia Miranda Filio, Felipe Krause, Roberto Zarour, Gustavo Secaf Rebello, Thais Moraes, Diego Fagundes, Celso Pereira Filho, Yana Chang, Sylvia Behring, Georg Predtechensky e Rodrigo Alves Rodrigues, sou grato pelo apoio profissional. Em especial, agradeço ao Rodrigo e ao Celso, também colegas de mestrado, pelas discussões inteligentes e sugestões de materiais, e à Glaucia, pelo fornecimento de subsídios importantes e pelos comentários feitos à dissertação.

Agradeço ao Julio e à Raquel Darahem pelas duas temporadas que passei em sua casa de praia, ocasiões valiosas para que as ideias aqui dispostas fluíssem. Obrigado também à Thais Darahem Marquardt pela ajuda na revisão de texto.

Aos meus amigos da Faculdade de Direito, Carolina Foss, Rafael Bellem de Lima, Luana Komatsu, Leonardo Muller, Marina Copola, Tiago Pavinatto, Mirella Sakamoto, Robertho Peternelli, Priscila Menezes, Marcos Garrido, Mariana Chapei, Paulo Menechelli, Mariana Mazzini, Valmir Vanucci, Rebecca Freitas, Lucas Ferreira, Maira Campos, Ricardo Medina, Maria Rita Floriano, Ricardo Silva e Maria Angélia Abud, sou grato pelos bons momentos que começaram nas Arcadas em 2003 e que, graças a nós, insistem em se prolongar. Especialmente à Carol, ao Lucas, ao Tiago, à Luana e à Priscila, agradeço a ajuda na obtenção de importantes fontes bibliográficas, e à Marina, por ter- me apresentado ao Professor Guerreiro.

Por fim, aos meus grandes amigos de infância, Frederico Barros, Tiago Calil, Pedro Vicentini, Matheus Bombig, Augusto Gabriel, Henrique Lian, Paulo Henrique Silva, Felipe Baracchini, Mauricio Domingues e Talita Matta, agradeço por estarem sempre presentes. Em especial, ao Fred, agradeço pela ajuda na confecção de gráficos e tabelas deste trabalho. 


\section{RESUMO}

Este trabalho descreve o comportamento do Judiciário brasileiro com relação aos derivativos. Para tanto, exploramos decisões dos Tribunais de Justiça entre os anos de 2006 e 2010, conforme metodologia específica. Como suporte da pesquisa jurimétrica, analisamos os aspectos financeiros (utilidade e risco, espécies e estratégias, locais de negociação) e as características jurídicas (jogo e aposta, natureza contratual, valores mobiliários) dos derivativos.

Palavras-chave: Derivativos, Análise Jurisprudencial, Valores Mobiliários, Bolsa e Balcão. 


\begin{abstract}
This paper describes the position of the Brazilian courts on derivatives. For this purpose, we examine decisions rendered by the Courts of Appeals between the years of 2006 and 2010, in accordance with a specific methodology. As a foundation for jurimetric research, we analyse the financial aspects (utility and risk, species and strategies, trade environment) and the legal characteristics (gambling, contractual nature, securities) of derivatives.
\end{abstract}

Key words: Derivatives, Analysis of Case Law, Securities, Stock Exchange and Over-theCounter. 


\section{SUMÁRIO}

I. INTRODUÇÃO .8

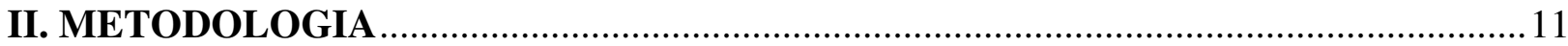

II.A. Metodologia de Pesquisa Dogmática ..................................................................... 11

II.B. Metodologia de Pesquisa Empírica .......................................................................... 12

III. ASPECTOS FINANCEIROS DOS DERIVATIVOS …....................................... 25

III.A. Origem e Utilidade: Proteção e Especulação sobre o Risco .........................................25

III.B. Espécies. Instrumentos Mais Comuns: Termo, Futuro, Opções e Swaps .......................38

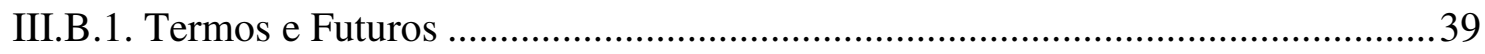

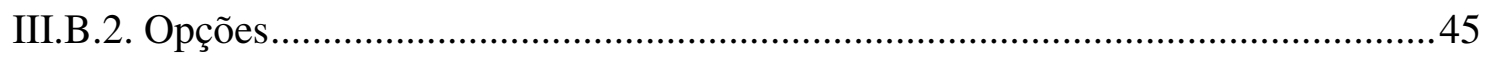

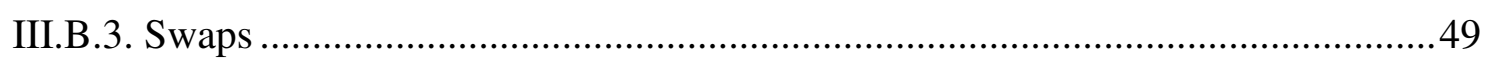

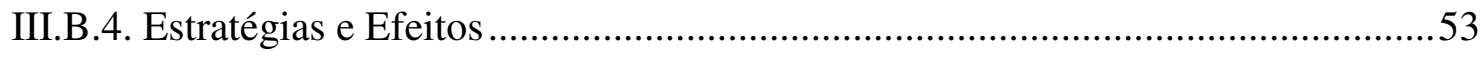

III.C. Local de Negociação: Balcão e Bolsa ............................................................................58

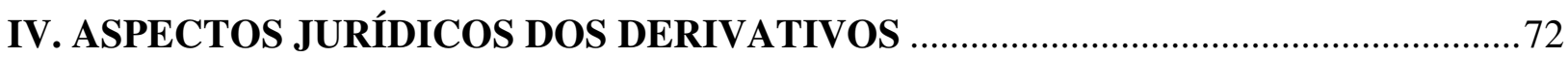

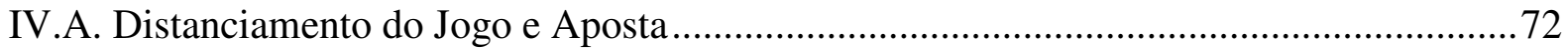

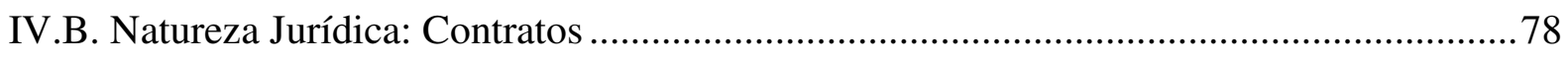

IV.C. Função Instrumental: Valores Mobiliários................................................................ 92

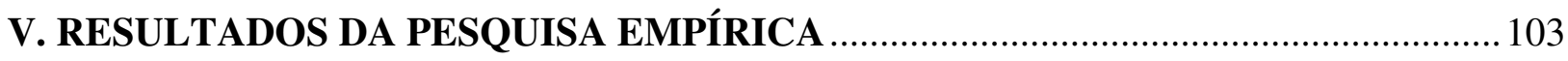

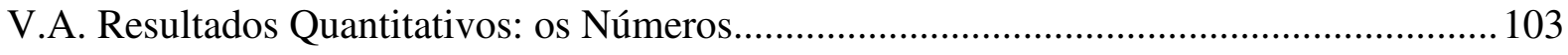

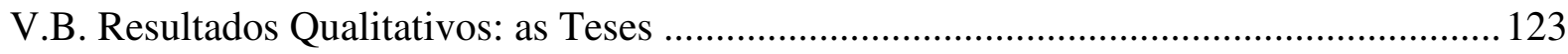

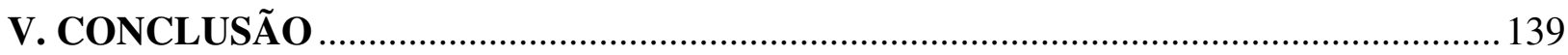

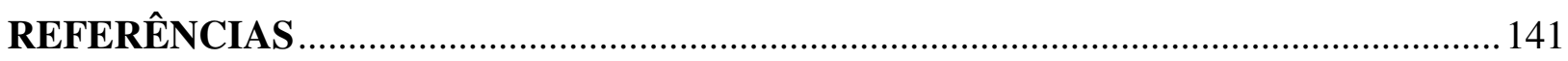

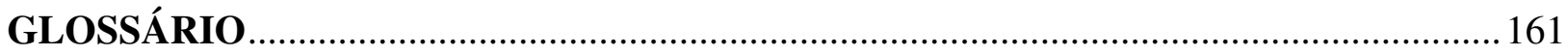

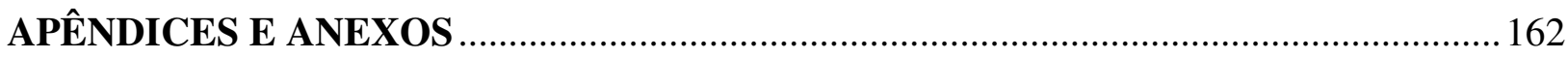




\section{INTRODUÇÃO}

O amadurecimento do mercado de capitais e a internacionalização da economia brasileira levaram os agentes econômicos a lançarem mão de sofisticados instrumentos financeiros antes desconhecidos. Dentre esses instrumentos, destacaram-se os derivativos, que adquiram relevância sistêmica considerável na última década a ponto de serem referidos como um dos maiores catalizadores da crise econômica mundial iniciada em 2008.

Ainda que muitos da academia jurídica brasileira entendam que o Direito nasça antes do mercado, ousamos discordar e partir do pressuposto que o Direito exerce uma função conformadora, portanto, posterior à criação de mecanismos financeiros pelo mercado. A autonomia privada dos agentes econômicos possibilita o surgimento de estruturas, tais como os derivativos, de difícil alcance e assimilação para o mundo jurídico.

Como se não bastasse a especificidade da matéria e o escasso conhecimento jurídico sobre o assunto, os órgãos jurisdicionais, que, recentemente, em decorrência da crise econômica mundial, foram cada vez mais instados a se manifestar sobre o instituto, são tidos pelo mercado como despreparados para entender os aspectos econômicos e, consequentemente, os aspectos jurídicos que cercam os derivativos.

Buscando entender se o receio com relação aos derivativos é fundamentado ou não e a real percepção do Judiciário sobre o tema, entendemos que o levantamento minucioso de julgados sobre o assunto, em esforço jurimétrico, ${ }^{1}$ é fundamental para quantificar e qualificar o entendimento de nossos magistrados sobre a matéria e, assim, dissipar ou corroborar determinados preconceitos. ${ }^{2}$

\footnotetext{
${ }^{1}$ ASSOCIAÇÃO BRASILEIRA DE JURIMETRIA. Palavra do Presidente. Disponível em: <http://abjur.org.br/>. Acesso em: 09 dez. 2013: A jurimetria utiliza modelos estatísticos e probabilísticos para compreender processos jurídicos de decisão, sejam eles processos judiciais, arbitrais, legislativos ou negociais. Diferentemente dos dispositivos de lei geral, as normas concretas se agrupam em populações numerosas, cujos indivíduos apresentam características variáveis. A estatística e probabilidade são ferramentas matemáticas concebidas para mensurar essa variabilidade, descrever as características desses grupos e mostrar como de fato o direito é produzido e aplicado, permitindo uma melhor administração da justiça, seja através da gestão dos tribunais, da elaboração de leis mais aderentes a realidade ou do desenvolvimento de estratégias advocatícias mais eficazes.

${ }^{2}$ NOBRE, Marcos. Apontamentos sobre a pesquisa em Direito no Brasil. Disponível em: <http://bibliotecadigital.fgv.br/dspace/bitstream/handle/10438/2779/Pesquisa_Direito_Cadernos_Direito_G V.pdf?sequence=1>. Acesso em: 07 jul. 2013, trata da extrema distinção entre prática, teoria e ensino jurídicos no Brasil, ressaltando o entrincheiramento mútuo entre o Direito e as demais ciências humanas. Nosso objetivo é, a partir da pesquisa empírica, tentar romper com este isolamento.
} 
Justifica-se a presente escolha pela relevância prática do tema, frente ao atual estágio de expansão dos derivativos no mercado de capitais brasileiro, as relativamente recentes perdas financeiras incorridas por muitas empresas e investidores dos mais variados setores da economia, ${ }^{3}$ a existência de julgados dissonantes sobre a mesma matéria e a ausência de análise quantitativa e qualitativa das decisões proferidas pelo Poder Judiciário brasileiro $^{4}$ com relação aos derivativos. ${ }^{5}$

Além disso, os aspectos jurídicos dos derivativos, cujos debates pela doutrina ainda caminham para um consenso, devem ser explicados e sistematizados de maneira mais aplicada e detida, levando-se em conta a racionalidade econômica do instituto financeiro.

Por fim, outra importante justificativa da pesquisa é o confronto da sistematização dos conceitos jurídicos com as decisões proferidas pelo Judiciário brasileiro, de forma a confirmar ou dissolver as percepções de mercado sobre o suposto viés anti-credor do Judiciário brasileiro. Busca-se confrontar a análise subjetiva de conceitos com a objetividade da realidade estatística.

Da análise da racionalidade econômica deste instituto financeiro e da dogmática e arcabouço legislativo e regulatório, tendo como pano de fundo o atual tratamento dispensado pelas cortes brasileiras à matéria, ficaremos à vontade para concluir, em linhas gerais: (i) de que forma o Judiciário brasileiro entende o tema dos derivativos; e (ii) se o Judiciário brasileiro aplica as regras postas e o conhecimento doutrinário ou se, valendo-se de outros microssistemas legislativos (como, por exemplo, determinadas regras do Código Civil e do Código de Defesa do Consumidor), os magistrados tendem a afastar as regras

\footnotetext{
${ }^{3}$ As perdas a partir da crise de 2008 não foram exclusividade de empresas do setor produtivo brasileiro. DODD, Randall. Exotic derivatives losses in emerging markets: questions of suitability, concerns for stability. International Monetary Fund Working Paper. Jul. 2009. Disponível em: <http://topwonks.org/wpcontent/uploads/2012/05/RDodd-Kiko-WP-2009.pdf>. Acesso em: 25 jun. 2013, nos dá conta de exemplos semelhantes em outros países emergentes.

${ }^{4} \mathrm{~A}$ academia jurídica está, de maneira geral, pouco habituada a trabalhos que analisam casos concretos lacuna esta que culminou na criação da Associação Brasileira de Jurimetria, em 2011, cuja missão declarada é disciplinar a jurimetria como um ramo do conhecimento jurídico, cf. ASSOCIAÇÃO BRASILEIRA DE JURIMETRIA. Palavra do Presidente. Disponível em: <http://abjur.org.br/>. Acesso em: 09 dez 2013.

${ }^{5}$ Não temos notícias de nenhuma análise de julgados sobre o tema dos derivativos. Devemos ressaltar, contudo, a existência de um ótimo texto que analisa as ações judiciais oriundas de quebras contratuais dos ditos "contratos de soja verde" (contratos de venda antecipada da commodity), ainda que tais contratos não sejam propriamente derivativos: ZYLBERSTAJN, Decio; REZENDE, Christine Leles. Pacta sunt servanda? o caso dos contratos de soja verde. Berkeley Program in Law and Economics, UC Berkeley, Maio 2007. (Series: Latin American and Caribbean Law and Economics Association (ALACDE) Annual Papers). Disponível em: <http://escholarship.org/uc/item/5jg1v63w>. Acesso em: 13 maio 2012.
} 
específicas criadas para os derivativos (muitas delas em sede regulamentar ou de competência delegada).

A partir do reconhecimento da contribuição de $\mathrm{NORTH}^{6}$ de que o desenvolvimento econômico é corolário de um melhor ambiente institucional e da lição de LEVINE $^{7}$ acerca da importância do sistema financeiro para o crescimento econômico, entendemos que a indústria dos derivativos, altamente relevante e necessária para o desenvolvimento do Brasil, deve ser estudada e, sobretudo, entendida pelo Direito para que possa se desenvolver em sua plenitude.

Em busca de segurança jurídica e previsibilidade ${ }^{8}$ no relacionamento entre os investidores, os especuladores e as empresas, pretende-se, com esse trabalho, contribuir para a elucidação de pontos relevantes para a matéria. É papel da academia aproximar-se da realidade dos mercados e adiantar situações e possibilidades. Afinal de contas, é inegável o caráter dinâmico e empírico do Direito Empresarial. ${ }^{9}$

${ }^{6}$ NORTH, Douglass C. Institutions, institutional change and economic performance. New York: Cambridge University Press, 1990.

${ }^{7}$ LEVINE, Ross. Financial development and economic growth: views and agenda. Journal of Economic Literature, American Economic Association, Pittsburgh, v. 35, Jun. 1997.

${ }^{8}$ FORGIONI, Paula. A interpretação dos negócios empresariais no novo Código Civil brasileiro. Revista de Direito Mercantil, Industrial, Econômico e Financeiro, São Paulo, v. 42, n. 130, p. 7-38, abr./jun. 2003.

"VIVANTE, Cesare. "Introdução" - Trattato de Diritto Comerciale. Trad. Haroldo Malheiros Duclerc Verçosa. Revista de Direito Mercantil, Industrial, Econômico e Financeiro, São Paulo, v. 102, p. 134-138, abr. 1996. 


\section{METODOLOGIA}

Para alcançar o objetivo proposto, o estudo terá como pano de fundo pesquisa empírica, mas será pautado também por uma metodologia dogmático-analítica no que se refere à descrição do arcabouço regulatório e doutrinário aplicável à matéria.

\section{II.A. Metodologia de Pesquisa Dogmática}

No que concerne aos aspectos descritivos do trabalho, aquilo que chamaremos de seus dois pilares de sustentação, analisaremos, de um lado, os conceitos econômicos e financeiros do instituto, em esforço interdisciplinar, e, paralelamente, as normas e a doutrina jurídica relacionadas.

Considerando que os derivativos são instrumentos importados de outro campo da ciência que não o Direito, originados da necessidade dos comerciantes e incorporados ao ordenamento tendo em vista a função conformadora do Direito, resta imprescindível a análise dos conceitos financeiros do instituto, sua racionalidade econômica, função, utilização e formas de negociação para o entendimento da motivação dos agentes econômicos racionais que utilizam este sofisticado instrumento financeiro, no contexto da autonomia da vontade privada.

Nesse ponto, discorreremos sobre as espécies-base dos derivativos: termos e futuros, opções e swaps, em busca de um conceito unitário. Também abordaremos os ambientes de negociação (bolsa e balcão) destas ferramentas financeiras, esmiuçando a opção brasileira. $^{10}$

Em um segundo plano, as fontes teórico-legais, incluindo a doutrina e a legislação, serão examinadas para que possamos delimitar o tratamento dispensado pela academia

\footnotetext{
${ }^{10} \mathrm{O}$ capítulo dedicado aos aspectos financeiros dos derivativos é dividido em três partes: (i) Origem e Utilidade: Proteção e Especulação Sobre o Risco; (ii) Espécies: Instrumentos Mais Comuns: Termo, Futuro, Opções e Swaps; e (iii) Local de Negociação: Balcão e Bolsa. Dada nossa convicção da função conformadora do Direito Comercial, pós criação de estruturas pelo mercado, entendemos que a descrição dos tipos-base dos derivativos e dos locais de negociação são aspectos preponderantemente financeiros. Por tratar-se de trabalho no âmbito da ciência do Direito, obviamente, aspectos jurídicos estão presentes em toda a dissertação, inclusive na seção dita financeira.
} 
jurídica e reguladores brasileiros. Apesar de tais instrumentos serem relativamente recentes, paralelamente ao método analítico, usaremos o modelo histórico como forma de pontuar a evolução dos derivativos no Brasil - sobretudo ao discorrermos sobre as polêmicas envolvendo a classificação dos derivativos como "jogo e aposta" e ao falarmos da evolução do conceito de valor mobiliário (e a caracterização dos derivativos como tais). Ainda, mencionaremos o enfoque dado aos derivativos enquanto contratos. ${ }^{11}$

Em esforço comparativo, ao longo de todo o texto, abordaremos, sem profundidade, a doutrina estrangeira e as soluções sugeridas pelos órgãos reguladores internacionais, de modo a confrontarmos as soluções legislativas e regulamentares externas com a brasileira.

Posteriormente, do entrelace dos conceitos jurídicos e financeiros e uma vez finalizada a pesquisa jurisprudencial, buscaremos analisar, de maneira pontual, os conflitos recentes com que o Poder Judiciário tem se deparado quando o assunto é derivativos.

Portanto, o estudo será desenvolvido sob a seguinte proposta metodológica: (i) aspectos financeiros dos derivativos, em esforço interdisciplinar; (ii) natureza jurídica da ferramenta financeira, incluindo as soluções estrangeiras; e (iii) análise da jurisprudência, a partir de pesquisa empírica.

\section{II.B. Metodologia de Pesquisa Empírica}

O cerne deste trabalho é a pesquisa empírica, que analisará o tratamento dispensado pelo Judiciário brasileiro aos derivativos, nos tribunais de segunda (Tribunais de Justiça das unidades da Federação) e terceira instâncias (Superior Tribunal de Justiça). Assim, o maior desafio deste trabalho (e também sua maior limitação) é traduzir de maneira objetiva uma realidade que é formada por uma miríade de decisões subjetivas, em tema cada vez mais judicializado. $^{12}$

\footnotetext{
${ }^{11} \mathrm{O}$ capítulo dedicado aos aspectos jurídicos dos derivativos é, igualmente, dividido em três partes: (i) Distanciamento do Jogo e Aposta; (ii) Natureza Jurídica: Contratos; e (iii) Função Instrumental: Valores Mobiliários. Optamos por classificar tais aspectos como preponderantemente jurídicos, haja vista a maior parte da produção acadêmica do Direito relacionada aos derivativos debruçar-se sobre tais assuntos.

${ }^{12} \mathrm{Em} 2004$, em inédito trabalho de análise de jurisprudência constitucional, VEIGA DA ROCHA apontava os seguintes desafios na análise de decisões do STF: (i) descomunal quantidade de ações já julgadas; (ii) inexistência de stare decisions e da noção de leading case; (iii) alternância de regimes democráticos e autoritários, com inúmeras constituições federais em pouco espaço de tempo; (iv) estratégias informais de decisões do STF. Cf. ROCHA, Jean Paul Cabra Veiga da. A capacidade de conjuntura no direito
} 
Quando o leitor se depara com dados prontos, tabelados, consolidados e demonstrados por meio de gráficos, pode-se ter a falsa impressão de um resultado neutro, estéril e imparcial - como toda pesquisa científica deveria ser. Contudo, o julgamento do pesquisador, que alimenta as tabelas originadoras dos resultados, é um vetor de subjetividade que pode contaminar os pretensos resultados objetivos. Além disso, no contexto de uma ciência social como o Direito, traduzir centenas de casos concretos, cada qual com suas características e especificidades, em respostas parametrizadas é uma tarefa árdua. Portanto, a dificuldade de catalogação de dados empíricos é o grande limitador deste trabalho.

Diante dessa constatação, a metodologia utilizada pelo autor durante as pesquisas jurisprudenciais é de importância suprema para a o trabalho. Por meio da metodologia, sistematizamos o esforço classificatório e adotamos padrões de conduta durante a coleta de dados subjetivos, em busca da melhor objetividade possível para a apresentação dos resultados jurisprudenciais.

Outro grande limitador da utilização de casos concretos, à parte da dificuldade classificatória, é a inexistência de dados públicos relacionados a decisões arbitrais. Como se sabe, ante o temor de eventual interpretação dada pelo Judiciário sobre matéria tão específica, muitos sujeitos preferem utilizar a arbitragem como método de solução de controvérsias. Tendo em vista a natureza sigilosa da arbitragem, apesar de impossível quantificarmos, deixa-se fora da base de dados muitas decisões que poderiam contribuir e enriquecer as estatísticas. ${ }^{13}$

A pesquisa é alimentada apenas com os subsídios encontrados nas sentenças (relatórios e votos) publicadas nos sites dos Tribunais, ainda que a decisão não tenha mérito ou seja interlocutória. Não há esforço de pesquisa adicional no âmbito dos autos de cada processo. Essa é uma reconhecida falha deste trabalho que, contudo, para ser suprida, demandaria esforço impossível de ser atingido, dadas as pretensões de amplitude do material a ser pesquisado. Ademais, entende-se que esse esforço adicional, ainda que

\footnotetext{
econômico: o déficit democrático da regulação financeira. 2004. Tese (Doutorado) - Faculdade de Direito, Universidade de São Paulo, São Paulo, 2004. p. 116-124. A presente pesquisa não busca analisar decisões do STF, mas, valendo-se da lição pretérita de VEIGA DA ROCHA, podemos concluir que a instabilidade regulatória/constitucional, a quantidade de processos relacionados ao tema, a inexistência de leading cases e o casuísmo das decisões também são dificuldades metodológicas aplicáveis ao nosso trabalho.

${ }^{13}$ É notório que muitas decisões (e talvez as mais importantes) se dão em juízo arbitral. Esse fato é facilmente vislumbrado, inclusive nesta pesquisa, dada a quantidade de decisões que versam sobre a legitimidade da cláusula compromissória ou, ainda que reconhecido o foro arbitral, sobre questões incidentais que correm paralelamente ao procedimento arbitral (como, por exemplo, execução de garantias ou sustação de protestos) cujo pano de fundo são dívidas contraídas por meio de operações de derivativos. Aqui reside uma lacuna muito importante da presente pesquisa, dado o processo sigiloso do procedimento arbitral.
} 
impossível de ser atingido, não traria grande contribuição, muito embora inegável a maior acuidade da pesquisa.

Para que a pesquisa possa ser realizada, elegemos determinadas palavras-chave a partir das quais iniciaremos a busca no site de cada Tribunal. Optou-se por eleger as seguintes palavras-chave para a realização da pesquisa: "derivativos", "swap" e "hedge".

Após alguns testes, optamos por não utilizar as palavras "futuro", "termo" e "opção" como palavras-chave elegíveis da pesquisa, tendo em vista serem afetas a inúmeros outros temas da dogmática que nada tem a ver com os derivativos, o que inviabilizaria a pesquisa. A título de exemplo da enormidade de retornos, ao buscarmos pela palavra "futuro" dentre os julgados de 2008 do Tribunal de Justiça de São Paulo, encontram-se 10.263 julgados. Com a palavra "termo", no mesmo período e no mesmo Tribunal, são 47.626 julgados.

Tais quantidades de retorno de busca inviabilizariam o esforço classificatório. Entendemos que essa escolha, apesar de distanciar o trabalho da máxima precisão que se pretende, não é tão significativa, pois, ao utilizarmos as palavras-chave "derivativos" ou "hedge", temas relacionados a "opção", "contratos futuro" ou "contratos a termo" tendem a aparecer. Isso sem mencionarmos que, dentre esses milhares de julgados potenciais a partir das palavras "opção", "futuro" e "termo", pouquíssimos seriam aqueles relacionados ao escopo da pesquisa.

Válido esclarecer que, se o tema dos derivativos é questão incidental ao julgado, opta-se por não contabilizá-lo como resultado válido, classificando-o, assim, como fora do escopo. A contabilização de uma decisão como dentro ou fora do escopo fica a critério do autor da pesquisa, o que, mais uma vez, pode contaminar a pretensa objetividade da pesquisa.

A título exemplificativo, na paradigmática e interessante decisão ${ }^{14}$ em que uma grande fabricante de alimentos insurge-se contra a decisão favorável ao seu ex-diretor financeiro e que versa sobre os artigos 134, Parágrafo $3^{\circ}$ e 159 da Lei 6.404/76, ainda que o tema subjacente da decisão tenha sido a negociação de derivativos (autorizada pelo diretor financeiro), não se trata de uma decisão que discuta os derivativos em si. Nesse sentido, opta-se por não contabilizá-la, pois fora do escopo da pesquisa.

${ }^{14}$ Embargos de Declaração TJ-SP 99009362587-3/50000. 
Em outra interessante decisão ${ }^{15}$ relacionada à falência de uma instituição financeira, na qual uma empresa do setor de limpeza apela contra decisão de primeira instância, notase que operações de swap foram realizadas para regular o fluxo financeiro de duas operações casadas, uma com o banco (mútuo) e outra com empresa a ele ligada ("export notes”), com o objetivo de ajustar índices e taxas das obrigações e créditos decorrentes dessas duas operações que a apelante busca anular ou compensar. Como a questão da realização do swap é incidental e não está sub-judice, opta-se por não contabilizar tal resultado.

Ainda que diferentes sentenças versem exatamente sobre o mesmo assunto (como, por exemplo, o caso de um banco que figura como agravante em um relatório e como agravado em outro), ${ }^{16}$ a critério do pesquisador, poderão ser contabilizadas duas decisões. ${ }^{17}$ Aqui, ao se incluir duas decisões, tem-se o inevitável risco de enviesamento das estatísticas, dado que as sentenças tendem a ser coerentes entre si. ${ }^{18}$

As decisões catalogadas terão os seguintes sinais distintivos expostos:

a) Número do processo;

b) Unidade da Federação;

c) Nome do juiz relator;

d) Data de julgamento;

e) Valor;

f) Data do fato;

g) Autor;

h) Réu;

i) Peça

j) Provimento;

k) Viés da Sentença;

\footnotetext{
${ }^{15}$ Apelação TJ-SP 4960184/0-00.

${ }^{16}$ Por exemplo: Agravo de Instrumento TJ-SP 7324656-7 e Agravo de Instrumento TJ-SP 7308955-5.

${ }^{17} \mathrm{O}$ critério para se contabilizar uma ou duas decisões decorre (i) da quantidade de retornos de cada TJ, se um ou dois; e/ou (ii) se as sentenças abordam detalhadamente e de maneira autônoma as teses levantadas pelas partes ora na qualidade de autora, ora na qualidade de ré.

${ }^{18}$ Nos citados Agravos de Instrumento TJ-SP 7324656-7 e TJ-SP 7308955-5 acima, ambas as decisões foram desfavoráveis ao Banco.
} 
1) Produto; e

m) Ambiente.

Com relação aos sinais distintivos de cada umas das sentenças, algumas considerações devem ser feitas desde logo, a saber:

No item "b", "unidade da Federação" significa o Tribunal de Justiça do Estado ou do Distrito Federal em que se desenrolou a lide, além do Superior Tribunal de Justiça. Quando estivermos diante dos julgados de terceira instância, cuidaremos de identificar que se trata de um julgado do Superior Tribunal de Justiça.

Busca-se analisar as decisões de todas as unidades da federação e do Superior Tribunal de Justiça que contenham as palavras-chave previamente determinadas (conforme explicado acima).

No item "c", ao elencarmos o "nome do juiz relator", poderemos traçar um diagnóstico acerca da especialização dos magistrados sobre o tema. Se constatarmos que inexiste concentração de julgados em determinados juízes, fica fácil concluir que as distribuições são aleatórias. Por outro lado, se diagnosticarmos que determinados nomes de relatores são citados e concentram as decisões de diversos processos sem conexão, poderemos concluir que os tribunais têm adotado a especialização de câmaras a determinadas matérias. Adicionalmente, quando algum juiz aparece reiteradamente julgando a matéria, pode-se diagnosticar eventualmente determinado viés decisório.

Contudo, não se pode esquecer que determinadas concentrações de processos em um único magistrado podem falsamente indicar especialização, como, por exemplo, no caso dos processos de derivativos envolvendo o então falido Banco Santos - tais processos, por sua conexão, acabam com o mesmo magistrado, que, inclusive, usa a mesmo conteúdo lógico para formalizar suas sentenças.

Sabe-se que os tribunais adotam a forma colegiada de decisão pela qual três juízes de segunda instância, também chamados desembargadores, julgam a lide conjuntamente. $\mathrm{Na}$ grande maioria dos julgados, existe consenso entre os desembargadores. Nestes casos, contabilizamos apenas a decisão do juiz relator, expondo seu nome, tendo em vista os outros dois membros não terem se pronunciado acerca da matéria. Nas hipóteses em que existe dissenso entre os desembargadores, contabilizamos todas as decisões de maneira 
independente, como se fossem decisões diferentes, incluindo o nome de cada respectivo juiz e suas respectivas razões de decidir e teses levantadas. ${ }^{19}$

A "data do julgamento" disposta no item "d" corresponde ao dia em que o juiz assinou o relatório, independentemente da data em que tenha sido publicado. Nossa pesquisa busca julgados entre os anos de 2006 e 2010.

No item "e", "valor" significa a quantia monetária envolvida na disputa. Nessa classificação, não contabilizamos demandas em que o valor seja inferior a R \$ 500.000,00. Vale ressaltar que serão contabilizados todos os casos em que o valor sub-judice não foi informado ou não pode ser depreendido da sentença. ${ }^{20}$

Assim, dividimos o campo "valor" em 29 possibilidades, quais sejam, (1) não informado; (2) de $\mathrm{R} \$ 500.000,00$ a $\mathrm{R} \$ 750.000,00 ; \quad$ (3) de $\mathrm{R} \$ 750.000,01$ a R\$1.000.000,00; (4) assim sucessivamente, com valores divididos em múltiplos de $\mathrm{R} \$ 250.000,00$, até o valor de $\mathrm{R} \$ 5.000 .000,00$, quando passamos a contabilizar múltiplos de $\mathrm{R} \$ 500.000,00$; (19) de $\mathrm{R} \$ 5.000 .000,01$ a $\mathrm{R} \$ 5.500 .000,00$; (20) $\mathrm{R} \$ 5.500 .000,01$ a $\mathrm{R} \$$ 6.000.000,00; (21) assim sucessivamente, com valores divididos em múltiplos de $\mathrm{R} \$ 500.000,00$, até o valor de $\mathrm{R} \$ 10.000 .000,00$, quando passamos a contabilizar todos os julgados como acima de $\mathrm{R} \$ 10.000 .000,01$ em um único campo; (29) acima de $\mathrm{R} \$ 10.000 .000,01$.

Ainda, apresentaremos na tabela relacionada ao número total de decisões quantas delas, mesmo que circunscritas à matéria do trabalho, não foram incluídas pela irrelevância do valor - no caso, sentenças cujo valor em litígio era menor do que $\mathrm{R} \$ 500.000,00$.

A "data do fato" disposta no item "f" é a data em que os fatos que motivaram a disputa aconteceram. Em muitas hipóteses, não é possível definir uma data, para o que assinalamos "não informado". Quando tal data é conhecida, optamos por elencar o mês e o ano do fato. A importância deste item reside na identificação (ou suposição) de determinados fatos (eventos sociais ou econômicos, por exemplo) que levaram as partes a contestar os derivativos contratados no Poder Judiciário.

\footnotetext{
${ }^{19}$ Há Tribunais que apresentam apenas a decisão vencedora por maioria (que obviamente, representa dois votos) e o voto vencido. Nestas situações, contabilizam-se duas decisões, muito embora, o conteúdo da terceira decisão esteja contido em uma das duas.

${ }^{20}$ Para valores em dólares norte-americanos, utilizados a cotação de 1,00 USD equivalente a R\$2,00.
} 
Nos itens "g" e "h" referentes a "autor" e "réu", a classificação será feita entre "pessoa física", "sociedade não financeira", "agente autônomo de investimento", "entidade de previdência" ou a denominação exata da instituição financeira litigante. Como são poucos os bancos e instituições financeiras equiparadas do país, podemos incluir todos eles em nossa parametrização. ${ }^{21}$

No campo "peça", exposto no item "i" acima, descrevemos o remédio processual utilizado pela parte autora. Como o escopo deste trabalho está delimitado aos Tribunais de Justiça e ao Superior Tribunal de Justiça, desnecessário dizer que peças típicas de julgados de primeira instância não aparecerão na pesquisa. Nesse sentido, o leitor se deparará, na grande maioria dos casos, com apelações, agravos e embargos.

No item “j”, "provimento", limitamos a dizer se o pedido foi provido ou não provido. O fato de uma ação iniciada por uma instituição financeira ser provida não significa que ela é pró instituição financeira. Tal ação pode simplesmente não ter mérito. Ao explicarmos o próximo item da tabela, esta afirmação se fará mais clara. ${ }^{22}$

Em "viés da sentença", o item "k" de nossa tabela, colocamos as seguintes possibilidades: (i) pró instituição financeira; (ii) contra instituição financeira; e (iii) sem mérito.

Alguns casos não possuem um posicionamento contra ou a favor da instituição financeira, vez que, a título exemplificativo, ou tratam de questões processuais, ${ }^{23}$ ou inexiste interesse de agir da parte autora, ${ }^{24}$ ou a questão central é a manutenção da cláusula

\footnotetext{
${ }^{21}$ Há situações em que as pessoas são, ao mesmo tempo, autor e réu (por exemplo, quando as duas partes da lide apelam da decisão, elas se tornam concomitantemente apelantes e apeladas). Fica a critério do pesquisador contabilizar tais decisões de maneira independente ou conjuntamente, a depender do enfoque dado pelo juiz - por exemplo, se o desembargador se apega apenas às razões de uma das partes para decidir, sequer mencionando a outra, não faz sentido desdobrarmos a decisão em duas.

${ }^{22} \mathrm{Em}$ grande parte dos casos, o provimento de uma sentença guarda conexão com o juízo de valor relacionado à sentença (aquilo que chamamos de "viés da sentença"). Por exemplo, no caso de ações interpostas por instituições financeiras, sentenças classificadas como "pró instituição financeira" tendem a ser providas e, a contrário senso, sentenças classificadas como "contra instituição financeira" tendem a ser não providas. Contudo, nem sempre essa regra se aplica. Tendo em vista o campo "pró" ou "contra" instituição financeira dizer respeito ao objeto do presente estudo (ou seja, teses levantadas acerca dos derivativos), o pesquisador fica à vontade para classificar uma decisão como "pró instituição financeira", ainda que a ação interposta pelo Banco não seja provida. Ainda que tais casos sejam raros, eles acontecem, tendo em vista inúmeras contestações processuais a que as partes lançam mão (i.e. Apelação TJ-SP 99209044140-0).

${ }^{23}$ Agravo de Instrumento TJ-SP 7399933-0, em que a pretensão é a negativação do nome do cliente perante os órgãos de proteção ao crédito.

${ }^{24}$ Apelação TJ-SP 881.476-0/6.
} 
compromissória, ${ }^{25}$ ou a sentença serve para o juiz simplesmente reconhecer a cláusula de eleição do foro do contrato. ${ }^{26}$ Para tais casos, utilizamos a classificação "sem mérito".

Cada decisão comporta as suas próprias peculiaridades. Muitas delas apresentam tão somente questões processuais e, nesses casos, muito embora sejam importantes para quantificar as teorias levantadas, não são importantes para quantificar o mérito, justamente por este inexistir.

Ainda que exista um posicionamento claro do juiz de maneira favorável ou contrária à instituição financeira, este posicionamento não significa necessariamente a existência de uma decisão definitiva da lide. Aqui, ter mérito não implica obrigatoriamente na existência de uma decisão final.

Aqui também o julgamento subjetivo do pesquisador se revela crucial. Na maioria dos casos, é claro se a sentença é pró ou contra instituição financeira. Todavia, existem aqueles julgados que ou são demasiadamente mal escritos ou abordam, em um mesmo julgado, muitas questões diferentes, sendo algumas delas pró e outras contra instituição financeira. Nestes casos, o pesquisador busca focar especificamente no tema dos derivativos e, dentro do contexto maior do julgado, toma sua decisão classificatória. ${ }^{27}$

Adicionalmente, uma vez consolidados os resultados de mérito, ainda que se crie uma linha de raciocínio acerca da tendência do Judiciário brasileiro e o autor opine sobre isso, não se pode esquecer que cada caso utilizado para compor o todo possui as suas próprias nuances, questões de fato próprias e pontos processuais únicos. Assim, ainda que as estatísticas relacionadas aos resultados finais "pró" ou "contra" instituição financeira possam demonstrar algo, o maior mérito deste trabalho será quantificar as teses levantadas pelas partes e a frequência com que tais teses ocorrem.

Não se pretende advogar aqui que sentenças pró instituição financeira sejam as mais corretas ou que as sentenças contra as instituições financeiras sejam as mais acertadas consoante o atual arcabouço legislativo e regulatório. Outrossim, busca-se entender o

\footnotetext{
${ }^{25}$ Agravo de Instrumento TJ-SP 7343768-4.

${ }^{26}$ Agravo de Instrumento TJ-SP 7343496-3.

${ }^{27}$ Cita-se como exemplo a Apelação TJ-SP 7032907-8, em que tanto a instituição financeira (Banco Ribeirão Preto) como a sociedade não financeira são apelantes e apeladas, com tantos pontos controversos e questionamentos de ambos os lados, sendo determinadas teses julgadas favoráveis e outras contra a instituição financeira. Neste caso, fez-se necessária a exegese do autor da pesquisa para, no contexto global do voto, decidir se o julgado é contra ou a favor da instituição financeira.
} 
posicionamento do Judiciário brasileiro (de maneira ampla) com relação aos derivativos, qualquer que seja este posicionamento.

No item "l", classificamos o "produto" objeto da lide em swap, termo, futuro, opção e fundo de investimento. Por fundo de investimento, entendem-se aqueles fundos cuja carteira está alocada em derivativos e que levaram seus quotistas ao Judiciário em busca de determinada pretensão.

Por fim, o item "m" traz o "ambiente" em que o produto é negociado, podendo ser bolsa, balcão, não informado ou não aplicável (neste caso, por se tratar de fundo de investimento).

Dando continuidade à classificação de cada julgado analisado, cada decisão traz 21 matérias a ela relacionadas, que significam 21 possibilidades de tese que podem ser alegadas em juízo pela parte autora ou que podem ser utilizadas pelo juiz para fundamentar a sua sentença. São as seguintes as matérias:
i. Suitability;
ii. Coação;
iii. Danos morais;
iv. Danos materiais;
v. Código de Defesa do Consumidor;
vi. Contrato de adesão;

vii. Lesão;

viii. Onerosidade excessiva;

ix. Cláusulas abusivas;

x. Teoria da Imprevisão;

xi. Defeito de representação ou formalização do negócio jurídico; ${ }^{28}$

\footnotetext{
${ }^{28}$ Por defeito de representação, muitas hipóteses podem ser capturadas. Desde a má formalização de uma operação, pela incapacidade de uma das partes trazer aos autos evidências do envio da ordem de compra ou venda do derivativo, até a discussão sobre ordens irregularmente repassadas por agentes autônomos de investimentos. Em todas as hipóteses descritas, julgou-se que, de alguma forma, as disposições acerca do mandato contidas no Código Civil foram explicitamente ou tacitamente mencionadas.
} 
xii. Hipo-suficiência;

xiii. Erro;

xiv. Estado de perigo;

xv. Dolo;

xvi. Boa-fé;

xvii. Pacta sunt servanda;

xviii. Autonomia da vontade;

xix. Inerência ao risco;

xx. Contrato aleatório; e

xxi.Simulação.

As hipóteses materiais acima são auto-explicativas. Muitas delas poderiam facilmente ser agrupadas em uma única tese (por ex., "Código de Defesa do Consumidor" e "contrato de adesão", ou "teoria da imprevisão" e "onerosidade excessiva"), mas optamos por não fazê-lo em busca de maior enriquecimento da base de alegações. Como dependemos de respostas parametrizadas, quanto maiores as hipóteses de matérias, mais rica a pesquisa.

Para cada tese possível de ser levantada, dividimos o campo em dois, quais sejam, autor e juiz. Com isso, buscamos demonstrar as teses mais alegadas pelas partes autoras da demanda (sejam ela instituições financeiras ou não) e as mais utilizadas pelo juízo para rebater ou afirmar determinado posicionamento.

Ainda que, da leitura dos relatórios, em esforço exegético, alguns juízes exponham também as alegações do réu, além das do autor, o trabalho apenas captura as teorias contidas nas alegações do autor e do juiz. Portanto, não foram contabilizadas as hipóteses materiais alegadas pelos réus. ${ }^{29}$

\footnotetext{
${ }^{29}$ Quando do efetivo voto do juiz, pode-se concluir, quando outras teorias que não as do autor são também colocadas, que as teses do réu foram ou aceitas ou refutadas. Em tais ocasiões, ainda que inexista um campo próprio para o réu, as questões levantadas pelo réu acabam sendo refletidas no campo do juiz.
} 
Não necessariamente uma tese alegada pela parte autora será trazida pelo juiz no voto e vice-versa. Como nos baseamos apenas nos relatórios das sentenças, ou seja, na descrição do caso feita pelo juiz e no seu respectivo voto, teses alegadas pelo autor em peça processual própria, se não mencionadas pelo juiz, ficam fora de nossa contabilização. Como este trabalho analisa apenas o relatório do juiz e não o processo inteiro, onde se poderia ter com maior riqueza de detalhes todas as teses levantadas, admite-se uma certa deficiência no rigor técnico classificatório.

Assim, para cada tese, nos campos autor e juiz, abrimos 3 possibilidades: "sim", "não" e "N/L" (acrônimo de "não levantada"). O "não" e o "sim" apresentam juízos de valor, quer do requerente (instituição financeira ou não) que demanda algo na justiça, quer do juiz que profere a sentença.

A diferença entre o "não" e o "N/L" reside no aparecimento ou não da tese no processo. Quando se opta pelo "não", existe a citação da tese, porém de maneira negativa, ou seja, sem a sua aceitação pelo juiz, por exemplo, ou com a negativa de sua aplicabilidade pela parte autora. Quando se opta pelo "N/L", infere-se que as teses sequer foram citadas, no todo ou em parte.

Frequentemente, o autor da ação alega a existência de determinada tese, devidamente citada no relatório, pelo que se assinala o "sim", e o juiz sequer a menciona em sua sentença, pelo que se assinala o "N/L".

Por exemplo, o autor pode alegar, em uma determinada apelação, a aplicabilidade do Código de Defesa do Consumidor e a existência de danos morais e materiais, pelo que se assinala o "sim". O juiz, por seu turno, pode sequer mencionar, na sentença, tais matérias, pelo que se marca o "N/L". De todo modo, para os fins estatísticos a que se presta este trabalho, deve-se quantificar as alegações do autor e o fato de tais teses não terem sido utilizadas pelo juiz, ainda que isso não signifique, de modo algum, o fato de juiz ter feito juízo de valor negativo sobre estas alegações.

A dificuldade da utilização da classificação "N/L" reside no fato de muitas teses estarem implícitas, ainda que não expressamente alegadas. Em vários casos, o relator não expõe as alegações e teses da parte autora ou, se as expõe, não as expõe completamente. Contudo, da leitura da sentença, pode-se imaginar que a parte tenha sim alegado tal tese, seja pela forma como redigido o voto, seja pela aceitação ou não de determinada tese no voto do juiz, levando-nos a crer que a tese tenha sido alegada nos autos. 
Mesmo que se imagine a alegação da tese pela parte autora, quando o relatório não a cita expressamente, assinala-se o "N/L", ainda que, eventualmente, na sentença, assinalese o juízo de valor do juiz pelo "sim" ou "não". Portanto, quando tais situações ocorrem (não alegação expressa da tese, mas inferência indireta pela leitura do voto), opta-se, como regra geral, por classificar a tese como "não levantada". Apenas quando restar inequívoca o levantamento de determinada tese pela parte autora, mesmo que sabido apenas pelo voto do juiz e não contido no relatório, opta-se por incluir tal tese dentre as levantadas, fazendo o juízo de valor (“sim” ou "não"). Mais uma vez, a subjetividade do pesquisador pode deixar o trabalho distante da pretensa objetividade.

A escolha, feita pelo pesquisador, sobre a utilização ou não de determinada tese dentro dos critérios classificatórios previamente definidos na tabela corrobora para o aspecto subjetivo do trabalho. ${ }^{30} \mathrm{O}$ julgamento no preenchimento dos quesitos, uma vez postas as possibilidades no julgado, é do pesquisador. Recorrentemente, tem-se que escolher se um conceito foi ou não levantado e, nessa tarefa, reside a subjetividade de um trabalho que se pretende objetivo, estéril e axiologicamente neutro. ${ }^{31}$

Pretende-se ainda trazer, para cada caso analisado, um sumário com a linha de raciocínio utilizada pelo juiz que entendemos ser a mais emblemática para ilustrar o caso. Assim, a critério do autor, cada caso trará uma ou mais frases de efeito que demonstram o caso ou o tratamento dispensado a determinada teoria levantada.

O esforço classificatório de cada julgado, com os sinais distintivos descritos nas alíneas "a" a "m" e as matérias dispostas nos itens "i” a "xxi” acima, gerará uma tabela, cujo formato será o seguinte:

\footnotetext{
${ }^{30}$ Por exemplo, no Agravo de Instrumento TJ-SP 7343768-4, pode-se ler o seguinte: Disserta [a agravante] sobre a operação de swap contratada como forma de redução dos juros pactuados cuja operação se revelou forma de perdas e ganhos desproporcionais entre as partes. Ao pesquisador, dado o contexto, optou-se por classificar a alegação de "desproporcionalidade" como "onerosidade excessiva", vez que inexistente um campo próprio denominado "obrigações desproporcionais". Tais nuances e entendimentos próprios de cada leitor da sentença frente ao esforço classificatório contribuem para acentuar o caráter subjetivo deste trabalho que busca mapear uma realidade objetivamente.

${ }^{31}$ Em outro exemplo, na sentença relacionada a Apelação TJ-SP 966117-0, o juiz dispõe que o apelante aduziu de que (sic) sempre foi informado de que as aplicações nos fundos em questão não representavam riscos de perda de capital investido, e o pesquisador deve escolher se o tema "inerência ao risco" foi citado ou não. No caso exemplificado, entendeu-se que, apesar da palavra "risco" ter sido citada, não houve, por parte do apelante a intenção de defender a inerência ao risco dos instrumentos de derivativos - muito pelo contrário, buscava-se demonstrar que a instituição financeira apelada não informou o apelante acerca da inerência ao risco, sendo certo que o contexto do relatório nos leva a essa conclusão. Por outro lado, apesar de inexistir qualquer menção expressa ao chamado "suitability", da leitura deste acórdão, depreende-se que o apelante propugna pela inadequação do investimento ao seu perfil - logo, tem-se um caso em que a matéria "suitability” foi incluída na análise estatística do julgado, apesar de não expressamente citada.
} 
Apêndice [---]-[UF]

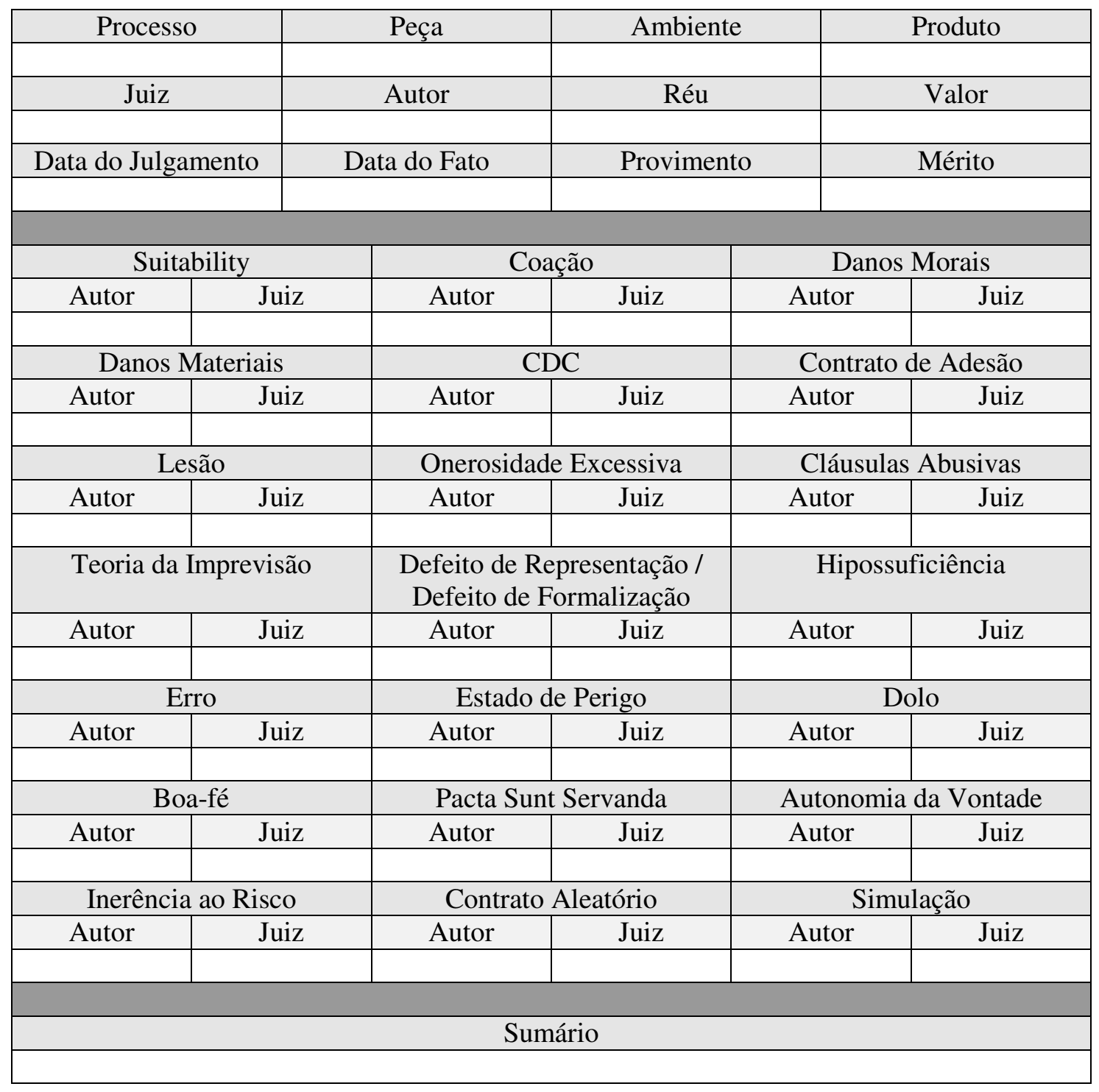

Imaginamos que os Apêndices possam refletir os julgados analisados e servir de fonte de consulta para os leitores. 


\section{ASPECTOS FINANCEIROS DOS DERIVATIVOS}

\section{III.A. Origem e Utilidade: Proteção e Especulação sobre o Risco}

Há muitas teorias sobre a origem histórica dos derivativos (ou daquilo que seria o gérmen do seu atual formato), com apontamentos que variam desde a antiga Mesopotâmia até o Japão do shogunato, passando pela Grécia antiga e pelas feiras medievais europeias.

Há relatos de instrumentos emitidos pelos reis da Babilônia, na antiga Mesopotâmia, que facultavam aos seus portadores o direito de, mediante o pagamento do preço nele inscrito, exigir a entrega de mercenários e escravos. Da mesma forma, aponta-se que mercadores da Grécia antiga ajustavam na Ágora o preço do azeite em data futura. ${ }^{32}$ Há, ainda, notícias sobre a negociação de arroz para entrega em data futura, em 2000 A.C., na China. ${ }^{33}$

Fala-se também sobre a negociação de mercadorias a termo nas feiras medievais do século XII, nos territórios hoje correspondentes à França e à Inglaterra, ${ }^{34}$ ou sobre a compra antecipada de algodão, nos séculos XIII e XIV, pelas companhias da península itálica. $^{35}$ Diz-se que o primeiro mercado de monta (ainda que não organizado) para liquidação futura de ativos (incluindo-se o lançamento de opções) aconteceu em Antuérpia, no século XVI, onde as mercadorias transacionadas eram as tulipas. ${ }^{36}$

Em todos os rudimentares exemplos dados até aqui, vislumbramos um dos traços distintivos dos atuais derivativos: a existência de lapso temporal entre a data de contratação e a data de liquidação do contrato. Contudo, tais operações ainda eram personalizadas, não massificadas e sem padronização.

Especula-se que o primeiro mercado futuro realmente organizado e relevante ocorreu no Japão do século XVII, baseado no arroz, o Cho-Ai-Mai-A-Kinai (ou "negócios

\footnotetext{
${ }^{32}$ ANTUNES, José A. Engracia. Os derivados. p. 91. Disponível em: <http://www.cmvm.pt/CMVM/Publicacoes/Cadernos/Documents/C30Artigo4.pdf>. Acesso em: 10 mar. 2012.

${ }^{33}$ SOUZA JUNIOR, Francisco Satiro. Regime jurídico das opções negociadas em bolsas de valores. 2002. Tese (Doutorado) - Faculdade de Direito, Universidade de São Paulo, 2002. p. 18.

${ }^{34}$ EIZIRIK, Nelson; GAAL, Ariádna B.; WALD, Arnold. Das funções econômicas dos mercados a termo e do Projeto de Código Civil. Revista de Informação Legislativa, Brasília, n. 86, p. 324, abr./jun. 1985.

${ }^{35}$ SOUZA JUNIOR, Francisco Satiro. op. cit., p. 18-19.

${ }^{36}$ Id., loc. cit.
} 
escriturais de arroz"), com regras que o aproximam do atual mercado de futuros das bolsas de valores. Já nesta época, os contratos eram padronizados, as mercadorias classificadas conforme sua qualidade, inexistia a possibilidade de entrega física do bem durante o prazo de duração do contrato, a liquidação se dava por diferença e por meio de uma espécie de contraparte central e, por fim, tem-se notícia, inclusive, de uma espécie de "comitê de arbitragem" para solucionar possíveis conflitos entre as partes contratantes, em um suposto exemplo de auto-regulação. ${ }^{37}$

Independente da mercadoria transacionada, se seres humanos, arroz, flores, especiarias ou azeite, e independentemente da sofisticação do mercado, nota-se um objetivo comum em todas essas negociações para liquidação a posteriori: proteger-se contra oscilações no preço futuro de um determinado bem. ${ }^{38}$ Tais negócios, derivados da compra e venda comum, por conta de necessidades negociais específicas que permearam os milênios, tinham como cerne o pré-estabelecimento de preço de determinado ativo com liquidação em data futura.

Parece intuitivo que inúmeras civilizações, nos mais variados pontos do planeta e em diferentes épocas e estágios evolutivos, tenham, de maneira independente, chegado ao mesmo racional estratégico - muitas vezes englobando o tráfego de produtos agrícolas, base das economias pré-industriais. ${ }^{39}$ Nesse sentido, SZTAJN coloca:

O desejo de garantir o fornecimento do produto agrícola de um lado e o de obter o melhor preço para a produção de outro criam as compras e vendas antecipadas que, a final, se transformaram nas operações a futuro atuais. ${ }^{40}$

\footnotetext{
${ }^{37}$ GORGA, Erica Cristina Rocha. A importância dos contratos a futuro para a economia de mercado. Revista de Direito Mercantil, Industrial, Econômico e Financeiro, São Paulo, n. 112, p. 164, out./dez. 1998. No mesmo sentido, a opinião de SZTAJN, Rachel. Contrato e inovação financeira: ensaio sobre contratos futuros e swaps. Tese (Professor Titular) - Faculdade de Direito da Universidade de São Paulo, 1996. p. 167-168.

${ }^{38}$ BERNSTEIN, Peter L. Desafio aos deuses: a fascinante história do risco. 23. ed. Rio de Janeiro: Campus, 1997. p. 319. Apesar do mistério que se formou em torno desses instrumentos nos últimos anos, não há nada de particularmente moderno neles. Os derivativos são tão antigos que não tem um inventor identificável: nenhum Cardano, Bernoulli Graunt ou Gauss. O uso de derivativos surgiu da necessidade de reduzir a incerteza, e certamente não há nada de novo nisso.

${ }^{39}$ HULL, John. Introdução aos mercados futuros e de opções. 2. ed. São Paulo: Bolsa de Mercadorias e Futuros; Cultura Editores Associados, 1996. p. 2: A história dos mercados futuros remonta à Idade Média. Eles foram originalmente desenvolvidos para atender às necessidades de produtores e comerciantes. Consideremos a posição de um produtor no mês de abril de certo ano, que fará a colheita em junho. Ele não tem certeza do preço que irá receber pelo produto pois, em épocas de escassez, poderá obter preços relativamente altos, especialmente se não precisar vendê-lo imediatamente. Por outro lado, a mercadoria poderá ser vendida por preços bem menores em épocas de superabundância. Concluímos, então, que tanto o produtor como sua família estão expostos a muitos riscos.

${ }^{40}$ SZTAJN, Rachel. Contratos de bolsa. In: BITTAR, Carlos Alberto (Coord.). Novos contratos empresariais. São Paulo: Ed. Revista dos Tribunais, 1990. p. 169.
} 
Assim como os prosaicos exemplos históricos, também o aparecimento dos derivativos em seus formatos atuais estão relacionados ao mercado agropecuário, a partir de meados do século XIX e início do século XX. A negociação do primeiro contrato a futuro de milho na Chicago Board of Trade, em 1851, ${ }^{41}$ e a criação da Options Dealers Association, em 1934, ${ }^{42}$ no caso das opções, nos parecem dois bons indicadores temporais para esta afirmação, muito embora seja impossível afirmar com precisão a origem dos derivativos atuais. ${ }^{43}$

De mais fácil constatação, contudo, é afirmar que, a partir da década de 1970, houve uma paulatina financeirização dos instrumentos derivativos. Isso significa dizer que os derivativos, muito embora com inegável origem em bens agrícolas tangíveis (as ditas “commodities”), passam a ter como ativos subjacentes possíveis também bens imateriais e outros referenciais teóricos. ${ }^{44}$ Nessa linha, SALOMÃO aponta a crescente desregulamentação e liberalização dos mercados financeiros e de capitais, bem como a imprevisibilidade de movimentação de taxas de juros e câmbio como causas para o surgimento de produtos financeiros mais sofisticados. ${ }^{45}$

Esta efetiva financeirização traduz-se na desnecessidade de entrega efetiva do ativo subjacente ao derivativo, reconhecendo-se que os efeitos da transação são mais importantes do que a operacionalização de todos os negócios jurídicos atrelados ao derivativo. Daí nasce a liquidação por diferença, que nada mais é do que o ganho ou perda líquida gerada pela operação, sem os custos de transação inerentes à operação (por exemplo, a entrega da mercadoria e sua posterior venda pelo mesmo preço) e com inegáveis ganhos de eficiência e rapidez. Nesse sentido, o nosso Código Civil, em 2002, ${ }^{46}$ positivou expressamente a

\footnotetext{
${ }^{41}$ CME GROUP. From water street to the world: a brief history of the Chicago board of trade and the Chicago mercantile exchange. Disponível em: <http://www.cmegroup.com/company/history/magazine/Summer2007/FromWaterStreetToTheWorld.html>. Acesso em: 09 maio 2013.

${ }^{42}$ SZTAJN, Rachel. Sobre a natureza jurídica das opções negociadas em bolsa. Revista de Direito Mercantil, Industrial, Econômico e Financeiro, São Paulo, v. 36, n. 105, p. 55, jan./mar. 1997.

${ }^{43}$ Já os swaps, o mais recente dos três arquétipos dos derivativos, surgem a partir da década de 1970, no contexto da falência das diretivas de Bretton Woods e dos controles de fluxos monetários pelos governos, conforme descrito em capítulo específico. Portanto, o aparecimento dos swaps não está relacionado ao mercado de commodities.

${ }^{44}$ YAZBEK, Otavio. Regulação do mercado financeiro e de capitais. 2. ed. Rio de Janeiro: Elsevier, 2009. p. 99, 104, 109 e 110.

${ }^{45}$ SALOMÃO NETO, Eduardo. Direito bancário. São Paulo: Atlas, 2005. p. 324-325.

${ }^{46}$ BRASIL. Lei n. ${ }^{\circ} 10.406$, de 10 de janeiro de 2002. Institui o Código Civil. Disponível em: $<$ http://www.planalto.gov.br>. Acesso em: 22 maio 2011. Parte Especial, Livro I (Direito das Obrigações), Título VI (Das Várias Espécies de Contrato), Capítulo XVII (Do Jogo e da Aposta). Art. 816. As disposições dos arts. 814 e 815 não se aplicam aos contratos sobre títulos de bolsa, mercadorias ou valores, em que se estipulem a liquidação exclusivamente pela diferença entre o preço ajustado e a cotação que eles tiverem no vencimento do ajuste.
} 
liquidação por diferença e, como veremos mais adiante, afastou as disposições do jogo e aposta dos derivativos.

Adicionalmente à economia de custos de transação e aos ganhos de celeridade, outro importante efeito da liquidação por diferença, neste movimento de inovação financeira dos derivativos, é a formação de um mercado líquido e fungível em que as partes podem, a qualquer tempo, reverter as suas posições, independentemente do termo do contrato. ${ }^{47}$ Tem-se um mercado massificado em que os participantes podem ter um way out ou, em outras palavras, a possibilidade de comprar ou vender a posição de derivativo igual e inversa à inicialmente assumida como forma de reverter sua posição, num verdadeiro "jogo de soma zero". ${ }^{48}$

Se não há trânsito de bens materiais (ou sequer esta possibilidade - como observado maioria dos casos), fácil concluir que inexiste um direito de recebimento ou uma obrigação de entrega de um ativo físico. Assim, as partes contratantes de derivativos possuem, na realidade, posições escriturais ou registrais, as quais originam direitos de recebimento ou obrigações de pagamento correspondentes à liquidação por diferença. ${ }^{49}$

Outro inegável aspecto da financeirização é a desnecessidade de transferência entre as partes do valor correspondente ao ativo subjacente. Este valor do bem passa a ter papel importante como referencial de cálculo do valor que, ao final, será liquidado pela diferença. Dá-se o nome de notional a esse balizador teórico, que é sabido na data de contratação do derivativo e que servirá de referência ao valor efetivamente devido ou recebido na data futura de liquidação do contrato. ${ }^{50}$

\footnotetext{
${ }^{47}$ SZTAJN, Rachel. Regulação e o mercado de valores mobiliários. Revista de Direito Mercantil, Industrial, Econômico e Financeiro, São Paulo, v, 53, n. 135, p. 143, jul./set. 2004: Liquidar por diferença, na verdade, é o mecanismo que resulta da fungibilidade dos contratos pelo que, se uma pessoa está comprada ou vendida e não precisa mais da proteção contra variação do preço do bem subjacente, basta negociar posição inversa com o que se têm mesmas partes, reciprocamente credora e devedora, a bolsa uma delas $e$ o mesmo agente econômico na outra ponta nos dois contratos, o que permite, a qualquer momento, pensar em compensar as obrigações até o limite da menor, após o que a parte devedora paga à outra, a título de extinção da obrigação o saldo devedor.

${ }^{48}$ SZTAJN, Rachel. Contratos de bolsa, cit., p. 173: Sendo possível, segundo as regras do mercado de futuros, a "liquidação" antecipada dos contratos, o locus fica sendo a bolsa e a adoção da posição oposta por qualquer operador resulta no que o jargão do mercado denomina "zerar" a posição, isto é, a confusão.

${ }^{49}$ YAZBEK, Otavio. Regulação do mercado financeiro e de capitais, cit., p. 101: Na maior parte dos instrumentos derivativos, contratos diferenciais que são, não se efetua a entrega dos ativos negociados "a futuro”, mas apenas o pagamento de valores correspondentes à diferença entre o preço pactuado e o preço de mercado na liquidação, como ainda se verá, tratando-se, assim, de operações financeiras puras. $O$ efeito de hedge é dado, assim, por essa movimentação financeira.

${ }^{50}$ Id. Ibid., p. 104.
} 
Esta idéia da liquidação por diferença, muito embora de grande engenho, não é imune a falhas. Por esse motivo, recomendável arranjo sistêmico que organize todo o mercado. Isso é possível graças à presença de uma contraparte central ou caixa de compensação e liquidação ou clearing house ou simplesmente clearing. ${ }^{51}$ Tal contraparte central atua como "vendedora" de todos os "compradores" de posições e "compradora" de todos os "vendedores" de posições, garantindo todas as operações. Além de gerar segurança aos agentes econômicos, mitigando riscos de créditos de uma parte à outra, a clearing possibilita a fluidez das relações e faz com que as reversões de posições sejam possíveis a qualquer tempo. ${ }^{52}$

Além da caixa de compensação e liquidação, outro importante sujeito no arranjo sistêmico dos mercados organizados de derivativos é a entidade administradora de bolsa ou de balcão, que não se confunde com a clearing, podendo ou não oferecer estes serviços aos seus participantes. ${ }^{53}$ Voltaremos ao tópico das entidades administradoras mais à frente,

\footnotetext{
${ }^{51}$ As contrapartes centrais são positivadas no ordenamento brasileiro pela Lei n. ${ }^{\circ} 10.214$, de 27 de março de 2001. Dando um passo à frente, a CVM publicou o Edital de Audiência Pública SDM 06/13, com proposta de regras sobre depósito centralizado, custódia e escrituração de valores mobiliários, aperfeiçoando o regime já existente sobre esta infra-estrutura de mercado, de modo a assegurar a regular emissão e existência dos ativos. Tal consulta pública resultou nas Instruções CVM 541/13, 542/13 e 543/13. COMISSÃO DE VALORES MOBILIÁRIOS. Edital de Audiência Pública SDM 06/13, de 26 de junho de 2013. Disponível em: <www.cvm.gov.br>. Acesso em: 22 set. 2013; COMISSÃO DE VALORES MOBILIÁRIOS. Instrução CVM no 541, de 20 de dezembro de 2013. Disponível em: <www.cvm.gov.br>. Acesso em: 31 dez. 2013; COMISSÃO DE VALORES MOBILIÁRIOS. Instrução CVM no 542, de 20 de dezembro de 2013. Disponível em: <www.cvm.gov.br>. Acesso em: 31 dez. 2013; COMISSÃO DE VALORES MOBILIÁRIOS. Instrução CVM $n^{o}$ 543, de 20 de dezembro de 2013. Disponível em: <www.cvm.gov.br>. Acesso em: $31 \mathrm{dez} .2013$.

${ }^{52}$ EUROPEAN COMMISSION. Commission of the European Communities. Commission Staff Working Paper. Accompanying the Commission Communication. Ensuring efficient, safe and sound derivatives market. July 03, 2009. p. 3. Disponível em: <http://ec.europa.eu/internal_market/financialmarkets/docs/derivatives/report_en.pdf> Acesso em: 14 jun. 2013, no contexto do pós crise de 2008, aponta a utilização de contraparte central (ou "CCP") também para os derivativos de balcão como uma das medidas para reforçar a estabilidade dos mercados: Even so, much can be done to strengthen these market segments so as to ensure financial stability. CCP clearing is the most effective way of reducing credit risk and is broadly feasible in all market segments. But, for CCP-eligible products, to increase the use of CCPs further in the EU, safe, sound and common requirements are necessary. Although CCP clearing can grow substantially to cover large parts of OTC derivatives, it cannot apply to all OTC derivatives as the necessary prerequisites are not always in place and not easily applicable. It is, therefore, also important to improve product and market standardisation, strengthen bilateral collateral management and ensuring central storage of contract details. No mesmo sentido, o Bacen e a CVM criaram grupo de trabalho para estudar a viabilidade e a conveniência da adoção da liquidação obrigatória por contrapartes centrais de operações realizadas no mercado de derivativos, alinhada com a recomendação do G20, expressa por meio da Declaração de Los Cabos, de 19 de junho de 2012: Cf. COMISSÃO DE VALORES MOBILIÁRIOS. Decisão Conjunta CVM e Bacen n. ${ }^{\circ}$ 18, de 15 de julho de 2013. Disponível em: <www.cvm.gov.br>. Acesso em: 15 jul. 2013.

${ }^{53}$ MAFUD, Pedro Darahem; PEREIRA FILHO, Celso Roberto. Uma nova bolsa: a quem interessa. In: Regulação e tributação do mercado financeiro e de capitais: temas atuais. São Paulo: Quartier Latin, 2014, no prelo, p. 6. Os serviços de infraestrutura para negociação não devem ser confundidos com outros serviços que as entidades administradoras de bolsa possam opcionalmente prestar, como, por exemplo, serviços de informação (como divulgação instantânea de informações de negociação) e de pós-negociação (como custódia de valores mobiliários, administração de riscos ou, ainda, atualização e coordenação de
} 
quando discorrermos sobre as operações de derivativos cursadas na BM\&F Bovespa e na CETIP, as duas entidades de bolsa e balcão existentes no Brasil. Vale ter em mente, neste momento, que, no Brasil, as operações de derivativos devem ser cursadas necessariamente por meio de bolsa ou balcão, não sendo obrigatório para todos os derivativos, contudo, o sistema de liquidação por diferença e contraparte central.

Essa financeirização dos derivativos faz com que os ativos subjacentes possam ser os mais variados, não sendo necessário tratar-se de mercadorias ou sequer de bens tangíveis. Dessa forma, os ativos subjacentes podem ser os mais diversos, englobando, além das commodities, bens intangíveis e referenciais teóricos, como, por exemplo, taxas, moedas, índices, entre outros. Como resultado, pode-se buscar proteção contra ou exposição aos riscos ${ }^{54}$ mais heterogêneos: riscos setoriais, riscos políticos, riscos jurídicos, riscos de liquidez, riscos de volatilidade, riscos de mercado, riscos de crédito, riscos de variações cambiais, riscos de inflação, riscos de taxas de juros, riscos de conversão de moedas, riscos soberanos, etc. ${ }^{55}$

Nesta paulatina financeirização dos mercados, frequentemente, o foco se desloca do ativo subjacente (que obviamente é importante e necessário para se configurar um derivativo) e passa a ser o risco pretendido, para o qual sempre será possível atrelar um ativo subjacente. Explica-se: em uma economia cada vez mais globalizada e sofisticada, o agente econômico preocupa-se em expor-se a ou proteger-se de riscos pré-definidos para os quais sempre há de existir (ou de inventar-se a existência de ou de mimetizar-se) um ativo subjacente correspondente.

Em conclusão, os derivativos centram-se na idéia de transferência de riscos entre os agentes econômicos racionais, sejam eles decorrentes de flutuação de preços de produtos ou de referenciais teóricos, como índices de valores mobiliários, de juros, de taxas, da

eventos corporativos a exemplo de pagamento, compensação e liquidação de proventos). Esses serviços integram verticalmente, junto com o serviço de infraestrutura para negociação, uma mesma cadeia produtiva, mas com ele não se confundem. A confusão entre esses serviços ditos opcionais e o serviço de oferta de infraestrutura de negociação decorre possivelmente do fato de que, no Brasil, especificamente quanto ao mercado de bolsa, a integração vertical dessa cadeia produtiva de serviços concentra-se em uma só entidade administradora de bolsa, que é a única operante do país.

${ }^{54}$ Cf. KNIGHT, Frank H. Risk, uncertainty and profit. 1. ed. Boston: Houghton Mifflin Company, 1921. p. 26. Disponível em: <http://www.econlib.org/LIBRARY/Knight/knRUP.html>. Acesso em: 11 dez. 2013, usaremos a palavra risco como sinônimo de medida de incerteza.

${ }^{55}$ Para a descrição dos diversos tipos de riscos, recomendamos FABOZZI, Frank J. The handbook of fixed income securities. 7. ed. New York: McGraw-Hill, 2005. Muito embora o autor trate de riscos relacionados ao mercado de securities de renda fixa, as explicações dos diversos tipos de risco são de grande valia e muito didáticas. 
insolvência de devedor contraparte ou de quaisquer variações mensuráveis (índices pluviométricos, por exemplo).

A partir do racional de transferência de riscos, intuitivamente se depreende que os derivativos possuem como função a proteção contra oscilações de variáveis de mercado ou, como mais comumente dito, o hedge. Além disso, também tendo a transferência de riscos como pano de fundo, tem-se uma segunda função, umbilicalmente ligada à primeira: a especulação. Na sequência, discorreremos sobre tais funções dos derivativos, ambas ligadas à possibilidade de se malear riscos.

A busca por proteção contra riscos oriundos da oscilação de preços pauta os derivativos, desde suas remotas formas de manifestação. Dado que os preços, assim entendidos como sinalizador natural dos valores de bens e serviços em uma economia de mercado, ${ }^{56}$ flutuam e este movimento significa acréscimo de riscos, parece legítimo que determinado agente busque proteção contra tais oscilações. Nesse sentido, os derivativos se apresentam como uma eficaz e simples ferramenta a que os agentes podem lançar mão para transferir riscos e, portanto, proteger-se de oscilações de preços.

A proteção contra riscos ou hedge é feita por agentes que atuam no mercado físico de determinado ativo subjacente ou estão expostos a oscilações de determinado ativo subjacente ou referencial teórico, como juros, câmbio ou índice pluviométrico. ${ }^{57}$ Assim, o hedger pode ser um produtor de soja, um exportador que tem suas receitas atreladas ao dólar, um empresário que tem suas dívidas fixadas a uma determinada taxa de juros ou um hotel de praia cujas receitas são afetadas em épocas de chuva.

\footnotetext{
${ }^{56}$ Cf. STIGLER, George J. The theory of price. 4. ed. NewYork; London: Macmillan, 1987. p. 11 e 18: Every economic system must somehow perform three functions: First, the composition of the output of goods and services must be determined. Productive resources are versatile so it is always possible to produce more of some goods by producing less of others. Second, the methods of producing the desired outputs must be determined. This is partly a question of technology, but it is also a question of economics: will goods be produced in a few large plants or many medium-sized plants, and with much labor and little machinery or vice versa? Third, the output of goods and services must be divided among the population. These tasks must be faced by Robison Crusoe, a gigantic western nation, an isolated tribe of aborigines, in fact by any society in which human beings dwell. We rely primarily on the price system to make these decisions in an enterprise economy (...) A golfer eventually learns to have immense respect for the golf ball, which unfailingly detects and registers every significant detail of the way in which it is hit. An indecisive thought or attention to a hovering wasp is clearly registered in the ball's course off light, if any. Similarly, the prices that are asked and offered for any commodity are, if not quite so infallible, still remarkably effective messages on demands and production. (...) So a society, even the poorest or most primitive of societies, could make many different things than it does. Correspondingly, consumers could buy many different things than they actually purchase, even putting aside the discovery of new products. Prices are the primary incentives to accommodate production to desires and desires to production possibilities.

${ }^{57}$ Muitas vezes, o "preço" que se busca proteção é um valor que pode ser inferido a partir da variação de determinado índice ou referencial teórico, o qual sozinho não seria precificável em uma economia de mercado, mas que, junto a um "nocional” financeiro, adquire um valor apreciável pecuniariamente.
} 
Tal agente econômico que é afetado por determinada variável deve assumir posição igual e inversa àquela que possui na economia real. Como os movimentos do ativo ou variável subjacente são os mesmos na economia real e no mercado de derivativos (graças ao sinalizador universal "preço"), a perda auferida em uma "ponta" compensa o ganho obtido na "ponta" inversa.

O pressuposto básico do hedger é que sua exposição a riscos na economia real seja proporcional com a posição assumida no mercado de derivativos. Isso quer dizer que um exportador de café, para ser considerado hedger, deve assumir posição no mercado de derivativos cujo nocional ${ }^{58}$ ou "base de cálculo" seja condizente à sua produção. Assumir posição no mercado futuro com nocional muito superior à sua produção faz do produtor especulador no que concerne a parcela que ultrapassa o necessário para proteção dos riscos de sua atividade. ${ }^{59}$

Se uma parte busca proteção contra determinado risco e está disposta a pagar por isso, parece lógica a necessidade de uma contraparte assumir este mesmo risco, mediante prestação pecuniária. Sobre o mercado de transferência de riscos em contratos a futuro, EIZIRIK e WALD dispõem sobre a lógica da proteção e assunção de riscos, utilizando a lição de OTTONI DE BRITO:

A função econômica essencial dos mercados futuros consiste na atividade do hedging, que constitui uma forma de redução de risco assumido pelas partes, porque, ao participarem de um contrato a futuro, elas estabelecem um preço certo para a conclusão do negócio. Como o preço da mercadoria pode, no futuro, diferir do preço antecipadamente fixado pelo Mercado Futuro, existe um processo de transferência de risco neste mercado. Assim, por exemplo, ao vender um contrato futuro de soja, o agricultor transfere à outra parte o risco de variações no preço futuro de soja. Por constituir essencialmente um mercado de risco, existe, nas operações a futuro, dois grupos de participantes: os que querem transferir risco obtendo um preço fixo e os que aceitam suportar o risco da eventual variação do preço de um bem determinado. Aqueles que querem transferir os riscos são os que estão envolvidos diretamente na produção da commodity objeto da transação e são denominados usualmente hedgers. O outro grupo de participantes, formado pelos "capitalistas" ou "investidores", é constituído pelos que aceitam assumir o risco que os hedgers querem transferir, absorvendo as suas

\footnotetext{
${ }^{58} \mathrm{O}$ nocional, neologismo do inglês notional, é o referencial teórico utilizado para o cálculo do valor final a ser liquidado pelos operadores no mercado de derivativos.

${ }^{59}$ EIZIRIK, Nelson. Aspectos jurídicos dos mercados futuros. Revista de Direito Mercantil, Industrial, Econômico e Financeiro, São Paulo, n. 81, p. 24, jan./mar. 1991, p. 24, nos dá conta que alguns estudos de finanças consideram o hedger também um especulador, ainda que o nocional do derivativo seja condizente à sua exposição na economia real.
} 
posições, sem estarem diretamente envolvidos no processo de produção da commodity negociada. ${ }^{60}$

Ainda que o excerto acima bem explique a interação entre uma parte que busca proteção contra riscos e outra que almeja especular em um mercado de risco, ele é incompleto. Dada a irrelevância dos objetivos e motivações das partes contratantes em um negócio de derivativos, pode-se ter, por exemplo, dois especuladores como contrapartes de um mesmo contrato - obviamente com visões antagônicas a respeito do comportamento de determinado preço.

Na existência de um mercado onde os objetivos de uma parte contratar pouco importam para sua contraparte, hedgers e especuladores interagem de maneira fluida. Por isso, hedge e especulação não são necessariamente duas faces da mesma moeda: um negócio pode ter dois hedgers ou dois especuladores no mesmo contrato. Além disso, não se pode analisar as funções dos derivativos como gavetas separadas e sem conexão. $\mathrm{O}$ hedger é muitas vezes especulador e arbitrador.

Pelo fato de a transferência de riscos decorrentes das oscilações de preços estar no âmago das negociações que originaram os derivativos, é muito fácil associá-los à função de hedge. Contudo, não menos importante, a função especulativa dos derivativos adquire vulto ainda maior numa economia em que a financeirização dos mercados busca a criação de valor sem que isso necessariamente esteja atrelado à chamada economia real ou produtiva.

Os investidores, como agentes racionais, são livres para tomar quaisquer decisões em busca de lucros e uma das alternativas que dispõem é a antecipação de tendências futuras. Nesse contexto, os instrumentos derivativos são o ferramental ideal para que um investidor "aposte" 61 na baixa ou na alta do preço de um determinado ativo subjacente, sem que ele esteja exposto ao mercado de tal ativo subjacente. A lógica é a exposição a um determinado risco, visando lucros (apesar das também presentes e pressupostas possibilidades de perdas), sem necessidade de envolver-se na economia real em que o ativo subjacente se relaciona.

\footnotetext{
${ }^{60}$ EIZIRIK, Nelson; GAAL, Ariádna B.; WALD, Arnold. Das funções econômicas dos mercados a termo e do Projeto de Código Civil, cit., p. 326.

${ }^{61}$ Ainda que este seja o jargão do mercado, há controvérsia na utilização do vocábulo "aposta", como demonstraremos no capítulo específico "Distanciamento do Jogo e Aposta".
} 
A liberdade de contratar e a existência de uma ampla gama de instrumentos derivativos propicia que agentes econômicos racionais possam, independentemente de estarem ligados a determinado setor econômico, investir capital em expectativas futuras. À essa atividade de alocação de capital em tendências futuras, sem que exista interesse de hedge, mas com expectativa econômica, dá-se o nome de especulação.

Como falado, uma vertente da especulação é sua dissociação da economia real. O especulador não contrata um derivativo porque sua atividade produtiva exige proteção contra a flutuação de preços futuros. O especulador não faz parte da economia real; ele busca tão somente ganhos financeiros em decorrência de seus conhecimentos sobre determinado fato futuro, ainda que esteja sujeito a perdas, caso suas previsões não se concretizem.

Uma das belezas dos derivativos associada aos especuladores é o efeito de alavancagem financeira, o chamado financial leverage. Exploraremos este tema mais à frente, mas por ora basta dizer que a mobilização de recursos reduzidos permite maior participação (mesmo proporcionalmente) nos ganhos e perdas decorrentes da variação do valor do ativo subjacente.

Empresas que utilizam derivativos como hedge de suas atividades produtivas podem, muitas vezes, tornar-se especuladoras ao negociarem quantidades acima do necessário para sua atividade real. Nessas hipóteses, ao dissociarem as suas reais necessidades do volume de derivativos negociados, pela incoerência do nocional, diz-se que tais empresas estão alavancadas financeiramente. Tal prática, ainda que não blindada a riscos, não é necessariamente perniciosa ou mal pensada, levando-se em conta que o agente econômico racional possui bom conhecimento sobre o mercado real em que atua e, assim, pode explorar oportunidades de maneira mais ágil e sem esperar o ciclo produtivo. De qualquer modo, é importante ter em mente que a alavancagem financeira é uma via de mão dupla pois, ao mesmo tempo em que propicia a multiplicação dos ganhos, também possibilita a multiplicação das perdas.

Ainda que sem "motivação" pautada na economia real, não se pode condenar este tipo de atuação no mercado de derivativos. Pode-se dizer, assim, que especuladores são necessários à economia, ao proverem liquidez ao mercado, aumentando a "oferta" de posições, possibilitando a atuação de hedgers ou, simplesmente, possibilitando a atuação de outros especuladores. Nas palavras de SZTAJN: 
A especulação promove a eficiência alocativa, aumenta o bem-estar, melhora a estimação do preço de mercado, o que favorece a presença do especulador, mas também se percebe as acentuadas diferenças entre as expectativas individuais dos agentes no mercado, o que induz supor que a especulação pode não ser menos benéfica do que se apregoa, uma vez que a grande assimetria informacional distorce os beneficios gerados pela arbitragem. ${ }^{62}$

Enquanto o hedge e a especulação são vertentes óbvias de quaisquer mercados financeiros, podemos dizer que a arbitragem é decorrência de um fenômeno conhecido como globalização. A arbitragem é frequentemente apontada nos manuais de finanças como o último elemento da tríade hedge-especulação-arbitragem. Preferimos encarar a arbitragem como uma sub-espécie da atividade especulativa, pois, em última instância, especula-se com ineficiências de dois ou mais microssistemas de mercado com vistas a auferir ganhos financeiros.

A arbitragem é possível quando o preço futuro de um ativo subjacente descola-se do seu preço à vista ou quando distorções monetárias influenciam o preço do mesmo ativo subjacente em diferentes mercados. Como premissa básica, deve-se ter em mente que os mesmos ativos subjacentes são cotados em diferentes mercados com preços em diferentes moedas. As rápidas oscilações dos custos das diferentes moedas, por si só, não fazem com que o preço do ativo subjacente convirja instantaneamente nos diferentes mercados. Estas distorções monetárias, aliadas ao fato de o mesmo ativo subjacente poder ter preços diferentes em mercados distintos (ainda que inexista oscilação monetária), formam o caldo criativo da arbitragem.

Dessa forma, a arbitragem sempre envolve dois ou mais mercados, em que transações simultâneas são realizadas, com objetivo de travamento de ganhos sem riscos. Vale ressaltar que a própria ação dos arbitradores faz com que os preços convirjam mais rapidamente, diminuindo ou neutralizando as ineficiências dos mercados, por meio da lei básica da economia conhecida como oferta e demanda. Isso significa dizer que as oportunidades de arbitragem são efêmeras e a própria ação dos arbitradores inibe distorções dos mercados e, com isso, oportunidades de arbitragem futuras.

Portanto, a arbitragem é a atividade de exploração de diferenças de preços em mercados distintos para um mesmo instrumento ou para instrumentos diferentes cujos

${ }^{62}$ SZTAJN, Rachel. Regulação e o mercado de valores mobiliários, cit., p. 145. 
preços guardam alguma corrrelação, ${ }^{63}$ tendo como pano de fundo a regra econômica segundo a qual tais preços tendem a convergir (já que os mesmos ativos subjacentes não deveriam ter preços diferentes) ou a regra segundo a qual tais correlações tendem a se modificar conforme padrões previamente conhecidos. $\mathrm{O}$ arbitrador se vale dos derivativos para explorar ineficiências momentâneas dos mercados, utilizando seu conhecimento e atuação global, como forma de especular com diferenças de preços ou correlações não justificadas do ponto de vista econômico.

Muito embora os objetivos primeiros dos derivativos sejam o hedge e a especulação, pelo fato de serem utilizados para projetar preços em datas futuras, diz-se que eles acabam funcionando como verdadeiros indicadores de preços ou de riscos ao mercado. ${ }^{64}$ Este mercado virtual acaba, assim, ditando ou indicando preços do mercado real, pois existe o pressuposto de que os agentes da economia real os utilizam para alinhar expectativas futuras, projetando preços e estabilizando as possibilidades de lucros ou perdas, ${ }^{65}$ dado o fenômeno da convergência de preços entre os mercados futuros e à vista. ${ }^{66}$

O risco que se tem como efeito colateral desta indicação de preços e riscos pelos derivativos, sobretudo com o aumento dos volumes negociados por especuladores (sem interesse algum na economia real), é que o mercado financeiro acabe influenciando os

\footnotetext{
${ }^{63}$ YAZBEK, Otavio. Regulação do mercado financeiro e de capitais, cit., p. 101-102.

${ }^{64} \mathrm{Cf}$. EUROPEAN COMMISSION. Commission of the European Communities. Commission Staff Working Paper. Accompanying the Commission Communication. Ensuring efficient, safe and sound derivatives market. July 03, 2009, cit., p. 7: Derivatives thus play a fundamental role in price discovery. For example, they provide the market's view on future developments in market variables. They may also provide a view on the default risk of a reference entity, on a company or a sovereign borrower, or of a particular segment of the credit market. Thereby, derivatives allow for pricing of risk that might otherwise be difficult to price because the underlying assets are not sufficiently traded.

${ }^{65}$ EIZIRIK, Nelson. Aspectos jurídicos dos mercados futuros, cit., p. 23: De suas origens até hoje, as negociações a futuro com mercadorias sempre tiveram como objetivo econômico essencial propiciar a redução de riscos, a chamada atividade de hedging. Tal se dá porque a venda a futuro (que não se confunde com a venda pura e simples para entrega futura da mercadoria) tem sido utilizada como forma de projetar os preços ao longo do tempo e estabilizar as possibilidades de lucros e prejuízos.

${ }^{66}$ HULL, John. Introdução aos mercados futuros e de opções, cit., p. 24 e 33: Quando se aproxima o mês de vencimento de um contrato futuro, o preço futuro converge para o preço à vista do objeto de negociação. Quando chega o período de vencimento, o preço futuro iguala-se ao preço à vista ou permanece bem próximo dele. Para mostrarmos o porquê disso, imeginemos primeiro que o preço futuro esteja acima do preço à vista durante o período de vencimento. Tal fato aumenta claramente as oportunidades de arbitragem para que os operadores: (1) vendam o contrato futuro; (2) comprem o ativo; ou (3) façam a entrega. Isso certamente leva a um lucro igual à quantia pela qual o preço futuro excede o preço à vista. $\grave{A}$ medida que os operadores exploram tal oportunidade de arbitragem, o preço futuro cai. Suponhamos agora que o preço futuro esteja abaixo do preço à vista durante o período de vencimento. As empresas interessadas em adquirir o ativo acharão interessante comprar um contrato futuro e, então, aguardar a entrega. Ao fazerem isso, o preço futuro tenderá a subir. O resultado de tudo isso é que o preço futuro fica bem próximo do preço à vista durante o período de entrega.
} 
preços da economia real, numa inversão da lógica em que o "rabo passa a abanar o cachorro". 67

Se a crítica é pertinente ou se este efeito colateral de inversão de lógica na formação de preços da economia é benéfico, não é o escopo deste trabalho avaliar. Fato inegável é que os derivativos, cujas funções primordiais são hedge e especulação, acabam tendo alguns outros efeitos colaterais, como, por exemplo, a indicação de preços e riscos futuros e, consequentemente, a geração de informação à sociedade, o que, por si só, é um bem de inestimável interesse público. ${ }^{68}$

Da formação de preços (em tese, de maneira eficiente) e da geração de informações pela existência de um mercado de derivativos, gera-se um terceiro efeito colateral: o aumento da liquidez dos mercados reais dos ativos subjacentes. É de fácil compreensão a idéia que um mercado eficiente e padronizado de derivativos (ainda que virtual, mas sempre pautado em ativos subjacentes reais) acabe por fomentar a economia real. Seja porque a economia passa a ter números confiáveis, seja porque o hedger precisará ter ativos subjacentes suficientes para assim ser caracterizado, seja porque os preços futuros nos diversos mercados do mundo precisarão convergir: o mercado de derivativos influencia a liquidez dos ativos subjacentes.

Por fim, toda esta engrenagem de transferências de riscos, hedge, especulação e formação de mercados líquidos e transparentes, claramente, transfere ou subtrai riquezas entre diversos agentes econômicos. Ainda que não haja uma geração efetiva de riqueza na economia real (o que também é discutível), tem-se um processo de mobilidade monetária muito grande com o desenvolvimento deste mercado, que acaba por influenciar as diversas

\footnotetext{
${ }^{67}$ HAZEN, Thomas Lee. Rational investments, speculation, or gambling? Derivative securities and financial futures and their effect on the underlying capital markets. Northwestern University Law Review, Chicago, v. 86, n. 4, p. 1036, 1992, reconhece o importante papel dos derivativos em monitorar os preços dos ativos subjacentes, destacando que a especulação não é, por si só, algo ruim. Contudo, ressalta o risco de o "rabo abanar o cachorro", nisso que chamamos de inversão da lógica em que os derivativos acabam ditando o preço da economia real: This Article has analyzed the role derivative securities and financial futures play in increasing or decreasing market efficiency. Without a doubt, derivative investments can play a valuable role in monitoring the pricing of the underlying commodities and securities. Derivative investments also provide an opportunity for speculation, which in itself may not be a bad thing. However, when the underlying markets are driven by the speculative activity surrounding options and futures, the tail is wagging the dog. Accordingly, it is time to rethink current regulatory policy, particularly the effect that options and futures trading has both with regard to the overall impact on the market and protection of individual investors.

${ }^{68}$ Vale descrever aqui a opinião de ROMANO, Roberta. Thumbnail sketch of derivative securities and their regulation. Maryland Law Review, Baltimore, v. 55, p. 5, 1996, que aponta a maleabilidade dos riscos como vetor de redução de custos de transações (cost of doing business), que, por seu turno, diminui os preços dos produtos ao consumidor final.
} 
economias mundiais a tal ponto de terem sido apontados como um dos grandes "vilões" da crise econômica mundial iniciada em $2008 .{ }^{69}$

Resumidamente, HENDERSON bem expressa a idéia deste capítulo: derivativos são elementos estruturais e significativos para o financiamento de dívidas e para o levantamento de capital, constituem negócio substancial para muitas instituições (financeiras ou não), são utilizados para o gerenciamento de diversos riscos (tais como riscos cambiais, de taxas de juros, contábeis, entre outros), criam uma miríade de oportunidades de investimento, complexos ou não, adequáveis às preferências e objetivos dos agentes de mercado, criam soluções criativas na modelagem de novos produtos financeiros ou na persecução de objetivos fiscais, contábeis ou regulatórios, podem mitigar riscos em quaisquer mercados, financeiros ou não, com rapidez e confidencialidade. Com isso, pode-se dizer que os derivativos foram um dos fatores decisivos para a criação de um mercado financeiro global, nos moldes atuais, ao quebrarem barreiras do fluxo monetário internacional, além de terem reduzido custos de financiamento para diversos tomadores de recursos. ${ }^{70}$

Em conclusão, os derivativos adquiriram importância tal que não podem ser mais encarados como um mero produto financeiro, mas sim como uma tecnologia que hoje direciona e molda as finanças internacionais. ${ }^{71}$

\section{III.B. Espécies. Instrumentos Mais Comuns: Termo, Futuro, Opções e Swaps}

Para que possamos falar dos derivativos, é preciso entender o funcionamento das suas formas fundamentais de manifestação: futuros, opções e swaps, também chamados de

\footnotetext{
${ }^{69}$ Há bons artigos que imputam aos derivativos (sobretudo os derivativos de crédito) parte das responsabilidades pela crise econômica mundial iniciada em 2008 nos Estados Unidos da América. Nesse sentido: (i) STOUT, Lynn A. How deregulating derivatives led to disaster, and why re-regulating them can prevent another. Lombard Street, v. 1, n. 7, 2009. Disponível em: <http://papers.ssrn.com/sol3/papers.cfm?abstract_id=1432654>. Acesso em: 10 dez. 2013; (ii) GREENBERGER, Michael. The role of derivatives in financial crisis. Washington DC, Financial Crisis Inquiry Commission Hearing, June 30, 2010. Disponível em: <http://fcicstatic.law.stanford.edu/cdn_media/fcic-testimony/2010-0630-Greenberger.pdf>. Acesso em: 11 jun. 2013; (iii) STOUT, Lynn A. Derivatives and the legal origin of the 2008 credit crisis. Harvard Business Law Review, v. 1. Jun. 2011. Disponível em: <http://papers.ssrn.com/sol3/papers.cfm?abstract_id=1874806\#\#>. Acesso em: 11 jun. 2013. A linha de argumentação comum é baseada no Commodities Futures Modernization Act of 2000 (CFMA), que afrouxou os requisitos regulatórios dos derivativos de balcão e, com isso, possibilitou a criação de um mercado desregulamentado, muito grande e invisível aos olhos das autoridades reguladoras.

${ }^{70}$ HENDERSON, Schuyler K. Henderson on derivatives. London: Reed Elsevier, 2003. p. 1-2.

${ }^{71}$ Id. Ibid., p. 2.
} 
derivativos de primeira geração. ${ }^{72}$ Estes três grupos constituem aquilo que GIRINO denominou arquétipos essenciais da categoria dos derivativos, ressaltando que as demais manifestações possíveis são ilimitadas e decorrem da combinação de um ou mais arquétipos. $^{73}$ Tais combinações, a partir dessas três estruturas fundamentais, ${ }^{74}$ também podem ser referidas como "estratégias". 75

\section{III.B.1. Termos e Futuros}

Ao descrevermos a origem e a utilidade dos derivativos no capítulo anterior, restou claro que um dos elementos comuns a todos os derivativos é o aspecto de liquidação futura. Por esse motivo, SATIRO nos conta que todos os contratos cuja liquidação se dá em data posterior podem ser referidos como "contratos futuros". ${ }^{76}$

Dentro deste vastíssimo gênero dos derivativos, que se poderia, em tese, referir como contratos futuros, pois todos com liquidação em data diferida, tem-se os derivativos mais simples, que são os contratos a termo (ou forwards) e os contratos "de" futuro (ou simplesmente "futuros", contratos "a" futuro ou futures). Para fins didáticos, classificaremos ambos, contratos a termo e contratos de futuro, como uma mesma espécie e, na sequência, os diferenciaremos.

Apesar de não poderem ser tipificados como tal, a origem ${ }^{77}$ dos forwards e dos futures encontra-se no contrato de compra e venda. ${ }^{78}$ Uma das peculiaridades deste

\footnotetext{
${ }^{72}$ Sobre a classificação das três gerações dos derivativos (de matriz muito mais econômica do que jurídica), recomendamos ANTUNES, José A. Engracia. op. cit., p. 102-103.

${ }^{73}$ GIRINO, Emilio. I contratti derivati. 2. ed. Milano: Giuffrè, 2001. p. 49-50.

${ }^{74} \mathrm{Um}$ bom texto norte-americano que descreve as estruturas fundamentais dos derivativos é ROMANO, Roberta. op. cit.

${ }^{75}$ Os três grupos essenciais, futuros, opções e swaps, não devem ser entendidos como sistemas fixos e incomunicáveis entre si. Menos ainda devem ser encarados como rol taxativo. Sendo esta uma categoria contratual, onde a vontade das partes prevalece, inexiste um rol taxativo de derivativos possíveis. Vale ressaltar que o legislador brasileiro assim entende os derivativos, ao elencá-los como quaisquer contratos, independente do ativo subjacente. De toda maneira, importante dispor sobre os três arquétipos para que possamos esboçar qualquer tipo de conclusão a respeito da matéria, na medida em que fornecem a base de todos os derivativos.

${ }^{76}$ Cf. SOUZA JUNIOR, Francisco Satiro. op. cit., p. 6.

${ }^{77}$ Os primeiros contratos a termo, que tinham mercadorias agrícolas como ativos subjacentes e possibilidade de efetiva entrega destas mercadorias, poderiam ser classificados como contratos de compra e venda diferida. Contudo, a diversificação dos ativos subjacentes, que hoje em dia compreendem objetos intangíveis ou referenciais teóricos, aliada à evolução dos contratos a futuro, operacionalizados em ambiente de bolsa, liquidados por diferença contra uma contraparte central e sem possibilidade de entrega física, são fatores que nos levam a afastar os forwards e os futures da tipificação como compra e venda, no âmbito do ordenamento jurídico brasileiro.

${ }^{78}$ BRASIL. Lei n. ${ }^{o}$ 10.406, de 10 de janeiro de 2002. Institui o Código Civil. Disponível em: <http://www.planalto.gov.br>. Acesso em: 22 maio 2011. Parte Especial, Livro I (Direito das Obrigações), Título VI (Das Várias Espécies de Contrato), Capítulo I (Da Compra e Venda). Artigo 481: Pelo contrato
} 
contrato reside na existência de lapso temporal - uma particularidade comum a todos os derivativos, conforme já dito. Dessa forma, para fins didáticos somente, podemos dizer que os contratos a termo e os contratos a futuro assemelham-se (mas não se confundem) aos contratos de compra e venda a prazo, com a existência de uma parte compradora e uma parte vendedora com vontades contrapostas, preço previamente estabelecido e liquidação do objeto contratual em data futura. ${ }^{79}$

Assim, ao celebrar um contrato a termo ou contratar um futuro, o sujeito possui o direito de "comprar ou vender" previamente preço, quantidade, prazo e outras especificidades do negócio. A combinação prévia dos valores e outras condições em data pretérita, quando da celebração do contrato ocasião em que este se aperfeiçoa, e a efetiva liquidação do contrato em data futura são os dois fatores que conferem os efeitos de proteção, especulação ou arbitragem aos contratos a termo e aos futuros, haja vista a oscilação do preço do bem entre a data de celebração e a data de liquidação do negócio. Precifica-se em data anterior um ativo, sendo a efetiva liquidação desta "compra e venda" em data futura - este lapso temporal, considerando a inserção do objeto contratual em uma economia de mercado com preços variáveis, causa os efeitos financeiros buscados nos derivativos.

de compra e venda, um dos contratantes se obriga a transferir o domínio de certa coisa, e o outro, a pagar-lhe certo preço em dinheiro. Artigo 482. A compra e venda, quando pura, considerar-se-á obrigatória e perfeita, desde que as partes acordarem no objeto e no preço.

${ }^{79}$ Muito embora inegável a semelhança, discordamos da posição de parte relevante da doutrina brasileira que considera os contratos a termo e os contratos de futuro como contratos de compra e venda com entrega futura. Nesse sentido, importantes expoentes: (i) SALLES, Marcos Paulo de Almeida. Contratos de bolsa de execução diferida. 1998. Tese (Doutorado) - Faculdade de Direito, Universidade de São Paulo, São Paulo, 1998. p. 101; e (ii) OLIVEIRA, Fernando Albino de. Contratos futuros: características jurídicas regulação dos mercados futuros. Revista de Direito Público, São Paulo, v. 21, n. 87, p. 224, jul./set. 1988: $O$ contrato a termo se aparta do à vista apenas quanto ao prazo de entrega do bem contratado. O acordo de vontades é concluído em certo momento e a liquidação do contrato vai se dar em momento posterior, quando o preço é pago e o bem recebido. Por aspectos ligados à garantia da transação, exige-se normalmente o pagamento antecipado de parte do preço, do comprador, e o depósito do bem ou evidência de sua propriedade, do vendedor. O que em nada altera a natureza do contrato. Preço, espécie e quantidade são definidos quando da celebração do contrato, sendo certos e determinados. Em resumo, trata-se do contrato de compra e venda para entrega futura.

${ }^{80}$ Deve-se notar que não existe propriamente o direito de comprar ou vender um ativo, e sim uma posição escritural que origina um direito de recebimento ou um dever de pagamento da diferença entre o preço do ativo na data da celebração e o preço do ativo na data de liquidação, a chamada "liquidação por diferença". Por motivos de fluidez do raciocínio e facilidade de compreensão do leitor, comparamos os termos e os futuros a "compra e venda" diferida, muito embora, em nosso entendimento, esta tipificação contratual não seja hoje possível, apesar de muitos autores utilizarem-na.

${ }^{81}$ Para facilitar a exposição do racional teórico, circunscreveremos essa "compra e venda" futura apenas a ativos. Como se verá, o ativo subjacente não necessariamente é um bem, podendo ser uma variável ou um referencial teórico, o que, por si só inviabiliza a tipificação dos termos e futuros como "compra e venda". 
A certeza do preço futuro do ativo subjacente, ainda que isso signifique abdicar de ganhos oriundos de oscilações favoráveis, é o grande objetivo do contratante de um forward e de um future. Dessa maneira, para se proteger de oscilações prejudiciais, abre-se mão de ganhos potenciais, em um movimento denominado travamento de preços. ${ }^{82}$

Conforme mencionado, a efetiva entrega do ativo subjacente é desnecessária, reconhecendo-se a liquidação por diferença como o grande atrativo destes instrumentos. Tal liquidação por diferença ou cash settlement faz com que os ditos "ativos subjacentes" dos derivativos não precisem ser necessariamente mercadorias tangíveis ou commodities, como café, boi gordo ou milho, incluindo-se ativos intangíveis ou mesmo variáveis futuras, como índices ou juros, no rol de possibilidades, num movimento de financeirização dos contratos a termo e futuros. Assim, esta variedade de "ativos subjacentes", muitos deles impossíveis de serem entregues, impede a tipificação dos contratos a termo e dos futuros como contratos de compra e venda. ${ }^{83}$

O travamento do preço do ativo subjacente (ou do valor do referencial teórico) em data futura é o grande denominador comum dos forwards e dos futures, duas modalidades de derivativos funcionalmente e estruturalmente similares. A diferença entre contratos a termo e futuros reside na forma de operacionalização, ${ }^{84}$ o que justifica a massificação de uma modalidade, os futuros, e a personalização (tailor made negotiations) de outra, os contratos a termo. ${ }^{85}$

\footnotetext{
${ }^{82}$ YAZBEK, Otavio. Regulação do mercado financeiro e de capitais, cit., p. 103-104.

${ }^{83} \mathrm{O}$ fato de o ativo subjacente poder ser uma variável ou um referencial teórico inviabiliza a qualificação dos forwards e futures como contratos de compra e venda. Ainda que a estrutura destes contratos tenha, indubitavelmente, origem na compra e venda, não se pode, hoje em dia, qualificá-los como tal. Assim, discordamos da posição de SZTAJN, Rachel. Contrato e inovação financeira: ensaio sobre contratos futuros e swaps, cit., p. 225, que afirma que futuros são compra e venda em nova função típica, socialmente aceita, função essa que deve ser tutelada pelo direito em face dos benefícios sociais para a comunidade.

${ }^{84}$ Cf. EUROPEAN COMMISSION. Commission of the European Communities. Commission Staff Working Paper. Accompanying the Commission Communication. Ensuring efficient, safe and sound derivatives market. July 03, 2009, cit., p. 7: A forward is a contract whereby two parties agree to exchange the underlying asset at a predetermined point in time in the future at fixed price. Therefore, the buyer agrees today to buy a certain asset in the future and the seller agrees to deliver that asset at that point in time. Futures are standardised forwards traded on-exchange.

${ }^{85}$ Muitos autores afirmam que os futuros são a evolução dos contratos a termo, pois possuem regras operacionais mais rígidas, como a necessidade de garantias (margens) e ajustes diários, estando eles inseridos em um arranjo sistêmico negocial muito mais complexo. Apesar de terem surgido anteriormente, o que reforça a afirmação de que os "futuros são a forma evoluída dos contratos a termo", entendemos que os contratos a termo ainda possuem grande importância para os agentes econômicos que necessitam de produtos personalizados. Destarte, entendemos que o adjetivo "evolução" não pode ser encarado como sinônimo de superioridade, mas sim como sinônimo de "maior complexidade".
} 
Afirmar que um contrato de derivativo é massificado significa dizer que o seu contratante, seja ele "vendedor ou comprador", 86 está impossibilitado de definir os termos e condições do contrato. Assim ocorre nos futuros, modalidade de derivativo em que as entidades administradoras de mercados organizados estabelecem as cláusulas contratuais da avença, incluindo-se a qualidade e quantidade do ativo subjacente, as garantias (ou margens) iniciais exigidas para se ingressar na negociação, os ajustes periódicos necessários, a data de vencimento diferida do contrato (ou seja, a data de sua liquidação), as formas de liquidação possíveis, entre outras definições. Cada conjunto de especificações contratuais predeterminadas forma uma unidade padronizada negociável ou um contrato de futuro, o qual poderá ser "comprado ou vendido" no âmbito dos mercados organizados de bolsa.

Por outro lado, no caso do forward, tem-se um contrato diferido personalizado, em que as especificações contratuais (qualidade e quantidade do ativo subjacente, prazo, etc.) ficam a cargo das partes, o que possibilita, em teoria, infinitas combinações. Necessário mencionar que, no Brasil, a criatividade humana esbarra em determinadas exigências regulatórias das entidades administradoras dos mercados organizados, como se verá no capítulo subsequente. De qualquer forma, mesmo entre nós, as combinações possíveis de contratos a termo são muito maiores do que as de contratos de futuro.

A estandardização dos futures é explicada por sua inserção em uma estrutura plurilateral de negociação, em que existem, além de compradores e vendedores, instituições intermediárias, contraparte central e entidade administradora do mercado organizado de bolsa - esta responsável por definir os termos e condições dos contratos de futuro. Assim, os interessados em "comprar ou vender" determinada posição precisam necessariamente cursar os seus negócios através de uma instituição intermediária ou corretora, a qual obrigatoriamente está adstrita às regras da bolsa. Neste arranjo sistêmico, ainda que para cada posição comprada exista necessariamente outra posição vendida (com vontades contrapostas), todos os contratos de futuro serão liquidados perante uma contraparte central que, como dito, atua como "vendedora" de todos os "compradores" de posições e "compradora" de todos os "vendedores" de posições. Por esse motivo, do ponto de vista de crédito da parte "compradora", o pronto adimplemento da contraparte

\footnotetext{
${ }^{86}$ Conforme exposto, não se pode tipificar os contratos a termo e os futuros como contratos de compra e venda. Contudo, pela origem em tal modalidade, as partes contratantes destes derivativos são denominadas "comprador" e "vendedor", o que equivale dizer, na realidade, que a parte possui um certo número de posições registradas em seu nome.
} 
"vendedora" é irrelevante, e vice-versa, dado que a clearing é a verdadeira garantidora da liquidação de todas as operações.

Diferentemente, nos contratos a termo, as posições são fechadas diretamente entre as partes contratantes. Nesse sentido, o inadimplemento de uma parte "compradora" impactará diretamente a parte "vendedora".

A massificação dos contratos de futuro exige regras mais rígidas ao longo do negócio diferido. Um dos mecanismos que traz maior segurança aos futuros são os "ajustes diários", ou seja, a liquidação financeira diária, até o vencimento do contrato, por meio de créditos e débitos em favor ou contra as partes contratantes, calculados a partir da comparação do preço do ativo subjacente do dia com o preço do dia imediatamente anterior.

Diversamente, nos contratos a termo, a liquidação por diferença ocorre uma única vez, na data do vencimento, comparando-se o preço do bem na data do vencimento com o preço do bem na data de celebração do contrato. ${ }^{87}$ Vale lembrar que o efeito financeiro dos contratos a termo é exatamente o mesmo dos futuros, já que a soma dos ajustes diários debitados e creditados (no contrato futuro) será necessariamente igual à variação do preço ocorrida no período todo (no contrato a termo).

Os ajustes diários ou liquidações periódicas objetivam manter a exposição de risco dos agentes em níveis pré-definidos pela contraparte central, o que, possibilita também que as posições sejam negociáveis, posto que as diferenças devidas a outra parte são periodicamente "zeradas" - tornando determinada posição fungível com relação às demais de seu tipo - além de possibilitar a chamada "reversão de posição" ou way out, ou seja, a compra ou venda de posição oposta como forma de neutralizar a posição inicialmente assumida. ${ }^{88}$

\footnotetext{
${ }^{87}$ No Brasil, a vasta maioria dos contratos a termo é liquidada por diferença uma única vez, na data de vencimento. Contudo, nada impede que as partes estabeleçam, por mera liberalidade, ajustes diários também nos contratos a termo.

${ }^{88}$ A reversão de posição significa receber e pagar o mesmo valor de ajuste diário, em um verdadeiro "jogo de soma zero". Esta possibilidade está presente nos futuros de bolsa, pois a padronização e a massificação dos contratos permite que uma parte atue, simultaneamente, como "compradora" e "vendedora" no mercado ou, mais tecnicamente, como detentora de posições registrais contrapostas. Nos contratos a termo, em que inexiste contraparte central e os contratos são personalizados, esta passa a ser uma possibilidade teórica: para sair do risco proposto antes do vencimento, a parte precisaria encontrar alguém disposto a assumir posição idêntica contraposta (o que é muito improvável) ou, alternativamente, encontrar alguém disposto a subrogar-se em sua posição, com a anuência da contraparte inicial (hipótese também improvável). Assim, nos contratos a termo, a forma de extinção natural da avença é a sua liquidação na data de vencimento, enquanto, nos futuros, pode-se optar (e a maioria o faz), como forma de extinção da obrigação, pela reversão de posição antes da data de liquidação, em um movimento de lançamentos escriturais, em que a posição de compra é anulada pela posição de venda.
} 
Os futuros negociados em bolsa são, dessa maneira, uniformes e fungíveis, ao contrário das operações a termo cursadas em balcão, que são personalizadas. Esta massificação dos futuros se, por um lado, traz inegáveis ganhos de escala, agilidade, liquidez e economia de custos de transação, por outro lado, pode levar o mercado a distorções. Como forma de evitar manipulações do mercado de futures e administrar riscos sistêmicos, as entidades administradoras de bolsa possuem discricionariedade para impor regras aos participantes, tais como limites de concentração de posições e de oscilação de preços. ${ }^{89}$

Adicionalmente, como expressão de higidez das operações padronizadas de futuros e da imposição de regras prudenciais pelas bolsas, tem-se a obrigatoriedade de depósito de garantias (em dinheiro ou em outros ativos líquidos, como, por exemplo, ações), também referidas como "margens iniciais" ou depósitos originais, para tornar-se elegível a operar no mercado. Estas são obrigatórias no início da contratação e podem ser requeridas pela entidade administradora de bolsa ao longo da vida do contrato de futuro, nas conhecidas “chamadas de margem" ou depósitos adicionais. ${ }^{90}$ Essas garantias são fundamentais no arranjo sistêmico das bolsas e na lógica da contraparte central: caso a parte compradora ou vendedora do futuro não adimpla com o ajuste diário, a margem depositada será utilizada.

A não obrigatoriedade de ajustes diários ou depósitos de margens, a ausência de intermediários e contraparte central responsável pela liquidação da avença e a inexistência de padronização dos contratos e regras para a operação são motivos pelos quais os contratos a termo são muito menos líquidos do que os futuros.

\footnotetext{
${ }^{89}$ No âmbito dos futures, as formas mais comuns de manipulação são os corners e squeezes, bem explicados por EIZIRIK, Nelson. Aspectos jurídicos dos mercados futuros, cit., p. 29-30: Os casos clássicos de manipulação nos mercados futuros são classificados como corners ou squeezes. Configura-se o corner quando um investidor ou grupo de investidores alcança substancial controle sobre determinado contrato futuro, com o objetivo de manipular os preços, Para tanto, ele adquire pesadas posições compradoras a futuro, sem que a oferta disponível no mercado à vista permita aos "vendidos" liquidar suas posições mediante a entrega dos bens objeto do contrato. Já a situação de squeeze ocorre quando os investidores com posições vendedoras não podem liquidar suas posições, exceto pagando preços excepcionalmente elevados, em consequência de alguma perturbação repentina ocorrida no processo de formação de preços no mercado futuro.

${ }^{90}$ Há quem considere os ajustes diários como um terceiro tipo de "margem" ou garantia, ao lado da margem inicial e das chamadas de margem. De fato, a experiência americana, que é nossa inspiração, denomina os ajustes diários como variation margins. Preferimos encarar os ajustes diários, contudo, como expressão da equalização diária das operações, dado que existe a transferência efetiva de valores (crédito ou débito) aos contratantes. Diferentemente, as margens iniciais e as chamadas permanecem depositadas, sendo utilizadas apenas se necessário.
} 


\section{III.B.2. Opções}

A opção é o negócio jurídico pelo qual um sujeito paga um preço para ter o direito de exigir de sua contraparte determinada contraprestação consistente na compra ou na venda $^{91}$ de um ativo em data futura ${ }^{92}$ por um valor previamente definido. O comprador da opção é chamado "titular" ou holder, ao passo que o vendedor da opção é denominado "lançador" ou writer. ${ }^{93} \mathrm{O}$ preço pago para se obter esta faculdade de exigir da contraparte determinada prestação é o "prêmio". O valor futuro do ativo subjacente, que é predeterminado quando do fechamento da contratação da opção, é o "preço de exercício" ou strike. Obviamente, o titular da opção não é obrigado exercê-la, por meio da compra ou venda do ativo subjacente - ele o fará apenas se o "preço de exercício" deste ativo subjacente em data futura (somado ao prêmio já pago) for vantajoso, quando comparado ao preço do mercado à vista deste mesmo ativo em igual data. ${ }^{94}$ Assim, YAZBEK precisamente sintetiza:

Com efeito, de um modo geral as opções são aquelas operações em que
uma das partes (o "comprador" ou "titular") adquire, a título oneroso
(pelo pagamento do prêmio), o direito de comprar da outra parte (o
"vendedor" ou "lançador") ou de a ela vender um determinado ativo,
em uma data futura, por um preço prefixado (o "preço de exercício" ou
"strike"). Se for do interesse do adquirente, tendo em vista os preços do
mercado à vista, exercer a opção ele adquire ou vende o bem pelo preço
inicialmente ajustado. Caso contrário, a opção "vira pó", e ele perde o
prêmio pago. As opçôes podem ser de compra (call options) ou de venda

${ }^{91} \mathrm{O}$ direito do titular da opção poderá ser de compra (call option) ou de venda (put option) de determinado ativo subjacente. Assim, podemos ter uma compra de opção de compra (long call), uma compra de opção de venda (long put), uma venda de opção de compra (short call) ou uma venda de opção de venda (short put).

${ }^{92} \mathrm{~A}$ data futura poderá ser durante um prazo determinado, ou seja, opção exercível até uma data estabelecida, no caso das ditas opções americanas, ou, diferentemente, apenas em uma ou algumas datas prédeterminadas, no caso das ditas opções europeias.

${ }^{93} \mathrm{HULL}$, John. Introdução aos mercados futuros e de opções, cit., p. 4: Há basicamente dois tipos de opções: calls (opções de compra) e puts (opções de venda). Na opção de compra, o detentor (titular ou comprador da opção) tem o direito de comprar um ativo em certa data por determinado preço. Na opção de venda, o detentor tem o direito de vender um ativo em certa data por determinado preço. $O$ preço do contrato (valor futuro pelo qual o bem será negociado) é conhecido como preço de exercício (strike price ou exercise price) e sua data (o dia em que a posição será exercida) é conhecida como data de vencimento (expiration date, exercise date ou maturity). Uma opção européia pode ser exercida somente na data de vencimento. Uma opção americana pode ser exercida a qualquer momento, até o vencimento.

${ }^{94} \mathrm{Se}$ o valor spot do ativo subjacente for vantajoso quando comparado ao preço strike, a opção é dita in the money ou "acima do par", ou seja, compensa o exercício. Ao contrário, se o valor spot desencorajar o exercício da opção, a partir da comparação com o preço de exercício, a opção é dita out of the money ou "abaixo do par". E, caso o preço de exercício corresponder à soma do spot e do prêmio já pago, sendo irrelevante o exercício, diz-se que a opção é at the money ou "ao par". 
(put options), americanas (com o exercício do direito até a data estabelecida) ou européias (com o exercício apenas naquela data). ${ }^{95}$

Nesse arranjo, o lançador da opção, ou seja, a parte que vendeu a opção está sujeita à discricionariedade do titular da opção, ou seja, da parte que pagou um prêmio para ter o direito de exigir a compra ou a venda de determinado ativo subjacente por preço já combinado. ${ }^{96}$ Assim, o titular da opção possui exposição a risco já sabida e quantificada: o prêmio pago para se ter determinado direito. Enquanto isso, o lançador, apesar de ter recebido o valor correspondente ao prêmio na data de celebração do contrato, está sujeito a perdas ilimitadas, a depender da oscilação do preço do ativo subjacente, que, por sua vez, determinará o exercício ou não da opção pelo titular. ${ }^{97}$

Conforme raciocínio norte-americano, a opção é tida como o derivativo em sua forma mais básica, a partir do reconhecimento que futuros e swaps podem ser fragmentados em opções mútuas de compra e venda com as mesmas (porém reversas) condições e exercíveis em datas pré-determinadas. Assim, um swap seria uma série de tais opções mútuas e um futuro ou um termo seriam apenas um par de tais opções mútuas. ${ }^{98}$

Apesar de um futuro, um termo e um swap poderem ser, do ponto de vista de seus resultados, desdobrados em uma série de opções, uma importante diferença das opções com relação a eles reside na gestão do risco. Enquanto nos futuros, termos e swaps existe distribuição simétrica e bilateral dos riscos (de perdas e ganhos financeiros) entre as partes contratantes, sempre dependentes das oscilações de preço do ativo subjacente; nas opções, tem-se distribuição assimétrica de riscos financeiros entre os contratantes, na medida em

\footnotetext{
${ }^{95}$ YAZBEK, Otavio. Regulação do mercado financeiro e de capitais, cit., p. 115.

${ }^{96}$ Partindo da premissa que os agentes econômicos são racionais, do ponto de vista econômico, não se pode falar na existência de um direito de exercício potencial do titular da opção, já que, se o que se busca é a maximização de resultados econômicos, tem-se a certeza que a opção será exercida, se vantajosa ao titular.

${ }^{97}$ OLIVEIRA, Fernando Albino de. op. cit., p. 224: Nesses ajustes, um participante do mercado, o "lançador da opção”, assume um compromisso unilateral de vender ou comprar determinado bem, por preço certo, em instante futuro. Em troca desse compromisso, cuja contrapartida é o direito dos outros participantes exercerem a opção, cobra um prêmio. Se a opção for "exercida", deve o "lançador" honrar sua obrigação, vendendo ou comprando; caso contrário, terá ganho o prêmio inicialmente pago.

${ }^{98} \mathrm{Cf}$. HENDERSON, Schuyler K. op. cit., p. 6. Curioso como a doutrina dos Estados Unidos tende a ver as opções como gênese de quaisquer derivativos, ao passo que a doutrina nacional enxerga nos contratos a termo a sua base. Reputamos este fato ao raciocínio dos norte-americanos estar pouco preocupado com formalismos, olhando muito mais o substrato econômico das transações. Enquanto isso, no Brasil, nossa tradição civilista busca rigor científico, classificatório, com pureza cronológica, em que os institutos devem ser encaixados cada qual em uma natureza jurídica - tanto melhor se já existente. Talvez por essa incessante busca pela "natureza jurídica", muitos brasileiros tendem a enxergar opções como declarações unilaterais de vontade, swaps como contratos de permuta e futuros como compra e venda - todas essas características por nós veementemente refutadas.
} 
que o titular da opção sabe, de antemão, as perdas que pode incorrer (equivalentes ao prêmio pago para adquirir esta prerrogativa) e o lançador está sujeito a perdas ilimitadas.

Por esse motivo, SZTAJN pontua que, do ponto de vista da gestão do risco, é preferível aos investidores adquirir uma opção ao celebrar um contrato a termo: ${ }^{99}$

\begin{abstract}
Da descrição dos contratos de opção fica evidente sua preferência pelos investidores em relação aos contratos a termo. Na opção, o titular da opção de compra se obriga e paga apenas o valor do prêmio para ter o direito de, até o final do prazo do exercício, poder adquirir o bem (valores mobiliários, mercadorias ou ativos financeiros), pelo preço fixado. Se o preço de exercício for menor ou igual à cotação do bem, incluindo o prêmio, durante o prazo da opção, o comprador exerce o direito; já se for maior não o exerce e terá pago apenas o prêmio, não fica obrigado a receber a coisa e pagar o preço como nos contratos a termo. $O$ vendedor da opção, dito lançador, tem o valor do prêmio como certo e, se afinal for obrigado a entregar a coisa pelo exercício da opção terá recebido o prêmio e fará jus ao preço que será sempre mais do que apenas receber o preço do contrato a termo. ${ }^{100}$
\end{abstract}

Similarmente aos contratos a termo e aos futuros, também as opções podem ser massificadas e negociadas em bolsa, em verdadeira estrutura plurilateral, ao que se denominam opções padronizadas, ou podem ser customizadas e negociadas no mercado de balcão, ao que se denominam opções flexíveis ou não padronizadas. ${ }^{101}$

A lógica de reversão de posições ou way out dos contratos futuros também se aplica às opções padronizadas, no âmbito de um mercado bursátil fungível e líquido. ${ }^{102}$ Assim, o lançador de uma opção de compra padronizada, que recebeu prêmio e está sujeito a riscos ilimitados, poderá comprar esta mesma opção e tornar-se também titular na ponta oposta,

\footnotetext{
${ }^{99}$ Este raciocínio é interessante e ilustrativo do ponto de vista da gestão de riscos financeiros, mas deve ser visto com ressalvas. Primeiro porque ele pressupõe a existência da mercadoria e sua propriedade pelo lançador, o que, conforme já discutido, é muito improvável com o atual movimento de financeirização dos derivativos, em que o ativo subjacente não é necessariamente uma mercadoria e as liquidações ocorrem por diferença. Segundo porque ele pressupõe a finalidade de hedge, o que desconsidera grande parte dos negócios, que são meramente especulativos. Terceiro porque ele compara opções não padronizadas (ou de balcão) com contratos a termo (também tailor made), não sendo aplicável, assim, aos futuros e às opções padronizadas, parcela relevante da realidade. Por fim, o raciocínio desconsidera que o lançador e o titular da opção, como agentes econômicos racionais, terão feito inúmeros cálculos como forma de se chegar a um valor vantajoso para cada um deles, sendo muito improvável que, na data de exercício, exista um equilíbrio nas perdas de um e nos correspondentes ganhos do outro.

${ }^{100}$ SZTAJN, Rachel. Contratos de bolsa, cit., p. 179.

${ }^{101}$ No mercado de balcão, podem existir, além das opções tradicionais ou plain vanilla options, também opções exóticas ou sintéticas, que são aquelas opções combinadas com outros derivativos ou que possuem determinadas cláusulas adicionais que conferem outros direitos e obrigações aos seus contratantes. Nesse sentido, ANTUNES, José A. Engracia. op. cit., p. 117-118.

${ }^{102}$ SOUZA JUNIOR, Francisco Satiro. op. cit., p. 154, pontua que não se pode falar em “cessão de posição contratual" nas reversões de posição.
} 
neutralizando os efeitos de sua negociação inicial. ${ }^{103}$ Já o lançador de uma opção de compra de balcão deverá esperar até o final do prazo pactuado (ou encontrar alguém disposto a ser titular na ponta contrária - o que pode ser improvável, dadas as características do balcão).

Assim como nos futuros e termos, neste movimento de paulatina financeirização dos derivativos, também nas opções os ativos subjacentes não precisam ser necessariamente mercadorias ou bens tangíveis, podendo ser ativos intangíveis, variáveis futuras, índices, obrigações, taxas ou referenciais teóricos.

Por fim, da mesma forma como os contratos a termo e os futuros não se encaixam em nenhuma tipificação existente no Código Civil, também as opções de bolsa e balcão carecem de identificação com alguma categoria formal de nosso ordenamento jurídico, o que nos leva a classificá-las como contratos. ${ }^{104}$ SATIRO, em brilhante e paradigmática conclusão, dispõe:

A opção pode ser vista sob dois prismas distintos: como direito, destaca-
se seu caráter potestativo; como negócio jurídico - atípico no direito
brasileiro - tem natureza controvertida. Afasta-se (i) da proposta
irrevogável, nos termos do art. 1331 do Código Civil italiano,
especialmente por seu caráter bilateral; (ii) da condição suspensiva, por
não ter caráter acessório ao negócio final que, diferentemente do que
ocorre nos casos de suspensão da eficácia, não está formado por lhe
faltar a declaração do titular; e (iii) do compromisso unilateral, porque a
simples manifestação do titular é suficiente para concretizar o negócio
final, dispensando assim, nova declaração do lançador. Por outro lado,
admite sua concepção sob o caráter oneroso, representado pelo
pagamento de prêmio ao lançador como contrapartida à sua
subordinação à vontade do titular. Esses aspectos levam a preferir a
conceituação das opçães como contrato "sui generis", criado a partir do
exercício da autonomia privada.

${ }^{103}$ Nos mercados de bolsa, na medida em que o tempo passa, o exercício da opção de venda ou de compra torna-se mais ou menos provável, o que ocasiona valorização ou desvalorização do prêmio. Portanto, no exemplo acima, o prêmio recebido pelo lançador no dia em que optou entrar neste mercado será muito provavelmente diferente (maior ou menor) do prêmio que deverá pagar, como titular da mesma opção, com o objetivo de reverter sua posição.

${ }^{104}$ Cumpre registrar aqui a posição de SZTAJN, que entende serem as opções declarações unilaterais de vontade. Cf. SZTAJN, Rachel. Sobre a natureza jurídica das opções negociadas em bolsa, cit., p. 69. Também cumpre descrever as críticas tecidas por YAZBEK, que rebate os argumentos de SZTAJN, com os seguintes pontos: (i) impossibilidade de se desconsiderar a natureza contratual da opção; (ii) ainda que se considere um negócio com condição potestativa, esta não invalida o contrato por não ser arbitrária; e (iii) o direito potestativo do titular decorre da natureza do negócio, em que o lançador recebe um prêmio para se sujeitar à opção conferida ao titular. Cf. YAZBEK, Otavio. Regulação do mercado financeiro e de capitais, cit., p. 117.

${ }^{105}$ Cf. SOUZA JUNIOR, Francisco Satiro. op. cit., p. 153. 


\section{III.B.3. Swaps}

A tradução da palavra inglesa "swap" nos apresenta "troca" ou "permuta". E esse é o objetivo do swap: uma troca de ativos, de rentabilidade, de fluxos financeiros ou, enfim, de posições jurídicas. ${ }^{106}$ A denominação desta espécie de derivativo (que expressa o efeito pretendido) causa alguma confusão entre nós, haja vista a existência de outros negócios jurídicos cujo objetivo também é a troca e que se denominam igualmente "swaps", ${ }^{107}$ mas que não são considerados derivativos. ${ }^{108}$ Adicionalmente, outro foco de confusão é o fato de a tradução da palavra, que expressa a finalidade econômica do negócio jurídico, não poder ser confundida com o contrato típico de troca ou permuta previsto no artigo 533 do Código Civil. ${ }^{109}$

\footnotetext{
${ }^{106}$ SALOMÃO NETO, Eduardo. op. cit., p. 325, afirma que o termo swap descreve a função do negócio, sua causa, considerando que a precisão jurídica está certamente ausente das mesas de operações e centros originadores de negócios.

${ }^{107}$ A primeira vez que a palavra swap apareceu em nosso ordenamento foi em 1964, nos termos de BRASIL. Lei n. ${ }^{\circ}$ 4.595, de 31 de dezembro de 1964, dispõe sobre a política e as instituições monetárias, bancárias e creditícias, cria o Conselho Monetário Nacional e dá outras providências. Disponível em: <www.planalto.gov.br>. Acesso em: 22 maio 2011: Art. 4o, XXI. Compete ao Conselho Monetário Nacional, segundo diretrizes estabelecidas pelo Presidente da República XXXI - Baixar normas que regulem as operações de câmbio, inclusive swaps, fixando limites, taxas, prazos e outras condições. Vale mencionar, ainda, a famosa frase proferida pelo então ministro da Fazenda Oswaldo Aranha ("Ora, swaps são swaps!"), que também demonstra a utilização da expressão anteriormente, na década de 1950, sem que se referisse à atual espécie de derivativos de que este trabalho cuida. Por muito tempo, o conceito "swap" se referiu a matéria cambial, sem ter sido definido expressamente pelas regras do CMN. Apenas em 1994, com a edição da Resolução CMN 2042/94, definiu-se swap como "troca de resultados financeiros decorrentes da aplicação de taxas ou índices sobre ativos ou passivos utilizados como referenciais". Cf. CORDEIRO FILHO, Ari. Swaps: aspectos jurídicos. Revista de Direito Bancário, do Mercado de Capitais e da Arbitragem, São Paulo, v. 4, n. 11, p. 71, jan./mar. 2001.

${ }^{108}$ CORDEIRO FILHO, Ari. op. cit., p. 69-70: Não foram estabelecidos elementos integrativos de uma definição, em qualquer lei. O referencial era de se tratar de instituto atinente à matéria cambial, eis que o dispositivo acima enunciado estabelece competência do Conselho Monetário para regular operações de câmbio, "inclusive swaps". Não havia tentativa sequer de um conceito, encontradiço em nossas normas de conteúdo econômico. O termo anglo-saxônico, assim, pousou em nossa legislação como de acepção supostamente conhecida, pelo menos dos economistas que opinaram na redação do projeto. A Lei 4.595/64, de certa forma, veio a transportar ao nosso direito positivo a interessante afirmativa: "Ora, swaps são swaps!”. Seriam as trocas que os agentes econômicos praticassem com a configuração de swap da época. Desprendeu-se, contudo, do significado original, por insuspeitada abertura. Tal consuetudinário mutante, tido como característico de disposições legais esparsas em países com sistema legislativo baseado na common law, na realidade nem naqueles países comporta uma tal elasticidade semântica.

${ }^{109}$ BRASIL. Lei n. ${ }^{\circ}$ 10.406, de 10 de janeiro de 2002. Institui o Código Civil. Disponível em: $<$ http://www.planalto.gov.br>. Acesso em: 22 maio 2011. Parte Especial, Livro I (Direito das Obrigações), Título VI (Das Várias Espécies de Contrato), Capítulo II (Da Troca ou Permuta). Art. 533. Aplicam-se à troca as disposições referentes à compra e venda, com as seguintes modificações: I - salvo disposição em contrário, cada um dos contratantes pagará por metade as despesas com o instrumento da troca; II - é anulável a troca de valores desiguais entre ascendentes e descendentes, sem consentimento dos outros descendentes e do cônjuge do alienante.
} 
Diferentemente dos contratos a termo, dos futuros e das opções, o primeiro swap foi realizado mais recentemente: conforme alguns autores, em meado dos anos $1970^{110}$ ou, conforme outros, no início dos anos 1980, cujo maior expoente seria negócio entre o Banco Mundial e a IBM. ${ }^{111}$ Se a doutrina diverge com relação ao que pode ser considerado o primeiro swap, ela é unânime, contudo, em apontar as restrições cambiais e de fluxos monetários como causa para o surgimento dos swaps, ${ }^{112}$ no contexto de falência de Bretton Woods.

Juridicamente, podemos caracterizar um derivativo da espécie swap como um contrato bilateral que possibilita uma troca de posições jurídicas apreciáveis pecuniariamente em (ou até) uma data futura previamente estabelecida e cujos resultados finais dependem de um (ou mais de um) ativo subjacente, calculados com base no mesmo nocional ficto. ${ }^{113}$

Trata-se de um instrumento que busca comparar duas rentabilidades futuras atreladas a determinados ativos subjacentes (mercadorias, taxas, juros, índices, entre outros), com base em um mesmo número abstrato, o nocional (base do tamanho do swap). As partes estabelecem cada qual o seu fluxo financeiro fictício, ${ }^{114}$ com fórmulas previamente estabelecidas, ao qual ficam obrigadas, e, a partir da subtração ou comparação de um resultado líquido pelo outro, uma das partes conferirá à outra o valor correspondente final.

Em um contrato de swap, estão presentes duas partes ou, no jargão de mercado, duas "pontas". Cada uma dessas partes possui uma posição jurídica apreciável pecuniariamente, objeto de uma ficção por elas acordada. Não se troca um objeto existente,

\footnotetext{
${ }^{110}$ HENDERSON, Schuyler K. op. cit., p. 1.

${ }^{111}$ YAZBEK, Otavio. Regulação do mercado financeiro e de capitais, cit., p. 112.

${ }^{112}$ MARSHALL, John F.; KAPNER, Kenneth R. Understanding swaps. New York: John Wiley \& Sons, 1993. p. 4.

${ }^{113}$ Uma ótima definição de swap encontra-se em CALHEIROS, Maria Clara. O contrato de swap. Coimbra: Coimbra Ed., 2000. p. 124: O swap surge-nos como contrato oneroso, consensual, de execução sucessiva, sinalagmático, intuitu personae e aleatório que, procurando alterar a posição financeira de cada uma e ambas partes, por referência a certas situações subjacentes, se traduz na cobertura de um risco financeiro, na realização de uma arbitragem ou mesmo numa operação especulativa. Logo, é detentor de uma peculiaridade, a vários níveis, que nos obriga a considerá-lo como categoria contratual autónoma, criada ao abrigo do princípio da liberdade contratual. É, pois, inegável que o contrato de swap possui uma função económico-social própria, reflectindo-se numa estrutura jurídica privativa. A causa (hoc sensu) do contrato de swap é a troca de fluxos financeiros, especificamente calculados, os quais alteram a situação financeira subjacente das partes. Frustradas as tentativas de inserção do swap numa categoria contratual tipificada e atendendo à análise que levamos a cabo das características específicas deste contrato, bem como das finalidades que presidem à sua celebração, temos de concluir pela classificação do swap como contrato sui generis.

${ }^{114}$ Nesse sentido, EIZIRIK, Nelson; GAAL, Ariádna B.; PARENTE, Flávia, HENRIQUES, Marcus de Freitas. Mercado de capitais: regime jurídico. 2. ed. Rio de Janeiro: Renovar, 2008. p. 113, valendo-se da lição de SZTAJN, apresenta swap como contrato pelo qual as partes ajustam a permuta de fluxos de caixa futuros, de acordo com fórmula predeterminada.
} 
como seria o caso de um contrato de permuta. Este "objeto a ser trocado" é uma abstração jurídica. Como bem descrito por CORDEIRO FILHO:

\begin{abstract}
No swap, com base num interesse econômico, as partes dão existência real a fluxos de resultados fictos, baseados na aplicação de taxas ou indices a um número abstrato (nocional). Ou então, dão existência real a fluxos de preços fictos a serem compensados com fluxos de preços observados ou auferidos no mundo real. Estes fluxos de resultados financeiros passam a ter existência real, passíveis de serem objetos de vínculo obrigacional, no momento em que se conjugam as duas vontades, neste sentido. Antes dessa conjugação de vontades, tais fluxos de resultados financeiros são imateriais e imaterializáveis como objeto de obrigações. ${ }^{115}$
\end{abstract}

Assim, muito embora o nome do contrato após tradução possa erroneamente levar o intérprete a tipificá-lo como contrato de permuta, esta caracterização está fora de cogitação. Não se pode trocar aquilo que não existe, ao que estamos a falar de fluxos financeiros abstratos, com base em nocionais meramente referenciais. ${ }^{116}$

Dadas as especificações dos casos concretos, os swaps nascem como instrumentos personalizados ou tailor made, muitas vezes utilizados para eficiente administração da atividade empresarial. ${ }^{117}$ Com o tempo, diante da financeirização e popularização dos derivativos, os swaps passam a contar também com possibilidades padronizadas e massificadas, com negociação em bolsa, e termos e condições previamente estabelecidos, em que o agente econômico pode assumir uma "posição comprada ou vendida" em uma das “pontas".

Também os swaps são registrais, com ilimitadas possibilidades de ativos subjacentes, liquidados por diferença. Não se confundem com os futures e forwards, pois a liquidação por diferença no caso dos swaps é referente aos valores do fluxo financeiro de cada ponta, que podem inclusive não ter o mesmo ativo subjacente.

O swap é, destarte, um contrato mercantil de criação consuetudinária, sancionada esta pela legislação positiva em várias jurisdições, inclusive a brasileira. A liquidação por diferença é uma característica imanente do conceito atual. $O$ swap não é, também, em sentido estrito, um contrato de

\footnotetext{
${ }^{115}$ CORDEIRO FILHO, Ari. op. cit., p. 78.

${ }^{116}$ Igualmente, não se pode falar em compra e venda, concessão de crédito, mútuo, financiamento, desconto, adiantamento ou qualquer outro contrato que possa sugerir desembolso de recursos. Recomendamos, nesse sentido, a leitura de CORDEIRO FILHO, Ari. op. cit., p. 78-79.

${ }^{117}$ YAZBEK, Otavio. Regulação do mercado financeiro e de capitais, cit., p. 113: Desta maneira, pode-se recorrer a swaps para "travar" os rendimentos de uma carteira de investimentos, atrelando-a à variação cambial ou dando-lhe características de renda fixa. Outro exemplo possível, dentre muitos, é o da "transformação" de endividamentos em renda variável em endividamentos de renda fixa ou vice-versa (vez que diferentes empresas podem ter vantagens comparativas ao tomar os empréstimos sob diversas condições, que não sejam aquelas que lhes interessavam).
} 
futuro (futures), embora seja também, um contrato de liquidação futura, como tantos outros. A liquidação, no swap, não ocorre por diferença entre um preço ajustado e cotação de mercado de um subjacente, em datas futuras, em face de contratos padronizados, negociados em bolsas ou sistemas eletrônicos (contrato futuro simples, futures). Muito menos um contrato de balcão, não negociado em bolsa (não padronizado, forwards), que pressuponha a entrega física futura de mercadorias ou títulos. A liquidação do swap ocorre por diferença entre fluxos de valores, calculados de forma diferente sobre subjacente idêntico em cada fluxo, ou, até, calculados em função de subjacentes distintos em cada um dos fluxos. ${ }^{118}$

Usualmente, mesmo quando negociados em balcão, ambiente no qual as partes teoricamente teriam maiores possibilidades de negociação dos termos e condições da operação, os contratos de swap revestem a forma de modelos contratuais padronizados, os master agreements - muitos deles elaborados por entidades auto-reguladoras, da qual o maior expoente é a International Swap Dealer Association (ISDA), em que as possibilidades de alteração de cláusulas são diminutas. ${ }^{119}$

As entidades financeiras podem atuar como intermediadoras de operações de swap, buscando duas pontas com interesses contrapostos, ou também como parte contratante de uma das pontas do swap, já que nem sempre é tarefa fácil encontrar duas partes com interesses comuns e opostos. Na bem da verdade, a atuação das instituições financeiras é, na maioria das vezes, como contratante direta do swap, passando elas a explorar este nicho de produtos financeiros. ${ }^{120}$

Por fim, vale mencionar que uma das modalidades de swap mais conhecidas é o credit default swap ou simplesmente "derivativo de crédito" ou "CDS". ${ }^{121}$ Neste, existe a

\footnotetext{
${ }^{118}$ CORDEIRO FILHO, Ari. op. cit., p. 73.

${ }^{119}$ Utilizar um modelo padronizado dos contratos de swap não faz, de maneira alguma, que eles sejam considerados contratos típicos em nosso ordenamento. Trata-se, na realidade, de um movimento de autoregulação transnacional, em que inúmeras entidades (financeiras ou não) aderem às regras de alguma instituição, como, por exemplo, a International Swap Dealer Association (ISDA).

${ }^{120}$ Como forma de mitigar os riscos desta atividade, quando contratante direta do swap, a instituição financeira pode encontrar outra posição contrária e ser dela também contratante direta de outro swap, sendo a diferença de remuneração das duas partes o seu spread. Neste exemplo, no limite, as partes poderiam ser contratantes diretas umas das outras, sendo apenas apresentadas pela instituição financeira - além da perda de agilidade, a instituição financeira não possui tantos incentivos econômicos para assim proceder (já que ficaria adstrita apenas ao fee de intermediação). Este raciocínio de mitigação de riscos pelas instituições financeiras é válido para quaisquer derivativos, não sendo, neste exemplo, necessariamente um swap em outra ponta a única possibilidade.

${ }^{121}$ Deve-se notar que existem outros "derivativos de crédito" que não são swaps (por exemplo, opções). De qualquer modo, entre nós, com a edição da Resolução CMN 2933/02, os derivativos de crédito que são swaps adquiriram importância e chamaram atenção da doutrina. Nesse sentido, (i) GOLDSTEIN, Sergio Mychkis. Aspectos jurídicos dos derivativos de crédito no Brasil. Revista de Direito Bancário e do Mercado de Capitais, São Paulo, v. 7, n. 25, p. 63-81, jul./set. 2004; e (ii) STUBER, Walter Douglas; STUBER, Adriana M. Godel. Novas modalidades de operações de derivativos de crédito. Revista de Direito Bancário, do Mercado de Capitais e da Arbitragem, v. 5, n. 17, p. 255-261, jul./set. 2002.
} 
transferência de risco de crédito ${ }^{122}$ a ser eventualmente suportado por uma parte, mediante o recebimento de determinada remuneração, sendo o ativo subjacente a respectiva posição credora (ou simplesmente o crédito). Caso o evento de crédito venha a ocorrer, ${ }^{123}$ a parte transferidora do risco, que pagou por essa proteção, receberá os valores combinados da parte que se dispôs a suportar o risco. ${ }^{124}$

Uma interessante curiosidade relacionada aos credit default swaps está ligada ao seu papel durante a crise econômica mundial de 2008, sendo este instrumento tido como um dos propulsores do contágio e transferência de riscos entre agentes de mercado e, consequentemente, entre governos. ${ }^{125}$ Notou-se, na prática (de maneira drástica), o importante efeito de mobilização monetária atribuído aos derivativos.

\section{III.B.4. Estratégias e Efeitos}

Esta seção não busca exaurir todos os possíveis efeitos financeiros dos derivativos. Tampouco buscamos exemplificar todas as combinações existentes entre os diferentes arquétipos de derivativos, que originam as chamadas estratégias. Para isso, os manuais de finanças prestam um trabalho muito mais detalhado, oportuno e eficiente, inclusive com

\footnotetext{
${ }^{122}$ Os riscos de crédito, que são os ativos subjacentes neste caso, podem ter inúmeros formatos, incluindo-se operações de mútuo, títulos de dívida, financiamentos, garantias fidejussórias, contratos financeiros, contratos mercantis, outros derivativos, entre outros.

${ }^{123}$ As partes estipulam em contrato quais eventos serão considerados para esta finalidade, como, por exemplo, falência, recuperação judicial ou extra-judicial dos sujeitos obrigados do ativo subjacente, alteração de controle acionário destes sujeitos, inadimplementos pecuniários ou não pecuniários de tais ativos subjacentes, entre outros.

${ }^{124}$ STUBER, Walter Douglas; STUBER, Adriana M. Godel. op. cit., p. 255: Desta forma, são derivativos de crédito os contratos em que as partes negociam o risco de crédito de operações, sem implicar, no ato de contratação, a transferência do ativo subjacente às aludidas operações.

${ }^{125}$ EUROPEAN COMMISSION. Commission of the European Communities. Commission Staff Working Paper. Accompanying the Commission Communication. Ensuring efficient, safe and sound derivatives market. July 03, 2009, cit., p. 3, no contexto do pós crise de 2008, demonstra a preocupação da União Européia especialmente com os derivativos de crédito do tipo swap (ou "CDS"): In terms of risk characteristics, the early focus on credit default swaps was justified in view of its binary and discontinuous pay-out structure, concentrated dealer market structure, difficulty of valuing the rights and obligations contained in the contract, especially for the less liquid single name part of the market, lack of solid risk management measures and disproportionate dimension of the derivative market with respect to the underlying market. Most other OTC derivatives appear less risky, as pay-out structures are more continuous in nature (e.g. interest rate swaps, foreign exchange derivatives, equity derivatives), the market more disperse (e.g. interest rate swaps, foreign exchange derivatives, equity derivatives, commodity derivatives), the underlying markets more liquid and the underlying risks more observable (e.g. foreign exchange, interest rate swaps, equity derivatives), risk management measures sometimes more solid (e.g. interest rate swaps, foreign exchange derivatives) and electronic systems more developed (e.g. credit default swaps, interest rate swaps).
} 
importantes exemplos numéricos. ${ }^{126}$ Outrossim, busca-se, em primeiro lugar, traçar um panorama geral deste mercado, de modo que o leitor possa entender a lógica de determinados conceitos utilizados pelos hedgers e especuladores. Ademais, como objetivo principal desta seção, buscamos demonstrar que as diferentes estratégias, fruto da combinação de diferentes espécies de derivativos, não podem ser entendidas, de modo algum, como um único negócio jurídico, a despeito da inequívoca finalidade econômica una.

Os derivativos possibilitam a chamada "alavancagem" ou "multiplicação monetária". Isso significa dizer que, com um gasto inicial zero ou relativamente pequeno, o agente econômico poderá assumir uma grande posição - maior do que possível no mercado à vista do mesmo ativo subjacente. Este "investimento inicial" é pago a título de depósito de margem (no caso de contratos a futuro) ou de compra da opção (no caso das opções) ou custos de estruturação, emolumentos e taxa de permanência (no caso dos swaps). ${ }^{127}$

Assim, o agente econômico que acredita na tendência (de queda ou de alta) de um preço pode vender ou comprar diretamente este ativo subjacente (por exemplo, vender ou comprar X unidades monetárias de moeda estrangeira ou X ações) ou, por um valor menor (a título de margem ou compra da opção ou contratação do swap), posicionar-se a futuro ou comprar opção ou valer-se do fluxo financeiro teórico desta mesma mercadoria ou ativo subjacente.

Em um exemplo simples, se o agente econômico acredita na subida de preço de uma determinada ação negociada em bolsa cujo valor atual é 10 unidades monetárias, ao invés de investir 10 unidades monetárias em uma ação e colher os frutos decorrentes da variação do preço desta única ação, pode-se investir este mesmo valor na compra de várias opções relacionadas à subida do preço deste ativo e, dessa forma, com o mesmo número de unidades monetárias, multiplicar os ganhos (ou maximizar as perdas).

Este posicionamento a futuro ou compra de opção ou contratação de swap significa dizer que, com desembolso financeiro menor, na data de fechamento da transação, o investidor terá o mesmo efeito financeiro que teria se tivesse comprado ou vendido diretamente o ativo subjacente na mesma data. Desse raciocínio, fácil concluir que, com o mesmo investimento financeiro necessário para comprar ou vender o ativo subjacente no mercado à vista, o agente econômico poderá, no mercado de derivativos, alavancar a sua posição, multiplicando os seus ganhos.

\footnotetext{
${ }^{126}$ Vide (i) HULL, John. Introdução aos mercados futuros e de opções, cit. (ii) HULL, John. Fundamentos dos mercados futuros e de opções. 4. ed. São Paulo: BM\&F, 2005.

${ }^{127}$ Para exemplos numéricos, vide HULL, John. Introdução aos mercados futuros e de opções, cit., p. 9-12.
} 
Conforme bem definido por ANTUNES, a alavancagem financeira significa dizer que, através de meios financeiros próprios reduzidos (minimização de investimento inicial), [derivativos] permitem participar mais do que proporcionalmente nas variações do valor do activo subjacente (maximização do ganho ou perda). ${ }^{128} \mathrm{Ou}$, conforme HULL, mais direto ao ponto: o uso de opções amplia os resultados financeiros: os bons tornam-se excelentes, mas os maus ficam piores. ${ }^{129}$

Outra característica marcante dos derivativos são as estratégias, entendidas como a combinação de uma ou mais espécies de derivativos com outros negócios jurídicos, estes do mercado financeiro ou não. Portanto, a compra de um ativo no mercado à vista (por exemplo, milho a granel ou ações) e a simultânea contratação de um derivativo que tenha o mesmo ativo subjacente é um tipo de estratégia. Também a negociação de dois derivativos, com determinada correspondência ou correlação, é considerada uma estratégia.

Do ponto de vista do contratante, cada um dos negócios jurídicos individualmente contratados apenas faz sentido pela existência de seu(s) correspondente(s). Assim, no viés econômico, o contratante enxerga estes contratos independentes como uma unidade, já que busca, na verdade, o efeito da combinação dos seus resultados.

Da mesma forma que os derivativos se prestam à alavancagem financeira, eles também são utilizados para formar estratégias com o objetivo de maximizar ganhos ou minimizar perdas, dada a correlação (ou “delta”) entre os diferentes negócios jurídicos.

Um tipo de estratégia bastante comum é o "financiamento", que utiliza contratos a termo ou futuros combinados com operações no mercado à vista, com vistas a travar ganhos, simulando um mercado de renda fixa, ainda que a operação do mercado à vista seja um título de renda variável. ${ }^{130}$

\footnotetext{
${ }^{128}$ ANTUNES, José A. Engracia. op. cit., p. 93.

${ }^{129}$ HULL, John. Introdução aos mercados futuros e de opções, cit., p. 11.

${ }^{130}$ Ao comprar uma determinada ação por 100 unidades monetárias e, ao mesmo termo celebrar um contrato a termo em que se adquire o direito de vender em data futura esta mesma ação por 130 unidades monetárias (pagando por esse direito um preço hipotético de 10 unidades monetárias), o agente econômico pratica uma operação de financiamento, em que gastou 110 unidades monetárias na data de fechamento de suas operações (100 unidades monetárias no mercado à vista e 10 unidades monetárias para celebrar o derivativo). Caso, na data futura avençada, esta ação valha 50 unidades monetárias, o agente econômico irá exercer o seu direito de venda do bem e embolsará 70 unidades monetárias pelo derivativo (130-10-50), continuará com uma ação precificada a 50 unidades monetárias (que pode ser vendida ou mantida em seu balanço), o que totaliza 120 unidades monetárias. Nesse primeiro cenário, como resultado líquido, obtem-se ganho de 10 unidades monetárias (120 unidades monetárias da operação na data futura menos 110 unidades monetárias para montar a operação de financiamento na data pretérita). Caso, ao contrário, exista tendência de alta desta ação e o preço esteja em 150 unidades monetárias na data futura, o agente terá 150 unidades
} 
Também são comuns estratégias envolvendo opções, que apostam na ocorrência de volatilidade de preços do ativo-objeto. Uma das combinações mais comuns é o straddle, que consiste na compra de opções de compra e na concomitante compra de opções de venda, em mesma quantidade, com mesmos vencimentos e mesmos preços de exercício. Como resultado, para o comprador das opções, há perdas limitadas, condizentes à soma dos prêmios pagos nos dois negócios jurídicos, e ganhos ilimitados, quando houver grande volatilidade dos preços do ativo subjacente, para cima ou para baixo, com o consequente exercício da opção de venda ou da opção de compra, respectivamente.

O straddle também pode ser montado com venda ou lançamento concomitante de opções de venda e de compra, em mesma quantidade, com mesmos vencimentos e mesmos preços de exercício. Neste caso, os ganhos são limitados à soma dos prêmios recebidos quando do lançamento das opções, e as perdas, por seu turno, ilimitadas na hipótese de grande volatilidade para cima ou para baixo dos preços do ativo objeto, ocasiões em que o agente "será exercido".

Uma das variantes da estratégia straddle é o strangle, cuja peculiaridade reside nos diferentes preços de exercício para as opções de venda e de compra, o que significa dizer que as variações de preço do ativo subjacente (volatilidade) deverão ser maiores, para cima ou para baixo, para o alcance dos mesmos resultados.

Apesar de ser possível a utilização de estratégias no ambiente bursátil, é no mercado de balcão que as combinações de diversos tipos de derivativos adquirem relevância sistêmica. Como explorado em capítulo específico, uma das grandes características diferenciadoras do mercado de balcão é a descentralização do ambiente de negociação, sem a existência de contraparte central ou intermediários, onde as operações podem ser fechadas diretamente entre as partes interessadas. Dessa forma, os agentes econômicos podem conformar os termos e condições de cada operação, conforme suas

monetárias em decorrência da ação (que pode ser vendida ou continuar como um ativo proprietário) e terá "perdido" 10 unidades monetárias na celebração do derivativo. Assim, em data futura, em termos líquidos finais, tem-se 40 unidades monetárias (150 unidades monetárias na data futura menos 110 monetárias para se montar a operação em data passada). Dessa forma, independentemente do cenário de precificação do ativo em data futura, se tendência de alta ou de baixa, o sujeito de direitos terá obtido ganhos líquidos pela combinação de duas operações. Assim, um investimento tipicamente de "renda variável" - como as ações terá viés de "renda fixa", numa operação dita "financiamento". Vale ressaltar, contudo, que a "certeza" desse ganho "renda fixa" é limitada pelo preço futuro do ativo: nesse mesmo exemplo, se o preço da ação tivesse despencado a 10 unidades monetárias, tem-se perda líquida de ((10+70)-110). 
necessidades específicas. Assim, operações mais complexas necessitam de um ambiente mais flexível e sem padronização, o ambiente de balcão. ${ }^{131}$

As estratégias feitas pelos agentes econômicos, que combinam uma ou mais espécies de derivativos, são enxergadas e possuem como motivação um único racional econômico. Contudo, apesar da unidade da operação econômica do ponto de vista do operador do mercado, jamais está-se diante de um negócio jurídico unitário ou unificado. No limite, tem-se contratos coligados, cada qual independente. ${ }^{132}$

Não se pode falar, assim, na formação de um contrato atípico pela coordenação de mais de um negócio, ou sequer da existência de um contrato misto. Nas palavras de SZTAJN:

Outras combinações econômicas dos contratos de bolsa são possíveis e frequentemente praticadas pelos operadores econômicos, seja para limitar perdas seja para buscar um ganho adicional, mas, do ponto de vista jurídico, a unidade de operação econômica deve ser desdobrada em tantos contratos quantas forem as relações estabelecidas. Não há que se pensar em contratos mistos ou atípicos, já que a unidade econômica dos diversos contratos não deve ser transposta unitariamente para o campo jurídico. Na maior parte das hipóteses cada um dos negócios que compõem a unidade econômica (contratos) poderia existir independentemente dos demais, que se ligam apenas para maximizar os resultados positivos e reduzir os negativos. ${ }^{133}$

E não poderia existir conclusão diferente, dado o arranjo institucional dos mercados. Imagine-se que um agente econômico utilize uma estratégia que consiste na negociação de um derivativo no mercado de balcão e outro em bolsa. Ainda que, para este agente econômico, a operação apenas faça sentido se os dois contratos existirem, ele jamais poderá alegar que eventual problema em um dos contratos (pela insolvência da clearing atrelada à bolsa, por exemplo) afeta o outro contrato. Encarar os vários contratos da estratégia como independentes não é apenas questão de boa-técnica jurídica, mas de higidez dos mercados.

\footnotetext{
${ }^{131}$ YAZBEK, Otavio. Crise, inovação e regulação no mercado financeiro: considerações sobre a regulamentação do mercado de derivativos de balcão. No prelo, 2011, p. 5, aponta também os menores custos, a não incidência de determinadas restrições e a ausência de obrigações gerenciais de controle como incentivadoras do mercado de balcão para estratégias de derivativos.

${ }^{132}$ VERÇOSA, Haroldo Malheiros Duclerc. Os contratos inonimados e o novo Código Civil. Revista de Direito Mercantil, Industrial, Econômico e Financeiro, São Paulo, v. 41, n. 126, p. 32, abr./jun. 2002: De outro lado, não se deve confundir contrato misto com união de contratos (contratos coligados). Enquanto o contrato misto é caracterizado pela unidade da causa, nos contratos coligados cada qual apresenta a sua causa própria, atingindo-se um determinado objetivo pela soma de seus resultados.

${ }^{133}$ SZTAJN, Rachel. Contratos de bolsa, cit., p. 179-180.
} 


\section{III.C. Local de Negociação: Balcão e Bolsa}

No Brasil, a simples necessidade de registro dos derivativos em mercados organizados (bolsa ou balcão) ${ }^{134}$ é apontada como um dos motivos pelos quais o país se saiu relativamente bem da crise econômica mundial de 2008. Nossas exigências regulatórias, tidas por muito tempo como sendo em demasiado restritivas, foram, de certo modo, aplaudidas pelo mundo após a crise, na medida em que propiciaram a criação de um mercado transparente. ${ }^{135}$

Não se pode negar que a transparência das negociações de derivativos existentes no Brasil (sobretudo as disposições relacionadas ao mercado de balcão) ${ }^{136}$ foi um excelente ativo do ponto de vista regulatório, o que propiciou à CVM traçar um diagnóstico preciso e

\footnotetext{
${ }^{134}$ Hoje, a obrigação de registro dos derivativos encontra-se positivada no $\$ 4^{\circ}$ do artigo $2^{\circ}$ da Lei $6.385 / 76$, conforme modificação da Lei 12.543/11, fruto da conversão da Medida Provisória 539/11: É condição de validade dos contratos derivativos, de que tratam os incisos VII e VIII do caput, celebrados a partir da entrada em vigor da Medida Provisória n 539, de 26 de julho de 2011, o registro em câmaras ou prestadores de serviço de compensação, de liquidação e de registro autorizados pelo Banco Central do Brasil ou pela Comissão de Valores Mobiliários. Anteriormente à Medida Provisória que disciplinou na lei base do mercado de capitais o registro de quaisquer derivativos como condição de validade, a necessidade de registro era inferida por uma série de normativos infra-legais e, de maneira incidental, pela própria dinâmica do mercado brasileiro (em que instituições financeiras, os maiores players do mercados, encontravam-se sujeitas ao registro de suas operações).

${ }^{135}$ PRADO, Fernando Almeida; LESSA, Tiago A. D. Thenudo. Derivatives in Brazil. Butterworths Journal of International Banking and Financial Law, London, v. 24, n. 1, p. 35, Jan. 2009.

${ }^{136}$ EUROPEAN COMMISSION. Commission of the European Communities. Commission Staff Working Paper. Accompanying the Commission Communication. Ensuring efficient, safe and sound derivatives market. July 03, 2009, cit., p. 4, no contexto do pós crise de 2008, relata os riscos sistêmicos para o mercado financeiro pelos derivativos de balcão - aqui descritos como instrumentos opacos: The ongoing financial crisis has brought unprecedented regulatory attention to over-thecounter (OTC) derivatives markets and to the way in which credit risk has been transferred. Indeed, one of the root causes of the crisis may be traced back to the misuse of the techniques that were developed to transfer credit risk (securitisation and credit derivatives). While some of the problems related to securitisation and to the excessive risk transfer and risk mispricing have already been addressed by the recent review of the Capital Requirement Directive (CRD), the risks inherent in Credit Default Swaps (CDS) and other types of OTC derivatives have not. Their use and their impact on financial stability generated the current political debate and are analysed in this report. The near-collapse of Bear Sterns in March 2008, the default of Lehman Brothers on 15 September 2008 and the bail-out of AIG on 16 September highlighted the fact that OTC derivatives in general and credit derivatives in particular carry systemic implications for the financial market. By their nature, OTC markets are markets for professional investors and are thus not directly accessible to the general public. As professional investors were deemed sophisticated enough to manage the risks inherent in the OTC market, the latter has been accorded fairly light regulatory treatment. However, the recent financial crisis has illustrated that professional investors not always understand the risks they face and the consequences of those. The bilateral nature of this market makes it opaque to parties outside a particular transaction. In addition, the level of concentration in the market in terms of participants tends to be high. Moreover, as the price determined in the derivatives markets may be used to calculate the price of other instruments, its opaque nature may affect other market segments. In the credit default swaps (CDS) market, for example, the prices of these instruments have a direct impact one the financing costs a firm faces. Furthermore, even if not directly accessible to the general public, the instruments traded in the OTC market may ultimately affect retail investors through other products or via professional investors. Finally, as the major financial institutions tend to participate in most (if not all) the segments of this market, the level of interconnection (and hence the spill-over effects) between these various segments are extremely high.
} 
tomar as medidas cabíveis com extrema agilidade, tais como o aprimoramento das regras de registro de operações, dos mecanismos de evidenciação contábil pelas companhias e de disclosure de informações. ${ }^{137}$

Some-se a isso o fato de que, no Brasil, necessariamente, muitos derivativos são negociados por meio de instituições financeiras e estas, por seu turno, precisam ter suas operações registradas no mercado de bolsa ou balcão, ${ }^{138}$ o que torna este mercado, além de transparente, extremamente restrito, praticamente um "mercado interbancário", sem a participação de outros players que, no resto do mundo, são extremamente relevantes, tais como fundos de hedge, fundos de pensão, seguradoras e outros investidores qualificados, mas que podem disseminar riscos de maneira muito mais rápida e pujante. ${ }^{139}$

Concordamos com a afirmação de que a experiência brasileira de regulação dos derivativos possa servir de exemplo ao resto do mundo, ${ }^{140}$ sobretudo no tocante ao registro e consequente transparência e supervisão do mercado, ${ }^{141}$ mas, ao mesmo tempo,

${ }^{137}$ Como exemplos de medidas do pós crise de 2008: (i) BRASIL. Medida Provisória n. ${ }^{\text {5 }}$ 539, de 26 de junho de 2011, Autoriza o Conselho Monetário Nacional, para fins da política monetária e cambial, a estabelecer condições específicas para negociação de contratos de derivativos, altera o art. $3^{\circ}$ do Decreto-Lei $\mathrm{n}^{\circ} 1.783$, de 18 de abril de 1980, e os arts. $1^{\circ}$ e $2^{\circ}$ da Lei n⿳o 8.894, de 21 de junho de 1994, e dá outras providências. Disponível em: <www.planalto.gov.br>. Acesso em: 10 jun. 2013; (ii) COMISSÃO DE VALORES MOBILIÁRIOS. Instrução CVM no 475, de 17 de Dezembro de 2008. Disponível em: <www.cvm.gov.br>. Acesso em: 22 maio 2011; (iii) COMISSÃO DE VALORES MOBILIÁRIOS. Nota Explicativa à Instrução CVM $n^{\circ}$ 475, de 17 de Dezembro de 2008. Disponível em: <www.cvm.gov.br>. Acesso em: 22 maio 2011; (iv) COMISSÃO DE VALORES MOBILIÁRIOS. Deliberação n. ${ }^{\circ}$ 550, de 17 de Outubro de 2008. Disponível em: <www.cvm.gov.br>. Acesso em: 22 maio 2011; e (v) COMISSÃO DE VALORES MOBILIÁRIOS. Instrução CVM no 480, de 07 de Dezembro de 2009. Disponível em: <www.cvm.gov.br>. Acesso em: 22 fev. 2013. Vale também ressaltar a criação da Central de Exposição de Derivativos (CED), associação civil sem fins lucrativos, capitaneada pela Febraban, com o objetivo de centralizar informações relacionadas aos derivativos registrados nos mercados organizados.

${ }^{138}$ Sobre as necessidades de registro das operações cursadas por instituições financeiras, cf. (i) COMISSÃO DE VALORES MOBILIÁRIOS. Deliberação $n .^{\circ}$ 20, de 15 de Fevereiro de 1985. Disponível em: <www.cvm.gov.br>. Acesso em: 11 maio 2013; e (ii) BANCO CENTRAL DO BRASIL. Conselho Monetário Nacional. Resolução n. ${ }^{o}$ 1.779, de 20 de dezembro de 1990. Disponível em: <www.bacen.gov.br>. Acesso em: 11 jun. 2013.

${ }^{139}$ PRADO, Fernando Almeida; LESSA, Tiago A. D. Thenudo. op. cit., p. 35.

${ }^{140}$ COMISSÃO DE VALORES MOBILIÁRIOS. Edital de Audiência Pública SDM 06/10, de 24 de setembro de 2010. Disponível em: <www.cvm.gov.br>. Acesso em: 22 fev. 2013: De um modo geral se considera, assim, que o sistema brasileiro encontra-se adequado aos padrões que se pretende começar a adotar ao redor do mundo e que muito da experiência brasileira pode servir de apoio ao desenvolvimento da infraestrutura de mercado em outras jurisdições. A CVM entende, porém, que o regime hoje existente ainda pode ser aprimorado.

${ }^{141}$ EUROPEAN COMMISSION. Commission of the European Communities. Commission Staff Working Paper. Accompanying the Commission Communication. Ensuring efficient, safe and sound derivatives market. July 03, 2009, cit., p. 4-5, no contexto do pós crise de 2008, nos dá conta da preocupação da União Européia com a opacidade dos derivativos de balcão do mundo desenvolvido e de como isso afeta as necessárias respostas regulatórias (ao contrário do que ocorreu no Brasil): These characteristics proved to be the Achilles heel of the OTC market during the current crisis and might have, absent prompt and forceful intervention from governments, wrecked havoc to the financial system. The three institutions mentioned above were important players in the OTC derivatives market, either as dealers or users of OTC 
entendemos ser extremamente ingênuo atribuir a isso o fato de o Brasil ter passado, até o presente momento, praticamente ileso à crise de 2008, que, como sabemos, teve nos derivativos um poderoso instrumento de dispersão. ${ }^{142}$

Talvez o melhor diagnóstico seja a pouca relevância de nosso mercado de derivativos (quando comparado a países desenvolvidos) que, ao mesmo tempo em que não permitiu maior transferência de riquezas (ainda que "artificial") nos tempos de bonança, também não permitiu a criação de um mercado relevante que pudesse causar danos substanciais ao setor real da economia.

Qualquer que seja o motivo que ensejou a não propagação de riscos na sociedade brasileira por meio dos derivativos, é necessário reconhecer que nosso arcabouço regulatório de registro das operações ${ }^{143}$ é, além de pioneiro com relação às hoje ditas melhores práticas mundiais, ${ }^{144}$ de grande valor. Nesse contexto, deparamo-nos com duas

derivatives, or both. Whilst the trouble they experienced originated outside the OTC derivatives markets and was initially confined to a small segment of the OTC market (i.e. credit derivatives), their crucial role in virtually all the segments of the OTC derivative market (in the case of Lehman and Bear Stearns) had a negative spill-over effect for the entire OTC market. The opaqueness of the market prevented, on the one hand, other market participants from knowing exactly what the exposures of their counterparties were to these three entities (the events in the credit default swaps market after Lehman's bankruptcy are a point in case), which resulted in mistrust and the drying up of liquidity in the inter-bank money market. It also prevented regulators from being able to identify early the risks building up in the system, the extent to which risks were being concentrated in a handful of institutions and consequently the effects that their default would have for financial stability. The light regulatory coverage of the market exacerbated this problem as supervisors did not have sufficient information. Even in case they had sufficient information, one could, argue that the lack of proper regulatory coverage might have deprived public authorities of an effective policy response.

${ }^{142}$ Sobre a crise financeiro de 2008 , que teve origem no mercado de títulos imobiliários dos Estados Unidos da América (hipotecas subprime), e o seu aprofundamento e alastramento por meio dos derivativos, sobretudo em um primeiro momento pelos derivativos de crédito intitulados credit default swaps (CDS), sugerimos a leitura de YAZBEK, Otavio. Crise, inovação e regulação no mercado financeiro: considerações sobre a regulamentação do mercado de derivativos de balcão, cit., p. 6-8.

${ }^{143}$ Após a promulgação da Lei $12.543 / 11$, alteradora da Lei 6.385/76, elegeu-se o registro como condição de validade dos derivativos. Na sequência, a Lei 12.810/13, em seu artigo 28, deu competência ao Bacen e à CVM para autorizar, supervisionar e condicionar o exercício da atividade de registro de ativos financeiros e valores mobiliários. Corporificando tais preocupações, a CVM divulgou o Edital de Audiência Pública SDM 09/13, que, por meio da Instrução CVM 544/13, visa alterou a Instrução CVM 461/07. Assim, aperfeiçoa-se nosso arcabouço regulatório no tocante ao registro das operações com derivativos. COMISSÃO DE VALORES MOBILIÁRIOS. Edital de Audiência Pública SDM 09/13, de 28 de agosto de 2013. Disponível em: <www.cvm.gov.br>. Acesso em: 22 set. 2013; COMISSÃO DE VALORES MOBILIÁRIOS. Instrução CVM n. ${ }^{\circ} 461$, de 23 de outubro de 2007. Disponível em: <www.cvm.gov.br>. Acesso em: 23 fev. 2013; COMISSÃO DE VALORES MOBILIÁRIOS. Instrução CVM no 544, de 20 de dezembro de 2013. Disponível em: <www.cvm.gov.br>. Acesso em: 09 jan. 2014.

${ }^{144}$ Vale mencionar que, em 2011, o BIS e a IOSCO estabeleceram, em dois diferentes relatórios, diversos princípios e recomendações com relação aos derivativos de balcão e com relação aos derivativos de commodities, os quais são há muito tempo utilizados no Brasil, reforçando o pioneirismo nacional não apenas do ponto de vista cronológico, mas também do ponto de vista de materialidade da regulação. Tais recomendações perpassam, entre outras, a disponibilização de informações, a transparência das operações e dos respectivos mercados, o formato de divulgação de dados e a padronização de classificações. Cf. BANK FOR INTERNATIONAL SETTLEMENTS (BIS). Report on OTC Derivatives Data Reporting and Aggregation Requirements. Disponível em: <http://www.bis.org/publ/cpss100.pdf>. Acesso em: 28 abr. 
figuras-chave de nossa estrutura, os mercados organizados de bolsa e de balcão, as quais devem ser entendidas em sua plenitude antes de descrevermos a experiência brasileira com relação aos derivativos.

Com esse objetivo em mente, depuraremos o conceito de bolsa e, na sequência, nós o diferenciaremos do conceito de balcão. Trataremos ainda da experiência dos mercados organizados no Brasil, encerrando com a experiência específica dos derivativos.

Entende-se que a expressão "bolsa" comporta diferentes sentidos, tais como o de local físico de encontro entre compradores e vendedores, o de sistema de negociação, o de instituição administradora (do local físico e dos sistema de negociação) e, por fim, o significado de comportamento ou status do mercado, assim entendido como locus ideal de interação entre oferta e demanda. YAZBEK muito bem sumariza:

Apesar desse esforço de definição inicial ser de alguma valia, deve-se ir um pouco além. Em primeiro lugar, porque, na prática, a expressão apresenta vários sentidos, podendo significar (i) o local em que se encontram os representantes dos compradores e vendedores para apresentar suas ofertas e fechar as operações; (ii) a instituição que administra aquele local e os sistemas de negociação nele existentes e que processa as operações ali realizadas; (iii) o mecanismo ou sistema adotado para as negociações de um determinado ativo; ou mais informalmente (iv) o estado das operações bursáteis em um dado período (quando se discute a tendência geral dos negócios, afirmando-se que a bolsa passa por uma "alta" ou por uma "baixa", por exemplo). ${ }^{145}$

Sobre a idéia de Bolsa como local físico adequado para a realização de negócios, por meio da reunião de pessoas para facilitação do encontro entre compradores e vendedores, SZTAJN aponta a prevalência dessa vertente no imaginário popular por conta da facilidade de se tangibilizar o conceito "bolsa", sobretudo na época dos pregões viva-voz. ${ }^{146}$

2013. Cf. INTERNATIONAL ORGANIZATION OF SECURITIES COMMISSIONS (IOSCO). Principles for the Regulation and Supervision of Commodity Derivatives Market. Final Report. Disponível em: $<$ http://www.iosco.org/library/pubdocs/pdf/IOSCOPD358.pdf>. Acesso em: 28 abr. 2013.

${ }^{145}$ YAZBEK, Otavio. A regulamentação das bolsas de valores e das bolsas de mercadorias e futuros e as novas atribuições da Comissão de Valores Mobiliários. Revista do Direito Bancário e do Mercado de Capitais, São Paulo, v. 9, n. 34, p. 204-205, out./dez. 2006.

${ }^{146}$ SZTAJN, Rachel. Contratos de bolsa, cit., p. 167: Bolsas são vistas como os locais em que se reúnem os intermediários, investidores e especuladores para a celebração de contratos com valores mobiliários, mercadorias e ativos financeiros, à vista, a termo, a futuro ou de opções sobre tais bens. Uma das funções da bolsa é a de manter local adequado para a realização dessas operações, mas não apenas essa seria a função das bolsas. O pregão da bolsa é o local em que, de viva voz, são realizadas as operações com valores mobiliários ou mercadorias e ativos financeiros e, talvez, por isso, a idéia de Bolsa como a de local, aparentemente prepondere sobre as demais. 
Fato é que o pregão viva-voz ficou nos livros de história e, hoje em dia, por mais que as quatro vertentes acima descritas sejam indissociáveis, o significado de "bolsa" como arranjo sistêmico ${ }^{147}$ é, sem dúvida alguma, o de maior relevo, com mecanismos eletrônicos de negociação cada vez mais sofisticados, ${ }^{148} \mathrm{em}$ um mundo totalmente interconectado, fruto da revolução da informática e da internet. ${ }^{149}$

Conceituada a instituição "bolsa", podemos traçar suas principais funções, todas elas alicerçadas no objetivo maior de um mercado eficiente, fruto do encontro entre compradores e vendedores em um ambiente de negociação único (centro de liquidez), com a obrigatoriedade do fechamento de negócios pelo melhor preço praticado no momento. ${ }^{150}$

Resumidamente, as funções das bolsas são as seguintes: aumento de liquidez no mercado, publicidade e transparência na formação de preços e na disseminação de informações (combate à assimetria informacional), especialização de intermediários, mitigação de riscos sistêmicos, controle e uniformização de ativos ofertados, e, por fim, estabelecimento de regras ${ }^{151}$ (algumas delas consuetudinárias, outras de adesão voluntária,

${ }^{147}$ Cf. MAFUD, Pedro Darahem; PEREIRA FILHO, Celso Roberto. op. cit., p. 3, o regulador brasileiro utilizou os significados de espaço físico e de sistemas para normatizar o conceito: Ambos os significados, espaço físico e sistema eletrônico, foram selecionados pelo regulador brasileiro para compor o significado normativo do gênero "mercado organizado de valores mobiliários", do qual bolsa é uma espécie. Assim, pode ser depreendido da Instrução CVM 461/07 um conceito normativo de bolsa, que se refere a um mercado organizado de valores mobiliários (gênero) qualificado por determinadas características que lhe especificam como bolsa.

${ }^{148}$ Como fruto de tal evolução sistêmica e tecnológica, não se pode deixar de mencionar a atual problemática das negociações de alta frequência (high frequency trading), com seus baixíssimos tempos de execução de ordens, e das dark pools, plataformas eletrônicas de negociação comumente detidas por grandes agentes de mercado cujo objetivo é casar ordens de compra e venda de maneira anônima. Sobre estes assuntos: VELOCIDADE controversa. Revista Capital Aberto, ano 10, n. 114, fev. 2013. Disponível em: $<$ http://www.capitalaberto.com.br>. Acesso em: 21 fev. 2013. IOSCO emite princípios sobre regulação das dark pools. Revista Capital Aberto, ano 8, n. 87, nov. 2010. Disponível em: $<$ http://www.capitalaberto.com.br>. Acesso em: 21 fev. 2013.

${ }^{149}$ Sobre o papel da revolução tecnológica e da comunicação no mundo representadas pela conectividade da internet e dos softwares, recomendamos FRIEDMAN, Thomas L. $O$ mundo é plano: uma breve história do século XXI. Rio de Janeiro: Objetiva, 2007.

${ }^{150}$ MAFUD, Pedro Darahem; PEREIRA FILHO, Celso Roberto. op. cit., p. 3: Tais atributos refletem essencialmente a racionalidade econômica observada nos mercados organizados como bolsas: previsão de que os negócios tenham por objeto bens padronizados e sejam realizados entre um comprador ou vendedor e o mercado, sem a distinção da contraparte em cada negócio, em um verdadeiro "arquétipo do mercado perfeito".

${ }^{151}$ Uma boa definição lato de "regulação" está em SZTAJN, Rachel. Regulação e o mercado de valores mobiliários, cit., p. 137: Regular significa formular e impor regras em forma de intervenção do Estado no domínio econômico. Essa matéria, regulação, interessa a diferentes áreas do conhecimento, particularmente ao direito e à economia. Regulação pode ser entendida como o conjunto de regras predispostas por um órgão ou agência de administração indireta, visando a fiscalizar e garantir, pela observância ou cumprimento, a disciplina de certas atividades ou setores da atividade econômica. Pode-se denominar regulação ao conjunto de normas visando determinado efeito ou, em sentido muito amplo, o conjunto de mecanismos de controle social. Vale notar que, nos termos da Instrução CVM 461/07, as regras estabelecidas pela Bolsa não são todas elas exemplos de auto-regulação. Existem regras emanadas pelas bolsas que não podem, do ponto de vista formal, serem definidas como atividade auto-reguladora. São apenas definidas como tal as regras relacionadas à fiscalização e supervisão das operações cursadas nos mercados organizados, nos termos do artigo 36 da Instrução CVM 461/07. 
e quase sempre com rápida implantação) em um microssistema próprio, com possibilidade de imposição de sanções aos seus participantes. ${ }^{152}$

A propósito da função normativa auto-reguladora das bolsas, há uma vertente (com a qual não concordamos) que reconhece o papel disciplinar delegado e complementar das entidades administradoras de bolsa. ${ }^{153}$ Assim, no Brasil, segundo este posicionamento, as bolsas seriam entidades incumbidas da fiscalização de seus respectivos membros e operações, na qualidade de auxiliares da CVM. ${ }^{154}$ Nosso raciocínio para discordar deste posicionamento, conforme MAFUD e PEREIRA FILHO, resume-se no seguinte:

\begin{abstract}
Muito embora inegável o interesse público da atividade bursátil, o serviço correspondente à atividade de administração de bolsa não é serviço público, pois não há norma que incumba o Estado de sua prestação. Nessa linha, entendemos que o artigo 17 da Lei 6.385/76 não pode ser interpretado como base legal para caracterização da atividade de administração de bolsa como serviço público delegado, pois se refere somente ao dever das entidades administradoras de bolsa, como auxiliares da CVM, de fiscalizar os membros e as operações do respectivo mercado administrado. Essa atividade de fiscalização constitui parcela da atividade de administração de bolsa e não pode ser confundida com a incumbência da CVM de exercer a fiscalização enquanto poder de polícia, que é atividade típica de Estado. A fiscalização exercida pelas entidades administradoras de bolsa, atividade privada, auxilia a Comissão a exercer o poder de polícia, atividade estatal. De qualquer modo, vale lembrar ainda que os conceitos de fiscalização e poder de polícia não coincidem com o conceito de serviço público. Ademais, o serviço correspondente à atividade de administração de bolsa não é prestado no Brasil pelo Poder Público, seja diretamente, seja sob regime de concessão ou permissão por meio de licitação. Não fosse assim, haveria patente inconstitucionalidade do regime legal e regulatório que vem sendo aplicado no Brasil a essas entidades, haja vista o artigo 175 da Constituição Federal. ${ }^{155}$
\end{abstract}

\footnotetext{
${ }^{152}$ GORGA, Erica Cristina Rocha. Direito societário atual. Rio de Janeiro: Elsevier, 2013. p. 77, ressalta que a lógica da regulação está ligada a questões de eficiência econômica, assimetria informacional e externalidades de mercado.

${ }^{153}$ COMPARATO, Fabio Konder. Natureza jurídica das bolsas de valores e delimitação do seu objeto. Revista de Direito Mercantil, Industrial, Econômico e Financeiro, São Paulo, n. 60, p. 45 e 47, out./dez. 19857 qualifica as bolsas como "autênticos agentes da Comissão" e prestadoras de "autêntico serviço público".

${ }^{154}$ GUERREIRO, José Alexandre Tavares. Sobre o poder disciplinar da CVM, in Revista de Direito Mercantil, Industrial, Econômico e Financeiro, São Paulo, n. 43, p. 72, jul./set. 1981: Preexistente à da própria CVM, a função disciplinar das Bolsas de Valores não se sobrepõe, contudo, à da Comissão, de vez que, com a reorganização do sistema de distribuição de valores mobiliários, procedida pela Lei 6.385/76, as Bolsas de Valores, dotadas embora de autonomia administrativa, financeira e patrimonial, passam a operar sob supervisão da autarquia, incumbindo-lhes, como órgãos auxiliares desta última, fiscalizar os respectivos membros e as operações nelas realizadas.

${ }^{155}$ MAFUD, Pedro Darahem; PEREIRA FILHO, Celso Roberto. op. cit., p. 6.
} 
Independente do reconhecimento das entidades administradoras de bolsa como prestadoras de serviço público, inegável e consensual é o interesse público que esta atividade desempenha. Uma das facetas recentes deste interesse público é a utilização da Bolsa $^{156}$ como propulsora do mercado de capitais, com a bem-sucedida experiência dos segmentos diferenciados de governança corporativa da Bovespa. ${ }^{157}$

Colocadas as funções das bolsas, as vertentes que as caracterizam e as polêmicas doutrinárias relacionadas ao conceito, cumpre-nos indagar quais seriam os aspectos que as diferenciam dos mercados de balcão, partindo-se do reconhecimento que ambos são locais de encontros entre compradores e vendedores.

Já em 1990, SZTAJN diferenciou o mercado de balcão do mercado de bolsa pela ausência do pregão e pela negociabilidade menos intensa. ${ }^{158}$ Se a ausência ou presença do pregão pouco importa nos dias atuais, parece-nos que a intensidade das negociações é um elemento de diferenciação ainda relevante. Nesse contexto, a padronização das operações de bolsa é, sem dúvida alguma, forte motivo para a criação de um mercado mais intenso, o que leva à formação de preços mais eficiente e a um mercado mais líquido.

Esta padronização ou não das operações como critério diferenciador de bolsa e balcão se reflete também nas operações com derivativos. Enquanto na bolsa, os derivativos negociados seguem modelos contratuais previamente definidos pelas entidades administradoras, no mercado de balcão existe maior flexibilidade para a definição dos tipos de contratuais (e respectivos ativos subjacentes), bem como dos próprios termos e condições contratuais e volumes negociados. ${ }^{159}$

Não se pode deixar de destacar que a centralização do processo de fechamento de negócios é outra característica da clássica diferenciação dos mercados de balcão e de

\footnotetext{
${ }^{156}$ YAZBEK, Otavio. Regulação do mercado financeiro e de capitais, cit., p. 214-215, calcado na Instrução CVM 461/07, explica que a criação de "segmentos diferenciados" de governança pela Bolsa não é uma atividade de auto-regulação formalmente reconhecida como tal, restando caracterizada como atividade negocial. Auto-regulação, em nosso regime, seriam as atividades de supervisão de mercado e de fiscalização e aplicação de penalidades (fundamentalmente, enforcement).

${ }^{157}$ Criou-se o Novo Mercado a partir de um diagnóstico dos motivos pelos quais o país possuía mercado de capitais tão fraco. Sobre tais causas e o sentimento à época do debate, vide: BLACK, Bernard S. Strengthening Brazil's securities market. Revista de Direito Mercantil, Industrial, Econômico e Financeiro, São Paulo, n. 120, out./dez. 2000.

${ }^{158}$ SZTAJN, Rachel. Contratos de bolsa, cit., p. 172.

${ }^{159}$ EIZIRIK, Nelson; GAAL, Ariádna B.; PARENTE, Flávia, HENRIQUES, Marcus de Freitas. Mercado de capitais: regime jurídico, cit., p. 113: Os contratos derivativos são negociados em bolsa e também no mercado de balcão. Nas bolsas, os contratos negociados são padronizados, observando termos e condições gerais estabelecidos pelas próprias bolsas. No mercado de balcão, por outro lado, eles são mais flexíveis, já que são normalmente celebrados entre uma instituição financeira e um cliente, de acordo com suas necessidades e interesses específicos.
} 
bolsa. ${ }^{160}$ A ausência de uma contraparte central ${ }^{161}$ para compensar e liquidar as operações e a possibilidade do fechamento direto de operações entre os agentes de mercado, sem intermediários - como é possível no mercado de balcão, também são elementos que historicamente o diferenciou da bolsa. ${ }^{162}$

Especificamente com relação às transações com derivativos, a possibilidade de negociação direta entre as partes, sem intermediários e com contratos "sob medida", possível apenas no ambiente de balcão, é apontada como o grande vetor dos processos de inovação financeira, onde o engenho e a criatividade humanos, pautados pela autonomia privada, instrumentalizam estratégias inovadoras conforme a necessidade das partes. ${ }^{163}$

A regra brasileira que trata dos mercados organizados de bolsa e de balcão, a Instrução CVM 461/07, positivou as duas diferenças acima apontadas entre bolsa e balcão, quais sejam, o volume negociado e a obrigatoriedade ou facultatividade de intermediários nas negociações. ${ }^{164}$ Não obstante, a regra da Comissão apontou outras diferenças, como a facultatividade de mecanismos de ressarcimento de prejuízos (que necessariamente estão presentes nas bolsas) e a possibilidade de divulgação a posteriori das informações relacionadas ao mercado de balcão (sem a pronta visibilidade e o pronto registro das

${ }^{160}$ YAZBEK, Otavio. A regulamentação das bolsas de valores e das bolsas de mercadorias e futuros e as novas atribuições da Comissão de Valores Mobiliários, cit., p. 204.

${ }^{161}$ YAZBEK, Otavio. Crise, inovação e regulação no mercado financeiro: considerações sobre a regulamentação do mercado de derivativos de balcão, cit., p. 15 as define como estruturas privadas destinadas a registrar as operações realizadas pelos seus participantes; assumir a posição de contraparte central para todas as operações (ou seja, de comprador para cada vendedor e de vendedor para cada comprador), compensando seus resultados de modo a ter uma única exposição líquida a cada participante; requerer as garantias e constituir as demais salvaguardas necessárias para assegurar o cumprimento das obrigações, evitando, assim, que o inadimplemento de qualquer contraparte afete os demais participantes do mercado.

${ }^{162}$ YAZBEK, Otavio. Crise, inovação e regulação no mercado financeiro: considerações sobre a regulamentação do mercado de derivativos de balcão, cit., p. 4, acrescenta que a definição de balcão como ambiente descentralizado, em que os negócios são fechados diretamente entre as partes, com maior capacidade de conformação dos termos e condições das operações, deve ser aceita com algumas ressalvas, já que se tem notícias, cada vez mais, de sistemas mais ou menos centralizados também para as operações de balcão.

${ }^{163}$ YAZBEK, Otavio. Crise, inovação e regulação no mercado financeiro: considerações sobre a regulamentação do mercado de derivativos de balcão, cit., p. 5 aponta a menor regulamentação das operações de balcão e seu menor custo como estimuladores da utilização do mercado de balcão em detrimento das bolsas. Esta constatação é verdadeira, sobretudo nos Estados Unidos, onde o mercado de derivativos de balcão é extremamente desregulamentado - conforme explorado em outras partes deste trabalho.

${ }^{164}$ COMISSÃO DE VALORES MOBILIÁRIOS. Instrução $n .^{\circ} 461$, de 23 de outubro de 2007. Disponível em: <www.cvm.gov.br>. Acesso em: 23 fev. 2013. Art. $5^{\circ}$. Um mercado organizado de valores mobiliários será considerado pela CVM como de bolsa ou de balcão organizado dependendo, principalmente, do seguinte: I -existência de sistema ou ambiente para o registro de operações realizadas previamente; II regras adotadas em seus ambientes ou sistemas de negociação para a formação de preços, conforme descrito nos arts. 65 e 73, no caso de bolsa, e arts. 95 e 96, no caso de balcão organizado; III possibilidade de atuação direta no mercado, sem a intervenção de intermediário; IV -possibilidade de diferimento da divulgação de informações sobre as operações realizadas; $V$-volume operado em seus ambientes e sistemas; e VI-público investidor visado pelo mercado. Parágrafo único. As características de que tratam os incisos I, III e IV só são admitidas para os mercados de balcão organizado, na forma prevista, respectivamente, nos arts. 92, inciso III, 93 e 105 desta Instrução. 
operações - o que necessariamente ocorreria nos sistemas de bolsa e traz impactos diretos nas cotações).

Em síntese, podemos concluir que, historicamente, mercados de balcão são muito semelhantes a mercados de bolsa, na medida em que ambos são mercados organizados e centros de liquidez, sendo elementos distintivos entre eles o volume de valores negociados, a ausência ou presença de padronização das operações e a sofisticação dos mecanismos por eles empregados (seja pela ausência de intermediários e contraparte central, seja pela ausência de sistema de transparência de preços tão eficaz). Vale ressaltar que ambos possuem necessariamente estrutura própria de auto-regulação, ${ }^{165}$ tendo a estrutura das bolsas, atualmente, no país, exigências mais complexas.

No Brasil, o mercado de derivativos conta com apenas uma bolsa de valores, mercadorias e futuros, a BM\&F Bovespa, e dois mercados de balcão organizados, a CETIP e a própria BM\&F Bovespa, também autorizada a negociar derivativos de balcão. Ambas as entidades, além de representarem mercados organizados de bolsa e balcão, são companhias abertas com ações negociadas em bolsa de valores.

A possibilidade das bolsas de valores, mercadorias e futuros possuírem a forma de sociedades anônimas data do ano $2000^{166}$, mas este movimento foi efetivamente tomado pela Bovespa e pela BM\&F, então duas diferentes entidades, apenas em $2007 .{ }^{167}$

Na esteira da tendência mundial de desmutualização ${ }^{168}$ iniciada no início dos anos 2000, a exemplo do que ocorreu em outros países, também surgiram no Brasil dúvidas e certo ceticismo com relação a este movimento. O cerne da indagação estava no antagonismo que as atividades de geração de lucro e auto-regulação possuem: o conflito de interesses clássico entre os objetivos comerciais e o interesse público. ${ }^{169}$

\footnotetext{
${ }^{165}$ YAZBEK, Otavio. Regulação do mercado financeiro e de capitais, cit., p. 211-216 traz brilhante exposição sobre o conceito de "auto-regulação".

${ }^{166}$ BANCO CENTRAL DO BRASIL. Conselho Monetário Nacional. Resolução n. ${ }^{\circ} 2.690$, de 28 de janeiro de 2000. Disponível em: <www.bacen.gov.br>. Acesso em: 22 maio 2011.

${ }^{167}$ Sobre o histórico detalhado da BM\&F e da Bovespa, recomendamos a leitura de YAZBEK, Otavio. A regulamentação das bolsas de valores e das bolsas de mercadorias e futuros e as novas atribuições da Comissão de Valores Mobiliários, cit.

${ }^{168}$ Desmutualização é a expressão utilizada pelo mercado para designar a transformação das bolsas, então associações civis sem fins lucrativos, em sociedades anônimas, empresariais por excelência.

${ }^{169}$ Cf. BOLSA de Valores S.A. Revista Capital Aberto, ano 3, n. 35, jul. 2006. Disponível em: <http://www.capitalaberto.com.br>. Acesso em: 21 fev. 2013, algumas questões foram colocadas à época acerca do movimento de desmutualização das bolsas. Em primeiro lugar, o receio de que a pressão por resultados, típica de qualquer companhia aberta, pudesse interferir nos padrões de listagem ou na supervisão das empresas listadas. Adicionalmente, alertou-se que a Bolsa, em uma situação monopolista de
} 
Como dito, as desmutualizações da BM\&F e da Bovespa ocorreram, finalmente, em 2007 e foram seguidas por aberturas de capital das duas novas companhias e, na sequência, em 2008, por uma junção entre as duas entidades, que formaram a atual e única Bolsa do mercado brasileiro, a BM\&F Bovespa.

Após esse movimento, algumas das preocupações decorrentes da interação entre interesse público e necessidade de lucro foram reforçadas, como por exemplo, a questão do monopólio (muito embora existam sinais de sua provável quebra, ${ }^{170}$ um movimento já no radar da Comissão). ${ }^{171}$ Outras preocupações foram dissipadas, sobretudo pela implementação de reformas regulatórias, como a Instrução CVM 461/07, ${ }^{172}$ enquanto novas questões surgiram (como o movimento de consolidação das bolsas mundiais e essa eventual implicação no cenário brasileiro).

Enquanto a única bolsa brasileira atual é fruto da união entre BM\&F e Bovespa, as quais, por seu turno, são frutos da consolidação de outras bolsas nelas próprias, ${ }^{173}$ cujas origens sempre tiveram forte conteúdo privado e corporativista de união entre corretores, ${ }^{174}$ a história da CETIP é um pouco diferente e muito mais recente.

\footnotetext{
mercado, poderia abusar dessa posição natural para aumentar as tarifas cobradas dos agentes regulados, que não teriam opção de listagem diversa. Outra dúvida recorrente dizia respeito ao incentivo que uma companhia aberta teria para aplicar recursos financeiros no contínuo desenvolvimento do mercado (por exemplo, em campanhas educativas), cujos resultados demoram muito tempo a aparecer, em detrimento de outras atividades cujos resultados sejam mais plausíveis aos investidores no balanço do exercício seguinte. Além disso, determinadas dúvidas surgiram com relação à supervisão da Bolsa, enquanto agente listado, pela própria Bolsa, enquanto agente regulador, na medida em que a auto-supervisão pode ser uma tarefa incrédula para os espectadores e inglória para o agente com dupla função de regulador e regulado. Por fim, a aplicação injustificada de multas aos participantes do pregão e a possibilidade de cerceamento dos concorrentes em áreas que a Bolsa dominava também se apresentaram como preocupações legítimas do mercado.

${ }^{170}$ BOLSAS em transição. Revista Capital Aberto, ano 10, n. 114, fev. 2013. Disponível em: $<$ http://www.capitalaberto.com.br>. Acesso em: 21 fev. 2013.

${ }^{171}$ COMISSÃO DE VALORES MOBILIÁRIOS. Relatório da Consultoria Oxera sobre os custos e benefícios para mudar a estutura competitiva do mercado para serviços de negociação e pós-negociação no Brasil, de junho de 2012. Disponível em: <http://www.cvm.gov.br/port/Public/publ/Oxera\%20report\%20180612\%20Portuguese\%20version.pdf>. Acesso em: 25 fev. 2013. COMISSÃO DE VALORES MOBILIÁRIOS. Edital de Audiência Pública 05/13, de 13 de junho de 2013. Disponível em: <www.cvm.gov.br>. Acesso em: 07 jul. 2013.

${ }^{172}$ Vale mencionar aqui a existência da BM\&F Bovespa Supervisão de Mercados (BSM), associação civil, que atua na análise, supervisão e fiscalização dos agentes do mercado, com orçamento próprio e independência do seu quadro de funcionários.

${ }^{173}$ Sobre o histórico da BM\&F e da Bovespa, cf. YAZBEK, Otavio. A regulamentação das bolsas de valores e das bolsas de mercadorias e futuros e as novas atribuições da Comissão de Valores Mobiliários, cit.

${ }^{174}$ Sobre as origens das bolsas no Brasil, recomenda-se BARRETO FILHO, Oscar. Natureza jurídica das bolsas de valores no direito brasileiro. Revista de Direito Bancário, do Mercado de Capitais e da Arbitragem, São Paulo, n. 12, 2001. (Ed. Original, 1959).
} 
Instituída em 1984, ${ }^{175}$ a CETIP passou a operar a partir de 1986 como uma associação civil para negociação de títulos privados do mercado inter-bancário, cujos associados eram as próprias instituições financeiras. Em 2008, nos moldes do que ocorreu com a Bovespa e a BM\&F, também passou por um processo de desmutualização e, em 2009, tornou-se companhia de capital aberto.

Com o tempo, a CETIP diversificou as suas atividades e passou a atuar em diferentes frentes, tais como registros de transações, central depositária de títulos e valores mobiliários, plataforma de negociações, liquidação, gestão de risco, dados de mercado e desenvolvimento de soluções. Em 31 de dezembro de 2012, era a maior registradora, depositária e plataforma eletrônica para ativos de renda fixa e derivativos de balcão da América Latina. ${ }^{176}$

Caso qualquer agente negocie, por conta própria e de terceiros, derivativos no Brasil, ele necessariamente baterá às portas da CETIP ou da BM\&F Bovespa, as duas entidades descritas acima. ${ }^{177}$ Esta constatação decorre do nosso arcabouço regulatório que, além de definir todos os derivativos como valores mobiliários sujeitos à competência da Comissão, ${ }^{178}$ independentemente da forma como negociados ou oferecidos ao público, ${ }^{179}$ também exige o registro de quaisquer transações como condição de validade dos derivativos. $^{180}$

\footnotetext{
${ }^{175}$ BANCO CENTRAL DO BRASIL. Conselho Monetário Nacional. Resolução n. 981, de 13 de dezembro de 1984. Disponível em: <www.bacen.gov.br>. Acesso em: 20 fev. 2013, é apontada como pontapé inicial dado pelo CMN para a criação da CETIP.

${ }^{176}$ CETIP S.A. Mercados Organizados. Apresentação Institucional do $2^{\circ}$ Trimestre de 2012. Disponível em: $<$ http://cetip.infoinvest.com.br/ptb/756/ApresentaoInstitucional_2T12.pdf>. Acesso em: 25 fev. 2013.

${ }^{177}$ Além da Lei 12.543/11, alteradora da Lei 6.385/76 e fruto da conversão da Medida Provisória 539/11, que elegeu o registro como condição de validade dos derivativos, e da Lei 12.810/13, importantes normativos nesse sentido são: (i) COMISSÃO DE VALORES MOBILIÁRIOS. Instrução CVM n. ${ }^{\circ} 467$, de 10 de Abril de 2008. Disponível em: <www.cvm.gov.br>. Acesso em: 22 fev. 2013; e (ii) BANCO CENTRAL DO BRASIL. Conselho Monetário Nacional. Resolução n. ${ }^{\circ} 3.505$, de 26 de outubro de 2007. Disponível em: $<$ http://www.bcb.gov.br/pre/normativos/res/2007/pdf/res_3505_v1_O.pdf >. Acesso em: 20 fev. 2013.

${ }^{178}$ A Lei $10.303 / 01$ definiu, no artigo $15^{\circ}$ da Lei $6.385 / 76$, todos os agentes que operam no sistema de distribuição de valores mobiliários como sujeitos ao regime da CVM.

${ }^{179}$ Derivativos são valores mobiliários porque definidos como tal, conforme tema explorado no capítulo IV.C do presente trabalho. Não se pode falar em "apelo à poupança popular" para os derivativos, na medida em que derivativos são instrumentos financeiros de transferência de riscos, enquanto outros valores mobiliários clássicos, estes sim, são instrumentos de captação da poupança pública. Mas podemos aqui nos referir ao apelo público de alguns derivativos - os de bolsa - que estão disponíveis a todos e são propagandeados sem restrições. De qualquer forma, os derivativos de balcão (frutos da autonomia privada e não padronizados), ainda que não tenham apelo público, são também valores mobiliários e, assim, sujeitos às regras da Comissão.

${ }^{180}$ A Lei 12.543/11, alteradora da Lei 6.385/76 e fruto da conversão da Medida Provisória 539/11, deu competência ao CMN para estabelecer condições específicas para a negociação de derivativos, independentemente da natureza do investidor.
} 
Vale ressaltar ainda que, nos termos da Instrução CVM 467/08, todos os modelos de contratos derivativos admitidos à negociação em mercado organizado devem ser aprovados pela CVM ou, caso a negociação se dê entre particulares mas com o registro no mercado organizado, pela respectiva entidade administradora do mercado organizado. ${ }^{181}$

Além das diferenças decorrentes das próprias peculiaridades inerentes aos conceitos de bolsa e balcão acima descritas, tais como a possibilidade ou impossibilidade de negociação direta entre os contratantes, os derivativos de balcão apresentam outras distinções com relação aos derivativos de bolsa.

Em primeiro lugar, cumpre ressaltar que os derivativos de balcão são contratos customizados ou, no jargão de mercado, contratos tailor made. Pode-se, em teoria, negociar qualquer tipo de derivativo (ou combinação de derivativos, as chamadas “estratégias”) em balcão, sem limitações para os potenciais ativos subjacentes. ${ }^{182}$

Os derivativos de bolsa, por seu turno, são contratos padronizados, sendo impossível aos negociantes definirem, por exemplo, o ativo subjacente ou a data de vencimento. Nestes casos, o investidor escolherá apenas a quantidade do contrato já padronizado pela bolsa.

Outro ponto de diferenciação dos derivativos de balcão frente aos de bolsa, relacionado às duas peculiaridades acima descritas (negociação direta entre os contratantes e contratos customizados), é o fato de, via de regra, inexistir depósito de margem ${ }^{183}$ ou

\footnotetext{
${ }^{181}$ Nos termos da Instrução CVM 467/08, derivativos negociados diretamente entre as partes e somente registrados em mercado de balcão organizado (ou seja, sem negociação no mercado de balcão, mas apenas com o seu registro) devem ser aprovados apenas pela entidade administradora de tal mercado de balcão, observados determinados critérios previamente estabelecidos pela Comissão. Esta providência de delegação de competência (que alia a flexibilidade necessária ao mercado de balcão sem abrir mão de supervisão), aliada ao fato de que os derivativos negociados pelos ou com intermediação dos grandes players do mercado, as instituições financeiras ou equiparadas, devem necessariamente ser registrados em mercado de balcão, faz com que o Brasil tenha um mercado em certa medida padronizado e transparente do ponto de vista de divulgação de informações, inexistindo um shadow market.

${ }^{182}$ No Brasil, tais "infinitas" possibilidades de derivativos são teóricas, pois a possibilidade de negociação do derivativo de balcão deve encontrar amparo nos manuais e regras internas da CETIP ou da BM\&F Bovespa. Vale ressaltar que existe uma grande flexibilidade e esforço adaptativo pelas entidades administradoras para as inovações do mercado.

${ }^{183} \mathrm{O}$ depósito de margem ou depósito de garantia é uma exigência típica de estruturas de bolsa, tendo em vista a existência de contraparte central liquidante das operações, que assume as obrigações dos participantes do mercado organizado em caso de inadimplemento. Para que a bolsa consiga selecionar seus participantes (com exigência prévia de determinado padrão de liquidez, consubstanciado nas garantias prévias exigíveis de alguém para que ele esteja apto a operar em tal mercado) e para que a contraparte central possa, caso necessário, fazer frente às obrigações de seus participantes, é necessário que existam recursos à sua disposição. Nessa linha, as garantias ou margens são fundamentais para o bom funcionamento do sistema.
} 
ajustes diários, ${ }^{184}$ restando o risco de inadimplemento de uma das partes totalmente nas mãos de sua contraparte do balcão (ainda que exista intermediário na operação). ${ }^{185}$

No mercado de bolsa, ao contrário, tem-se a figura da contraparte central ${ }^{186} \mathrm{e}$ necessariamente também a dos intermediários (corretores, por exemplo), que serão, em última instância, os responsáveis pelo pagamento em caso de inadimplemento de um dos contratantes do derivativo. Por esse motivo, as corretoras intermediárias das negociações são as maiores interessadas em que todas as regras da bolsa sejam cumpridas, como, por exemplo, as relacionadas ao "chamamento" de margem adicional ou ao tempestivo envio dos ajustes diários, conforme a evolução do preço dos ativos subjacentes. Também por isso, as corretoras são obrigadas a manter perante a bolsa determinadas garantias. ${ }^{187}$

Assim, em bolsa, em que apenas contratos padronizados de massa são negociados, com apelo ao grande público, o risco de crédito dos negociadores de derivativos é satisfatoriamente mitigado pelo arranjo sistêmico da contraparte central e dos intermediários. Atualmente, a liquidação por meio de contraparte central não é exigida para os derivativos de balcão, mas estuda-se a possibilidade de ampliação deste mecanismo também para estes instrumentos, em linha com os debates internacionais. ${ }^{188}$

\footnotetext{
${ }^{184} \mathrm{Via}$ de regra, a maioria das operações de bolsa (como os futuros, por exemplo) possui ajuste diário. No entanto, há exceções como, por exemplo, as opções negociadas na BM\&F Bovespa que possuem liquidação apenas em seu vencimento. Já no balcão, a regra é oposta, ou seja, a regra é ter ajuste apenas no vencimento. Contudo, em raras exceções, há ajustes periódicos nas operações cursadas na CETIP que, no limite, podem ocorrer diariamente.

${ }^{185}$ A existência de intermediários no mercado CETIP é facultativa. Via de regra, não há intermediários nas operações atualmente cursadas na CETIP. Ainda que exista a figura do intermediador no mercado de balcão CETIP (conforme permitido por suas regras), sua função é tão somente encontrar uma contraparte para a operação pretendida, jamais garantindo a liquidação financeira da operação (ao contrário do mercado de bolsa, em que as corretoras intermediárias podem ser chamadas a assumir a liquidação financeira).

${ }^{186}$ Vale mencionar que as operações de balcão podem, caso contratado pelas partes, dispor de sistema de clearing. Tal faculdade da contraparte central outorgada aos agentes do mercado de balcão é o que se denomina "operação com garantia". Sobre os motivos da pouca utilização desta faculdade pelos agentes de mercado (custos, padronização, mercado ilíquido), sugere-se a leitura de YAZBEK, Otavio. Crise, inovação e regulação no mercado financeiro: considerações sobre a regulamentação do mercado de derivativos de balcão, cit., p. 23-25.

${ }^{187}$ WALD, Arnoldo. O mercado de opções e a responsabilidade das corretoras. Revista de Direito Bancário e do Mercado de Capitais, São Paulo, n. 61, jul./set. 2013, trata do poder-dever das corretoras de liquidar posições de seus clientes inadimplentes, bem como excutir as garantias (margens) no mercado de opções.

${ }^{188} \mathrm{Cf}$. COMISSÃO DE VALORES MOBILIÁRIOS. Decisão Conjunta CVM e Bacen n. ${ }^{\circ} 18$, de 15 de julho de 2013. Disponível em: <www.cvm.gov.br>. Acesso em: 15 jul. 2013, que criou grupo de trabalho para estudar a viabilidade e a conveniência da adoção da liquidação obrigatória por contrapartes centrais de operações realizadas no mercado de derivativos, mesmo os de balcão: A infraestrutura do mercado de derivativos doméstico se encontra em estágio de desenvolvimento mais avançado do que as de outros países, uma vez que todas as operações realizadas no Brasil devem ser registradas em bolsas ou entidades de registro e de liquidação financeira de ativos devidamente autorizadas e, no que concerne especificamente à exigência de liquidação por meio de contraparte central, a maior parte dos contratos de derivativos contratados no país já são liquidados dessa forma.
} 
Conforme YAZBEK, a menor regulamentação das operações de balcão e a existência de custos adicionais para se operar em ambiente de bolsa, como os depósitos de garantias ou margem e as liquidações periódicas ou ajustes, são motivos pelos quais, no mundo, os volumes negociados em mercado de balcão são muito maiores que os volumes negociados em bolsa. ${ }^{189}$ Diferentemente, no Brasil, a maior parte das operações é realizada em bolsa - talvez pelo fato de o mercado de balcão ser, no país, também muito regulado, conforme descrito ao longo deste capítulo, e sobretudo, pela relativa incipiência de grandes players típicos deste mercado. ${ }^{190}$

${ }^{189}$ YAZBEK, Otavio. Crise, inovação e regulação no mercado financeiro: considerações sobre a regulamentação do mercado de derivativos de balcão, cit., p. 4-6.

${ }^{190}$ BAKER, Colleen M. Regulating the Invisible: the Case of Over-the-Counter Derivatives. Notre Dame Law Review. v. 85, Nov. 2010. Disponível em: <http://papers.ssrn.com/sol3/papers.cfm?abstract_id=1739882>. Acesso em: 10 jun. 2011, relata a necessidade de maior regulação dos derivativos de balcão, defendendo reformas e maior cooperação internacional. 


\title{
IV. ASPECTOS JURÍDICOS DOS DERIVATIVOS
}

\author{
IV.A. Distanciamento do Jogo e Aposta
}

Muito se discutiu sobre a aplicabilidade das regras atinentes ao jogo e à aposta para os derivativos. ${ }^{191}$ A polêmica era de fato relevante, o que levou o legislador pátrio a dedicar um artigo do Código Civil brasileiro, quando de sua reforma em 2002, no âmbito do capítulo específico sobre esta matéria, ${ }^{192}$ para, finalmente, dirimir a controvérsia:

\begin{abstract}
Art. 816 do Código Civil Brasileiro. As disposições dos arts. 814 e 815 não se aplicam aos contratos sobre títulos de bolsa, mercadorias ou valores, em que se estipulem a liquidação exclusivamente pela diferença entre o preço ajustado e a cotação que eles tiverem no vencimento do ajuste.
\end{abstract}

\footnotetext{
${ }^{191}$ A polêmica equiparação dos mercados especulativos ao jogo e aposta não é nova e nem exclusividade brasileira. Cf. HAZEN, Thomas Lee. Disparate regulatory schemes for parallel activities: securities regulation, derivatives regulation, gambling, and insurance. Annual Review of Banking \& Financial Law, Boston, v. 24, p. 402-403, 2005: The analogy between investment markets and gambling has been made by others but not in a way which indicates that there should be a greater parallel in applicable regulatory structures. For example, in a letter to President Washington, Thomas Jefferson wrote: "the wealth acquired by speculation and plunder is frugacious in its nature and fills society with the spirit of gambling". More than a century later, Theodore Roosevelt commented that " $[t]$ here is no moral difference between gambling at cards and in lotteries or on the race track and gambling in stock market. One method is just as pernicious to the body politic as the other in kind, and in degree the evil worked is far greater". The analogy has not been limited to policymakers and politicians. John Maynard Keynes observed: "It is usually agreed that casinos should, in the public interest, be inaccessible and expensive. And perhaps the same is true of Stock Exchanges". As diferentes sociedades, conforme seus valores e ao sabor de diferentes épocas, positivam o tratamento a certas condutas sociais, de modo a incentivá-las ou coibi-las, em movimentos de política pública. Se a atividade de bolsa de valores já foi encarada no passado como cassino no berço do capitalismo, a situação hoje é muito diferente.

${ }^{192}$ BRASIL. Lei n. ${ }^{\circ}$ 10.406, de 10 de janeiro de 2002. Institui o Código Civil. Disponível em: <http://www.planalto.gov.br>. Acesso em: 22 maio 2011. Parte Especial, Livro I (Direito das Obrigações), Título VI (Das Várias Espécies de Contrato), Capítulo XVII (Do Jogo e da Aposta). Art. 814. As dívidas de jogo ou de aposta não obrigam a pagamento; mas não se pode recobrar a quantia, que voluntariamente se pagou, salvo se foi ganha por dolo, ou se o perdente é menor ou interdito. § $1^{\circ}$ Estende-se esta disposição a qualquer contrato que encubra ou envolva reconhecimento, novação ou fiança de dívida de jogo; mas a nulidade resultante não pode ser oposta ao terceiro de boa-fé. $\S 2^{\circ} O$ preceito contido neste artigo tem aplicação, ainda que se trate de jogo não proibido, só se excetuando os jogos e apostas legalmente permitidos. $\$ 3^{\circ}$ Excetuam-se, igualmente, os prêmios oferecidos ou prometidos para o vencedor em competição de natureza esportiva, intelectual ou artística, desde que os interessados se submetam às prescrições legais e regulamentares. Art. 815. Não se pode exigir reembolso do que se emprestou para jogo ou aposta, no ato de apostar ou jogar. Art. 816. As disposições dos arts. 814 e 815 não se aplicam aos contratos sobre títulos de bolsa, mercadorias ou valores, em que se estipulem a liquidação exclusivamente pela diferença entre o preço ajustado e a cotação que eles tiverem no vencimento do ajuste. Art. 817. O sorteio para dirimir questões ou dividir coisas comuns considera-se sistema de partilha ou processo de transação, conforme o caso.
} 
Não obstante esta questão classificatória restar sepultada ${ }^{193}$ pela via legislativa, ${ }^{194}$ é importante discorrermos sobre esta controvérsia tão importante para a formação e sedimentação do conceito jurídico dos derivativos. A impressão que se tem é que, por muito tempo, os derivativos eram frequentemente objeto de análise pelos juristas brasileiros preponderantemente por conta deste artigo.

O revogado Código Civil de 1916 inaugurou a discussão quando equiparou ao jogo os contratos sobre títulos de bolsa, mercadorias ou valores, em que se estipule a liquidação exclusivamente pela diferença entre o preço ajustado e a cotação que eles tiverem, no vencimento do ajuste. ${ }^{195}$

Preliminarmente, vale destacar o conceito genérico do jogo e da aposta, dois institutos unidos pelo fator "sorte", em que uma parte se obriga a pagar algo a outra conforme o resultado de um evento futuro e fortuito. A maioria da doutrina civilista ${ }^{196}$ enxerga no jogo e na aposta caráter contratual (bilateral, oneroso e aleatório), na medida em que existe um acordo de vontades contrapostas em relação a um objeto. ${ }^{197}$

Existem inúmeras teorias que diferenciam o jogo da aposta, fundadas em diversos parâmetros. Segundo o critério do motivo, a aposta buscaria provar uma afirmação ou confirmar um fato, ao passo que o jogo visaria um ganho apenas. Pelo critério da participação, na aposta inexistiria qualquer atitude ou ação dos contratantes, sendo no jogo tal participação mais ativa. De acordo com a característica da álea, os jogadores criam ou assumem risco que outrem criou, enquanto na aposta o risco pode ser anterior e sem origem humana. Essas são apenas algumas teorias que, ao lado das teorias do fim lúdico e

\footnotetext{
${ }^{193}$ Este "sepultamento" da polêmica é relativizado pela menção expressa apenas aos derivativos de bolsa, deixando os derivativos de balcão de fora. De qualquer modo, resta inegável sua aplicabilidade a quaisquer derivativos.

${ }^{194}$ SZTAJN, Rachel. Regulação e o mercado de valores mobiliários, cit., p. 144, discorda desta posição. Para a autora, a nova redação não resolve o problema pois, de um lado, não estende a regra a contratos fora de bolsa (por não mencionar operações em balcão, por exemplo), e, de outro, não abarca aqueles derivativos em que não haja a previsão de liquidação exclusivamente por diferença.

${ }^{195}$ BRASIL. Lei n. ${ }^{\text {3 3.071, de }} 01$ de janeiro de 1916, instituiu o Código Civil, hoje revogado. Disponível em: <www.planalto.gov.br>. Acesso em: 05 jan. 2013. Parte Especial, Livro III (Do Direito das Obrigações), Título II (Dos Efeitos das Obrigações), Capítulo XV (Do Jogo e da Aposta). Art. 1.479 (revogado): São equiparados ao jogo, submetendo-se, como tais, ao disposto nos artigos antecedentes, os contratos sobre títulos de bolsa, mercadorias ou valores, em que se estipule a liquidação exclusivamente pela diferença entre o preço ajustado e a cotação que eles tiverem, no vencimento do ajuste.

${ }^{196}$ RODRIGUES, Silvio. Dos Contratos e das declarações unilaterais da vontade. 30. ed. São Paulo: Saraiva, 2004, é exemplo de civilista que não concorda com a natureza contratual do jogo e da aposta, calcado na negação de efeitos que a lei lhes nega.

${ }^{197}$ SAMPAIO, Francisco José Marques. Mercados derivativos: aspectos jurídicos e suas semelhanças e dessemelhanças com o jogo e a aposta. Revista de Direito Privado, São Paulo, v. 3, n. 9, p. 207-108, jan./mar. 2002.
} 
da relevância do resultado, tentam distinguir o jogo da aposta. ${ }^{198}$ Destaque-se que o legislador brasileiro equiparou tais contratos, no famigerado artigo 1.479, a uma categoria de jogo e não de aposta.

Entendemos que os possíveis traços distintivos do jogo e da aposta são irrelevantes, sendo, na realidade, os efeitos e as (não) consequências destes dois tipos contratuais seus elementos unificadores e os motivos pelos quais o jogo e a aposta são tão peculiares no ordenamento jurídico.

Sobre os efeitos, PONTES DE MIRANDA esclarece que os jogos proibidos e as apostas proibidas sequer vinculam ou, em outras palavras, não criam relações jurídicas. Já os jogos não proibidos e as apostas não proibidas, via de regra, ${ }^{199}$ vinculam, porém, não criam pretensão, ou, em outras palavras, está-se diante de dívida sem obrigação. ${ }^{200}$ Assim, a inexigibilidade e a falta de coercibilidade do jogo e da aposta são os traços definidores do instituto.

O revogado Código Bevilaqua ${ }^{201}$ de 1916 buscava inibir uma negociação que, pela sua aparente álea total, poderia caracterizar uma prática de jogo, de modo a impedir a institucionalização de tais operações e, assim, desestimular o desenvolvimento das operações a termo com títulos ou mercadorias. ${ }^{202}$

Para driblar o inconveniente texto legislativo de 1916, no contexto de um mercado de derivativos nascente e cada vez mais pujante, muito antes da promulgação do Código Reale (que, a nosso ver, resolveu essa questão), a doutrina e a jurisprudência valiam-se dos mais variados (e até surpreendentes) argumentos. Tais linhas de defesa iam desde a função social das bolsas, passando pelo peculiar sistema de liquidações e garantias aplicável aos derivativos e pela possibilidade de entrega física do bem negociado, até a superação legislativa pelos usos e costumes, assim entendido como a usual prática dos negócios e sua importância econômica.

\footnotetext{
${ }^{198}$ Cf. PONTES DE MIRANDA, Francisco Cavalcanti. Tratado de direito privado: parte especial. Rio de Janeiro: Borsoi, 1964. v. 45, p. 231-234.

${ }^{199}$ Id. Ibid., p. 223, esclarece que leis especiais podem estabelecer que as dívidas oriundas de determinados jogos ou apostas tenham pretensão e ação. Como exemplo de tais contratos, temos a loteria, que é não só permitida e autorizada.

${ }^{200}$ Id., loc. cit.

${ }^{201}$ Cf. Id. Ibid., p. 246, o artigo 1.479 do Código Civil brasileiro equivalia ao Parágrafo 764 do Código Civil alemão e ao artigo 513, $2^{\text {a }}$ alínea do Código das Obrigações suíço.

${ }^{202}$ Cf. EIZIRIK, Nelson; GAAL, Ariádna B.; WALD, Arnold. Das funções econômicas dos mercados a termo e do Projeto de Código Civil, cit., p. 323.
} 
Uma das construções mais utilizadas à época baseou-se na natureza jurídica das bolsas de valores, mercadorias e futuros, que supostamente teriam função pública ${ }^{203}$ e poder normativo delegado para fiscalizar e punir seus próprios membros. ${ }^{204}$ Nessa argumentação, a existência de um ambiente regulado, eivado de legitimidade (seja governamental, seja negocial), afastaria a equiparação dos derivativos aos contratos de jogo. ${ }^{205}$

Dando continuidade a essa argumentação, a publicidade dada pelo arranjo institucional das bolsas, dotado de clearing houses (cuja responsabilidade é objetiva, na qualidade de contraparte central de compradores e vendedores), a existência de mecanismos de ajustes de preços diários, a obrigatoriedade de prestação de fiança pelos participantes do ambiente bursátil, além do depósito de margens e outras garantias, seriam a senha para afastar os derivativos da idéia de pura especulação que permeia o jogo e a aposta. ${ }^{206}$

Outra resposta comum para afastar o revogado artigo 1.479 dos derivativos dizia respeito à não subsunção do assunto à lei civil. Os derivativos deveriam ser entendidos como contratos atípicos, ainda não disciplinados em lei, cuja interpretação seria consoante os princípios do direito e os usos e costumes do comércio. ${ }^{207}$

Nessa linha de argumentação, PONTES DE MIRANDA já defendia serem eficazes os negócios jurídicos de diferença levados a cabo no ambiente bursátil, conforme os regulamentos de cada bolsa. De acordo com o civilista, o revogado artigo 1.479 equiparava ao jogo apenas os negócios jurídicos de diferença que utilizavam os "preços da bolsa", assim entendidos como "preços de mercado", como balizadores de cálculos - sendo, desse modo, estes negócios jurídicos (fora do ambiente bursátil) apenas tolerados (com eficácia diminuída porque carentes de pretensão). Dessa forma, os contratos diferenciais existentes no ambiente regulado de cada bolsa teriam eficácia plena, não se confundindo com a

\footnotetext{
${ }^{203}$ A despeito do paradigmático texto do professor Comparato, não concordamos que as bolsas possuem natureza jurídica de serviço público, embora inegável o interesse público que essa atividade representa: (i) Cf. COMPARATO, Fabio Konder. op. cit.; (ii) Cf. MAFUD, Pedro Darahem; PEREIRA FILHO, Celso Roberto. op. cit., p. 6.

${ }^{204}$ SAMPAIO, Francisco José Marques. op. cit., p. 111-112.

${ }^{205}$ Id. Ibid., p. 114: Somando-se a natureza jurídica e função pública das bolsas de derivativos com a competência de fiscalização às negociações, bem como a aplicação imediata de sanções aos infratores das regras, juntamente com o sistema de oferta de garantias e ajustes diários, torna-se insustentável a tese que afirma serem as operações realizadas no pregão de tais entidades equiparadas ao jogo.

${ }^{206}$ SZTAJN, Rachel. Contratos de bolsa, cit., p. 176-178.

${ }^{207}$ Cf. OLIVEIRA, Fernando Albino de. op. cit., p. 226, ao descrever os contratos futuros. Cf. EIZIRIK, Nelson. Negócio jurídico de hedging. Revista de Direito Mercantil, Industrial, Econômico e Financeiro, São Paulo, v. 32, n. 90, p. 21, abr./jun. 1993, também ao descrever sobre os efeitos de "hedging" com contratos a futuro.
} 
permissão para o jogo e sim como garantia. ${ }^{208}$ Com esse raciocínio, até um dos maiores civilistas brasileiros, valendo-se de grande esforço interpretativo, buscou construir uma teoria para afastar a incidência do incoveniente artigo 1.479 aos derivativos cursados em ambiente de bolsa de valores, mercadorias e futuros.

A possibilidade de entrega física da coisa ou do pagamento pela diferença de preço era outro argumento utilizado para afastar a incidência do polêmico artigo 1.479 aos derivativos de bolsa, dado o vocabulário "exclusivamente" no comando normativo. ${ }^{209}$ Solução esta, ainda que naive, agradava aos positivistas, mas era insuficiente. Com a sofisticação do mercado, como ficariam os contratos de derivativos de índices, taxas ou outros bens intangíveis? Mesmo no caso de mercadorias, seria plausível ou desejável imaginar a entrega de bois ou sacas de café no pregão?

À conveniência do tempo, muitas foram as linhas de argumentação para se afastar a incidência do hoje revogado artigo 1.479 aos derivativos. Todas elas construções brilhantes e bem intencionadas, mas, incapazes de apagar o inoportuno comando legislativo. ${ }^{210}$

A tutela do jogo e da aposta pelo Direito é explicada pela criação de relações entre particulares (não necessariamente patrimoniais), ainda que tais relações sejam criadas em um contexto de fuga da "realidade ambiente e da previsibilidade", com "choques entre o humano, de quem joga, e o inumano do azar", com intuito de ganho e de diversão. ${ }^{211}$

Não nos parece que os derivativos sejam fruto de "fuga da realidade ambiente", muito pelo contrário, o contratante de um derivativo busca precaver-se da realidade ou, conscientemente, lucrar com as alterações da realidade ambiente. Nesse contexto, ao propugnarem por mudança legislativa, EIZIRIK e WALD observaram que a função econômica dos mercados futuros é exatamente inversa àquela do jogo, uma vez que atuam eles como sistemas de redução de riscos futuros enquanto o jogo é vinculado a álea e se baseia exclusivamente no risco. ${ }^{212}$

\footnotetext{
${ }^{208}$ PONTES DE MIRANDA, Francisco Cavalcanti. op. cit., v. 45, p. 246-248.

${ }^{209}$ SZTAJN, Rachel. Contratos de bolsa, cit., p. 170 e 176.

${ }^{210}$ Além de incapazes de apagar o inoportuno comando legislativo do artigo 1479 do Código Bevilaqua, as construções seriam, atualmente, insuficientes, pois sempre focadas na premissa da existência de um mercado de bolsa, sem levar em conta os mercados de balcão, os quais têm adquirido crescente relevância.

${ }^{211}$ PONTES DE MIRANDA, Francisco Cavalcanti. op. cit., v. 45, p. 223-224.

${ }^{212}$ EIZIRIK, Nelson; GAAL, Ariádna B.; WALD, Arnold. Das funções econômicas dos mercados a termo e do Projeto de Código Civil, cit., p. 326, no contexto de supressão do artigo 816 do Projeto de Código Civil (PLC 118, de 1984).
} 
É fato que os derivativos, assim como qualquer investimento em títulos e valores mobiliários, bem como o seguro, o jogo e a aposta, lidam com medidas de incerteza, ou seja, lidam com o risco. ${ }^{213}$ Contudo, cada uma dessas atividades possui as suas peculiaridades e é valorada socialmente, o que leva o legislador a encará-las de uma ou outra forma, incentivando-as ou desincentivando-as. Ainda que o objetivo do contratante do derivativo não seja o hedge e sim a especulação - que, como defendemos, é legítima e possui o seu papel no âmbito do mercado, os derivativos não devem ter a sua exigibilidade prejudicada pela comparação com o jogo.

Portanto, do ponto de vista finalístico da norma - revogação do artigo 1.479 do Código Civil de 1916 e promulgação do artigo 816 do Código Civil de 2002 (que afastou os derivativos do raio de incidência do jogo) - tem-se uma acertada decisão de política pública, que, a nosso ver, sepultou uma grande celeuma, incompatível com o atual estágio evolutivo do capitalismo brasileiro. ${ }^{214}$

Com o tempo, percebeu-se não fazer o menor sentido a tutela do Direito no sentido de negar exigibilidade e coercibilidade aos derivativos, só porque tais contratos trazem em si um elemento de risco. O legislador corrigiu uma esquizofrenia constante do Código Civil de 1916 que levou, por muito tempo, doutrinadores e juízes a lançarem mão de criativas teorias e mirabolantes interpretações com o objetivo de "desdizer" aquilo que estava escrito.

\footnotetext{
${ }^{213}$ HAZEN, Thomas Lee. Disparate regulatory schemes for parallel activities: securities regulation, derivatives regulation, gambling, and insurance, cit., p. 375, 2005, traça um paralelo entre as atividades de mercado de capitais (securities e derivativos), seguros e jogo e aposta (gambling), todas elas baseadas no risco, e as diferentes respostas regulatórias a tais atividades nos Estados Unidos. O autor faz essa analogia (This article takes the position that there is still some merit to the gambling/investment analogy) para chamar atenção aos diferentes enfoques dados pelo legislador para quatro atividades baseadas no risco, com o objetivo de expor a pouca regulação que se tinha, em 2005, nos Estados Unidos, para os derivativos. Como se viu posteriormente, com a crise de 2008, o mercado altamente desregulamentado dos derivativos criou um shadow market que, de certa forma, propiciou o alastramento e crescimento da crise e dificultou a resposta do regulador norte-americano. Em nossa opinião, o artigo tem seu mérito, sobretudo por antecipar fatos, mas não é pertinente à realidade brasileira. Em primeiro lugar, diferentemente dos Estados Unidos, o Brasil tem um mercado de derivativos altamente regulado e, acima de tudo, transparente - conforme explorado no capítulo "Local de Negociação: Balcão e Bolsa". Em segundo lugar, o mercado de derivativos brasileiro não é tão grande e nem tão sofisticado, a ponto de criar a inversão de lógica em que os preços de ativos reais passam a ser influenciados pela atividade dos derivativos. Por fim, o Brasil possui uma estrutura regulatória organizada, com apenas uma agência competente para a matéria, diferentemente dos Estados Unidos, em que existem conflitos entre agências, arbitragem regulatória e zonas não reguladas.

${ }^{214}$ Cf. SZTAJN, Rachel. Regulação e o mercado de valores mobiliários, cit., p. 144, critica a redação dada ao artigo 816 do Código Civil de 2002, sugerindo que ele não engloba os derivativos cursados fora de bolsa, além de não solucionar de vez o problema dos contratos diferenciais ou o problema criado por outros derivativos que haja previsão de liquidação por diferença. Concordamos que o vernáculo no referido artigo 816 poderia ter sido melhor empregado, mas entendemos que a revogação do artigo 1479 do Código Civil de 1916 é de inegável ajuda.
} 
Tudo isso para que o texto legislativo pudesse, finalmente, estar adequado àquilo que o mercado já praticava e entendia de maneira perfeita e racional: a gestão do risco ou a especulação com o risco de maneira contratual não é, a priori, danosa às relações entre particulares, muito pelo contrário, é necessária e desejável à fluidez das relações econômicas. ${ }^{215}$

Assim, os derivativos devem ser entendidos como negócios em que o "risco" funciona não como uma vicissitude colateral e não desejada, mas sim como a própria causa e objeto do acordo de vontades. ${ }^{216}$

\section{IV.B. Natureza Jurídica: Contratos}

Conforme HULL, derivativos são títulos cujos valores dependem dos valores de outras variáveis mais básicas. ${ }^{217}$ Esta definição financeira de derivativos ${ }^{218}$ como instrumentos cujo valor deriva de um ativo subjacente é precisa e amplamente difundida, ${ }^{219}$ porém insuficiente.

Para HENDERSON, a insuficiência deste conceito econômico (verdadeiro, na maioria dos casos) não englobaria, por exemplo, derivativos climáticos, em que não se tem um "ativo" subjacente propriamente dito, mas sim um índice cujo valor é estabelecido pelo próprio mercado organizado. ${ }^{220}$

\footnotetext{
${ }^{215}$ Cf. SOUZA JUNIOR, Francisco Satiro. op. cit., p. 21: Não se pode mais, entretanto, imaginar a gestão financeira e empresarial sem o auxílio dos derivativos, que quando corretamente utilizados, podem representar não um instrumento de aposta mas, em sentido diametralmente oposto, uma potente ferramenta de gestão e transferência de riscos, em face do que se tem notado não o esmorecimento de seu uso mas sim a criação de novos derivativos visando a satisfação de necessidades específicas.

${ }^{216}$ ANTUNES, José A. Engracia. op. cit., p. 101.

${ }^{217}$ HULL, John. Introdução aos mercados futuros e de opções, cit., p. 13.

${ }^{218}$ A palavra "derivativo" é oriunda do inglês "derivatives", que exprime o racional econômico do termo. Por isso, derivativos não podem ser confundidos com "contratos derivados" previstos no âmbito do Direito Civil. Cf. SALLES, Marcos Paulo de Almeida. op. cit., p. 97: [Um contrato derivado] nasce da existência de um contrato anterior, em que o objeto é o mesmo, e ao menos uma das partes, a mesma, quando esta subcontrata com base no primeiro contrato. A existência do contrato derivado é dependente daquela do contrato do qual deriva.

${ }^{219}$ No mesmo sentido, cf. BLACK'S law dictionary. 8. ed. Saint Paul: Thomson West, 2004. p. 475: Derivative, n.: A financial instrument whose value depends on or is derived from the performance of a secondary source such as an underlying bond, currency, or commodity.

${ }^{220}$ HENDERSON, Schuyler K. op. cit., p. 3: Saindo da definição financeira, uma segunda definição, segundo o autor, seria a de que derivativos são contratos para trocas financeiras ou de fluxos firmados entre duas partes, avaliados por referência a taxas de mercado, preços ou níveis. Para ele, esta segunda definição, apesar de expressar o âmago financeiro da tecnologia (avaliação atual de uma relação financeira), não funciona bem para as opções. Assim, para Henderson, uma terceira definição, a partir do gancho contratual, seria a de que derivativos são negócios bilaterais (contratos) nos quais as partes imitam ou fingem fazer algo, alocando riscos e benefícios entre elas, como se tivessem efetivamente praticado este negócio (que foi uma ficção) - ou seja, um derivativo é um contrato nocional com consequências reais.
} 
Em esforço para alargar o conceito de "ativo subjacente", ANTUNES esclarece que os derivativos, conforme o próprio nome indica, são instrumentos financeiros cujo valor deriva, provem, constrói-se e valora-se por referência a uma outra realidade primária, o ativo subjacente. Esta realidade primária (os ativos subjacentes ou derivantes), por sua vez, é ilimitada, podendo ter natureza corpórea ou incorpórea, real ou virtual, industrial ou financeira, jurídica ou econômica. ${ }^{221}$

Alarga-se o conceito de ativo subjacente, esclarecendo que ele não é um ativo necessariamente físico e sim uma "realidade primária" ilimitada. ${ }^{222}$ De todo modo, ainda que resolvido o alcance da expressão "ativo subjacente" - conceito amplo que adotamos ao longo deste trabalho, continua-se sem uma definição jurídica, ou seja, tem-se uma construção ("instrumento financeiro cujo valor deriva de ativo subjacente") de pouca ajuda para análises comerciais, regulatórias, contábeis ou legais. ${ }^{223}$

Talvez poucos institutos sejam tão criticados e mal entendidos como os derivativos, já referidos como os "mais sofisticados, os mais intricados, os mais misteriosos e mesmo os mais arriscados" 224 instrumentos financeiros existentes. Muito dessa pecha, dominante no mundo financeiro, é transportada para o mundo jurídico. Creditamos essa percepção ao desentendimento que se tem a respeito dos derivativos (sua racionalidade econômica e modalidades de negociação) e ao inegável fato de que muitas das crises econômicas recentes (incluindo-se a grande crise de 2008) terem, em menor ou maior grau, estes "misteriosos" instrumentos envolvidos em seu âmago.

Por certo, é muito difícil chegar a uma conceituação unitária e jurídica do gênero dos derivativos. ${ }^{225}$ Retirando-se a função instrumental de transferência ou assunção de riscos, por nós debatida no capítulo III. A, ${ }^{226}$ qual seria o denominador comum dos

${ }^{221}$ ANTUNES, José A. Engracia. op. cit., p. 99.

${ }^{222}$ Vale deixar claro que, ao longo do presente trabalho, ao usarmos o conceito "ativo subjacente", estamos sempre nos referindo a uma realidade primária ilimitada.

${ }^{223}$ HENDERSON, Schuyler K. op. cit., p. 3.

${ }^{224}$ BERNSTEIN, Peter L. op. cit., p. 319.

${ }^{225}$ CHEDIAK, Julian Fonseca Peña. A reforma do mercado de valores mobiliários. In: LOBO, Jorge; KANDIR, Antonio (Coords.). Reforma da Lei das Sociedades Anônimas: inovações e questões controvertidas da Lei 10.303, de 31.10.2001. 2.ed. Rio de Janeiro: Forense, 2002. p. 531, pontuou serem os derivativos "termo não jurídico e de complexa definição".

${ }^{226}$ Cf. SZTAJN, Rachel. Regulação e o mercado de valores mobiliários, cit., p. 143: Derivativos são ativos cujo valor deriva ou decorre do valor de outro ativo ou de uma posição jurídica patrimonial, sujeita a risco. Combinando incerteza com propensão ou aversão à risco, tem-se o caldo necessário para o surgimento dos derivativos que refletem a busca por proteção contra a volatilidade que pode afetar o valor das posições ou dos bens; derivativos são negócios que permitem que os particulares transfiram o risco a que são avessos para quem tenha propensão ou disposição para suportá-los. Assim, é evidente que qualquer posição jurídica suscetível de avaliação econômica e sujeita a risco pode encontrar algum mecanismo de defesa. 
diversos arquétipos de derivativos? Propomo-nos nesta seção a esmiuçar as características definidoras do gênero para, então, esboçarmos nossa opinião.

A partir do conceito financeiro, SATIRO pontuou dois fatores marcantes dos derivativos: a liquidação futura e a referência a um ativo subjacente.

Derivativos são instrumentos financeiros cujo valor deriva do valor de um outro ativo ou instrumento. Têm como característica, portanto, dois fatores marcantes: a referência direta a certo ativo ou índice financeiro e o diferimento de liquidação ou execução. Dessa forma, o valor de um derivativo decorre ("deriva") da expectativa do valor futuro do ativo ou instrumento ao qual está relacionado. ${ }^{227}$

Este lapso temporal materializado na execução diferida do contrato significa afirmar a existência de dois períodos fundamentais e não coincidentes na vida de um derivativo: a data de contratação, ou seja, a data em que duas partes decidem convergir suas vontades para um determinado fim, e a data de produção dos efeitos oriundos de tal contratação. Frisamos que a validade, vigência e eficácia do derivativo é perfeita na data de sua contratação, sendo apenas os resultados (o quantum) da relação negocial conhecidos neste segundo momento.

Assim, a liquidação futura do contrato, que assenta o conceito unitário do instituto jurídico, está totalmente relacionada aos objetivos de proteção e especulação já mencionados anteriormente. Partindo-se dos postulados financeiros mais básicos de que o dinheiro possui valor no tempo e de que as medidas indicativas (do qual o preço é o maior expoente) oscilam ao longo dos períodos, conforme a irrevogável lei fundamental da oferta e da demanda, nada mais natural que a existência de lapso temporal paute este instituto criado para combater ou aproveitar as oscilações de preços, caracterizando os derivativos como negócios diferenciais. ${ }^{228}$

Ao tratarmos de cada uma das espécies-base dos derivativos e ao mencionarmos a existência de estratégias, ficou claro que o lapso temporal pode ser determinado ou

\footnotetext{
${ }^{227}$ SOUZA JUNIOR, Francisco Satiro. op. cit., p. 21.

${ }^{228}$ Ao falar da caracterização dos derivativos como contratos futuros, de natureza financeira, com lapso temporal, em que se comparam preços de mercado e atual do ativo subjacente, YAZBEK pontua: Tal caracterização não porta uma definição propriamente jurídica de derivativo (até porque ela não ajuda muito na identificação da eventual "natureza jurídica" daqueles instrumentos), mas destaca um traço comum para os instrumentos por ela abarcados - neles, as partes pactuam um preço para um bem (o ativo subjacente) em uma data futura e, na data da execução do contrato, contrapõem este preço ao preço de mercado, transferindo apenas as diferenças entre si. Todo derivativo, assim, é um "contrato diferencial". Cf. YAZBEK, Otavio. Regulação do mercado financeiro e de capitais, cit., p. 100.
} 
determinável, certo ou incerto, conhecido ou dependente do comportamento do ativo subjacente. $^{229}$ Esta constatação reforça a caracterização de todos os derivativos como negócios jurídicos diferenciais, dada a comparação de valores em lapso temporal - ainda que indefinido.

Com relação à necessária existência de ativo subjacente (ou "realidade primária"), busca-se com os derivativos proteção ou exploração de determinadas variações calcadas justamente neste referencial teórico - reside aqui o âmago da função de maleabilidade de riscos. ${ }^{230}$ Por tal motivo, coloca-se este tal ativo subjacente como uma "realidade primária" ilimitada de onde deriva uma segunda realidade ou um instrumento de segundo grau, que é o próprio derivativo. ${ }^{231}$

No Brasil, inexiste um rol taxativo de ativos subjacentes, podendo, teoricamente, respeitados os critérios estabelecidos pela Comissão, qualquer tipo de "realidade primária", determinada e apurável, ser utilizada como base para um derivativo na qualidade de seu ativo subjacente. ${ }^{232}$

Vale destacar a autonomia e a abstração do derivativo frente aos eventuais vícios do seu ativo subjacente - racional este já bem conhecido no direito cambial. Dessa maneira, eventual nulidade de um contrato de empréstimo que embase um swap ou a eventual irregularidade no processo de emissão de ações que embase uma opção de compra de ações jamais poderão ser invocados frente a um contrato derivativo validamente constituído.

\footnotetext{
${ }^{229}$ Como exemplo de lapso temporal que se encerra necessariamente em uma data previamente estabelecida, temos os contratos futuros. Por outro lado, como exemplo de derivativo em que existe um prazo condicionado a outras variantes, temos as opções que, conforme explanado acima, podem ser ou não exercidas e, caso o sejam, podem ter uma ou mais datas específicas para o exercício ou serem exercíveis durante um lapso temporal. De qualquer modo, sempre existe um lapso temporal, sendo este um elemento comum das várias espécies de derivativos.

${ }^{230} \mathrm{O}$ paradigmático case norte-americano Procter \& Gamble Co. v. Bankers Trust Co foca justamente na questão do ativo subjacente. Cf. UNITED STATES DISTRICT COURT. Procter \& Gamble Co. v. Bankers Trust Co., [1996-1997 Transfer Binder] Fed. Sec. L. Rep. (CCH) 99,229, at 95,238 (S.D. Ohio). Disponível em: <http://users.wfu.edu/palmitar/Courses/SecReg-MBA/CaseStudies/Cases/ProcterGamble-925FSupp1270.htm>. Acesso em: 11 jun. 2013: Derivatives transactions may be based on the value of foreign currency, U.S. Treasury bonds, stock indexes, or interest rates. The values of these underlying financial instruments are determined by market forces, such as movements in interest rates. Within the broad panoply of derivatives transactions are numerous innovative financial instruments whose objectives may include a hedge against market risks, management of assets and liabilities, or lowering of funding costs; derivatives may also be used as speculation for profit.

${ }^{231}$ ANTUNES, José A. Engracia. op. cit., p. 100.

${ }^{232}$ Cf. COMISSÃO DE VALORES MOBILIÁRIOS. Instrução n. ${ }^{\circ} 467$, de 10 de Abril de 2008. Disponível em: <www.cvm.gov.br>. Acesso em: 22 fev. 2013, que trata da aprovação de contratos derivativos admitidos à negociação ou registrados nos mercados organizados, os ativos subjacentes devem ter seu valor apurado com base em preços e metodologias consistentes e passíveis de verificação.
} 
Conclui-se, ao cabo, que os derivativos são unidos pela função transferência de ou exposição a riscos e pela existência de duas características fundamentais: lapso temporal e ativo subjacente. Mas qual seria a natureza jurídica comum a todos esses instrumentos financeiros ora caracterizados? Em nossa opinião, a autonomia da vontade privada e a permissividade do ordenamento jurídico em tutelar a vontade dos particulares nos parecem ser a resposta que comporta a enorme diversidade de derivativos já existentes e as infinitas possibilidades de criação de novos negócios jurídicos. Portanto, inevitável caracterizá-los como contratos.

As próprias características destes instrumentos financeiros cujo cerne está no binômio ativo subjacente e lapso temporal nos levam a reforçar seu caráter contratual. Que outra natureza jurídica que não o contrato diferencial poderia ter um instrumento financeiro que permite que as partes convirjam seus interesses em uma data, sendo o efetivo resultado da negociação apenas produzido a posteriori? Que outra natureza jurídica reputar a um instrumento financeiro cujo valor (exigível de parte a parte) é uma ficção consensual e dependente de um referencial teórico $?^{233}$ Que outra natureza jurídica serviria tão bem à autonomia privada criadora de inúmeras estratégias financeiras?

O contrato, como ferramenta de auto-composição e fonte de obrigações em que existe a construção de regras de comportamento juridicamente exigíveis por ambas as partes, comporta o binômio ativo subjacente e lapso temporal. O contrato, enquanto instrumento apto a captar declarações jurídico-negociais geneticamente bilaterais, que possuem congruência quanto aos meios e convergência quanto aos fins, certamente comporta a função de assunção de riscos trazida pelos derivativos (seja para finalidade de proteção, seja para fins de especulação).

\footnotetext{
${ }^{233}$ SZTAJN, Rachel. Contrato e inovação financeira: ensaio sobre contratos futuros e swaps, cit., p. 73, sobre as funções dos contratos: As pessoas fazem e aceitam promessas com a certeza de que serão cumpridas o que as torna valiosas por si. Além disso, admitir que promessas possam ser cumpridas no futuro, que as prestações possam ser parceladas, levou ao aparecimento do comerciante, intermediário e do especulador, duas figuras importantes para o funcionamento da troca econômica. Nenhuma sociedade ou economia desenvolvida (que tenha ultrapassado a fase das trocas domésticas) pode funcionar sem disciplina dos contratos, pois essa disciplina que permite o funcionamento do mercado. Cada participante do mercado procura aumentar seu bem estar e com isso o sistema de formação de preços opera de forma eficiente. Contrato e mercado são tão ligados que a falta de estrutura de mercado poderia tornar a autonomia privada inoperante; de outro lado, um mercado livre não existe sem. Mesmo nos sistemas totalitários, os contratos exercem função vital no desenvolvimento econômico. Incluída na função de instrumento de planejamento futuro desempenhada pelos contratos, está a distribuição de riscos, a responsabilidade por inadimplemento, ou adimplemento imperfeito, parcial, como instrumento de aplicação de sanções; o contrato desempenha muitas e variadas funções.
} 
A partir da análise dos três arquétipos fundamentais base para a construção de quaisquer derivativos, contratos a termo e futuros, opções e swaps, pudemos constatar que nenhum deles pode ser encontrado no Código Civil brasileiro. Muito embora guardem semelhança com um ou outro instituto, sendo a analogia muitas vezes utilizada para explicar o funcionamento de cada espécie de derivativo, demonstramos que não se pode tipificar um contrato a termo ou um futuro como contrato de compra e venda, não se pode confundir uma opção com declaração unilateral de vontade e não se pode tipificar um swap como contrato de permuta. ${ }^{234}$

A tipicidade de um contrato se dá em decorrência de lei que estipule o conteúdo e a formação do negócio, os direitos e obrigações das partes, delimitando a atuação privada. ${ }^{235}$ Filiamo-nos ao entendimento segundo o qual a simples menção do tipo ou a descrição de alguns poucos pressupostos em lei é insuficiente para se classificar um contrato como típico. ${ }^{236}$ De tal modo, a singela menção aos derivativos na Lei $6.385 / 76$, por si só, não os torna contratos típicos.

Mais tormentosa é a questão da hierarquia das regras necessárias para se atribuir tipicidade a um contrato: apenas leis possuem esta capacidade ou instruções e resoluções também eivam um contrato de tipicidade ${ }^{237}$ Não obstante opiniões contrárias, entendemos que os normativos do CMN, do Bacen e da CVM teriam sim o condão de tipificar os contratos, até mesmo pela dinâmica dos sistemas financeiros hodiernos e dos inexoráveis

\footnotetext{
${ }^{234}$ Vale aqui notar a opinião de MARTINS-COSTA, Judith. Contratos de derivativos cambiais. Contratos aleatórios. Abuso de direito e abusividade contratual. Boa-fé objetiva. Dever de informar e ônus de se informar. Teoria da imprevisão. Excessiva onerosidade superveniente. Revista de Direito Bancário e do Mercado de Capitais, São Paulo, n. 55, p. 4, jan./mar. 2012, segundo a qual, por conta dos artigos $112 \mathrm{e}$ 425 do Código Civil e da regra hermenêutica da analogia, aos contratos de swap se aplicam as regras previstas imediatamente para a troca e, mediatamente, para a compra e venda (...) e pertence ao grande tipo contratual da compra e venda a operação denominada "contrato de forward" (...).

${ }^{235}$ SANCHEZ, Sydney. Os contratos atípicos no direito privado. Revista de Direito Público, Sao Paulo, v. 21, n. 86 , p. 238, abr./jun. 1988, destaca os seguintes princípios a serem seguidos pelos contratantes: (i) ninguém pode transferir mais direitos do que tem; (ii) ninguém deve ser condenado sem ser ouvido; (iii) ninguém pode invocar a própria malícia; (iv) quem exercita o próprio direito não prejudica a ninguém; (v) pacta sunt servanda (ou "os acordos devem ser cumpridos") (vi) quod initium vitiosum est non potest tractu temporis convalescere (ou "o que no princípio é vicioso, não pode ganhar força com o decurso do tempo"); e, ainda (i) princípio da autonomia da vontade; (ii) princípio da supremacia da ordem pública; e (iii) princípio da obrigatoriedade da convenção.

${ }^{236}$ Id. Ibid., p. 237, informa que parte da doutrina entende que contratos inonimados não são necessariamente atípicos. A falta de regulamentação específica faz do negócio um contrato atípico, ao passo que a falta de nomen juris faz dele um contrato inonimado. Por esse raciocínio, diversos derivativos seriam contratos nominados e, segundo nosso entendimento, muitos deles atípicos. Como contraponto, muitos utilizam a expressão "inonimado" e "atípico" como sinônimos. Vide, nesse sentido: VERÇOSA, Haroldo Malheiros Duclerc. Os contratos inonimados e o novo Código Civil, cit., p. 31.

${ }^{237}$ Indo além, autorizações dadas pela CVM ao mercado de balcão fariam com que um contrato se torne típico? Entidades de mercado, como o já citado ISDA, tipificam negócios?
} 
movimentos de decodificação. Por esse entendimento, um credit default swap seria um contrato típico porque regulado pela Resolução CMN 2.933/02 e pela Circular Bacen 3.106/02. Vale destacar que, diferentemente do CDS, que possui moldura regulamentar, muitos derivativos não são tipificados.

Os contratos atípicos, a grande realidade da maioria dos derivativos, são expressão das mutáveis e constantes necessidades da vida - definição que cai muito bem aos derivativos e ao processo de financeirização dos mercados. Lembramos, contudo, que a autonomia da vontade privada está sempre adstrita aos princípios gerais do direito e à teoria geral dos contratos. ${ }^{238}$ A existência de regras genéricas para os contratos atípicos ganha especial importância no âmbito das estratégias ou combinações de derivativos, em que a criatividade humana das mesas de operação pode ser imprudente. Desse modo, é importante que a inovação das partes contratantes esteja sempre adstrita à moldura legislativa (não contravenção à lei, aos bons costumes, à ordem pública e aos princípios gerais do direito). ${ }^{239}$

Dito isso, resta-nos a inevitável conclusão que derivativos são contratos bilaterais, ${ }^{240}$ sinalagmáticos, diferenciais, aleatórios, ${ }^{241}$ muitos deles atípicos ${ }^{242}$ e frutos da autonomia da vontade privada, que possuem o lapso temporal e a valoração determinada por um ativo subjacente como elementos unificadores de suas diversas espécies.

O direito europeu também assenta os derivativos na categoria contratual. PELTIER defende a gênese contratual como sendo o denominador comum de todos os derivativos, independentemente do ambiente de negociação. ${ }^{243} \mathrm{Na}$ mesma linha, GIRINO define os

\footnotetext{
${ }^{238}$ SANCHEZ, Sydney. op. cit., p. 238.

${ }^{239}$ VILLAÇA, Álvaro Azevedo. Teoria geral dos contratos típicos e atípicos. São Paulo: Atlas, 2002. p. 61.

${ }^{240}$ Importante afirmar que, padronizados ou não, existindo condições previamente estabelecidas ou não (adesão), tendo ou não contraparte central, todos os derivativos devem sempre ser encarados como contratos bilaterais. Vale mencionar que, para os derivativos de bolsa, partindo do exemplo das opções, SATIRO enxerga a existência da contraparte central como geradora de "não um - mas dois contratos jurídico-formais, cada um deles tendo como parte uma corretora e a caixa de liquidação", o que faz com que "a discussão acerca da natureza jurídica do instituto perca importância". SOUZA JUNIOR, Francisco Satiro. op. cit., p. 154 e 156.

${ }^{241}$ THEODORO JUNIOR, Humberto. O contrato e seus princípios. 2. ed. Rio de Janeiro: Aide, 1999. p. 72 : $O$ risco de haver ou não a contraprestação, ou de ser ela maior ou menor, segundo a dependência de fatores imprevisíveis ou incontroláveis, é que configura a essência do contrato aleatório, distinguindo-o, nitidamente, do comutativo.

${ }^{242}$ BRASIL. Lei n. ${ }^{\circ} 10.406$, de 10 de janeiro de 2002. Institui o Código Civil. Disponível em: <http://www.planalto.gov.br>. Acesso em: 22 maio 2011. Parte Especial, Livro I (Direito das Obrigações), Título V (Dos Contratos em Geral), Capítulo I (Disposições Gerais). Art. 425. É lícito às partes estipular contratos atípicos, observadas as normas gerais fixadas neste Código.

${ }^{243}$ PELTIER, Frederic. Marchés financiers et droit commun. Paris: Banque Éditeur, 1997. p. 156.
} 
derivativos como contratos que geram instrumentos financeiros. ${ }^{244}$ Por fim, ANTUNES destrincha a natureza contratual dos derivativos, dizendo que, além da característica fundamental de contratos a prazo, os derivativos possuem natureza consensual, sem formato rígido (salvo nos casos em que sejam padronizados por decorrência de regulamentos do ambiente de negociação), não real (cuja mera declaração de vontade basta, com exceção das opções em que se exige o pagamento de prêmio para o aperfeiçoamento do liame obrigacional), sinalagmática (nexo de reciprocidade entre as partes), patrimonial (afastamento do intuitus personae), onerosa (atribuições patrimoniais para ambas as partes) e aleatória (no sentido em que é o risco e a incerteza que fornecem a própria causa e objeto contratuais). ${ }^{245}$

Igualmente, nos Estados Unidos, a doutrina aponta os derivativos como contratos. Conforme HENDERSON, todos eles devem ser presumidamente contratos:

There is, however, one underlying principle it is useful for all observers to bear in mind when analysing a derivative: a derivative is first and foremost a contract between two parties. There is no "magic"to it, nor should it be presumed to be a separate "thing" except to the extent a given legal system has expressly chosen to treat it as such for a particular purpose. All of the laws, court decisions and practices with respect to contracts in general should be presumed to apply to derivatives unless there is an identifiable reason not to do so. ${ }^{246}$

A conclusão segundo a qual, também no Brasil, os derivativos devam ser categorizados como contratos possui algumas implicações. A devida classificação permite que o fenômeno dos derivativos possa ser compreendido de maneira mais nítida, assim como o tratamento jurídico daí decorrente. Dado que o escopo deste trabalho é a análise do tratamento dispensado pelo Judiciário às demandas que envolvem derivativos, imperioso termos como premissa, após o referencial teórico exposto, a categorização dos derivativos como contratos com determinadas qualificadoras. Como tais qualidades desencadeiam ou não certos efeitos jurídicos, passemos a discutir cada uma destas duas características básicas: bilateralidade e aleatoriedade.

As normas, em geral, possuem o cidadão como mero destinatário. Já os contratos, por sua vez, conseguem trazer os indivíduos simultaneamente como destinatários e autores das regras, em um modelo consensualista. Esta capacidade de se auto-obrigar, observados

\footnotetext{
${ }^{244}$ GIRINO, Emilio. op. cit., p. 169.

${ }^{245}$ ANTUNES, José A. Engracia. op. cit., p. 98.

${ }^{246}$ HENDERSON, Schuyler K. op. cit., p. 5.
} 
determinados limites e requisitos legais, é chamada autonomia da vontade privada, base da teoria contratual. Válido mencionar que, uma vez formada a avença, o contrato se torna intocável para as próprias partes que, de autoras, passam a ser destinatárias de suas próprias regras. Têm-se, assim, os princípios da irrevogabilidade e da irretratatividade contratuais que, apesar de cogentes, não são absolutos, podendo ser afastados apenas pelo Judiciário e em certas circunstâncias especiais. ${ }^{247}$

A análise de julgados cujo objeto são os derivativos demonstra quais são as circunstâncias ditas especiais evocadas pelas partes que buscam afastar o pacta sunt servanda, princípio mais caro à teoria contratual e fruto da autoimposição de regras bilaterais. Esta mesma análise jurisprudencial, de forma quantitativa, demonstra se as partes logram êxito nesta tarefa ou não.

Os contratos podem ser unilaterais, quando geram obrigações a apenas uma das partes, ou bilaterais, quando ambas as partes se obrigam e mantêm entre si uma interdependência recíproca e teleológica. ${ }^{248}$ Os derivativos são - todos eles - contratos bilaterais.

Essa conclusão nos remete à possibilidade da exceptio non adimpleti contractus, conforme Código Civil brasileiro. ${ }^{249}$ Tal comando deve ser lido com ressalvas. Primeiramente, ser bilateral não significa necessariamente a aplicação da regra da exceção de contrato não cumprido de maneira automática, dado que a correspectividade entre as obrigações que irradiam do negócio jurídico pode não estar presente. ${ }^{250} \mathrm{Em}$ segundo lugar,

\footnotetext{
${ }^{247}$ Idéias deste parágrafo foram extraídas das anotações de aula do curso de Direito Civil ministrado pelo professor João Alberto Schutzer Del Nero, na graduação da Faculdade de Direito da Universidade de São Paulo, no segundo semestre de 2004.

${ }^{248}$ PONTES DE MIRANDA, Francisco Cavalcanti. Tratado de direito privado: parte especial. Rio de Janeiro: Borsoi, 1959. v. 26, p. 96: Chamam-se contratos bilaterais aqueles contratos em que cada um dos figurantes assume o dever de prestar para que outro ou outros lhes contraprestem. A contratação é, precisamente, a prestação que o outro figurante ou os outros figurantes têm de fazer.

${ }^{249}$ BRASIL. Lei n. ${ }^{\circ}$ 10.406, de 10 de janeiro de 2002. Institui o Código Civil. Disponível em: <http://www.planalto.gov.br>. Acesso em: 22 maio 2011. Parte Especial, Livro I (Direito das Obrigações), Título V (Dos Contratos em Geral), Capítulo II (Da Extinção do Contrato). Art. 476 Nos contratos bilaterais, nenhum dos contratantes, antes de cumprida a sua obrigação, pode exigir o implemento da do outro. Art. 477. Se, depois de concluído o contrato, sobrevier a uma das partes contratantes diminuição em seu patrimônio capaz de comprometer ou tornar duvidosa a prestação pela qual se obrigou, pode a outra recusar-se à prestação que lhe incumbe, até que aquela satisfaça a que lhe compete ou dê garantia bastante de satisfazê-la.

${ }^{250}$ Cf. PONTES DE MIRANDA, Francisco Cavalcanti. op. cit., 1959. v. 26, p. 97: Por outros lado, nem todas as dívidas e obrigações que se originam dos contratos bilaterais são dívidas e obrigações bilaterais, em sentido estrito, isto é, em relação de reciprocidade. (...) A bilateralidade - prestação, contraprestação faz ser bilateral o contrato; mas o ser bilateral o contrato não implica que tôdas as dívidas e obrigações que dêle se irradiam sejam bilaterais.
} 
é necessária a simultaneidade de prestações para que se pleiteie a exceção: ${ }^{251} \mathrm{em}$ contrato pautado pelo lapso temporal e pelo fator diferencial, a determinação do quantum devido (e se devido) é sabida em momento posterior. Isso posto, devemos ter em mente que a cronologia das prestações e a natureza do contrato podem impossibilitar a aplicabilidade da exceptio non adimpleti contractus - como no caso dos derivativos, sobretudo dado que o contrato é válido, vigente e eficaz na data de sua contratação, mas os resultados e a dinâmica das prestações serão sabidos a posteriori.

É claramente identificável o sinalagma de um contrato a termo, de um contrato de futuro ou de um contrato de swap, justamente pela proximidade funcional que tais derivativos possuem com os contratos de compra e venda e os contratos de permuta, respectivamente - muito embora, como já desenvolvido, não possam ser tipificados como tais. É útil citar estes contratos (compra e venda e permuta) como forma de visualização da interdependência recíproca de prestação e contraprestação, ou seja, sinalagma, existente nos contratos a termo, nos contratos de futuro e nos swaps.

Este nexo de reciprocidade das obrigações das partes é mais difícil de ser visualizado nas opções, vez que existe distribuição assimétrica de riscos financeiros entre os contratantes: as obrigações do titular da opção estão limitadas ao prêmio pago pela aquisição da opção e as obrigações do lançador da opção são ilimitadas. O preço pago para adquirir a prerrogativa do exercício da opção (que limita o risco do seu titular) não pode ser enxergado como impeditivo do sinalagma contratual, muito pelo contrário, deve ser visto como reforço da ideia de reciprocidade. Isso porque o valor do prêmio (ainda que fixo e imutável) é reflexo das expectativas de variação do preço do ativo subjacente em um certo tempo e espaço. Portanto, o prêmio nada mais é do que a precificação do risco (novamente entendido como medida de incerteza quantificável) em um dado momento presumida pelo lançador. ${ }^{252}$ Assim, ainda que a distribuição de riscos financeiros seja aparentemente assimétrica, pode-se afirmar que existe reciprocidade de direitos e obrigações também nas opções.

\footnotetext{
${ }^{251}$ THEODORO JUNIOR, Humberto. op. cit., p. 85: Ainda, pois, que se trate de contrato bilateral, para aplicar-se a exceptio do art. 1092 do Código Civil é preciso apurar se há conexidade causal entre a prestação cobrada e aquela que o excipiente invoca como não cumprida.

${ }^{252}$ Por esse motivo, quanto mais perto da data de exercício, em que o strike poderá ser mais facilmente "adivinhado", o valor do prêmio terá uma correlação mais próxima com a realidade. Nesse sentido, se improvável o exercício, mais barato o prêmio pago pelo titular; se provável o exercício, mais caro o prêmio pago pelo titular.
} 
No âmbito dos contratos onerosos, há uma subdivisão classificatória entre contratos comutativos - com vantagens e desvantagens objetivamente equivalentes às partes, e contratos aleatórios, estes com vantagens e desvantagens não equivalentes ou desproporcionais. ${ }^{253} \mathrm{O}$ contrato aleatório é, portanto, um tipo contratual cuja natureza permite uma diferenciação das vantagens e desvantagens entre as partes, uma distinção objetiva e aceita pelos contraentes e que existe por conta do fator risco. ${ }^{254}$ De toda descrição teórica feita até o momento, expusemos a maleabilidade do risco como o cerne de todos os derivativos, como o motivo que leva as partes a utilizarem este instrumento de execução diferida; ${ }^{255}$ portanto, nada mais lógico do que classificá-los como contratos aleatórios.

A aleatoriedade é um conceito dependente do risco, que, por seu turno, é alheio e não influenciável pelas partes contratantes. É a possibilidade de existência do risco que estrutura o contrato aleatório, sendo natural a diferença das prestações e mais natural ainda a desproporcionalidade objetiva entre elas. Os derivativos são contratos cujo objetivo do ajuste é o risco, sendo a prestação devida apenas quantificável (positiva ou negativamente) em função de um fato futuro e incerto, o valor do ativo subjacente. Assim, as partes do derivativo, na data de contratação, sujeitam-se ao risco e aceitam a incerteza (de ganho ou de perda) dependente de uma circunstância aleatória. Nota-se, ainda, que a alocação dos resultados dessa sujeição ao risco será conhecida apenas em data futura, quando os efeitos da contratação serão conhecidos. ${ }^{256}$

Ao afirmarmos que o elemento unificador de todos os derivativos é a álea, mais uma vez, deparamo-nos com o "problema" das opções, em que se tem aparente distribuição assimétrica dos riscos, com uma das partes, o titular, com risco financeiro

\footnotetext{
${ }^{253}$ SANZ CABALLERO, Juan Ignacio. Derivados financieros. Madrid: Marciel Pons, 2000. p. 295, menciona como os três elementos diferenciadores dos contratos aleatórios frente aos comutativos (i) indeterminação inicial do resultado; (ii) dependência definitiva de circunstâncias aleatórias; e (iii) vontade das partes em assumir tais riscos.

${ }^{254}$ Idéias deste parágrafo foram extraídas das anotações de aula do curso de Direito Civil ministrado pelo professor João Alberto Schutzer Del Nero, na graduação da Faculdade de Direito da Universidade de São Paulo, no segundo semestre de 2004.

${ }^{255}$ Conta-nos SZTAJN, Rachel. Contrato e inovação financeira: ensaio sobre contratos futuros e swaps, cit., p. 75, que todos os contratos trazem, em menor ou maior grau, risco para os seus contratantes, observando, contudo, que a álea resultante dos contratos de execução instantânea é muito menor, pois o risco se dissipa logo após a conclusão do negócio. Já os contratos de execução diferida trazem em seu bojo o elemento risco de maneira muito mais contundente - como os derivativos, que, como vimos, possuem dois períodos fundamentais e não coincidentes, a data de contratação (em que o negócio jurídico é válido, vigente e eficaz) e a data de efetiva produção de efeitos, com dependência nas oscilações de preços calcadas no ativo subjacente.

${ }^{256}$ Vale pontuar que o contrato aleatório não se confunde com o contrato condicional. Neste, as partes antecipam a existência de um fato futuro que, uma vez ocorrido, criará o vínculo jurídico. No contrato aleatório, por sua vez, o vínculo jurídico é criado na data de contratação, sendo apenas a extensão dos resultados desta contratação (dependente da álea) conhecida e materializada no futuro. Portanto, a relação contratual do derivativo é certa e vinculante desde a data de contratação, independentemente de qualquer condição.
} 
previamente conhecido (estipulado no travamento do preço do prêmio). Esta exposição ao risco já sabida e quantificada (consubstanciada no prêmio) não é suficiente, contudo, para afastar a aleatoriedade das opções. O motivo desta conclusão, novamente, é o fato de o prêmio, apesar de limitar riscos financeiros, ser entendido como um valor estipulado por ambas as partes que, em um determinado tempo e espaço, reflete pecuniariamente esta medida de incerteza. A distribuição de riscos é dita assimétrica, pois, na data de contratação, as partes decidem que uma delas, o titular da opção, pagará um determinado valor antecipadamente para não se sujeitar às oscilações do ativo subjacente em data futura; e não porque inexiste álea para uma das partes. A alocação das consequências dos riscos é, em uma das pontas, pré-determinada e valorada por ambas as partes. Tanto existe álea para o titular que ele deve, antecipadamente, pagar o prêmio para ingressar na relação jurídica, sujeitando-se, igualmente, ao risco de o prêmio "virar pó".

A partir da caracterização dos derivativos como contratos aleatórios, tem-se, consequentemente, maior dificuldade para a aplicação de determinadas alegações relacionadas a defeitos do negócio jurídico - dado que a álea é conceito alheio às partes, ou para a aplicação das teorias referentes a mudanças significativas de conjuntura ${ }^{257}$ - o contrato não pode se frustrar justamente pela ocorrência de sua previsão inicial: o risco. Outra conclusão não poderia existir, já que a utilização de tais remédios atenuantes do pacta sunt servanda nos contratos aleatórios contradiria a própria finalidade do pacto.

Se, nos contratos derivativos, a determinação de ganho ou perda é alheia à vontade das partes, sendo necessário apenas que ambas concordem em momento prévio sobre suas sujeições ao evento futuro e incerto que irá determinar o quantum devido, não se pode cogitar que uma parte impute à outra responsabilidade sobre a futura perda. ${ }^{258}$ Nesse contexto, a alegação de vício de consentimento como causadora de eventual perda torna-se frágil e de difícil sustentação, afastando determinados defeitos do negócio jurídico do rol de possibilidades alegáveis.

\footnotetext{
${ }^{257}$ Conta-nos o AZEVEDO, Antônio Junqueira de. A lesão como vício do negócio jurídico. A lesão entre comerciantes. Formalidades pré-contratuais. Proibição de venire contra factum proprium e ratificação de atos anuláveis. Resolução ou revisão por fatos supervenientes. Excessiva onerosidade, base do negócio e impossibilidade da prestação In: Novos estudos e pareceres de direito privado. São Paulo: Saraiva, 2004. p. 120, que a primeira explicação da resolução ou revisão dos contratos de execução periódica ou diferida no tempo, por força de alteração nas circunstâncias iniciais sob as quais as partes acordaram, se prende à teoria rebus sic stantibus, do século XII, com a elaboração posterior, pelos juristas modernos, dos seguintes esquemas teóricos: (1) a teoria da imprevisão, na França; (2) a excessiva onerosidade, na Itália; (3) a teoria da pressuposição, na Alemanha; e (4) a da base do negócio jurídico, no mesmo país.

${ }^{258}$ Descreve-se aqui uma situação normal, sem que qualquer parte tenha agido com dolo ou culpa para induzir a perda ou o próprio evento futuro, o qual deve ser, por essência, incerto.
} 
Dado que as partes voluntariamente aceitaram o risco, não há de se falar em lesão ${ }^{259}$ em decorrência da desproporcionalidade das prestações finais. ${ }^{260}$ A lesão, como exclusiva dos contratos comutativos, funda-se na equivalência prestacional no momento da avença $^{261}$ - o que, por todo o exposto, não é o caso dos contratos derivativos, aleatórios em sua essência, ${ }^{262}$ com a produção de resultados desproporcionais apenas a posteriori e decorrentes de fatos não controlados pelas partes. ${ }^{263}$

Também o erro, ${ }^{264}$ assim entendido como a falsa ideia da realidade, não deve macular um negócio jurídico cujas circunstâncias arriscadas e álea inerente são presumidas como ato de vontade de parte a parte. Evidentemente que a verificação do caso concreto é sempre necessária, mas, de pronto, é possível excluir alegações de erro fundadas nas circunstâncias aleatórias próprias dos derivativos.

\footnotetext{
${ }^{259}$ BRASIL. Lei n. $^{\text {10.406, de }} 10$ de janeiro de 2002. Institui o Código Civil. Disponível em: <http://www.planalto.gov.br>. Acesso em: 22 maio 2011. Parte Geral, Livros III (Dos Fatos Jurídicos), Título I (Dos Negócios Jurídicos), Capítulo IV (Dos Defeitos dos Negócios Jurídicos), Seção V (Da Lesão). Art. 157. Ocorre a lesão quando uma pessoa, sob premente necessidade, ou por inexperiência, se obriga a prestação manifestamente desproporcional ao valor da prestação oposta. $\$ 1^{\circ}$ Aprecia-se a desproporção das prestações segundo os valores vigentes ao tempo em que foi celebrado o negócio jurídico. $\$ 2^{-}$Não se decretará a anulação do negócio, se for oferecido suplemento suficiente, ou se a parte favorecida concordar com a redução do proveito.

${ }^{260}$ THEODORO JUNIOR, Humberto. op. cit., p. 72: Dessa especial essência do contrato aleatório decorre que a eventual disparidade entre prestação e contraprestação jamais poderá ser considerada como "lesão" para a parte frustrada na sua expectativa de ganho ou lucro no negócio convencionado sob cláusula de risco.

${ }^{261}$ De suma importância o momento do acontecimento do ato lesivo, não podendo ser invocado para situações após fechamento da avença. Cf. MAZEAUD, Henri et Léon; MAZEAUD, Jean; CHABAS, François. Leçons de droit civil. 8. ed. Paris: Montchrestien, 1991. t. 2, v. 1, p. 869.

${ }^{262}$ MARTINS-COSTA, Judith. op. cit., p. 12, também adota este entendimento para os derivativos: Como é sabido, a lesão vem prevista no art. 157 do CC/2002 como um defeito do negócio jurídico que serve de fundamento para a anulação do contrato do qual resulte prestação manifestamente desproporcional ao valor da contraprestação. Se é marca característica dos contratos aleatórios a impossibilidade de se avaliar, no momento da sua celebração, o valor da prestação afetada pela álea, compreende-se a razão de, nessa seara, obstar-se a lesão cuja aplicação resulta, justamente, da avaliação e comparação pelo juiz ou árbitro dos valores das prestações contrapostas no momento da celebração do contrato.

${ }^{263}$ Também a doutrina italiana afasta a rescisão por lesão dos contratos aleatórios. Cf. BIANCA, Massimo. Diritto civile. Milano: Giuffrè, 1987. v. 3, p. 649-650.

${ }^{264}$ BRASIL. Lei n. ${ }^{\circ}$ 10.406, de 10 de janeiro de 2002. Institui o Código Civil. Disponível em: $<$ http://www.planalto.gov.br>. Acesso em: 22 maio 2011. Parte Geral, Livros III (Dos Fatos Jurídicos), Título I (Dos Negócios Jurídicos), Capítulo IV (Dos Defeitos dos Negócios Jurídicos), Seção I (Do Erro ou Ignorância). Art. 138. São anuláveis os negócios jurídicos, quando as declarações de vontade emanarem de erro substancial que poderia ser percebido por pessoa de diligência normal, em face das circunstâncias do negócio. Art. 139. O erro é substancial quando: I - interessa à natureza do negócio, ao objeto principal da declaração, ou a alguma das qualidades a ele essenciais; II - concerne à identidade ou à qualidade essencial da pessoa a quem se refira a declaração de vontade, desde que tenha influído nesta de modo relevante; III - sendo de direito e não implicando recusa à aplicação da lei, for o motivo único ou principal do negócio jurídico.
} 
A teoria da imprevisão ${ }^{265}$ cuida de contratos de trato sucessivo mediante comparação entre o momento da execução contratual e o momento da efetiva prestação. Ocorre que esta teoria, segundo pensamento dominante, aplica-se apenas a contratos comutativos, pois, nos contratos aleatórios, o desequilíbrio é a regra da contratação buscada pelas partes. Vale mencionar que, mesmo os doutrinadores que admitem sua aplicação aos contratos aleatórios colocam como condição que o motivo imprevisível não esteja caracterizado como parte do risco normal do negócio. ${ }^{266}$ Disso, inegável concluir que a efetiva ocorrência dos riscos dispostos nos contratos derivativos equivale à materialização da previsão objetivamente ${ }^{267}$ ajustada entre as partes, logo, inaplicável, em qualquer cenário, a teoria da imprevisão. Admitir o contrário seria advogar contra a própria natureza e utilidade dos contratos derivativos, que possuem o risco como causa do pacto.

Se o objetivo do contrato aleatório é a transferência de riscos previamente aceitos pelas partes, invocar a onerosidade excessiva ${ }^{268}$ por conta da consagração de tais riscos revela-se não apenas inoportuno, como também incoerente com a própria sistemática deste tipo contratual. Em primeiro lugar, o risco previsto no próprio contrato não pode ser entendido como acontecimento extraordinário ou imprevisível; ao contrário, sua materialização, apesar de incerta, é prevista. Em segundo lugar, a bilateralidade dos riscos (que atingem ambas as partes, em condições iguais) ${ }^{269}$ não deve ser vislumbrada como causadora de extrema vantagem, visto que contemplada pelos contraentes e objeto mesmo da contratação. Nos derivativos, inexiste sacrifício demasiado de uma parte

\footnotetext{
${ }^{265}$ BRASIL. Lei n. 10.406 , de 10 de janeiro de 2002. Institui o Código Civil. Disponível em: $<$ http://www.planalto.gov.br>. Acesso em: 22 maio 2011. Parte Especial, Livro I (Do Direito das Obrigações), Título V (Dos Contratos em Geral), Capítulo I (Do Pagamento), Seção III (Do Objeto do Pagamento e sua Prova). Art. 317. Quando, por motivos imprevisíveis, sobrevier desproporção manifesta entre o valor da prestação devida e o do momento de sua execução, poderá o juiz corrigi-lo, a pedido da parte, de modo que assegure, quanto possível, o valor real da prestação.

${ }^{266}$ MARTINS-COSTA, Judith. op. cit., p. 24.

${ }^{267}$ Id. Ibid., p. 25, relembra-nos que, nos procedimentos para caracterização da imprevisibilidade, é preciso compor elementos de ordem objetiva (como a natureza do negócio) e elementos de ordem subjetiva (eventual hipossuficiência e experiência dos contratantes). Na presente dissertação, possível afastar apenas os elementos de ordem objetiva, ao analisarmos a natureza dos derivativos como contratos aleatórios. Os elementos de ordem subjetiva devem ser inferidos do caso concreto - tarefa impossível ao tentarmos criar uma classificação ampla.

${ }^{268}$ BRASIL. Lei n. ${ }^{\circ} 10.406$, de 10 de janeiro de 2002. Institui o Código Civil. Disponível em: $<$ http://www.planalto.gov.br>. Acesso em: 22 maio 2011. Parte Especial, Livro I (Do Direito das Obrigações), Título III (Do Adimplemento e Extinção das Obrigações), Capítulo II (Da Extinção do Contrato), Seção IV (Da Resolução por Onerosidade Excessiva). Art. 478. Nos contratos de execução continuada ou diferida, se a prestação de uma das partes se tornar excessivamente onerosa, com extrema vantagem para a outra, em virtude de acontecimentos extraordinários e imprevisíveis, poderá o devedor pedir a resolução do contrato. Os efeitos da sentença que a decretar retroagirão à data da citação.

${ }^{269}$ Este segundo raciocício deve ser enxergado com determinadas adaptações para as opções, que, como dito, possuem aparente distribuição assimétrica do risco.
} 
em benefício da outra, pois, quando da materialização do pacto, está-se diante dos efeitos pretendidos pelas próprias partes em momento anterior, restando tal onerosidade como o próprio objeto da avença.

A teoria da transformação da base objetiva do negócio, ${ }^{270}$ que não tem correspondência em nosso direito positivo, indaga se a finalidade real de ambos contratantes pode ser atingida após lapso temporal modificativo das circunstâncias. ${ }^{271}$ Nos derivativos, em que a causa da contratação buscada por ambas as partes é justamente a álea futura, impossível falarmos em alterações circunstanciais de algo conceitualmente desejado e previsto pelas partes. Como o risco faz parte da própria base objetiva do negócio em momento formativo do vínculo juris, não se pode lançar mão da teoria do desaparecimento da base objetiva nos contratos aleatórios, tais quais os derivativos.

Em resumo, as hipóteses de revisão, quaisquer que sejam, são incompatíveis aos derivativos, contrato por essência desequilibrado, cuja natureza, objeto e motivo negocial essencial é o próprio risco. Nas sábias palavras de MARTINS-COSTA:

(...) a finalidade das normas legais asseguradoras da revisão/resolução contratual é a de retomar ao equilíbrio esfacelado pelo evento superveniente que desequilibra a equação econômico-financeira do ajuste. Sendo essa a finalidade das normas permissivas da revisibilidade ou da resolubilidade por excessiva onerosidade superveniente, consequência necessária é concluir que só nascerá o mencionado direito formativo se estiver em causa um contrato que deva ser equilibrado, $e$ nos limites do equilíbrio devido. ${ }^{272}$

\section{IV.C. Função Instrumental: Valores Mobiliários}

A grande dificuldade que se tem para aceitar a conceituação dos derivativos como valores mobiliários (dada em lei) assenta-se em alguns motivos. Em primeiro lugar, um motivo cultural: a necessidade que a academia jurídica brasileira possui em encontrar a "natureza jurídica" de todos os institutos, sendo avessa a definições instrumentais. Em segundo lugar, o fato de nosso sistema jurídico ser romano-germânico, com a existência de

\footnotetext{
${ }^{270}$ LARENZ, Karl. Base del negocio juridico y cumplimento de los contratos. Madrid: Editorial Revista de Derecho Privado, 1956.

${ }^{271}$ AZEVEDO, Antônio Junqueira de. op. cit., p. 121, entende que essa teoria é hoje considerada uma fórmula vazia e nos dá notícia que ela se encontra abandonada na própria Alemanha. Segundo ele, a suposta objetividade se perde na interpretação e perquirição da vontade das partes.

${ }^{272}$ MARTINS-COSTA, Judith. op. cit., p. 23.
} 
institutos que exigem rigor formal e classificatório, em busca de conceitos herméticos, abstratos e perfeitos. Em terceiro lugar e ligado à segunda e à primeira razões, a força que o conceito dos "títulos de crédito" sempre exerceu sobre os nossos comercialistas e a proximidade de tal instituto com muitos dos valores mobiliários. Por fim, a forma pela qual se alargou o conceito de valores mobiliários, de maneira gradual, à conveniência do tempo, talvez sem maiores reflexões e com um viés declarado de finalidade regulatória.

Para que consigamos entender os desafios que a classificação dos derivativos como valores mobiliários pela legislação brasileira impõe, é necessário discorrer sobre o aparecimento do conceito entre nós e de que forma seu significado foi sendo paulatinamente aumentado, sem deixarmos de mencionar as reações dos doutrinadores brasileiros a esses movimentos.

O termo "valor mobiliário" aparece no direito positivo brasileiro pela primeira vez em 1965 com a edição da Lei 4.728/65, promulgada com o objetivo de disciplinar o mercado de capitais e estabelecer medidas para o seu desenvolvimento. ${ }^{273}$ Curiosamente, a lei dispôs sobre a emissão, o registro, a distribuição e a fiscalização dos valores mobiliários, mas, em momento algum, determinou o que deveria ser considerado um valor mobiliário. $^{274}$ Etimologicamente, o termo valor mobiliário deriva do francês valeur mobilière, onde possui cunho pragmático de busca de renda para o seu titular, sendo ele um ativo negocial. ${ }^{275}$

MATTOS FILHO esclarece que a falta de conceituação legislativa de valor mobiliário não trouxe, na ocasião, maiores transtornos, considerando o incipiente mercado, com pequeno número de valores mobiliários ofertados e o reduzido número de sociedades que colocavam valores mobiliários junto ao público. ${ }^{276}$ Válido mencionar que LEÃES, ainda no começo da década de 1970, época em que o conceito ainda era indeterminado, vislumbrou no direito americano um caminho "livre de embaraços formais" a ser seguido pelo legislador brasileiro. ${ }^{277}$

\footnotetext{
${ }^{273}$ BRASIL. Lei n. ${ }^{4}$ 4.728, de 14 de julho de 1965, disciplina o mercado de capitais e estabelece medidas para o seu desenvolvimento. Disponível em: <www.planalto.gov.br>. Acesso em: 20 fev. 2012.

${ }^{274}$ MOTTA, Rita de Cassia Luz Teixeira. O conceito de valor mobiliário no direito brasileiro. 2002. Dissertação (Mestrado) - Faculdade de Direito, Universidade de São Paulo, 2002. p.76.

${ }^{275}$ COSTA, Philomeno Joaquim da. Anotações às companhias. São Paulo: Ed. Revista dos Tribunais, 1980. v. 1, p. 111-112.

${ }^{276}$ MATTOS FILHO, Ary Oswaldo. O conceito de valor mobiliário. Revista de Direito Mercantil, Industrial, Econômico e Financeiro, São Paulo, n. 59, p. 32, jul./set. 1985.

${ }^{277}$ LEÃES, Luiz Gastão Paes de Barros. O conceito de "security" no direito norte-americano e conceito análogo no direito brasileiro. Revista de Direito Mercantil, Industrial, Econômico e Financeiro, São Paulo,
} 
A partir de 1969, com o crescimento do mercado, ganha corpo a necessidade de alteração da lei das sociedades anônimas e a criação de uma comissão de valores mobiliários, fatos estes que culminam na edição das duas leis irmãs que são, até hoje, base para o mercado de capitais brasileiro, a Lei 6.385/76, e a Lei 6.404/76. ${ }^{278}$

Nesse contexto, o legislador de 1976 não cometeu o mesmo equívoco de não conceituar o que seriam os valores mobiliários e, finalmente, os definiu, ${ }^{279}$ muito embora sem levar em conta as sugestões pretéritas de LEÃES, que provocara o regulador brasileiro a utilizar a experiência dos securities e a abrir mão de critérios formalistas. ${ }^{280}$

Aparece, assim, a primeira conceituação taxativa de valores mobiliários pela Lei 6.385/76, inspirada pelo direito francês, que os colocou basicamente como os títulos ofertados pelas sociedades anônimas (ações, partes beneficiárias e debêntures, cupões desses títulos, bônus de subscrição e os seus certificados de depósito), além de deixar uma importante porta aberta para outros títulos a serem criados ou emitidos pelas sociedades anônimas, a critério do $\mathrm{CMN}$. $^{281}$

Por muito tempo, provavelmente em decorrência de nossa formação civilista e da profunda influência que os comercialistas italianos sempre exerceram em nossa doutrina, buscou-se na definição vivantiana de título de crédito (“documento necessário para o exercício do direito literal e autônomo nele mencionado") um ponto de partida para a conceituação dos valores mobiliários.

n. 14, p. 60, 1974, em 1974, antes, portanto da Lei 6.385/76, expunha a experiência dos Estados Unidos da América com relação ao conceito de securities, livre de embaraços formais e com largo elastério, como uma lição que não pode deixar de ser cogitada pelos intérpretes do direito brasileiro de mercado de capitais. Como veremos, pode-se dizer que o texto de Leães foi, de certo modo, profético, tendo em vista a inclusão dos "contratos de investimento coletivo" como valores mobiliários em nossa legislação, quase 25 anos após o paradigmático texto.

${ }^{278}$ MATTOS FILHO, Ary Oswaldo. op. cit., p. 32.

${ }^{279}$ Id., loc. cit., comenta que o legislador de 1976 já conhecia as dificuldades que outros países enfrentavam para a conceituação de valores mobiliários e que a escolha de se delegar à competência da CVM apenas os valores mobiliários emitidos por sociedades anônimas teve forte viés político, qual seja, a oposição do Bacen à criação de um novo centro de poder regulatório.

${ }^{280}$ LEÃES, Luiz Gastão Paes de Barros. op. cit.

${ }^{281}$ BRASIL. Lei n. ${ }^{\circ}$ 6.385, de 7 de dezembro de 1976, conforme alterada, dispõe sobre o mercado de valores mobiliários e cria a Comissão de Valores Mobiliários. Disponível em: <www.planalto.gov.br>. Acesso em: 22 maio 2011. Art. $2^{\circ}$ (revogado): São valores mobiliários sujeitos ao regime desta Lei: I - as ações, partes beneficiárias e debêntures, os cupões desses títulos e os bônus de subscrição; II - os certificados de depósito de valores mobiliários; III - outros títulos criados ou emitidos pelas sociedades anônimas, a critério do Conselho Monetário Nacional. Parágrafo único - Excluem-se no regime desta Lei: I - os títulos da dívida pública federal, estadual ou municipal; II - os títulos cambiais de responsabilidade de instituição financeira, exceto as debêntures. 
BULGARELLI defendeu a subordinação da noção de valor mobiliário à condição de título de crédito, ressaltando que, apesar de não se confundirem, o conceito de valor mobiliário deveria ser entendido como título de massa impregnado de vários requisitos característicos dos títulos de crédito. ${ }^{282}$

Retomando a linha do tempo legislativa, a definição de valores mobiliários dada pela Lei 6.385/76 foi inicialmente taxativa, deixando-os adstritos aos títulos societários. Diferentemente, ${ }^{283}$ nossa cultura jurídica, muito influenciada pela tradição do direito europeu continental, está acostumada aos conceitos abstratos, sem a elaboração de listas extensas de tipos. ${ }^{284}$

Assim, em um primeiro momento, ao abrir mão do estabelecimento de critérios comuns e abstratos para a definição do tipo valor mobiliário, o legislador fomentou a doutrina a tentar encaixá-lo dentro de outro instituto abstrato que já nos era familiar, o dos títulos de crédito. Aliado a isso, nada ajudou o fato de a maioria dos valores mobiliários de então guardarem, de fato, similitudes com os títulos de crédito, o que levou muitos doutrinadores a se referirem aos valores mobiliários como "títulos de crédito de massa com apelo à poupança popular".

Passaram-se os anos e o rol de valores mobiliários foi ampliado, não só pela atuação do CMN (conforme originalmente previsto pela própria Lei 6.385/76), mas também por meio de leis, decretos-lei e medidas provisórias de autoria do Poder Executivo. $^{285}$ Ressaltamos aqui, no âmbito de alterações ocorridas entre 1976 e 2001, a

\footnotetext{
${ }^{282}$ BULGARELLI, Waldirio. Os valores mobiliários brasileiros como títulos de crédito, in Revista de Direito Mercantil, Industrial, Econômico e Financeiro, São Paulo, n. 37, p. 111, jan./mar. 1980: Por outro lado, é bom lembrar que ao dispor a Lei 6.385 (art. $2^{\circ}$ ), sobre a possibilidade de virem a ser considerados como Valores Mobiliários, a critério do CMN, outros títulos, não falou em papéis ou documentos, mas referiu-se expressamente a títulos, comprovando de certa forma a assertiva da subordinação da noção de Valor Mobiliário à condição de título de crédito. Tem-se à guisa de conclusão, que os valores mobiliários não se confundem com os chamados efeitos de comércio, nem com os títulos meramente cambiais, nem com todos os títulos de crédito (por ex., os conhecimentos de transporte, de depósito, de depósito bancário a prazo fixo, etc.). Mas, são títulos de massa, títulos negociáveis e títulos societários. Participam e devem se integrar à teoria dos títulos de crédito, não só para se manter a unidade conceitual e sistemática, mas, porque estão impregnados senão de todo ao menos de vários requisitos característicos dos títulos de crédito.

${ }^{283}$ CHEDIAK, Julian Fonseca Peña. op. cit., p. 534, entende que nosso regulador seguiu o sistema europeu, diferentemente do que sustentamos no presente trabalho, dada a evolução do conceito ao longo do tempo.

${ }^{284}$ DIAS, Luciana Pires. Regulação e auto-regulação no mercado de valores mobiliários. 2005. Dissertação (Mestrado) - Faculdade de Direito, Universidade de São Paulo, 2005. p. 22, descreve bem as duas formas possíveis de se lidar com o conceito de valor mobiliário, a forma abstrata e a taxativa.

${ }^{285}$ MOTTA, Rita de Cassia Luz Teixeira. op. cit., p. 76-77, relaciona a inclusão a posteriori dos seguintes como valores mobiliários: notas promissórias comerciais (Resolução CMN 1723/90), direitos de subscrição e recibos de subscrição de valores mobiliários (Resolução CMN 1907/92), certificados representativos de contratos mercantis de compra e venda a termo de energia elétrica (Resolução CMN 2405/97), certificados de recebíveis imobiliários (Lei 9.514/97 e Resolução CMN 2517/98), debêntures e ações emitidas por
} 
inclusão de duas figuras no rol valores mobiliários, que demonstram a virada de rumo tomado pelo legislador nessa matéria: em primeiro lugar, os derivativos do tipo índices representativos de carteiras de ações e opções de compra e venda de valores mobiliários e, em segundo lugar, os contratos de investimento coletivo.

A importância da inclusão, pelo Decreto-lei 2.286/86, dos derivativos de índices e das opções como valores mobiliários sujeitos ao regime da Lei 6.385/76 reside no reconhecimento de que os derivativos cujos ativos subjacentes já fossem valores mobiliários deveriam também ser tratados como tal. Nesse momento, não obstante a existência de derivativos entre nós remonte à década de 1910 (sem um regime próprio ou uma estrutura regulatória especializada, é verdade), ${ }^{286}$ o legislador inaugurou a competência da CVM para determinados derivativos, as opções, ao reconhecê-las como valores mobiliários. $^{287}$

Com a inclusão dos derivativos cujos ativos subjacentes fossem valores mobiliários na órbita de competência da CVM, pode-se dizer que, na década de 1980, o legislador brasileiro ficou, de certa forma e por certo tempo, ${ }^{288}$ mais próximo da experiência americana, onde os derivative securities estão sujeitos à regulação da Securities and Exchange Commission. ${ }^{289}$

Destaque-se que, na década de 1980, o mercado criou outros instrumentos derivativos, que não os "derivados" dos já então classificados valores mobiliários. A solução da época foi tratá-los como instrumentos financeiros sujeitos à regulação do Bacen e das Bolsas em que eram negociados. ${ }^{290}$ Nesse passo, estes derivativos não eram ainda considerados valores mobiliários.

securitizadoras de créditos financeiros (Resolução CMN 2493), certificados representativos de contratos mercantis de compra e venda a termo de mercadorias e serviços (Resolução CMN 2801/00), índices representativos de carteiras de ações e opções de compra e venda de valores mobiliários (Decreto-lei 2286/86), títulos emitidos por companhias beneficiárias de recursos oriundos de incentivos fiscais (Decreto-lei 2298/86), quotas de fundos de investimento imobiliário (Lei 8.668/93), certificado de investimento em obras visuais (Lei 8.685/93) e contratos de investimento coletivo (Medida Provisória 1.637/98).

${ }^{286}$ YAZBEK, Otavio. Regulação do mercado financeiro e de capitais, cit., p. 120.

${ }^{287}$ BANCO CENTRAL DO BRASIL. Conselho Monetário Nacional. Resolução $n .^{\circ} 1.190$, de 17 de setembro de 1986. Disponível em: <www.bacen.gov.br>. Acesso em: 20 fev. 2013, dividiu a competência regulatória entre a CVM e o Bacen, conforme ativo subjacente.

${ }^{288}$ Deve-se relativizar esta afirmação de que o legislador brasileiro passou a seguir a experiência americana pois os demais derivativos (que não os baseados em securities) estão sujeitos à regulação da $C F T C$, uma outra agência reguladora que não encontra paralelo no Brasil.

${ }^{289}$ PALMITER, Alan R. Securities regulations: examples \& explanations. 3. ed. New York: Aspen Publishers, 2005. p. 6-7.

${ }^{290}$ BANCO CENTRAL DO BRASIL. Conselho Monetário Nacional. Resolução $n .{ }^{\circ} 1.190$, de 17 de setembro de 1986. Disponível em: <www.bacen.gov.br>. Acesso em: 20 fev. 2013. 
Mais tarde, a segunda grande inovação no conceito de valores mobiliários trazida pela Medida Provisória 1.637/98, é a inclusão dos contratos de investimento coletivo no rol da Lei 6.385/76. ${ }^{291}$ A importância desse movimento legislativo é trazer ao direito brasileiro a clássica conceituação abstrata do investment contract como security, dada pelo Howey Test ${ }^{292}$ alinhando-se definitivamente ao direito americano.

Se, por um lado, a conceituação dos valores mobiliários continuou taxativa, por outro lado, trouxe um novo conceito genérico, elástico e abstrato, o contrato de investimento coletivo, possível de abarcar qualquer título ou contrato quando ofertado publicamente. $^{293}$

Há de se notar que, mesmo antes da promulgação da Medida Provisória 1.637/98, a doutrina brasileira já clamava por um conceito amplo como esse. ${ }^{294}$ Pedia-se uma correção de rota no conceito de valor mobiliário, então muito estreito, com tratamento que chegou a ser chamado por EIZIRIK de "defeituoso ou incompleto". ${ }^{295}$ Foi necessário um escândalo com implicações na poupança popular, o famoso caso do "contrato de boi gordo", 296 para que o legislador finalmente acatasse uma sugestão que há décadas era aventada pelos comercialistas, baseada na doutrina americana.

\footnotetext{
${ }^{291}$ BRASIL. Medida Provisória n. ${ }^{\mathbf{0}} 1.637$, de 08 de janeiro de 1998, dispõe sobre a regulação, fiscalização e supervisão dos mercados de títulos ou contratos de investimento coletivo, e dá outras providências. Disponível em: <www.planalto.gov.br>. Acesso em: 22 maio 2011, art. 1: Constituem valores mobiliários, sujeitos ao regime da Lei $n^{\circ}$ 6.385, de 7 de dezembro de 1976, quando ofertados publicamente, os títulos ou contratos de investimento coletivo, que gerem direito de participação, de parceria ou de remuneração, inclusive resultante de prestação de serviços, cujos rendimentos advêm do esforço do empreendedor ou de terceiros.

${ }^{292}$ UNITED STATES SUPREME COURT. SEC v. W. J. Howey Co., 328 U.S. 293. Disponível em: $<$ http://supreme.justia.com/cases/federal/us/328/293/case.html>. Acesso em: 21 fev. 2013: For purposes of the Securities Act, an investment contract (undefined by the Act) means a contract, transaction, or scheme whereby a person invests his money in a common enterprise and is led to expect profits solely from the efforts of the promoter or a third party, it being immaterial whether the shares in the enterprise are evidenced by formal certificates or by nominal interests in the physical assets employed in the enterprise. Assim, segundo a jurisprudência do Howey Test, são quatro os elementos que dão o tom do contrato de investimento como um security: (i) investimento de dinheiro, (ii) em um empreendimento comum, (iii) com expectativa de lucros, e (iv) cujos resultados dependem do esforço de terceiros. Conforme exposto por LEÃES, Luiz Gastão Paes de Barros, op. cit., com o tempo, a jurisprudência adicionou outros elementos característicos dos securities, tais como a captação pública e a existência de risco no empreendimento. Assim, o conceito de securities é antes dinâmico do que estático.

${ }^{293}$ DIAS, Luciana Pires. op. cit., p. 34.

${ }^{294}$ VERÇOSA, Haroldo Malheiros Duclerc. Notas sobre o regime jurídico das ofertas ao público de produtos, serviços e valores mobiliários no direito brasileiro: uma questão de complementação da proteção de consumidores e de investidores. Revista de Direito Mercantil, Industrial, Econômico e Financeiro, São Paulo, v. 36, n. 105, p. 82, jan./mar. 1997.

${ }^{295}$ EIZIRIK, Nelson. A urgente reforma da Lei 6.385/76. Revista de Direito Mercantil, Industrial, Econômico e Financeiro, São Paulo, v. 34, n. 98, p. 58-61, abr.jun. 1995.

${ }^{296}$ Sobre o histórico da edição da MP $1637 / 98$ e os "contratos de boi gordo", vide MOTTA, Rita de Cassia Luz Teixeira. op. cit., p. 78.
} 
Finalmente, em 2001, a Lei 10.303/01, além de consolidar as esparsas alterações conceituais havidas até então (incluindo-se os derivativos de valores mobiliários e os contratos de investimento coletivo - dois movimentos que tomamos a liberdade de referirmos aqui como "virada de rumo"), expressamente também elencou no rol de valores mobiliários sujeitos ao regime da Lei 6.385/76 todos os contratos derivativos, cujos ativos subjacentes fossem ou não valores mobiliários. ${ }^{297}$ Dessa feita, o legislador consolidou a posição de utilizar o conceito de valor mobiliário de maneira instrumental.

Assim, especificamente com relação aos derivativos, até 2001, existia uma situação regulatória em que a CVM era competente para regular apenas os derivativos que tinham como ativos subjacentes os valores mobiliários já sujeitos à sua competência (por exemplo, opções de ações) e o Bacen ${ }^{298}$ competente para regular todos os demais derivativos (por exemplo, swaps e futuros de commodities) - então não classificáveis como valores mobiliários. $^{299}$

Ao definir todos os derivativos como valores mobiliários, ${ }^{300}$ o legislador delimitou as fronteiras da atuação estatal, trazendo para a órbita da CVM tais instrumentos, ${ }^{301}$ ainda

\footnotetext{
${ }^{297}$ BRASIL. Lei n. ${ }^{\circ}$ 6.385, de 7 de dezembro de 1976, conforme alterada, dispõe sobre o mercado de valores mobiliários e cria a Comissão de Valores Mobiliários. Disponível em: <www.planalto.gov.br>. Acesso em: 22 maio 2011. Art. 2: São valores mobiliários sujeitos ao regime desta Lei: I - as ações, debêntures e bônus de subscrição; II - os cupons, direitos, recibos de subscrição e certificados de desdobramento relativos aos valores mobiliários referidos no inciso II; III - os certificados de depósito de valores mobiliários; $I V$ - as cédulas de debêntures; $V$ - as cotas de fundos de investimento em valores mobiliários ou de clubes de investimento em quaisquer ativos; VI - as notas comerciais; VII - os contratos futuros, de opções e outros derivativos, cujos ativos subjacentes sejam valores mobiliários; VIII - outros contratos derivativos, independentemente dos ativos subjacentes; e IX - quando ofertados publicamente, quaisquer outros títulos ou contratos de investimento coletivo, que gerem direito de participação, de parceria ou de remuneração, inclusive resultante de prestação de serviços, cujos rendimentos advêm do esforço do empreendedor ou de terceiros.

${ }^{298}$ COMISSÃO DE VALORES MOBILIÁRIOS. Decisão Conjunta CVM e Bacen n. ${ }^{o} 10$, de 02 de maio de 2002. Disponível em: <www.cvm.gov.br>. Acesso em: 24 fev. 2013, como forma de transição regulatória, estabeleceu que, enquanto não baixadas normas pela CVM sobre os derivativos, permaneceriam em vigor todas as medidas editadas pelo Bacen e pelo CMN.

${ }^{299}$ CHEDIAK, Julian Fonseca Peña. op. cit., p. 530.

${ }^{300}$ Há muitas críticas sobre a técnica legislativa utilizada, sobretudo pela utilização de dois incisos, o VII (os contratos futuros, de opções e outros derivativos, cujos ativos subjacentes sejam valores mobiliários) e o VIII (outros contratos derivativos, independentemente dos ativos subjacentes), que remetem à mesma idéia. Talvez a má técnica jurídica tenha sido propositalmente utilizada pelo legislador, de forma a ressaltar a competência absoluta da CVM sobre o assunto. Sobre este assunto, cf. EIZIRIK, Nelson; GAAL, Ariádna B.; PARENTE, Flávia, HENRIQUES, Marcus de Freitas. Mercado de capitais: regime jurídico, cit., p. 114.

${ }^{301}$ Cf. DIAS, Luciana Pires. op. cit., p. 38: A primeira conclusão é que há uma tendência mundial de adoção de conceitos de valores mobiliários abertos, para que títulos não ortodoxos criados pelo mercado possam ser abarcados pela definição legal. A razão para tal tendência parece ser a função instrumental desempenhada pelo conceito de valor mobiliário nos sistemas jurídicos estudados. Ou seja, o conceito de valor mobiliário é utilizado para delimitar as fronteiras de intervenção estatal ou supra-estatal em uma certa área da economia.
} 
que a própria CVM trate as suas diversas espécies de maneira heterogênea. ${ }^{302}$ Portanto, em 2001, entendeu o legislador, com a reforma da Lei 6.385/76, que a regulação de todos derivativos ficaria melhor normatizada, incentivada e supervisionada se feita pela CVM. Muito embora haja críticas sobre esta escolha, ${ }^{303}$ fato é que hoje todos os derivativos são valores mobiliários por decorrência legal.

Uma observação importante com relação à competência regulatória é o fato de que os derivativos cursados necessariamente por meio de bancos (por envolverem questões cambiais, por exemplo) ou cuja contraparte é necessariamente uma instituição financeira continuam também sujeitos ao Bacen. ${ }^{304}$ Como, obviamente, todas as instituições financeiras e equiparadas estão na órbita regulatória do Bacen e considerando-se que a escolha do legislador com relação a determinados tipos de derivativos envolve a negociação por meio ou tendo como contraparte instituição financeira, natural que o Bacen tenha competência sobre tais matérias. Isso não invalida a afirmação de que todos os derivativos passaram a ser, a partir de 2001, valores mobiliários sujeitos à CVM.

Para sumarizarmos a evolução legislativa brasileira: o termo valor mobiliário foi importado do direito francês (valeur mobilière) como título negociável emitido por pessoa jurídica, transmissível por registro ou tradição e que confere direitos de participação ou remuneração a seu titular. Paralelamente, tem-se uma influência muito grande do conceito de securities norte-americano, seja com a utilização de listas ou com a inclusão dos contratos de investimento coletivo no rol dos instrumentos classificáveis como valores mobiliários. Em momento posterior, abarcam-se instrumentos financeiros bastante diversos, que nada têm a ver com atividades de financiamento ou investimento, como os derivativos. ${ }^{305}$

Os valores mobiliários, em geral, são tradicionalmente colocados pela doutrina como direitos negociados em massa no mercado de capitais, representativos de participação em propriedade ou patrimônio. ${ }^{306}$ Portanto, os valores mobiliários (na acepção clássica do termo) são ferramentas que estão relacionadas à transferência de poupança com

\footnotetext{
${ }^{302}$ Sobre a forma como a CVM lida com os derivativos de bolsa e os de balcão, vide: COMISSÃO DE VALORES MOBILIÁRIOS. Instrução $n^{\circ}$ 467, de 10 de Abril de 2008. Disponível em: <www.cvm.gov.br>. Acesso em: 22 fev. 2013.

${ }^{303}$ Vide, por exemplo, FERREIRA, Kenneth Antunes. Contrato derivativo não padronizado: a impropriedade de sua classificação como valor mobiliário. 2008. Dissertação (Mestrado) - Faculdade de Direito, Pontifícia Universidade Católica, 2008.

${ }^{304}$ Importantes milestones nesse sentido são a Resolução CMN 2921/02, a Resolução CMN 2933/02, a Resolução CMN 3312/05 e a Resolução CMN 3505/07.

${ }^{305}$ YAZBEK, Otavio. Regulação do mercado financeiro e de capitais, cit., p. 83.

${ }^{306}$ CARVALHOSA, Modesto. Comentários à Lei de Sociedades Anônimas. 2. ed. São Paulo: Saraiva, 1997. v. 1, p. $38-40$.
} 
apelo junto ao público, ao passo que os derivativos, conforme analisado em capítulo específico, são instrumentos que se prestam à transferência de riscos entre particulares, sendo muitos deles com características intuitu personae e não massificados.

Também por isso, colocar os derivativos (inclusive aqueles que não possuem outros valores mobiliários como ativos subjacentes) ${ }^{307}$ no rol de valores mobiliários foi uma decisão regulatória não ilesa a traumas pelos mais puristas, ${ }^{308}$ chegando alguns autores a defender a existência de competência concorrente do Bacen para determinados derivativos. $^{309}$

Sobre "o tempo e o esforço despendidos pela doutrina brasileira", para usarmos a expressão de GOLDBERG,${ }^{310}$ a respeito da possibilidade de conceituar valores mobiliários no campo dos títulos de crédito, preferimos encará-los como dois sistemas distintos, sem correspondência lógica entre eles. O que torna um papel um título de crédito é algo totalmente diferente do que o faz considerá-lo um valor mobiliário, muito embora, as duas qualificações possam ser cumulativas. ${ }^{311}$ Assim, na vã busca de conceitos herméticos e perfeitos, não há lógica em tentar forçar uma classificação que, simplesmente, não faz sentido por se tratarem de dois sistemas distintos.

Sobre a inclusão dos derivativos no rol dos valores mobiliários, CHEDIAK classificou a reforma trazida pela Lei 10.303/01 como "revolução na regulação no mercado de valores mobiliários”, e, muito embora criticasse essa inclusão (decisão, segundo o autor,

\footnotetext{
${ }^{307}$ A propósito dos ativos subjacentes, vale lembrar que, no Brasil, inexiste um rol taxativo de ativos subjacentes possíveis de serem utilizados para originarem derivativos. Diferente é a situação europeia, em que houve a consagração de extensivo elenco exaustivo de ativos relevantes, como nos conta José A. Engracia Antunes, Os derivados, cit., p. 100.

${ }^{308}$ SZTAJN, Rachel. Regulação e o mercado de valores mobiliários, cit., p. 145 e 147, classifica a competência ampla da CVM sobre os derivativos como um "problema institucional" e entende que determinados assuntos continuarão na órbita do Bacen.

${ }^{309}$ VERÇOSA, Haroldo Malheiros Duclerc. A arbitragem e o mercado de capitais. Revista de Direito Mercantil, Industrial, Econômico e Financeiro, São Paulo, v. 46, n. 146, p. 158, abr./jun. 2007, sustenta a superposição de competência da CVM e do Bacen para alguns derivativos (como os de câmbio, ouro ou juros), baseando-se nos artigo $4^{\circ}$, IX, e 11, III da Lei 4595/64.

${ }^{310}$ GOLDBERG, Daniel Krepel. A Lei 10.303, de 2001, e a Inclusão dos Derivativos no Rol dos Valores Mobiliários. Revista de Direito Mercantil, Industrial, Econômico e Financeiro, São Paulo, v. 42, n. 129, p. 74, jan./mar. 2003.

${ }^{311}$ DE LUCCA, Newton. Aspectos da teoria geral dos títulos de crédito. São Paulo: Pioneira, 1979. p. 37: (...) percebe-se que a conotação dada aos valores mobiliários é a de que se trata de papéis que, por serem negociados em massa, necessitam de proteção legal específica pelo legislador (...). Fixadas tais premissas, diríamos que o conceito de "valores mobiliários" não possui qualquer liame lógico com o de "títulos de crédito” (....). Podem os títulos de crédito, em alguns casos, assumir as feições de valores mobiliários e, vice-versa, estes poderão, concomitantemente, ser considerado como aqueles. Mas são dois sistemas distintos, sem uma correspondência lógica entre ambos. Em outras palavras, o que torna um papel um título de crédito é algo completamente diverso daquilo que faz considerá-lo, eventualmente, um valor mobiliário (....). Mas, de qualquer forma, a identificação de um papel como valor mobiliário somente assume interesse à medida em que a ele se pretenda aplicar dispositivos da Lei 6385/76.
} 
imprecisa e incoerente), ressaltou a competência da CVM para os derivativos como adequada. $^{312} \mathrm{O}$ autor chega a mencionar a criação de uma agência reguladora específica para operações com derivativos, a exemplo do que ocorre nos Estados Unidos, ${ }^{313}$ como alternativa ao alargamento de competências da CVM, mas pondera que isso aumentaria o custo da máquina administrativa federal, o que parece não fazer sentido em razão de restrições orçamentárias dos países em desenvolvimento. ${ }^{314}$

Dessa forma, dada a evolução histórica do instituto - cujo significado foi paulatinamente alargado em decorrência do processo de inovação financeira, podemos concluir que o conceito de valor mobiliário destina-se muito mais a estabelecer o campo de incidência de regras do que a significar uma categoria jurídica una e abstrata. Inexiste, assim, rigor formal e classificatório para os valores mobiliários brasileiros.

Muito embora tenha surgido de uma expressão francesa com rigor conceitual, podese dizer que valor mobiliário hoje, no Brasil, é um conceito polissemântico, eminentemente instrumental, com finalidade regulatória de definição das fronteiras de atuação estatal, que abarca títulos e contratos diversos entre si, incluindo-se os derivativos (talvez os maiores estranhos no ninho).

Da mesma forma como LEÃES, em 1974, quando a legislação mencionava "valores mobiliários" mas não os definia, conclamava os intérpretes brasileiros do mercado de capitais a ter uma leitura generosa do conceito, livre de embaraços formais ${ }^{315}$ - o que, após muitos desdobramentos históricos, acabou posteriormente prevalecendo, podemos hoje sugerir que os intérpretes se atenham ao caráter instrumental do conceito, no atual contexto das inovações financeiras.

\footnotetext{
${ }^{312}$ CHEDIAK, Julian Fonseca Peña. op. cit., p. 526, 533 e 537.

${ }^{313}$ Conforme dito acima, a regulação dos derivativos é, nos Estados Unidos, dividida entre a SEC e a CFTC. Vale aqui mencionarmos a constante tensão entre as duas agências acerca das zonas cinzentas de competência em decorrência do dualismo regulatório. Sobre este assunto, um bom "case" que revela a tensão regulatória e que trata de derivativos de índices: UNITED STATES COURT OF APPEALS. Chicago Mercantile Exchange v. SEC, 883 F.2d 537 (7th Circ. 1989). Disponível em: <https://bulk.resource.org/courts.gov/c/F2/883/883.F2d.537.89-2012.89-1786.89-1763.89-1538.html>. Acesso em: 21 fev. 2013.

${ }^{314} \mathrm{O}$ modelo brasileiro de competência da CVM para todos os derivativos, que já foi antes criticado (GOLDBERG, Daniel Krepel. op. cit., p. 81), parece hoje, do ponto de vista regulatório, muito mais eficaz do que o modelo americano. A partir da crise econômica de 2008, além das já conhecidas zonas cinzentas de atuação do regulador, descobriu-se que muitos instrumentos derivativos sequer tinham qualquer regulação - algo que, do ponto de vista regulatório, nos termos do modelo escolhido pelo legislador em 2001, seria impossível de acontecer no Brasil.

${ }^{315}$ LEÃES, Luiz Gastão Paes de Barros, op. cit., p. 60.
} 
Vale lembrar que o fato de todos os derivativos serem valores mobiliários, por conveniência instrumental regulatória, não significa que eles não possam ter outras classificações - como a de contratos, conforme tema explorado no item IV.B) do presente trabalho. 


\section{RESULTADOS DA PESQUISA EMPÍRICA}

\section{V.A. Resultados Quantitativos: os Números}

Foram analisadas 632 decisões do STJ e de todos os TJ do Brasil (com exceção do Pará, cujo site não permite a busca de jurisprudência por palavras-chave), entre os anos de 2006 e 2010, utilizando-se as palavras-chave "derivativos", "hedge" e "swap". Dentre estas decisões, 68 encaixaram-se no escopo da nossa pesquisa e, por isso, foram consideradas, analisadas e descritas.

A tabela abaixo resume os retornos consolidados totais obtidos nos sites do STJ e de 26 Tribunais de Justiça brasileiros (todos do país, com exceção do Pará), divididos por ano e palavra-chave, bem como os resultados válidos.

\begin{tabular}{|c|c|c|c|c|c|c|}
\hline $\begin{array}{l}\text { Palavra- } \\
\text { Chave }\end{array}$ & Ano & $\begin{array}{l}\text { Retorno } \\
\text { Total }\end{array}$ & $\begin{array}{ll}\text { Fora pelo } & \text { pelo } \\
\text { Escopo/Produto }\end{array}$ & $\begin{array}{l}\text { Fora pelo } \\
\text { Valor }\end{array}$ & Repetidos & $\begin{array}{l}\text { Resultados } \\
\text { Válidos } \\
\end{array}$ \\
\hline \multirow[t]{5}{*}{ Derivativos } & 06 & 25 & 21 & 1 & 0 & 3 \\
\hline & 07 & 19 & 12 & 1 & 0 & 6 \\
\hline & 08 & 125 & 121 & 1 & 0 & 3 \\
\hline & 09 & 58 & 36 & 3 & 1 & 18 \\
\hline & 10 & 40 & 26 & 6 & 2 & 6 \\
\hline \multirow[t]{5}{*}{ Hedge } & 06 & 74 & 69 & 1 & 3 & $2^{316}$ \\
\hline & 07 & 39 & 31 & 1 & 6 & 1 \\
\hline & 08 & 36 & 35 & 0 & 0 & 1 \\
\hline & 09 & 24 & 19 & 1 & 4 & 0 \\
\hline & 10 & 22 & 20 & 0 & 0 & 2 \\
\hline \multirow[t]{5}{*}{ Swap } & 06 & 55 & 50 & 2 & 0 & 3 \\
\hline & 07 & 32 & 25 & 0 & 3 & 4 \\
\hline & 08 & 21 & 18 & 1 & 1 & 1 \\
\hline & 09 & 35 & 12 & 1 & 13 & $11^{317}$ \\
\hline & 10 & 27 & 12 & 2 & 6 & 7 \\
\hline \multicolumn{2}{|c|}{ TOTAL GERAL } & 632 & & \multicolumn{2}{|c|}{ TOTAL VÁLIDOS } & 68 \\
\hline
\end{tabular}

\footnotetext{
${ }^{316}$ Nesta pesquisa, "dois mais dois" não é necessariamente "igual a quatro". Assim como ocorrido em São Paulo no ano de 2009 para a palavra-chave "swap" (vide nota de rodapé subsequente), também no Estado do Rio de Janeiro, no ano de 2006 para a palavra-chave "hedge", um único retorno deu origem a dois resultados válidos. Isso porque houve divergência entre os desembargadores da câmara, o que ocasionou a divulgação de 2 votos (voto vencido e voto vencedor), como se fossem resultados válidos diferentes (Apêndices 47-RJ e 48-RJ). O terceiro desembargador que votou com o voto vencedor não publicou sua fundamentação. Portanto, um retorno originou dois votos válidos.

${ }^{317}$ Também aqui trinta e cinco menos vinte e seis não resultou em nove e sim em onze. Assim como ocorrido no Rio de Janeiro no ano de 2006 para a palavra-chave "hedge", também em São Paulo no ano de 2009 para a palavra-chave "swap", um único retorno deu origem a três resultados válidos, tendo em vista ter sido registrada a opinião dos três desembargadores sobre o mesmo assunto - com o registro de 3 votos no mesmo sentido, cada qual com sua fundamentação - o que nos levou a contar os 3 votos.
} 
A mesma tabela acima foi reproduzida em 27 Anexos ao presente trabalho com os resultados individualizados de cada unidade da Federação (com exceção do Pará, indisponível) e do STJ. Assim, é possível observar com precisão os retornos individualizados de todas as buscas empreendidas nos sites dos diversos tribunais.

Cada uma das 68 decisões analisadas está detalhada nos Apêndices 1-SP a 42-SP, 43-RJ a 48-RJ, 49-ES a 50-ES, 51-PR a 59-PR, 60-SC a 65-SC, 66-RS a 67-RS e, por fim, 68-STJ. Assim, há 42 decisões dos Estados de São Paulo, 6 do Rio de Janeiro, 2 do Espírito Santo, 9 do Paraná, 6 de Santa Catarina, 2 do Rio Grande do Sul e 1 do STJ. Notase concentração de decisões no estado de São Paulo - 61,76\% das decisões, que pode ser explicada pelo poder econômico deste estado e pelo fato de a maioria das instituições financeiras estar localizada em sua capital.

Não há representantes de nenhuma unidade da Federação localizada nas regiões Norte, Nordeste, e Centro-Oeste. Todas os estados do Sudeste (com exceção de Minas Gerais) e do Sul possuem votos analisados no presente trabalho. Abaixo demonstração gráfica da divisão dos julgados analisados entre os Tribunais.

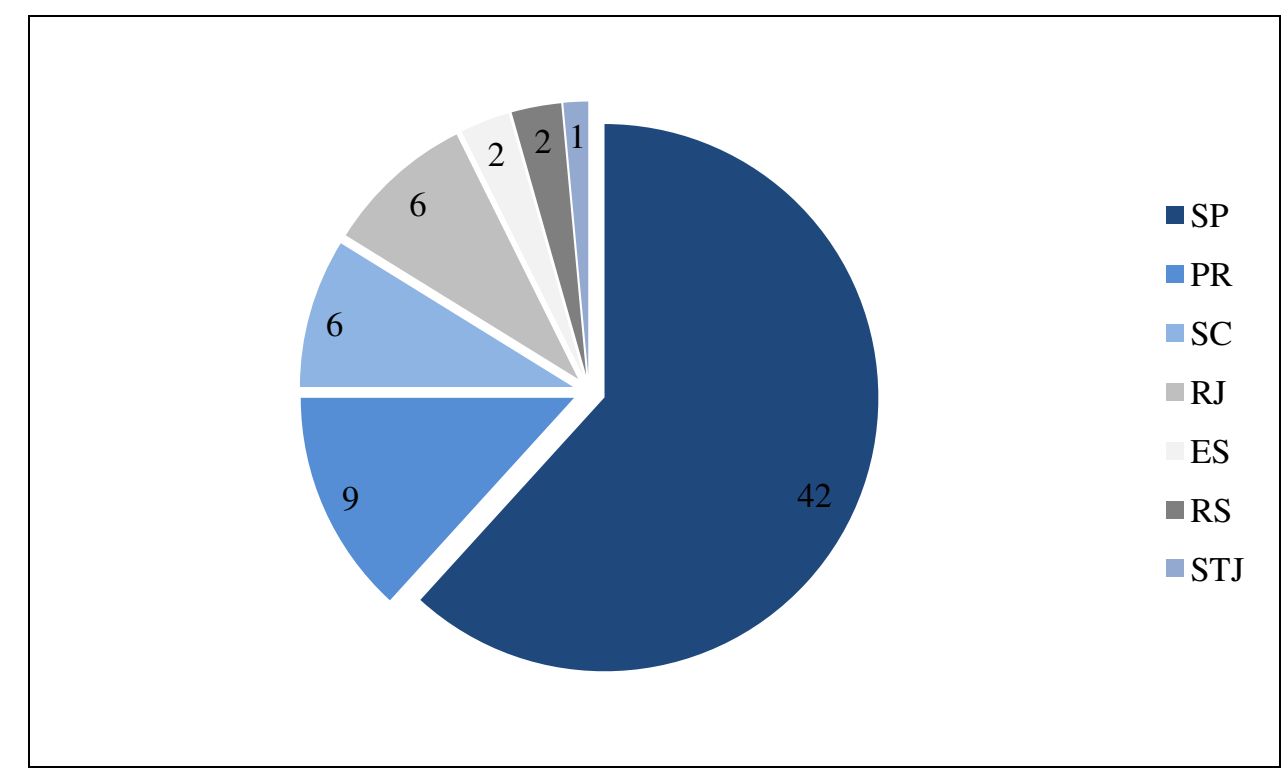

Uma das hipóteses para a ausência de representantes das regiões citadas é o desenvolvimento econômico e social de tais estados ${ }^{318}$. Considerando que as palavraschave buscadas são condizentes com uma matéria que exige certa sofisticação dos

\footnotetext{
${ }^{318}$ Com exceção de Minas Gerais, temos julgados de 5 dos 6 maiores estados (do ponto de vista do tamanho do PIB).
} 
demandantes, o elemento econômico parece ser uma explicação intuitiva para o não retorno de julgados nos sites dos tribunais. Esta hipótese faz muito sentido para os estados do Norte e Nordeste, mas não encontra eco necessariamente para os estados da região Centro-Oeste ou para o Estado de Minas Gerais.

Outra hipótese é o possível não cadastro de muitos julgados nos respectivos sites de tais estados para os anos pesquisados (2006 a 2010). No estado da Bahia, por exemplo, ainda que a busca possa ser executada (de maneira inócua), existe aviso expresso do TJBA sobre a disponibilização de jurisprudência apenas a partir do ano de 2011. Assim, levanta-se aqui uma segunda hipótese para a ausência de resultados para os demais estados em que a pesquisa apontou zero retornos: ainda que não tenham expresso aviso, talvez inexista cadastramento de julgados para o período pesquisado. Quiçá esta possa ser a hipótese aplicável ao estado de Minas Gerais que, mesmo sendo desenvolvido, não obteve retornos para as palavras-chave pesquisadas.

Das 632 decisões analisadas, a maioria foi desconsiderada por tratar de outros assuntos ou por ter os "derivativos", "swaps" e "hedge" como tema incidental e não como objeto do litígio em si. Nesse sentido, tais decisões são classificadas como "fora pelo escopo / produto".

Por exemplo, no ano de 2008, em São Paulo, há 58 decisões de um mesmo juiz que usa determinada citação com a palavra "derivativos" no contexto de elucubrações sobre o dano moral ${ }^{319}$ (portanto, algo não relacionado ao contexto da nossa pesquisa) e 48 de outro juiz que, ao discorrer sobre a inflação, nos casos do plano Verão, Collor e Bresser, usa outra citação que também traz a palavra "derivativos" como sinônimo de derivados. ${ }^{320}$ No contexto da massificação das ações e despachos judiciais, notamos que um mesmo juiz tende a usar o mesmo conteúdo em dezenas de sentenças que

\footnotetext{
${ }^{319}$ Conforme Apelação 7055502-1 do TJ-SP, p. 8, sobre dano moral, em que existe determinada citação de doutrina que usa a palavra "derivativos" como sinônimo de "derivados": Augusto Zenun (in "Dano Morai, Forense, 6a . ed., 1.997., págs. 109/139) reserva à reparação dos danos morais a finalidade compensatória pelos "derivativos", sugerindo "o arbitramento de derivativos suficientes e capazes de minorar a dor, ou por melhor explicar, as seqüelas que a dor morai causa (sentimentos, depressão, desvios da normalidade de vida, alheiamento parcial ou total)".

${ }^{320}$ Conforme Apelação 7242023-4 do TJ-SP, p. 8, em que existe determinada fundamentação do desembargador utilizando-se a palavra "derivativos" não como instrumento financeiro cujo valor deriva de um ativo subjacente: Deve-se, enfim, reconhecer que a Lei $n^{\circ} 7.730 / 89$, apesar de possuir conteúdo econômico, não se caracteriza como sendo de Direito Econômico, pois não houve a eliminação do fenômeno inflacionário e, sobretudo, porque os mecanismos da realidade econômica encontraram derivativos que tornaram o controle ineficaz. Assim, por não ter a norma em questão o caráter de ordem pública não lhe é permitido alterar a manifestação de vontade expressa em contratos firmados anteriormente à sua edição.
} 
versam sobre a mesma matéria. Quando isso ocorre, é necessário analisar todos os retornos para, então, descartá-los.

Além da utilização das palavras-chave eleitas em contextos não relacionados à nossa pesquisa (conforme acima exemplificado), existem julgados que abordam os derivativos de maneira incidental, sem discuti-los. Por exemplo, a maioria dos 82 retornos obtidos no site do STJ com a palavra-chave "hedge" e "swap" trata de uma discussão tributária acerca da incidência de tributos na fonte para as operações financeiras. ${ }^{321}$ Logo, tais litígios são descartados e também tabelados como "fora pelo escopo / produto".

Há também 21 decisões desconsideradas porque, apesar de estarem dentro do escopo de pesquisa, possuíam valor abaixo de $\mathrm{R} \$ 500.000,00$, o threshold eleito na metodologia como valor mínimo para que a decisão fosse analisada. Ressalte-se que as decisões que não mencionam valor foram consideradas - outra escolha metodológica arbitrária do pesquisador.

Abaixo mostramos a divisão das 68 decisões analisadas com os respectivos valores envolvidos nas disputas. Na grande maioria dos julgados (42), o relator não mencionou o valor em litígio e tais decisões foram consideradas.

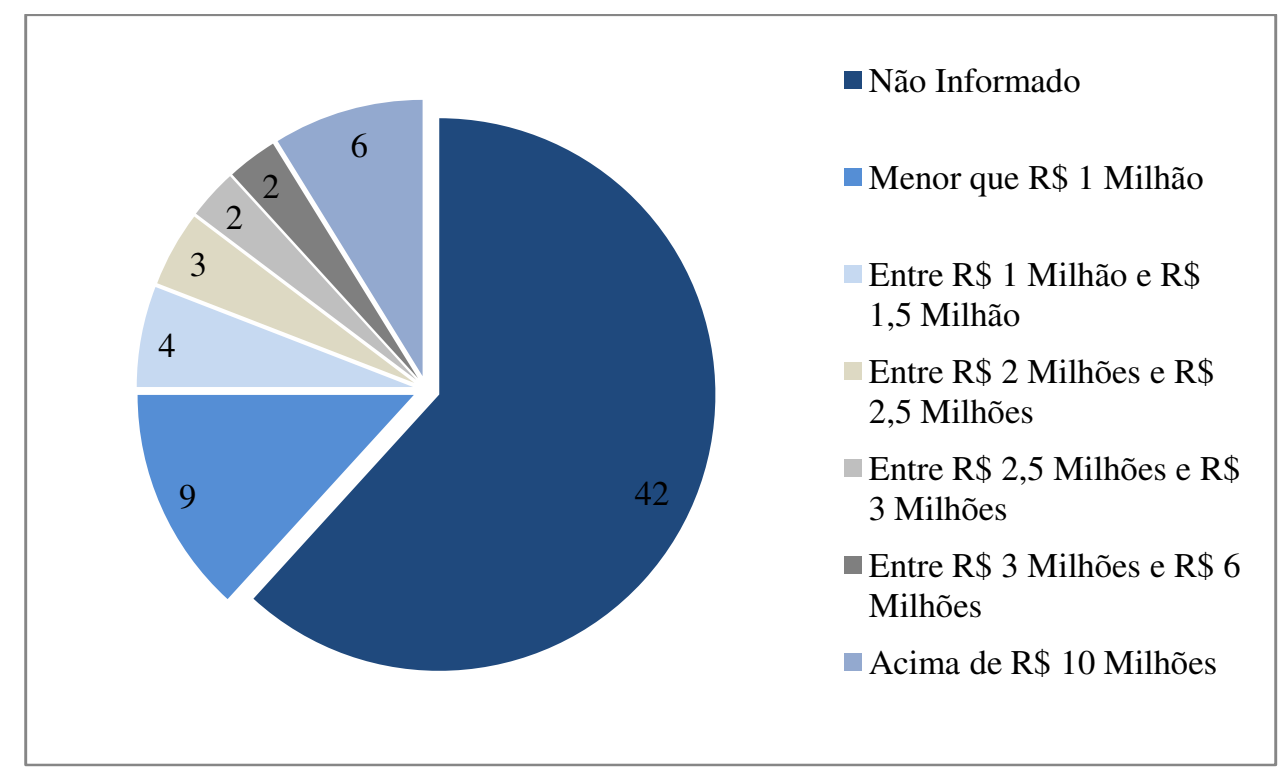

\footnotetext{
${ }^{321}$ Vide, por exemplo, a Ementa do Agravo Regimental no Agravo de Instrumento 2009/0051492/9 do STJ, cujo conteúdo é repetido diversas vezes: Tributário. Agravo regimental. Recurso especial. Operações de swap com cobertura hedge. Imposto de renda. Questão acolhida pelo Supremo Tribunal Federal (RE567.454-1/BA). Incidência. Lei 9.779/99. Artigo 543-b, do CPC. Repercussão geral. Sobrestamento do feito quando da análise do recurso especial. Impossibilidade. Precedentes do STJ.
} 
Dentre os 26 julgados em que o valor é informado, nota-se maior concentração de casos quando este se situa entre $\mathrm{R} \$ 500.000,00$ e R $\$ 1.500 .000,00$ (13 decisões de 26 cujo valor é sabido - o que corresponde a 50\%), muito embora, na população analisada, exista alta concentração de demandas com valor acima de R\$10.000.000,00 (23\% das decisões em que o valor é informado).

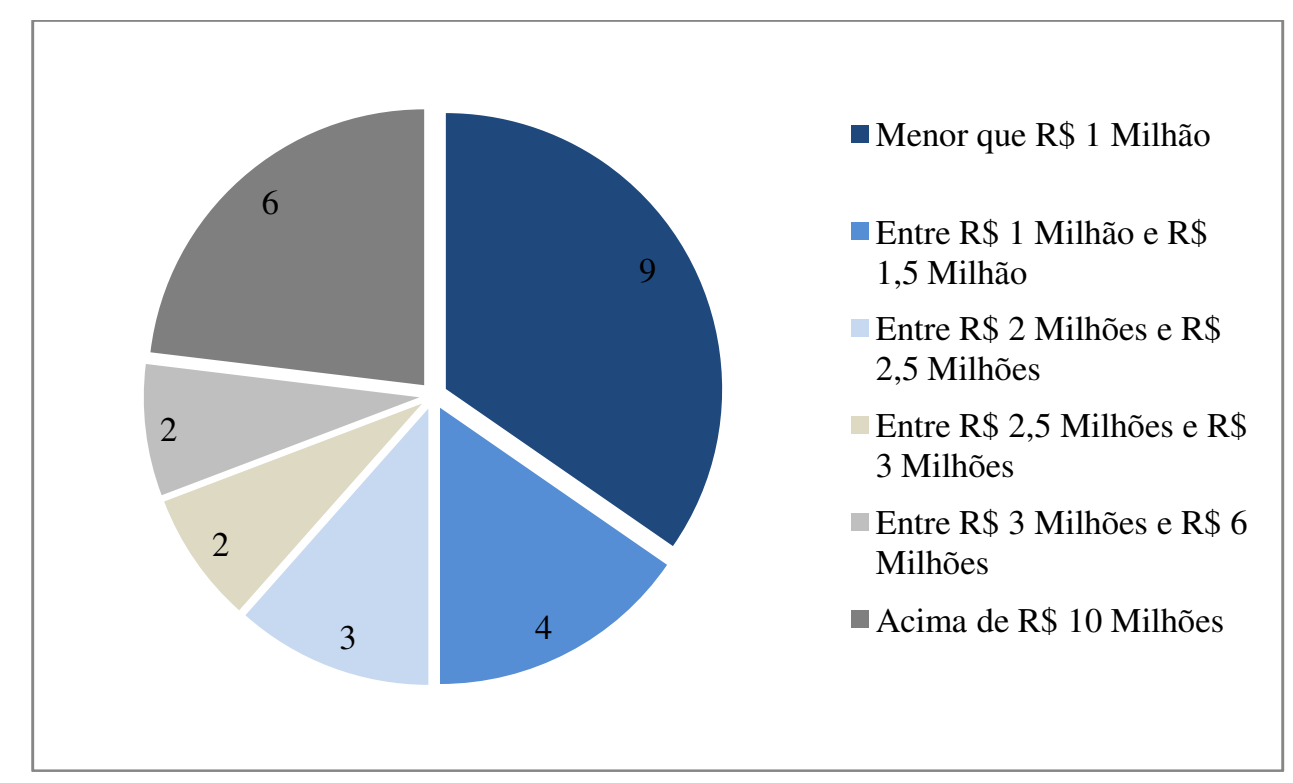

Como dito anteriormente, uma grande lacuna desta pesquisa (impossível de ser preenchida) é a ausência de decisões cujo deslinde se deu em foro arbitral. Muito provavelmente, as disputas com valores mais altos ocorrem à margem do Judiciário e escapam de nossa análise.

Por fim, concluindo-se a explicação do tabelamento das 632 decisões, necessário mencionar que os "resultados repetidos" foram excluídos. Estes resultados são aqueles que já apareceram no mesmo ano, em buscas anteriores, utilizando-se outra palavra-chave. Por exemplo, no ano de 2006, no TJ-SP, com a palavra-chave "hedge", tem-se a ocorrência de 1 "resultado repetido" que, certamente, foi contabilizado no ano de 2006, quando do emprego da palavra "derivativos" na busca. Com esse procedimento de coleta de dados, já que existem julgados que citam mais de uma das palavras-chave eleitas, elimina-se a dupla contagem de resultados elegíveis. Vale esclarecer que, em todos os sites dos diversos Tribunais, a sequência de palavras-chave na pesquisa foi "derivativos", "hedge" e "swap". 
Uma das propostas do trabalho é analisar a incidência da distribuição dos julgados dentre os desembargadores dos tribunais. Em 45 das 68 decisões analisadas, o desembargador analisou casos apenas $1 \mathrm{vez}$ (23 desembargadores) ou apenas 2 vezes (11 desembargadores).

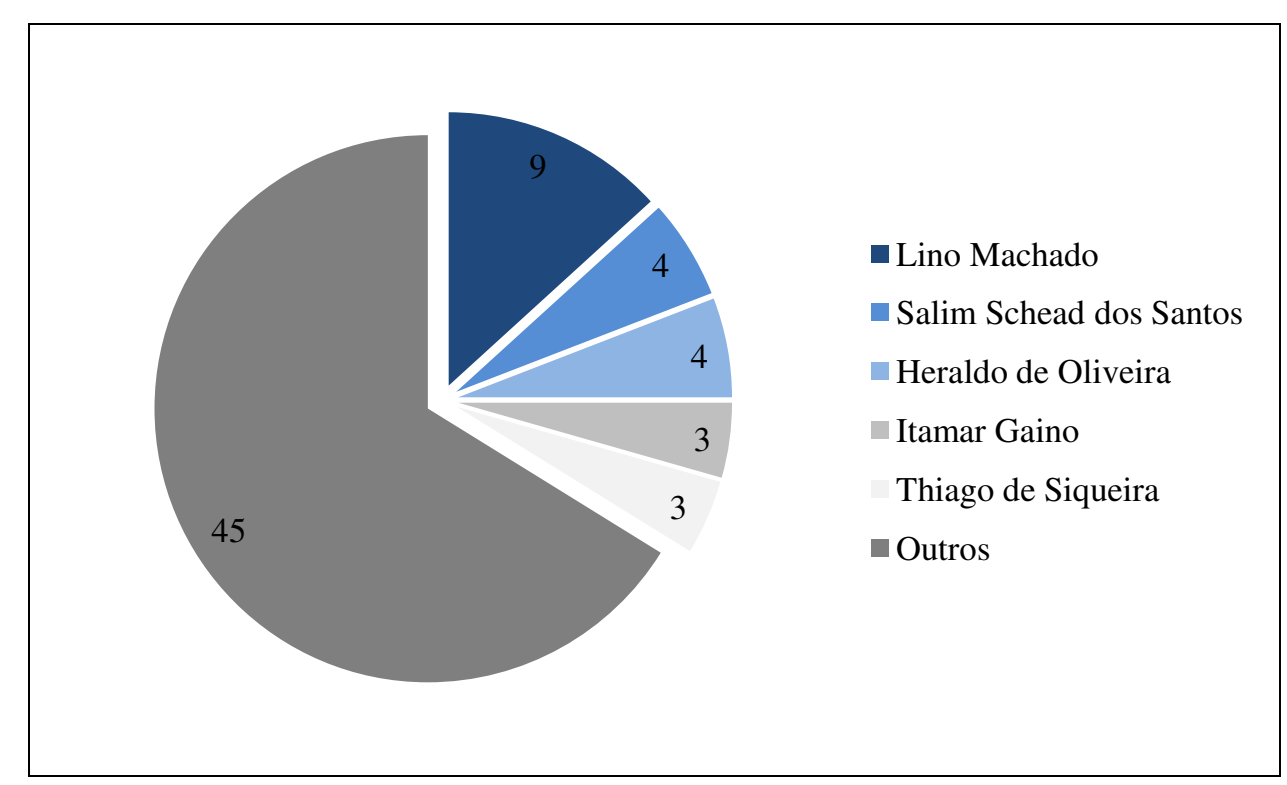

Excluindo-se os casos relacionados ao Banco Santos - 11 julgados em que o Banco é autor (8) ou réu (3) -, que enviesam os resultados, posto que todos eles foram julgados na Câmara Especial de Falências e Recuperações Judiciais de Direito Privado do TJ-SP (e, nesse sentido, com maiores chances de cair com o mesmo relator), não se nota grande concentração nos 57 casos remanescentes.

Com referida exclusão dos casos do Banco Santos, analisando-se a fundo todas as situações em que os nomes dos desembargadores aparecem na pesquisa por duas (11 casos), três ( 2 casos) ou quatro vezes ( 2 casos), a afirmação de que inexiste concentração dos processos com um ou mais juízes é reforçada. Isso porque, na grande maioria das 15 situações em que o juiz aparece mais de uma vez, está-se diante do mesmo caso. Explicase tal curiosidade por dois motivos.

Em primeiro lugar, como a pesquisa analisa todos os retornos obtidos nos sites dos tribunais, quando o autor e também o réu, ambos inconformados com a decisão de primeira 
instância, apelam ou agravam tal decisão, contabilizam-se dois resultados diversos (que são julgados pelo mesmo juiz). Isso ocorreu em 5 ocasiões. ${ }^{322}$

Além desse fato, muitos autores, valendo-se dos infindáveis remédios processuais da legislação brasileira, diante do mesmo caso concreto, usam remédios processuais distintos. Assim, um autor pode lançar mão de um agravo de instrumento e, três meses depois, valer-se de um agravo regimental. ${ }^{323}$ Ainda, o autor pode apelar e depois embargar. ${ }^{324}$ Ou agravar e, na sequência, embargar. ${ }^{325}$ Agravar por duas vezes. ${ }^{326}$ Ou a parte pode agravar a decisão e sua contra-parte embargá-la. ${ }^{327}$ Em todos esses casos, temse a mesma lide e, por conseguinte, o juiz da causa é o mesmo.

$\mathrm{Na}$ sequência, gráfico da divisão das decisões por juízes, excluindo-se os 11 julgados do Banco Santos (que entendemos enviesar os resultados).

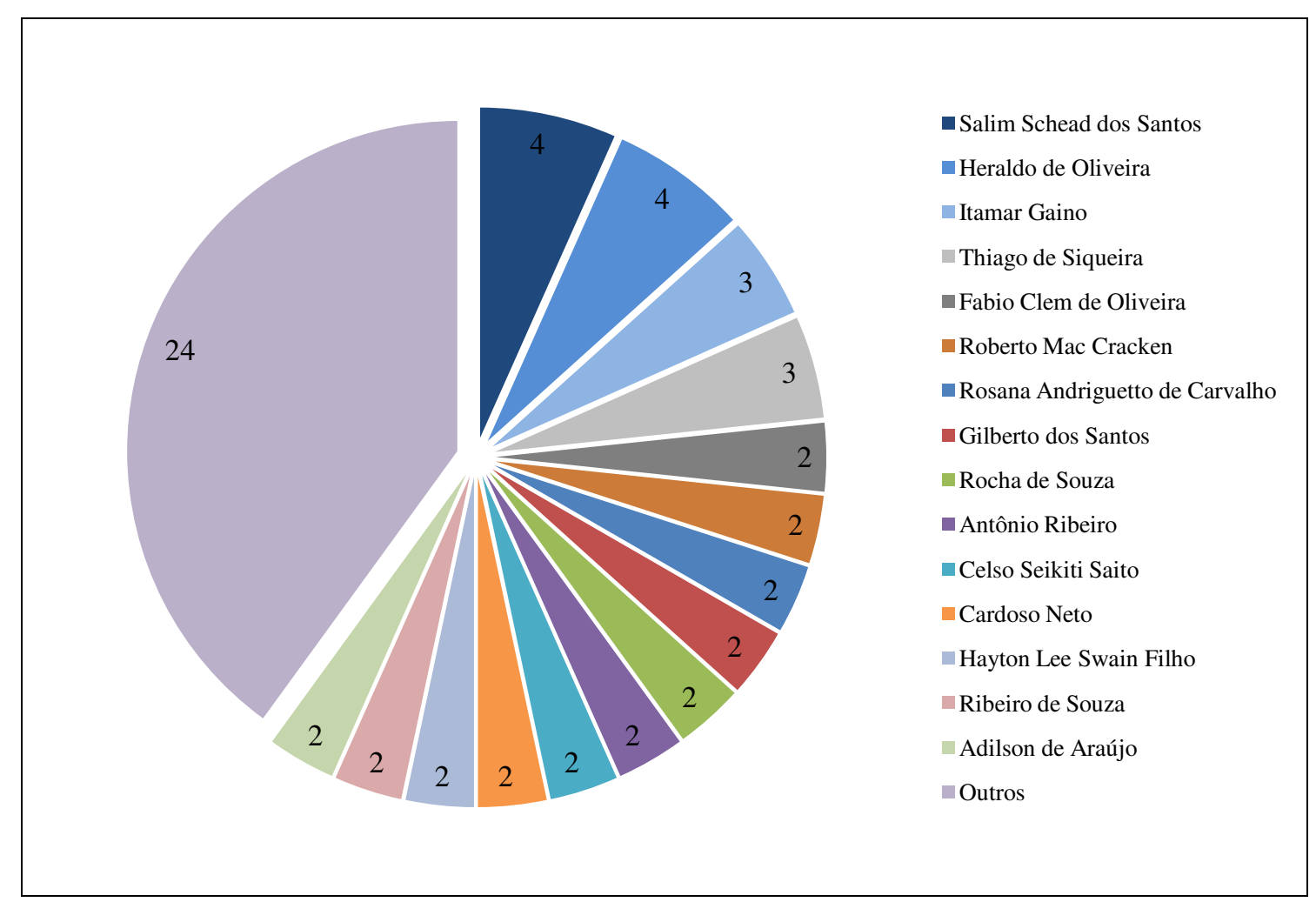

\footnotetext{
${ }^{322}$ Os nomes dos juízes Adilson Araújo, Roberto Mac Cracken, Thiago Siqueira, Itamar Gaino e Celso Saito aparecem 2 vezes porque julgam processos em que apelante e apelado são a mesma pessoa e, nesse sentido, contabilizamos 2 decisões para cada.

${ }^{323}$ Foi o que ocorreu com os resultados do juiz Cardoso Neto, em São Paulo.

${ }^{324}$ Caso do juiz Rocha de Souza, em São Paulo, e de Rosana Andriguetto de Carvalho, no Paraná.

${ }^{325}$ Vide os dois casos do juiz Antonio Ribeiro e do juiz Gilberto dos Santos, em São Paulo.

${ }^{326}$ Caso de Hayton Lee Swain Filho, no Paraná.

${ }^{327}$ Caso de Fabio Clem de Oliveira, no Espírito Santo.
} 
De um lado, justifica-se a contabilização dupla porque a pesquisa leva em conta apenas as teses levantadas pelo autor. Oras, para os casos em que um sujeito é autor em uma decisão e réu em outra decisão (i.e. apelação), não corremos o risco, por exemplo, de deixar de fora teses levantadas pelo autor instituição financeira e pelo autor não instituição financeira dentro do processo dialético (ainda que a decisão do juiz tenda a usar a mesma fundamentação e as mesmas teses, provavelmente, as teses usadas pelos dois diferentes autores que se valem do mesmo remédio processual serão diferentes). Como um dos grandes objetivos desta pesquisa é a exposição das matérias levantadas pelos diferentes sujeitos autores - dividindo-as quando o sujeito é instituição financeira e quando não é assim caracterizado, tal sistematização de contabilização dupla enriquece o trabalho.

Por outro lado, com relação aos casos em que o mesmo autor utiliza remédios processuais distintos (muitos deles claramente protelatórios), entendemos que também devemos contabilizar cada uma das decisões oriundas de cada provocação. Primeiro porque não necessariamente, em cada remédio processual, o autor usará as mesmas teses. Segundo porque seria impossível, ao final de uma pesquisa que se pretende nacional, agrupar cada um dos casos isolados em que existe mais de uma decisão relacionada (ainda que interlocutória), escolhendo apenas um deles para representar o grupo. E terceiro porque o objetivo declarado em nossa Metodologia é a análise de todas as decisões de segunda e terceira instâncias relacionadas aos derivativos, ainda que não sejam finais, e desde que publicadas nos respectivos sites.

Voltando à divisão dos julgados entre os juízes, diante dos resultados, conclui-se pela inexistência de concentração de juízes nos casos relacionados aos derivativos, o que pode denotar a ausência de especialização sobre o tema a determinadas câmaras ou a determinados magistrados ${ }^{328}$ ou a baixa judicialização da matéria (pela existência de um mercado não relevante ou pela escolha do foro arbitral).

Certamente, tratando-se de tema tão específico e não relacionado à rotina dos desembargadores e ministros, além de sensível à economia nacional, a inexistência de especialização entre os magistrados dos tribunais pode ser encarada como um incentivo negativo a mais para que os agentes de mercado não escolham o foro comum, optando pelo juízo arbitral.

\footnotetext{
${ }^{328}$ Necessário incluir uma ressalva nesta afirmação. O juiz de Santa Catarina Salim Schead dos Santos possui 4 contabilizações, sendo 2 relacionadas ao mesmo caso e 2 de casos diferentes. Portanto, este juiz concentrou 4 dos 6 casos existentes em Santa Catarina, estado em que o Tribunal de Justiça possui Câmara Especializada em Direito Comercial.
} 
Ainda que a próxima análise gráfica não diga muita coisa - a não ser que a Justiça brasileira é muito lenta, ${ }^{329}$ nossa pesquisa também catalogou a distribuição dos 68 julgados no tempo (ou seja, as datas em que foram relatados), conforme resultado exposto no gráfico a seguir.

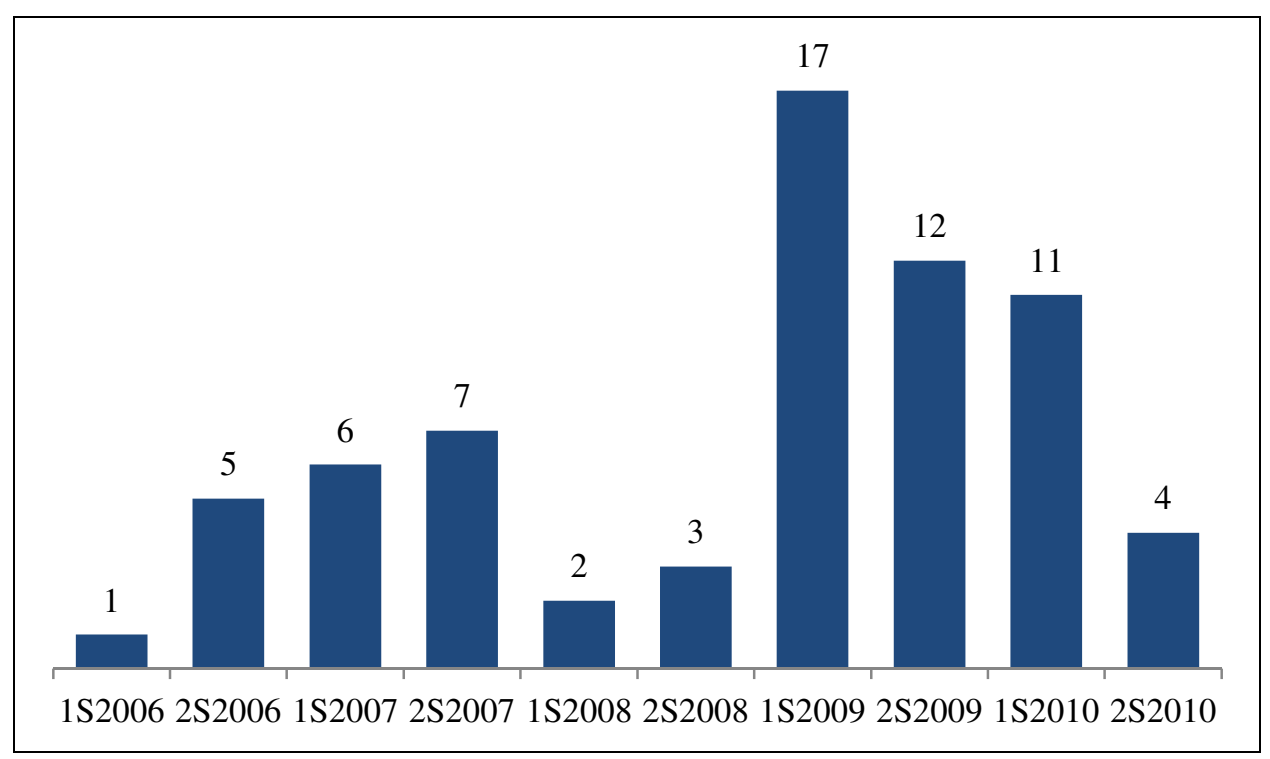

Muito mais importante é a distribuição das datas dos fatos que desencadearam os litígios objeto de nossa análise. Apesar de 42\% dos relatórios (ou 29 dos 68 casos) não informar as datas dos fatos geradores das lides, em 58\% dos casos (39 julgados) em que tal data é sabida, vislumbra-se determinadas tendências.

Da análise do gráfico abaixo, bem se nota a existência de concentração de litígios cujos fatos geradores ocorreram em três datas-chave: (i) o primeiro semestre de 1999, (ii) o segundo semestre de 2004 combinado com o primeiro semestre de 2005 e (iii) o segundo semestre de 2008 combinado com o primeiro semestre de 2009.

\footnotetext{
${ }^{329}$ Não incomumente, julgados entre 2006 e 2009 dizem respeito a fatos geradores de 1999.
} 


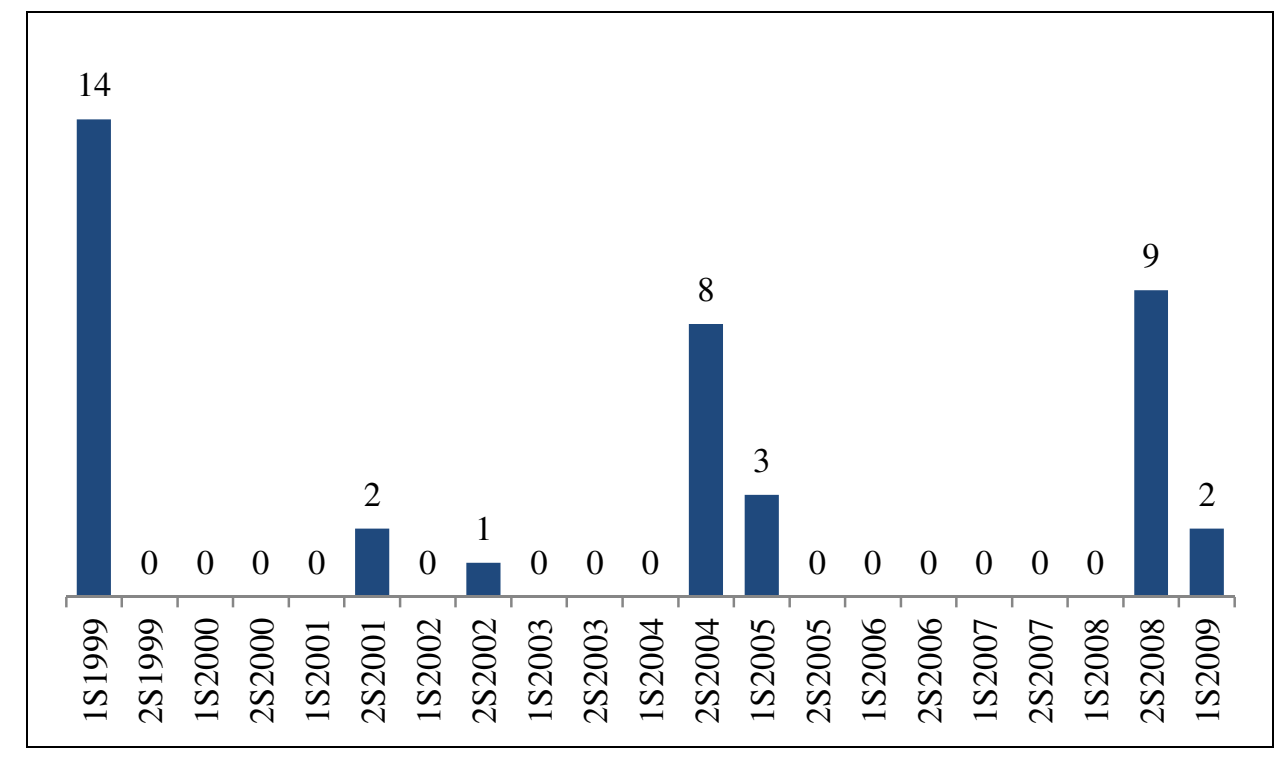

Com relação ao primeiro semestre de 1999, muito provavelmente está-se diante de fatos ocorridos em janeiro e oriundos da chamada máxi desvalorização do Real, logo após a posse do presidente Fernando Henrique Cardoso em seu segundo mandato.

No segundo semestre de 2004 e no primeiro semestre de 2005, todos os casos mostrados são relacionados à quebra do Banco Santos, que desencadeou processos em que contratos de derivativos negociados por tal instituição encontravam-se vigentes. O próximo gráfico contempla todos os litígios em que a data do fato gerador é sabida mas exclui os processos relacionados ao Banco Santos (11 casos em que ele figura como autor ou réu); confirmando, assim, nossa afirmação.

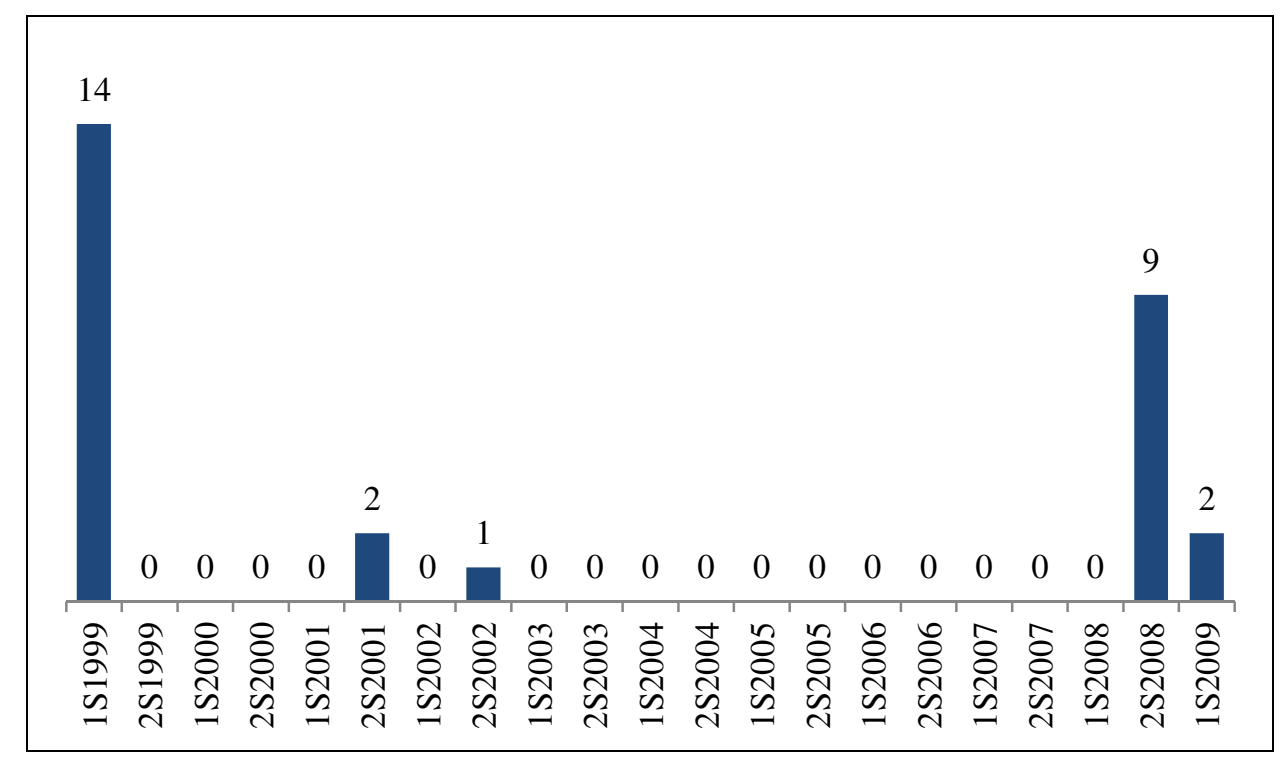


Por fim, com relação ao terceiro período em que existe concentração de resultados, o segundo semestre de 2008 e o primeiro semestre de 2009, está-se diante da recente crise financeira internacional, cujo estopim foi a quebra do Lehman Brothers em setembro de 2008. Deve-se notar que muitos julgados com data de fato gerador entre final de 2008 e começo de 2009 ainda não chegaram à segunda e terceira instâncias - se a presente pesquisa compreendesse julgados realizados a partir de 2011, certamente os números aumentariam.

Assim, excluindo-se os casos relacionados ao Banco Santos, que, como dito, enviesam nossos resultados, temos que, dentre os julgados em que a data do respectivo fato gerador é sabida, existe concentração em dois períodos definidos: primeiro semestre de 1999 e segundo semestre de 2008 combinado com o primeiro semestre de 2009. Não por acaso, são dois períodos de grande volatilidade cambial, conforme se nota abaixo.

\section{Gráfico Dólar x Real ${ }^{330}$}

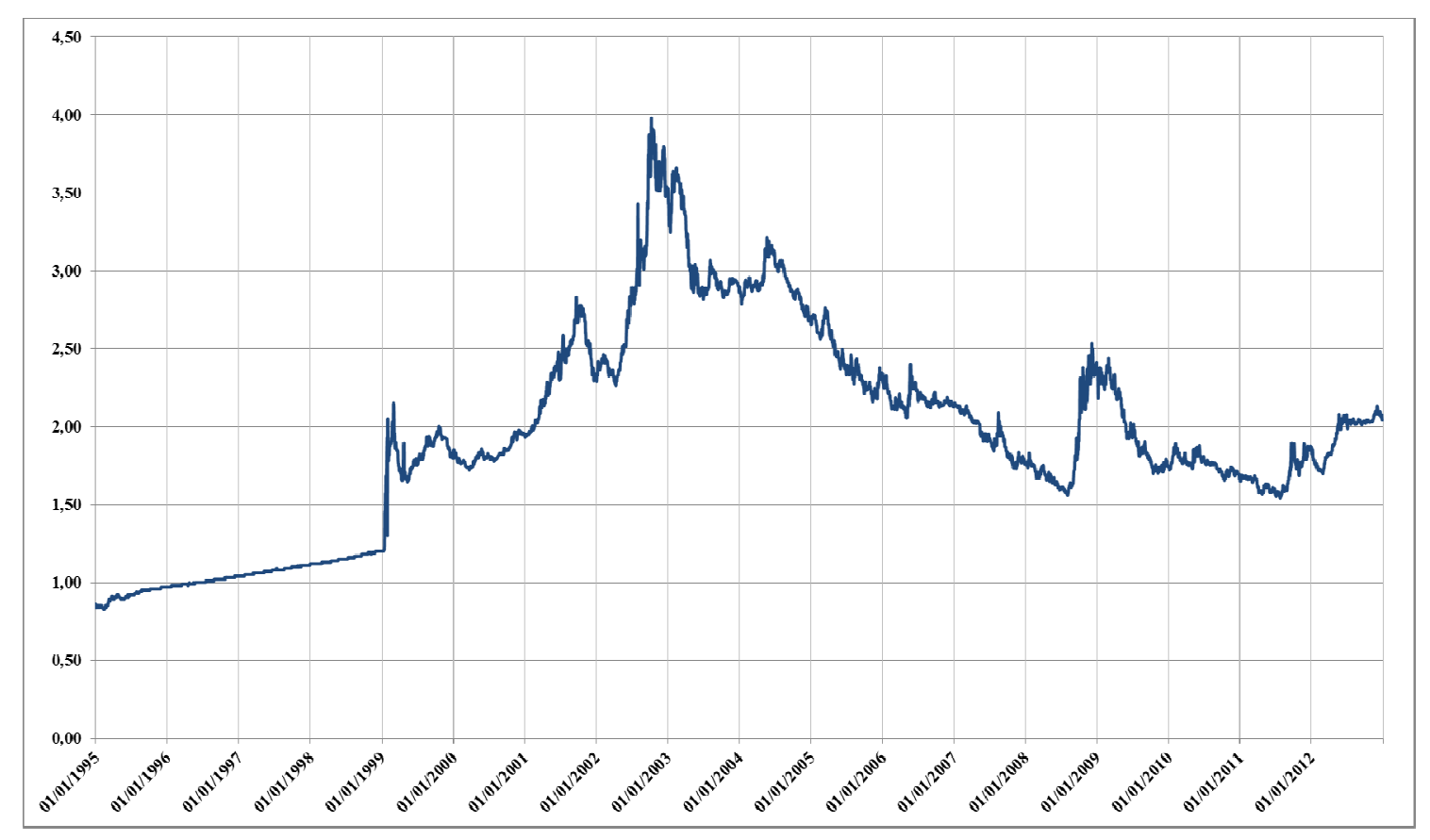

Tais mudanças econômicas, ainda que possíveis (apesar de imprevisíveis), são a chave para que as partes das ações judiciais reiterem ou refutem determinadas teses relacionadas ao pacta sunt servanda, à teoria da imprevisão, à aleatoriedade dos contratos, à onerosidade excessiva ou à inerência ao risco. Mais adiante, ao falarmos sobre os méritos mais alegados, veremos que essas teses estão constantemente presentes.

\footnotetext{
${ }^{330}$ Fonte dos dados: Bloomberg.
} 
A próxima tabela demonstra a divisão dos julgados entre todos os sujeitos autores de ações. Nota-se a existência de equilíbrio tênue entre autores não financeiros (57\%) assim entendidos como sociedades, pessoas naturais e entidades de previdência - e autores que são instituições financeiras ou equiparadas (em torno de 43\%). Assim, nesse momento, tem-se a leve impressão que sujeitos não financeiros tendem a acionar mais os Tribunais do que sujeitos financeiros.

\begin{tabular}{|c|c|c|}
\hline Autores & $\begin{array}{l}\text { Números de } \\
\text { Casos }\end{array}$ & $\%$ \\
\hline Sociedade não financeira & 29 & $42,65 \%$ \\
\hline Pessoa física & 9 & $13,24 \%$ \\
\hline Banco Santos S.A. & 8 & $11,76 \%$ \\
\hline Banco Santander & 4 & $5,88 \%$ \\
\hline HSBC Bank Brasil S.A. Banco Múltiplo & 4 & $5,88 \%$ \\
\hline Banco Itaú & 2 & $2,94 \%$ \\
\hline Banco West LB & 2 & $2,94 \%$ \\
\hline $\begin{array}{l}\text { Solidez Corretora de Câmbio Títulos e Valores Mobiliários } \\
\text { Ltda. }\end{array}$ & 2 & $2,94 \%$ \\
\hline Banco Industrial e Comercial S.A. - BIC Banco & 1 & $1,47 \%$ \\
\hline Citibank & 1 & $1,47 \%$ \\
\hline BES Boavista Espírito Santo DTVM S.A. & 1 & $1,47 \%$ \\
\hline Banco Ribeirão Preto S.A. & 1 & $1,47 \%$ \\
\hline Banco BMC S.A. & 1 & $1,47 \%$ \\
\hline Banco Crefisul S.A. & 1 & $1,47 \%$ \\
\hline Banco do Brasil & 1 & $1,47 \%$ \\
\hline Entidade de Previdência Privada & 1 & $1,47 \%$ \\
\hline Total & 68 & $100 \%$ \\
\hline
\end{tabular}

Mais uma vez, nota-se certo volume de casos ( 8 de 68) em que o autor é o Banco Santos (ou, mais tecnicamente falando, sua massa falida). Excluindo-se os 8 casos em que o Banco Santos é autor, que, como já dissemos, enviesam os resultados, nota-se maior desequilíbrio entre autores não financeiros (65\%) e autores que são instituições financeiras ou equiparadas (em torno de 35\%). Portanto, fica mais fácil afirmar que sujeitos não financeiros tendem a acionar mais o Judiciário do que sujeitos financeiros. A tabela abaixo nos auxilia nesta conclusão. 


\begin{tabular}{|l|l|l|}
\hline Autores (excluindo-se Banco Santos) & $\begin{array}{l}\text { Números } \\
\text { Casos }\end{array}$ & de \\
\hline Sociedade não financeira & 29 & $48,33 \%$ \\
\hline Pessoa física & 9 & $15,00 \%$ \\
\hline Banco Santander & 4 & $6,67 \%$ \\
\hline HSBC Bank Brasil S.A. Banco Múltiplo & 4 & $6,67 \%$ \\
\hline Banco Itaú & 2 & $3,33 \%$ \\
\hline $\begin{array}{l}\text { Solidez Corretora de Câmbio Títulos e Valores Mobiliários } \\
\text { Ltda. }\end{array}$ & 2 & $3,33 \%$ \\
\hline Banco West LB & 2 & $3,33 \%$ \\
\hline Entidade de Previdência Privada & 1 & $1,67 \%$ \\
\hline Banco Ribeirão Preto S.A. & 1 & $1,67 \%$ \\
\hline BES Boavista Espírito Santo DTVM S.A. & 1 & $1,67 \%$ \\
\hline Banco do Brasil & 1 & $1,67 \%$ \\
\hline Citibank & 1 & $1,67 \%$ \\
\hline Banco Industrial e Comercial S.A. - BIC Banco & 1 & $1,67 \%$ \\
\hline Banco BMC S.A. & 1 & $1,67 \%$ \\
\hline Banco Crefisul S.A. & 1 & $1,67 \%$ \\
\hline Total & $\mathbf{6 0}$ & $\mathbf{1 0 0 \%}$ \\
\hline
\end{tabular}

Com relação a contagem de réus, a contrario sensu, 57\% dos réus da amostragem são instituições financeiras. ${ }^{331}$ Se esta conclusão é óbvia, mais difícil seria identificar os nomes dos réus instituições financeiras sem a ajuda da tabela. Abaixo descritivo com todos os réus.

\begin{tabular}{|l|l|l|}
\hline Réus & $\begin{array}{l}\text { Números } \\
\text { Casos }\end{array}$ & de \\
\hline Sociedade não financeira & 28 & $41,18 \%$ \\
\hline Banco Boavista Interatlântico S.A. & 6 & $8,82 \%$ \\
\hline Banco Itaú & 5 & $7,35 \%$ \\
\hline Banco Itaú BBA S.A. & 4 & $5,88 \%$ \\
\hline Banco Prosper S.A. & 4 & $5,88 \%$ \\
\hline Citibank & 3 & $4,41 \%$ \\
\hline Banco Santos S.A. & 3 & $4,41 \%$ \\
\hline Banco do Estado do Rio Grande do Sul & 2 & $2,94 \%$ \\
\hline Banco do Brasil & 2 & $2,94 \%$ \\
\hline Banco Santander & 2 & $2,94 \%$ \\
\hline BES Boavista Espírito Santo DTVM S.A. & 2 & $2,94 \%$ \\
\hline Entidade de Previdência Privada & 1 & $1,47 \%$ \\
\hline Banco Bradesco & 1 & $1,47 \%$ \\
\hline Banco Comercial e de Investimentos Sudameris & 1 & $1,47 \%$ \\
\hline Banco Crefisul S.A. & 1 & $1,47 \%$ \\
\hline Marka Nikko Asset Management & 1 & $1,47 \%$ \\
\hline Banco ABN Amro Real S.A. & 1 & $1,47 \%$ \\
\hline Banco Ribeirão Preto S.A. & 1 & $1,47 \%$ \\
\hline Total & $\mathbf{6 8}$ & $\mathbf{1 0 0 \%}$ \\
\hline
\end{tabular}

\footnotetext{
${ }^{331}$ Vale ressaltar que o Banco Santos figura como réu em 3 ações.
} 
Tanto para os autores como para os réus, com exceção dos casos relacionados ao Banco Santos, não se pode concluir que exista concentração maciça de processos em uma ou mais instituições financeiras. Nos chama atenção apenas a inclusão do Boavista ${ }^{332}$ e do Prosper, duas instituições com baixo market share, como réus em 8 e 4 ações, respectivamente. ${ }^{333}$

Com relação ao provimento das ações cujos autores são instituições financeiras, tem-se, à primeira vista, equilíbrio entre os remédios jurisdicionais providos e os não providos. Assim, num primeiro momento, poder-se-ia concluir que, nos Tribunais, quando uma instituição financeira busca a tutela de algum direito, não se tem um cenário de certeza ou incerteza quanto ao provimento.

\begin{tabular}{|l|l|l|}
\hline Autores Instituição Financeira: Provimento & Números de casos & $\mathbf{\%}$ \\
\hline Não Provida & 15 & $51,72 \%$ \\
\hline Provida & 14 & $48,28 \%$ \\
\hline Total & $\mathbf{2 9}$ & $\mathbf{1 0 0 , 0 0 \%}$ \\
\hline
\end{tabular}

Contudo, analisando-se friamente os números da tabela acima, nota-se que na maioria (8) dos 15 casos em que o autor instituição financeira não teve seu remédio provido, estava-se diante de casos relacionados ao Banco Santos. Como dito acima, entendemos que os casos relacionados ao Banco Santos enviesam os resultados, dada a peculiaridade de sua situação, sua fragilidade após a decretação da intervenção e a tendência de o juiz considerar sua alegada má-fé também no contexto de operações com derivativos, ainda que tais operações tenham sido realizadas antes da intervenção.

Assim, excluindo-se os casos em que o Banco Santos figura como autor, tem-se situação muito diferente, em que apenas a minoria $(33,33 \%)$ das ações iniciadas por instituições não foram providas. Daí se pode concluir que, quando uma instituição financeira busca algum remédio jurisdicional para suas demandas, as chances de provimento são maiores do que a negativa da tutela.

\footnotetext{
${ }^{332}$ Banco Boavista Interatlântico S.A. e BES Boavista Espírito Santo DTVM S.A. contabilizados como uma única entidade, muito embora, na tabela, estejam separados.

${ }^{333}$ As ações do Boavista são relacionadas a quotas de fundos de investimento que investiam em derivativos, com perdas expressivas no início de 1999. Atualmente, com as regras mais estritas da CVM para os fundos de investimento (sobretudo as normas de disclosure, uniformidade de materiais publicitários e adequação do produto ao cliente), muito provavelmente, tais ações não existiriam.
} 


\begin{tabular}{|l|l|l|}
\hline $\begin{array}{l}\text { Autores Instituição Financeira (sem Banco Santos): } \\
\text { Provimento }\end{array}$ & Números de casos & $\%$ \\
\hline Provida & 14 & $66,67 \%$ \\
\hline Não Provida & 7 & $33,33 \%$ \\
\hline Total & $\mathbf{2 1}$ & $\mathbf{1 0 0 , 0 0 \%}$ \\
\hline
\end{tabular}

Quando estamos diante de autores não financeiros ou equiparados, o número de ações não providas é enorme: na esmagadora maioria dos casos $(87,18 \%)$ em que uma parte não financeira iniciou um procedimento contra uma instituição financeira, a tendência dos Tribunais foi pelo não provimento do remédio (o que pode significar manutenção da sentença de primeira instância ou alguma negativa processual). ${ }^{334}$

\begin{tabular}{|l|l|l|}
\hline Autores Não Instituição Financeira: Provimento & Números de casos & $\mathbf{\%}$ \\
\hline Não Provida & 34 & $87,18 \%$ \\
\hline Provida & 5 & $12,82 \%$ \\
\hline Total & $\mathbf{3 9}$ & $\mathbf{1 0 0 , 0 0 \%}$ \\
\hline
\end{tabular}

Como explicado na metodologia, ainda que o provimento ou não de uma sentença possa estar, de algum modo, relacionado ao mérito final da demanda, não necessariamente, em todos os casos, existe uma correlação com a decisão final. Assim, é importante analisar o comportamento do Judiciário com relação ao viés de cada uma das sentenças. Nesse contexto, catalogamos as decisões como "pró instituição financeira", "contra instituição financeira" e "sem mérito".

O viés da sentença demonstra o posicionamento do juiz de maneira pró ou contra a instituição financeira ou, ainda, de maneira indiferente (o que chamamos de "sem mérito"). Ressalta-se novamente que não necessariamente o viés, ainda que pró ou contra, significa que houve uma decisão terminativa de mérito. Outra importante consideração já feita quando da descrição de nossa "Metodologia de Pesquisa Empírica" e que merece ser repetida é que cada caso comporta suas próprias peculiaridades, sendo a classificação subjetiva pelo pesquisador um elemento bem sensível nesta parametrização.

Feitas essas ressalvas, podemos concluir que a esmagadora maioria dos casos $(64,71 \%)$ teve decisões de maneira favorável às instituições financeiras, a minoria

\footnotetext{
${ }^{334} \mathrm{~A}$ negativa de provimento do remédio pelo tribunal não significa necessariamente manutenção da decisão de primeira instância - isso seria verdade apenas nas apelações. Muitas vezes, está-se diante de questões processuais, com a utilização de embargos ou agravos. De qualquer modo, entendemos que esse dado é relevante.
} 
$(16,18 \%)$ dos votos se posicionou de maneira contrária às instituições financeiras, ao passo que não nos foi possível enxergar nenhum viés em uma quantidade relevante de votos $(19,12 \%)$ - o que demonstra que a profunda judicialização brasileira, muitas vezes, acaba por debater questões processuais até mesmo na segunda instância.

\begin{tabular}{|l|l|l|}
\hline Mérito Total & $\begin{array}{l}\text { Números de } \\
\text { casos }\end{array}$ & $\%$ \\
\hline Pró IF & 44 & $64,71 \%$ \\
\hline Sem mérito & 13 & $19,12 \%$ \\
\hline Contra IF & 11 & $16,18 \%$ \\
\hline Total & $\mathbf{6 8}$ & $\mathbf{1 0 0 , 0 0 \%}$ \\
\hline
\end{tabular}

O resultado acima é bem surpreendente e deve ser melhor entendido. Como vimos afirmando, os resultados em que o Banco Santos é parte enviesam os resultados - seja pela peculiar situação da parte, seja pela quantidade expressiva de julgados ( $8 \mathrm{em}$ que figura como autor e 3 como réu - totalizando 11, num universo de 68). Desse modo, necessário fazer o mesmo exercício da tabela anterior, porém excluindo-se os 11 resultados em que o Banco Santos é parte (8 como autor e 3 como réu). Quando nos propomos a isso, temos uma resultado ainda mais incrível: em $71,93 \%$ dos casos, o voto tem viés pró instituição financeira, contra apenas 5,26\% dos casos em que o viés é negativo e $22,81 \%$ em que o viés é neutro.

\begin{tabular}{|l|l|l|}
\hline Mérito Total & $\begin{array}{l}\text { Números de } \\
\text { casos }\end{array}$ & $\mathbf{\%}$ \\
\hline Pró IF & 41 & $71,93 \%$ \\
\hline Sem mérito & 13 & $22,81 \%$ \\
\hline Contra IF & 3 & $5,26 \%$ \\
\hline Total & $\mathbf{5 7}$ & $\mathbf{1 0 0 , 0 0 \%}$ \\
\hline
\end{tabular}

Tendo em vista que nossa pesquisa traz 42 julgados do Estado de São Paulo (em um universo de 68), podemos fazer o mesmo exercício, excluindo os resultados do TJ-SP de todos os demais estados analisados. O resto do Brasil ex São Paulo tende a ser um pouco mais pró instituição financeira - muito embora as decisões estejam em linha com os resultados consolidados. 


\begin{tabular}{|l|l|l|}
\hline Mérito Total (sem julgados de São Paulo) & $\begin{array}{l}\text { Números de } \\
\text { casos }\end{array}$ & $\mathbf{\%}$ \\
\hline Pró IF & 19 & $73,08 \%$ \\
\hline Sem mérito & 6 & $23,08 \%$ \\
\hline Contra IF & 1 & $3,85 \%$ \\
\hline Total & $\mathbf{2 6}$ & $\mathbf{1 0 0 , 0 0 \%}$ \\
\hline
\end{tabular}

Apresentados os resultados acima, dissolve-se toda e qualquer percepção acerca do viés contrário às instituições financeiras do Judiciário, ao menos no tema dos derivativos. Tão surpreendente é esta conclusão que entendemos mereça ser depurada, dividindo-se as ações em que o autor é instituição financeira e aquelas em que o autor não é instituição financeira.

Se considerarmos apenas as ações em que o autor é instituição financeira, incluindo-se aquelas iniciadas pelo Banco Santos, tem-se a seguinte divisão entre os méritos dos casos: $37,93 \%$ dos casos são favoráveis às instituições financeiras, $31,03 \%$ dos casos são desfavoráveis e os remanescentes $31,03 \%$ não possuem viés negativo ou positivo com relação aos credores.

\begin{tabular}{|l|l|l|}
\hline Autores Instituição Financeira: Mérito & $\begin{array}{l}\text { Números de } \\
\text { casos }\end{array}$ & $\%$ \\
\hline Contra IF & 9 & $31,03 \%$ \\
\hline Pró IF & 11 & $37,93 \%$ \\
\hline Sem mérito & 9 & $31,03 \%$ \\
\hline Total & $\mathbf{2 9}$ & $\mathbf{1 0 0 , 0 0 \%}$ \\
\hline
\end{tabular}

Como já explicado, considerando que os casos relacionados ao Banco Santos enviesam os resultados, ao excluirmos tais sentenças, nota-se que o Judiciário costuma ser muito mais favorável $(52,38 \%$ dos casos) às instituições financeiras do que contra $(4,76 \%$ dos casos). Chama nossa atenção aqui a grande quantidade $(42,86 \%)$ de decisões sem mérito quanto o autor é instituição financeira - o que nos leva a crer que bancos são levados a questionar muitos temas processuais.

\begin{tabular}{|l|l|l|}
\hline $\begin{array}{l}\text { Autores Instituição Financeira (sem Banco Santos): } \\
\text { Mérito }\end{array}$ & $\begin{array}{l}\text { Números de } \\
\text { casos }\end{array}$ & $\%$ \\
\hline Pró IF & 11 & $52,38 \%$ \\
\hline Sem mérito & 9 & $42,86 \%$ \\
\hline Contra IF & 1 & $4,76 \%$ \\
\hline Total & $\mathbf{2 1}$ & $\mathbf{1 0 0 , 0 0 \%}$ \\
\hline
\end{tabular}


Quando analisamos somente os casos cujos autores não são instituições financeiras, os tribunais são ainda mais favoráveis aos bancos. Em 84,62\% dos casos, os juízes proferiram votos pró instituição financeira, contra apenas $5,13 \%$ dos casos em que as decisões foram contra.

\begin{tabular}{|l|l|l|}
\hline Autores Não Instituição Financeira: Mérito & $\begin{array}{l}\text { Números de } \\
\text { casos }\end{array}$ & $\%$ \\
\hline Pró IF & 33 & $84,62 \%$ \\
\hline Sem mérito & 4 & $10,26 \%$ \\
\hline Contra IF & 2 & $5,13 \%$ \\
\hline Total & $\mathbf{3 9}$ & $\mathbf{1 0 0 , 0 0 \%}$ \\
\hline
\end{tabular}

Diante dos resultados (consolidados e divididos pela qualidade da parte autora) supra analisados nos Tribunais superiores, devemos concluir, a contrario sensu da percepção do mercado e de algumas publicações sobre o assunto, que o Judiciário tende a ser mais favorável às instituições financeiras e equiparadas quando a lide se relaciona aos derivativos.

Analisamos também os remédios processuais mais utilizados pelas partes em nossa amostragem. Como era de se esperar, tendo em vista estarmos diante de decisões de tribunais superiores, a nossa população está dividida entre agravos ${ }^{335}(47,06 \%)$ - sendo a maioria deles agravos de instrumento ${ }^{336}(44,12 \%)$, apelações ${ }^{337}(39,71 \%)$, embargos de declaração ${ }^{338}(11,76 \%)$ e, por fim, um recurso especial ${ }^{339}(1,47 \%)$ - este correspondente ao único caso do STJ encontrado.

\footnotetext{
${ }^{335} \mathrm{O}$ agravo é a medida passível de ser tomada frente a decisões interlocutórias, ou seja, frente àquelas questões processuais intercorrentes (decisões proferidas ao longo do processo, mas que não põem término ao processo). BRASIL. Lei n. ${ }^{\circ}$ 5.869, de 11 de janeiro de 1973. Institui o Código de Processo Civil. Disponível em $<$ http://www.planalto.gov.br>. Acesso 04 set. 2013. Art. 522. Das decisões interlocutórias caberá agravo, no prazo de 10 (dez) dias, na forma retida, salvo quando se tratar de decisão suscetível de causar à parte lesão grave e de difícil reparação, bem como nos casos de inadmissão da apelação e nos relativos aos efeitos em que a apelação é recebida, quando será admitida a sua interposição por instrumento.

${ }^{336}$ Os agravos de instrumento questionam, normalmente, decisões interlocutórias do juízo de primeiro grau.

${ }^{337}$ A apelação é o remédio processual que, por excelência, exprime o duplo grau de jurisdição, o direito de não se conformar com uma decisão. Cabe apelação após o proferimento de sentença, assim entendida como ato pelo qual o juiz põe termo ao processo, decidindo ou não o mérito da causa. Cf. BRASIL. Lei n. ${ }^{\circ}$ 5.869, de 11 de janeiro de 1973. Institui o Código de Processo Civil. Disponível em $<$ http://www.planalto.gov.br>. Acesso 04 set. 2013. Art. 162. \$ $1^{o}$ Sentença é o ato do juiz que implica alguma das situações previstas nos arts. 267 e 269 desta Lei. Art. 513. Da sentença caberá apelação.

${ }^{338}$ BRASIL. Lei n. ${ }^{\circ}$ 5.869, de 11 de janeiro de 1973. Institui o Código de Processo Civil. Disponível em $<$ http://www.planalto.gov.br>. Acesso 04 set. 2013. Art. 535 Cabem embargos de declaração quando: I houver, na sentença ou no acórdão, obscuridade ou contradição; II - for omitido ponto sobre o qual devia pronunciar-se o juiz ou tribunal.

${ }^{339}$ BRASIL. Constituição da República Federativa do Brasil de 1988. Disponível em <http://www.planalto.gov.br>. Acesso em: 04 set. 2013. Art. 105. Compete ao Superior Tribunal de
} 


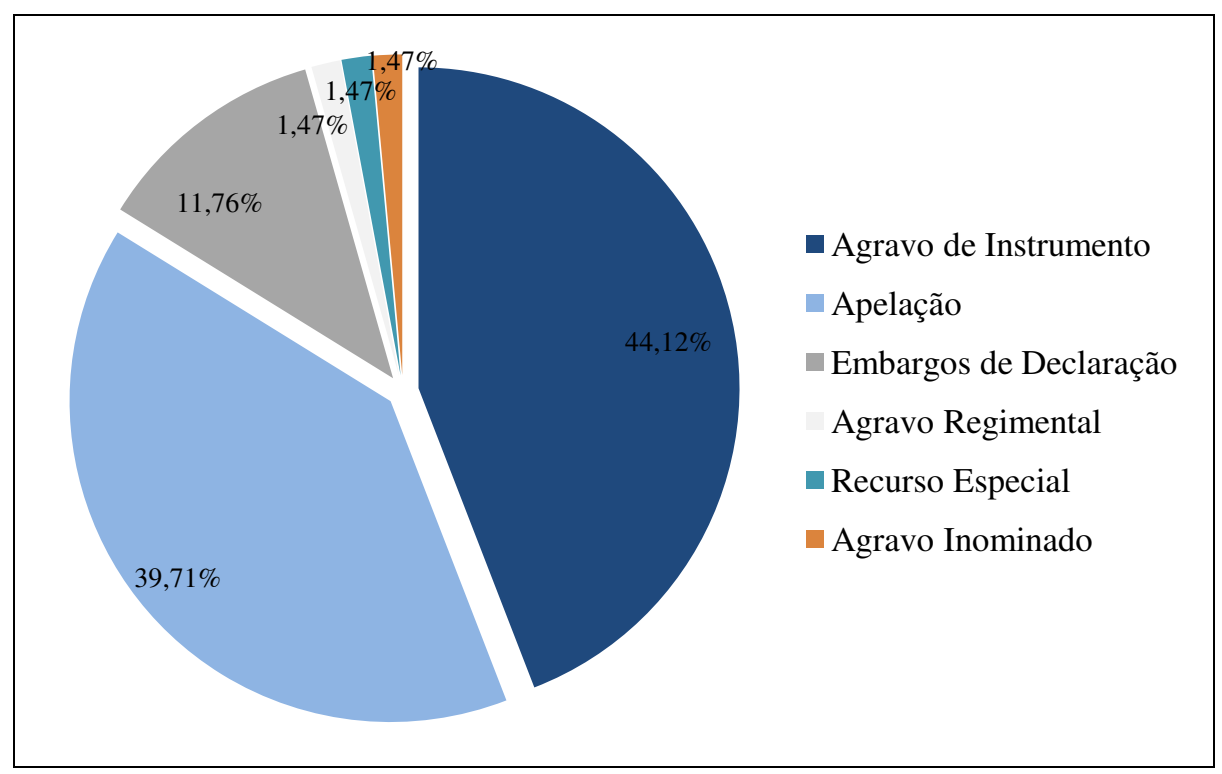

O declarado propósito em nossa "Metodologia" sempre foi restringir nossas análises aos Tribunais superiores, então natural que as peças processuais encontradas fossem típicas de segunda e terceira instância. A grande surpresa aqui ficou pela grande porcentagem de recursos que atacam decisões interlocutórias, os chamados agravos, conforme a divisão esquemática acima demonstra.

Mesmo excluindo-se os 11 casos relacionados ao Banco Santos, temos resultado muito semelhante ao acima: agravos $(43,86 \%)$ - sendo a maioria destes agravos de instrumento $(40,35 \%)$, apelações $(42,11 \%)$, embargos de declaração $(12,28 \%)$ e um recurso especial $(1,75 \%)$.

Justiça: III - julgar, em recurso especial, as causas decididas, em única ou última instância, pelos Tribunais Regionais Federais ou pelos tribunais dos Estados, do Distrito Federal e Territórios, quando a decisão recorrida: a) contrariar tratado ou lei federal, ou negar-lhes vigência; b) julgar válido ato de governo local contestado em face de lei federal; c) der a lei federal interpretação divergente da que the haja atribuído outro tribunal. 


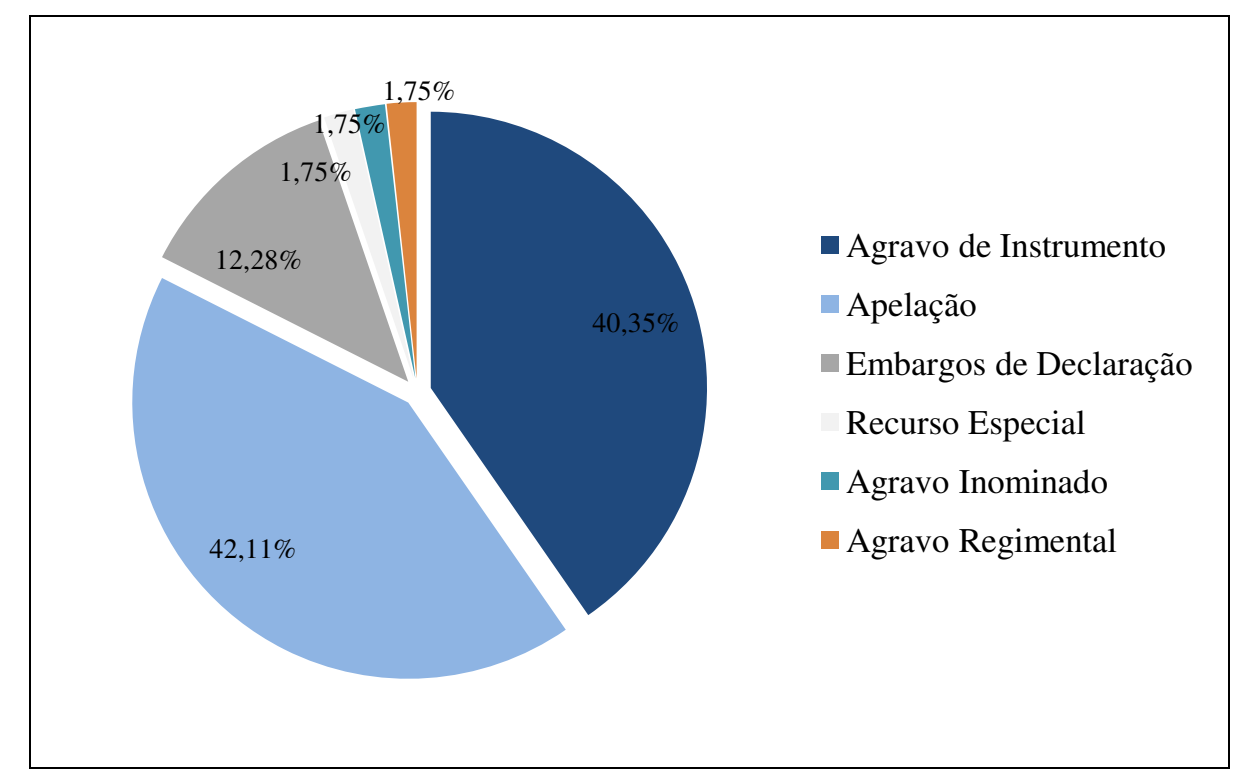

Com relação aos produtos de nossa pesquisa, a grande maioria dos casos está relacionado a derivativos do tipo "swap". Como dito no capítulo dedicado à "Metodologia", uma das grandes limitações da presente pesquisa diz respeito à impossibilidade de incluirmos "futuros", "termos" e "opções" como palavras-chave da busca. Ainda assim, obtivemos 19,12\% de retornos para "opções", muito provavelmente quando utilizamos as palavras "hedge" ou "derivativos" na busca.

\begin{tabular}{|l|l|l|}
\hline Produto & Números de casos & $\mathbf{\%}$ \\
\hline Swap & 40 & $58,82 \%$ \\
\hline Opção & 13 & $19,12 \%$ \\
\hline Fundo de Investimento & 11 & $16,18 \%$ \\
\hline Não informado & 3 & $4,41 \%$ \\
\hline Termo & 1 & $1,47 \%$ \\
\hline Total & $\mathbf{6 8}$ & $\mathbf{1 0 0 , 0 0 \%}$ \\
\hline
\end{tabular}

Aqui nos intriga a grande quantidade (11 casos, correspondentes a 16,18\% do total) de produtos categorizados como fundos de investimento. Trata-se de demandas relativas a fundos que operavam derivativos e que, na máxi desvalorização do real de 1999, experimentaram vultosas perdas. Ressaltamos que, dentre estas 11 ações judiciais, quase todas, com exceção de 2, são relacionadas ao mesmo reú - o que nos leva a levantar a hipótese de comportamento de manada para essas ações judiciais ou de conduta pouco heterodoxa deste réu. De todo modo, em 10 das 11 ações envolvendo fundos, o veredito foi pró instituição financeira. 
A respeito dos ambientes de negociação dos derivativos, na metade dos casos não foi possível determiná-lo, muito embora, pela descrição destas operações, tudo nos leva a crer que se trata do ambiente de balcão - optamos por não efetuar esta educated guess e mantivemos a classificação como "não informado". Ressalte-se que em 16,18\% dos casos, estávamos diante de litígios que envolviam as perdas de quotistas em fundos de investimento e, nesse sentido, a classificação do ambiente resta não aplicável para estes casos.

\begin{tabular}{|l|l|l|}
\hline Ambiente & Números de casos & $\mathbf{\%}$ \\
\hline Não Informado & 34 & $50,00 \%$ \\
\hline Balcão & 21 & $30,88 \%$ \\
\hline N/A - Fundo & 11 & $16,18 \%$ \\
\hline Bolsa & 2 & $2,94 \%$ \\
\hline Total & $\mathbf{6 8}$ & $\mathbf{1 0 0 , 0 0 \%}$ \\
\hline
\end{tabular}

Para os casos em que o ambiente foi informado, a grande maioria dos litígios envolveu derivativos negociados em balcão e não em bolsa de valores. Pode-se levantar, assim, a hipótese de que a segurança propiciada pelas bolsas de valores, que possuem mecanismos de ajustes diários e contraparte liquidante central, é um mitigador de riscos, afastando questionamentos judiciais.

\section{V.B. Resultados Qualitativos: as Teses}

O grande objetivo da catalogação dos julgados é o levantamento das teses utilizadas pelos autores (financeiros ou não) no processo de convencimento dos magistrados, bem como das teses usadas pelos juízes no contexto do racional decisório.

Na sequência, demonstramos a incidência das 21 teses usadas pelos autores e pelos juízes nos 68 casos analisados. As tabelas seguintes dividem as 21 teses em 2 colunas cada para mostrar a arguição da matéria pelo autor e a forma de reação do juiz.

A Tabela A demonstra as teses alegadas pelos 68 autores, independentemente de sua qualificação, e as respostas dadas pelos magistrados. A Tabela B é exatamente a mesma que a Tabela A, excluindo-se a opção "N/L", de modo a facilitar a visualização. A Tabela $\mathrm{C}$ analisa apenas os casos de autores que sejam sociedades não financeiras (29 casos) ou pessoas naturais ( 9 casos) ou entidades de previdência (1 caso) - totalizando 39 
casos cujos autores não são financeiros ou equiparados. A Tabela D traz apenas sociedades financeiras (29 casos), enquanto a Tabela $\mathrm{E}$ traz os mesmos casos da Tabela D, menos os 8 casos em que o Banco Santos é autor, pois enviesam nossos resultados, totalizando 21 casos.

Como já explicado em "Metodologia", a catalogação em "sim" e "não" demonstra juízo de valor positivo ou negativo acerca da matéria, quer do requerente, quer do juiz. Por sua vez, a utilização do "N/L" denota que a tese sequer foi levantada. Como era de se esperar, ao elegermos grande número de matérias (21 no total), na maioria dos casos, nem todas as teses são levantadas, pelo que assinalamos o "N/L". Com isso, na distribuição geral dos julgados há forte prevalência do "N/L" - por isso a importância da Tabela B, que exclui tais situações. 


\section{$\underline{\text { Tabela A - Todos os Autores }}$}

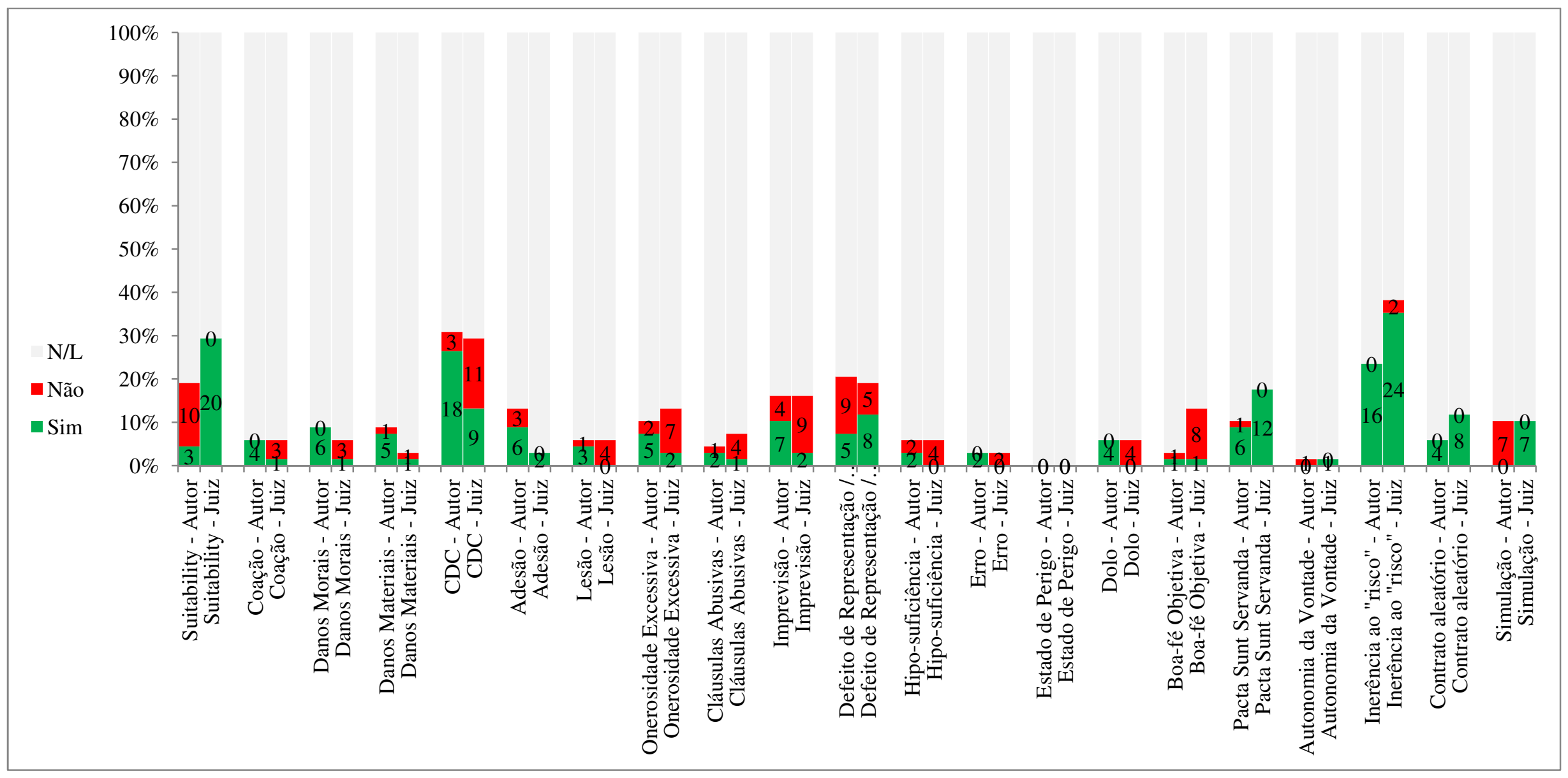




\section{$\underline{\text { Tabela B - Todos os Autores (desconsiderando "N/L") }}$}

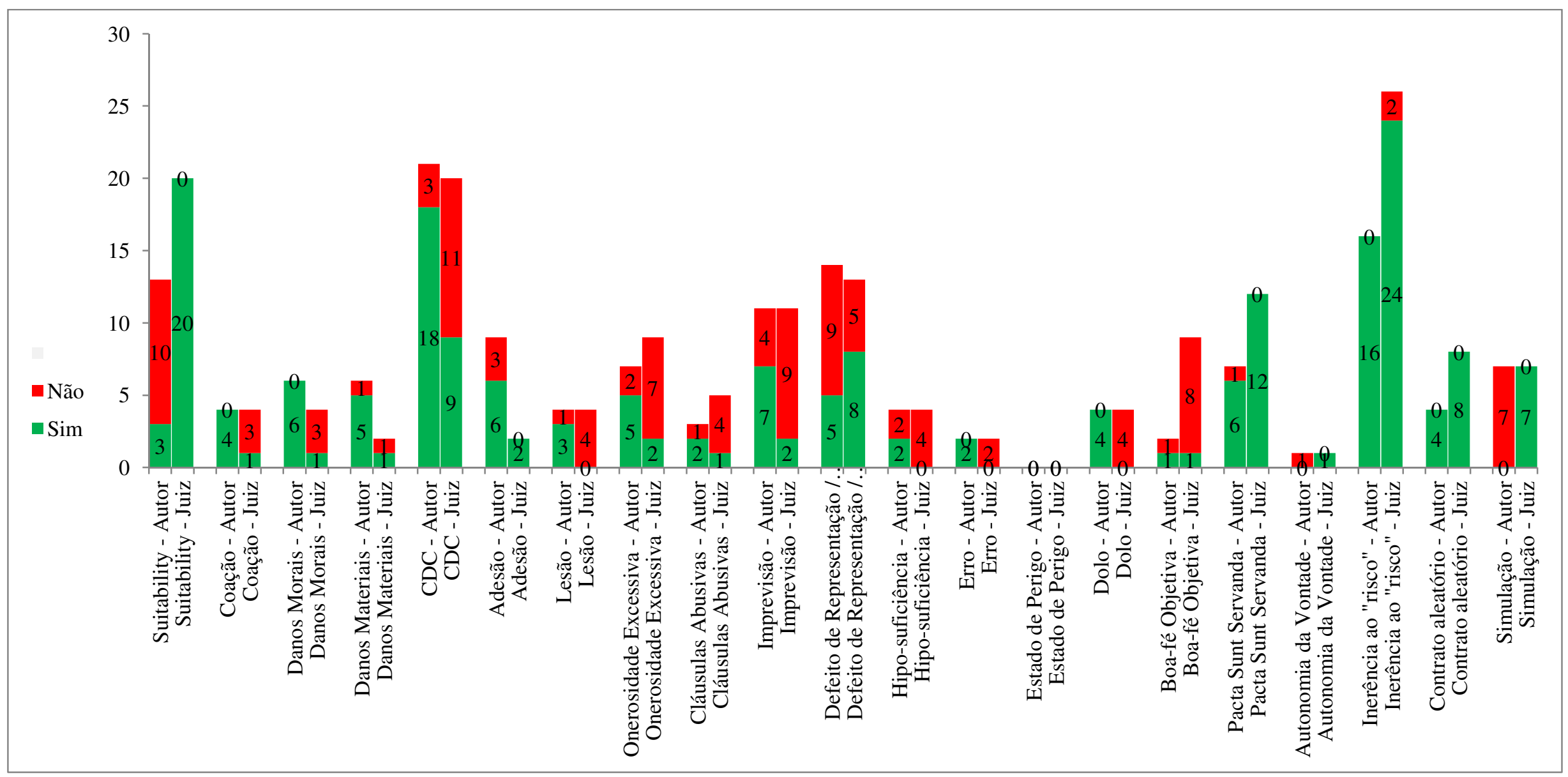




\section{$\underline{\text { Tabela C }- \text { Autores Não Financeiros }}$}

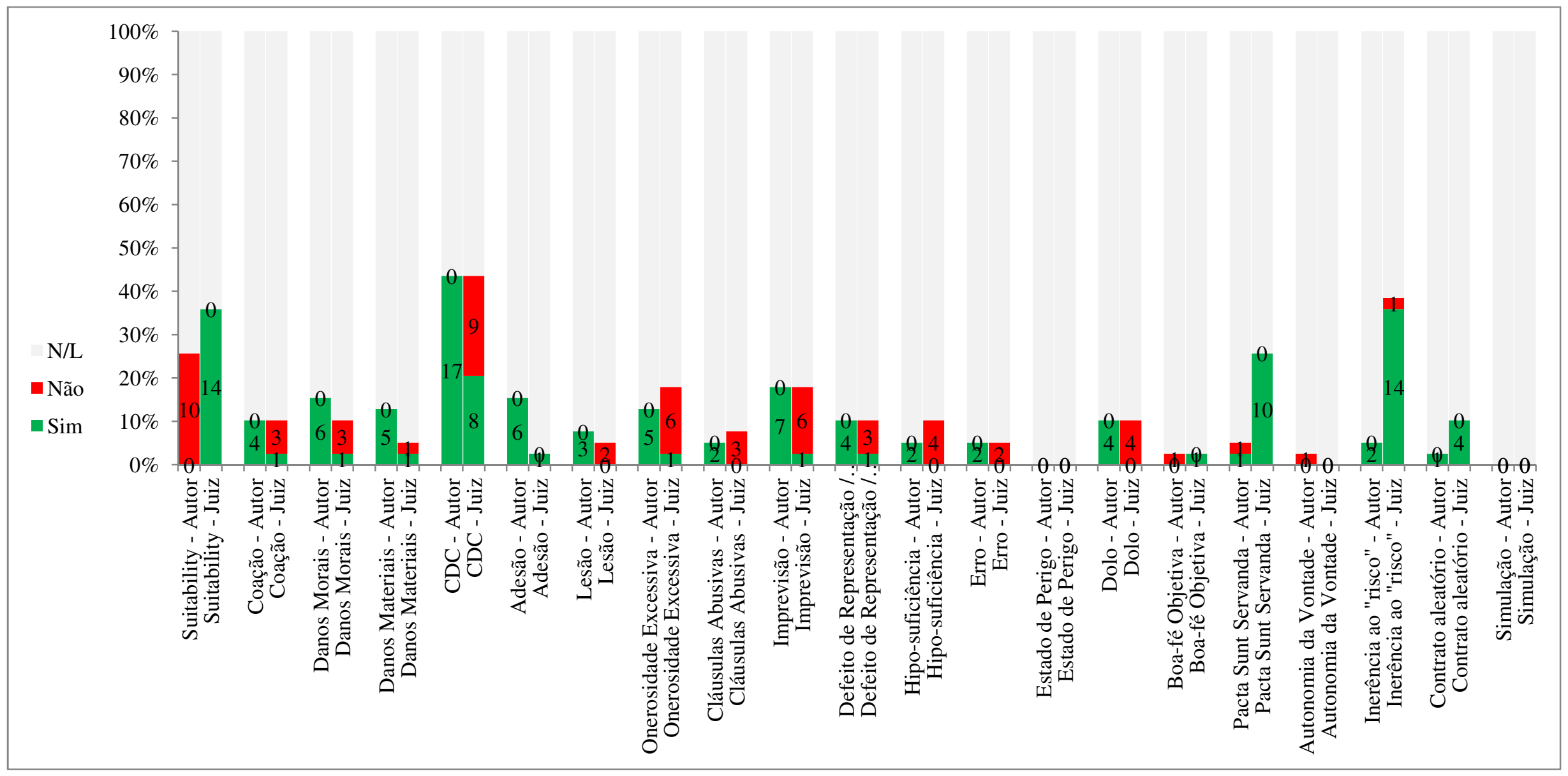




\section{$\underline{\text { Tabela D - Autores Instituições Financeiras }}$}

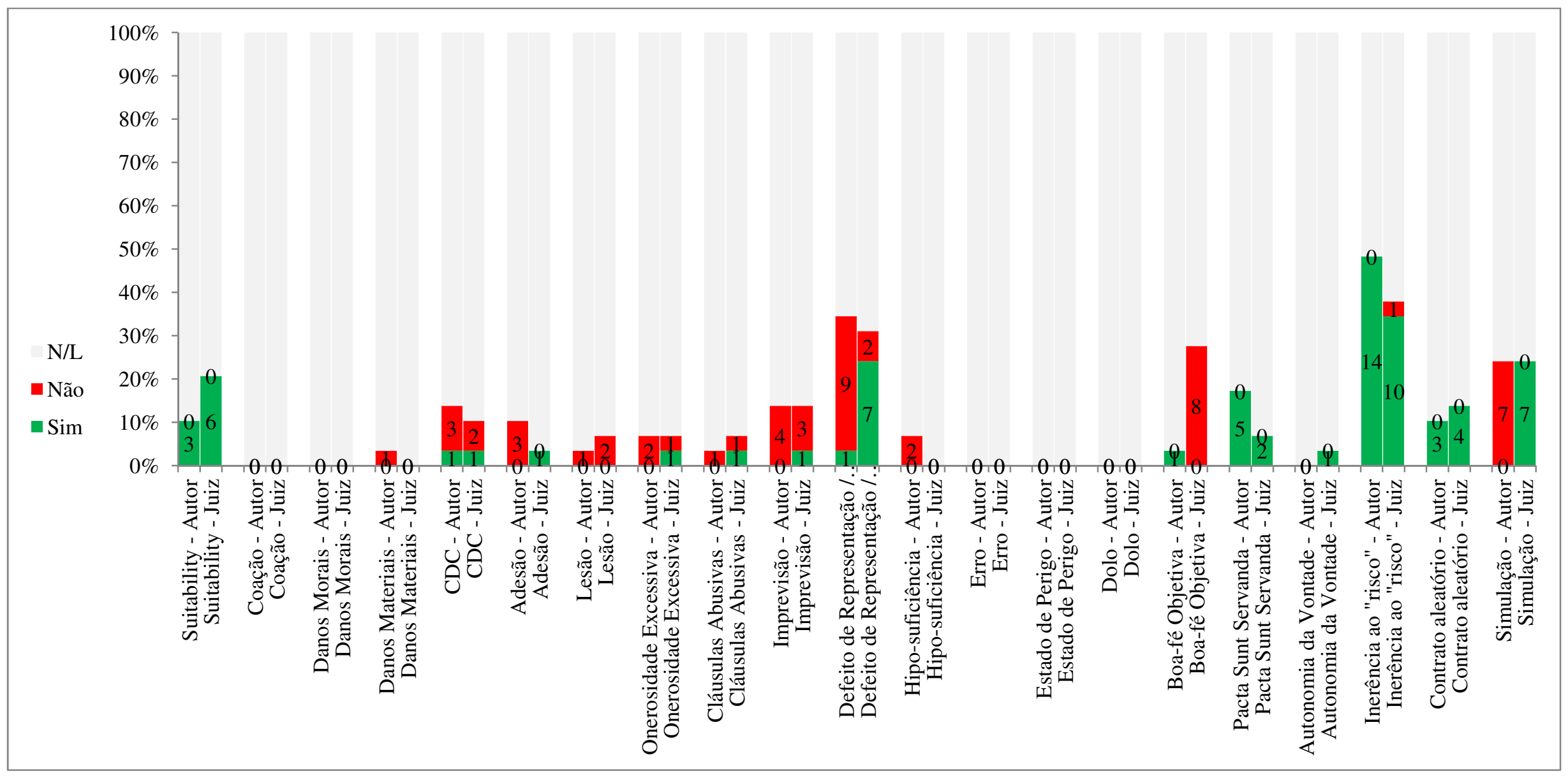




\section{$\underline{\text { Tabela E - Autores Instituições Financeiras (menos Banco Santos) }}$}

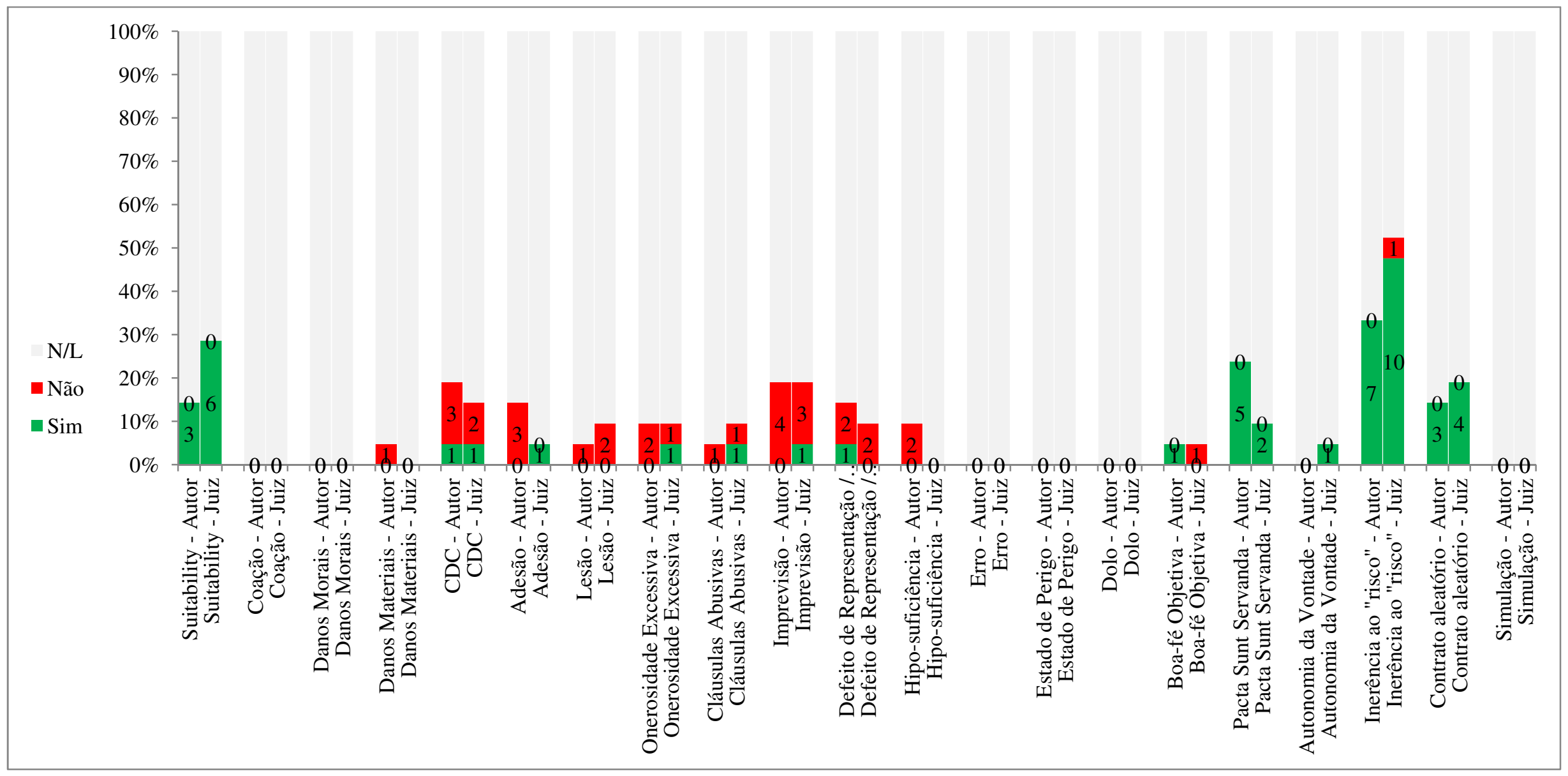


Com as tabelas, é possível visualizar a tendência de aparecimento (ou pelo autor ou pelo juiz) das seguintes matérias nos litígios, em ordem de importância: inerência ao risco (26 casos ou 38,23\%), Código de Defesa do Consumidor (21 casos ou 30,88\%), suitability (20 casos ou 29,41\%), defeito de representação ou formalização (14 casos ou 20,58\%), pacta sunt servanda (12 casos ou 17,64\%), teoria da imprevisão (11 casos ou 16,17\%), onerosidade excessiva ( 9 casos ou 13,23\%), contrato de adesão (9 casos ou 13,23\%), boafé ( 9 casos ou 13,23\%) e aleatoriedade ( 8 casos ou $11,76 \%)$.

A inerência ao risco é lembrada em 26 fundamentações de juízes e em 16 alegações de autores. Não por acaso, dentre as 16 vezes em que o risco é lembrado pelos autores como aplicável, em 14 delas está-se diante de autores instituições financeiras, que reiteram esta característica basilar dos derivativos.

Nas 26 fundamentações em que o risco é invocado pelos desembargadores, em 24 delas eles o fazem de maneira positiva, ou seja, colocando o risco como ínsito aos contratos de derivativos, consoante o exposto por nós na parte teórica deste trabalho. Abaixo trecho do julgado detalhado no Apêndice 12-SP:

É difícil crer que uma empresa do porte do agravante e com excelente assessoria jurídica, poderia ter desconhecimento do contrato que estava assinando, ou não ter conhecimento dos riscos de um contrato com a variação do câmbio em dólar.

Em apenas 2 situações, detalhadas nos Apêndices 14-SP e 15-SP (dois agravos de instrumento de um mesmo caso concreto), o desembargador, apesar de não propalar sentença terminativa de mérito, relativiza o risco dos contratos de derivativos, contrariando todo o arcabouço teórico existente sobre a matéria. Abaixo péssimo exemplo de questionamento do risco pelo ativismo Judiciário:

Ainda que tais operações envolvam risco de mercado, afigura-se cabivel questionar-se a respeito dos limites desse risco, não podendo ser ilimitado ou muito desproporcional entre as partes contratantes, sob pena de ensejar o enriquecimento sem causa de uma delas em grave prejuízo da outra, notadamente se chegar a ponto de inviabilizar o regular desempenho das atividades da empresa agravada.

Como era de se esperar, as totais 21 menções ao CDC estão concentradas em autores não financeiros (17 casos). Considerando o universo de 39 ações cujo autor não é 
financeiro, são recorrentes as tentativas de aplicação do Código de Defesa do Consumidor (17 dos 39 casos de autores não financeiros ou 43,58\% do grupo).

Nas sentenças, os juízes se dividem sobre a aplicabilidade de referido Código: em 8 dos 17 casos, os desembargadores decidiram pela sua aplicabilidade, ao passo que em 9 deles os juízes afastaram o diploma consumeirista. Vale mencionar que, dentre as 8 ocasiões em que o CDC foi tido como aplicável, em 4 (ou 50\% do universo) estava-se diante de litígios envolvendo quotas de fundo de investimento. Nesse sentido, fundamentação evidenciada no Apêndice 68-STJ:

Determina o artigo $8^{o}$ do Código de Defesa do Consumidor que o fornecedor de serviços que causem riscos, normais e previsíveis, aos consumidores, tem o dever de dar as informações necessárias e adequadas a seu respeito, ou seja, acerca da natureza e fruição dos serviços, considerando, para tanto, o conhecimento do homem médio, consumidor-padrão. Dessa forma, no investimento em fundos derivativos, principalmente os vinculados ao dólar-americano, é ínsito o alto grau de risco, tanto para grandes ganhos, como para perdas consideráveis. Aqueles que se encorajam a investir em fundos arrojados estão cientes dos riscos do negócio, caso contrário depositariam suas reservas investimentos mais conservadores, como, por exemplo, na poupança.

Não se pode afastar a aplicabilidade do CDC às instituições financeiras e equiparadas a priori - como bem decidiu o STJ no caso descrito acima relacionado a quotas de fundos de investimentos. Outrossim, deve-se entender o consumidor como "destinatário final" de produto ou serviço, perquirindo a existência de ato de consumo e não de atividade de insumo, consoante teoria finalista adotada pelo próprio Código. ${ }^{340}$

Bem por isso, não raro, os desembargadores rechaçaram a aplicação do CDC no caso concreto. Neste interessante julgado detalhado no Apêndice 20-SP, após dispor que as agravantes não são tomadoras dos serviços da instituição financeira como consumidoras finais, o desembargador sentenciou:

Nem de longe a ré se caracteriza como consumidora, nem o contrato de swap é capaz de configurar uma relação consumerista, para que as obrigações criadas com o contrato sejam tratadas pelas regras do $C D C$.

\footnotetext{
${ }^{340}$ MARTINS-COSTA, Judith. Contratos de derivativos cambiais. Contratos aleatórios. Abuso de direito e abusividade contratual. Boa-fé objetiva. Dever de informar e ônus de se informar. Teoria da imprevisão. Excessiva onerosidade superveniente, cit., p. 6-8.
} 
Com relação ao tema que denominamos "suitability", cumpre-nos, antes de mais nada, um esclarecimento. Utilizamos tal palavra de modo amplo e sem tecnicidade, como sinônimo de "adequação do produto ao usuário". No Brasil, a definição legal de suitability é muito recente, sendo inaugurada pelo COREMEC em $2009^{341}$ e, após alguns anos de debates, ${ }^{342}$ especificada pela CVM para o mercado de capitais apenas em $2013 .^{343}$ Portanto, neste trabalho, em que tomamos a liberdade de verificar alegações acerca da (in)adequação dos derivativos aos seus contratantes entre os anos de 2006 e 2010, nós o fazemos sem rigor técnico normativo.

O assunto aparece em 13 autores, 10 deles sujeitos não financeiros. Como era de se supor, em todas as 10 vezes em que uma pessoa não financeira levanta o tema, ela o faz de modo a demonstrar que o produto não deveria ser por ela utilizado. Uma alegação interessante sobre a inadequação dos derivativos contratados pelo usuário é encontrada no Apêndice 18-SP, in verbis:

Escudando-se também na teoria da imprevisão, aqui aplicável em razão da súbita e inesperada desvalorização do real frente ao dólar norteamericano, alega a agravante que firmou com os agravados "instrumento particular de contrato para realização de swap e outras do mercado de derivativos e outras avenças", operação que "continha uma complexa estrutura técnica, altamente prejudicial à Agravante e extremamente vantajosa apenas aos Agravados, estrutura essa que não foi explicitada em sua plenitude na ocasião da celebração do contrato", a par do que "de nada adianta uma liminar parcial que não impede os Agravados de executarem as garantias do contrato, não os impede de levar a protesto qualquer título de crédito que tenha vinculação com o contrato em exame, bem como obriga a Agravante a depositar o montante integral de cada parcela de verificação".

Nas 20 ocasiões em que o assunto foi abordado pelos desembargadores, em 100\% das vezes se conclui pela adequação do produto ao usuário. O Apêndice 1-SP aqui representa este universo:

\footnotetext{
${ }^{341}$ MINISTÉRIO DA FAZENDA. Comitê de Regulação e Fiscalização dos Mercados Financeiros, de Capitais, de Seguros, de Previdência e Capitalização - COREMEC. Deliberação $n^{\circ}$ 7, de 19 de junho de 2009. Disponível em: <http://www.mps.gov.br/arquivos/office/3_090630-161947-899.pdf>. Acesso 29 maio 2013.

${ }^{342}$ Nesse sentido, conferir: (i) COMISSÃO DE VALORES MOBILIÁRIOS. Edital de Audiência Pública 04/07, de 30 de março de 2007. Disponível em: <www.cvm.gov.br>. Acesso em: 23 dez. 2013; (ii) COMISSÃO DE VALORES MOBILIÁRIOS. Edital de Audiência Pública 04/09, de 28 de abril de 2009. Disponível em: <www.cvm.gov.br>. Acesso em: 23 dez. 2013; e (iii) COMISSÃO DE VALORES MOBILIÁRIOS. Edital de Audiência Pública SDM 15/11, de 13 de dezembro de 2011. Disponível em: $<$ Www.cvm.gov.br>. Acesso em: 23 dez. 2013.

${ }^{343}$ COMISSÃO DE VALORES MOBILIÁRIOS. Instrução CVM no 539, de 13 de novembro de 2013. Disponível em: <www.cvm.gov.br>. Acesso em: 22 dez. 2013.
} 
Sendo os apelantes, consoante se infere de suas qualificações, pessoas esclarecidas e experientes, tinham, por isso, plenas condições de saber que se cuidava de investimentos que envolviam risco de mercado, sujeitos, assim, a perda ou rendimento negativo, sendo suficientes para esclarecer a este respeito as informações constantes deste folheto emitido pelo banco.

Prosseguindo-se com as teses mais alegadas, chegamos ao tema "defeito de representação ou formalização". Cuidamos de mapear problemas que são relacionados a controles internos das instituições financeiras, tais como procurações, gravações, transmissões de ordens, entre outros. O assunto é a quarta matéria mais recorrente nos julgados, aparecendo em 20,58\% dos julgados, o que demonstra a necessidade de investimentos em controles internos e back-office pelas instituições financeiras e intermediários como forma de mitigar futuras contingências.

Trata-se de assunto muito mais fático do que qualquer outra coisa, sem grandes elaborações doutrinárias. Abaixo excerto do Apêndice 2-SP em que o desembargador conclui pela ausência de autorização para a prática das operações financeiras:

Além disso, embora o contrato de abertura de conta corrente tenha previsto, na sua cláusula 17, estar o banco autorizado por seu correntista a efetivar operações de investimento por instruções transmitidas por telefone, fax e internet (fl. 308), cabia ao falido demonstrar ter recebido tal autorização, do que não se tem notícia nos autos.

Enquanto juízes concluíram pelo defeito de representação ou formalização em 8 dos $13 \operatorname{casos}^{344}$, em 5 deles afastou-se qualquer vício nesse sentido. Na sequência, trecho do Apêndice 24-SP, em que se afasta qualquer tipo de defeito de formalização:

A apelada era conhecedora do sistema por ter feito diversas operações, $e$ quando recebeu os contratos para assinatura, deveria verificar se estavam de acordo com a ordem dada, e deveria ter tomado providência na oportunidade, ou pelo menos fazer as ordens por escrito da forma como queria as aplicações, não sendo crível que a instituição financeira pudesse fazer aplicação ao arrepio do interesse da apelada.

\footnotetext{
${ }^{344}$ Vale notar que em 7 dos 8 casos em que o juiz declara defeito de representação, estava-se diante de julgados do Banco Santos, sendo que o juiz usou mesma fundamentação para sua conclusão. Como dito repetidas vezes, entendemos que tais julgados enviesam os resultados.
} 
O pacta sunt servanda apareceu em 12 ocasiões. Em todas as 12 fundamentações propaladas por juízes em que o assunto aparece, conclui-se pela aplicabilidade deste cânone tão caro à teoria geral dos contratos. Abaixo trecho do julgado disposto no Apêndice 29-SP:

Por outro lado, o contrato firmado, como constituído, evidentemente, deve ser cumprido integralmente, em face do princípio do "pacta sunt servanda”.

$\mathrm{Na}$ única ação em que o autor solicita a relativização do pacta sunt servanda, ele o faz amparado na função social do contrato. A propósito, a função social é uma das faces da "socialidade", um dos três pilares que, ao lado da "eticidade" e "operabilidade", formam o tripé principiológico do Código Civil de 2002. Assim, a função social como expoente dessa "socialidade" $" 345$ deve ser vislumbrada como "superação do caráter individualista"346 do Código de 1916, mas de modo algum como possibilidade de intervenção estatal desmotivada na vida particular ou como excusa para se relativizar o pacta sunt servanda. Portanto, "socialidade" dos contratos não se confunde com "socialização" dos negócios privados, e deve ser encarada como reconhecimento da inserção dos negócios entre particulares dentro de realidade social contextualizada. Dada a existência de um único julgado tentando afastar o pacta sunt servanda pela função social do contrato, podemos concluir que, ao menos no universo dos derivativos (no âmbito desta pesquisa), aparentemente, entendeu-se o verdadeiro significado de "função social". Na sequência, o nosso único contra-exemplo disposto no Apêndice 33-SP:

Por outro lado, deve ser considerado que atualmente os princípios da autonomia da vontade e o "pacta sunt servanda" foram mitigados pelo principio da função social do contrato, de modo que se ajuste às necessidades da coletividade. Deste modo, injusta a cláusula que permite compensação de valores, nos termos do art. 424, Código Civil.

\footnotetext{
${ }^{345}$ REALE, Miguel. Função social do contrato. 20 nov. 2003. Disponível em <http://www.miguelreale.com.br/artigos/funsoccont.htm>. Acesso em: 27 maio 2013, enxerga a socialidade inserida na codificação de modo parcimonioso, em que o legislador deixa os interesses individuais sujeitos a cláusulas abertas propícias a soluções equitativas. Na elaboração do ordenamento jurídico das relações privadas, o legislador se encontra perante três opções possíveis: ou dá maior relevância aos interesses individuais, como ocorria no Código Civil de 1916, ou dá preferência aos valores coletivos, promovendo a "socialização dos contratos"; ou, então, assume uma posição intermédia, combinando o individual com o social de maneira complementar, segundo regras ou cláusulas abertas propícias a soluções eqüitativas $e$ concretas. Não há dúvida que foi essa terceira opção a preferida pelo legislador do Código Civil de 2.002.

${ }^{346}$ Id. Visão geral do novo Código Civil. In: NOVO Código Civil brasileiro. 3. ed. São Paulo: Ed. Revista dos Tribunais, 2003. p. 13.
} 
A teoria da imprevisão aparece 11 vezes, tanto em alegações de autores como em respostas de juízes. Como esperado, em todas as 7 vezes em que o autor não financeiro falou do assunto, ele o fez defendendo a sua aplicabilidade. Por seu turno, em todas as 4 vezes em que um autor financeiro o mencionou, ele refutou a aplicabilidade da teoria da imprevisão aos derivativos.

As respostas dos desembargadores foram, de modo geral (em 9 dos 11 casos), coerentes e condizentes com a parte teórica deste trabalho, em que concluímos ser a teoria da imprevisão inaplicável aos derivativos. Abaixo demonstrativo de afastamento da teoria disposto no Apêndice 9-SP:

Mas, com o devido respeito, a modificação do valor do câmbio não era de todo imprevisível e o risco dessa flutuação fora albergado pela autora.

Nos 2 únicos contra-exemplos em que o juiz defendeu a aplicabilidade da teoria da imprevisão, estava-se diante do mesmo caso concreto já acima referido em que houve relativização do risco (Apêndices 14-SP e 15-SP). Abaixo fundamentação dada pelo desembargador pela possível aplicabilidade da teoria da imprevisão também em contratos aleatórios, escorando-se na doutrina de NERY e na já criticada (e por alguns, superada) teoria da destruição da base objetiva do negócio que, como dissemos, sequer é positivada no Brasil:

\begin{abstract}
Note-se, outrossim, que mesmo que se considere que cuida-se, no caso, a propósito, de contrato aleatório, conforme afirma o agravante, isto não obsta, ainda que em princípio, o ajuizamento da presente ação, pois como afirma, também, Nelson Nery Júnior, "nos contratos aleatórios, a base objetiva do negócio se caracteriza pela equivalência do risco de cada contratante: se o risco for de apenas um ou se for desproporcional, muito mais arriscado para um, que para o outro contratante, há quebra da base objetiva do negócio, que pode ensejar a revisão do contrato ou a sua resolução, de acordo com o que vem previsto no sistema (v. CC 421, 422, 317 e 478), para que se recomponha a equivalência perdida do risco da desigualdade das prestações " (in "Código Civil Comentado", Ed. RT, 5 a ed., nota $n .7$ ao art. 458, parte final, pág. 508).
\end{abstract}

Outro assunto muito lembrado, a onerosidade excessiva, foi afastado em 7 das 9 ocasiões em que mencionado por julgadores. Assim como a teoria da imprevisão não se aplica aos derivativos, também a onerosidade excessiva deve ser veementemente refutada, conforme por nós desenvolvido em capítulo específico, já que o objeto do próprio negócio 
é a transferência de riscos previamente e mutuamente aceitos pelas partes. Um bom exemplo de negativa da onerosidade excessiva está no Apêndice 62-SC, que transcrevemos a seguir:

Para tanto, afirma que houve onerosidade excessiva no pacto, decorrente da desvalorização do real frente ao dólar, em consequência da crise ecônomica mundial iniciada pela inadimplência dos créditos hipotecários subprime nos Estados Unidos. Segundo o apelante, o contrato de derivativos foi efetuado para proteção das operações de 'adiantamento sobre contratos de câmbio', também firmadas com o apelado, e teriam sido assinados sob forte influência da instituição financeira, que não teria deixado claro ao apelante os riscos do negócio. (...) Portanto, deve ser relativizada a afirmação de que o contrato se tornou oneroso em demasia para o apelante, pois assim como perdeu com a desvalorização do real nos derivativos, passou a ganhar com a valorização de suas exportações, que agora pagam muito mais reais pelo seu equivalente em dólar, compensando o prejuízo nas operações de antecipação cambial. De igual forma, se o movimento do câmbio tivesse sido de forma inversa, teria perdido nas antecipações, mas ganho nos derivativos. $O$ objetivo das operações era neutralizar os efeitos do câmbio para a empresa exportadora, tanto em caso de valorização do real quanto no caso de sua desvalorização. A não ocorrência do cenário previsto pelo apelante, de desvalorização, não deve ser motivo de revisão ou mesmo resolução forçada do contrato, que serviu a seu fim.

Os dois únicos julgados em que o juiz aventa a aplicabilidade da onerosidade excessiva aos derivativos são aqueles do caso concreto em que houve relativização do risco, já acima descritos e que apontamos como péssimos exemplos de técnica jurídica (Apêndices 14-SP e 15-SP).

Dando continuidade, o assunto "contrato de adesão" aparece em 9 dos 68 julgados. Normalmente, o tema é alegado em conjunto com a aplicabilidade do CDC. Em todas as 6 vezes que alegado pelos autores não financeiros, propugna-se pela característica da adesividade como forma de reiterar a hipossuficiência e a falta de paridade entre as partes.

Assim ocorreu no caso concreto descrito no Apêndice 67-RS, em que o juiz reconhece o contrato de adesão, mas afasta a hipossuficiência do contratante e, nesse sentido, mantém a eleição de foro estipulada em referido contrato:

Alega a agravante da ocorrência, in casu, de contrato de adesão e que a decisão fustigada avaliou incorretamente a condição da empresa frente ao banco agravado, pois vulnerável econômica e tecnicamente. (...) A desconsideração da cláusula de eleição de foro, em princípio válida e eficaz, somente é possível na ocorrência de determinados requisitos, conforme voto do Min. Sálvio de Figueiredo Teixeira, no REsp 58138 / SP: "A cláusula de eleição de foro inserida em contrato de adesão é, em 
princípio, válida e eficaz, salvo: a) se, no momento da celebração, a parte aderente não dispunha de intelecção suficiente para compreender o sentido e as conseqüências da estipulação contratual; b) se da prevalência de tal estipulação resultar inviabilidade ou especial dificuldade de acesso ao Judiciário; c) se se tratar de contrato de obrigatória adesão, assim entendido o que tenha por objetivo produto ou serviço fornecido com exclusividade por determinada empresa. Reconhecida qualquer dessas circunstâncias excepcionais, a definição da competência se impõe seja procedida segundo as regras gerais estabelecidas no diploma processual (no caso, art. 100, IV, " $b$ ”, CPC)." (...) Efetivamente, as partes firmatárias são pessoas jurídicas, sendo que a agravante é empresa de grande porte, que tem entre suas atividades a importação e exportação; portanto conhecedora do mercado internacional. Ademais, a natureza do contrato implica risco $e$ investimento de valores, o que por si só afasta a idéia de fragilidade da parte aqui recorrente. Não está, pois, caracterizada a hipossuficiência.

Por seu turno, instituições financeiras autoras tendem a refutar a formalização de suas relações contratuais por meio de contratos de adesão, alegando a possibilidade de negociação dos clientes nos modelos previamente definidos. Assim o foi no caso descrito no Apêndice 13-SP:

Alega o agravante, em augusto relato, não se tratar de contrato de adesão, havendo possibilidade de escolha e negociação, livremente pactuado; e que a eleição de foro não submete a agravada a dificuldades ao exercício de sua defesa.

A penúltima matéria mais alegada pelas partes é a boa-fé, que apareceu por 9 ocasiões em nossa pesquisa. Válido mencionar que a boa-fé ou, no caso, a ausência dela foi defendida pelo juiz em 8 julgados relacionados ao Banco Santos. Essa constatação, por si só, enviesa os nossos resultados e mostra que o tema da boa-fé, na realidade, não é recorrente em nossa pesquisa. De toda forma, abaixo excerto do Apêndice 2-SP relacionado ao falido Santos em que o desembargador conclui pela violação da cláusula geral de boa-fé:

Não tendo assim agido o falido, segundo está dito no segundo parágrafo de fl. 101, "violou a cláusula geral de boa-fé contratual, agasalhada pelo Código de Defesa do Consumidor muito antes da disposição do artigo 422 do Código Civil, merecendo realce o fato de o diploma consumerista gozar do caráter de norma pública (REsp $n^{\circ}$ 292.942/MG - Rei. Min. Sálvio de Figueiredo Teixeira - DJ 07.05.2001)”, disso decorrendo que "o negócio entabulado - Contrato de Opção Flexível de Compra sobre Ibovespa - é passível do reconhecimento da prática de dolo pelo falido", de tal arte que "a impugnação apresentada pela parte agravada (leia-se. agravante), sob o manto de nulidade ou omissão do falido que a induziu 
a negócio diverso do pretendido, pode ser considerada como pleito de anulação'.

Excluindo-se os 8 casos do Banco Santos, temos um único e bom exemplo em que o juiz trata da boa-fé, refutando sua violação pelos contratantes, conforme disposto no Apêndice 50-ES:

Não há que se falar em violação aos artigos $37, \S 1^{\circ}$, e 51, inciso $I V$, do Código de Defesa do Consumidor, e aos artigos 112, 122 e 422 [boa-fé], do CCB/2002, quando verificado, na via estreita do agravo de instrumento, que as cláusulas limitativas do contrato bancário de hedge foram redigidas de forma clara, com destaques suficientes para que o contratante se ativesse ao seu conteúdo e às suas possíveis implicações e que o mesmo afirmou ter experiência na contratação de mecanismos financeiros destinados a garantir operações de exportação contra oscilações do câmbio (dólar).

Por fim, o último tema mais recorrente nos 68 julgados é a aleatoriedade dos derivativos, que foi lembrada em 8 ocasiões. Em todas elas, reconheceu-se a aleatoriedade destes contratos, em linha com nossas conclusões obtidas na parte teórica. Para este assunto, muito ligado à inerência ao risco, elegemos o excerto do Apêndice 46-RJ:

Há que se mencionar, ainda, que o contrato de derivativos celebrados pelas partes impõe risco a ambas e o resultado é totalmente aleatório no momento da celebração. 


\section{CONCLUSÃO}

Com inúmeros exemplos históricos, o racional dos derivativos sempre esteve ligado às necessidades de redução de incertezas dos agentes. $\mathrm{O}$ desenvolvimento do capitalismo e a globalização priorizaram os efeitos da transação em detrimento da operacionalização dos negócios a ela atrelados, com economia de custos de transação e ganhos de celeridade, deslocando-se o foco do ativo subjacente (já não necessariamente um bem tangível) para o risco pretendido. Esta manipulação de riscos apresenta as funções básicas dos derivativos, proteção e especulação, e o surgimento de um mercado relevante passa a ter na indicação de preços, na geração de informações, no aumento de liquidez e na mobilidade monetária as suas faces mais notáveis.

As entidades administradoras de mercado organizado, bolsa e balcão, adquirem importância crescente e sistêmica com o movimento de financeirização dos derivativos, passando o registro de operações a compor a agenda regulatória mundial a partir de 2008. No Brasil, atualmente, CETIP e BM\&F Bovespa corporificam os mercados de bolsa e balcão, sendo o registro de operações em tais entidades condição de validade dos derivativos.

São arquétipos essenciais da categoria dos derivativos os contratos a termo (e os correspondentes massificados, os futuros), as opções e os swaps, sendo suas demais manifestações ilimitadas e decorrentes da combinação e sofisticação destas três espéciesbase. Como denominador comum de todos os derivativos temos a referência a um ativo subjacente e o lapso temporal entre a data do fechamento do negócio e a data de produção de seus efeitos, o que leva à desejada manipulação de riscos.

Finalmente sepultada a comparação dos derivativos aos jogos de azar, em 2002, o ordenamento jurídico passou a tutelar a exigibilidade destes instrumentos financeiros, reconhecendo-se a gestão contratual do risco como necessária e desejável à fluidez das relações econômicas.

A definição financeira dos derivativos como instrumentos cujo valor depende ou deriva de outras variáveis subjacentes é insuficiente do ponto de vista jurídico, o que nos leva a conceituá-los como contratos bilaterais, diferenciais, aleatórios, muitos deles atípicos e frutos da autonomia da vontade privada. Tal conceituação aliada às 
características dos derivativos, por si só, afasta a regra da exceção de contrato não cumprido, dificulta determinadas alegações referentes a defeitos do negócio jurídico (tais como erro e lesão) e impossibilita a aplicação das teorias de revisão contratual relacionadas a mudanças significativas de conjuntura (teorias da imprevisão, onerosidade excessiva e destruição da base objetiva do negócio).

Esta natureza jurídica contratual convive com a classificação legislativa de todos os derivativos como valores mobiliários, conceito este polissemântico, de caráter instrumental e viés regulatório, trazendo todos os derivativos para a órbita da CVM.

Em nossa pesquisa jurisprudencial, os seguintes temas foram recorrentes nos julgados: inerência ao risco (26 casos ou 38,23\%), Código de Defesa do Consumidor (21 casos ou 30,88\%), suitability (20 casos ou 29,41\%), defeito de representação ou formalização (14 casos ou 20,58\%), pacta sunt servanda (12 casos ou 17,64\%), teoria da imprevisão (11 casos ou 16,17\%), onerosidade excessiva (9 casos ou 13,23\%), contrato de adesão (9 casos ou 13,23\%), boa-fé (9 casos ou 13,23\%) e aleatoriedade (8 casos ou $11,76 \%)$.

Outros importantes achados na pesquisa empírica são (i) a inexistência de concentração de juízes aos casos analisados (o que pode denotar falta de câmaras especializadas ou baixa judicialização da matéria); (ii) a concentração de fatos desencadeadores das demandas em datas de turbulência econômica (máxi-desvalorização do Real em 1999 e crise mundial de 2008); (iii) sujeitos não financeiros tendem (65\%) a acionar mais os Tribunais do que sujeitos financeiros; (iv) não se vislumbra concentração maciça de processos em nenhuma instituição financeira; (v) a maioria dos remédios judiciais iniciadas por instituições financeiras $(66,67 \%)$ é provida; (vi) a maioria das demandas iniciadas por sujeitos não financeiros $(87,18 \%)$ não é provida; (vii) a maioria dos casos $(71,93 \%)$ teve posicionamento pró instituição financeira, a minoria $(5,26 \%)$ viés contrário às instituições financeiras e o viés decisório restou inconclusivo em parte relevante $(22,81 \%)$ das ações; (viii) agravos $(43,86 \%)$ e apelações $(42,11 \%)$ foram as peças mais analisadas. ${ }^{347}$

\footnotetext{
${ }^{347}$ As conclusões aqui dispostas excluem os casos relacionados ao Banco Santos, que enviesam os resultados. Para o detalhamento das conclusões, consultar o capítulo V.
} 


\section{REFERÊNCIAS}

ABRÃO, Nelson. Direito bancário. 9. ed. São Paulo: Saraiva, 2005.

ANDREZO, Andrea Fernandes. Introdução ao mercado financeiro. In: LIMA, Iran Siqueira; LIMA, Gerlando Augusto Sampaio Franco de; PIMENTEL, Renê Coppe (Coords.) Curso de mercado financeiro: tópicos especiais. São Paulo: Atlas, 2009.

; LIMA, Iran Siqueira. Mercado financeiro: aspectos históricos e conceituais. São Paulo: Thomson Learning, 2002.

ANTUNES, José A. Engracia. Os derivados. Disponível em: <http://www.cmvm.pt/CMVM/Publicacoes/Cadernos/Documents/C30Artigo4.pdf>. Acesso em: 10 mar. 2012.

ARAÚJO NETO, Lauro Silva. Derivativos. 3. ed. São Paulo: Atlas, 1999.

ARIDA, Pérsio. In: GALA, Paulo; REGO, José Márcio (Coords.). A história do pensamento econômico como teoria e retórica: ensaios sobre metodologia em economia. São Paulo: Ed. 34, 2003.

; BACHA, Edmar; LARA RESENDE, André. Credit, interest and jurisdictional uncertainty: conjectures on the case of Brazil. In: GIAVAZZI, Francesco; GOLDFAJN, Ilan; HERRERA, Santiago (Coords.). Inflation targeting, debt, and the Brazilian experience: 1999 to 2003. Cambridge: MIT Press, 2005.

ARROW, Kenneth J. Collected papers of Kenneth J. Arrow: the economics of information. Cambridge: Harvard University Press, 1984. v. 4.

ARRUDA, Daniel Sivieri. Os contratos derivativos e a inaplicabilidade da revisão ou resolução por excessiva onerosidade. Monografia, 2009. Disponível em <http://www.bmfbovespa.com.br/pt-br/educacional/download/BMFBOVESPAMonografia-vencedora-Daniel-Sivieri-Arruda.pdf>. Acesso em: 10 abr. 2012.

AZEVEDO, Antônio Junqueira de. Contrato de opção de venda de participações societárias. Variação imprevisível do valor da coisa prometida em relação ao preço do mercado. Possibilidade de revisão por onerosidade excessiva, com base nos arts. 478 a 480 do Código Civil em contrato unilateral. In: . Novos estudos e pareceres de direito privado. São Paulo: Saraiva, 2010. 
AZEVEDO, Antônio Junqueira de. A lesão como vício do negócio jurídico. A lesão entre comerciantes. Formalidades pré-contratuais. Proibição de venire contra factum proprium e ratificação de atos anuláveis. Resolução ou revisão por fatos supervenientes. Excessiva onerosidade, base do negócio e impossibilidade da prestação In: Novos estudos $e$ pareceres de direito privado. São Paulo: Saraiva, 2004.

. Relação jurídica que não é de consumo. Destinatário final. Cláusula abusiva. In: Novos estudos e pareceres de direito privado. São Paulo: Saraiva, 2004.

BAKER, Colleen M. Regulating the invisible: the case of over-the-counter derivatives. Notre Dame Law Review. v. 85, Nov. 2010. Disponível em: <http://papers.ssrn.com/sol3/papers.cfm?abstract_id=1739882>. Acesso em: 10 jun. 2011.

BALDWIN, Robert; CAVE, Martin. Understanding regulation. London: Oxford University Press, 1999.

BANDEIRA, Paula Greco. Contratos aleatórios no direito brasileiro. Rio de Janeiro: Renovar, 2010.

BARRETO FILHO, Oscar. Natureza jurídica das bolsas de valores no direito brasileiro. Revista de Direito Bancário, do Mercado de Capitais e da Arbitragem, São Paulo, n. 12, 2001. (Ed. Original, 1959).

As operações a termo sobre mercadorias (hedging). Revista de Direito Mercantil, Industrial, Econômico e Financeiro, São Paulo, n. 29, jan./mar. 1979.

BERNSTEIN, Peter L. Desafio aos deuses: a fascinante história do risco. 23. ed. Rio de Janeiro: Campus, 1997.

BIANCA, Massimo. Diritto civile. Milano: Giuffrè, 1987. v. 3.

BITTAR FILHO, Carlos Alberto. Teoria da imprevisão: dos poderes do juiz. São Paulo: Ed. Revista dos Tribunais, 1993.

BLACK, Bernard S. Strengthening Brazil's securities market. Revista de Direito Mercantil, Industrial, Econômico e Financeiro, São Paulo, n. 120, out./dez. 2000.

BONFIM, Antulio Neves. Derivativos de crédito e outros instrumentos. Rio de Janeiro: Elsevier, 2007.

BORGES, Nelson. A teoria da imprevisão no direito civil e no processo civil. São Paulo: Malheiros Ed., 2002. 
BULGARELLI, Waldirio. Os valores mobiliários brasileiros como títulos de crédito. Revista de Direito Mercantil, Industrial, Econômico e Financeiro, São Paulo, n. 37, jan./mar. 1980.

CALHEIROS, Maria Clara. O contrato de swap. Coimbra: Coimbra Ed., 2000.

CARVAlHOSA, Modesto. Comentários à Lei de Sociedades Anônimas. 2. ed. São Paulo: Saraiva, 1997. v. 1.

; EIZIRIK, Nelson. A nova Lei das S.A. São Paulo: Saraiva, 2002.

CHEDIAK, Julian Fonseca Peña. A reforma do mercado de valores mobiliários. In: LOBO, Jorge; KANDIR, Antonio (Coords.). Reforma da Lei das Sociedades Anônimas: inovações e questões controvertidas da Lei 10.303, de 31.10.2001. 2.ed. Rio de Janeiro: Forense, 2002. p. 525-551.

CHEW, Lilian. Gerenciando os riscos de derivativos: o uso e o abuso da alavancagem. Rio de Janeiro: Qualitymark, 1999.

COELHO, Fábio Ulhoa. Curso de direito comercial. São Paulo: Saraiva, 2005. 3 v.

COMPARATO, Fabio Konder. Natureza jurídica das bolsas de valores e delimitação do seu objeto. Revista de Direito Mercantil, Industrial, Econômico e Financeiro, São Paulo, n. 60 , out./dez. 1985.

CORDEIRO FILHO, Ari. Swaps: aspectos jurídicos. Revista de Direito Bancário, do Mercado de Capitais e da Arbitragem, São Paulo, v. 4, n. 11, p. 69-79, jan./mar. 2001.

COSTA, Philomeno Joaquim da. Anotações às companhias. São Paulo: Ed. Revista dos Tribunais, 1980.

CUNHA, Luciana Gross. Segurança jurídica: performance das instituições e desenvolvimento. In: PODER Judiciário e desenvolvimento do mercado de valores mobiliários brasileiros. São Paulo: Saraiva, 2008. p. 131-143.

CUSTÓDIO, Pedro Miguel Ferreira. Operações com derivativos como instrumentos de hedge. Revista Dialética de Direito Tributário, São Paulo: Dialética, n. 100, jan. 2004.

DE LUCCA, Newton. Aspectos da teoria geral dos títulos de crédito. São Paulo: Pioneira, 1979.

DIAS, Luciana Pires. Regulação e auto-regulação no mercado de valores mobiliários. 2005. Dissertação (Mestrado) - Faculdade de Direito, Universidade de São Paulo, 2005. 
DODD, Randall. Exotic derivatives losses in emerging markets: questions of suitability, concerns for stability. International Monetary Fund Working Paper. Jul. 2009. Disponível em: <http://topwonks.org/wp-content/uploads/2012/05/RDodd-Kiko-WP-2009.pdf>. Acesso em: 25 jun. 2013.

EIZIRIK, Nelson. Aspectos jurídicos dos mercados futuros. Revista de Direito Mercantil, Industrial, Econômico e Financeiro, São Paulo, n. 81, jan./mar. 1991.

. Negócio jurídico de hedging. Revista de Direito Mercantil, Industrial, Econômico e Financeiro, São Paulo, v. 32, n. 90, p. 13-22, abr./jun. 1993.

Reforma das S.A. e do mercado de capitais. Rio de Janeiro: Renovar, 1997.

A urgente reforma da Lei 6.385/76. Revista de Direito Mercantil, Industrial, Econômico e Financeiro, São Paulo, v. 34, n. 98, p. 58-61, abr./jun. 1995.

; GAAL, Ariádna B.; PARENTE, Flávia, HENRIQUES, Marcus de Freitas. Mercado de capitais: regime jurídico. 2. ed. Rio de Janeiro: Renovar, 2008.

; __ _ WALD, Arnold.. Das funções econômicas dos mercados a termo e do Projeto de Código Civil. Revista de Informação Legislativa, Brasília, n. 86, abr./jun. 1985.

FABOZZI, Frank J. The handbook of fixed income securities. 7. ed. New York: McGrawHill, 2005.

FERRÃO, Brisa Lopes de Mello; RIBEIRO, Ivan César. Os juízes brasileiros favorecem a parte mais fraca? Latin American and Caribbean Law and Economics Association (ALACDE) Annual Papers, Berkeley Program in Law and Economics, UC Berkeley, Maio 2006. Disponível em: <http://escholarship.org/uc/item/0715991z>. Acesso em: 16 maio 2012.

FERREIRA, Kenneth Antunes. Contrato derivativo não padronizado: a impropriedade de sua classificação como valor mobiliário. 2008. Dissertação (Mestrado) - Faculdade de Direito, Pontifícia Universidade Católica, 2008.

FONSECA, Arnoldo Medeiros da. Caso fortuito e teoria da imprevisão. Rio de Janeiro: Forense, 1958.

FORGIONI, Paula. A interpretação dos negócios empresariais no novo Código Civil brasileiro. Revista de Direito Mercantil, Industrial, Econômico e Financeiro, São Paulo, v. 42, n. 130, p. 7-38, abr./jun. 2003. 
FORTUNA, Eduardo. Mercado financeiro: produtos e serviços. Rio de Janeiro: Qualitymark, 2005.

FRANCO, Vera Helena de Mello; SZTAJN, Rachel. Manual de direito comercial: sociedade anônima e mercado de valores mobiliários. São Paulo: Ed. Revista dos Tribunais, 2005. $2 \mathrm{v}$.

FRIEDMAN, Thomas L. O mundo é plano: uma breve história do século XXI. Rio de Janeiro: Objetiva, 2007.

GIRINO, Emilio. I contratti derivati. 2. ed. Milano: Giuffrè, 2001.

GODOY, Claudio. Função social do contrato: novos princípios contratuais. São Paulo: Saraiva, 2004.

GOLDBERG, Daniel Krepel. A Lei 10.303, de 2001, e a inclusão dos derivativos no rol dos valores mobiliários. Revista de Direito Mercantil, Industrial, Econômico e Financeiro, São Paulo, v. 42, n. 129, p. 73-82, jan./mar. 2003.

GOLDSTEIN, Sergio Mychkis. Aspectos jurídicos dos derivativos de crédito no Brasil. Revista de Direito Bancário e do Mercado de Capitais, São Paulo, v. 7, n. 25, p. 63-81, jul./set. 2004.

GOMES, Orlando. Contratos. Rio de Janeiro: Forense, 2007.

GORGA, Erica Cristina Rocha. Direito societário atual. Rio de Janeiro: Elsevier, 2013.

A importância dos contratos a futuro para a economia de mercado. Revista de Direito Mercantil, Industrial, Econômico e Financeiro, São Paulo, n. 112, p. 157-248, out./dez. 1998.

GREENBERGER, Michael. The role of derivatives in financial crisis. Washington DC, Financial Crisis Inquiry Commission Hearing, June 30, 2010. Disponível em: <http://fcicstatic.law.stanford.edu/cdn_media/fcic-testimony/2010-0630-Greenberger.pdf $>$. Acesso em: 11 jun. 2013.

GUERREIRO, José Alexandre Tavares. Sobre o poder disciplinar da CVM. Revista de Direito Mercantil, Industrial, Econômico e Financeiro, São Paulo, n. 43, jul./set. 1981.

HAZEN, Thomas Lee. Disparate regulatory schemes for parallel activities: securities regulation, derivatives regulation, gambling, and insurance. Annual Review of Banking \& Financial Law, Boston, v. 24, 2005. 
HAZEN, Thomas Lee. Rational investments, speculation, or gambling? Derivative securities and financial futures and their effect on the underlying capital markets. Northwestern University Law Review, Chicago, v. 86, n. 4, 1992.

HENDERSON, Schuyler K. Henderson on derivatives. London: Reed Elsevier, 2003.

HULL, John. Fundamentos dos mercados futuros e de opções. 4. ed. São Paulo: BM\&F, 2005.

Introdução aos mercados futuros e de opções. 2. ed. São Paulo: Bolsa de Mercadorias e Futuros; Cultura Editores Associados, 1996.

KNIGHT, Frank H. Risk, uncertainty and profit. 1. ed. Boston: Houghton Mifflin Company, 1921. Disponível em: <http://www.econlib.org/LIBRARY/Knight/knRUP.html>. Acesso em: 11 dez. 2013.

KÜMPEL, Siegfried. Direito do mercado de capitais: do ponto de vista do direito europeu, alemão e brasileiro. Rio de Janeiro: Renovar, 2007.

LARENZ, Karl. Base del negocio juridico y cumplimento de los contratos. Madrid: Editorial Revista de Derecho Privado, 1956.

LEÃES, Luiz Gastão Paes de Barros. O conceito de "security" no direito norte-americano e conceito análogo no direito brasileiro. Revista de Direito Mercantil, Industrial, Econômico e Financeiro, São Paulo, n. 14, 1974.

A estrutura jurídica do mercado de futuro. In: Pareceres. São Paulo: Ed. Singular, 2004. v. 1.

Heding com futuros de índices representativos de ações. In: Pareceres. São Paulo: Ed. Singular, 2004. v. 2.

. Liquidação compulsória de contratos futuros. Revista dos Tribunais, São Paulo, v. 81, n. 675, p. 44-55, jan. 1992.

LEVINE, Ross. Financial development and economic growth: views and agenda. Journal of Economic Literature, American Economic Association, Pittsburgh, v. 35, Jun. 1997.

LOBO, Carlos Augusto da Silveira. Os valores mobiliários. Revista do Direito Bancário e do Mercado de Capitais, São Paulo, v. 10, n. 36, p. 27-42, abr./jun. 2007. 
LOPES, Alexsandro Broedel. Operações com derivativos: uma introdução multidisciplinar e algumas lições da crise no Brasil. Revista de Direito Mercantil, Industrial, Econômico e Financeiro, São Paulo, v. 46, n. 148, p. 17-26, out./dez. 2007.

; GALDI, Fernando Caio; LIMA, Iran Siqueira. Manual de contabilidade $e$ tributação de instrumentos financeiros e derivativos: (IAS39, IAS 32, CPC 14, minutas do CPC 38, 39, 40 normas da CVM, do BACEN e da Receita Federal do Brasil). São Paulo: Atlas, 2009.

; LIMA, Iran Siqueira. Contabilidade e controle de operações com derivativos. São Paulo: Thomsom, 2003.

LOZARDO, Ernesto. Derivativos no Brasil: fundamentos e práticas. São Paulo: BM\&F, 1998.

MAFUD, Pedro Darahem; PEREIRA FILHO, Celso Roberto. Uma nova bolsa: a quem interessa. In: Regulação e tributação do mercado financeiro e de capitais: temas atuais. São Paulo: Quartier Latin, 2014. No prelo.

MAGNO, Fernando R. Vila. A cédula de produto rural como instrumento de hedge: breve análise da evolução do entendimento do Superior Tribunal de Justiça. Revista de Direito Bancário e do Mercado de Capitais, São Paulo, n. 56, abr./jun. 2012.

MARSHALL, John F.; KAPNER, Kenneth R. Understanding swaps. New York: John Wiley \& Sons, 1993.

MARTINS-COSTA, Judith. A boa-fé no direito privado. São Paulo: Ed. Revista dos Tribunais, 1999.

Comentários ao novo Código Civil: do Direito das Obrigações - Adimplemento e Extinção das Obrigações. Rio de Janeiro: Forense, 2005. v. 5, t. 1.

Contratos de derivativos cambiais. Contratos aleatórios. Abuso de direito e abusividade contratual. Boa-fé objetiva. Dever de informar e ônus de se informar. Teoria da imprevisão. Excessiva onerosidade superveniente. Revista de Direito Bancário e do Mercado de Capitais, São Paulo, n. 55, jan./mar. 2012.

Reflexão sobre o princípio da função social dos contratos. Revista Direito $G V$, São Paulo, maio 2005.

MATTOS FILHO, Ary Oswaldo. O conceito de valor mobiliário. Revista de Direito Mercantil, Industrial, Econômico e Financeiro, São Paulo, n. 59, jul./set. 1985. 
MAZEAUD, Henri et Léon; MAZEAUD, Jean; CHABAS, François. Leçons de droit civil. 8. ed. Paris: Montchrestien, 1991. t. 2, v. 1.

MOSQUERA, Roberto Quiroga. Tributação no mercado financeiro e de capitais. São Paulo: Dialética, 1998.

MOTTA, Rita de Cassia Luz Teixeira. O conceito de valor mobiliário no direito brasileiro. 2002. Dissertação (Mestrado) - Faculdade de Direito, Universidade de São Paulo, 2002.

NASSAR, Paulo André Silva; DIAS, Vitor Martins. Regulação financeira transnacional: superando a crise dos derivativos financeiros. Disponível em http://www.conpedi.org.br/manaus/arquivos/anais/fortaleza/3527.pdf. Acesso em 13 jan. 2013.

NOBRE, Marcos. Apontamentos sobre a pesquisa em Direito no Brasil. Disponível em: $<$ http://bibliotecadigital.fgv.br/dspace/bitstream/handle/10438/2779/Pesquisa_Direito_Cad ernos_Direito_GV.pdf?sequence=1>. Acesso em: 07 jul. 2013.

NORTH, Douglass C. Institutions, institutional change and economic performance. New York: Cambridge University Press, 1990.

ODITAH, Fidelis. The future for the global securities market: legal and regulatory aspects. New York: Clarendon Press - Oxford, 1996.

OLIVEIRA, Fernando Albino de. Contratos futuros: características jurídicas - regulação dos mercados futuros. Revista de Direito Público, São Paulo, v. 21, n. 87, p. 224-228, jul./set. 1988.

PALMITER, Alan R. Securities regulations: examples \& explanations. 3. ed. New York: Aspen Publishers, 2005.

PELTIER, Frederic. Marchés financiers et droit commun. Paris: Banque Éditeur, 1997.

PEREIRA, Caio Mário da Silva. Instituições de direito civil. 10. ed. Rio de Janeiro: Forense, 1997. v. 3.

PINHEIRO, Armando Castelar. Judiciário, reforma e economia: a visão dos magistrados. In: Addressing Judicial Reform in Brazil: Institutions and Constituency Building. Instituto de Estudos Econômicos, Sociais e Políticos de São Paulo (IDESP). Dezembro, 2002. Disponível em: $<$ http://www.febraban.org.br/arquivo/destaques/armando_castelar_pinheiro2.pdf>. Acesso em: 30 jun. 2012. 
PONTES DE MIRANDA, Francisco Cavalcanti. Tratado de direito privado: parte especial. Rio de Janeiro: Borsoi, 1959. v. 26.

Tratado de direito privado: parte especial. Rio de Janeiro: Borsoi, 1964. v. 45.

PRADO, Fernando Almeida; LESSA, Tiago A. D. Thenudo. Derivatives in Brazil. Butterworths Journal of International Banking and Financial Law, London, v. 24, n. 1, Jan. 2009.

PRADO, Viviane Muller. Reflexões sobre enforcement de normas societárias. In: PODER Judiciário e desenvolvimento do mercado de valores mobiliários brasileiros. São Paulo: Saraiva, 2008. p. 115-129.

RAJAN, Raghuram G. Has financial development made the world riskier? National Bureau of Economic Research, Working Paper No. 11728, Nov. 2005. Disponível em: <http://www.nber.org/papers/w11728.pdf?new_window=1>. Acesso em: 25 jun. 2012.

REALE, Miguel. A boa-fé no Código Civil. 16 ago. 2003. Disponível em $<$ http://www.miguelreale.com.br/index.html>. Acesso em: 27 maio 2013.

Função social do contrato. 20 nov. 2003. Disponível em <http://www.miguelreale.com.br/artigos/funsoccont.htm>. Acesso em: 27 maio 2013.

Visão geral do novo Código Civil. In: NOVO Código Civil brasileiro. 3. ed. São Paulo: Ed. Revista dos Tribunais, 2003.

REQUIÃO, Rubens. Curso de direito comercial. 23. ed. São Paulo: Saraiva, 2003. 2 v.

RIBEIRO, Ivan César. Robin Hood versus King John: como os juízes locais decidem casos no Brasil? IPEA - Instituto de Pesquisa Econômica Aplicada, 2006. Disponível em: <http://www.ipea.gov.br/ipeacaixa/premio2006/docs/trabpremiados/IpeaCaixa2006_Profis sional_01lugar_tema01.pdf>. Acesso em: 09 maio 2012.

ROCHA, Jean Paul Cabra Veiga da. A capacidade de conjuntura no direito econômico: o déficit democrático da regulação financeira. 2004. Tese (Doutorado) - Faculdade de Direito, Universidade de São Paulo, São Paulo, 2004.

RODRIGUES, Silvio. Dos Contratos e das declarações unilaterais da vontade. 30. ed. São Paulo: Saraiva, 2004. 
ROMANO, Roberta. Against financial regulation harmonization: a comment. Nov. 2010. Disponível em: <http://papers.ssrn.com/sol3/papers.cfm?abstract_id=1697348\#\#>. Acesso em: 29 jun. 2012.

Thumbnail sketch of derivative securities and their regulation. Maryland Law Review, Baltimore, v. 55, p. 1-83, 1996.

SALAMA, Bruno Meyerhof. Rumo a uma teorização jurídica da inovação financeira: os negócios bancários indiretos. Revista da Procuradoria Geral do Banco Central, Cejur Brasília, v.4, n.1, jul./dez. 2010.

SALLES, Marcos Paulo de Almeida. Aspectos da competência do CMN e da CVM no mercado de valores mobiliários. Revista de Direito Mercantil, Industrial, Econômico e Financeiro, São Paulo, v. 36, n. 108, p. 101-115, out./dez. 1997.

Contratos de bolsa de execução diferida. 1998. Tese (Doutorado) - Faculdade de Direito, Universidade de São Paulo, São Paulo, 1998.

O contrato futuro. São Paulo: Cultura, 2000.

Os valores mobiliários na Lei das S/A. Revista de Direito Mercantil, Industrial, Econômico e Financeiro, São Paulo, v. 36, n. 107, p. 123-128, jul./set. 1997.

SALOMÃO FILHO, Calixto. Regulação da atividade econômica: princípios e fundamentos jurídicos. São Paulo: Malheiros Ed., 1998.

SALOMÃO NETO, Eduardo. Direito bancário. São Paulo: Atlas, 2005.

SAMPAIO, Francisco José Marques. Mercados derivativos: aspectos jurídicos e suas semelhanças e dessemelhanças com o jogo e a aposta. Revista de Direito Privado, São Paulo, v. 3, n. 9, jan./mar. 2002.

SANCHEZ, Sydney. Os contratos atípicos no direito privado. Revista de Direito Público, Sao Paulo, v. 21, n. 86, p. 237-241, abr./jun. 1988.

SANZ CABALLERO, Juan Ignacio. Derivados financieros. Madrid: Marciel Pons, 2000.

SOUZA JUNIOR, Francisco Satiro. Derivativos de bolsa. In: Mercado de Capitais. São Paulo: Saraiva, no prelo, 2011. (Série Gvlaw).

Derivativos e mercado de bolsa. Revista Jurídica Logos, São Paulo, n. 1, jan. 2005. 
SOUZA JUNIOR, Francisco Satiro. Regime jurídico das opções negociadas em bolsas de valores. 2002. Tese (Doutorado) - Faculdade de Direito, Universidade de São Paulo, 2002.

SQUASSONI, Christian Max Finardi. Riscos operacionais nos mercados de futuros, opçoes e de swaps na bolsa de mercadorias e futuros - BM\&F. Revista de Direito Mercantil, Industrial, Econômico e Financeiro. São Paulo, n. 120, out./dez. 2000.

STIGLER, George J. The theory of price. 4. ed. New York; London: Macmillan, 1987.

STOUT, Lynn A. Derivatives and the legal origin of the 2008 credit crisis. Harvard Business Law Review, v. 1. Jun. 2011. Disponível em: $<$ http://papers.ssrn.com/sol3/papers.cfm?abstract_id=1874806\#\#>. Acesso em: 11 jun. 2013.

How deregulating derivatives led to disaster, and why re-regulating them can prevent another. Lombard Street, v. 1, n. 7, 2009. Disponível em: <http://papers.ssrn.com/sol3/papers.cfm?abstract_id=1432654>. Acesso em: 10 dez. 2013.

STUBER, Walter Douglas; STUBER, Adriana M. Godel. Novas modalidades de operações de derivativos de crédito. Revista de Direito Bancário, do Mercado de Capitais e da Arbitragem, v. 5, n. 17, p. 255-261, jul./set. 2002.

SZTAJN, Rachel. Contrato e inovação financeira: ensaio sobre contratos futuros e swaps. Tese (Professor Titular) - Faculdade de Direito da Universidade de São Paulo, 1996.

Contratos de bolsa. In: BITTAR, Carlos Alberto (Coord.). Novos contratos empresariais. São Paulo: Ed. Revista dos Tribunais, 1990.

A função social do contrato e o direito da empresa. In: TIMM, Luciano; MACHADO, Rafael (Coords.). A função social do direito. São Paulo: Quartier Latin, 2009.

. Futuros e swaps: uma visão jurídica. São Paulo: Cultural Paulista, 1999.

. Regulação e o mercado de valores mobiliários. Revista de Direito Mercantil, Industrial, Econômico e Financeiro, São Paulo, v, 53, n. 135, p. 136-147, jul./set. 2004.

. Sobre a natureza jurídica das opções negociadas em bolsa. Revista de Direito Mercantil, Industrial, Econômico e Financeiro, São Paulo, v. 36, n. 105, p. 53-69, jan./mar. 1997.

THEODORO JUNIOR, Humberto. O contrato e seus princípios. 2. ed. Rio de Janeiro: Aide, 1999. 
THEODORO JUNIOR, Humberto. O contrato e sua função social. Rio de Janeiro: Forense, 2004.

VENOSA, Silvio de Salvo. Teoria geral das obrigações e teoria geral dos contratos. 7. ed. São Paulo: Atlas, 2007.

VERÇOSA, Haroldo Malheiros Duclerc. A arbitragem e o mercado de capitais. Revista de Direito Mercantil, Industrial, Econômico e Financeiro, São Paulo, v. 46, n. 146, p. 155 164, abr./jun. 2007.

Os contratos inonimados e o novo Código Civil. Revista de Direito Mercantil, Industrial, Econômico e Financeiro, São Paulo, v. 41, n. 126, p. 31-36, abr./jun. 2002.

Curso de direito comercial. São Paulo: Malheiros Ed., 2006. 2 v.

. Notas sobre o regime jurídico das ofertas ao público de produtos, serviços e valores mobiliários no direito brasileiro: uma questão de complementação da proteção de consumidores e de investidores. Revista de Direito Mercantil, Industrial, Econômico e Financeiro, São Paulo, v. 36, n. 105, p. 74-83, jan./mar. 1997.

VILLAÇA, Álvaro Azevedo. Teoria geral dos contratos típicos e atípicos. São Paulo: Atlas, 2002.

VIVANTE, Cesare. "Introdução" - Trattato de Diritto Comerciale. Trad. Haroldo Malheiros Duclerc Verçosa. Revista de Direito Mercantil, Industrial, Econômico e Financeiro, São Paulo, v. 102, p. 134-138, abr. 1996.

WALD, Arnoldo. O mercado de futuro de índices e os valores mobiliários. Revista de Direito Mercantil, Industrial, Econômico e Financeiro, São Paulo, n. 57, jan.mar. 1985.

O mercado de opções e a responsabilidade das corretoras. Revista de Direito Bancário e do Mercado de Capitais, São Paulo, n. 61, jul./set. 2013.

WINTER, Marcelo Franchi. Cédula de produto rural e teoria da imprevisão. Revista de Direito Bancário e do Mercado de Capitais, São Paulo, n. 57, jul./set. 2012.

YAZBEK, Otavio. Crise, inovação e regulação no mercado financeiro: considerações sobre a regulamentação do mercado de derivativos de balcão. No prelo, 2011.

Regulação do mercado financeiro e de capitais. 2. ed. Rio de Janeiro: Elsevier, 2009. 
YAZBEK, Otavio. A regulamentação das bolsas de valores e das bolsas de mercadorias e futuros e as novas atribuições da Comissão de Valores Mobiliários. Revista do Direito Bancário e do Mercado de Capitais, São Paulo, v. 9, n. 34, p. 198-218, out./dez. 2006.

YEUNG, Luciana Luk-Tai; AZEVEDO, Paulo Furquim. Pró-devedor ou pró-credor? Medindo o viés dos juízes brasileiros. Insper Working Paper n. 240, 2011. Disponível em: $<$ http://www.iepecdg.com.br/uploads/artigos/111122_wpe240.pdf>. Acesso em 18 jun. 2012.

ZANCHIM, Kleber Luiz. Cada contrato tem uma função social. Valor Econômico, São Paulo, ano 14, n. 3263, 27 maio 2013. Disponível em: $<$ http://www.valoreconomico.com.br>. Acesso em: 27 mai. 2013.

ZYLBERSTAJN, Decio; REZENDE, Christine Leles. Pacta sunt servanda? o caso dos contratos de soja verde. Berkeley Program in Law and Economics, UC Berkeley, Maio 2007. (Series: Latin American and Caribbean Law and Economics Association (ALACDE) Annual Papers). Disponível em: <http://escholarship.org/uc/item/5jg1v63w>. Acesso em: 13 maio 2012.

; SZTAJN, Rachel. Direito e economia: análise econômica do direito das organizações. Rio de Janeiro: Elsevier, 2005.

\section{LEGISLAÇÃO / RELATÓRIOS OFICIAIS / JULGADOS ESTRANGEIROS:}

ASSOCIAÇÃO BRASILEIRA DE JURIMETRIA. Palavra do Presidente. Disponível em: $<$ http://abjur.org.br/>. Acesso em: 09 dez. 2013.

BANCO CENTRAL DO BRASIL. Circular $n^{\circ}$ 2.348, de 30 de julho de 1993. Disponível em: <www.bacen.gov.br>. Acesso em: 20 fev. 2013.

Circular 3.057, de 31 de agosto de 2001. Disponível em: <www.bacen.gov.br>. Acesso em: 22 maio 2011.

Circular n. ${ }^{\circ}$ 3.106, de 10 de abril de 2002. Disponível em: <www.bacen.gov.br>. Acesso em: 20 fev. 2013.

Circular n. ${ }^{o}$ 3.291, de 08 de setembro de 2005. Disponível em: <www.bacen.gov.br>. Acesso em: 20 fev. 2013. 
BANCO CENTRAL DO BRASIL. Conselho Monetário Nacional. Resolução $n .^{\circ}$ 981, de 13 de dezembro de 1984. Disponível em: <www.bacen.gov.br>. Acesso em: 20 fev. 2013.

Conselho Monetário Nacional. Resolução n. ${ }^{\circ} 1.190$, de 17 de setembro de 1986. Disponível em: <www.bacen.gov.br>. Acesso em: 20 fev. 2013.

Conselho Monetário Nacional. Resolução $n^{\circ}$ 1.655, de 25 de outubro de 1989. Disponível em: <www.bacen.gov.br>. Acesso em: 22 mai. 2011.

. Conselho Monetário Nacional. Resolução n. ${ }^{\circ}$ 1.779, de 20 de dezembro de 1990. Disponível em: <www.bacen.gov.br>. Acesso em: 11 jun. 2013.

Conselho Monetário Nacional. Resolução n. ${ }^{\circ}$ 2.012, de 30 de julho de 1993. Disponível em: <www.bacen.gov.br>. Acesso em: 20 fev. 2013.

Conselho Monetário Nacional. Resolução n. ${ }^{\circ}$ 2.690, de 28 de janeiro de 2000. Disponível em: <www.bacen.gov.br>. Acesso em: 22 maio. 2011.

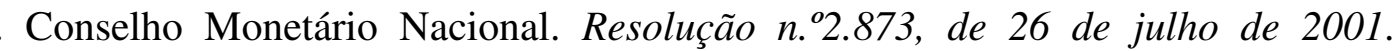
Disponível em: <www.bacen.gov.br>. Acesso em: 20 fev. 2013.

Conselho Monetário Nacional. Resolução n. ${ }^{\circ}$ 2.882, de 30 de agosto de 2001. Disponível em: <www.bacen.gov.br>. Acesso em: 22 maio 2011.

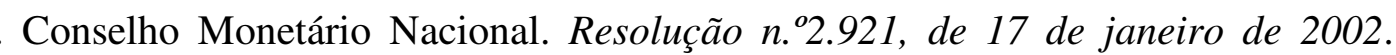
Disponível em: <www.bacen.gov.br>. Acesso em: 20 fev. 2013.

Conselho Monetário Nacional. Resolução n. ${ }^{\circ 2.933, ~ d e ~} 28$ de fevereiro de 2002. Disponível em: <www.bacen.gov.br>. Acesso em: 20 fev. 2013.

Conselho Monetário Nacional. Resolução n. ${ }^{\circ} 3.312$, de 31 de agosto de 2005. Disponível em: <www.bacen.gov.br>. Acesso em: 20 fev. 2013.

Conselho Monetário Nacional. Resolução n. ${ }^{\circ}$ 3.505, de 26 de outubro de 2007. Disponível em: $<$ http://www.bcb.gov.br/pre/normativos/res/2007/pdf/res_3505_v1_O.pdf>.Disponível em: <www.bacen.gov.br>. Acesso em: 20 fev. 2013.

BANK FOR INTERNATIONAL SETTLEMENTS (BIS). Report on OTC Derivatives Data Reporting and Aggregation Requirements. Disponível em: <http://www.bis.org/publ/cpss100.pdf>. Acesso em: 28 abr. 2013. 
BERKSHIRE Hathaway Inc. 2002 Annual Report. Disponível em: <http://www.berkshirehathaway.com/2002ar/2002ar.pdf>. Acesso em: 29 maio. 2013.

BLACK'S law dictionary. 8. ed. Saint Paul: Thomson West, 2004.

BM\&FBOVESPA. Bolsa de Valores, Mercadorias e Futuros. Modelos de Contratos Futuros Opções. $e$ Disponível em: $<\mathrm{http}: / / \mathrm{www}$. bmfbovespa.com.br/Sumario2 .aspx ?menu=2\&sitemap=22219\&idioma=ptbr>. Acesso em: 22 maio 2011.

Bolsa de Valores, Mercadorias e Futuros. Regulamento de Operações da Clearing de Derivativos. Disponível em: <http://www.bmfbovespa.com.br/pt$\mathrm{br} /$ regulacao/download/Regulamento-de-Operacoes-da-Clearing-de-Derivativos.pdf $>$. Acesso em: 22 maio 2011.

Bolsa de Valores, Mercadorias e Futuros. Regulamento de Operações do Segmento Bovespa: Ações, Futuros e Derivativos de Ações. Disponível em: $<$ http://www.bmfbovespa.com.br/pt-br/regulacao/download/0_manual_regula_completo231210.pdf>. Acesso em: 22 maio 2011.

- Bolsa de Valores, Mercadorias e Futuros. Regulamento de Operações do Segmento BM\&F - Sistemas de Negociação de Derivativos: Pregões Viva-Voz e Eletrônico. Disponível em: <http://www.bmf.com.br/bmfbovespa/pages/boletim1/bd_manual/regulamento-operacoessegmento-BMF.pdf>. Acesso em: 22 maio 2011.

BOLSAS em transição. Revista Capital Aberto, ano 10, n. 114, fev. 2013. Disponível em: <http://www.capitalaberto.com.br>. Acesso em: 21 fev. 2013.

BOLSA de Valores S.A. Revista Capital Aberto, ano 3, n. 35, jul. 2006. Disponível em: <http://www.capitalaberto.com.br>. Acesso em: 21 fev. 2013.

BRASIL. Constituição da República Federativa do Brasil de 1988. Disponível em $<$ http://www.planalto.gov.br>. Acesso em: 04 set. 2013.

. Decreto-Lei n. ${ }^{\circ}$ 2.268, de 23 de julho de 1986, dispõe sobre cobrança de imposto nas operações a termos de bolsas de mercadorias e dá outras providências. Disponível em <www.planalto.gov.br>. Acesso 22 maio 2011.

Lei n. ${ }^{\circ}$ 3.071, de 01 de janeiro de 1916, instituiu o Código Civil, hoje revogado. Disponível em <www.planalto.gov.br>. Acesso 05 jan. 2013. 
BRASIL. Lei n. ${ }^{\circ}$ 4.595, de 31 de dezembro de 1964, dispõe sobre a política e as instituições monetárias, bancárias e creditícias, cria o Conselho Monetário Nacional e dá outras providências. Disponível em: <www.planalto.gov.br>. Acesso em: 22 maio 2011.

Lei . $^{\circ} 4.728$, de 14 de julho de 1965, disciplina o mercado de capitais e estabelece medidas para o seu desenvolvimento. Disponível em: <www.planalto.gov.br>. Acesso em: 20 fev. 2012.

Lei n. ${ }^{\circ}$ 5.869, de 11 de janeiro de 1973. Institui o Código de Processo Civil. Disponível em <http://www.planalto.gov.br>. Acesso 04 set. 2013.

Lei n. ${ }^{\circ}$ 6.385, de 7 de dezembro de 1976, conforme alterada, dispõe sobre o mercado de valores mobiliários e cria a Comissão de Valores Mobiliários. Disponível em: <www.planalto.gov.br>. Acesso em: 22 maio. 2011.

Lei n. ${ }^{\circ}$ 6.404, de 15 de dezembro de 1976, conforme alterada, dispõe sobre as Sociedades Anônimas. Disponível em: <www.planalto.gov.br>. Acesso em: 22 maio 2011.

Lei n. ${ }^{\circ} 10.214$, de 27 de março de 2001, dispõe sobre a atuação das câmaras e dos prestadores de serviços de compensação e de liquidação, no âmbito do sistema de pagamentos brasileiro, e dá outras providências. Disponível em: <www.planalto.gov.br>. Acesso em: 22 maio 2011.

Lei n. ${ }^{\circ}$ 10.406, de 10 de janeiro de 2002. Institui o Código Civil. Disponível em: <http://www.planalto.gov.br>. Acesso em: 22 maio 2011.

Lei n. ${ }^{\circ}$ 12.543, de 08 de dezembro de 2011. Autoriza o Conselho Monetário Nacional, para fins de política monetária e cambial, a estabelecer condições específicas para negociação de contratos derivativos; altera os arts. $2^{\underline{0}}$ e $3^{\underline{0}}$ da Lei $n^{\circ}$ 6.385, de 7 de dezembro de 1976, o inciso IV do art. $3^{\underline{0}}$ do Decreto-Lei $n^{\mathrm{o}} 1.783$, de 18 de abril de 1980 , os arts. $1^{1^{\circ}}$, $2^{\circ}$ e $3^{\underline{0}}$ da Lei $\mathrm{n}^{\mathrm{o}}$ 8.894, de 21 de junho de 1994, e a Lei $\mathrm{n}^{\mathrm{o}} 10.931$, de 2 de agosto de 2004; e dá outras providências. Disponível em: <www.planalto.gov.br>. Acesso em: 10 jun. 2013.

Lei n. ${ }^{\circ} 12.810$, de 15 de maio de 2013. Dispõe sobre o parcelamento de débitos com a Fazenda Nacional relativos às contribuições previdenciárias de responsabilidade dos Estados, do Distrito Federal e dos Municípios; altera as Leis $\mathrm{n}^{\mathrm{os}}$ 8.212, de 24 de julho de 1991, 9.715, de 25 de novembro de 1998, 11.828, de 20 de novembro de 2008, 10.522, de 19 de julho de 2002, 10.222, de 9 de maio de 2001, 12.249, de 11 de junho de 2010, 11.110, de 25 de abril de 2005, 5.869, de 11 de janeiro de 1973 - Código de Processo Civil, 6.404, de 15 de dezembro de 1976, 6.385, de 7 de dezembro de 1976, 6.015, de 31 de dezembro de 1973, e 9.514, de 20 de novembro de 1997; e revoga dispositivo da Lei $\mathrm{n}^{\mathrm{o}}$ 12.703, de 7 de agosto de 2012. Disponível em: <www.planalto.gov.br>. Acesso em: 10 jun. 2013. 
BRASIL. Medida Provisória n. ${ }^{\circ}$ 1.637, de 08 de janeiro de 1998, dispõe sobre a regulação, fiscalização e supervisão dos mercados de títulos ou contratos de investimento coletivo, e dá outras providências. Disponível em: <www.planalto.gov.br>. Acesso em: 22 maio. 2011.

Medida Provisória n..$^{\circ}$ 539, de 26 de junho de 2011, Autoriza o Conselho Monetário Nacional, para fins da política monetária e cambial, a estabelecer condições específicas para negociação de contratos de derivativos, altera o art. $3^{\circ}$ do Decreto-Lei $\mathrm{n}^{\mathrm{o}} 1.783$, de 18 de abril de 1980, e os arts. $1^{0}$ e $2^{0}$ da Lei $\mathrm{n}^{\mathrm{o}} 8.894$, de 21 de junho de 1994, e dá outras providências. Disponível em: <www.planalto.gov.br>. Acesso em: 10 jun. 2013.

Mensagem número 160, de 10 de junho de 1975. In: Novo Código Civil: Exposição de Motivos e Texto Sancionado. Disponível em: <http://www2.senado.gov.br/bdsf/bitstream/handle/id/70319/743415.pdf?sequence=2>. Acesso em: 27 maio 2013.

CETIP S.A. - Mercados Organizados. Apresentação Institucional do $2^{\circ}$ Trimestre de 2012. Disponível em: <http://cetip.infoinvest.com.br/ptb/756/ApresentaoInstitucional_2T12.pdf>. Acesso em: 25 fev. 2013.

CME GROUP. From water street to the world: a brief history of the Chicago board of trade and the Chicago mercantile exchange. Disponível em: $<$ http://www.cmegroup.com/company/history/magazine/Summer2007/FromWaterStreetTo TheWorld.html>. Acesso em: 09 maio. 2013.

COMISSÃO DE VALORES MOBILIÁRIOS. Decisão Conjunta CVM e Bacen $n .^{\circ} 10$, de 02 de maio de 2002. Disponível em: <www.cvm.gov.br>. Acesso em: 24 fev. 2013.

Decisão Conjunta CVM e Bacen n. ${ }^{\circ} 18$, de 15 de julho de 2013. Disponível em: <www.cvm.gov.brwww.cvm.gov.br>. Acesso em: 15 jul. 2013.

Deliberação $n^{\circ}$ 20, de 15 de Fevereiro de 1985. Disponível em: <www.cvm.gov.br>. Acesso em: 11 maio 2013.

Deliberação n. ${ }^{\circ}$ 142, de 04 de Fevereiro de 1992. Disponível em: <www.cvm.gov.br>. Acesso em: 22 maio 2011.

- Deliberação . $^{o}$ 550, de 17 de Outubro de 2008. Disponível em: <www.cvm.gov.br>. Acesso em: 22 mai. o 2011.

Edital de Audiência Pública 04/07, de 30 de março de 2007. Disponível em: <www.cvm.gov.br>. Acesso em: 23 dez. 2013. 
COMISSÃO DE VALORES MOBILIÁRIOS. Edital de Audiência Pública 04/09, de 28 de abril de 2009. Disponível em: <www.cvm.gov.br>. Acesso em: 23 dez. 2013.

Edital de Audiência Pública SDM 06/10, de 24 de setembro de 2010. Disponível em: <www.cvm.gov.br>. Acesso em: 22 fev. 2013.

Edital de Audiência Pública SDM 15/11, de 13 de dezembro de 2011. Disponível em: <www.cvm.gov.br>. Acesso em: 23 dez. 2013.

. Edital de Audiência Pública 05/13, de 13 de junho de 2013. Disponível em: <www.cvm.gov.br>. Acesso em: 07 jul. 2013.

Edital de Audiência Pública SDM 06/13, de 26 de junho de 2013. Disponível em: <www.cvm.gov.br>. Acesso em: 22 set. 2013.

Edital de Audiência Pública SDM 09/13, de 28 de agosto de 2013. Disponível em: <www.cvm.gov.br>. Acesso em: 22 set. 2013.

- Instrução CVM n. ${ }^{\circ}$ 168, de 23 de dezembro de 1991. Disponível em: <www.cvm.gov.br>. Acesso em: 01 maio 2013.

Instrução CVM n. ${ }^{o}$ 283, de 10 de Julho de 1998. Disponível em: <www.cvm.gov.br>. Acesso em: 22 maio 2011.

Instrução CVM n. ${ }^{\circ}$ 301, de 16 de abril de 1999. Disponível em: <www.cvm.gov.br>. Acesso em: 22 maio 2011.

Instrução CVM n. 310 , de 09 de julho de 1999. Disponível em: <www.cvm.gov.br>. Acesso em: 22 maio 2011.

- Instrução CVM n. ${ }^{o}$ 380, de 23 de dezembro de 2002. Disponível em: <www.cvm.gov.br>. Acesso em: 22 maio 2011.

- Instrução CVM n. ${ }^{o}$ 387, de 28 de abril de 2003. Disponível em: <www.cvm.gov.br>. Acesso em: 22 maio 2011.

Instrução CVM n. ${ }^{\circ}$ 402, de 27 de janeiro de 2004. Disponível em: <www.cvm.gov.br>. Acesso em: 22 maio 2011.

- Instrução CVM n. ${ }^{\circ}$ 461, de 23 de outubro de 2007. Disponível em: <www.cvm.gov.br>. Acesso em: 23 fev. 2013. 
COMISSÃO DE VALORES MOBILIÁRIOS. Instrução CVM n. ${ }^{\circ}$ 467, de 10 de Abril de 2008. Disponível em: <www.cvm.gov.br>. Acesso em: 22 fev. 2013.

. Instrução CVM no 475, de 17 de Dezembro de 2008. Disponível em: <www.cvm.gov.br>. Acesso em: 22 maio. 2011.

. Instrução CVM $n^{o} 480$, de 07 de Dezembro de 2009. Disponível em: <www.cvm.gov.br>. Acesso em: 22 fev. 2013.

. Instrução CVM n. ${ }^{\circ}$ 505, de 27 de setembro de 2011. Disponível em: <www.cvm.gov.br>. Acesso em: 01 maio 2013.

Instrução CVM no 539, de 13 de Novembro de 2013. Disponível em: <www.cvm.gov.br>. Acesso em: 22 dez. 2013.

- Instrução CVM $n^{o}$ 541, de 20 de dezembro de 2013. Disponível em: <www.cvm.gov.br>. Acesso em: 31 dez. 2013.

- Instrução CVM no 542, de 20 de dezembro de 2013. Disponível em: <www.cvm.gov.br>. Acesso em: 31 dez. 2013.

Instrução CVM $n^{o}$ 543, de 20 de dezembro de 2013. Disponível em: <www.cvm.gov.br>. Acesso em: 31 dez. 2013.

. Instrução CVM no 544, de 20 de dezembro de 2013. Disponível em: <www.cvm.gov.br>. Acesso em: 09 jan. 2014.

Nota Explicativa à Instrução CVM $n^{o} 475$, de 17 de Dezembro de 2008. Disponível em: <www.cvm.gov.br>. Acesso em: 22 maio 2011.

. Relatório da Consultoria Oxera sobre os custos e benefícios para mudar a estutura competitiva do mercado para serviços de negociação e pós-negociação no Brasil, de junho de 2012. Disponível em: $<$ http://www.cvm.gov.br/port/Public/publ/Oxera\%20report\%20180612\%20Portuguese\%20ver sion.pdf>. Acesso em: 25 fev. 2013.

EUROPEAN COMMISSION. Commission of the European Communities. Commission Staff Working Paper. Accompanying the Commission Communication. Ensuring efficient, safe and sound derivatives market. dated July 03, 2009. Disponível em: <http://ec.europa.eu/internal_market/financial-markets/docs/derivatives/report_en.pdf.> Acesso em: 14 jun. 2013. 
G20. London Summit - Leaders' Statement dated April 02, 2009. Disponível em: <https://www.imf.org/external/np/sec/pr/2009/pdf/g20_040209.pdf> Acesso em: 14 jun. 2013.

INTERNATIONAL ORGANIZATION OF SECURITIES COMMISSIONS (IOSCO). Principles for the Regulation and Supervision of Commodity Derivatives Market. Final Report. Disponível em: <http://www.iosco.org/library/pubdocs/pdf/IOSCOPD358.pdf>. Acesso em: 28 abr. 2013.

IOSCO emite princípios sobre regulação das dark pools. Revista Capital Aberto, ano 8, n. 87, nov. 2010.Ano 8, Número 87, Novembro 2010. Disponível em: <http://www.capitalaberto.com.br>. Acesso em: 21 fev. 2013.

MINISTÉRIO DA FAZENDA. Comitê de Regulação e Fiscalização dos Mercados Financeiros, de Capitais, de Seguros, de Previdência e Capitalização - COREMEC. Deliberação $n^{\circ} 7$, de 19 de junho de 2009. Disponível em: <http://www.mps.gov.br/arquivos/office/3_090630-161947899.pdf>. Acesso 29 maio 2013.

UNITED STATES COURT OF APPEALS. Chicago Mercantile Exchange v. SEC, 883 F.2d (7th 537 Circ. 1989). Disponível em: <https://bulk.resource.org/courts.gov/c/F2/883/883.F2d.537.89-2012.89-1786.89-1763.891538.html>. Acesso em: 21 fev. 2013.

Praxair Inc. v. Hinshaw Culbertson, 235 F.3d 1028 (7th Circ. 2000). Disponível em: <http://caselaw.findlaw.com/us-7th-circuit/1286675.html>. Acesso em: 06 mar. 2013.

UNITED STATES DISTRICT COURT. Procter \& Gamble Co. v. Bankers Trust Co., [19961997 Transfer Binder] Fed. Sec. L. Rep. (CCH) 99,229, at 95,238 (S.D. Ohio). Disponível em: $<$ http://users.wfu.edu/palmitar/Courses/SecReg-MBA/CaseStudies/Cases/ProcterGamble925FSupp1270.htm>. Acesso em: 11 jun. 2013.

UNITED STATES SUPREME COURT. SEC v. W. J. Howey Co., 328 U.S. 293. Disponível em: <http://supreme.justia.com/cases/federal/us/328/293/case.html>. Acesso em: 21 fev. 2013.

VELOCIDADE controversa. Revista Capital Aberto, ano 10, n. 114, fev. 2013. Ano 10, Número 114, Fevereiro 2013. Disponível em: <http://www.capitalaberto.com.br>. Acesso em: 21 fev. 2013. 


\section{GLOSSÁRIO}

\begin{tabular}{|c|c|}
\hline Sigla & Denominação \\
\hline Bacen & Banco Central do Brasil \\
\hline BIS & Banco de Compensações Internacionais \\
\hline $\mathrm{BM} \& \mathrm{~F}$ & Bolsa de Mercadorias e Futuros \\
\hline Bovespa & Bolsa de Valores de São Paulo \\
\hline BM\&F Bovespa & BM\&F Bovespa S.A. - Bolsa de Valores, Mercadorias e Futuros \\
\hline Bolsa & BM\&F Bovespa S.A. - Bolsa de Valores, Mercadorias e Futuros \\
\hline $\mathrm{CDC}$ & Código de Defesa do Consumidor \\
\hline CED & Central de Exposição de Derivativos \\
\hline CETIP & CETIP S.A. - Mercados Organizados \\
\hline CFTC & Commodities Futures Trading Commission \\
\hline $\mathrm{CMN}$ & Conselho Monetário Nacional \\
\hline Comissão & Comissão de Valores Mobiliários \\
\hline COREMEC & $\begin{array}{l}\text { COREMEC - Comitê de Regulação e Fiscalização dos Mercados } \\
\text { Financeiro, de Capitais, de Seguros, de Previdência e } \\
\text { Capitalização }\end{array}$ \\
\hline CVM & Comissão de Valores Mobiliário \\
\hline Febraban & Federação Brasileira de Bancos \\
\hline IOSCO & Organização Internacional das Comissões de Valores \\
\hline SEC & Securities and Exchange Commission \\
\hline STJ & Superior Tribunal de Justiça \\
\hline
\end{tabular}


APÊNDICES E ANEXOS 
Apêndice 1-SP

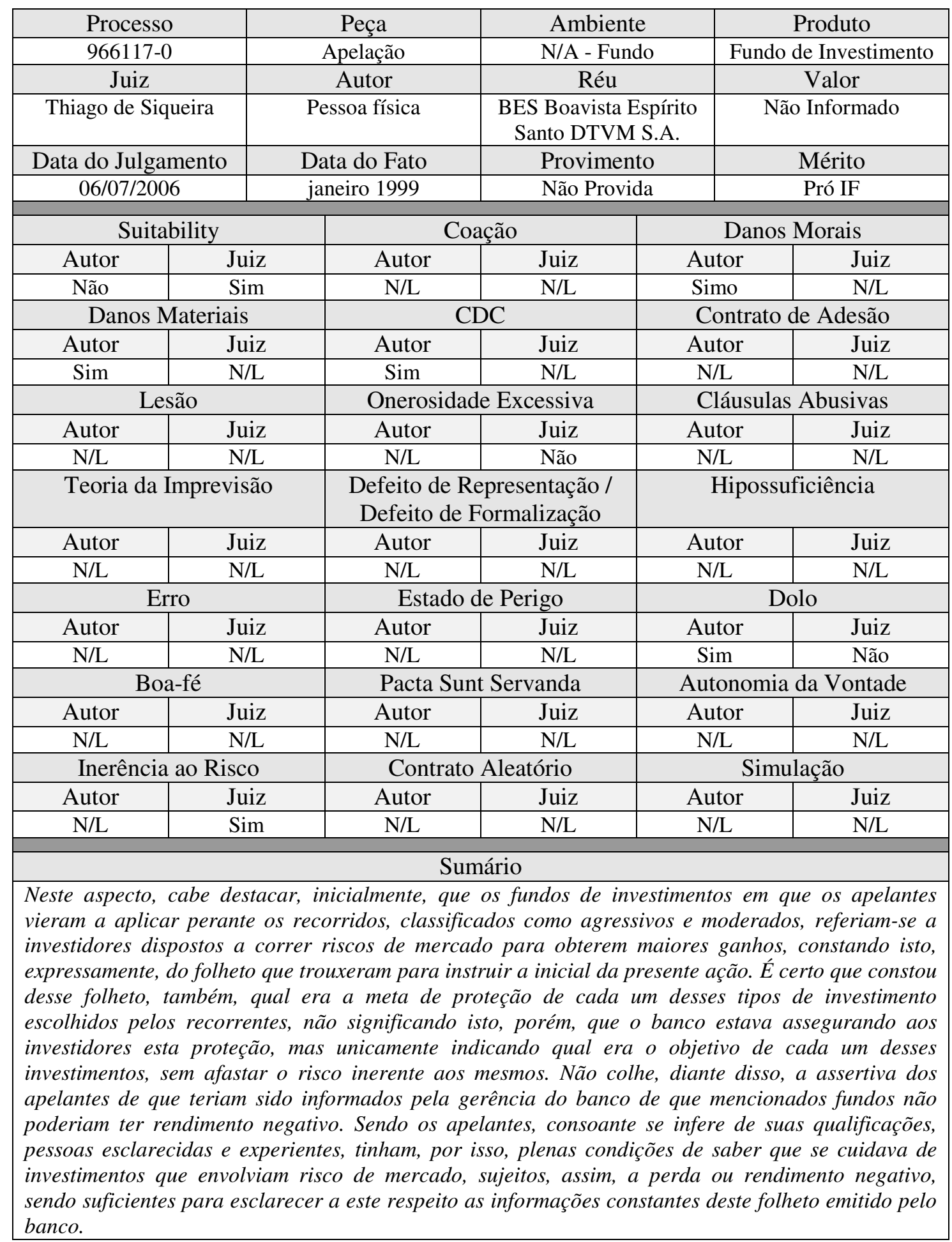


Apêndice 2-SP

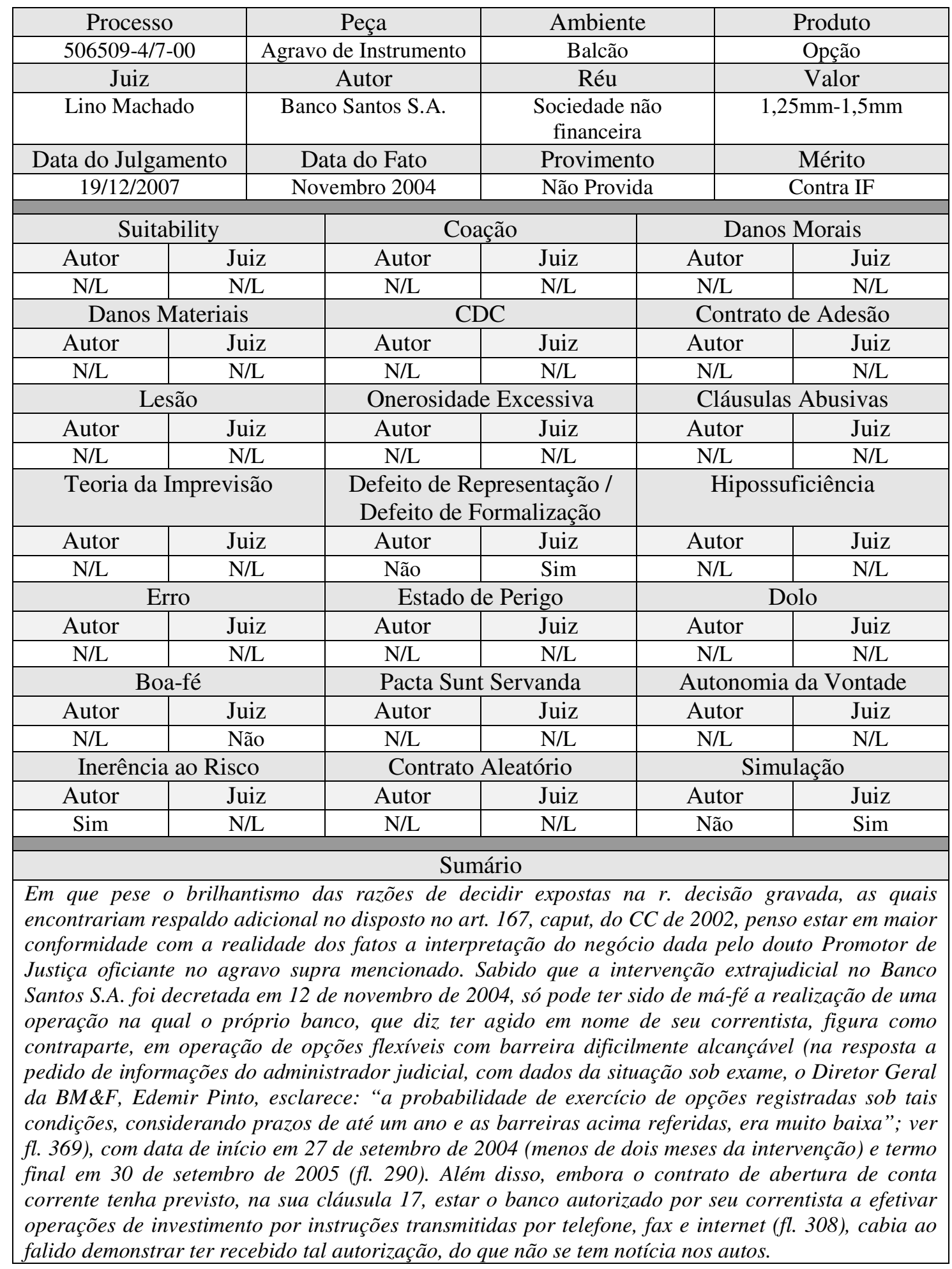


Apêndice 3-SP

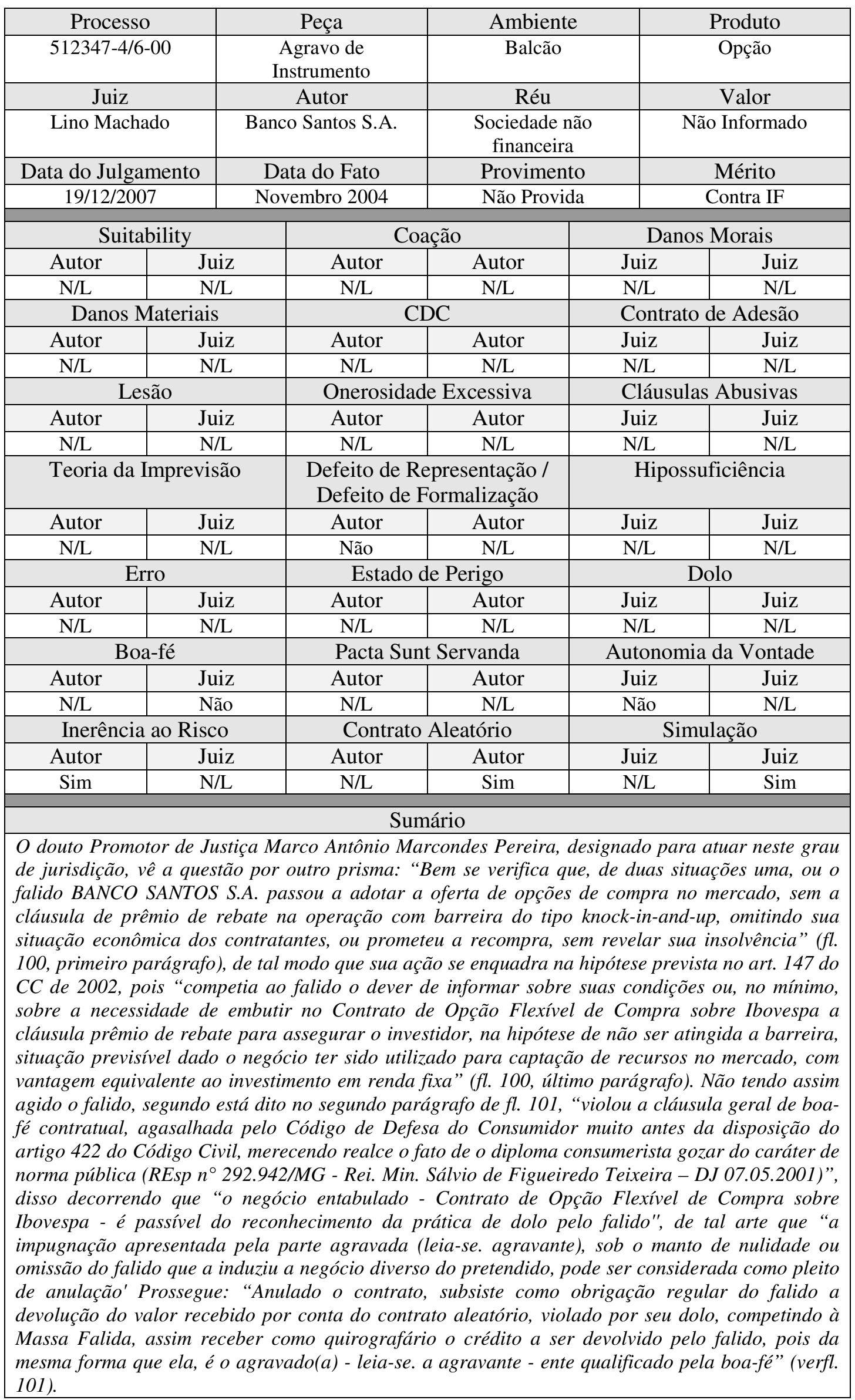


Apêndice 4-SP

\begin{tabular}{|c|c|c|c|c|c|c|}
\hline \multicolumn{2}{|c|}{ Processo } & \multicolumn{2}{|r|}{ Peça } & \multicolumn{2}{|c|}{ Ambiente } & Produto \\
\hline \multicolumn{2}{|c|}{$510710-4 / 9-00$} & \multicolumn{2}{|c|}{$\begin{array}{l}\text { Agravo de } \\
\text { Instrumento }\end{array}$} & \multicolumn{2}{|c|}{ Balcão } & Opção \\
\hline \multicolumn{2}{|c|}{ Juiz } & \multicolumn{2}{|c|}{ Autor } & \multicolumn{2}{|c|}{ Réu } & Valor \\
\hline \multicolumn{2}{|c|}{ Lino Machado } & \multicolumn{2}{|c|}{ Banco Santos S.A. } & \multicolumn{2}{|c|}{$\begin{array}{l}\text { Sociedade não } \\
\text { financeira }\end{array}$} & cima $10 \mathrm{~mm}$ \\
\hline \multicolumn{2}{|c|}{ Data do Julgamento } & \multicolumn{2}{|c|}{ Data do Fato } & \multicolumn{2}{|c|}{ Provimento } & Mérito \\
\hline $19 / 12 /$ & & & mbro 2004 & Não Pro & & ontra IF \\
\hline \multicolumn{2}{|c|}{ Suitability } & & \multicolumn{2}{|c|}{ Coação } & \multicolumn{2}{|c|}{ Danos Morais } \\
\hline Autor & & & Autor & Autor & Juiz & Autor \\
\hline $\mathrm{N} / \mathrm{L}$ & & & $\mathrm{N} / \mathrm{L}$ & $\mathrm{N} / \mathrm{L}$ & $\mathrm{N} / \mathrm{L}$ & $\mathrm{N} / \mathrm{L}$ \\
\hline \multicolumn{3}{|c|}{ Danos Materiais } & \multicolumn{2}{|c|}{$\frac{1}{\mathrm{CDC}}$} & \multicolumn{2}{|c|}{ Contrato de Adesão } \\
\hline Autor & & & Autor & Autor & Juiz & Autor \\
\hline $\mathrm{N} / \mathrm{L}$ & & & $\mathrm{N} / \mathrm{L}$ & $\mathrm{N} / \mathrm{L}$ & \multirow{2}{*}{\multicolumn{2}{|c|}{\begin{tabular}{l|r}
$\mathrm{N} / \mathrm{L}$ & $\mathrm{N} / \mathrm{L}$ \\
Cláusulas Abusivas
\end{tabular}}} \\
\hline \multicolumn{2}{|c|}{$\frac{1}{\text { Lesão }}$} & & \multicolumn{2}{|c|}{ Onerosidade Excessiva } & & \\
\hline Autor & & & Autor & Autor & Juiz & Autor \\
\hline $\mathrm{N} / \mathrm{L}$ & & & $\mathrm{N} / \mathrm{L}$ & $\mathrm{N} / \mathrm{L}$ & $\mathrm{N} / \mathrm{L}$ & $\mathrm{N} / \mathrm{L}$ \\
\hline \multicolumn{3}{|c|}{ Teoria da Imprevisão } & \multicolumn{2}{|c|}{$\begin{array}{l}\text { Defeito de Representação / } \\
\text { Defeito de Formalização }\end{array}$} & Hip & iciência \\
\hline Autor & & & Autor & Autor & Juiz & Autor \\
\hline $\mathrm{N} / \mathrm{L}$ & & & Não & $\mathrm{N} / \mathrm{L}$ & $\mathrm{N} / \mathrm{L}$ & Não \\
\hline & & & Esta & erigo & & \\
\hline Autor & & & Autor & Autor & Juiz & Autor \\
\hline $\mathrm{N} / \mathrm{L}$ & & & $\mathrm{N} / \mathrm{L}$ & $\mathrm{N} / \mathrm{L}$ & $\mathrm{N} / \mathrm{L}$ & $\mathrm{N} / \mathrm{L}$ \\
\hline & & & Pacta: & rvanda & Autons & la Vontade \\
\hline Autor & & & Autor & Autor & Juiz & Autor \\
\hline $\mathrm{N} / \mathrm{L}$ & & & $\mathrm{N} / \mathrm{L}$ & $\mathrm{N} / \mathrm{L}$ & Não & $\mathrm{N} / \mathrm{L}$ \\
\hline Inerên & Ris & & Contr & atório & & acão \\
\hline Autor & & & Autor & Autor & Juiz & Autor \\
\hline Sim & & & $\mathrm{N} / \mathrm{L}$ & Sim & $\mathrm{N} / \mathrm{L}$ & $\mathrm{N} / \mathrm{L}$ \\
\hline & & & & & & \\
\hline $\begin{array}{l}\text { O falido, ass } \\
\text { opção (no c } \\
\text { remuneraçã } \\
\text { caso destes } \\
\text { de vencimen } \\
\text { data do exer } \\
\text { opção, ao } \\
\text { estabelecido } \\
\text { isso: fez umo } \\
\text { a termo), e } \\
\text { quadro gera }\end{array}$ & & & $\begin{array}{l}\text { a sua verso } \\
\text { que toma o } \\
\text { denominado } \\
\text { a exercerá } \\
\text { tem uma op } \\
\text { ça será ex } \\
\text { ão Paulo } \\
\text { ecorrida pe } \\
\text { lerivativos } \\
\text { agora rech } \\
\text { rimeiro e se }\end{array}$ & $\begin{array}{l}\text { gócio havi } \\
\text { la variação } \\
\text { o. Natural } \\
\text { eço previst } \\
\text { ompra de } \\
\text { No caso co } \\
\text { ESPA, e e } \\
\text { prêmio qu } \\
\text { o de jogo, }\end{array}$ & $\begin{array}{l}\text { e as par } \\
\text { tações, } \\
\text { o comp } \\
\text { ção est } \\
R \$ 2,00 \\
\text { a agra } \\
\text { lice não } \\
\text { u pela } \\
\text { nanceirc }\end{array}$ & $\begin{array}{l}\text { vendedor da } \\
\text { por isso uma } \\
\text { da opção (no } \\
\text { ntajoso no dia } \\
\text { stá cotado, na } \\
\text { e vinculou, na } \\
\text { iu o patamar } \\
\text { Simples como } \\
\text { ndices e ativos } \\
\text { eja inscrita no }\end{array}$ \\
\hline
\end{tabular}


Apêndice 5-SP

\begin{tabular}{|c|c|c|c|c|c|c|}
\hline \multicolumn{2}{|c|}{ Processo } & \multicolumn{2}{|r|}{ Peça } & \multicolumn{2}{|c|}{ Ambiente } & Produto \\
\hline \multicolumn{2}{|c|}{$511858-4 / 0-00$} & \multicolumn{2}{|c|}{$\begin{array}{l}\text { Agravo de } \\
\text { Instrumento }\end{array}$} & \multicolumn{2}{|c|}{ Balcão } & Opção \\
\hline \multicolumn{2}{|c|}{ Juiz } & \multicolumn{2}{|r|}{ Autor } & \multicolumn{2}{|c|}{ Réu } & Valor \\
\hline \multicolumn{2}{|c|}{ Lino Machado } & \multicolumn{2}{|c|}{ Banco Santos S.A. } & \multicolumn{2}{|c|}{$\begin{array}{l}\text { Sociedade não } \\
\text { financeira }\end{array}$} & ma $10 \mathrm{~mm}$ \\
\hline \multirow{2}{*}{\multicolumn{2}{|c|}{$\begin{array}{c}\text { Data do Julgamento } \\
19 / 12 / 2007\end{array}$}} & \multicolumn{2}{|c|}{ Data do Fato } & \multicolumn{2}{|c|}{ Provimento } & Mérito \\
\hline & & & embro 2004 & Não P1 & & ontra IF \\
\hline \multicolumn{2}{|c|}{ Suitability } & & \multicolumn{2}{|c|}{ Coação } & \multicolumn{2}{|c|}{ Danos Morais } \\
\hline Autor & $\mathrm{Ju}$ & & Autor & Autor & Juiz & Autor \\
\hline $\mathrm{N} / \mathrm{L}$ & $\mathrm{N} /$ & & $\mathrm{N} / \mathrm{L}$ & $\mathrm{N} / \mathrm{L}$ & $\mathrm{N} / \mathrm{L}$ & $\mathrm{N} / \mathrm{L}$ \\
\hline \multicolumn{2}{|c|}{ Danos Materiais } & & \multicolumn{2}{|c|}{$\mathrm{CDC}$} & \multicolumn{2}{|c|}{ Contrato de Adesão } \\
\hline Autor & $\mathrm{Ju}$ & & Autor & Autor & Juiz & Autor \\
\hline $\mathrm{N} / \mathrm{L}$ & $\mathrm{N} /$ & & $\mathrm{N} / \mathrm{L}$ & $\mathrm{N} / \mathrm{L}$ & $\mathrm{N} / \mathrm{L}$ & $\mathrm{N} / \mathrm{L}$ \\
\hline \multicolumn{2}{|c|}{ Lesão } & & \multicolumn{2}{|c|}{ Onerosidade Excessiva } & \multicolumn{2}{|c|}{ Cláusulas Abusivas } \\
\hline Autor & $\mathrm{Ju}$ & & Autor & Autor & Juiz & Autor \\
\hline $\mathrm{N} / \mathrm{L}$ & $\mathrm{N} /$ & & $\mathrm{N} / \mathrm{L}$ & $\mathrm{N} / \mathrm{L}$ & $\mathrm{N} / \mathrm{L}$ & $\mathrm{N} / \mathrm{L}$ \\
\hline \multicolumn{2}{|c|}{ Teoria da Imprevisão } & & \multicolumn{2}{|c|}{$\begin{array}{l}\text { Defeito de Representação } \\
\text { Defeito de Formalização }\end{array}$} & \multicolumn{2}{|c|}{ Hipossuficiência } \\
\hline Autor & $\mathrm{Ju}$ & & Autor & Autor & Juiz & Autor \\
\hline $\mathrm{N} / \mathrm{L}$ & $\mathrm{N} /$ & & Não & $\mathrm{N} / \mathrm{L}$ & $\mathrm{N} / \mathrm{L}$ & Não \\
\hline \multicolumn{2}{|c|}{ Erro } & & Estad & erigo & & \\
\hline Autor & $\mathrm{Ju}$ & & Autor & Autor & Juiz & Autor \\
\hline $\mathrm{N} / \mathrm{L}$ & $\mathrm{N} /$ & & $\mathrm{N} / \mathrm{L}$ & $\mathrm{N} / \mathrm{L}$ & $\mathrm{N} / \mathrm{L}$ & $\mathrm{N} / \mathrm{L}$ \\
\hline & & & Pacta S & rvanda & Auton & la Vontade \\
\hline Autor & $\mathrm{Ju}$ & & Autor & Autor & Juiz & Autor \\
\hline $\mathrm{N} / \mathrm{L}$ & $\mathrm{Nã}$ & & $\mathrm{N} / \mathrm{L}$ & $\mathrm{N} / \mathrm{L}$ & Não & $\mathrm{N} / \mathrm{L}$ \\
\hline Inerêr & Risc & & Contr: & atório & & ação \\
\hline Autor & $\mathrm{Ju}$ & & Autor & Autor & Juiz & Autor \\
\hline Sim & $\mathrm{N} /$ & & $\mathrm{N} / \mathrm{L}$ & Sim & $\mathrm{N} / \mathrm{L}$ & $\mathrm{N} / \mathrm{L}$ \\
\hline & & & & & & \\
\hline $\begin{array}{l}\text { Agravo de } \\
\text { falência, na } \\
\text { realizada er } \\
\text { parágrafo), } \\
\text { negócio jur } \\
\text { invocada po } \\
\text { caso, a } m \\
\text { improvimen } \\
\text { Público (fls. }\end{array}$ & $\begin{array}{l}\text { ento } \\
\text { sob } \\
\text { eqte. } \\
\text { hida } \\
\text { etuad } \\
\text { s sim } \\
\text { lida. }\end{array}$ & & $\begin{array}{l}r \text { r. decisão } \\
\text { lento de obs } \\
\text { lo encobria } \\
\text { ição ao créd } \\
\text { ainda, que } \\
\text { principalme } \\
\text { ontraminuta, } \\
\text { (178), acomp }\end{array}$ & $\begin{array}{l}\text { lada a fl. } \\
\text { e que, "e } \\
\text { eração de } \\
\text { agravada. } \\
\text { o se simu } \\
\text { ante terce } \\
\text { preliminc }\end{array}$ & $\begin{array}{l}\text { 60, pro } \\
\text { lade, a } \\
\text { fixa" (fl } \\
\text { não ter } \\
\text { houvesse } \\
\text { oa-fé, a } \\
\text { deserçẫ } \\
\text { último } p\end{array}$ & $\begin{array}{l}\text { nos autos de } \\
\text { cão financeira } \\
\text { antepenúltimo } \\
\text { simulação no } \\
\text { não pode ser } \\
\text { onsiderada, no } \\
\text { recurso, pelo } \\
\text { elo Ministério }\end{array}$ \\
\hline
\end{tabular}


Apêndice 6-SP

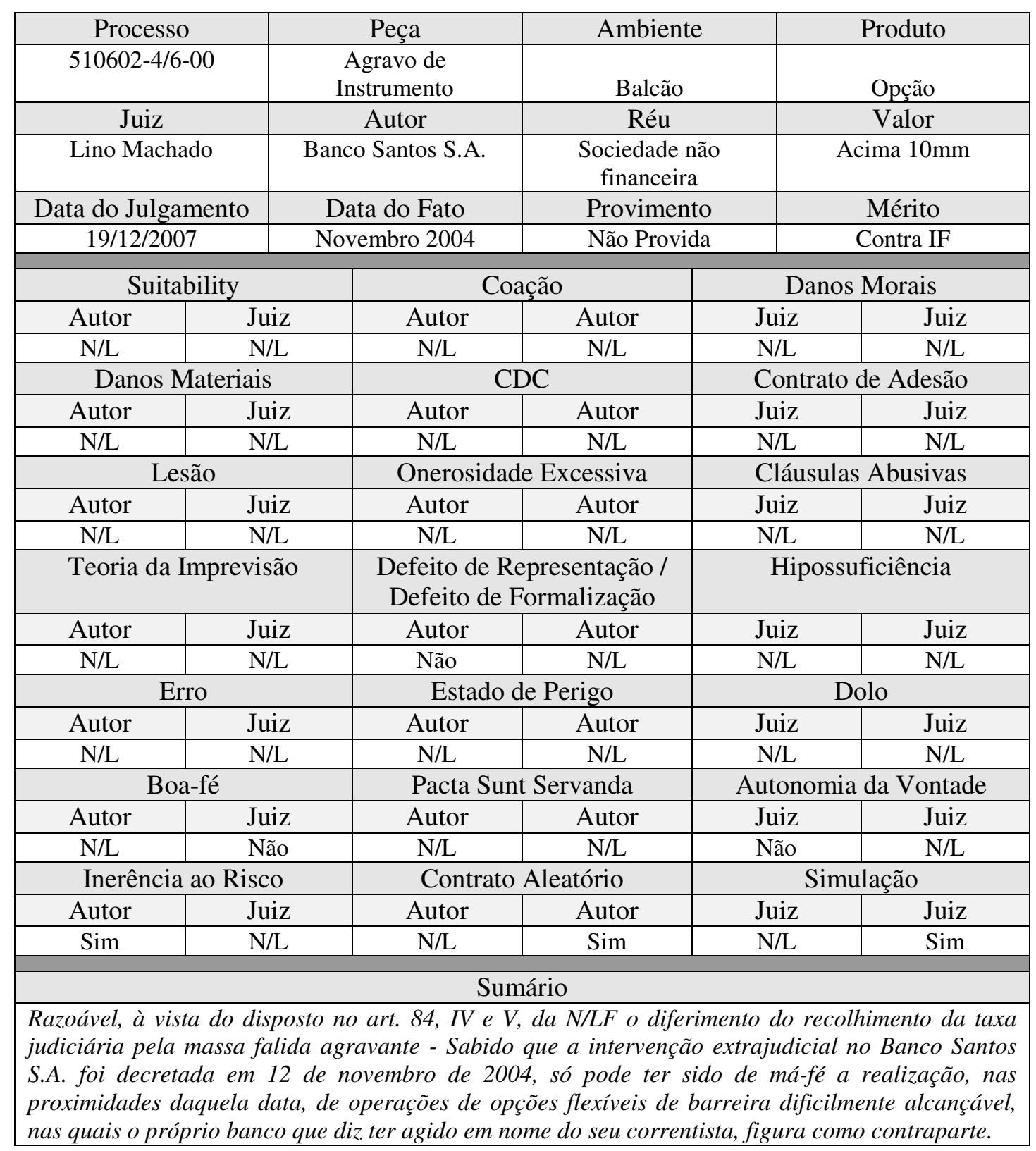


Apêndice 7-SP

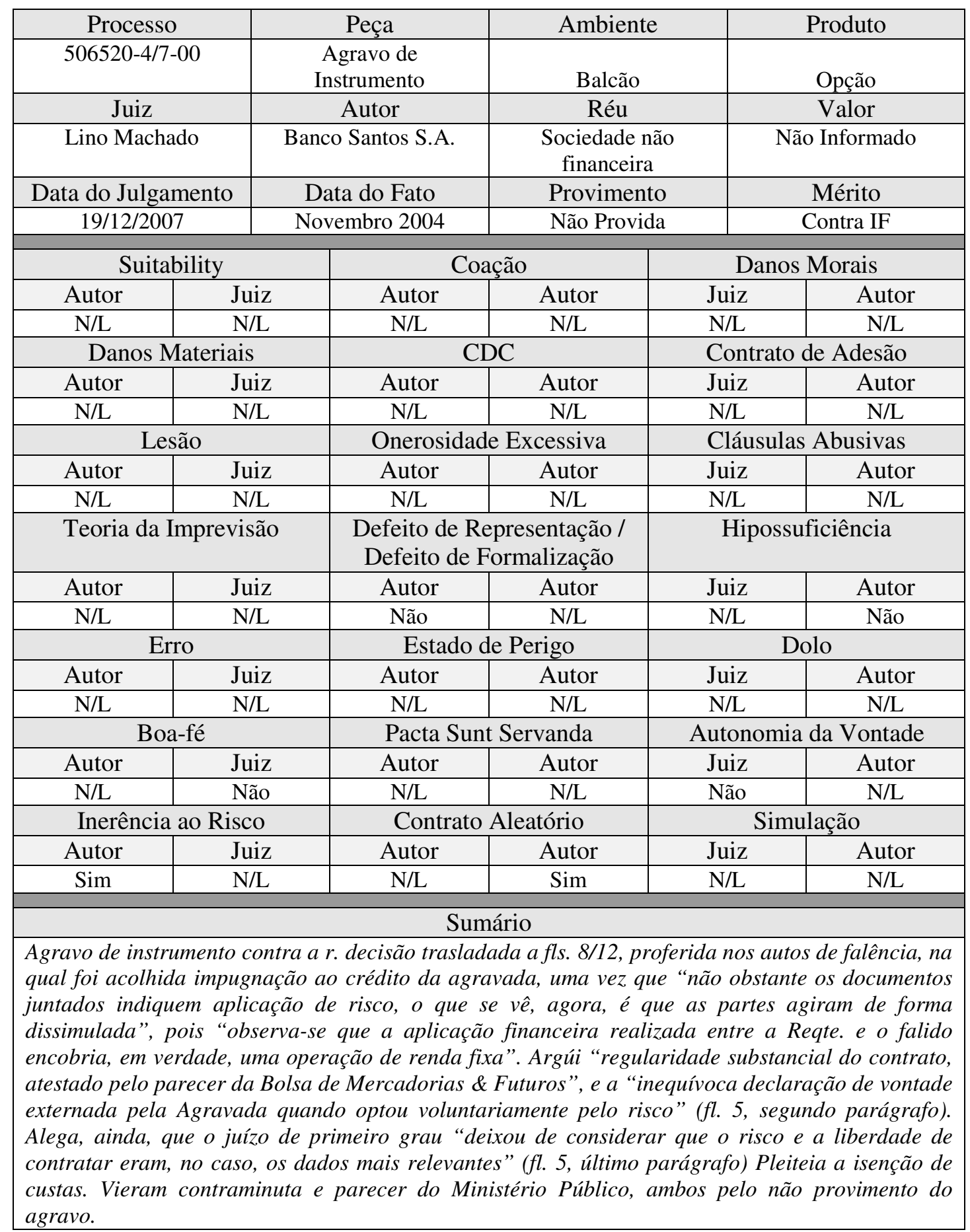


Apêndice 8-SP

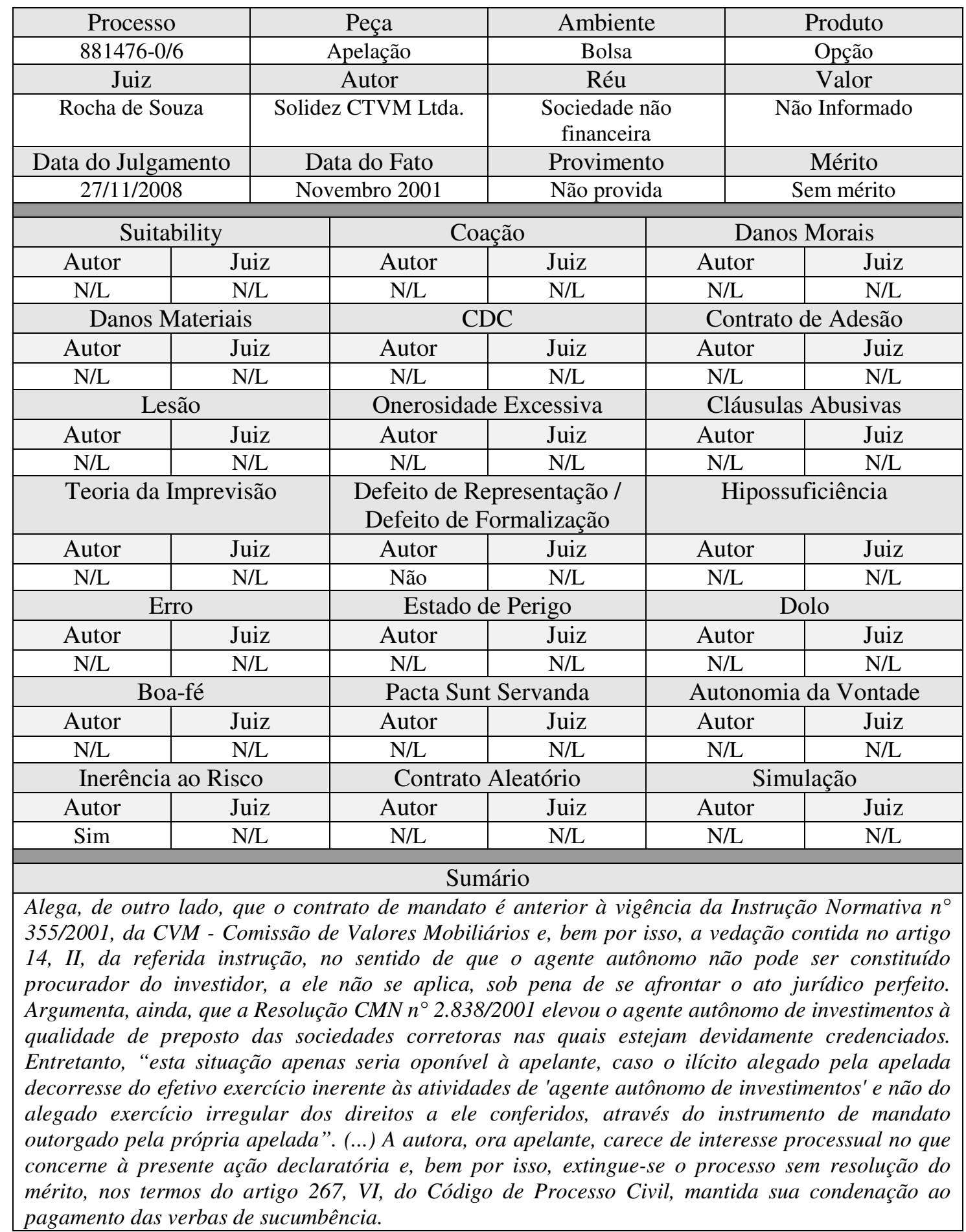


Apêndice 9-SP

\begin{tabular}{|c|c|c|c|c|c|c|}
\hline \multicolumn{2}{|c|}{ Processo } & \multicolumn{2}{|r|}{ Peça } & \multicolumn{2}{|c|}{ Ambiente } & Produto \\
\hline \multicolumn{2}{|c|}{ 7399933-0 } & \multicolumn{2}{|c|}{ Agravo de Instrumento } & \multicolumn{2}{|c|}{ Não Informado } & Swap \\
\hline \multicolumn{2}{|c|}{ Juiz } & \multicolumn{2}{|r|}{ Autor } & \multicolumn{2}{|l|}{ Réu } & Valor \\
\hline \multicolumn{2}{|c|}{ Gilberto dos Santos } & \multicolumn{2}{|c|}{ Banco Itaú S.A. } & \multicolumn{2}{|c|}{$\begin{array}{l}\text { Sociedade não } \\
\text { financeira }\end{array}$} & ão Informado \\
\hline \multicolumn{2}{|c|}{ Data do Julgamento } & \multicolumn{2}{|c|}{ Data do Fato } & \multicolumn{2}{|c|}{ Provimento } & Mérito \\
\hline $26 / 11$ & & & informado & Provid & & em mérito \\
\hline \multicolumn{3}{|c|}{ Suitability } & \multicolumn{2}{|c|}{ Coação } & \multicolumn{2}{|c|}{ Danos Morais } \\
\hline Autor & & & Autor & Juiz & Autor & Juiz \\
\hline Sim & & & $\mathrm{N} / \mathrm{L}$ & $\mathrm{N} / \mathrm{L}$ & $\mathrm{N} / \mathrm{L}$ & $\mathrm{N} / \mathrm{L}$ \\
\hline \multicolumn{3}{|c|}{ Danos Materiais } & \multicolumn{2}{|c|}{$\mathrm{CDC}$} & \multicolumn{2}{|c|}{ Contrato de Adesão } \\
\hline Autor & & & Autor & Juiz & Autor & Juiz \\
\hline $\mathrm{N} / \mathrm{L}$ & $\mathrm{N}$ & & $\mathrm{N} / \mathrm{L}$ & $\mathrm{N} / \mathrm{L}$ & $\mathrm{N} / \mathrm{L}$ & $\mathrm{N} / \mathrm{L}$ \\
\hline \multicolumn{3}{|c|}{ Lesão } & \multicolumn{2}{|c|}{ Onerosidade Excessiva } & \multicolumn{2}{|c|}{ Cláusulas Abusivas } \\
\hline Autor & & & Autor & Juiz & Autor & Juiz \\
\hline $\mathrm{N} / \mathrm{L}$ & & & $\mathrm{N} / \mathrm{L}$ & $\mathrm{N} / \mathrm{L}$ & $\mathrm{N} / \mathrm{L}$ & $\mathrm{N} / \mathrm{L}$ \\
\hline \multicolumn{3}{|c|}{ Teoria da Imprevisão } & \multicolumn{2}{|c|}{$\begin{array}{c}\text { Defeito de Representação / } \\
\text { Defeito de Formalização }\end{array}$} & Hip & ficiência \\
\hline Autor & $\mathrm{Ju}$ & & Autor & Juiz & Autor & Juiz \\
\hline Não & $\mathrm{N}$ & & $\mathrm{N} / \mathrm{L}$ & $\mathrm{N} / \mathrm{L}$ & $\mathrm{N} / \mathrm{L}$ & $\mathrm{N} / \mathrm{L}$ \\
\hline & & & Estado & erigo & & \\
\hline Autor & $\mathrm{Ju}$ & & Autor & Juiz & Autor & Juiz \\
\hline $\mathrm{N} / \mathrm{L}$ & & & $\mathrm{N} / \mathrm{L}$ & $\mathrm{N} / \mathrm{L}$ & $\mathrm{N} / \mathrm{L}$ & $\mathrm{N} / \mathrm{L}$ \\
\hline & & & Pacta Sur & rvanda & Autono & da Vontade \\
\hline Autor & $\mathrm{Ju}$ & & Autor & Juiz & Autor & Juiz \\
\hline $\mathrm{N} / \mathrm{L}$ & & & Sim & $\mathrm{N} / \mathrm{L}$ & $\mathrm{N} / \mathrm{L}$ & Sim \\
\hline Inerêt & Risc & & Contratc & atório & & lação \\
\hline Autor & $\mathrm{Ju}$ & & Autor & Juiz & Autor & Juiz \\
\hline Sim & & & $\mathrm{N} / \mathrm{L}$ & $\mathrm{N} / \mathrm{L}$ & $\mathrm{N} / \mathrm{L}$ & $\mathrm{N} / \mathrm{L}$ \\
\hline & & & & & & \\
\hline $\begin{array}{l}\text { Mas, como } \\
\text { dessa flutuc } \\
\text { cláusula er } \\
\text { Nesse sentic } \\
\text { tão atraente } \\
\text { que: "Não a } \\
\text { por aquelas } \\
\text { norte-ameri } \\
\text { redução do } \\
\text { praticadas }\end{array}$ & $\begin{array}{l}\text { pra, } \\
\text { o aq } \\
\text { u m } \\
\text { das } \\
\text { ue } \\
\text { cobr } \\
\text { corr }\end{array}$ & $\begin{array}{l}\text { ito, } \\
\text { berg } \\
\text { pois } \\
\text { auto } \\
\text { ıelas } \\
\text { ito } \\
\text { belo } \\
m \text { te }\end{array}$ & $\begin{array}{l}\text { dificação do val } \\
\text { pela autora (fl } \\
\text { amente a conts } \\
\text { clarece que po: } \\
\text { ecidas pela ger } \\
\text { o para a Autor } \\
\text { o réu, posto q } \\
\text { oderia lhe ser } \\
\text { rincipalmente, } \\
\text { 44); }\end{array}$ & $\begin{array}{l}\text { câmbio nã } \\
\text { 5). Demais, } \\
\text { e tinha out } \\
\text { linhas de cr } \\
\text { do Banco }, \\
\text { liar as cond } \\
\text { pesar de su } \\
\text { avorável, a } \\
\text { fato de exi }\end{array}$ & $\begin{array}{l}\text { de todo } \\
\text { ume-se } \\
\text { lternative } \\
\text { em cond } \\
\text { chegand } \\
\text { existente } \\
\text { a variaç } \\
\text { ntava-se } \\
\text { arantia b }\end{array}$ & $\begin{array}{l}\text { visível e o risco } \\
\text { adoção dessa } \\
\text { financiamento. } \\
\text { que "não eram } \\
\text { mo a descrever } \\
\text { nercado e optar } \\
\text { mbial do dólar } \\
\text { ajosa quanto à } \\
\text { nferior àquelas }\end{array}$ \\
\hline
\end{tabular}


Apêndice 10-SP

\begin{tabular}{|c|c|c|c|c|c|c|}
\hline \multicolumn{2}{|c|}{ Processo } & \multicolumn{2}{|r|}{ Peça } & \multicolumn{2}{|l|}{ Ambiente } & Produto \\
\hline \multicolumn{2}{|c|}{$7324890-9$} & \multicolumn{2}{|c|}{ Agravo de Instrumento } & \multicolumn{2}{|l|}{ Balcão } & Opção \\
\hline \multicolumn{2}{|c|}{ Juiz } & \multicolumn{2}{|r|}{ Autor } & \multicolumn{2}{|l|}{ Réu } & Valor \\
\hline \multicolumn{2}{|c|}{ Salles Vieira } & \multicolumn{2}{|c|}{ Banco Itaú S.A. } & \multicolumn{2}{|l|}{$\begin{array}{l}\text { Sociedade não } \\
\text { financeira }\end{array}$} & $500 \mathrm{k}-750 \mathrm{k}$ \\
\hline \multicolumn{2}{|c|}{ Data do Julgamento } & \multicolumn{2}{|c|}{ Data do Fato } & Provimento & & Mérito \\
\hline $04 / 06$ & & & informado & Provida & & Pró IF \\
\hline \multicolumn{3}{|c|}{ Suitability } & \multicolumn{2}{|c|}{ Coação } & \multicolumn{2}{|c|}{ Danos Morais } \\
\hline Autor & $\mathrm{Ju}$ & & Autor & Juiz & Autor & Juiz \\
\hline $\mathrm{N} / \mathrm{L}$ & $\mathrm{N}$ & & $\mathrm{N} / \mathrm{L}$ & $\mathrm{N} / \mathrm{L}$ & $\mathrm{N} / \mathrm{L}$ & $\mathrm{N} / \mathrm{L}$ \\
\hline \multicolumn{3}{|c|}{ Danos Materiais } & \multicolumn{2}{|c|}{$\mathrm{CDC}$} & \multicolumn{2}{|c|}{ Contrato de Adesão } \\
\hline Autor & $\mathrm{Ju}$ & & Autor & Juiz & Autor & Juiz \\
\hline $\mathrm{N} / \mathrm{L}$ & $\mathrm{N}$ & & $\mathrm{N} / \mathrm{L}$ & $\mathrm{N} / \mathrm{L}$ & $\mathrm{N} / \mathrm{L}$ & $\mathrm{N} / \mathrm{L}$ \\
\hline \multicolumn{3}{|c|}{ Lesão } & \multicolumn{2}{|c|}{ Onerosidade Excessiva } & \multicolumn{2}{|c|}{ Cláusulas Abusivas } \\
\hline Autor & $\mathrm{Ju}$ & & Autor & Juiz & Autor & Juiz \\
\hline $\mathrm{N} / \mathrm{L}$ & $\mathrm{N}$ & & $\mathrm{N} / \mathrm{L}$ & $\mathrm{N} / \mathrm{L}$ & $\mathrm{N} / \mathrm{L}$ & $\mathrm{N} / \mathrm{L}$ \\
\hline \multicolumn{3}{|c|}{ Teoria da Imprevisão } & \multicolumn{2}{|c|}{$\begin{array}{c}\text { Defeito de Representação / } \\
\text { Defeito de Formalização }\end{array}$} & Hip & ficiência \\
\hline Autor & $\mathrm{Ju}$ & & Autor & Juiz & Autor & Juiz \\
\hline $\mathrm{N} / \mathrm{L}$ & $\mathrm{N}$ & & $\mathrm{N} / \mathrm{L}$ & $\mathrm{N} / \mathrm{L}$ & $\mathrm{N} / \mathrm{L}$ & $\mathrm{N} / \mathrm{L}$ \\
\hline & & & Estado & erigo & & lo \\
\hline Autor & $\mathrm{Ju}$ & & Autor & Juiz & Autor & Juiz \\
\hline $\mathrm{N} / \mathrm{L}$ & $\mathrm{N}$ & & $\mathrm{N} / \mathrm{L}$ & $\mathrm{N} / \mathrm{L}$ & $\mathrm{N} / \mathrm{L}$ & $\mathrm{N} / \mathrm{L}$ \\
\hline & & & Pacta Suı & vanda & Autono & da Vontade \\
\hline Autor & $\mathrm{Ju}$ & & Autor & Juiz & Autor & Juiz \\
\hline $\mathrm{N} / \mathrm{L}$ & & & $\mathrm{N} / \mathrm{L}$ & Sim & $\mathrm{N} / \mathrm{L}$ & $\mathrm{N} / \mathrm{L}$ \\
\hline Inerêt & Risc & & Contratc & atório & & lação \\
\hline Autor & $\mathrm{Ju}$ & iiz & Autor & Juiz & Autor & Juiz \\
\hline $\mathrm{N} / \mathrm{L}$ & & $\mathrm{m}$ & $\mathrm{N} / \mathrm{L}$ & $\mathrm{N} / \mathrm{L}$ & $\mathrm{N} / \mathrm{L}$ & $\mathrm{N} / \mathrm{L}$ \\
\hline & & & Sul & & & \\
\hline $\begin{array}{l}\text { Os documen } \\
\text { entre as pa } \\
\text { inclusive no } \\
\text { variação ca } \\
\text { do "Contrat }\end{array}$ & & $r i$ & $\begin{array}{l}51 \text { e } 134 / 135,1 \\
\text { ulas contratuc } \\
\text { istentes em de } \\
\text { através de sim } \\
s "(f l s .43 \text { e } 46\end{array}$ & $\begin{array}{l}\text { a a existência } \\
\text { esentadas, er } \\
\text { cia da realiz } \\
\text { itura, por ext } \\
\text { ctivamente). }\end{array}$ & $\begin{array}{l}\text { s negóci } \\
\text { rincípio, } \\
\text { ão de op }\end{array}$ & $\begin{array}{l}\text { rídicos firmados } \\
\text { mostram claras, } \\
\text { ôes atreladas à } \\
\text { ulas "2" e "16" }\end{array}$ \\
\hline
\end{tabular}


Apêndice 11-SP

\begin{tabular}{|c|c|c|c|c|c|c|}
\hline \multicolumn{2}{|c|}{ Processo } & Peça & \multicolumn{2}{|c|}{ Ambiente } & \multicolumn{2}{|r|}{ Produto } \\
\hline \multicolumn{2}{|c|}{ 1241701-3 } & Apelação & \multicolumn{2}{|c|}{ N/A - Fundo } & \multicolumn{2}{|c|}{ Fundo de Investimento } \\
\hline \multicolumn{2}{|c|}{ Juiz } & Autor & \multicolumn{2}{|c|}{ Réu } & \multicolumn{2}{|r|}{ Valor } \\
\hline \multicolumn{2}{|c|}{ Miguel Petroni Neto } & Pessoa física & \multicolumn{2}{|c|}{$\begin{array}{l}\text { Banco Comercial e de } \\
\text { Investimentos } \\
\text { Sudameris }\end{array}$} & \multicolumn{2}{|c|}{ Não Informado } \\
\hline \multicolumn{2}{|c|}{ Data do Julgamento } & \multirow{2}{*}{$\begin{array}{c}\text { Data do Fato } \\
\text { Não informado }\end{array}$} & \multicolumn{2}{|c|}{ Provimento } & \multicolumn{2}{|r|}{ Mérito } \\
\hline $18 / 05$ & & & Não Prc & & & Pró IF \\
\hline \multicolumn{2}{|c|}{ Suitability } & \multicolumn{2}{|c|}{ Coação } & \multicolumn{3}{|c|}{ Danos Morais } \\
\hline Autor & Juiz & Autor & Juiz & & & Juiz \\
\hline Não & Sim & $\mathrm{N} / \mathrm{L}$ & $\mathrm{N} / \mathrm{L}$ & & & Não \\
\hline \multicolumn{2}{|c|}{ Danos Materiais } & \multicolumn{2}{|c|}{$\mathrm{CDC}$} & \multicolumn{3}{|c|}{ Contrato de Adesão } \\
\hline Autor & Juiz & Autor & Juiz & & & Juiz \\
\hline Sim & Não & Sim & Sim & & & $\mathrm{N} / \mathrm{L}$ \\
\hline \multicolumn{2}{|c|}{ Lesão } & \multicolumn{2}{|c|}{ Onerosidade Excessiva } & \multicolumn{3}{|c|}{ Cláusulas Abusivas } \\
\hline Autor & Juiz & Autor & Juiz & & & Juiz \\
\hline $\mathrm{N} / \mathrm{L}$ & $\mathrm{N} / \mathrm{L}$ & $\mathrm{N} / \mathrm{L}$ & $\mathrm{N} / \mathrm{L}$ & & & $\mathrm{N} / \mathrm{L}$ \\
\hline \multicolumn{2}{|c|}{ Teoria da Imprevisão } & \multicolumn{2}{|c|}{$\begin{array}{l}\text { Defeito de Representação / } \\
\text { Defeito de Formalização }\end{array}$} & & Hipo & iciência \\
\hline Autor & Juiz & Autor & Juiz & & tor & Juiz \\
\hline Sim & $\mathrm{N} / \mathrm{L}$ & $\mathrm{N} / \mathrm{L}$ & $\mathrm{N} / \mathrm{L}$ & & $\mathrm{L}$ & $\mathrm{N} / \mathrm{L}$ \\
\hline & & Esta & Perigo & & & \\
\hline Autor & Juiz & Autor & Juiz & & tor & Juiz \\
\hline $\mathrm{N} / \mathrm{L}$ & $\mathrm{N} / \mathrm{L}$ & $\mathrm{N} / \mathrm{L}$ & $\mathrm{N} / \mathrm{L}$ & & $\mathrm{L}$ & $\mathrm{N} / \mathrm{L}$ \\
\hline & & Pacta & Servanda & & onor & da Vontade \\
\hline Autor & Juiz & Autor & Juiz & & tor & Juiz \\
\hline $\mathrm{N} / \mathrm{L}$ & $\mathrm{N} / \mathrm{L}$ & $\mathrm{N} / \mathrm{L}$ & $\mathrm{N} / \mathrm{L}$ & & $\mathrm{L}$ & $N / L$ \\
\hline Inerê & Risco & Cont & leatório & & & ação \\
\hline Autor & Juiz & Autor & Juiz & & tor & Juiz \\
\hline Sim & Sim & $\mathrm{N} / \mathrm{L}$ & $\mathrm{N} / \mathrm{L}$ & & $\mathrm{L}$ & $\mathrm{N} / \mathrm{L}$ \\
\hline & & & irio & & & \\
\hline $\begin{array}{l}\text { E que, } \\
\text { financeir } \\
\text { condutas }\end{array}$ & 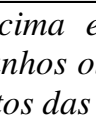 & . & & & & as \\
\hline
\end{tabular}


Apêndice 12-SP

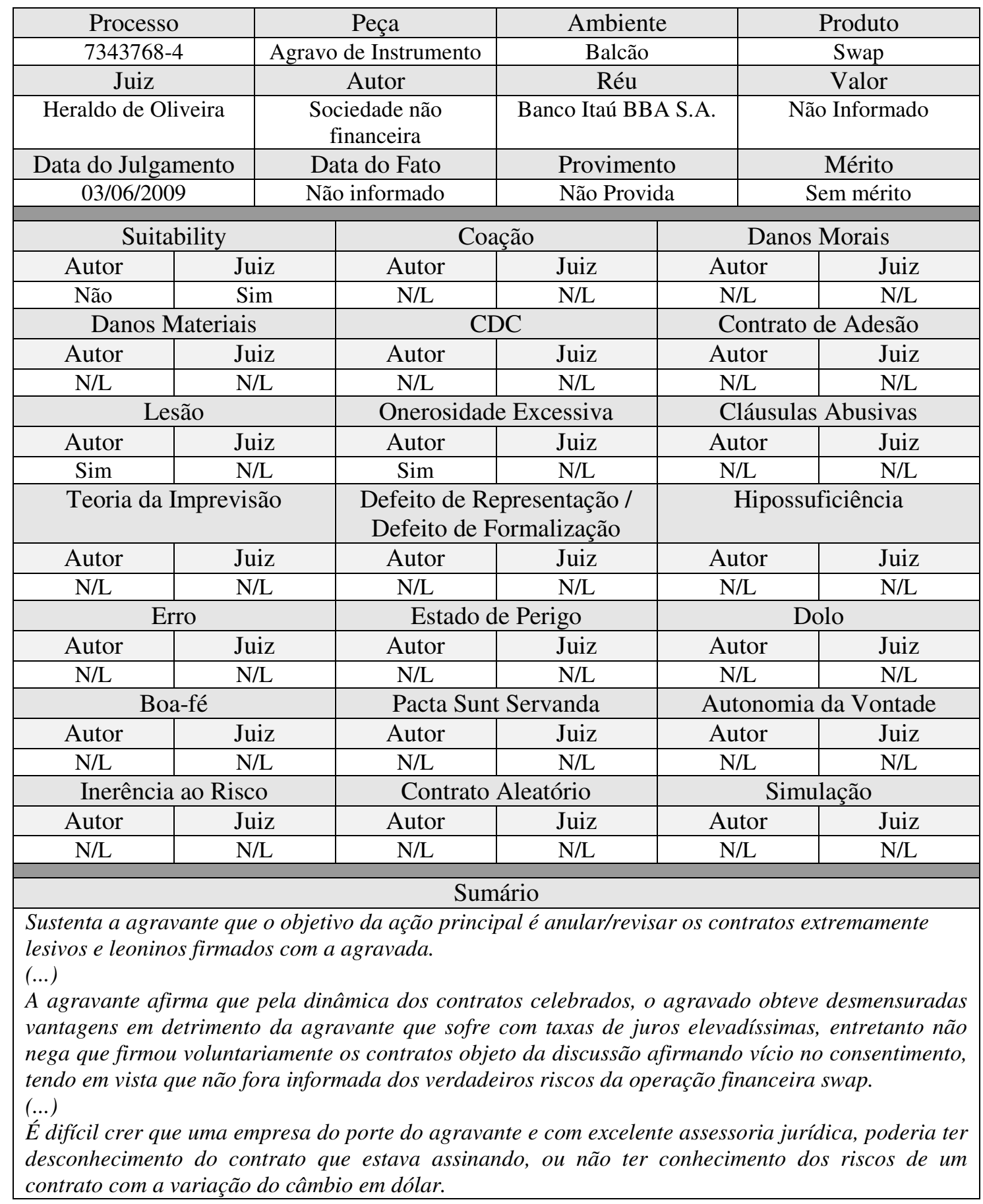


Apêndice 13-SP

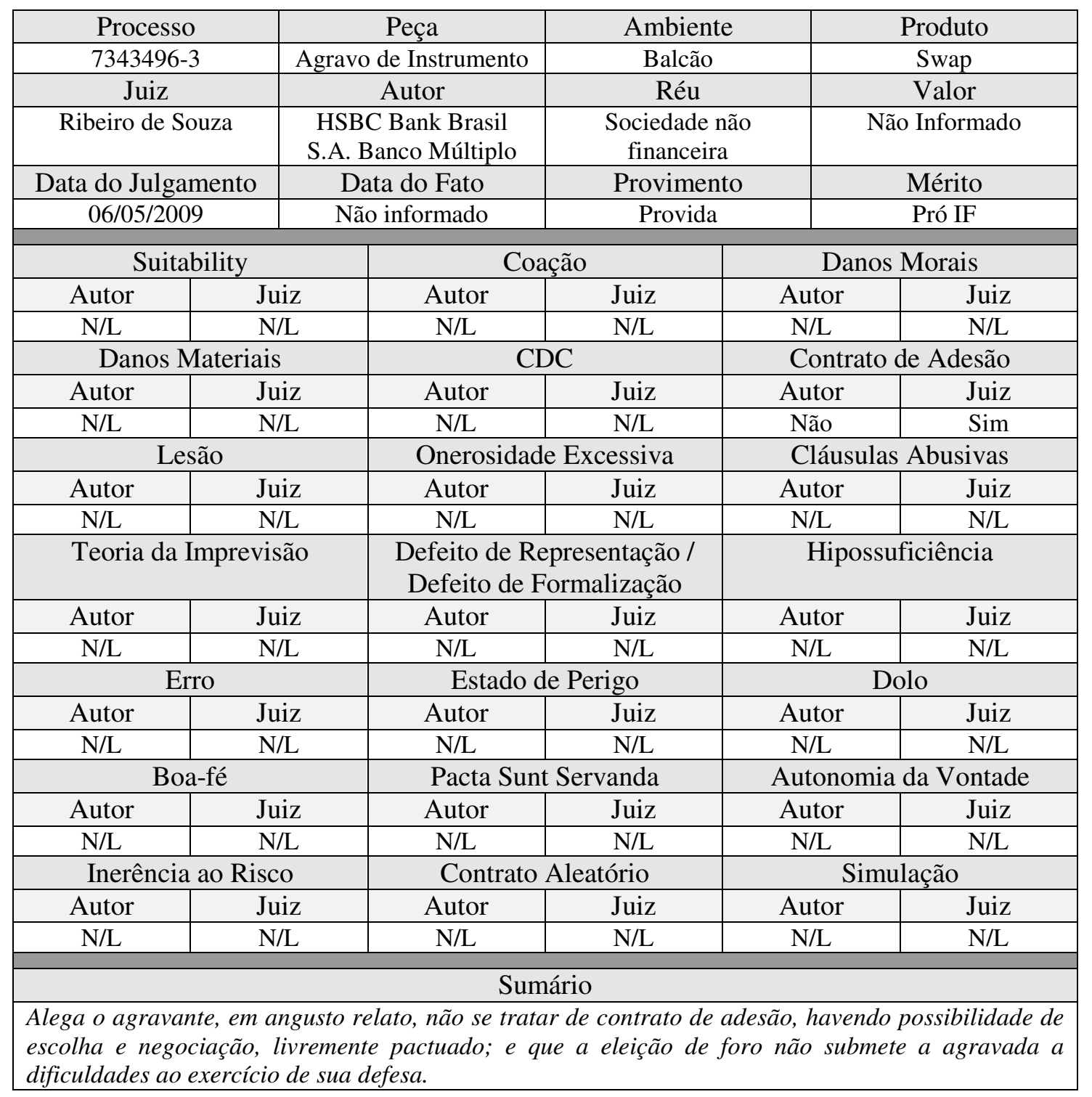


Apêndice 14-SP

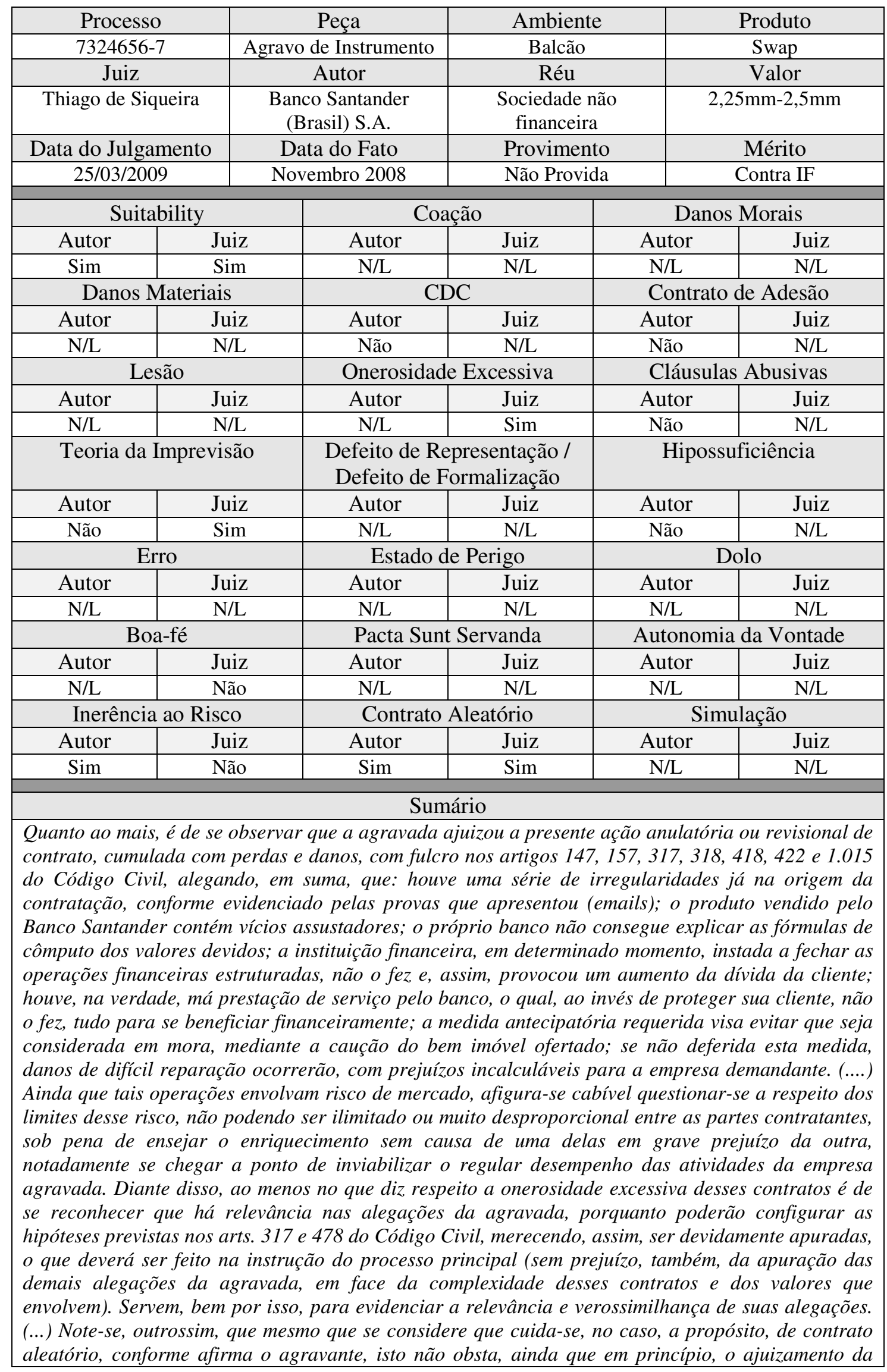

${ }^{1}$ Vide Apêndice 15-SP, em que a sociedade não financeira é requerente e o Banco Santander requerido. 
presente ação, pois como afirma, também, Nelson Nery Júnior, “nos contratos aleatórios, a base objetiva do negócio se caracteriza pela equivalência do risco de cada contratante: se o risco for de apenas um ou se for desproporcional, muito mais arriscado para um, que para o outro contratante, há quebra da base objetiva do negócio, que pode ensejar a revisão do contrato ou a sua resolução, de acordo com o que vem previsto no sistema (v. CC 421, 422, 317 e 478), para que se recomponha a equivalência perdida do risco da desigualdade das prestações " (in "Código Civil Comentado", Ed. RT, 5 a ed., nota $n .7$ ao art. 458, parte final, pág. 508). 
$\underline{\text { Apêndice } 15-\mathrm{SP}^{2}}$

\begin{tabular}{|c|c|c|c|c|c|c|}
\hline \multicolumn{2}{|c|}{ Processo } & \multicolumn{2}{|r|}{ Peça } & \multicolumn{2}{|c|}{ Ambiente } & Produto \\
\hline \multicolumn{2}{|c|}{$7308955-5$} & \multicolumn{2}{|c|}{ Agravo de Instrumento } & \multicolumn{2}{|l|}{ Balcão } & Swap \\
\hline \multicolumn{2}{|c|}{ Juiz } & \multicolumn{2}{|r|}{ Autor } & \multicolumn{2}{|l|}{ Réu } & Valor \\
\hline \multicolumn{2}{|c|}{ Thiago de Siqueira } & \multicolumn{2}{|c|}{$\begin{array}{l}\text { Sociedade não } \\
\text { financeira }\end{array}$} & \multicolumn{2}{|c|}{$\begin{array}{l}\text { Banco Santander } \\
\text { (Brasil) S.A. }\end{array}$} & $2,25 \mathrm{~mm}-2,5 \mathrm{~mm}$ \\
\hline \multicolumn{2}{|c|}{ Data do Julgamento } & \multicolumn{2}{|c|}{ Data do Fato } & \multicolumn{2}{|c|}{ Provimento } & Mérito \\
\hline $25 / 03 /$ & & & embro 2008 & Provida & & Contra IF \\
\hline \multicolumn{3}{|c|}{ Suitability } & \multicolumn{2}{|c|}{ Coação } & \multicolumn{2}{|c|}{ Danos Morais } \\
\hline Autor & & & Autor & Juiz & Autor & Juiz \\
\hline $\mathrm{N} / \mathrm{L}$ & & & $\mathrm{N} / \mathrm{L}$ & $\mathrm{N} / \mathrm{L}$ & $\mathrm{N} / \mathrm{L}$ & $\mathrm{N} / \mathrm{L}$ \\
\hline \multicolumn{3}{|c|}{ Danos Materiais } & \multicolumn{2}{|c|}{$\mathrm{CDC}$} & \multicolumn{2}{|c|}{ Contrato de Adesão } \\
\hline Autor & $\mathrm{Ju}$ & & Autor & Juiz & Autor & Juiz \\
\hline $\mathrm{N} / \mathrm{L}$ & & & $\mathrm{N} / \mathrm{L}$ & $\mathrm{N} / \mathrm{L}$ & Sim & $\mathrm{N} / \mathrm{L}$ \\
\hline \multicolumn{3}{|c|}{ Lesão } & \multicolumn{2}{|c|}{ Onerosidade Excessiva } & \multicolumn{2}{|c|}{ Cláusulas Abusivas } \\
\hline Autor & $\mathrm{Ju}$ & & Autor & Juiz & Autor & Juiz \\
\hline Sim & & & $\mathrm{N} / \mathrm{L}$ & Sim & $\mathrm{N} / \mathrm{L}$ & $\mathrm{N} / \mathrm{L}$ \\
\hline \multicolumn{3}{|c|}{ Teoria da Imprevisão } & \multicolumn{2}{|c|}{$\begin{array}{c}\text { Defeito de Representação / } \\
\text { Defeito de Formalização }\end{array}$} & Hipc & íciência \\
\hline Autor & $\mathrm{Ju}$ & & Autor & Juiz & Autor & Juiz \\
\hline $\mathrm{N} / \mathrm{L}$ & & & $\mathrm{N} / \mathrm{L}$ & $\mathrm{N} / \mathrm{L}$ & $\mathrm{N} / \mathrm{L}$ & $\mathrm{N} / \mathrm{L}$ \\
\hline & & & Estado & erigo & & \\
\hline Autor & $\mathrm{Ju}$ & & Autor & Juiz & Autor & Juiz \\
\hline $\mathrm{N} / \mathrm{L}$ & & & $\mathrm{N} / \mathrm{L}$ & $\mathrm{N} / \mathrm{L}$ & $\mathrm{N} / \mathrm{L}$ & $\mathrm{N} / \mathrm{L}$ \\
\hline & & & Pacta Sur & rvanda & Autono & da Vontade \\
\hline Autor & $\mathrm{Ju}$ & & Autor & Juiz & Autor & Juiz \\
\hline $\mathrm{N} / \mathrm{L}$ & & & $\mathrm{N} / \mathrm{L}$ & $\mathrm{N} / \mathrm{L}$ & $\mathrm{N} / \mathrm{L}$ & $\mathrm{N} / \mathrm{L}$ \\
\hline Inerên & Risc & & Contratc & atório & & lação \\
\hline Autor & $\mathrm{Ju}$ & & Autor & Juiz & Autor & Juiz \\
\hline $\mathrm{N} / \mathrm{L}$ & & & $\mathrm{N} / \mathrm{L}$ & $\mathrm{N} / \mathrm{L}$ & $\mathrm{N} / \mathrm{L}$ & $\mathrm{N} / \mathrm{L}$ \\
\hline & & & $\mathrm{Sul}$ & & & \\
\hline $\begin{array}{l}\text { Cautelar inc } \\
\text { contrato - } M \\
\text { prestação } d \\
\text { conseqüente } \\
e \text { de protest } \\
\text { para permiti } \\
\text { lhe são lesiv } \\
\text { do "periculu }\end{array}$ & & $\begin{array}{l}\text { do a } \\
\text { ope } \\
\text { la a } \\
\text { em se } \\
\text { te di }\end{array}$ & $\begin{array}{l}\text { o em caráter } \\
\text { os efeitos da } \\
\text { financeira e } \\
o \text { do nome da } \\
\text { me - Deferime } \\
\text { em juízo, os } t \\
\text { equilíbrio na } r \\
\text { los - Liminar }\end{array}$ & $\begin{array}{l}\text { aratório à c } \\
\text { a contratual, } \\
\text { lecida com } \\
\text { esa requeren } \\
\text { iminar - Ad } \\
\text { s da contrato } \\
\text { io jurídica - }\end{array}$ & $\begin{array}{l}\text { revisiono } \\
\text { liante o a } \\
\text { anco San } \\
\text { os cadast } \\
\text { bilidade. } \\
\text { em tela, o } \\
\text { isitos do }\end{array}$ & $\begin{array}{l}\text { l anulatória de } \\
\text { ito em juízo de } \\
\text { er S.A., com a } \\
\text { e inadimplentes } \\
\text { dida necessária } \\
\text { ais sustenta que } \\
\text { us boni iuris" e } \\
\text { do para tanto. }\end{array}$ \\
\hline
\end{tabular}

${ }^{2}$ Vide Apêndice 14-SP, em que o Banco Santander é requerente e a sociedade não financeira requerida. 
Apêndice 16-SP

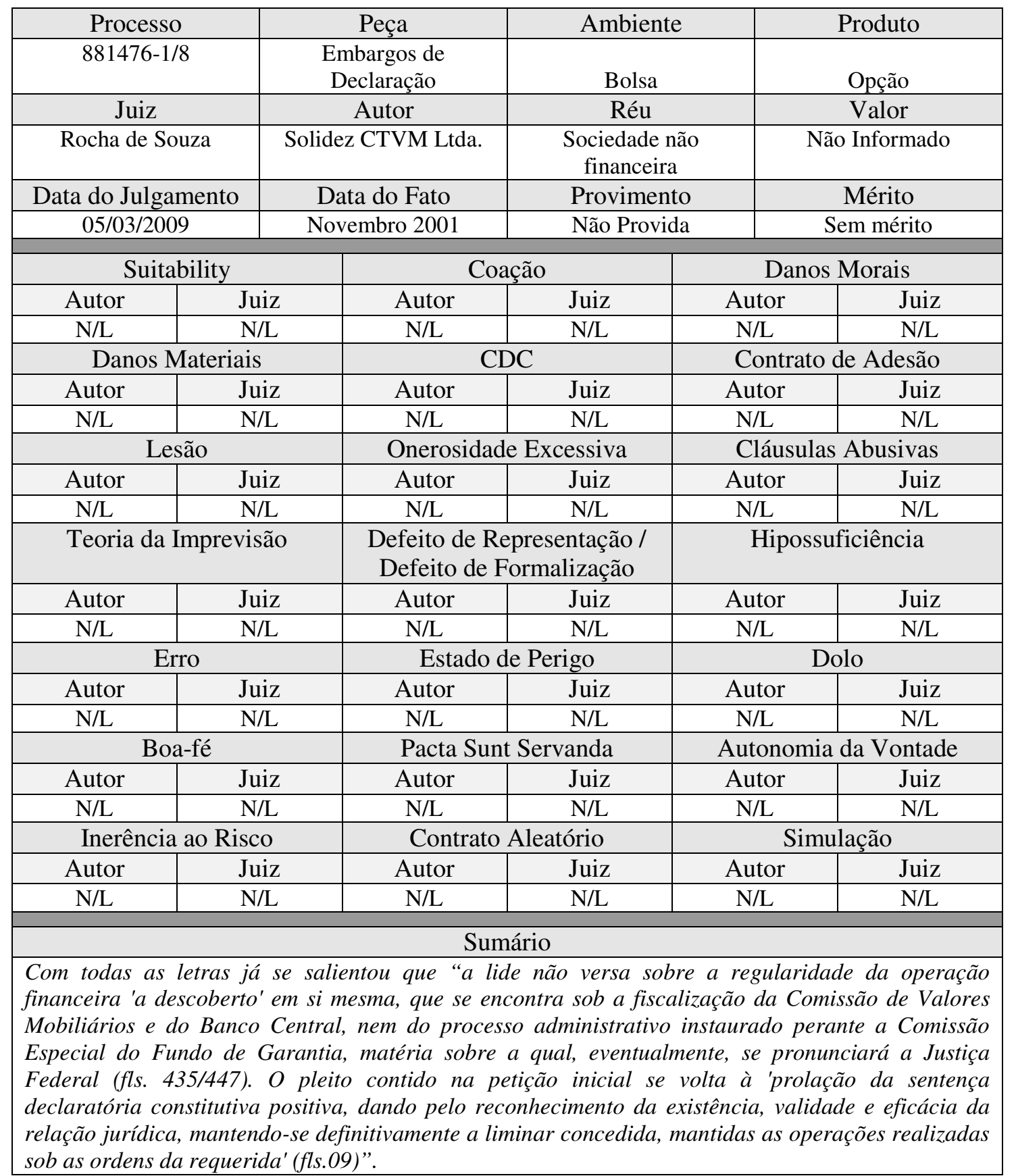


Apêndice 17-SP

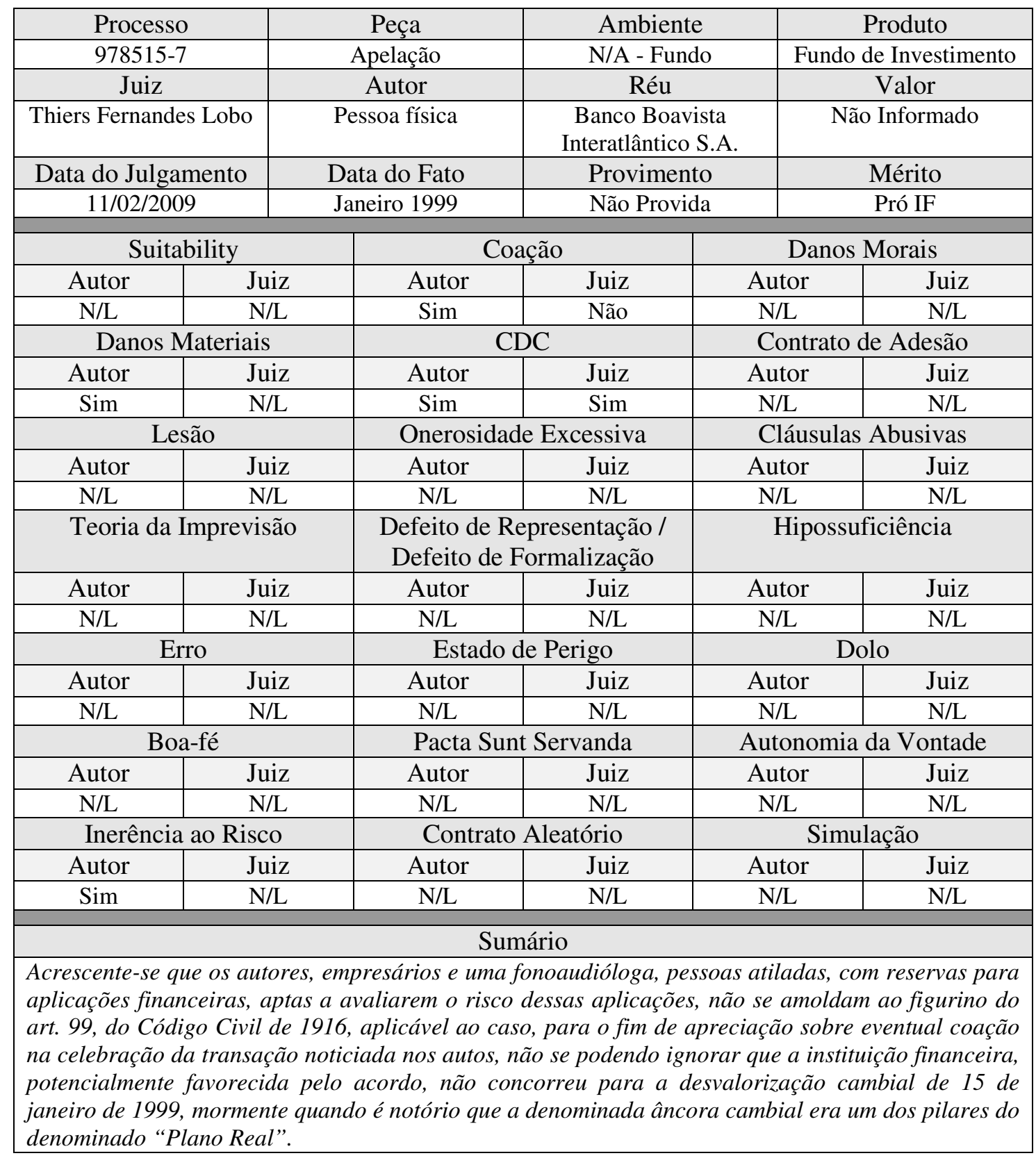




\begin{tabular}{|c|c|c|c|c|c|c|}
\hline \multicolumn{2}{|c|}{ Processo } & \multicolumn{2}{|r|}{ Peça } & \multicolumn{2}{|c|}{ Ambiente } & Produto \\
\hline \multicolumn{2}{|c|}{$7317620-6$} & \multicolumn{2}{|c|}{ Agravo de Instrumento } & \multicolumn{2}{|l|}{ Balcão } & Swap \\
\hline \multicolumn{2}{|c|}{ Juiz } & \multicolumn{2}{|r|}{ Autor } & \multicolumn{2}{|l|}{ Réu } & Valor \\
\hline \multicolumn{2}{|c|}{ Jacob Valente } & \multicolumn{2}{|c|}{$\begin{array}{l}\text { Sociedade não } \\
\text { financeira }\end{array}$} & \multicolumn{2}{|c|}{ Banco Citibank S.A. } & $751 \mathrm{k}-1 \mathrm{~mm}$ \\
\hline \multicolumn{2}{|c|}{ Data do Julgamento } & \multicolumn{2}{|c|}{ Data do Fato } & \multicolumn{2}{|c|}{ Provimento } & Mérito \\
\hline \multicolumn{2}{|c|}{$22 / 01 / 2009$} & \multicolumn{2}{|c|}{ Não informado } & \multicolumn{2}{|c|}{ Não Provida } & Pró IF \\
\hline \multicolumn{3}{|c|}{ Suitability } & \multicolumn{2}{|c|}{ Coação } & \multicolumn{2}{|c|}{ Danos Morais } \\
\hline Autor & Jui & & Autor & Juiz & Autor & Juiz \\
\hline Não & Sir & & $\mathrm{N} / \mathrm{L}$ & $\mathrm{N} / \mathrm{L}$ & $\mathrm{N} / \mathrm{L}$ & $\mathrm{N} / \mathrm{L}$ \\
\hline \multicolumn{3}{|c|}{ Danos Materiais } & \multicolumn{2}{|c|}{$\mathrm{CDC}$} & \multicolumn{2}{|c|}{ Contrato de Adesão } \\
\hline Autor & Jui & & Autor & Juiz & Autor & Juiz \\
\hline $\mathrm{N} / \mathrm{L}$ & $\mathrm{N} / \mathrm{L}$ & & $\mathrm{N} / \mathrm{L}$ & $\mathrm{N} / \mathrm{L}$ & $\mathrm{N} / \mathrm{L}$ & $\mathrm{N} / \mathrm{L}$ \\
\hline \multicolumn{3}{|c|}{ Lesão } & \multicolumn{2}{|c|}{ Onerosidade Excessiva } & \multicolumn{2}{|c|}{ Cláusulas Abusivas } \\
\hline Autor & Jui & & Autor & Juiz & Autor & Juiz \\
\hline $\mathrm{N} / \mathrm{L}$ & $\mathrm{N} / \mathrm{I}$ & & Sim & Não & $\mathrm{N} / \mathrm{L}$ & $\mathrm{N} / \mathrm{L}$ \\
\hline Teoria & Imprevis? & & $\begin{array}{l}\text { Defeito de R } \\
\text { Defeito de I }\end{array}$ & $\begin{array}{l}\text { resentação / } \\
\text { rmalização }\end{array}$ & Hipo & ficiência \\
\hline Autor & Jui & & Autor & Juiz & Autor & Juiz \\
\hline Sim & Não & & $\mathrm{N} / \mathrm{L}$ & $\mathrm{N} / \mathrm{L}$ & $\mathrm{N} / \mathrm{L}$ & $\mathrm{N} / \mathrm{L}$ \\
\hline & rro & & Estado & e Perigo & & lo \\
\hline Autor & Jui & & Autor & Juiz & Autor & Juiz \\
\hline $\mathrm{N} / \mathrm{L}$ & $\mathrm{N} / 1$ & & $\mathrm{~N} / \mathrm{L}$ & $\mathrm{N} / \mathrm{L}$ & $\mathrm{N} / \mathrm{L}$ & $\mathrm{N} / \mathrm{L}$ \\
\hline & a-fé & & Pacta Sun & Servanda & Autonor & da Vontade \\
\hline Autor & Jui & & Autor & Juiz & Autor & Juiz \\
\hline $\mathrm{N} / \mathrm{L}$ & $\mathrm{N} / \mathrm{s}$ & & $\mathrm{N} / \mathrm{L}$ & Sim & $\mathrm{N} / \mathrm{L}$ & $\mathrm{N} / \mathrm{L}$ \\
\hline Inerên & ao Riscc & & Contrato & Aleatório & & lação \\
\hline Autor & Jui & & Autor & Juiz & Autor & Juiz \\
\hline $\mathrm{N} / \mathrm{L}$ & Sir & & $\mathrm{N} / \mathrm{L}$ & Sim & $\mathrm{N} / \mathrm{L}$ & $\mathrm{N} / \mathrm{L}$ \\
\hline & & & Sun & ário & & \\
\hline $\begin{array}{l}\text { Escudando-s } \\
\text { desvalorizaçc } \\
\text { agravados "} \\
\text { derivativos e } \\
\text { prejudicial à } \\
\text { explicitada e } \\
\text { uma liminar } \\
\text { impede de le } \\
\text { bem como ob } \\
\text { (...) } \\
\text { No caso dos } \\
\text { partes à osci } \\
\text { mutuados, ra } \\
\text { ocorrência d } \\
\text { dólar americ } \\
\text { reveste de pl } \\
\text { exigibilidade } \\
\text { como indexa } \\
\text { (...) } \\
\text { Com efeito, } \\
\text { empresa exp } \\
\text { alimentício e } \\
\text { lícito alegar, } \\
\text { e extensão dd }\end{array}$ & $\begin{array}{l}\text { ambém } \\
\text { do real } \\
\text { trumento } \\
\text { utras ave } \\
\text { gravante e } \\
\text { sua plenit } \\
\text { rcial que } \\
\text { a protest } \\
\text { a a Agrav } \\
\text { ttos, o ris } \\
\text { ão da coto } \\
\text { o pela quo } \\
\text { ato superv } \\
\text { o, a pont } \\
\text { sibilidade } \\
\text { crédito o } \\
\text { dos enca } \\
\text { elebração } \\
\text { adora do } \\
\text { eterinário, } \\
\text { ora, mudc }\end{array}$ & $\begin{array}{l}\text { a tec } \\
\text { frent } \\
\text { parti } \\
\text { enças } \\
\text { e extr } \\
\text { tude } \\
\text { não } \\
\text { to qu } \\
\text { vante } \\
\text { sco, } \\
\text { tação } \\
\text { al, ao } \\
\text { venier } \\
\text { to de } \\
\text { e jurí } \\
\text { origin } \\
\text { argos, } \\
\text { o de }\end{array}$ & $\begin{array}{l}\text { da imprevisão, } \\
\text { dólar norte-a } \\
\text { tr de contrato I } \\
\text { eeração que "c } \\
\text { mente vantajosc } \\
\text { casião da celeb } \\
\text { ede os Agravad } \\
\text { er título de créd } \\
\text { epositar o montc } \\
\text { istente na vincu } \\
\text { lólar comercial, } \\
\text { nos em sede de } \\
\text { mprevisivel, con } \\
\text { ificar a resoluç } \\
\text { suficiente para } \\
\text { do contrato, un } \\
\text { a essência do pr } \\
\text { contrato dessa } \\
\text { de distribuição } \\
\text { mo a intermedic } \\
\text { intigo cenário e }\end{array}$ & 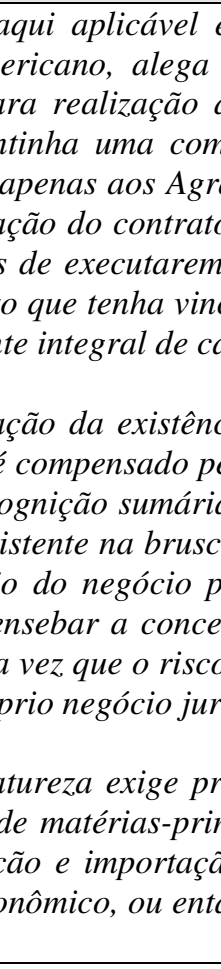 & $\begin{array}{l}\text { m razão da } \\
\text { a agravante } \\
\text { e swap e out } \\
\text { plexa estrutra } \\
\text { vados, estruth } \\
\text { ", a par do qu } \\
\text { as garantias } \\
\text { ulação com o } \\
\text { da parcela de } \\
\text { ia e extensão } \\
\text { la menor taxa } \\
\text { em ação cau } \\
\text { desvalorizaç } \\
\text { r onerosidad } \\
\text { são de limina } \\
\text { advindo das } \\
\text { dico firmado } \\
\text { vidência e ca } \\
\text { as para os se } \\
\text { dessas merc }\end{array}$ & $\begin{array}{l}\text { ta e inesperada } \\
\text { firmou com os } \\
\text { do mercado de } \\
\text { nica, altamente } \\
\text { essa que não foi } \\
\text { de nada adianta } \\
\text { ontrato, não os } \\
\text { trato em exame, } \\
\text { fficação". } \\
\text { prestações das } \\
\text { juro dos valores } \\
\text { r, a alegação de } \\
\text { lo real frente ao } \\
\text { ccessiva, não se } \\
\text { ara suspender a } \\
\text { lações cambiais, } \\
\text { e as partes. } \\
\text { a, mormente de } \\
\text { es farmacêutico, } \\
\text { rias, não sendo } \\
\text { rca do conteúdo }\end{array}$ \\
\hline
\end{tabular}


Apêndice 19-SP

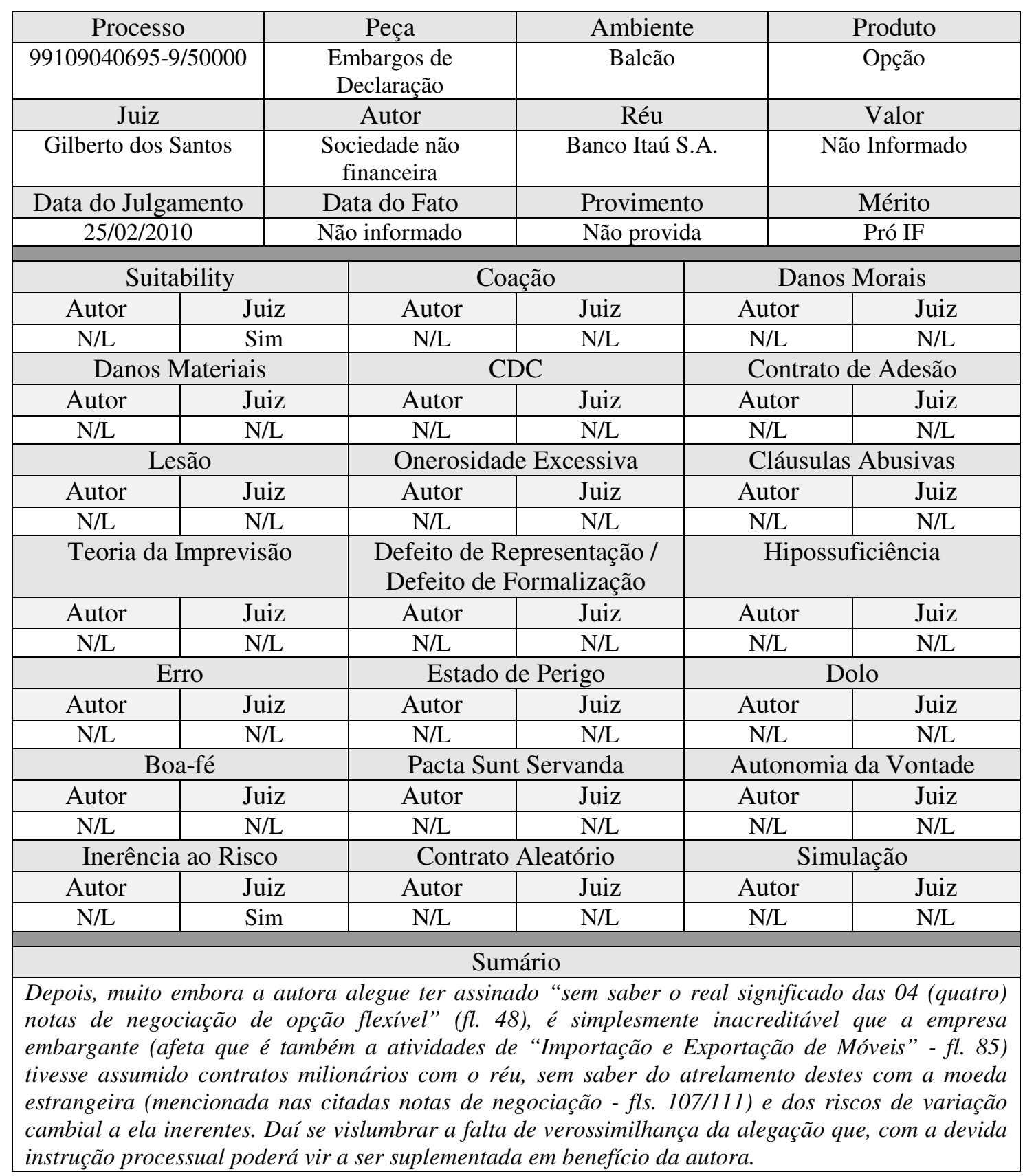


Apêndice 20-SP

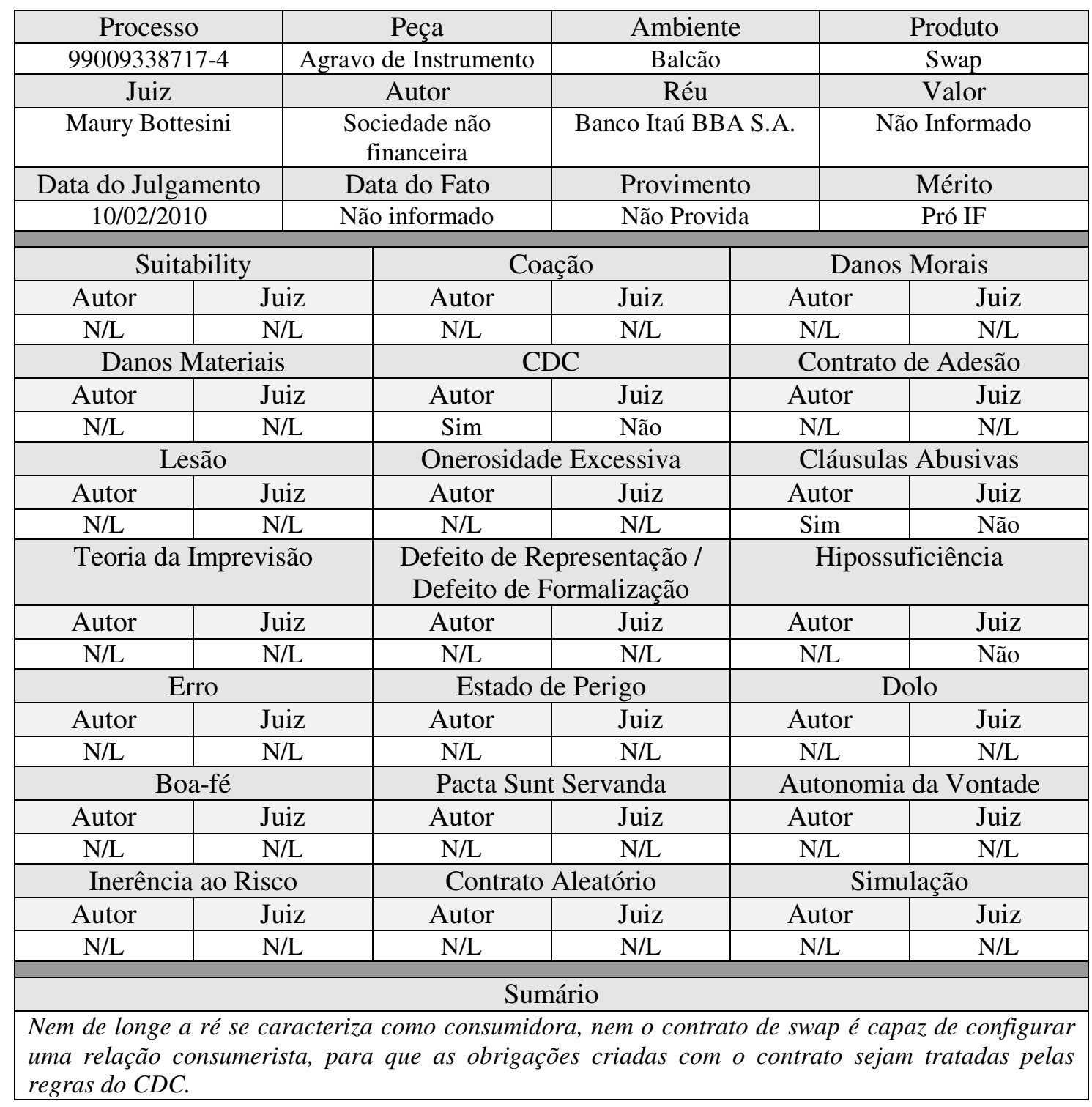


Apêndice 21-SP

\begin{tabular}{|c|c|c|c|c|c|}
\hline \multicolumn{2}{|c|}{ Processo } & Peça & \multicolumn{2}{|c|}{ Ambiente } & Produto \\
\hline \multicolumn{2}{|c|}{$1020102-6$} & Apelação & \multicolumn{2}{|c|}{ N/A - Fundo } & Fundo de Investimento \\
\hline \multicolumn{2}{|c|}{ Juiz } & Autor & \multicolumn{2}{|c|}{ Réu } & Valor \\
\hline \multicolumn{2}{|c|}{ Edgard Jorge Lauand } & essoa física & \multicolumn{2}{|c|}{$\begin{array}{l}\text { Banco Boavista } \\
\text { Interatlântico S.A. }\end{array}$} & Não Informado \\
\hline \multicolumn{2}{|c|}{ Data do Julgamento } & \multirow{2}{*}{$\begin{array}{l}\text { ata do Fato } \\
\text { aneiro } 1999\end{array}$} & \multicolumn{2}{|c|}{ Provimento } & Mérito \\
\hline \multicolumn{2}{|c|}{$23 / 01 / 2007$} & & \multicolumn{2}{|c|}{ Não Provida } & Pró IF \\
\hline \multicolumn{2}{|c|}{ Suitability } & \multicolumn{2}{|c|}{ Coação } & \multicolumn{2}{|c|}{ Danos Morais } \\
\hline Autor & Juiz & Autor & Juiz & Autor & Juiz \\
\hline Não & Sim & Sim & Não & Sim & Não \\
\hline \multicolumn{2}{|c|}{ Danos Materiais } & \multicolumn{2}{|c|}{$\mathrm{CDC}$} & \multicolumn{2}{|c|}{ Contrato de Adesão } \\
\hline Autor & Juiz & Autor & Juiz & Autor & Juiz \\
\hline $\mathrm{N} / \mathrm{L}$ & $\mathrm{N} / \mathrm{L}$ & Sim & Sim & $\mathrm{N} / \mathrm{L}$ & $\mathrm{N} / \mathrm{L}$ \\
\hline \multicolumn{2}{|c|}{ Lesão } & \multicolumn{2}{|c|}{ Onerosidade Excessiva } & \multicolumn{2}{|c|}{ Cláusulas Abusivas } \\
\hline Autor & Juiz & Autor & Juiz & Autor & Juiz \\
\hline $\mathrm{N} / \mathrm{L}$ & $\mathrm{N} / \mathrm{L}$ & $\mathrm{N} / \mathrm{L}$ & $\mathrm{N} / \mathrm{L}$ & $\mathrm{N} / \mathrm{L}$ & $\mathrm{N} / \mathrm{L}$ \\
\hline \multicolumn{2}{|c|}{ Teoria da Imprevisão } & $\begin{array}{l}\text { Defeito c } \\
\text { Defeito }\end{array}$ & $\begin{array}{l}\text { esentação } \\
\text { malização }\end{array}$ & Hip & ficiência \\
\hline Autor & Juiz & Autor & Juiz & Autor & Juiz \\
\hline $\mathrm{N} / \mathrm{L}$ & $\mathrm{N} / \mathrm{L}$ & $\mathrm{N} / \mathrm{L}$ & $\mathrm{N} / \mathrm{L}$ & $\mathrm{N} / \mathrm{L}$ & $\mathrm{N} / \mathrm{L}$ \\
\hline & & Esta & Perigo & & olo \\
\hline Autor & Juiz & Autor & Juiz & Autor & Juiz \\
\hline $\mathrm{N} / \mathrm{L}$ & $\mathrm{N} / \mathrm{L}$ & $\mathrm{N} / \mathrm{L}$ & $\mathrm{N} / \mathrm{L}$ & $\mathrm{N} / \mathrm{L}$ & $\mathrm{N} / \mathrm{L}$ \\
\hline & & Pacta & ervanda & Autons & da Vontade \\
\hline Autor & Juiz & Autor & Juiz & Autor & Juiz \\
\hline $\mathrm{N} / \mathrm{L}$ & $\mathrm{N} / \mathrm{L}$ & $\mathrm{N} / \mathrm{L}$ & $\mathrm{N} / \mathrm{L}$ & $\mathrm{N} / \mathrm{L}$ & $\mathrm{N} / \mathrm{L}$ \\
\hline Inerên & Risco & Cont & eatório & & lação \\
\hline Autor & Juiz & Autor & Juiz & Autor & Juiz \\
\hline $\mathrm{N} / \mathrm{L}$ & Sim & $\mathrm{N} / \mathrm{L}$ & $\mathrm{N} / \mathrm{L}$ & $\mathrm{N} / \mathrm{L}$ & $\mathrm{N} / \mathrm{L}$ \\
\hline & & & & & \\
\hline $\begin{array}{l}\text { Ao escolher } \\
\text { de sua aplic } \\
\text { de dinheiro } \\
\text { quando, nem } \\
\text { uma signific } \\
\text { poucos dias }\end{array}$ & $\begin{array}{l}\text { iment } \\
\text { ercad } \\
\text { idores }\end{array}$ & $\begin{array}{l}\text { o estaria } \\
\text { eiro. Aliá } \\
\text { cado de ri } \\
\text { resultam e } \\
\text { da alteras } \\
99 .\end{array}$ & $\begin{array}{l}\text { a investid } \\
\text { stra possí } \\
\text { mo a título } \\
\text { para os }\end{array}$ & $\begin{array}{l}\text { formar } \\
\text { tece co } \\
\text { lo cita- } \\
\text { e. No c }\end{array}$ & $\begin{array}{l}\text { m os resultados } \\
\text { qüência a perda } \\
\text { bolsa de valores } \\
\text { m exame, houve } \\
\text { erda brusca em }\end{array}$ \\
\hline
\end{tabular}


Apêndice 22-SP

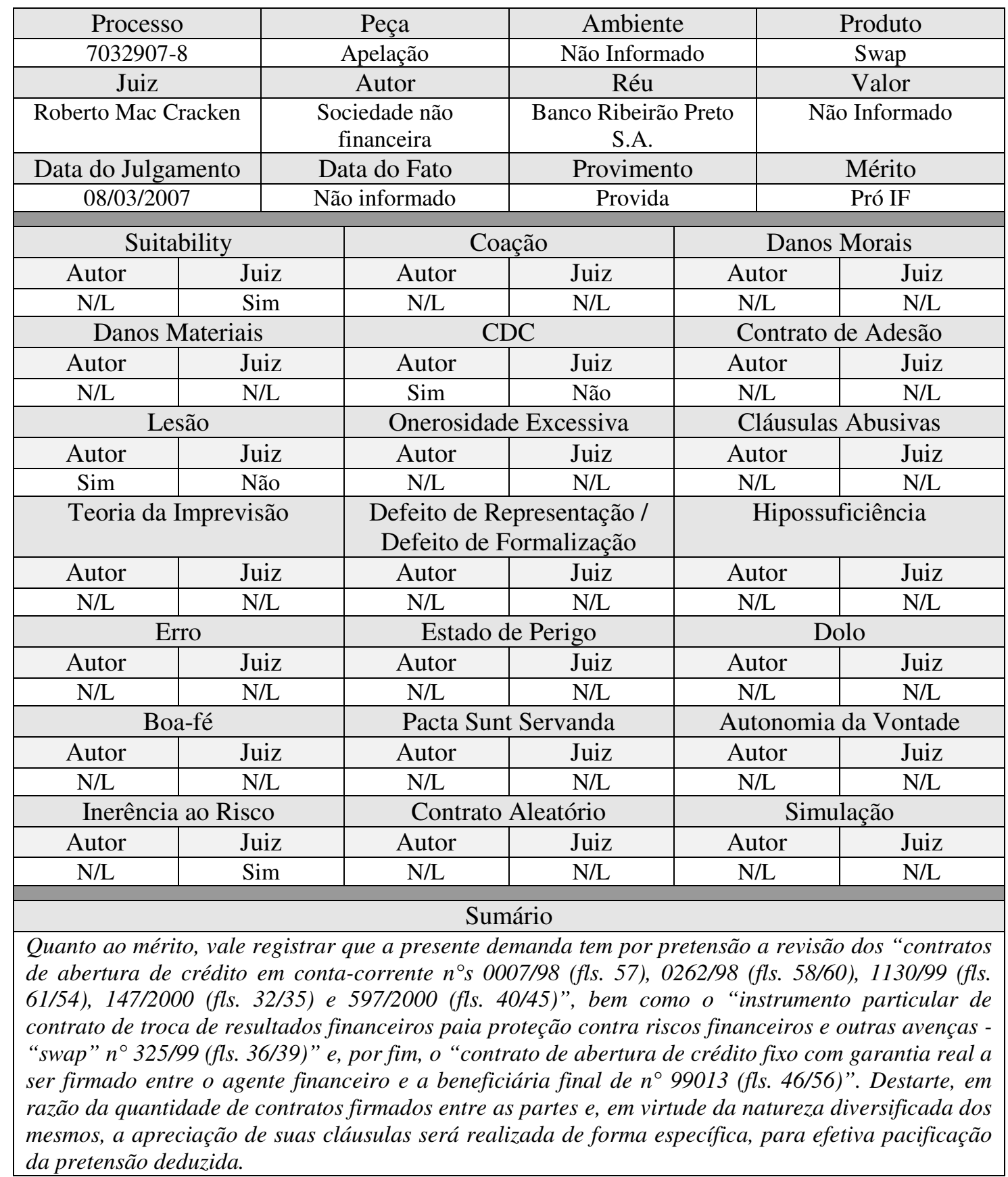

${ }^{3}$ Vide Apêndice 23-SP em que o Banco Ribeirão Preto é requerente e a sociedade não financeira requerida. 
Apêndice 23-SP

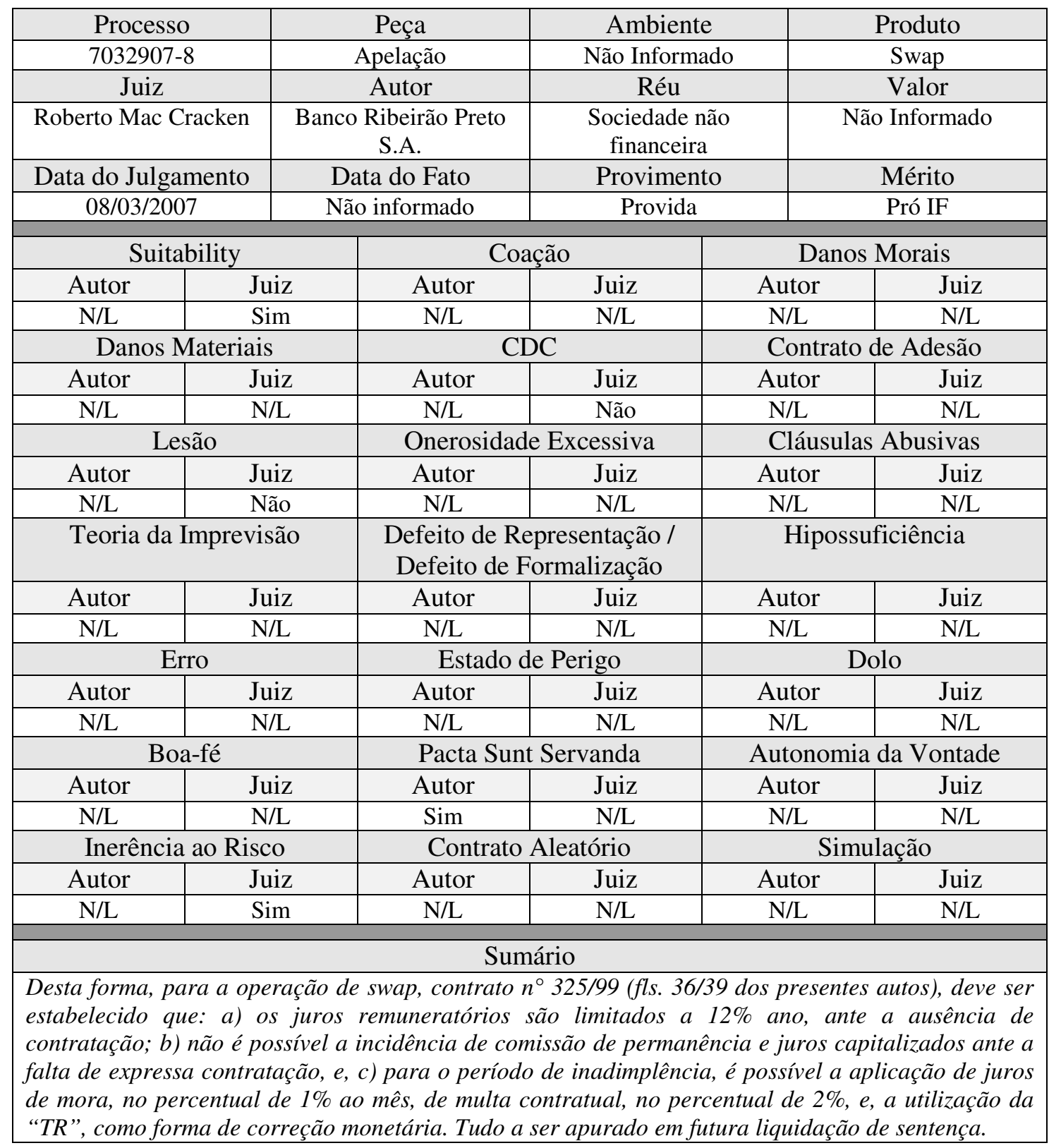

${ }^{4}$ Vide Apêndice 22-SP em que a sociedade não financeira é requerente e o Banco Ribeirão Preto é requerido. 
Apêndice 24-SP

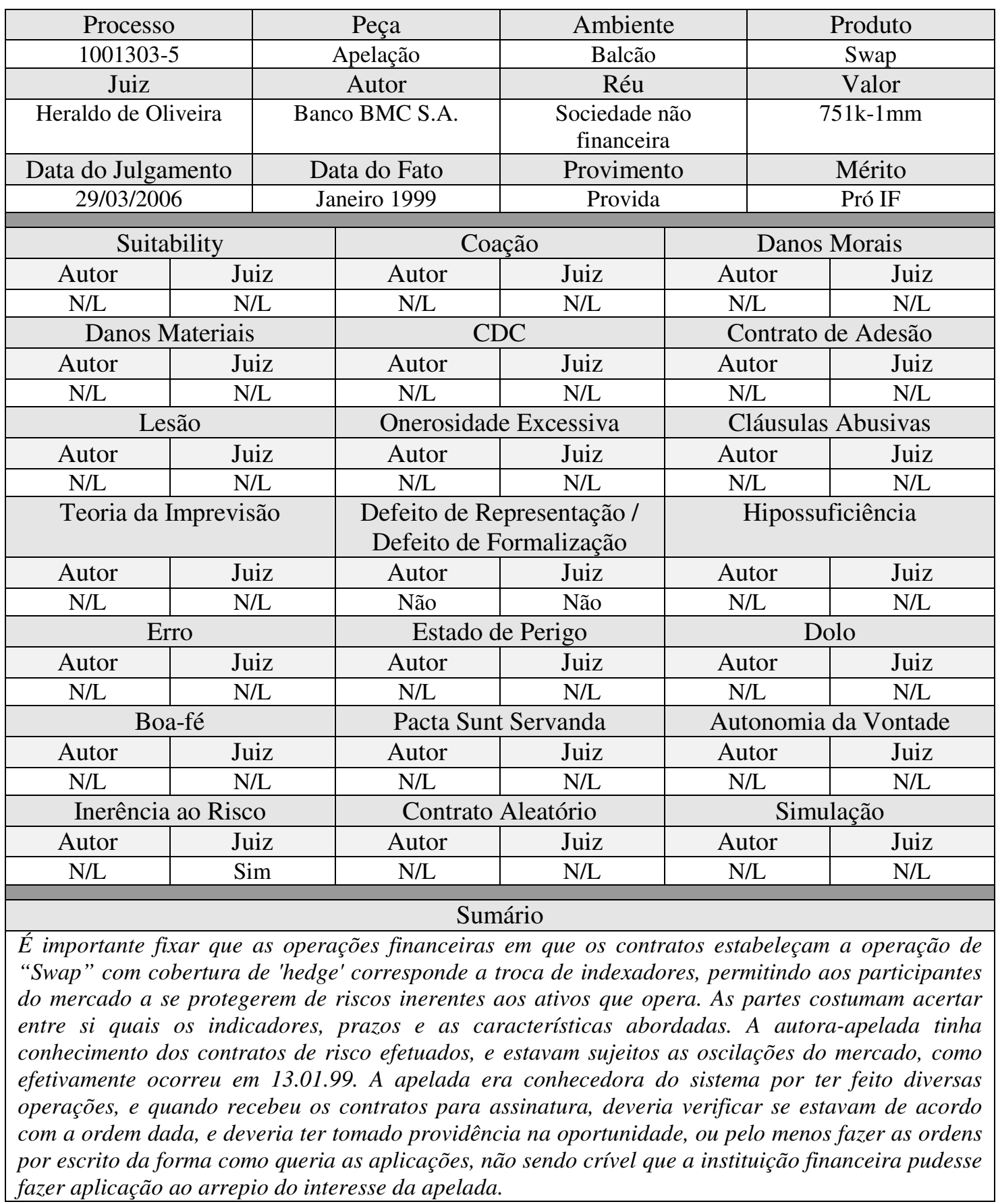


Apêndice 25-SP

\begin{tabular}{|c|c|c|c|c|c|c|}
\hline \multicolumn{2}{|c|}{ Processo } & \multicolumn{2}{|r|}{ Peça } & \multicolumn{2}{|c|}{ Ambiente } & Produto \\
\hline \multicolumn{2}{|c|}{$510919-4 / 2-00$} & \multicolumn{2}{|c|}{ Agravo de Instrumento } & \multicolumn{2}{|c|}{ Balcão } & Opção \\
\hline \multicolumn{2}{|c|}{ Juiz } & \multicolumn{2}{|r|}{ Autor } & \multicolumn{2}{|c|}{ Réu } & Valor \\
\hline \multicolumn{2}{|c|}{ Lino Machado } & \multicolumn{2}{|c|}{ Banco Santos S.A. } & \multicolumn{2}{|c|}{$\begin{array}{c}\text { Sociedade não } \\
\text { financeira }\end{array}$} & cima $10 \mathrm{~mm}$ \\
\hline \multicolumn{2}{|c|}{ Data do Julgamento } & \multicolumn{2}{|c|}{ Data do Fato } & \multicolumn{2}{|c|}{ Provimento } & Mérito \\
\hline \multicolumn{2}{|c|}{$19 / 12 / 2007$} & \multicolumn{2}{|c|}{ Novembro 2004} & \multicolumn{2}{|c|}{ Não Provida } & Contra IF \\
\hline \multicolumn{3}{|c|}{ Suitability } & \multicolumn{2}{|c|}{ Coação } & \multicolumn{2}{|c|}{ Danos Morais } \\
\hline Autor & & iiz & Autor & Juiz & Autor & Juiz \\
\hline $\mathrm{N} / \mathrm{L}$ & & $/ \mathrm{L}$ & $\mathrm{N} / \mathrm{L}$ & $\mathrm{N} / \mathrm{L}$ & $\mathrm{N} / \mathrm{L}$ & $\mathrm{N} / \mathrm{L}$ \\
\hline \multicolumn{3}{|c|}{ Danos Materiais } & \multicolumn{2}{|c|}{$\mathrm{CDC}$} & \multicolumn{2}{|c|}{ Contrato de Adesão } \\
\hline Autor & & iiz & Autor & Juiz & Autor & Juiz \\
\hline $\mathrm{N} / \mathrm{L}$ & & $/ \mathrm{L}$ & $\mathrm{N} / \mathrm{L}$ & $\mathrm{N} / \mathrm{L}$ & $\mathrm{N} / \mathrm{L}$ & $\mathrm{N} / \mathrm{L}$ \\
\hline \multicolumn{3}{|c|}{ Lesão } & \multicolumn{2}{|c|}{ Onerosidade Excessiva } & Cláus & Abusivas \\
\hline Autor & & liz & Autor & Juiz & Autor & Juiz \\
\hline $\mathrm{N} / \mathrm{L}$ & & $/ \mathrm{L}$ & $\mathrm{N} / \mathrm{L}$ & $\mathrm{N} / \mathrm{L}$ & $\mathrm{N} / \mathrm{L}$ & $\mathrm{N} / \mathrm{L}$ \\
\hline Teoria & & & $\begin{array}{c}\text { Defeito de R } \\
\text { Defeito de I }\end{array}$ & $\begin{array}{l}\text { sentação } \\
\text { halização }\end{array}$ & Hip & íciência \\
\hline Autor & & iiz & Autor & Juiz & Autor & Juiz \\
\hline $\mathrm{N} / \mathrm{L}$ & & $/ \mathrm{L}$ & Não & Sim & $\mathrm{N} / \mathrm{L}$ & $\mathrm{N} / \mathrm{L}$ \\
\hline & & & Estado & erigo & & \\
\hline Autor & & liz & Autor & Juiz & Autor & Juiz \\
\hline $\mathrm{N} / \mathrm{L}$ & & $/ \mathrm{L}$ & $\mathrm{N} / \mathrm{L}$ & $\mathrm{N} / \mathrm{L}$ & $\mathrm{N} / \mathrm{L}$ & Sim \\
\hline & & & Pacta Sun & rvanda & Autonc & da Vontade \\
\hline Autor & & liz & Autor & Juiz & Autor & Juiz \\
\hline $\mathrm{N} / \mathrm{L}$ & & ão & $\mathrm{N} / \mathrm{L}$ & $\mathrm{N} / \mathrm{L}$ & $\mathrm{N} / \mathrm{L}$ & $\mathrm{N} / \mathrm{L}$ \\
\hline Inerêt & & & Contrato & atório & & lação \\
\hline Autor & & liz & Autor & Juiz & Autor & Juiz \\
\hline Sim & & $/ \mathrm{L}$ & $\mathrm{N} / \mathrm{L}$ & $\mathrm{N} / \mathrm{L}$ & Não & Sim \\
\hline & & & Sun & & & \\
\hline $\begin{array}{l}\text { Ao apresen } \\
\text { “destinava- } \\
\text { de swap, fic } \\
\text { da carta de } \\
\text { uma causa } \\
\text { fornecedore } \\
\text { parágrafo). } \\
\text { fixa”, atrel } \\
\text { inatingivel, } \\
\text { primeiro, te }\end{array}$ & $\begin{array}{l}\text { seu } p \\
\text { Pa } \\
\text { mica } \\
\text { ingei } \\
\text { va-se }\end{array}$ & 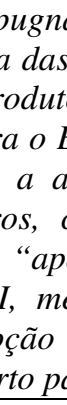 & $\begin{array}{l}\text { a a agravada } \\
\text { tas de crédito, ur } \\
\text { relado à compens } \\
\text { eiro, a operação } \\
\text { ição e remessa } \\
\text { a intermediaçãa } \\
\text { de se tratar de } \\
\text { "porque o ina } \\
\text { impraticável, fix } \\
\text { rafos). }\end{array}$ & $\begin{array}{l}\text { u que a } \\
\text { z que, po } \\
\text { do contr } \\
\text { sar de ju } \\
\text { oeda est } \\
\text { igatória } \\
\text { ção com } \\
\text { le 'barre } \\
\text { ustament }\end{array}$ & $\begin{array}{l}\text { cão rea } \\
\text { de carta } \\
\text { âmbio o } \\
\text { ente con } \\
\text { a para } \\
\text { nco San } \\
\text { ivo", de } \\
\text { lizado n } \\
\text { nunca }\end{array}$ & $\begin{array}{l}\text { com o falido } \\
\text { nhor e contrato } \\
\text { ado da abertura } \\
\text { - tinha apenas } \\
\text { nento dos seus } \\
\text { (fl. 36, último } \\
\text { cação de renda } \\
\text { operaçoses era } \\
\text { ercido" (fl. 37, }\end{array}$ \\
\hline
\end{tabular}


Apêndice 26-SP

\begin{tabular}{|c|c|c|c|c|c|c|}
\hline \multicolumn{2}{|c|}{ Processo } & \multicolumn{2}{|r|}{ Peça } & \multicolumn{2}{|c|}{ Ambiente } & Produto \\
\hline \multicolumn{2}{|c|}{ 7107429-2 } & \multicolumn{2}{|r|}{ Apelação } & \multicolumn{2}{|c|}{ Não Informado } & Swap \\
\hline \multicolumn{2}{|c|}{ Juiz } & \multicolumn{2}{|r|}{ Autor } & \multicolumn{2}{|l|}{ Réu } & Valor \\
\hline \multicolumn{2}{|c|}{ Itamar Gaino } & \multicolumn{2}{|c|}{ Banco do Brasil S.A. } & \multicolumn{2}{|c|}{$\begin{array}{l}\text { Sociedade não } \\
\text { financeira }\end{array}$} & $500 \mathrm{k}-750 \mathrm{k}$ \\
\hline \multicolumn{2}{|c|}{ Data do Julgamento } & \multicolumn{2}{|c|}{ Data do Fato } & \multicolumn{2}{|c|}{ Provimento } & Mérito \\
\hline $28 / 03$ & & & neiro 1999 & Provida & & Pró IF \\
\hline \multicolumn{3}{|c|}{ Suitability } & \multicolumn{2}{|c|}{ Coação } & \multicolumn{2}{|c|}{ Danos Morais } \\
\hline Autor & & & Autor & Juiz & Autor & Juiz \\
\hline $\mathrm{N} / \mathrm{L}$ & & & $\mathrm{N} / \mathrm{L}$ & $\mathrm{N} / \mathrm{L}$ & $\mathrm{N} / \mathrm{L}$ & $\mathrm{N} / \mathrm{L}$ \\
\hline \multicolumn{3}{|c|}{ Danos Materiais } & \multicolumn{2}{|c|}{$\mathrm{CDC}$} & \multicolumn{2}{|c|}{ Contrato de Adesão } \\
\hline Autor & & & Autor & Juiz & Autor & Juiz \\
\hline Não & & & $\mathrm{N} / \mathrm{L}$ & $\mathrm{N} / \mathrm{L}$ & $\mathrm{N} / \mathrm{L}$ & $\mathrm{N} / \mathrm{L}$ \\
\hline \multicolumn{3}{|c|}{ Lesão } & \multicolumn{2}{|c|}{ Onerosidade Excessiva } & \multicolumn{2}{|c|}{ Cláusulas Abusivas } \\
\hline Autor & & & Autor & Juiz & Autor & Juiz \\
\hline $\mathrm{N} / \mathrm{L}$ & & & N/L & $\mathrm{N} / \mathrm{L}$ & $\mathrm{N} / \mathrm{L}$ & $\mathrm{N} / \mathrm{L}$ \\
\hline \multicolumn{3}{|c|}{ Teoria da Imprevisão } & \multicolumn{2}{|c|}{$\begin{array}{l}\text { Defeito de Representação / } \\
\text { Defeito de Formalização }\end{array}$} & Hip & ficiência \\
\hline Autor & & & Autor & Juiz & Autor & Juiz \\
\hline $\mathrm{N} / \mathrm{L}$ & & & Sim & $\mathrm{N} / \mathrm{L}$ & $\mathrm{N} / \mathrm{L}$ & $\mathrm{N} / \mathrm{L}$ \\
\hline & & & Estado & erigo & & lo \\
\hline Autor & & & Autor & Juiz & Autor & Juiz \\
\hline $\mathrm{N} / \mathrm{L}$ & & & $\mathrm{N} / \mathrm{L}$ & $\mathrm{N} / \mathrm{L}$ & $\mathrm{N} / \mathrm{L}$ & $\mathrm{N} / \mathrm{L}$ \\
\hline & & & Pacta Su & rvanda & Autono & da Vontade \\
\hline Autor & & & Autor & Juiz & Autor & Juiz \\
\hline $\mathrm{N} / \mathrm{L}$ & & & $\mathrm{N} / \mathrm{L}$ & $\mathrm{N} / \mathrm{L}$ & $\mathrm{N} / \mathrm{L}$ & $\mathrm{N} / \mathrm{L}$ \\
\hline Inerêl & & & Contrat & atório & & lação \\
\hline Autor & & & Autor & Juiz & Autor & Juiz \\
\hline $\mathrm{N} / \mathrm{L}$ & & & $\mathrm{N} / \mathrm{L}$ & $\mathrm{N} / \mathrm{L}$ & $\mathrm{N} / \mathrm{L}$ & $\mathrm{N} / \mathrm{L}$ \\
\hline & & & & & & \\
\hline $\begin{array}{l}\text { Ela se bene } \\
\text { percebendo } \\
\text { submeter-se } \\
\text { Adiantou-se }\end{array}$ & & & o crédit & $\begin{array}{l}\text { no } C D \\
\text { erior do }\end{array}$ & $\begin{array}{l}a o f a \\
\text { ão } q u\end{array}$ & $\begin{array}{l}\text { último resgate, } \\
\text { nvenientemente, } \\
\text { iaria o banco. }\end{array}$ \\
\hline
\end{tabular}

\footnotetext{
${ }^{5}$ Vide Apêndice 27-SP e Apêndice 28-SP em que a sociedade não financeira é requerente e o Banco do Brasil é requerido.
} 
$\underline{\text { Apêndice 27-SP }}$

\begin{tabular}{|c|c|c|c|c|c|}
\hline \multicolumn{2}{|c|}{ Processo } & Peça & \multicolumn{2}{|c|}{ Ambiente } & Produto \\
\hline 71074 & & Apelação & \multicolumn{2}{|c|}{ Não Informado } & Swap \\
\hline \multicolumn{2}{|c|}{ Juiz } & Autor & \multicolumn{2}{|c|}{ Réu } & Valor \\
\hline \multicolumn{2}{|c|}{ Itamar Gaino } & $\begin{array}{l}\text { Sociedade não } \\
\text { financeira }\end{array}$ & Banco do $\mathrm{F}$ & & $500 \mathrm{k}-750 \mathrm{k}$ \\
\hline \multicolumn{2}{|c|}{ Data do Julgamento } & Data do Fato & \multicolumn{2}{|c|}{ Provimento } & Mérito \\
\hline \multicolumn{2}{|c|}{$28 / 03 / 2007$} & Janeiro 1999 & \multicolumn{2}{|c|}{ Não Provida } & Pró IF \\
\hline \multicolumn{2}{|c|}{ Suitability } & \multicolumn{2}{|c|}{ Coação } & \multicolumn{2}{|c|}{ Danos Morais } \\
\hline Autor & & Autor & Juiz & Autor & Juiz \\
\hline $\mathrm{N} / \mathrm{L}$ & & $\mathrm{N} / \mathrm{L}$ & $\mathrm{N} / \mathrm{L}$ & $\mathrm{N} / \mathrm{L}$ & $\mathrm{N} / \mathrm{L}$ \\
\hline \multicolumn{2}{|c|}{ Danos Materiais } & \multicolumn{2}{|c|}{$\mathrm{CDC}$} & \multicolumn{2}{|c|}{ Contrato de Adesão } \\
\hline Autor & & Autor & Juiz & Autor & Juiz \\
\hline $\mathrm{N} / \mathrm{L}$ & & $\mathrm{N} / \mathrm{L}$ & $\mathrm{N} / \mathrm{L}$ & $\mathrm{N} / \mathrm{L}$ & $\mathrm{N} / \mathrm{L}$ \\
\hline \multicolumn{2}{|c|}{ Lesão } & \multicolumn{2}{|c|}{ Onerosidade Excessiva } & \multicolumn{2}{|c|}{ Cláusulas Abusivas } \\
\hline Autor & & Autor & Juiz & Autor & Juiz \\
\hline $\mathrm{N} / \mathrm{L}$ & & $\mathrm{N} / \mathrm{L}$ & $\mathrm{N} / \mathrm{L}$ & $\mathrm{N} / \mathrm{L}$ & $\mathrm{N} / \mathrm{L}$ \\
\hline \multicolumn{2}{|c|}{ Teoria da Imprevisão } & \multicolumn{2}{|c|}{$\begin{array}{l}\text { Defeito de Representação } \\
\text { Defeito de Formalização }\end{array}$} & \multicolumn{2}{|c|}{ Hipossuficiência } \\
\hline Autor & & Autor & Juiz & Autor & Juiz \\
\hline $\mathrm{N} / \mathrm{L}$ & & $\mathrm{N} / \mathrm{L}$ & $\mathrm{N} / \mathrm{L}$ & $\mathrm{N} / \mathrm{L}$ & $\mathrm{N} / \mathrm{L}$ \\
\hline \multicolumn{2}{|c|}{ Erro } & Esta & e Perigo & & olo \\
\hline Autor & & Autor & Juiz & Autor & Juiz \\
\hline $\mathrm{N} / \mathrm{L}$ & & $\mathrm{N} / \mathrm{L}$ & $\mathrm{N} / \mathrm{L}$ & $\mathrm{N} / \mathrm{L}$ & $\mathrm{N} / \mathrm{L}$ \\
\hline & & Pacta & Servanda & Autone & da Vontade \\
\hline Autor & & Autor & Juiz & Autor & Juiz \\
\hline $\mathrm{N} / \mathrm{L}$ & & $\mathrm{N} / \mathrm{L}$ & $\mathrm{N} / \mathrm{L}$ & $\mathrm{N} / \mathrm{L}$ & $\mathrm{N} / \mathrm{L}$ \\
\hline Inerêl & & Cont & Aleatório & & lação \\
\hline Autor & & Autor & Juiz & Autor & Juiz \\
\hline $\mathrm{N} / \mathrm{L}$ & & $\mathrm{N} / \mathrm{L}$ & $\mathrm{N} / \mathrm{L}$ & $\mathrm{N} / \mathrm{L}$ & $\mathrm{N} / \mathrm{L}$ \\
\hline & & & ário & & \\
\hline $\begin{array}{l}\text { Embora ef } \\
\text { questionada } \\
\text { também ela } \\
\text { nada indica } \\
\text { registro dos }\end{array}$ & & $\begin{array}{l}\text { presen } \\
\text { relacio } \\
\text { WAP CD } \\
\text { haja ace } \\
\text { ao Banc }\end{array}$ & $\begin{array}{l}s \text { autos os } \\
\text { to histórico } \\
\text { RO. Não ha } \\
\text { o. Reforça } \\
\text { tral. }\end{array}$ & $\begin{array}{l}\text { itos relo } \\
\text { s partes } \\
\text { io plausí }\end{array}$ & $\begin{array}{l}\text { às operações } \\
\text { resunção de que } \\
\text { ara alteração. E } \\
\text { ncontroverso do }\end{array}$ \\
\hline
\end{tabular}

${ }^{6}$ Vide Apêndice 26-SP em que a o Banco Ribeirão Preto é requerente e a sociedade não financeira requerida, bem como Apêndice 28-SP em que a sociedade não financeira é requerente e o Banco do Brasil é requerido. 
Apêndice 28-SP

\begin{tabular}{|c|c|c|c|c|c|}
\hline \multicolumn{2}{|c|}{ Processo } & Peça & \multicolumn{2}{|c|}{ Ambiente } & Produto \\
\hline \multicolumn{2}{|c|}{$7107429-2 / 01$} & $\begin{array}{l}\text { Embargos de } \\
\text { Declaração }\end{array}$ & \multicolumn{2}{|c|}{ Não Informado } & Swap \\
\hline \multicolumn{2}{|c|}{ Juiz } & Autor & \multicolumn{2}{|c|}{ Réu } & Valor \\
\hline \multicolumn{2}{|c|}{ Itamar Gaino } & $\begin{array}{l}\text { Sociedade não } \\
\text { financeira }\end{array}$ & \multicolumn{2}{|c|}{ Banco do Brasil S.A. } & $500 \mathrm{k}-750 \mathrm{k}$ \\
\hline \multicolumn{2}{|c|}{ Data do Julgamento } & \multirow{2}{*}{$\begin{array}{c}\text { Data do Fato } \\
\text { Janeiro } 1999\end{array}$} & \multicolumn{2}{|c|}{$\begin{array}{l}\text { Provimento } \\
\text { Não Provida }\end{array}$} & Mérito \\
\hline $27 / 06$ & & & Não Pr & & Pró IF \\
\hline \multicolumn{2}{|c|}{ Suitability } & \multicolumn{2}{|c|}{ Coação } & \multicolumn{2}{|c|}{ Danos Morais } \\
\hline Autor & & Autor & Juiz & Autor & Juiz \\
\hline $\mathrm{N} / \mathrm{L}$ & & $\mathrm{N} / \mathrm{L}$ & $\mathrm{N} / \mathrm{L}$ & $\mathrm{N} / \mathrm{L}$ & $\mathrm{N} / \mathrm{L}$ \\
\hline \multicolumn{2}{|c|}{ Danos Materiais } & \multicolumn{2}{|c|}{$\mathrm{CDC}$} & \multicolumn{2}{|c|}{ Contrato de Adesão } \\
\hline Autor & & Autor & Juiz & Autor & Juiz \\
\hline $\mathrm{N} / \mathrm{L}$ & & $\mathrm{N} / \mathrm{L}$ & $\mathrm{N} / \mathrm{L}$ & $\mathrm{N} / \mathrm{L}$ & $\mathrm{N} / \mathrm{L}$ \\
\hline \multicolumn{2}{|c|}{ Lesão } & \multicolumn{2}{|c|}{ Onerosidade Excessiva } & \multicolumn{2}{|c|}{ Cláusulas Abusivas } \\
\hline Autor & & Autor & Juiz & Autor & Juiz \\
\hline $\mathrm{N} / \mathrm{L}$ & & $\mathrm{N} / \mathrm{L}$ & $\mathrm{N} / \mathrm{L}$ & $\mathrm{N} / \mathrm{L}$ & $\mathrm{N} / \mathrm{L}$ \\
\hline \multicolumn{2}{|c|}{ Teoria da Imprevisão } & \multicolumn{2}{|c|}{$\begin{array}{l}\text { Defeito de Representação / } \\
\text { Defeito de Formalização }\end{array}$} & Hip & íciência \\
\hline Autor & & Autor & Juiz & Autor & Juiz \\
\hline $\mathrm{N} / \mathrm{L}$ & & Sim & $\mathrm{N} / \mathrm{L}$ & $\mathrm{N} / \mathrm{L}$ & $\mathrm{N} / \mathrm{L}$ \\
\hline & & Esta & Perigo & & lo \\
\hline Autor & & Autor & Juiz & Autor & Juiz \\
\hline $\mathrm{N} / \mathrm{L}$ & & $\mathrm{N} / \mathrm{L}$ & $\mathrm{N} / \mathrm{L}$ & $\mathrm{N} / \mathrm{L}$ & $\mathrm{N} / \mathrm{L}$ \\
\hline & & Pacta & Servanda & Autono & da Vontade \\
\hline Autor & & Autor & Juiz & Autor & Juiz \\
\hline $\mathrm{N} / \mathrm{L}$ & & $\mathrm{N} / \mathrm{L}$ & Sim & $\mathrm{N} / \mathrm{L}$ & $\mathrm{N} / \mathrm{L}$ \\
\hline Inerêt & Risc & Cont1 & leatório & & lação \\
\hline Autor & & Autor & Juiz & Autor & Juiz \\
\hline $\mathrm{N} / \mathrm{L}$ & & $\mathrm{N} / \mathrm{L}$ & $\mathrm{N} / \mathrm{L}$ & $\mathrm{N} / \mathrm{L}$ & $\mathrm{N} / \mathrm{L}$ \\
\hline & & & rio & & \\
\hline $\begin{array}{l}\text { Como ficou } \\
\text { operações d } \\
\text { efeito infrin } \\
\text { conveniente }\end{array}$ & & $\begin{array}{l}\text { o débito } \\
\text { iente contı } \\
\text { deseja imt }\end{array}$ & $\begin{array}{l}\text { nta corrent } \\
\text { s entre as } p\end{array}$ & $\begin{array}{l}\text { ora foi } r \\
\text { ndo, por }\end{array}$ & $\begin{array}{l}\text { resultado de } \\
\text { injustificado o } \\
\text { do não lhe ser }\end{array}$ \\
\hline
\end{tabular}

${ }^{7}$ Vide Apêndice 26-SP em que a o Banco Ribeirão Preto é requerente e a sociedade não financeira requerida, bem como Apêndice 27-SP em que a sociedade não financeira é requerente e o Banco do Brasil é requerido. 


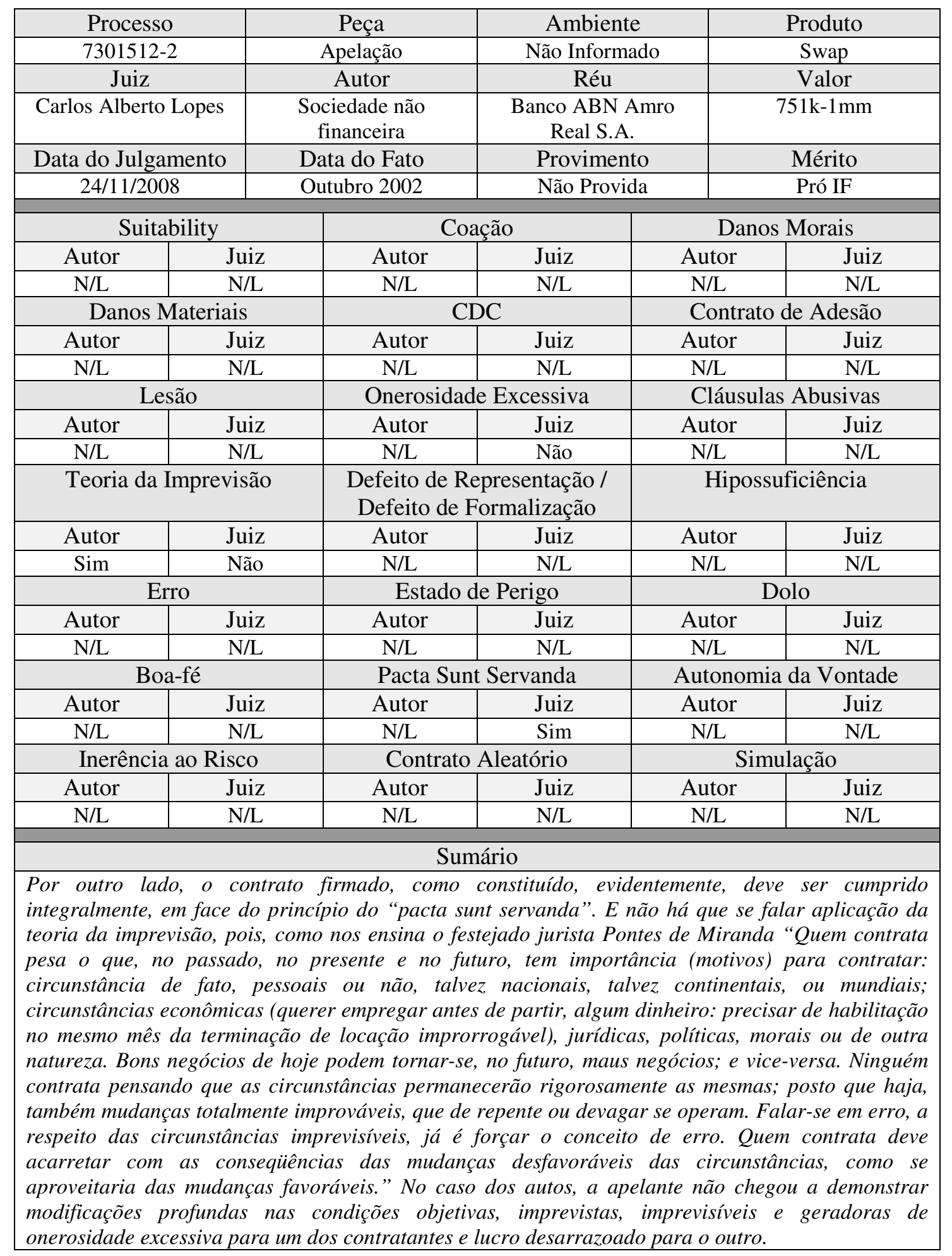


Apêndice 30-SP

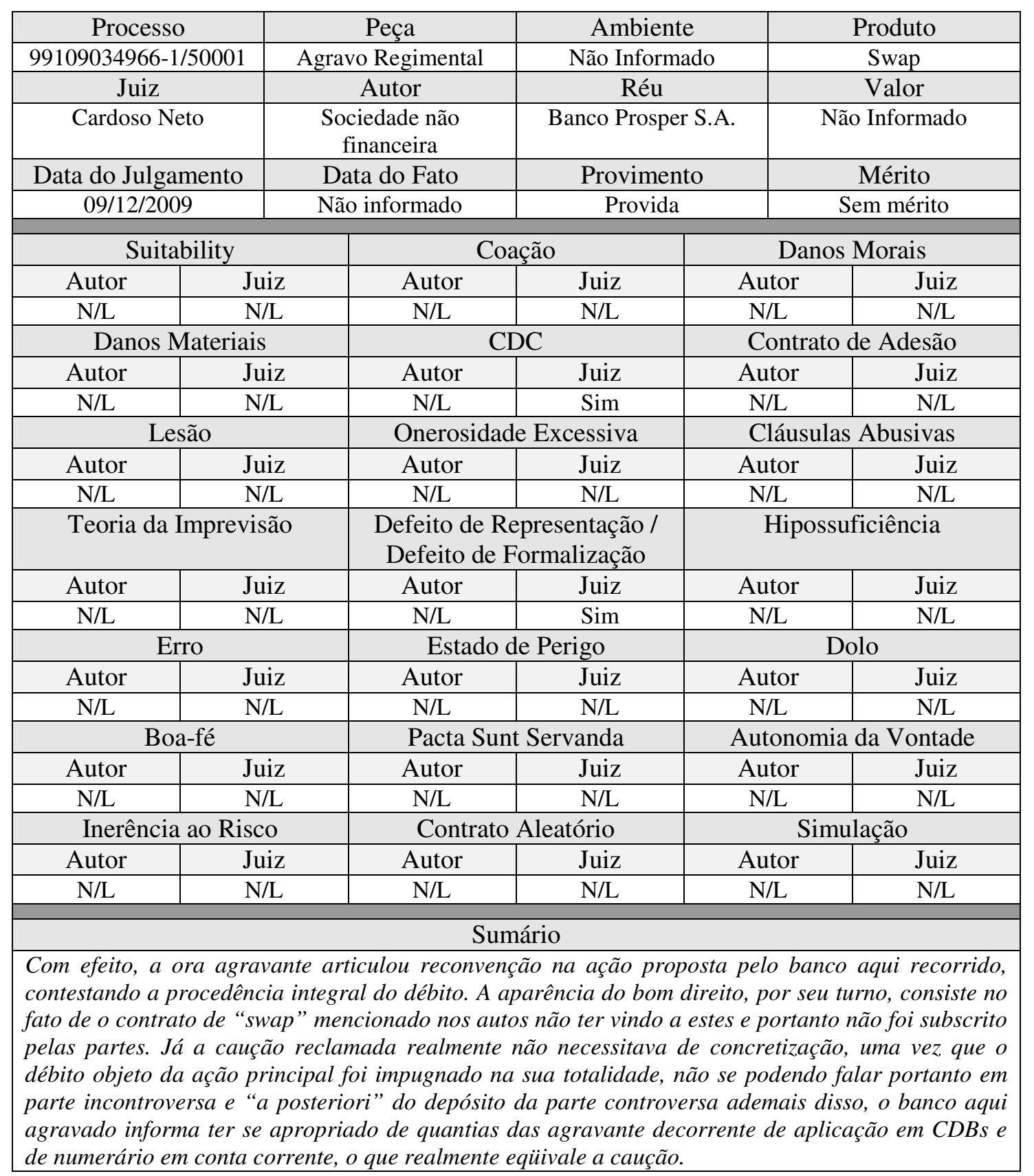


Apêndice 31-SP

\begin{tabular}{|c|c|c|c|c|c|c|}
\hline & \multicolumn{2}{|r|}{ Peça } & \multicolumn{2}{|c|}{ Ambiente } & Produto \\
\hline & \multicolumn{2}{|c|}{$\begin{array}{l}\text { Embargos de } \\
\text { Declaração }\end{array}$} & \multicolumn{2}{|c|}{ Balcão } & Opção \\
\hline \multicolumn{2}{|c|}{ Juiz } & \multicolumn{2}{|c|}{ Autor } & \multicolumn{2}{|c|}{ Réu } & Valor \\
\hline \multicolumn{2}{|c|}{ Lino Machado } & \multicolumn{2}{|c|}{ Banco Santos S.A. } & \multicolumn{2}{|c|}{$\begin{array}{l}\text { Sociedade não } \\
\text { financeira }\end{array}$} & cima $10 \mathrm{~mm}$ \\
\hline \multicolumn{2}{|c|}{ Data do Julgamento } & \multicolumn{2}{|c|}{ Data do Fato } & \multicolumn{2}{|c|}{ Provimento } & Mérito \\
\hline $27 / 10$ & & & mbro 2004 & Não P & & Contra IF \\
\hline \multicolumn{2}{|c|}{ Suitability } & & \multicolumn{2}{|c|}{ Coação } & \multicolumn{2}{|c|}{ Danos Morais } \\
\hline Autor & & & Autor & Juiz & Autor & Juiz \\
\hline $\mathrm{N} / \mathrm{L}$ & & & $\mathrm{N} / \mathrm{L}$ & $\mathrm{N} / \mathrm{L}$ & $\mathrm{N} / \mathrm{L}$ & $\mathrm{N} / \mathrm{L}$ \\
\hline \multicolumn{3}{|c|}{ Danos Materiais } & \multicolumn{2}{|c|}{$\mathrm{CDC}$} & \multicolumn{2}{|c|}{ Contrato de Adesão } \\
\hline Autor & & & Autor & Juiz & Autor & Juiz \\
\hline $\mathrm{N} / \mathrm{L}$ & & & $\mathrm{N} / \mathrm{L}$ & $\mathrm{N} / \mathrm{L}$ & $\mathrm{N} / \mathrm{L}$ & $\mathrm{N} / \mathrm{L}$ \\
\hline \multicolumn{2}{|c|}{ Lesão } & & \multicolumn{2}{|c|}{ Onerosidade Excessiva } & \multicolumn{2}{|c|}{ Cláusulas Abusivas } \\
\hline Autor & & & Autor & Juiz & Autor & Juiz \\
\hline $\mathrm{N} / \mathrm{L}$ & & & $\mathrm{N} / \mathrm{L}$ & $\mathrm{N} / \mathrm{L}$ & $\mathrm{N} / \mathrm{L}$ & $\mathrm{N} / \mathrm{L}$ \\
\hline \multicolumn{3}{|c|}{ Teoria da Imprevisão } & \multicolumn{2}{|c|}{$\begin{array}{l}\text { Defeito de Representação } \\
\text { Defeito de Formalização }\end{array}$} & Hip & iciência \\
\hline Autor & & & Autor & Juiz & Autor & Juiz \\
\hline $\mathrm{N} / \mathrm{L}$ & & & $\mathrm{N} / \mathrm{L}$ & $\mathrm{N} / \mathrm{L}$ & $\mathrm{N} / \mathrm{L}$ & $\mathrm{N} / \mathrm{L}$ \\
\hline & & & Esta & rigo & & \\
\hline Autor & & & Autor & Juiz & Autor & Juiz \\
\hline $\mathrm{N} / \mathrm{L}$ & & & $\mathrm{N} / \mathrm{L}$ & $\mathrm{N} / \mathrm{L}$ & $\mathrm{N} / \mathrm{L}$ & $\mathrm{N} / \mathrm{L}$ \\
\hline & & & Pacta & vanda & Autono & da Vontade \\
\hline Autor & & & Autor & Juiz & Autor & Juiz \\
\hline $\mathrm{N} / \mathrm{L}$ & & & $\mathrm{N} / \mathrm{L}$ & $\mathrm{N} / \mathrm{L}$ & $\mathrm{N} / \mathrm{L}$ & $\mathrm{N} / \mathrm{L}$ \\
\hline Inerêl & Risc & & Cont1 & atório & & lação \\
\hline Autor & $\mathrm{Ju}$ & & Autor & Juiz & Autor & Juiz \\
\hline $\mathrm{N} / \mathrm{L}$ & & & $\mathrm{N} / \mathrm{L}$ & $\mathrm{N} / \mathrm{L}$ & $\mathrm{N} / \mathrm{L}$ & $\mathrm{N} / \mathrm{L}$ \\
\hline & & & & & & \\
\hline $\begin{array}{l}\text { Em síntese, } \\
\text { movidos pel } \\
\text { favorável à } \\
\text { irreformáve } \\
\text { sua pretensa } \\
\text { impressione } \\
\text { o equivalent } \\
\text { honorários } \\
R \$ 2.900 .000 \\
\text { um bom aco } \\
\text { risco de tud } \\
\text { conciliação }\end{array}$ & $\begin{array}{l}\text { tido } \\
\text { ins } \\
\text { im c } \\
\text { enta } \\
\text { cios } \\
245 \\
\text { ihan } \\
\text { Is } \\
\text { umir }\end{array}$ & dit & $\begin{array}{l}\text { amentos de } \\
\text { luais fez aco } \\
\text { esso movido } \\
\text { né de ser co } \\
\text { periores, se } \\
\text { altíssimo val } \\
\text { equivalente } \\
\text { o pagos aos } \\
\text { revela desar } \\
\text { o ponto, am } \\
\text { da mais fort } \\
\text { sso Direito.' }\end{array}$ & $\begin{array}{l}\text { grau fa } \\
\text { ja julgan } \\
\text { eiro, con } \\
\text { lo que as } \\
\text { n nas ins } \\
\text { sa falida } \\
5.528 .126 \\
\text { dos cont } \\
\text { o celebr } \\
\text { artes, as } \\
\text { quando } s\end{array}$ & $\begin{array}{l}\text { à massa } \\
\text { ta Câma } \\
\text { er duvid } \\
\text { avadas } \\
\text { ordináric } \\
\text { ncordaa } \\
\text { 1) "fora } \\
\text { ela mas. } \\
\text { as deved } \\
\text { o mesmo }\end{array}$ & $\begin{array}{l}\text { la em processos } \\
\text { special, também } \\
\text { solução final e } \\
\text { l levar, em tese, } \\
\text { or isso, embora } \\
\text { receber apenas } \\
\text { rgos relativos a } \\
\text { ida no valor de } \\
\text { sabido que, em } \\
\text { o, se livram do } \\
\text { nde papel que a }\end{array}$ \\
\hline
\end{tabular}


Apêndice 32-SP

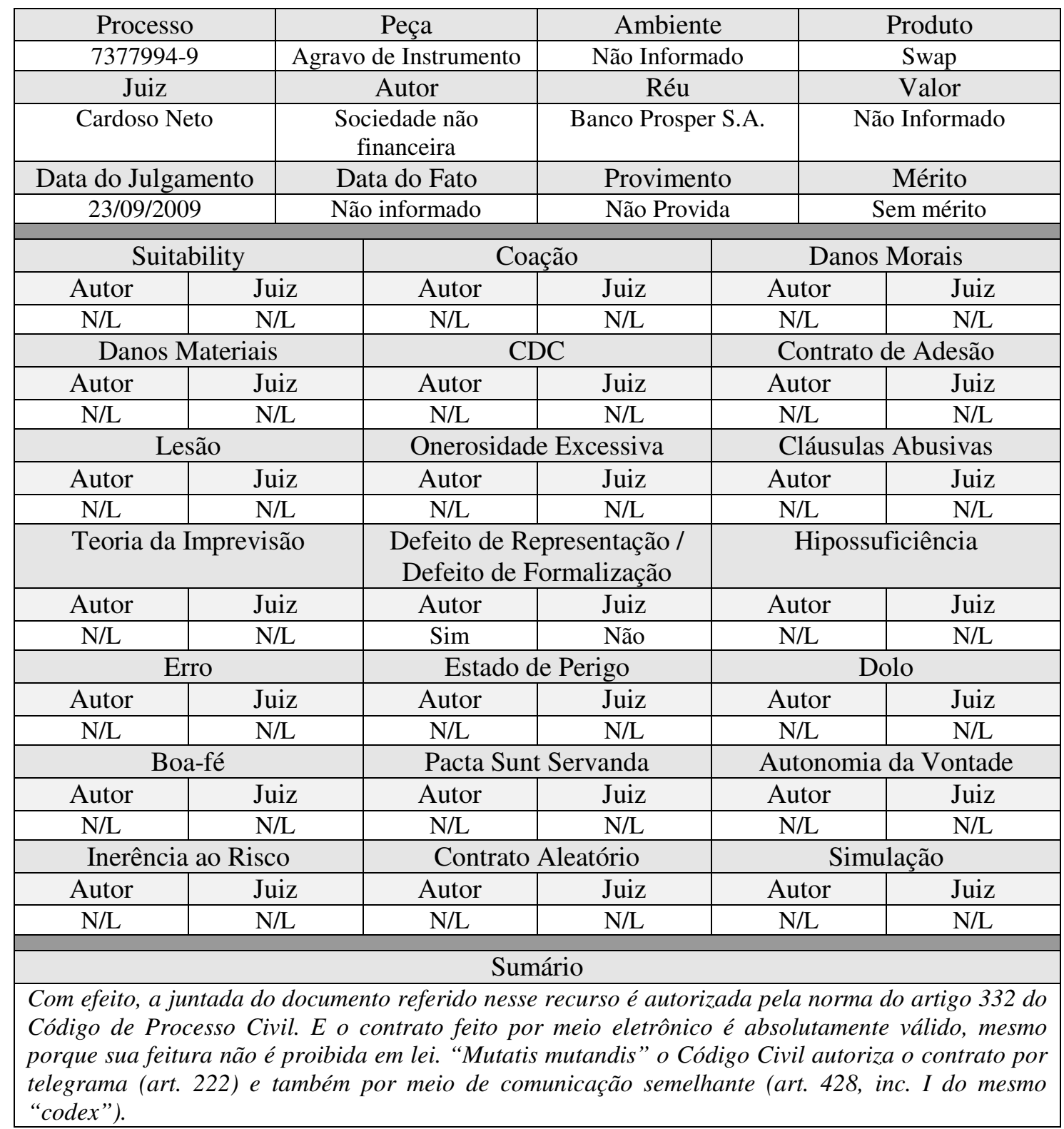


Apêndice 33-SP

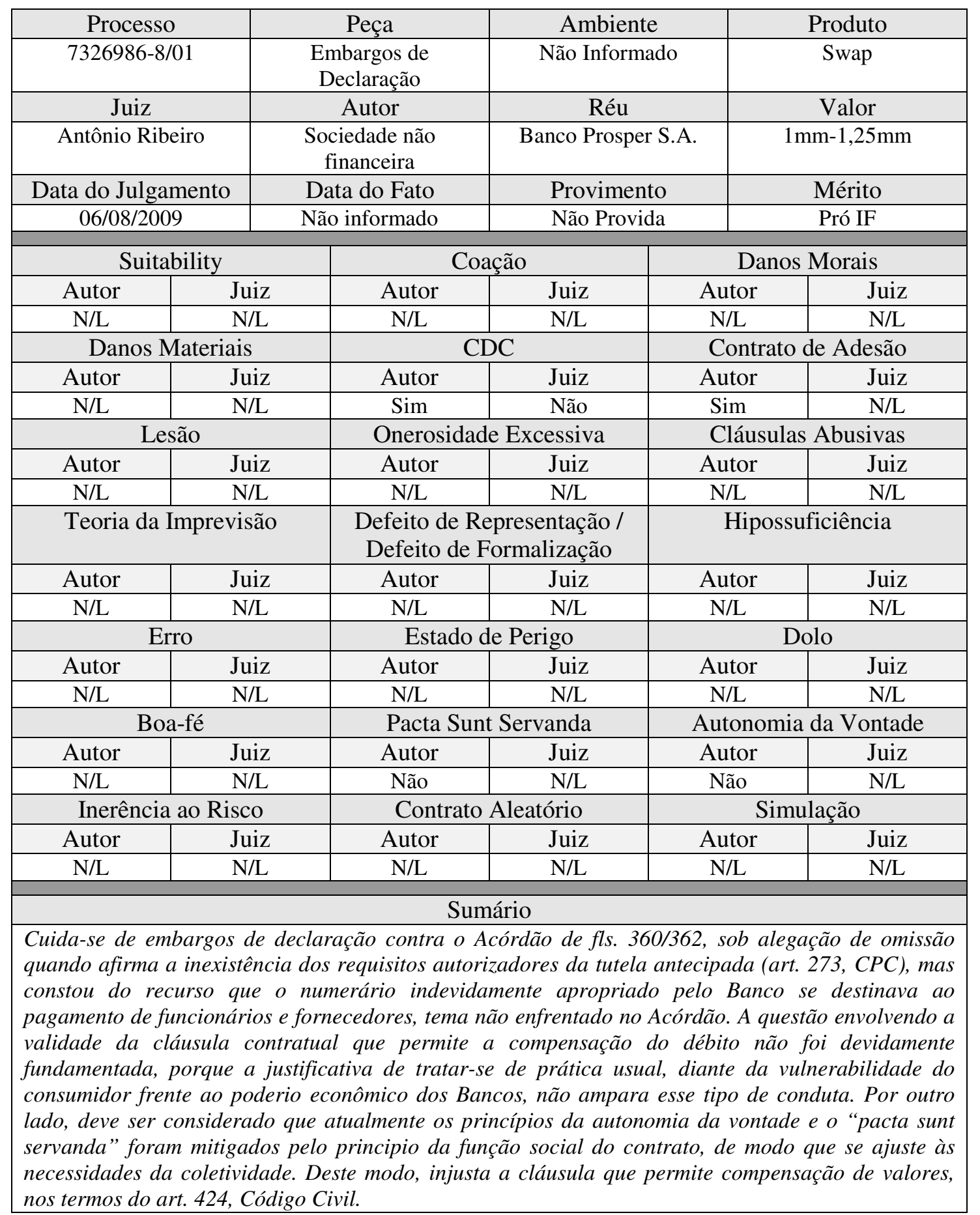


Apêndice 34-SP

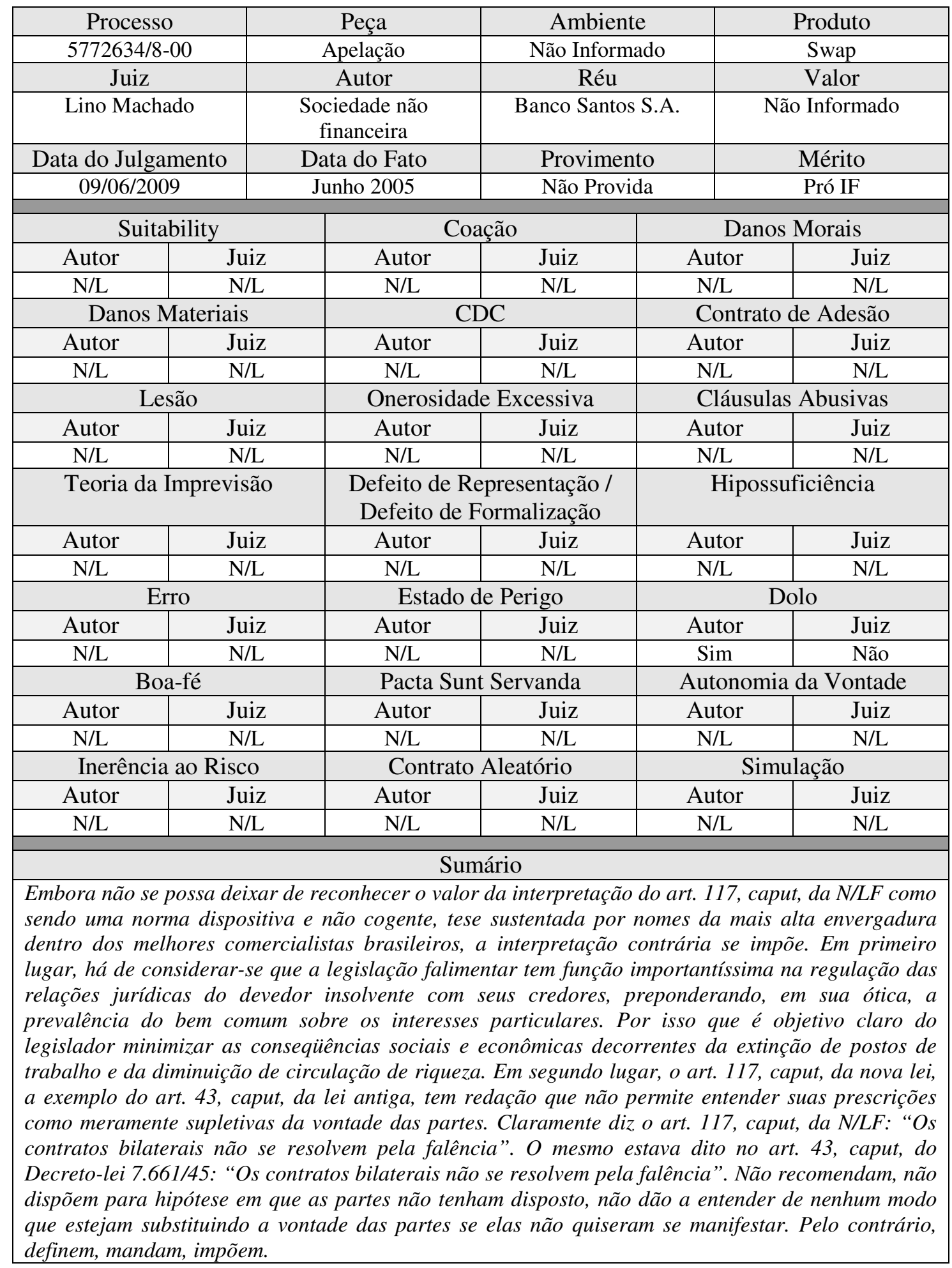

${ }^{8}$ Os Apêndices 34-SP, 35-SP e 36-SP trazem os votos de 3 desembargadores sobre o mesmo caso. Atipicamente, nesta apelação, os 3 juízes proferiram cada um o seu voto. 
$\underline{\text { Apêndice } 35-\mathrm{SP}^{9}}$

\begin{tabular}{|c|c|c|c|c|c|}
\hline \multicolumn{2}{|c|}{ Processo } & Peça & \multicolumn{2}{|c|}{ Ambiente } & Produto \\
\hline \multicolumn{2}{|c|}{$5772634 / 8-00$} & Apelação & \multicolumn{2}{|c|}{ Não Informado } & Swap \\
\hline \multicolumn{2}{|c|}{ Juiz } & Autor & \multicolumn{2}{|c|}{ Réu } & Valor \\
\hline \multicolumn{2}{|c|}{ Romeu Ricupero } & $\begin{array}{l}\text { Sociedade não } \\
\text { financeira }\end{array}$ & \multicolumn{2}{|c|}{ Banco Santos S.A. } & Não Informado \\
\hline \multicolumn{2}{|c|}{ Data do Julgamento } & Data do Fato & \multicolumn{2}{|c|}{ Provimento } & Mérito \\
\hline \multicolumn{2}{|c|}{$09 / 06 / 2009$} & Junho 2005 & \multicolumn{2}{|c|}{ Não Provida } & Pró IF \\
\hline \multicolumn{2}{|c|}{ Suitability } & \multicolumn{2}{|c|}{ Coação } & \multicolumn{2}{|c|}{ Danos Morais } \\
\hline Autor & Juiz & Autor & Juiz & Autor & Juiz \\
\hline $\mathrm{N} / \mathrm{L}$ & $\mathrm{N} / \mathrm{L}$ & $\mathrm{N} / \mathrm{L}$ & $\mathrm{N} / \mathrm{L}$ & $\mathrm{N} / \mathrm{L}$ & $\mathrm{N} / \mathrm{L}$ \\
\hline \multicolumn{2}{|c|}{ Danos Materiais } & \multicolumn{2}{|c|}{$\mathrm{CDC}$} & \multicolumn{2}{|c|}{ Contrato de Adesão } \\
\hline Autor & Juiz & Autor & Juiz & Autor & Juiz \\
\hline $\mathrm{N} / \mathrm{L}$ & $\mathrm{N} / \mathrm{L}$ & $\mathrm{N} / \mathrm{L}$ & $\mathrm{N} / \mathrm{L}$ & $\mathrm{N} / \mathrm{L}$ & $\mathrm{N} / \mathrm{L}$ \\
\hline \multicolumn{2}{|c|}{ Lesão } & \multicolumn{2}{|c|}{ Onerosidade Excessiva } & \multicolumn{2}{|c|}{ Cláusulas Abusivas } \\
\hline Autor & Juiz & Autor & Juiz & Autor & Juiz \\
\hline $\mathrm{N} / \mathrm{L}$ & $\mathrm{N} / \mathrm{L}$ & $\mathrm{N} / \mathrm{L}$ & $\mathrm{N} / \mathrm{L}$ & $\mathrm{N} / \mathrm{L}$ & $\mathrm{N} / \mathrm{L}$ \\
\hline \multicolumn{2}{|c|}{ Teoria da Imprevisão } & \multicolumn{2}{|c|}{$\begin{array}{c}\text { Defeito de Representação / } \\
\text { Defeito de Formalização }\end{array}$} & Hipc & iciência \\
\hline Autor & Juiz & Autor & Juiz & Autor & Juiz \\
\hline $\mathrm{N} / \mathrm{L}$ & $\mathrm{N} / \mathrm{L}$ & $\mathrm{N} / \mathrm{L}$ & $\mathrm{N} / \mathrm{L}$ & $\mathrm{N} / \mathrm{L}$ & $\mathrm{N} / \mathrm{L}$ \\
\hline & & Esta & Perigo & & \\
\hline Autor & Juiz & Autor & Juiz & Autor & Juiz \\
\hline $\mathrm{N} / \mathrm{L}$ & $\mathrm{N} / \mathrm{L}$ & $\mathrm{N} / \mathrm{L}$ & $\mathrm{N} / \mathrm{L}$ & Sim & Não \\
\hline & & Pacta & ervanda & Autono & la Vontade \\
\hline Autor & Juiz & Autor & Juiz & Autor & Juiz \\
\hline $\mathrm{N} / \mathrm{L}$ & $\mathrm{N} / \mathrm{L}$ & Sim & $\mathrm{N} / \mathrm{L}$ & $\mathrm{N} / \mathrm{L}$ & $\mathrm{N} / \mathrm{L}$ \\
\hline Inerêr & Risco & Cont & eatório & & ação \\
\hline Autor & Juiz & Autor & Juiz & Autor & Juiz \\
\hline $\mathrm{N} / \mathrm{L}$ & $\mathrm{N} / \mathrm{L}$ & Sim & Sim & $\mathrm{N} / \mathrm{L}$ & $\mathrm{N} / \mathrm{L}$ \\
\hline & & & & & \\
\hline $\begin{array}{l}\text { Em suma, } n \\
\text { ser o pacto } \\
\text { (...) É evider } \\
\text { ele os artigo } \\
\text { do contrato } \\
\text { parte perdea }\end{array}$ & acusc & $\begin{array}{l}\text { banco de ter } \\
\text { ia saber, naqu } \\
\text { e swap não é } \\
76 \text { e } 477 \text { do } C \\
\text { ia interpelaçã } \\
\text { ra. }\end{array}$ & $\begin{array}{l}\text { om dolo ac } \\
\text { nento, se } r \\
\text { rato bilater } \\
\text { livil). (...) I } \\
\text { na, e sim a }\end{array}$ & $\begin{array}{l}\text { ar o contr } \\
\text { l, ao final } \\
\text { ito e, ass } \\
\text { de, diant }\end{array}$ & $\begin{array}{l}\text { e swap, se, por } \\
\text { edor ou credor. } \\
\text { áo se aplicam a } \\
\text { características } \\
\text { da avença pela }\end{array}$ \\
\hline
\end{tabular}

${ }^{9}$ Os Apêndices 34-SP, 35-SP e 36-SP trazem os votos de 3 desembargadores sobre o mesmo caso. Atipicamente, nesta apelação, os 3 juízes proferiram cada um o seu voto. 
Apêndice $36-\mathrm{SP}^{10}$

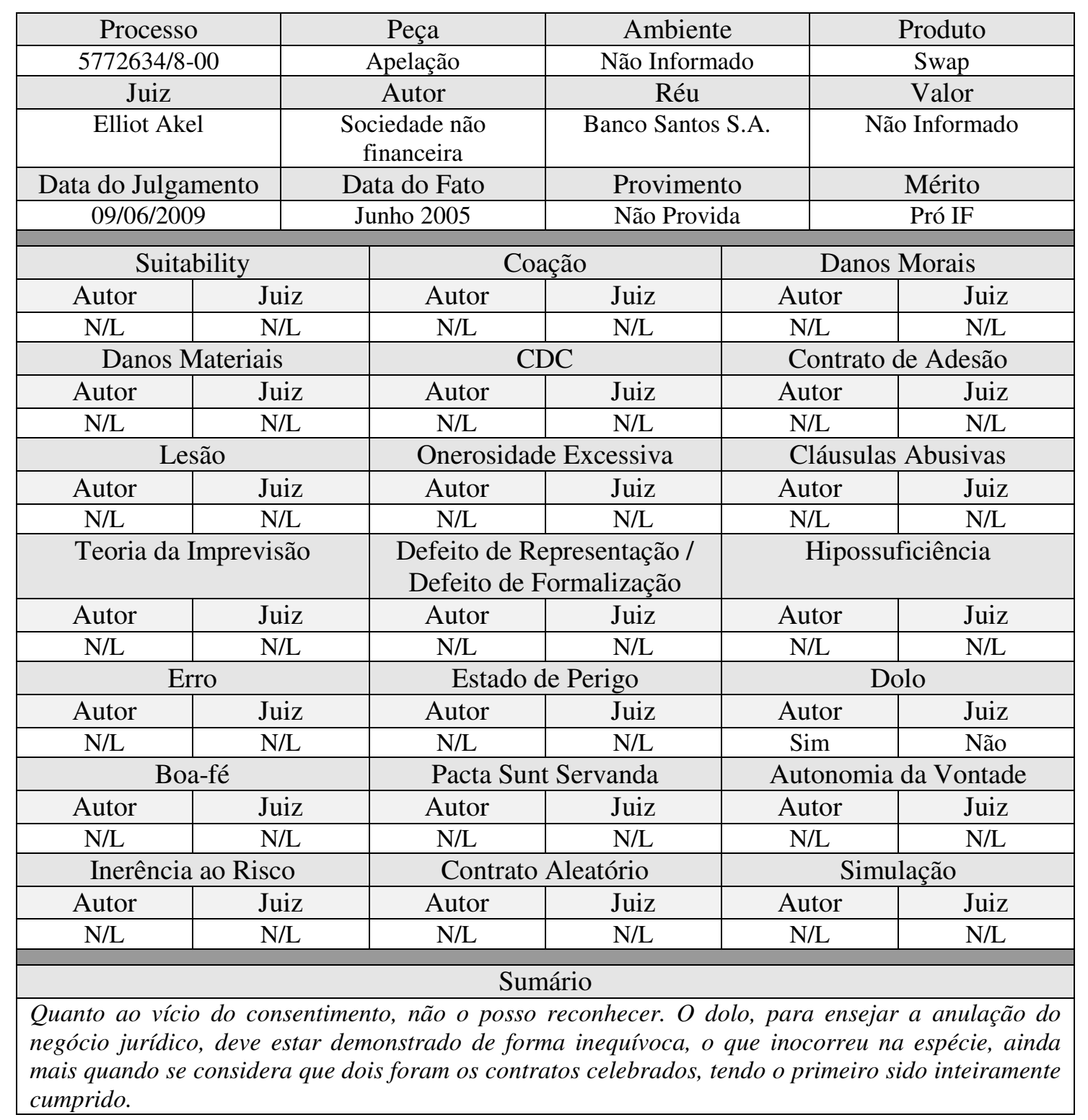

${ }^{10}$ Os Apêndices 34-SP, 35-SP e 36-SP trazem os votos de 3 desembargadores sobre o mesmo caso. Atipicamente, nesta apelação, os 3 juízes proferiram cada um o seu voto. 
Apêndice 37-SP

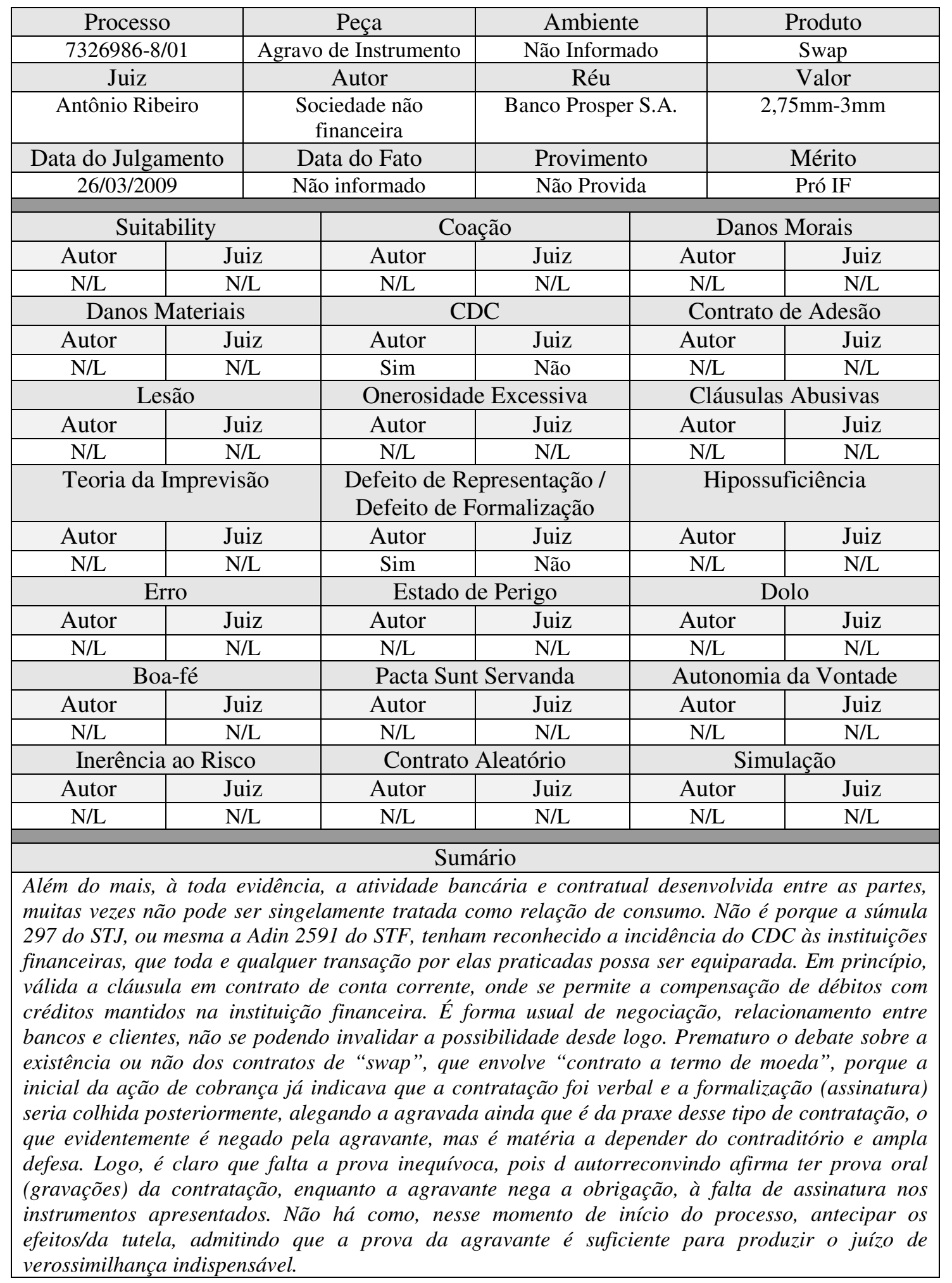


Apêndice 38-SP

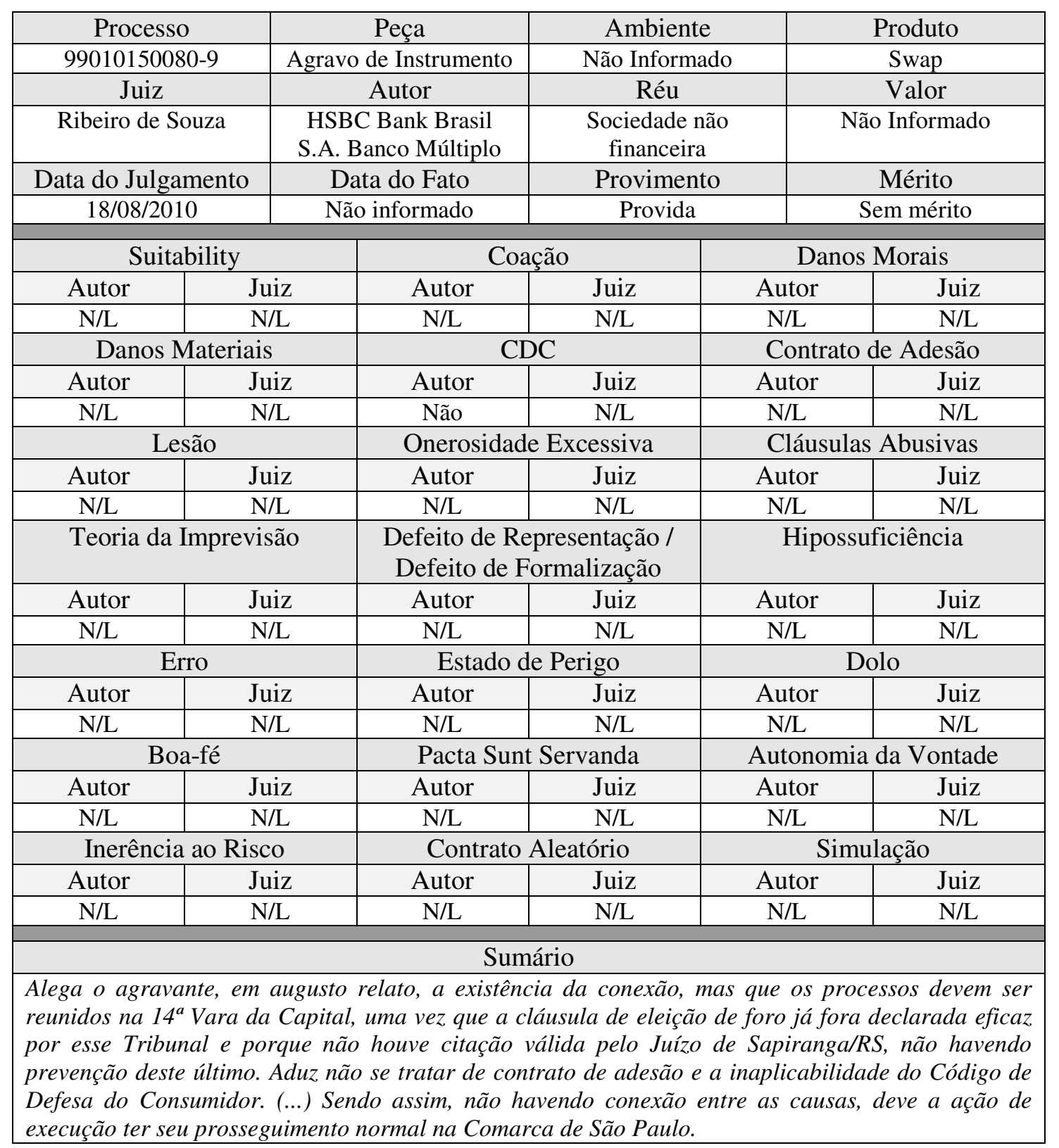


Apêndice $39-\mathrm{SP}^{11}$

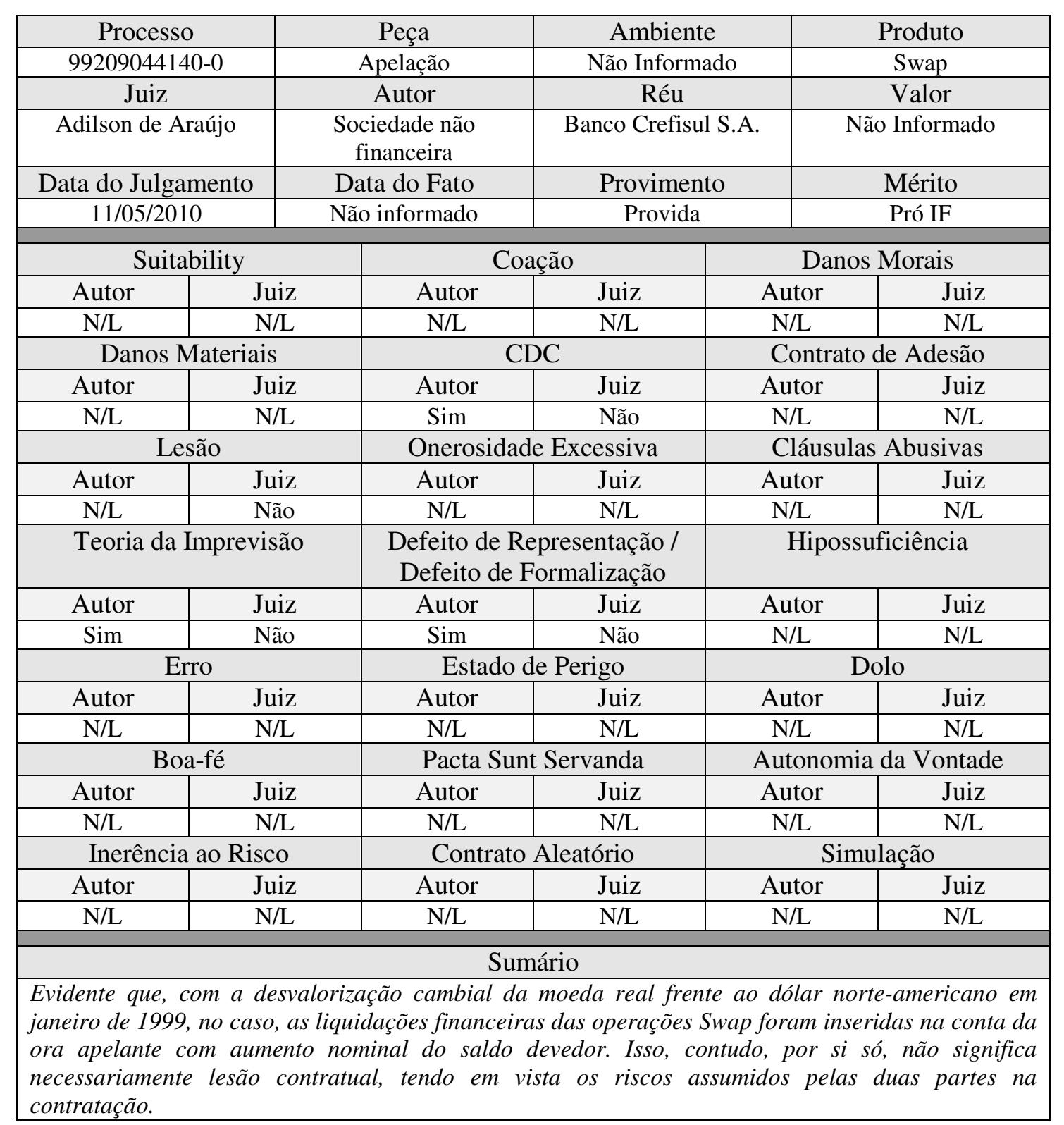

\footnotetext{
${ }^{11}$ Vide Apêndice 40-SP, em que o Banco Crefisul é requerente e a sociedade não financeira requerida.
} 
$\underline{\text { Apêndice } 40-\mathrm{SP}^{12}}$

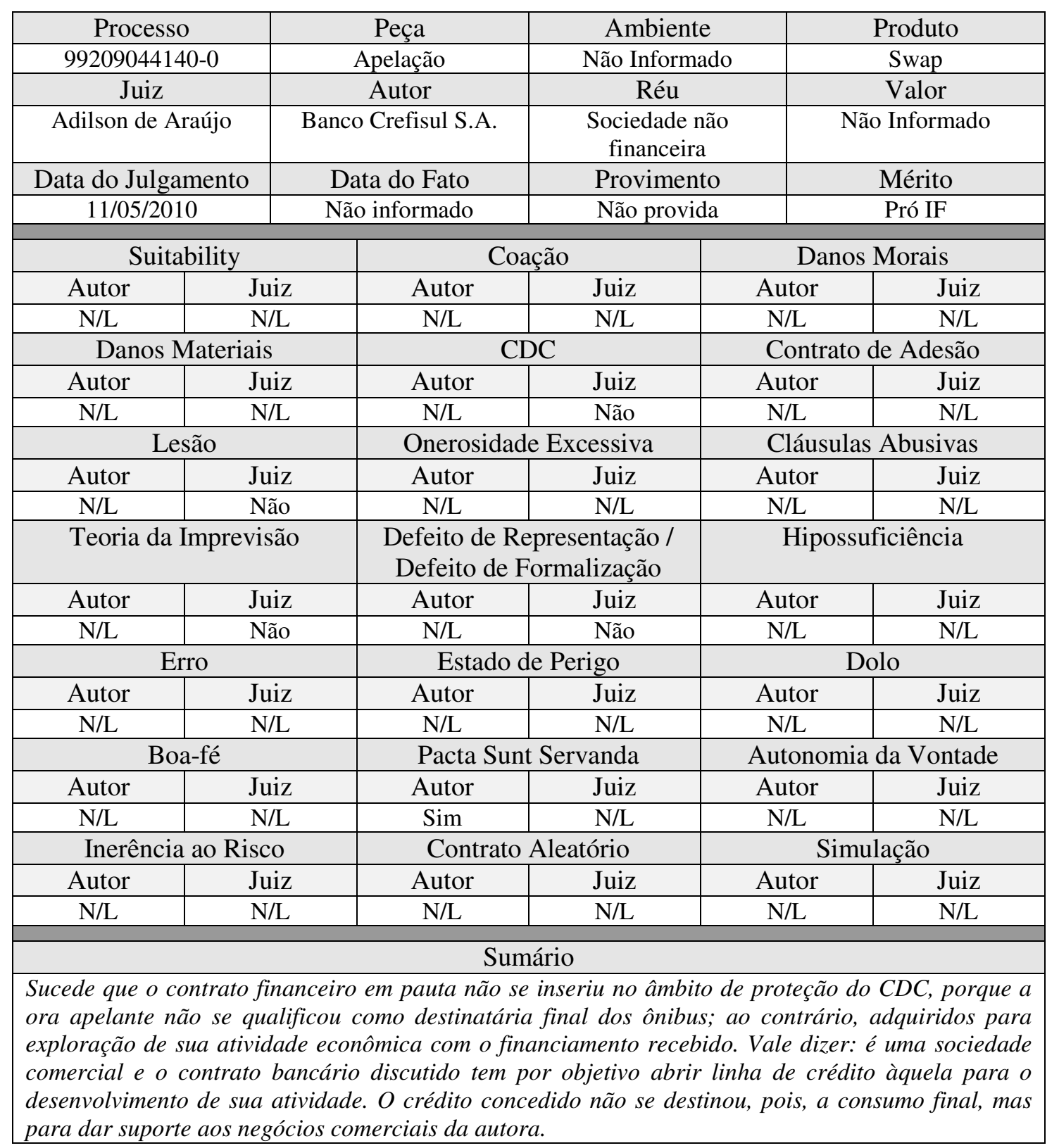

\footnotetext{
${ }^{12}$ Vide Apêndice 39-SP, em que a sociedade não financeira é requerente e o Banco Crefisul requerido.
} 
$\underline{\text { Apêndice } 41-\mathrm{SP}^{13}}$

\begin{tabular}{|c|c|c|c|c|c|c|c|}
\hline \multicolumn{2}{|c|}{ Processo } & \multicolumn{2}{|r|}{ Peça } & \multicolumn{2}{|c|}{ Ambiente } & \multicolumn{2}{|c|}{ Produto } \\
\hline \multicolumn{2}{|c|}{$99009338721-2 / 50000$} & \multicolumn{2}{|c|}{$\begin{array}{l}\text { Embargos de } \\
\text { Declaração }\end{array}$} & \multicolumn{2}{|c|}{ Não Informado } & \multicolumn{2}{|r|}{ Swap } \\
\hline \multicolumn{2}{|c|}{ Juiz } & \multicolumn{2}{|r|}{ Autor } & \multicolumn{2}{|l|}{ Réu } & \multicolumn{2}{|r|}{ Valor } \\
\hline \multicolumn{2}{|c|}{ Heraldo de Oliveira } & \multicolumn{2}{|c|}{$\begin{array}{c}\text { Sociedade não } \\
\text { financeira }\end{array}$} & \multicolumn{2}{|c|}{ Banco Itaú BBA S.A. } & \multicolumn{2}{|c|}{ Não Informado } \\
\hline \multicolumn{2}{|c|}{ Data do Julgamento } & \multirow{2}{*}{\multicolumn{2}{|c|}{$\begin{array}{c}\text { Data do Fato } \\
\text { Não informado } \\
\end{array}$}} & \multicolumn{2}{|c|}{ Provimento } & \multicolumn{2}{|r|}{ Mérito } \\
\hline $14 / 04$ & & & & Não Prov & & & Pró IF \\
\hline \multicolumn{2}{|c|}{ Suitability } & & \multicolumn{2}{|c|}{ Coação } & \multicolumn{3}{|c|}{ Danos Morais } \\
\hline Autor & $\overline{\mathrm{Ju}}$ & & Autor & Juiz & & & Juiz \\
\hline $\mathrm{N} / \mathrm{L}$ & $\mathrm{N} /$ & & $\mathrm{N} / \mathrm{L}$ & $\mathrm{N} / \mathrm{L}$ & & & $\mathrm{N} / \mathrm{L}$ \\
\hline \multicolumn{2}{|c|}{ Danos Materiais } & & \multicolumn{2}{|c|}{$\mathrm{CDC}$} & \multicolumn{3}{|c|}{ Contrato de Adesão } \\
\hline Autor & Jui & & Autor & Juiz & & & Juiz \\
\hline $\mathrm{N} / \mathrm{L}$ & $\mathrm{N} /$ & & Sim & Não & & & $\mathrm{N} / \mathrm{L}$ \\
\hline \multicolumn{2}{|c|}{ Lesão } & & \multicolumn{2}{|c|}{ Onerosidade Excessiva } & \multicolumn{3}{|c|}{ Cláusulas Abusivas } \\
\hline Autor & $\mathrm{Ju}$ & & Autor & Juiz & & & Juiz \\
\hline $\mathrm{N} / \mathrm{L}$ & $\mathrm{N} /$ & & $\mathrm{N} / \mathrm{L}$ & $\mathrm{N} / \mathrm{L}$ & & & $\mathrm{N} / \mathrm{L}$ \\
\hline \multicolumn{2}{|c|}{ Teoria da Imprevisão } & & \multicolumn{2}{|c|}{$\begin{array}{l}\text { Defeito de Representação / } \\
\text { Defeito de Formalização }\end{array}$} & & Hipos & iciência \\
\hline Autor & $\mathrm{Ju}$ & & Autor & Juiz & & & Juiz \\
\hline $\mathrm{N} / \mathrm{L}$ & $\mathrm{N} /$ & & $\mathrm{N} / \mathrm{L}$ & $\mathrm{N} / \mathrm{L}$ & & & $\mathrm{N} / \mathrm{L}$ \\
\hline & & & Est: & Perigo & & & \\
\hline Autor & Jui & & Autor & Juiz & & & Juiz \\
\hline $\mathrm{N} / \mathrm{L}$ & $\mathrm{N} /$ & & $\mathrm{N} / \mathrm{L}$ & $\mathrm{N} / \mathrm{L}$ & & & $\mathrm{N} / \mathrm{L}$ \\
\hline & & & Pacta & Servanda & & onom & la Vontade \\
\hline Autor & Jui & & Autor & Juiz & & & Juiz \\
\hline $\mathrm{N} / \mathrm{L}$ & $\mathrm{N} /$ & & $\mathrm{N} / \mathrm{L}$ & $\mathrm{N} / \mathrm{L}$ & & $\mathrm{L}$ & $\mathrm{N} / \mathrm{L}$ \\
\hline Inerê & Risce & & Cont & Aleatório & & & ação \\
\hline Autor & Jui & & Autor & Juiz & & & Juiz \\
\hline $\mathrm{N} / \mathrm{L}$ & $\mathrm{N} /$ & & $\mathrm{N} / \mathrm{L}$ & $\mathrm{N} / \mathrm{L}$ & & & $\mathrm{N} / \mathrm{L}$ \\
\hline & & & & ário & & & \\
\hline $\begin{array}{l}\text { Ademais, to } \\
\text { do contrato } \\
\text { investiment } \\
\text { Consumidor } \\
\text { se verifica } \\
\text { não restou } \\
\text { caso, o disp }\end{array}$ & $\begin{array}{l}\text { estô } \\
\text { não } \\
\text { ro }\end{array}$ & & $\begin{array}{l}\text { idas foram } \\
\text { desão, um } \\
\text { to, não s } \\
\text { usividaded } \\
\text { to de defes } \\
\text { prejuizo e }\end{array}$ & $\begin{array}{l}\text { iadas pelo v. } \\
\text { que se trata de } \\
\text { uadra nas hip } \\
\text { sula de foro de } \\
\text { equerida ou a } \\
\text { para o exercíc }\end{array}$ & & $\begin{array}{l}\text { dame } \\
\text { de ri } \\
\text { Cód } \\
\text { omo b } \\
\text { a refe } \\
\text { direit }\end{array}$ & $\begin{array}{l}\text { quanto ao fato } \\
\text { e alto grau de } \\
\text { de Defesa do } \\
\text { explanado, não } \\
\text { z cláusula, pois } \\
\text { plicando-se, no }\end{array}$ \\
\hline
\end{tabular}

${ }^{13}$ Os Apêndices 41-SP e 42-SP representam duas medidas protelatórias diferentes (embargos de declaração e agravo de instrumento, respectivamente) propostos pelo mesmo autor e sobre a mesma matéria (incompetência do juízo). 
$\underline{\text { Apêndice } 42-\mathrm{SP}^{14}}$

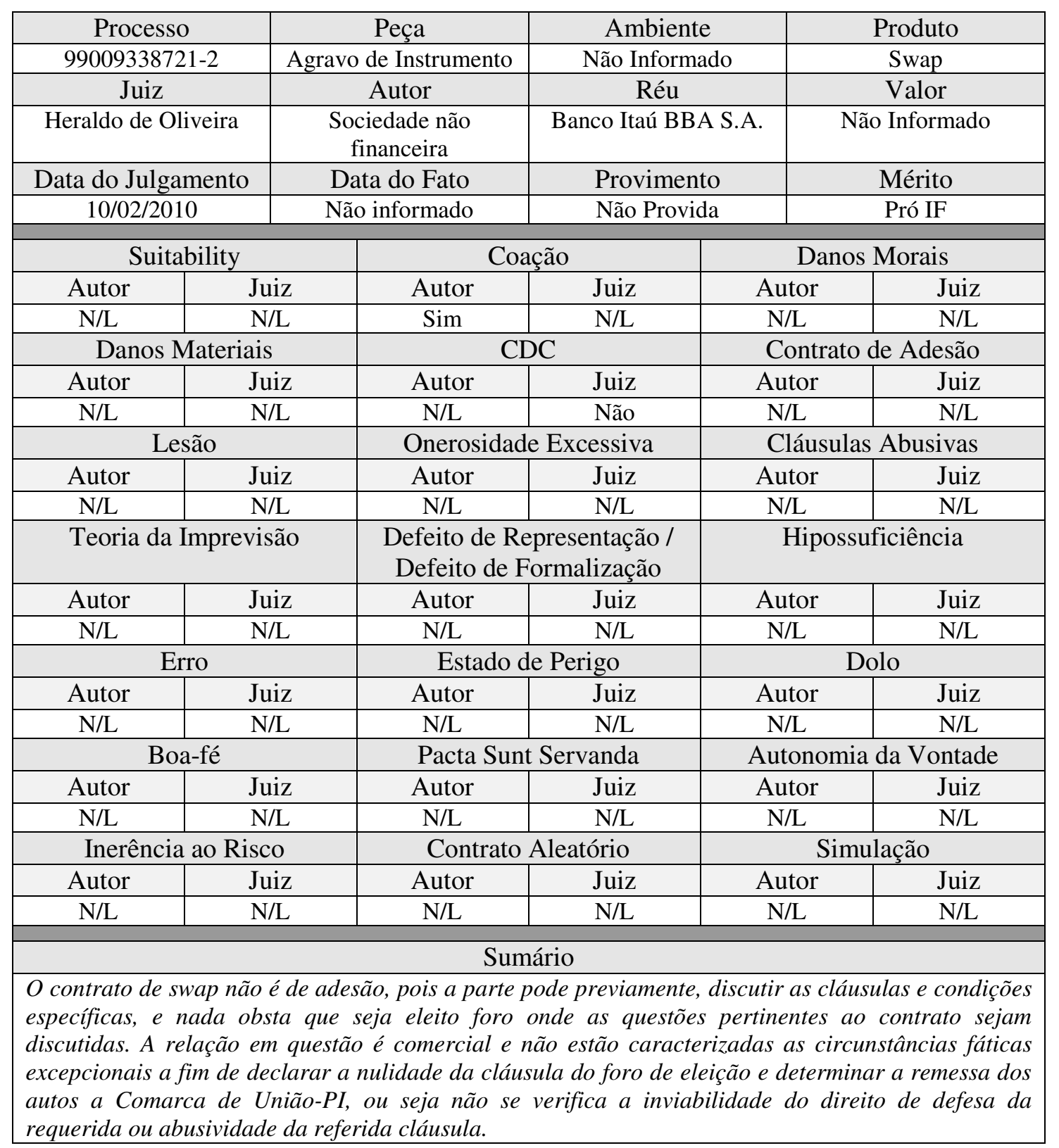

${ }^{14}$ Os Apêndices 41-SP e 42-SP representam duas medidas protelatórias diferentes (embargos de declaração e agravo de instrumento, respectivamente) propostos pelo mesmo autor e sobre a mesma matéria (incompetência do juízo). 
Apêndice 43-RJ

\begin{tabular}{|c|c|c|c|c|c|c|}
\hline \multicolumn{2}{|c|}{ Processo } & Peça & \multicolumn{2}{|c|}{ Ambiente } & \multicolumn{2}{|r|}{ Produto } \\
\hline \multicolumn{2}{|c|}{2006.001 .48804} & Apelação & \multicolumn{2}{|c|}{ N/A - Fundo } & \multicolumn{2}{|c|}{ Fundo de Investimento } \\
\hline \multicolumn{2}{|c|}{ Juiz } & Autor & \multicolumn{2}{|c|}{ Réu } & \multicolumn{2}{|r|}{ Valor } \\
\hline \multicolumn{2}{|c|}{$\begin{array}{c}\text { Vera Maria Van } \\
\text { Hombeeck }\end{array}$} & Pessoa Física & \multicolumn{2}{|c|}{$\begin{array}{l}\text { BES Boavista Espírito } \\
\text { Santo DTVM S.A. }\end{array}$} & \multicolumn{2}{|c|}{ Não Informado } \\
\hline \multicolumn{2}{|c|}{ Data do Julgamento } & Data do Fato & \multicolumn{2}{|c|}{ Provimento } & \multicolumn{2}{|r|}{ Mérito } \\
\hline \multicolumn{2}{|c|}{ 19/09/2006 } & Janeiro 1999 & \multicolumn{2}{|c|}{ Não Provida } & & Pró IF \\
\hline \multicolumn{2}{|c|}{ Suitability } & \multicolumn{2}{|c|}{ Coação } & \multicolumn{3}{|c|}{ Danos Morais } \\
\hline Autor & Juiz & Autor & Juiz & & & Juiz \\
\hline Não & Sim & Sim & Não & & & Não \\
\hline \multicolumn{2}{|c|}{ Danos Materiais } & \multicolumn{2}{|c|}{$\mathrm{CDC}$} & \multicolumn{3}{|c|}{ Contrato de Adesão } \\
\hline Autor & Juiz & Autor & Juiz & & tor & Juiz \\
\hline $\mathrm{N} / \mathrm{L}$ & $\mathrm{N} / \mathrm{L}$ & Sim & Não & & & $\mathrm{N} / \mathrm{L}$ \\
\hline \multicolumn{2}{|c|}{ Lesão } & \multicolumn{2}{|c|}{ Onerosidade Excessiva } & & láus & Abusivas \\
\hline Autor & Juiz & Autor & Juiz & & & Juiz \\
\hline $\mathrm{N} / \mathrm{L}$ & $\mathrm{N} / \mathrm{L}$ & $\mathrm{N} / \mathrm{L}$ & $\mathrm{N} / \mathrm{L}$ & & & $\mathrm{N} / \mathrm{L}$ \\
\hline Teoria & evisão & $\begin{array}{c}\text { Defeito d } \\
\text { Defeito }\end{array}$ & $\begin{array}{l}\text { presentação } \\
\text { prmalização }\end{array}$ & & Hipo & ficiência \\
\hline Autor & Juiz & Autor & Juiz & & & Juiz \\
\hline $\mathrm{N} / \mathrm{L}$ & $\mathrm{N} / \mathrm{L}$ & $\mathrm{N} / \mathrm{L}$ & $\mathrm{N} / \mathrm{L}$ & & & $\mathrm{N} / \mathrm{L}$ \\
\hline & & Esta & Perigo & & & \\
\hline Autor & Juiz & Autor & Juiz & & & Juiz \\
\hline $\mathrm{N} / \mathrm{L}$ & $\mathrm{N} / \mathrm{L}$ & $\mathrm{N} / \mathrm{L}$ & $\mathrm{N} / \mathrm{L}$ & & & $\mathrm{N} / \mathrm{L}$ \\
\hline & & Pacta & Servanda & & ono & da Vontade \\
\hline Autor & Juiz & Autor & Juiz & & & Juiz \\
\hline $\mathrm{N} / \mathrm{L}$ & $\mathrm{N} / \mathrm{L}$ & $\mathrm{N} / \mathrm{L}$ & $\mathrm{N} / \mathrm{L}$ & & & $\mathrm{N} / \mathrm{L}$ \\
\hline Inerên & Risco & Contr & Aleatório & & & lação \\
\hline Autor & Juiz & Autor & Juiz & & & Juiz \\
\hline Não & Sim & $\mathrm{N} / \mathrm{L}$ & $\mathrm{N} / \mathrm{L}$ & & & $\mathrm{N} / \mathrm{L}$ \\
\hline & & & ário & & & \\
\hline $\begin{array}{l}O \text { alegado } \\
\text { merece prev } \\
\text { alto risco, } \\
\text { ainda, trata } \\
\text { riscos em qu } \\
\text { artigo } 51 \text { do }\end{array}$ & $\begin{array}{l}\text { ment } \\
\text { a ve } \\
\text { er a } \\
\text { inve }\end{array}$ & $\begin{array}{l}\text { S riscos do ne } \\
\text { e a aplicação f } \\
\text { ivada como as } \\
\text { ores de pessoa } \\
\text { tarem por este }\end{array}$ & $\begin{array}{l}\text { realizado, } \\
\text { eira escolhi } \\
\text { va e mode } \\
\text { nivel super }\end{array}$ & & & $\begin{array}{l}\text { es, também não } \\
\text { ecidas como de } \\
\text { Acrescenta-se, } \\
\text { discernirem os } \\
\text { a aplicação do }\end{array}$ \\
\hline
\end{tabular}


Apêndice 44-RJ

\begin{tabular}{|c|c|c|c|c|c|}
\hline Processo & \multicolumn{2}{|r|}{ Peça } & \multicolumn{2}{|c|}{ Ambiente } & Produto \\
\hline 2008.001 .18099 & \multicolumn{2}{|c|}{ Apelação } & \multicolumn{2}{|c|}{ N/A - Fundo } & Fundo de Investimento \\
\hline Juiz & \multicolumn{2}{|r|}{ Autor } & \multicolumn{2}{|c|}{ Réu } & Valor \\
\hline $\begin{array}{c}\text { Antonio Saldanha } \\
\text { Palheiro }\end{array}$ & \multicolumn{2}{|c|}{$\begin{array}{c}\text { Entidade de } \\
\text { Previdência Privada }\end{array}$} & \multicolumn{2}{|c|}{$\begin{array}{l}\text { Banco Boavista } \\
\text { Interatlântico S.A. }\end{array}$} & $1,25 \mathrm{~mm}-1,5 \mathrm{~mm}$ \\
\hline Data do Julgamento & \multicolumn{2}{|c|}{ Data do Fato } & \multicolumn{2}{|c|}{ Provimento } & Mérito \\
\hline $13 / 05$ & \multicolumn{2}{|c|}{ Janeiro 1999} & \multicolumn{2}{|c|}{ Não Provida } & $5 \mathrm{IF}$ \\
\hline Suitability & & \multicolumn{2}{|c|}{ Coação } & \multicolumn{2}{|c|}{ Danos Morais } \\
\hline Autor & & Autor & Juiz & Autor & Juiz \\
\hline Não & & $\mathrm{N} / \mathrm{L}$ & $\mathrm{N} / \mathrm{L}$ & $\mathrm{N} / \mathrm{L}$ & $\mathrm{N} / \mathrm{L}$ \\
\hline Danos Materiais & & \multicolumn{2}{|c|}{$\mathrm{CDC}$} & \multicolumn{2}{|c|}{ Contrato de Adesão } \\
\hline Autor & & Autor & Juiz & Autor & Juiz \\
\hline $\mathrm{N} / \mathrm{L}$ & & Sim & Não & $\mathrm{N} / \mathrm{L}$ & $\mathrm{N} / \mathrm{L}$ \\
\hline Lesão & & \multicolumn{2}{|c|}{ Onerosidade Excessiva } & \multicolumn{2}{|c|}{ Cláusulas Abusivas } \\
\hline Autor & & Autor & Juiz & Autor & Juiz \\
\hline $\mathrm{N} / \mathrm{L}$ & & $\mathrm{N} / \mathrm{L}$ & $\mathrm{N} / \mathrm{L}$ & $\mathrm{N} / \mathrm{L}$ & $\mathrm{N} / \mathrm{L}$ \\
\hline Teoria & & $\begin{array}{l}\text { Defeito de } \\
\text { Defeito d }\end{array}$ & $\begin{array}{l}\text { sentação } \\
\text { nalização }\end{array}$ & Hipc & Ècia \\
\hline Autor & & Autor & Juiz & Autor & Juiz \\
\hline $\mathrm{N} / \mathrm{L}$ & & $\mathrm{N} / \mathrm{L}$ & $\mathrm{N} / \mathrm{L}$ & Sim & Não \\
\hline & & Estad & Perigo & & \\
\hline Autor & & Autor & Juiz & Autor & Juiz \\
\hline $\mathrm{N} / \mathrm{L}$ & & $\mathrm{N} / \mathrm{L}$ & $\mathrm{N} / \mathrm{L}$ & $\mathrm{N} / \mathrm{L}$ & $\mathrm{N} / \mathrm{L}$ \\
\hline & & Pacta $S$ & Servanda & Autono & Vontade \\
\hline Autor & & Autor & Juiz & Autor & Juiz \\
\hline $\mathrm{N} / \mathrm{L}$ & & $\mathrm{N} / \mathrm{L}$ & $\mathrm{N} / \mathrm{L}$ & $\mathrm{N} / \mathrm{L}$ & $\mathrm{N} / \mathrm{L}$ \\
\hline Inerêr & & Contra & leatório & & \\
\hline Autor & & Autor & Juiz & Autor & Juiz \\
\hline $\mathrm{N} / \mathrm{L}$ & & $\mathrm{N} / \mathrm{L}$ & $\mathrm{N} / \mathrm{L}$ & $\mathrm{N} / \mathrm{L}$ & $\mathrm{N} / \mathrm{L}$ \\
\hline & & & & & \\
\hline $\begin{array}{l}\text { O demandar } \\
\text { Com ampar } \\
\text { estamos dia } \\
\text { serviço, não } \\
\text { justifique a } \\
\text { A vulnerabi } \\
\text { serviço que } \\
\text { experiente, } \\
\text { hipossuficiê } \\
\text { conhecimen } \\
\text { previdência } \\
\text { áreas, demo } \\
\text { desempenho } \\
\text { vulnerabilid } \\
\text { fornecedor } \\
\text { - fático ou } \\
\text { Pela anális } \\
\text { ocorreram, } \\
\text { poder econ } \\
\text { diretamente } \\
\text { fato ficou cc } \\
\text { oficial (fl.20 } \\
\text { não institu } \\
\text { disponibilizc } \\
\text { das partes }\end{array}$ & & $\begin{array}{l}\text { de previdêncic } \\
\text { profundada } \\
\text { nsumo. Além } \\
\text { e técnica, jurí } \\
\text { ova. } \\
\text { e da ausência } \\
\text { sendo razoár } \\
\text { iscos do inves } \\
\text { Inerabilidade } \\
\text { iências jurídi } \\
\text { ganização con } \\
\text { nto dessas } \\
\text { ogo, não há } \\
\text { nômica, obse } \\
\text { ele contratan } \\
\text { nde poder ec } \\
\text { verifica-se ob } \\
\text { penas a incia } \\
\text { equilibrar a } \\
\text { fundo provo } \\
\text { Banco, com } \\
\text { a realizar o r } \\
\text { ue a confian } \\
\text { be de investim } \\
\text { submissão }\end{array}$ & $\begin{array}{l}\text { vada, aplico } \\
\text { nceito de co } \\
\text { ato de não } \\
\text { ou fática qu } \\
\text { conheciment } \\
\text { xigir-lhe tal } \\
\text { to realizado } \\
\text { ídica ou } \\
\text { contábil ou } \\
\text { a devidame } \\
\text { as, tanto po } \\
\text { assinalar a } \\
\text { a existência } \\
\text { sa superiori } \\
\text { nico ou em } \\
\text { amente que } \\
\text { a do segunc } \\
\text { ção jurídic } \\
\text { m danos gr } \\
\text { jetivo de rec } \\
\text { cimento dos } \\
\text { soserional }\end{array}$ & $\begin{array}{l}\text { sos em fur } \\
\text { lor é corr } \\
\text { tinatário } \\
\text { acterize c } \\
\text { cíficos do } \\
\text { O dema } \\
\text { forma, } \\
\text { a, origin } \\
\text { nica. A e } \\
\text { uturada e } \\
\text { ua forma } \\
\text { cidade ci } \\
\text { posição } \\
\text { de decorr } \\
\text { la essenci } \\
\text { meiro e } \\
\text { caso cono } \\
\text { revés, os } \\
\text { imagem a } \\
\text { a sua ime } \\
\text { suportad } \\
o \text { desemp }\end{array}$ & $\begin{array}{l}\text { nvestimento. } \\
\text { nar que não } \\
\text { imediato do } \\
\text { usumidor ou } \\
\text { dor sobre o } \\
\text { é investidor } \\
\text { se falar em } \\
\text { a falta de } \\
\text { fechada de } \\
\text { uma dessas } \\
\text { anto para o } \\
\text { A terceira, } \\
\text { ioridade do } \\
\text { n monopólio } \\
\text { do produto. } \\
\text { fator não } \\
\text { o revela um } \\
\text { os sofridos } \\
\text { ndado. Esse } \\
\text { vulgou nota } \\
\text { investidores } \\
\text { a atividade } \\
\text { e econômico } \\
\text { vontade do }\end{array}$ \\
\hline
\end{tabular}


investidor que dispõe de adequada assessoria para colher e assumir dos riscos de investimentos mais agressivos. Portanto, a hipossuficência fática não está presente no caso em análise.

(...)

O prejuízo sofrido com a modificação da política cambial não pode ser imputado ao administrador do fundo e, muito menos, caracterizar afronta ao princípio da obrigatoriedade dos contratos. 
Apêndice 45-RJ

\begin{tabular}{|c|c|c|c|c|c|c|c|}
\hline & \multicolumn{2}{|r|}{ Peça } & \multicolumn{2}{|c|}{ Ambiente } & \multicolumn{2}{|r|}{ Produto } \\
\hline \multicolumn{2}{|c|}{2007.001 .69503} & \multicolumn{2}{|r|}{ Apelação } & \multicolumn{2}{|c|}{ N/A - Fundo } & \multicolumn{2}{|c|}{ Fundo de Investimento } \\
\hline \multicolumn{2}{|c|}{ Juiz } & \multicolumn{2}{|r|}{ Autor } & \multicolumn{2}{|l|}{ Réu } & \multicolumn{2}{|r|}{ Valor } \\
\hline \multicolumn{2}{|c|}{$\begin{array}{c}\text { Ricardo Rodrigues } \\
\text { Cardozo }\end{array}$} & \multicolumn{2}{|c|}{$\begin{array}{c}\text { Entidade de } \\
\text { Previdência Privada }\end{array}$} & \multicolumn{2}{|c|}{$\begin{array}{l}\text { BES Boavista Espírito } \\
\text { Santo DTVM }\end{array}$} & \multicolumn{2}{|c|}{$2,75 \mathrm{~mm}-3,00 \mathrm{~mm}$} \\
\hline \multicolumn{2}{|c|}{ Data do Julgamento } & \multicolumn{2}{|c|}{ Data do Fato } & \multicolumn{2}{|c|}{ Provimento } & \multicolumn{2}{|r|}{ Mérito } \\
\hline $29 / 01$ & & & neiro 1999 & Provid & & & Pró IF \\
\hline \multicolumn{3}{|c|}{ Suitability } & \multicolumn{2}{|c|}{ Coação } & \multicolumn{3}{|c|}{ Danos Morais } \\
\hline Autor & \multicolumn{2}{|c|}{ Juiz } & Autor & Juiz & \multicolumn{2}{|c|}{ Autor } & Juiz \\
\hline $\mathrm{N} / \mathrm{L}$ & $\mathrm{S}$ & & $\mathrm{N} / \mathrm{L}$ & $\mathrm{N} / \mathrm{L}$ & & $/ \mathrm{L}$ & $\mathrm{N} / \mathrm{L}$ \\
\hline \multicolumn{3}{|c|}{ Danos Materiais } & \multicolumn{2}{|c|}{$\mathrm{CDC}$} & \multicolumn{3}{|c|}{ Contrato de Adesão } \\
\hline Autor & $\mathrm{Ju}$ & & Autor & Juiz & & itor & Juiz \\
\hline $\mathrm{N} / \mathrm{L}$ & $\mathrm{N}$ & & $\mathrm{N} / \mathrm{L}$ & $\mathrm{N} / \mathrm{L}$ & & $/ \mathrm{L}$ & $\mathrm{N} / \mathrm{L}$ \\
\hline \multicolumn{3}{|c|}{ Lesão } & \multicolumn{2}{|c|}{ Onerosidade Excessiva } & \multicolumn{3}{|c|}{ Cláusulas Abusivas } \\
\hline Autor & $\mathrm{Ju}$ & & Autor & Juiz & & itor & Juiz \\
\hline $\mathrm{N} / \mathrm{L}$ & $\mathrm{N}$ & & $\mathrm{N} / \mathrm{L}$ & $\mathrm{N} / \mathrm{L}$ & & $/ \mathrm{L}$ & $\mathrm{N} / \mathrm{L}$ \\
\hline Teoria & evis & & $\begin{array}{l}\text { Defeito de } \\
\text { Defeito de }\end{array}$ & $\begin{array}{l}\text { presentação / } \\
\text { ormalização }\end{array}$ & & Hipo & iciêencia \\
\hline Autor & $\mathrm{Ju}$ & & Autor & Juiz & & itor & Juiz \\
\hline $\mathrm{N} / \mathrm{L}$ & & & $\mathrm{N} / \mathrm{L}$ & $\mathrm{N} / \mathrm{L}$ & & $/ \mathrm{L}$ & $\mathrm{N} / \mathrm{L}$ \\
\hline & & & Estado & e Perigo & & & \\
\hline Autor & $\mathrm{Ju}$ & & Autor & Juiz & & itor & Juiz \\
\hline $\mathrm{N} / \mathrm{L}$ & & & $\mathrm{N} / \mathrm{L}$ & $\mathrm{N} / \mathrm{L}$ & & $/ \mathrm{L}$ & $\mathrm{N} / \mathrm{L}$ \\
\hline & & & Pacta St & Servanda & & tonor & da Vontade \\
\hline Autor & $\mathrm{Ju}$ & & Autor & Juiz & & itor & Juiz \\
\hline $\mathrm{N} / \mathrm{L}$ & & & $\mathrm{N} / \mathrm{L}$ & $\mathrm{N} / \mathrm{L}$ & & $/ \mathrm{L}$ & $\mathrm{N} / \mathrm{L}$ \\
\hline Inerêl & Risc & & Contra & Aleatório & & & lação \\
\hline Autor & $\mathrm{Ju}$ & & Autor & Juiz & & tor & Juiz \\
\hline Sim & & & $\mathrm{N} / \mathrm{L}$ & $\mathrm{N} / \mathrm{L}$ & & $/ \mathrm{L}$ & $\mathrm{N} / \mathrm{L}$ \\
\hline & & & & ário & & & \\
\hline $\begin{array}{l}O \text { mencionc } \\
\text { ganhos acin } \\
\text { aonteceu. } F \\
o \text { investidor } \\
\text { propalada } n\end{array}$ & & & $\begin{array}{l}\text { cado em dólc } \\
\text { a esteira trazi } \\
\text { ão é poupançc } \\
\text { ir. O autor ar } \\
\text { plicados. }\end{array}$ & $\begin{array}{l}\text { futuro certame } \\
\text { possibilidade } \\
\text { expectativa d } \\
\text { ou e perdeu, }\end{array}$ & no & $\begin{array}{l}\text { ava } \\
\text { expre } \\
\text { ropo }\end{array}$ & $\begin{array}{l}\text { obabilidade de } \\
\text { as, como de fato } \\
\text { nal ao risco que } \\
\text { há indícios da }\end{array}$ \\
\hline
\end{tabular}


Apêndice 46-RJ

\begin{tabular}{|c|c|c|c|c|c|c|}
\hline \multicolumn{2}{|c|}{ Processo } & & Peca & \multicolumn{2}{|c|}{ Ambiente } & Produto \\
\hline \multicolumn{2}{|c|}{2009.002 .02506} & \multicolumn{2}{|c|}{ Agravo de Instrumento } & \multicolumn{2}{|c|}{ Não Informado } & Opção \\
\hline \multicolumn{2}{|c|}{ Juiz } & \multicolumn{2}{|r|}{ Autor } & \multicolumn{2}{|c|}{ Réu } & Valor \\
\hline \multicolumn{2}{|c|}{ Celso Ferreira Filho } & \multicolumn{2}{|c|}{$\begin{array}{l}\text { Sociedade Não } \\
\text { Financeira }\end{array}$} & \multicolumn{2}{|c|}{ Banco Itaú } & 00k-750k \\
\hline \multicolumn{2}{|c|}{ Data do Julgamento } & \multicolumn{2}{|c|}{ Data do Fato } & \multicolumn{2}{|c|}{ Provimento } & Mérito \\
\hline \multicolumn{2}{|c|}{$15 / 04 / 2009$} & & 2008 & \multicolumn{2}{|c|}{ Não Provida } & Pró IF \\
\hline \multicolumn{3}{|c|}{ Suitability } & \multicolumn{2}{|c|}{ Coação } & \multicolumn{2}{|c|}{ Danos Morais } \\
\hline Autor & $\mathrm{Ju}$ & & Autor & Juiz & Autor & Juiz \\
\hline $\mathrm{N} / \mathrm{L}$ & $\mathrm{S}$ & & $\mathrm{N} / \mathrm{L}$ & $\mathrm{N} / \mathrm{L}$ & $\mathrm{N} / \mathrm{L}$ & $\mathrm{N} / \mathrm{L}$ \\
\hline \multicolumn{3}{|c|}{ Danos Materiais } & \multicolumn{2}{|c|}{$\mathrm{CDC}$} & \multicolumn{2}{|c|}{ Contrato de Adesão } \\
\hline Autor & $\mathrm{Ju}$ & & Autor & Juiz & Autor & Juiz \\
\hline $\mathrm{N} / \mathrm{L}$ & $\mathrm{N}$ & & $\mathrm{N} / \mathrm{L}$ & $\mathrm{N} / \mathrm{L}$ & $\mathrm{N} / \mathrm{L}$ & $\mathrm{N} / \mathrm{L}$ \\
\hline \multicolumn{3}{|c|}{ Lesão } & \multicolumn{2}{|c|}{ Onerosidade Excessiva } & \multicolumn{2}{|c|}{ Cláusulas Abusivas } \\
\hline Autor & $\mathrm{Ju}$ & & Autor & Juiz & Autor & Juiz \\
\hline $\mathrm{N} / \mathrm{L}$ & $\mathrm{N}$ & & $\mathrm{N} / \mathrm{L}$ & $\mathrm{N} / \mathrm{L}$ & $\mathrm{N} / \mathrm{L}$ & Não \\
\hline \multicolumn{3}{|c|}{ Teoria da Imprevisão } & \multicolumn{2}{|c|}{$\begin{array}{c}\text { Defeito de Representação / } \\
\text { Defeito de Formalização }\end{array}$} & \multicolumn{2}{|c|}{ Hipossuficiência } \\
\hline Autor & $\mathrm{Ju}$ & & Autor & Juiz & Autor & Juiz \\
\hline $\mathrm{N} / \mathrm{L}$ & $\mathrm{N}$ & & $\mathrm{N} / \mathrm{L}$ & $\mathrm{N} / \mathrm{L}$ & $\mathrm{N} / \mathrm{L}$ & Não \\
\hline & & & Estado & erigo & & \\
\hline Autor & $\mathrm{Ju}$ & & Autor & Juiz & Autor & Juiz \\
\hline $\mathrm{N} / \mathrm{L}$ & & & $\mathrm{N} / \mathrm{L}$ & $\mathrm{N} / \mathrm{L}$ & $\mathrm{N} / \mathrm{L}$ & $\mathrm{N} / \mathrm{L}$ \\
\hline & & & Pacta Sur & ervanda & Autone & da Vontade \\
\hline Autor & & & Autor & Juiz & Autor & Juiz \\
\hline $\mathrm{N} / \mathrm{L}$ & & & $\mathrm{N} / \mathrm{L}$ & Sim & $\mathrm{N} / \mathrm{L}$ & $\mathrm{N} / \mathrm{L}$ \\
\hline Inerêt & Risc & & Contrato & eatório & & lação \\
\hline Autor & & & Autor & Juiz & Autor & Juiz \\
\hline $\mathrm{N} / \mathrm{L}$ & & & $\mathrm{N} / \mathrm{L}$ & Sim & $\mathrm{N} / \mathrm{L}$ & $\mathrm{N} / \mathrm{L}$ \\
\hline & & & & & & \\
\hline $\begin{array}{l}\text { Há que se } \\
\text { ambas e o r } \\
\text { Por fim, na } \\
\text { mencionar } \\
\text { (dólar norte } \\
\text { beneficiaria } \\
\text { Ocorre que } \\
\text { chamadas } h \\
\text { e incontida } \\
\text { nacional, co } \\
\text { pretende se } \\
\text { (...) } \\
\text { Portanto, ta }\end{array}$ & $\begin{array}{l}\text { do a } \\
\text { te de } \\
\text { ano } \\
\text { ante } \\
\text { açaa } \\
\text { st su } \\
\text { oriza } \\
\text { o col }\end{array}$ & $\begin{array}{l}\text { alme } \\
\text { pect } \\
\text { agro } \\
\text { sofri } \\
\text { amen } \\
\text { b pri } \\
\text { ção } \\
\text { heci }\end{array}$ & $\begin{array}{l}\text { e o contrato de } \\
\text { aleatório no mor } \\
\text { ntual dos prazos } \\
\text { ite que celebrou } \\
\text { istemática quedo } \\
\text { para ela agrav } \\
\text { negociadas pel } \\
\text { moedas intern } \\
\text { to público, acar } \\
\text { lidade de opção }\end{array}$ & $\begin{array}{l}\text { ivativos ce } \\
\text { o da celebr } \\
\text { tuados no } \\
\text { instrumen } \\
\text { longo do } \\
\text { a crise } \\
\text { ancos norte } \\
\text { nais frente } \\
\text { ado o inest } \\
\text { pois, de re }\end{array}$ & $\begin{array}{l}\text { s pelas } \\
\text { o de deri } \\
\text { omento } \\
\text { nte ao re } \\
\text { de liqu } \\
\text { canos pr } \\
\text { S\$, esp } \\
\text { prejuízo } \\
\text { aleatóri }\end{array}$ & $\begin{array}{l}\text { s impõe risco a } \\
\text { os em tela, cabe } \\
\text { o o ativo objeto } \\
\text { to que somente } \\
\text { decorrente das } \\
\text { uram a imediata } \\
\text { nente a moeda } \\
\text { ual a agravante }\end{array}$ \\
\hline
\end{tabular}


Apêndice $47-\mathrm{RJ}^{15}$

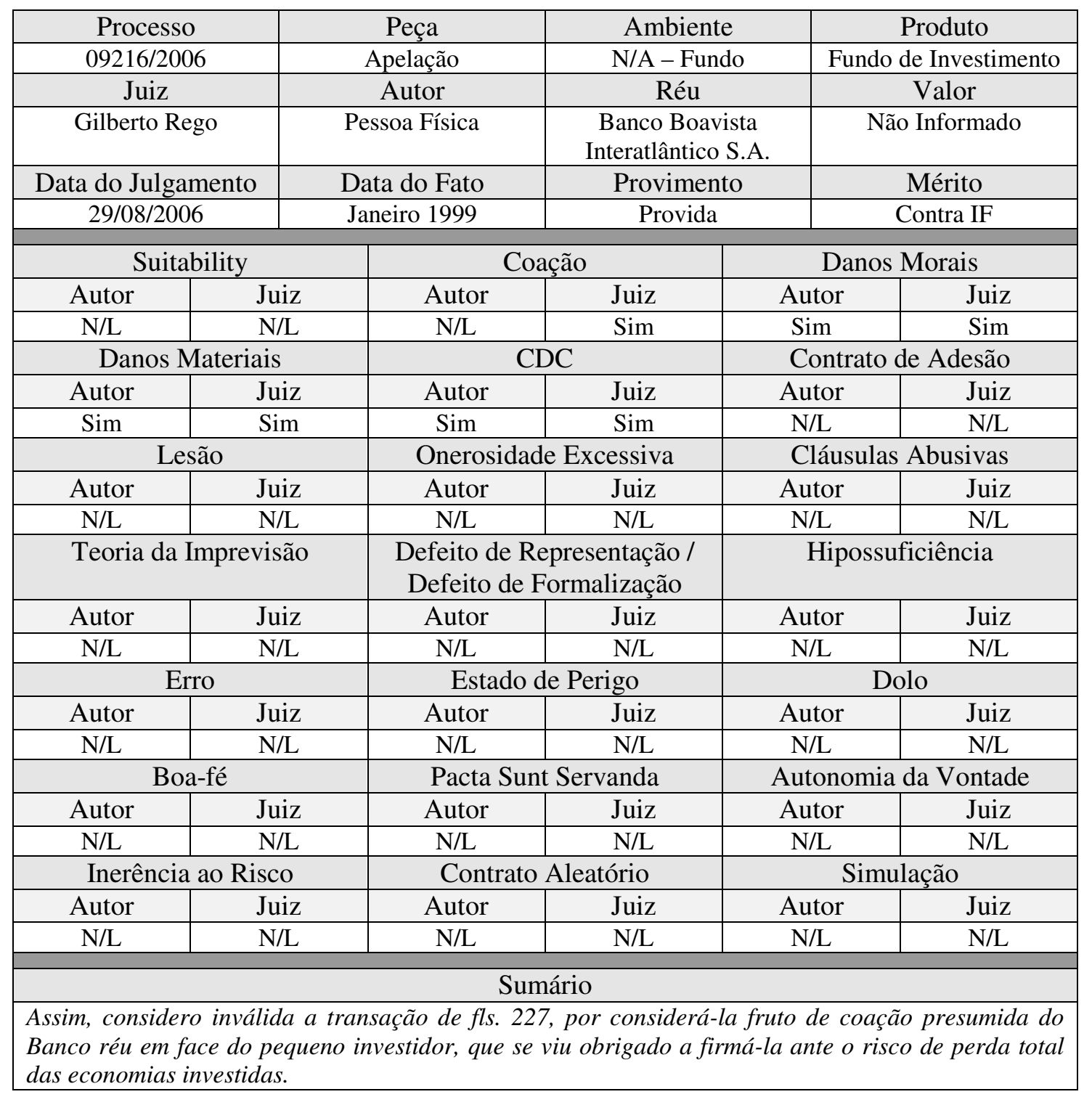

${ }^{15} \mathrm{O}$ Apêndice 47-RJ engloba a decisão do desembargador relator Gilberto Rego e uma segunda (não possível de ser identificada), que votou conforme o relator, perfazendo a maioria do órgão colegiado. Por sua vez, o Apêndice 48-RJ representa a decisão do desembargador Nagib Slaibi Filho, que foi o terceiro voto dissonante da Sexta Câmara Cível do Rio de Janeiro. Finalmente, vale ressaltar que, da leitura do Acórdão, as partes são, ao mesmo tempo, apelantes e apeladas. Optamos, neste caso, por considerar apenas a pessoa física como apelante e não computar a pessoa jurídica como apelante (como se fosse nova decisão), visto que os votos concentram-se apenas nas razões da apelante pessoa física. 
Apêndice $48-\mathrm{RJ}^{16}$

\begin{tabular}{|c|c|c|c|c|c|}
\hline \multicolumn{2}{|c|}{ Processo } & Peça & \multicolumn{2}{|c|}{ Ambiente } & Produto \\
\hline 09216 & & Apelação & \multicolumn{2}{|c|}{ N/A - Fundo } & Fundo de Investimento \\
\hline \multicolumn{2}{|c|}{ Juiz } & Autor & \multicolumn{2}{|c|}{ Réu } & Valor \\
\hline \multicolumn{2}{|c|}{ Nagib Slaibi Filho } & Pessoa Física & $\begin{array}{r}\text { Banco Bo } \\
\text { Interatlânti }\end{array}$ & & Não Informado \\
\hline \multicolumn{2}{|c|}{ Data do Julgamento } & Data do Fato & Provim & & Mérito \\
\hline \multicolumn{2}{|c|}{$29 / 08 / 2006$} & Janeiro 1999 & \multicolumn{2}{|c|}{ Não Provida } & Pró IF \\
\hline \multicolumn{2}{|c|}{ Suitability } & \multicolumn{2}{|c|}{ Coação } & \multicolumn{2}{|c|}{ Danos Morais } \\
\hline Autor & $\mathrm{Ju}$ & Autor & Juiz & Autor & Juiz \\
\hline $\mathrm{N} / \mathrm{L}$ & $\mathrm{N} /$ & $\mathrm{N} / \mathrm{L}$ & $\mathrm{N} / \mathrm{L}$ & $\mathrm{N} / \mathrm{L}$ & $\mathrm{N} / \mathrm{L}$ \\
\hline \multicolumn{2}{|c|}{ Danos Materiais } & \multicolumn{2}{|c|}{$\mathrm{CDC}$} & \multicolumn{2}{|c|}{ Contrato de Adesão } \\
\hline Autor & Jui & Autor & Juiz & Autor & Juiz \\
\hline $\mathrm{N} / \mathrm{L}$ & $\mathrm{N} /$ & $\mathrm{N} / \mathrm{L}$ & $\mathrm{N} / \mathrm{L}$ & $\mathrm{N} / \mathrm{L}$ & $\mathrm{N} / \mathrm{L}$ \\
\hline \multicolumn{2}{|c|}{ Lesão } & \multicolumn{2}{|c|}{ Onerosidade Excessiva } & \multicolumn{2}{|c|}{ Cláusulas Abusivas } \\
\hline Autor & $\mathrm{Ju}$ & Autor & Juiz & Autor & Juiz \\
\hline $\mathrm{N} / \mathrm{L}$ & $\mathrm{N} /$ & $\mathrm{N} / \mathrm{L}$ & $\mathrm{N} / \mathrm{L}$ & $\mathrm{N} / \mathrm{L}$ & $\mathrm{N} / \mathrm{L}$ \\
\hline \multicolumn{2}{|c|}{ Teoria da Imprevisão } & \multicolumn{2}{|c|}{$\begin{array}{l}\text { Defeito de Representação / } \\
\text { Defeito de Formalização }\end{array}$} & \multicolumn{2}{|c|}{ Hipossuficiência } \\
\hline Autor & Jui & Autor & Juiz & Autor & Juiz \\
\hline $\mathrm{N} / \mathrm{L}$ & $\mathrm{N} /$ & $\mathrm{N} / \mathrm{L}$ & $\mathrm{N} / \mathrm{L}$ & $\mathrm{N} / \mathrm{L}$ & $\mathrm{N} / \mathrm{L}$ \\
\hline & & Esta & Perigo & & blo \\
\hline Autor & $\mathrm{Ju}$ & Autor & Juiz & Autor & Juiz \\
\hline $\mathrm{N} / \mathrm{L}$ & $\mathrm{N} /$ & $\mathrm{N} / \mathrm{L}$ & $\mathrm{N} / \mathrm{L}$ & $\mathrm{N} / \mathrm{L}$ & $\mathrm{N} / \mathrm{L}$ \\
\hline & & Pacta & ervanda & Autono & da Vontade \\
\hline Autor & $\mathrm{Ju}$ & Autor & Juiz & Autor & Juiz \\
\hline $\mathrm{N} / \mathrm{L}$ & $\mathrm{N} /$ & $\mathrm{N} / \mathrm{L}$ & Sim & $\mathrm{N} / \mathrm{L}$ & $\mathrm{N} / \mathrm{L}$ \\
\hline Inerêr & Risc & Contr & eatório & & lação \\
\hline Autor & $\mathrm{Ju}$ & Autor & Juiz & Autor & Juiz \\
\hline $\mathrm{N} / \mathrm{L}$ & $\mathrm{N} /$ & $\mathrm{N} / \mathrm{L}$ & Sim & $\mathrm{N} / \mathrm{L}$ & $\mathrm{N} / \mathrm{L}$ \\
\hline & & & & & \\
\hline $\begin{array}{l}\text { A aplicação } \\
\text { que foi aplic } \\
\text { O objeto do } \\
\text { o investimen } \\
\text { Não há que } \\
\text { o contrato sc } \\
\text { ou ignorânc }\end{array}$ & $\begin{array}{l}\text { con } \\
\text { nder }\end{array}$ & $\begin{array}{l}\text { e investimer } \\
\text { ela álea, nã } \\
\text { lo. } \\
\text { mento dos to } \\
\text { ntrato de in }\end{array}$ & $\begin{array}{l}\text { constitui c } \\
\text { um contra } \\
\text { contratuais, } \\
\text { ento, não pc }\end{array}$ & $\begin{array}{l}\text { de que ho } \\
\text { esultado, } \\
\text { ue o apel }\end{array}$ & $\begin{array}{l}\text { i valorização do } \\
\text { garantia de que } \\
\text { quando assinou } \\
\text { lesconhecimento }\end{array}$ \\
\hline
\end{tabular}

${ }^{16} \mathrm{O}$ Apêndice 47-RJ engloba a decisão do desembargador relator Gilberto Rego e uma segunda (não possível de ser identificada), que votou conforme o relator, perfazendo a maioria do órgão colegiado. Por sua vez, o Apêndice 48-RJ representa a decisão do desembargador Nagib Slaibi Filho, que foi o terceiro voto dissonante da Sexta Câmara Cível do Rio de Janeiro. Finalmente, vale ressaltar que, da leitura do Acórdão, as partes são, ao mesmo tempo, apelantes e apeladas. Optamos, neste caso, por considerar apenas a pessoa física como apelante e não computar a pessoa jurídica como apelante (como se fosse nova decisão), visto que os votos concentram-se apenas nas razões da apelante pessoa física. 
Apêndice 49-ES

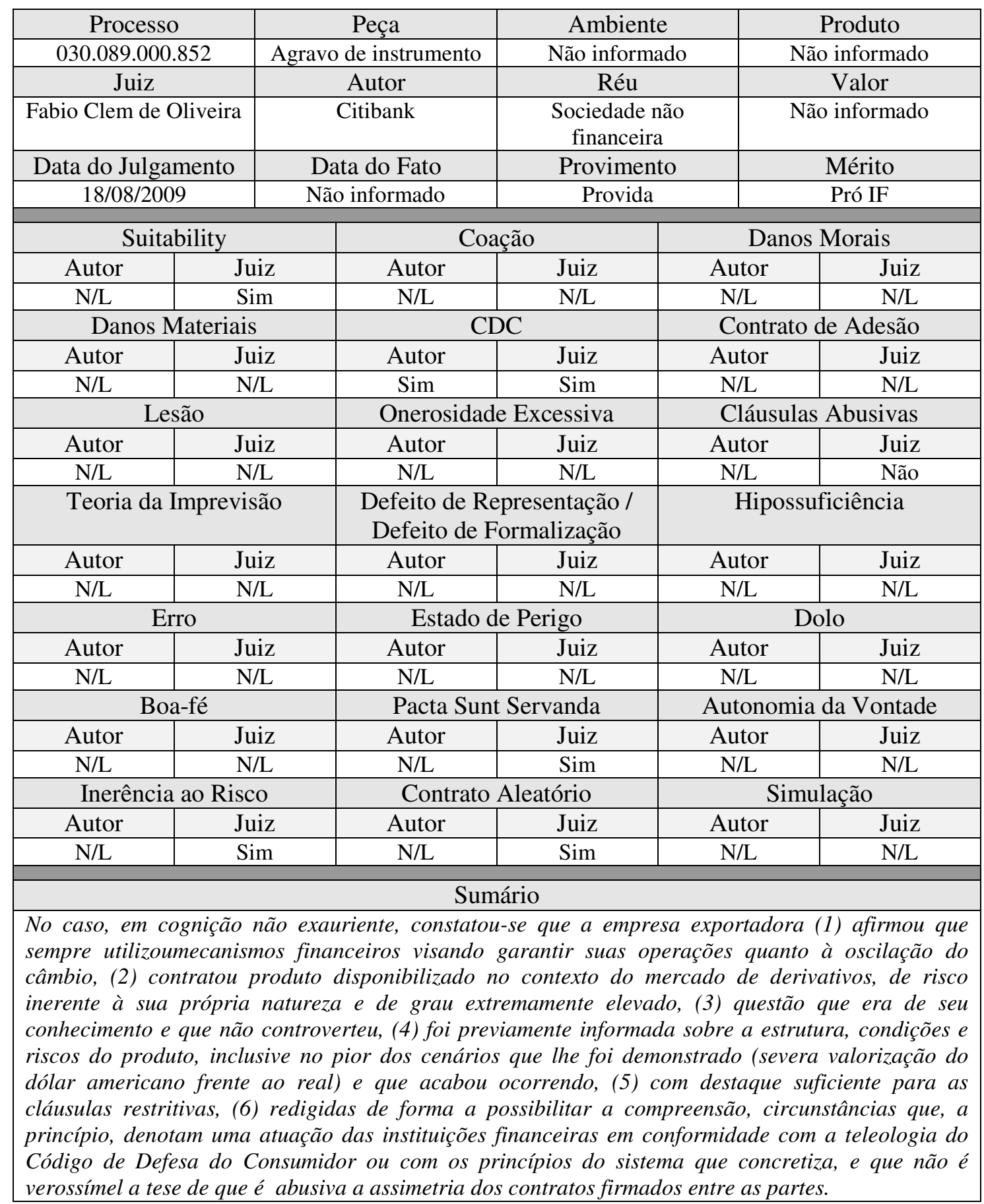


Apêndice 50-ES

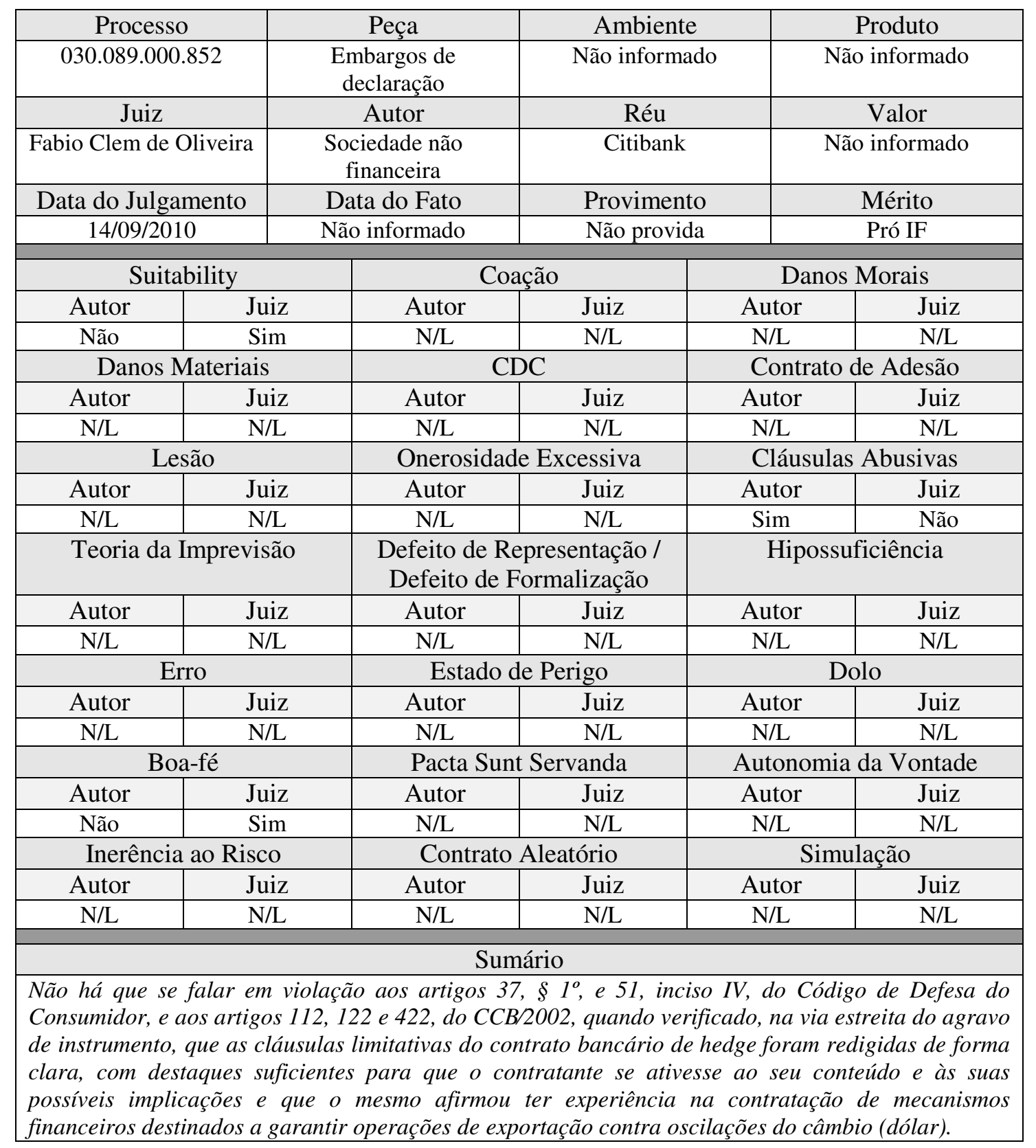


Apêndice 51-PR

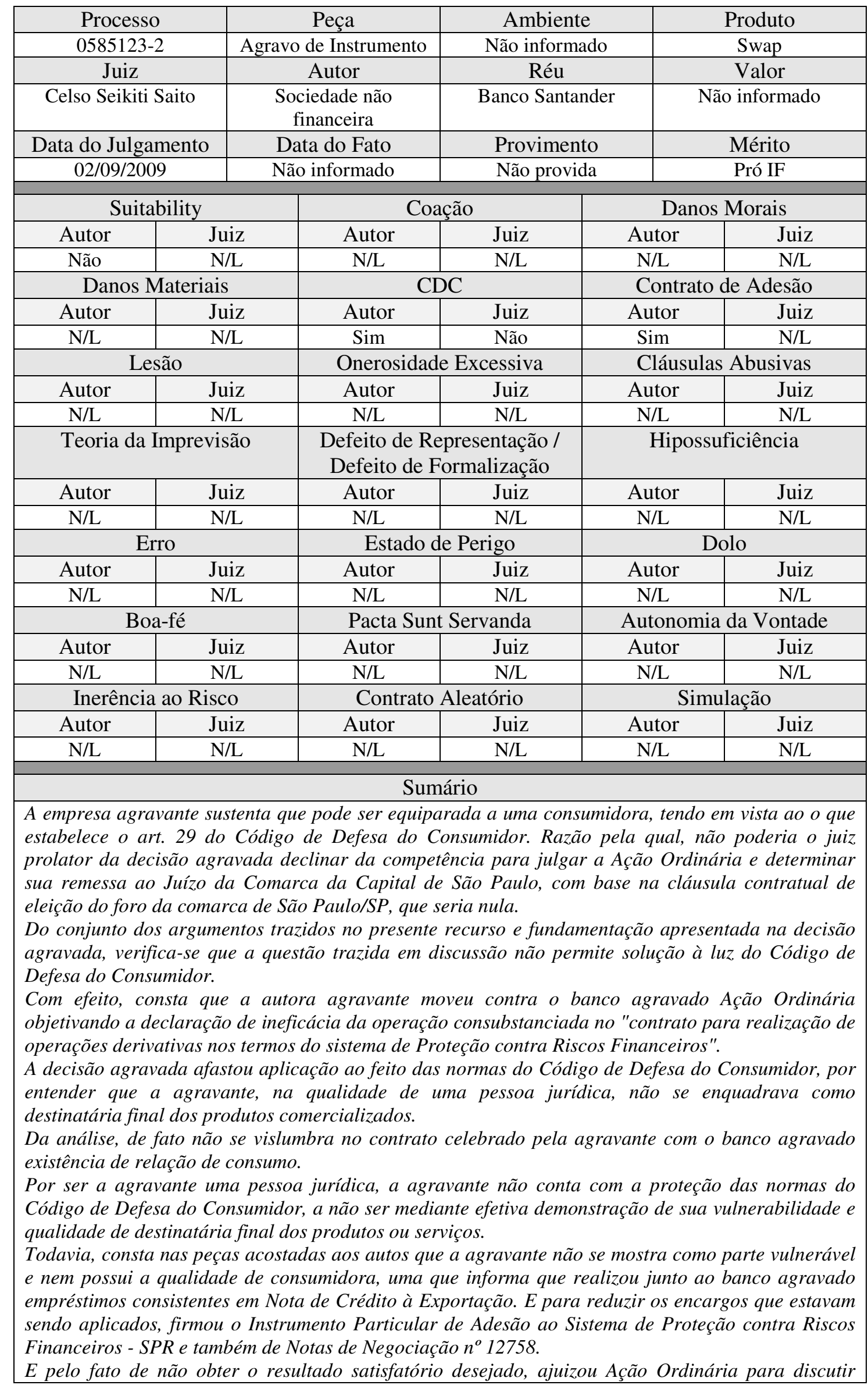


acerca do "contrato para realização de operações de derivativos nos termos do sistema de proteção contra riscos financeiros", ou seja, da contratação de derivativos vinculados à moeda estrangeira (SWAP).

Ora, se a agravante contratou empréstimos junto ao banco agravado para incrementar e favorecer seus negócios, mediante redução dos encargos, inexistiu em tais operações qualquer configuração de relação de consumo. E de conseqüência, afasta-se a sua qualidade de consumidora final dos produtos ou serviços.

Inexistindo a relação de consumo defendida pela agravante, torna-se descabida a invocação das normas do Código de Defesa do Consumidor. 
Apêndice 52-PR

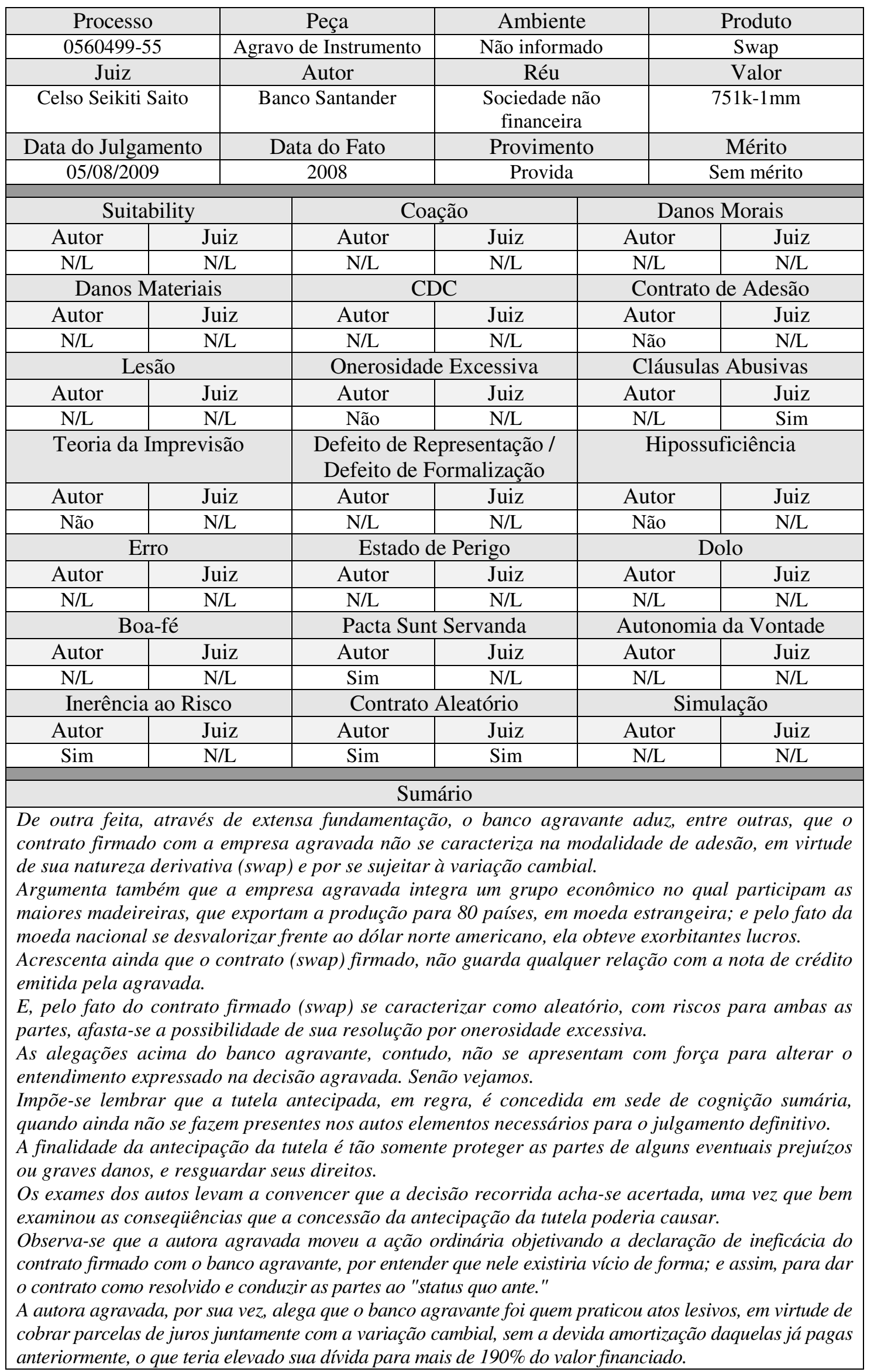


Apêndice 53-PR

\begin{tabular}{|c|c|c|c|c|c|c|}
\hline \multicolumn{2}{|c|}{ Processo } & \multicolumn{2}{|r|}{ Peça } & \multicolumn{2}{|l|}{ Ambiente } & Produto \\
\hline \multicolumn{2}{|c|}{$542901-2$} & \multicolumn{2}{|c|}{ Agravo de instrumento } & Não informado & \multicolumn{2}{|c|}{ Swap } \\
\hline \multicolumn{2}{|c|}{ Juiz } & \multicolumn{2}{|r|}{ Autor } & \multicolumn{2}{|l|}{ Réu } & lor \\
\hline \multicolumn{2}{|c|}{ Luiz Taro Oyama } & \multicolumn{2}{|c|}{$\begin{array}{l}\text { HSBC Bank Brasil } \\
\text { S.A. Banco Múltiplo }\end{array}$} & $\begin{array}{c}\text { Sociedade não } \\
\text { financeira }\end{array}$ & \multicolumn{2}{|c|}{$2 \mathrm{~mm}-2,25 \mathrm{~mm}$} \\
\hline \multicolumn{2}{|c|}{ Data do Julgamento } & \multicolumn{2}{|c|}{ Data do Fato } & Provimento & \multicolumn{2}{|c|}{ Mérito } \\
\hline $24 / 06 /$ & & & 2008 & Provida & & \\
\hline \multicolumn{3}{|c|}{ Suitability } & \multicolumn{2}{|c|}{ Coação } & \multicolumn{2}{|c|}{ Danos Morais } \\
\hline Autor & & & Autor & Juiz & Autor & Juiz \\
\hline Sim & $\mathrm{Si}$ & & $\mathrm{N} / \mathrm{L}$ & $\mathrm{N} / \mathrm{L}$ & $\mathrm{N} / \mathrm{L}$ & $\mathrm{N} / \mathrm{L}$ \\
\hline \multicolumn{3}{|c|}{ Danos Materiais } & \multicolumn{2}{|c|}{$\mathrm{CDC}$} & \multicolumn{2}{|c|}{ Contrato de Adesão } \\
\hline Autor & & & Autor & Juiz & Autor & Juiz \\
\hline $\mathrm{N} / \mathrm{L}$ & $\mathrm{N}$ & & $\mathrm{N} / \mathrm{L}$ & $\mathrm{N} / \mathrm{L}$ & $\mathrm{N} / \mathrm{L}$ & $\mathrm{N} / \mathrm{L}$ \\
\hline \multicolumn{3}{|c|}{ Lesão } & \multicolumn{2}{|c|}{ Onerosidade Excessiva } & \multicolumn{2}{|c|}{ Cláusulas Abusivas } \\
\hline Autor & & & Autor & Juiz & Autor & Juiz \\
\hline Não & $\mathrm{N}$ & & $\mathrm{N} / \mathrm{L}$ & $\mathrm{N} / \mathrm{L}$ & $\mathrm{N} / \mathrm{L}$ & $\mathrm{N} / \mathrm{L}$ \\
\hline \multicolumn{3}{|c|}{ Teoria da Imprevisão } & \multicolumn{2}{|c|}{$\begin{array}{c}\text { Defeito de Representação / } \\
\text { Defeito de Formalização }\end{array}$} & \multicolumn{2}{|c|}{ Hipossuficiência } \\
\hline Autor & & & Autor & Juiz & Autor & Juiz \\
\hline $\mathrm{N} / \mathrm{L}$ & $\mathrm{N}$ & & $\mathrm{N} / \mathrm{L}$ & $\mathrm{N} / \mathrm{L}$ & $\mathrm{N} / \mathrm{L}$ & $\mathrm{N} / \mathrm{L}$ \\
\hline & & & Estado & erigo & & \\
\hline Autor & $\mathrm{Ju}$ & & Autor & Juiz & Autor & Juiz \\
\hline $\mathrm{N} / \mathrm{L}$ & $\mathrm{N}$ & & $\mathrm{N} / \mathrm{L}$ & $\mathrm{N} / \mathrm{L}$ & $\mathrm{N} / \mathrm{L}$ & $\mathrm{N} / \mathrm{L}$ \\
\hline & & & Pacta Sur & vanda & Autono & Vontade \\
\hline Autor & & & Autor & Juiz & Autor & Juiz \\
\hline $\mathrm{N} / \mathrm{L}$ & $\mathrm{N}$ & & $\mathrm{N} / \mathrm{L}$ & $\mathrm{N} / \mathrm{L}$ & $\mathrm{N} / \mathrm{L}$ & $\mathrm{N} / \mathrm{L}$ \\
\hline Inerêl & Risc & & Contrato & atório & & \\
\hline Autor & $\mathrm{Ju}$ & & Autor & Juiz & Autor & Juiz \\
\hline $\mathrm{N} / \mathrm{L}$ & $\mathrm{Si}$ & & Sim & $\mathrm{N} / \mathrm{L}$ & $\mathrm{N} / \mathrm{L}$ & $\mathrm{N} / \mathrm{L}$ \\
\hline & & & Sur & & & \\
\hline $\begin{array}{l}\text { Além das c } \\
\text { financeira, } \\
\text { Extrai-se qu } \\
\text { realizadas r } \\
\text { informações } \\
\text { Consta que } \\
\text { possibilidad } \\
\text { A agravada } \\
\text { contratos en } \\
O \text { "swap" } t \\
\text { generis, fir } \\
\text { diferença er } \\
\text { regra, não } \\
\text { exigindo su } \\
\text { resultados } f \\
\text { Não se olvi } \\
\text { seja, o clien } \\
\text { dos índices } \\
\text { Trata-se de } \\
\text { sujeito às os }\end{array}$ & $\begin{array}{l}\text { as } \\
\text { tpra } \\
\text { tratc } \\
\text { estr } \\
\text { le ur } \\
\text { bre } \\
\text { xa a } \\
\text { efe } \\
\text { idad } \\
\text { os. } \\
\text { "su }\end{array}$ & $\begin{array}{l}\text { tem } \\
\text { uma } \\
\text { nto } \\
\text { le de } \\
\text { conve } \\
\text { opc } \\
\text { de } \\
\text { ange } \\
\text { n mi } \\
\text { ativo } \\
\text { justa } \\
\text { tiva } \\
\text { e po } \\
\text { ap" } \\
\text { efet }\end{array}$ & $\begin{array}{l}\text { us trocas de "e- } \\
\text { avaçães telefônic } \\
\text { contratação, a a } \\
\text { ativos, não have } \\
\text { ções telefônicas } \\
\text { u o "fold" na po } \\
\text { oa leiga em ma } \\
\text { de permuta, apo } \\
\text { nanceiros, nos q } \\
\text { e a cotação que } \\
\text { ativos. Os ativos } \\
\text { arte dos contrat } \\
\text { n contrato bilate } \\
\text { á o pagamento a } \\
\text { sco já que o ina }\end{array}$ & $\begin{array}{l}\text { " entre o gerer } \\
\text { da tinha pleno } \\
\text { ue se falar em } \\
\text { encionada as } p \\
\text { ntrárial6, instr } \\
\text { de operações a } \\
\text { seguro, sendo c } \\
\text { se estipula a li } \\
\text { ativos tiverem n } \\
\text { usados apenas } \\
\text { Em outras pal } \\
\text { a sua formação } \\
\text { l do prazo, data } \\
\text { actuado está ba }\end{array}$ & $\begin{array}{l}\text { financ } \\
\text { onhecin } \\
\text { incípio } \\
\text { teções } \\
\text { nentos n } \\
\text { rmo, te } \\
\text { siderad } \\
\text { idação } \\
\text { vencin } \\
\text { omo re } \\
\text { ras, re. } \\
\text { unilate } \\
\text { tipulad } \\
\text { ado em }\end{array}$ & $\begin{array}{l}\text { instituição } \\
\text { operações } \\
\text { ou vício de } \\
\text { ção como a } \\
\text { ttados. } \\
\text { zado outros } \\
\text { peração sui } \\
\text { imente pela } \\
\text { ajuste. Em } \\
\text {, sequer se } \\
\text { la troca de } \\
\text { estação, ou } \\
\text { equalização } \\
\text { estrangeira, }\end{array}$ \\
\hline
\end{tabular}


Apêndice 54-PR

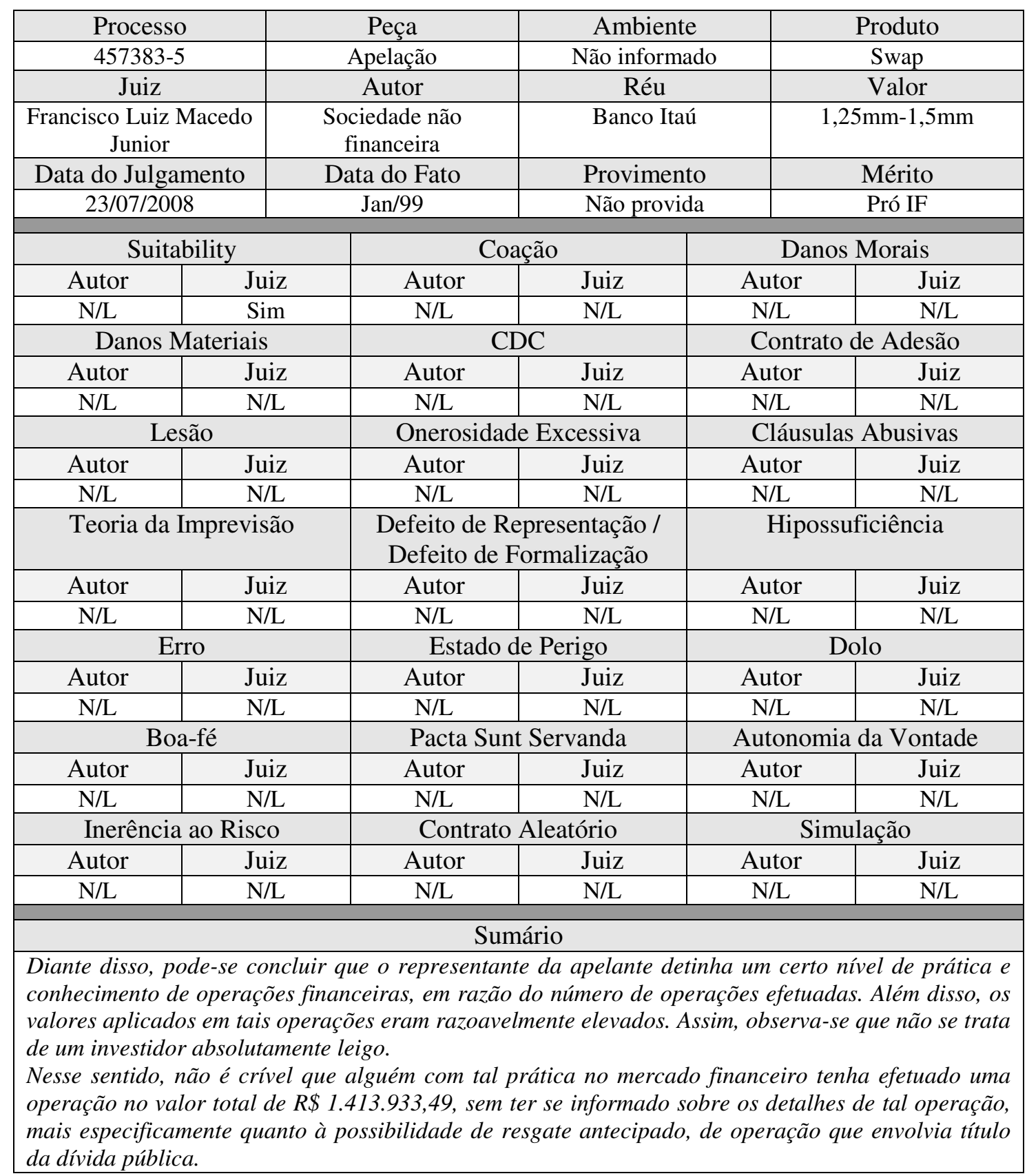


Apêndice 55-PR

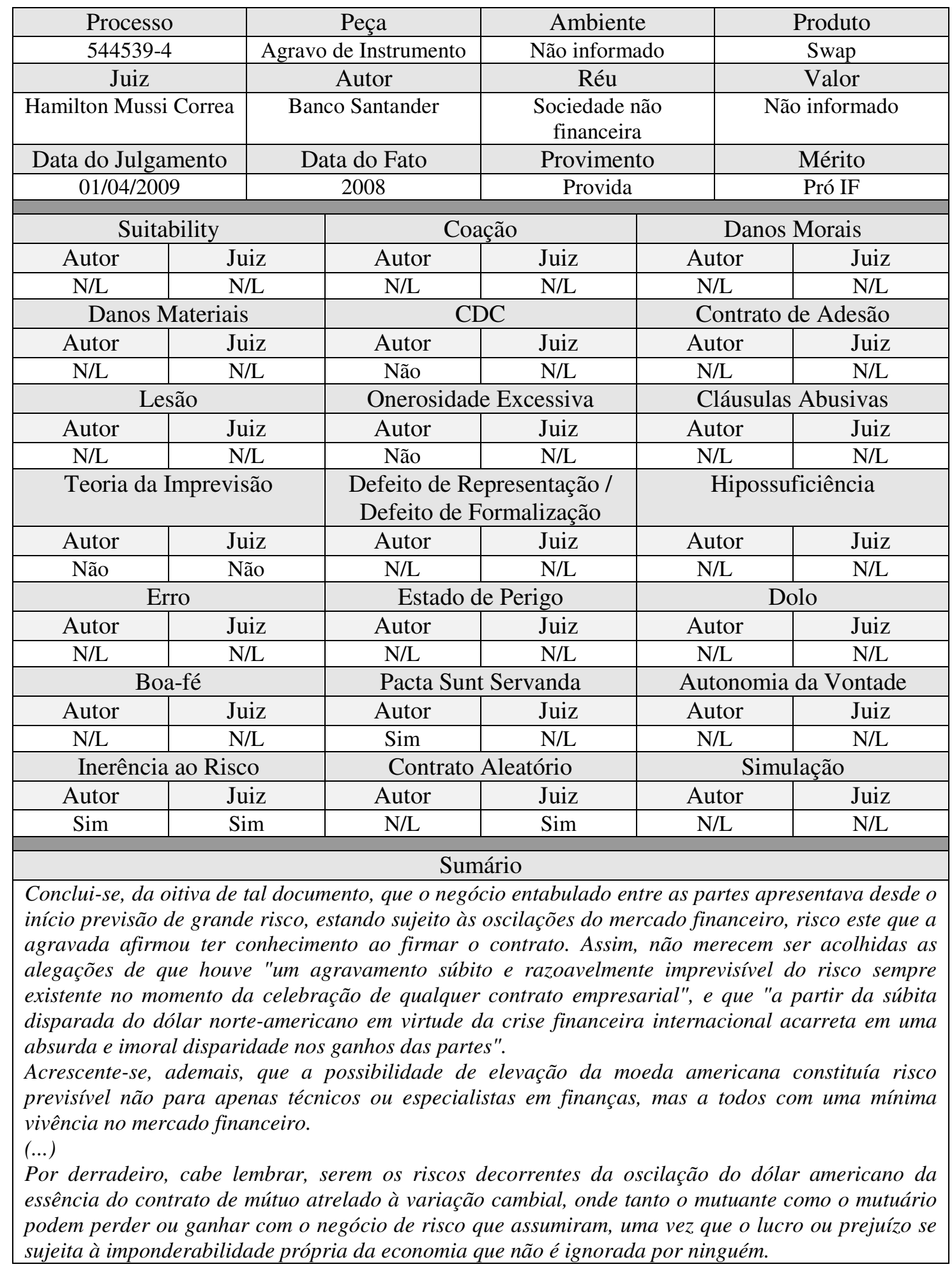


Apêndice 56-PR

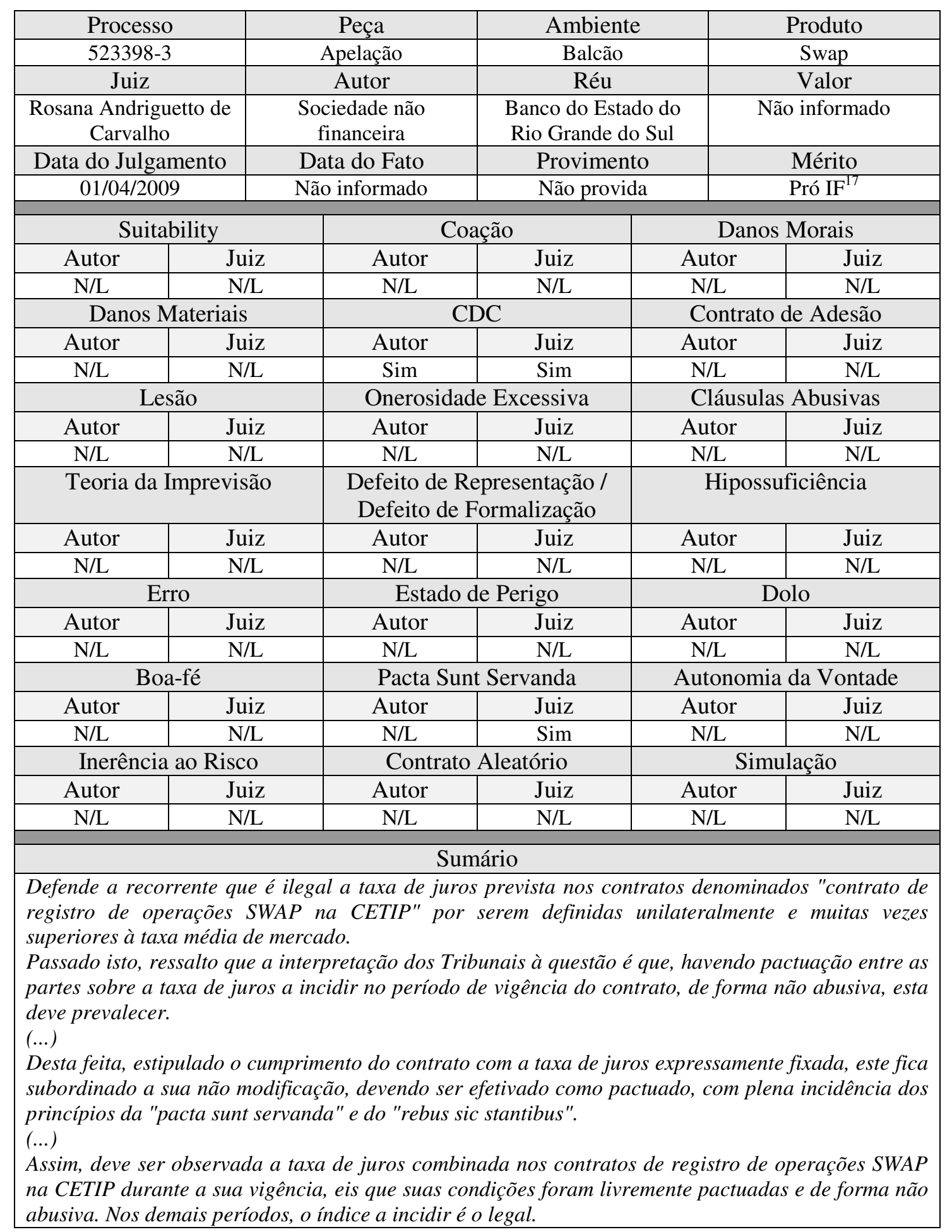

\footnotetext{
${ }^{17} \mathrm{O}$ recurso de apelação foi parcialmente provido. Os pedidos da apelante eram amplos e versavam sobre determinada cédula de crédito comercial e industrial, sobre contrato de abertura de crédito em conta corrente e, por fim, sobre um swap no ambiente CETIP. Especificamente sobre o derivativo do tipo swap, o recurso não foi provido e, por esse motivo, classificamos a decisão como "pró IF", pois, nesse aspecto, a decisão foi favorável ao Banco.
} 
Apêndice 57-PR

\begin{tabular}{|c|c|c|c|c|c|}
\hline & Peça & \multicolumn{2}{|c|}{ Ambiente } & Produto \\
\hline \multicolumn{2}{|c|}{$523398-3 / 01$} & $\begin{array}{l}\text { Embargos de } \\
\text { declaração }\end{array}$ & \multicolumn{2}{|c|}{ Balcão } & Swap \\
\hline \multicolumn{2}{|c|}{ Juiz } & Autor & \multicolumn{2}{|c|}{ Réu } & Valor \\
\hline \multicolumn{2}{|c|}{$\begin{array}{c}\text { Rosana Andriguetto de } \\
\text { Carvalho }\end{array}$} & $\begin{array}{l}\text { Sociedade não } \\
\text { financeira }\end{array}$ & \multicolumn{2}{|c|}{$\begin{array}{l}\text { Banco do Estado do } \\
\text { Rio Grande do Sul }\end{array}$} & Não informado \\
\hline \multicolumn{2}{|c|}{ Data do Julgamento } & Data do Fato & \multicolumn{2}{|c|}{ Provimento } & Mérito \\
\hline $15 / 07$ & & informado & Não pr & & Pró IF \\
\hline \multicolumn{2}{|c|}{ Suitability } & \multicolumn{2}{|c|}{ Coação } & \multicolumn{2}{|c|}{ Danos Morais } \\
\hline Autor & & Autor & Juiz & Autor & Juiz \\
\hline $\mathrm{N} / \mathrm{L}$ & $\mathrm{N}$ & $\mathrm{N} / \mathrm{L}$ & $\mathrm{N} / \mathrm{L}$ & $\mathrm{N} / \mathrm{L}$ & $\mathrm{N} / \mathrm{L}$ \\
\hline \multicolumn{2}{|c|}{ Danos Materiais } & \multicolumn{2}{|c|}{$\mathrm{CDC}$} & \multicolumn{2}{|c|}{ Contrato de Adesão } \\
\hline Autor & & Autor & Juiz & Autor & Juiz \\
\hline $\mathrm{N} / \mathrm{L}$ & & $\mathrm{N} / \mathrm{L}$ & $\mathrm{N} / \mathrm{L}$ & $\mathrm{N} / \mathrm{L}$ & $\mathrm{N} / \mathrm{L}$ \\
\hline \multicolumn{2}{|c|}{ Lesão } & \multicolumn{2}{|c|}{ Onerosidade Excessiva } & \multicolumn{2}{|c|}{ Cláusulas Abusivas } \\
\hline Autor & & Autor & Juiz & Autor & Juiz \\
\hline $\mathrm{N} / \mathrm{L}$ & & $\mathrm{N} / \mathrm{L}$ & $\mathrm{N} / \mathrm{L}$ & $\mathrm{N} / \mathrm{L}$ & $\mathrm{N} / \mathrm{L}$ \\
\hline \multicolumn{2}{|c|}{ Teoria da Imprevisão } & \multicolumn{2}{|c|}{$\begin{array}{l}\text { Defeito de Representação } \\
\text { Defeito de Formalização }\end{array}$} & Hip & ficiência \\
\hline Autor & $\mathrm{Ju}$ & Autor & Juiz & Autor & Juiz \\
\hline $\mathrm{N} / \mathrm{L}$ & & $\mathrm{N} / \mathrm{L}$ & $\mathrm{N} / \mathrm{L}$ & $\mathrm{N} / \mathrm{L}$ & $\mathrm{N} / \mathrm{L}$ \\
\hline & & Esta & e Perigo & & \\
\hline Autor & $\mathrm{Ju}$ & Autor & Juiz & Autor & Juiz \\
\hline $\mathrm{N} / \mathrm{L}$ & & $\mathrm{N} / \mathrm{L}$ & $\mathrm{N} / \mathrm{L}$ & $\mathrm{N} / \mathrm{L}$ & $\mathrm{N} / \mathrm{L}$ \\
\hline & & Pacta & Servanda & Autong & da Vontade \\
\hline Autor & $\mathrm{Ju}$ & Autor & Juiz & Autor & Juiz \\
\hline $\mathrm{N} / \mathrm{L}$ & & $\mathrm{N} / \mathrm{L}$ & Sim & $\mathrm{N} / \mathrm{L}$ & $\mathrm{N} / \mathrm{L}$ \\
\hline Inerê & Risc & Cont & Aleatório & & lação \\
\hline Autor & & Autor & Juiz & Autor & Juiz \\
\hline $\mathrm{N} / \mathrm{L}$ & & $\mathrm{N} / \mathrm{L}$ & $\mathrm{N} / \mathrm{L}$ & $\mathrm{N} / \mathrm{L}$ & $\mathrm{N} / \mathrm{L}$ \\
\hline & & & ário & & \\
\hline $\begin{array}{l}\text { Como se vê } \\
\text { previam a t } \\
\text { para a rejei } \\
\text { Questão sur } \\
\text { já tenha e } \\
\text { fundamento } \\
\text { pelos litigar }\end{array}$ & se 1 & $\begin{array}{l}\text { tratou de } \\
\text { los contrato } \\
\text { ela apelante } \\
\text { o está obrig } \\
\text { iciente par } \\
\text { ¿, tampouco }\end{array}$ & $\begin{array}{l}\text { clara e espe } \\
\text { minados } S W \\
\text { responder to } \\
\text { lar a decis } \\
\text { ponder um }\end{array}$ & $\begin{array}{l}\text { a nulidar } \\
\text { endo suf } \\
\text { alegaçõ } \\
m \text { se ol } \\
\text { dos os a }\end{array}$ & $\begin{array}{l}\text { s cláusulas que } \\
\text { tes fundamentos } \\
\text { s partes quando } \\
\text { a ater-se aos } \\
\text { entos deduzidos }\end{array}$ \\
\hline
\end{tabular}

\footnotetext{
${ }^{18}$ Embargos de declaração que contestam a decisão referente ao swap dada em sede da apelação descrita no Apêndice 56-PR.
} 
Apêndice 58-PR

\begin{tabular}{|c|c|c|c|c|c|c|}
\hline \multicolumn{2}{|c|}{ Processo } & \multicolumn{2}{|r|}{ Peça } & \multicolumn{2}{|c|}{ Ambiente } & Produto \\
\hline \multicolumn{2}{|c|}{$672902-0$} & \multicolumn{2}{|c|}{ Agravo de instrumento } & \multicolumn{2}{|c|}{ Não informado } & Swap \\
\hline \multicolumn{2}{|c|}{ Juiz } & \multicolumn{2}{|r|}{ Autor } & \multicolumn{2}{|c|}{ Réu } & Valor \\
\hline \multicolumn{2}{|c|}{$\begin{array}{l}\text { Hayton Lee Swain } \\
\text { Filho } \\
\end{array}$} & \multicolumn{2}{|c|}{ Banco West LB } & \multicolumn{2}{|c|}{$\begin{array}{l}\text { Sociedade não } \\
\text { financeira }\end{array}$} & $5,5 \mathrm{~mm}-6,0 \mathrm{~mm}$ \\
\hline \multicolumn{2}{|c|}{ Data do Julgamento } & \multicolumn{2}{|c|}{ Data do Fato } & \multicolumn{2}{|c|}{ Provimento } & Mérito \\
\hline \multicolumn{2}{|c|}{$04 / 05 / 2010$} & \multicolumn{2}{|c|}{2009} & \multicolumn{2}{|c|}{ Não provida } & Sem mérito ${ }^{19}$ \\
\hline \multicolumn{3}{|c|}{ Suitability } & \multicolumn{2}{|c|}{ Coação } & \multicolumn{2}{|c|}{ Danos Morais } \\
\hline Autor & & & Autor & Juiz & Autor & Juiz \\
\hline $\mathrm{N} / \mathrm{L}$ & $\mathrm{N}$ & & $\mathrm{N} / \mathrm{L}$ & $\mathrm{N} / \mathrm{L}$ & $\mathrm{N} / \mathrm{L}$ & $\mathrm{N} / \mathrm{L}$ \\
\hline \multicolumn{3}{|c|}{ Danos Materiais } & \multicolumn{2}{|c|}{$\mathrm{CDC}$} & \multicolumn{2}{|c|}{ Contrato de Adesão } \\
\hline Autor & & & Autor & Juiz & Autor & Juiz \\
\hline $\mathrm{N} / \mathrm{L}$ & & & $\mathrm{N} / \mathrm{L}$ & $\mathrm{N} / \mathrm{L}$ & $\mathrm{N} / \mathrm{L}$ & $\mathrm{N} / \mathrm{L}$ \\
\hline \multicolumn{3}{|c|}{ Lesão } & Onerosida & cessiva & Cláus & usivas \\
\hline Autor & & & Autor & Juiz & Autor & Juiz \\
\hline $\mathrm{N} / \mathrm{L}$ & $\mathrm{N}$ & & $\mathrm{N} / \mathrm{L}$ & $\mathrm{N} / \mathrm{L}$ & $\mathrm{N} / \mathrm{L}$ & $\mathrm{N} / \mathrm{L}$ \\
\hline Teoria & & & $\begin{array}{c}\text { Defeito de R } \\
\text { Defeito de }\end{array}$ & $\begin{array}{l}\text { sentação } \\
\text { alizaçãc }\end{array}$ & Hip & ncia \\
\hline Autor & & & Autor & Juiz & Autor & Juiz \\
\hline $\mathrm{N} / \mathrm{L}$ & $\mathrm{N}$ & & $\mathrm{N} / \mathrm{L}$ & $\mathrm{N} / \mathrm{L}$ & $\mathrm{N} / \mathrm{L}$ & $\mathrm{N} / \mathrm{L}$ \\
\hline & & & Estado & erigo & & \\
\hline Autor & $\mathrm{Ju}$ & & Autor & Juiz & Autor & Juiz \\
\hline $\mathrm{N} / \mathrm{L}$ & $\mathrm{N}$ & & $\mathrm{N} / \mathrm{L}$ & $\mathrm{N} / \mathrm{L}$ & $\mathrm{N} / \mathrm{L}$ & $\mathrm{N} / \mathrm{L}$ \\
\hline & & & Pacta Sur & vanda & Autono & Vontade \\
\hline Autor & & & Autor & Juiz & Autor & Juiz \\
\hline $\mathrm{N} / \mathrm{L}$ & $\mathrm{N}$ & & $\mathrm{N} / \mathrm{L}$ & $\mathrm{N} / \mathrm{L}$ & $\mathrm{N} / \mathrm{L}$ & $\mathrm{N} / \mathrm{L}$ \\
\hline Inerêl & & & Contrato & atório & & \\
\hline Autor & $\mathrm{Ju}$ & & Autor & Juiz & Autor & Juiz \\
\hline $\mathrm{N} / \mathrm{L}$ & & & $\mathrm{N} / \mathrm{L}$ & $\mathrm{N} / \mathrm{L}$ & $\mathrm{N} / \mathrm{L}$ & $\mathrm{N} / \mathrm{L}$ \\
\hline & & & & & & \\
\hline $\begin{array}{l}\text { Em somatór } \\
\text { título mani } \\
\text { monitórios, } \\
\text { exame), estc } \\
\text { circunstânct } \\
\text { inocorrênci } \\
\text { vencimento } \\
\text { alegaçôes e } \\
\text { Alie-se a dis } \\
\text { pelos agrav } \\
\text { reconhecer } \\
\text { deduzidas } n \\
\text { financeira. } \\
\text { Por tais ra } \\
\text { constantes } \\
\text { quantos nec } \\
\text { credor. } \\
\text { Por derrade } \\
\text { extrai a gra } \\
\text { provimento }\end{array}$ & $\begin{array}{l}\text { se } \\
\text { na } \\
\text { do d } \\
\text { os a } \\
\text { oder } \\
\text { ra, } \\
\text { do a } \\
\text { m xe } \\
\text { ind } \\
\text { im } \\
\text { lênc } \\
\text { irgo } \\
\text { ue s } \\
\text { ado, } \\
\text { par } \\
\text { bém }\end{array}$ & $\begin{array}{l}\text { que } \\
\text { o re } \\
\text { a im } \\
\text { ato } \\
\text { as de } \\
\text { que } \\
\text { eferi } \\
\text { le de } \\
\text { a da } \\
\text { mor } \\
\text { e rev } \\
\text { con } \\
\text { a ass } \\
\text { não }\end{array}$ & $\begin{array}{l}\text { Jue, neste juízo d } \\
\text { nitória encontr } \\
\text { contratos onde } \\
\text { hecimento da on } \\
\text { ar em significati } \\
\text { no caso concre } \\
\text { is operaçóes, fl. } \\
\text { ova escrita sem } \\
\text { to (por meio de a } \\
\text { ustrar a tese def } \\
\text { uo, objeto da sen } \\
\text { rios (fls. } 152 / 17 \\
\text { prematuro nest } \\
\text { r medida com } \\
\text { rar a satisfação } \\
\text { confere o requisi } \\
\text { ceira dos agravo } \\
\text { tmo alega o agra }\end{array}$ & $\begin{array}{l}\text { nição su } \\
\text { istência } \\
\text { iação da } \\
\text { dade exc } \\
\text { teração } \\
\text { oderia s } \\
\text {, situaçã } \\
\text { ia de títu } \\
\text { cho sane } \\
\text { a nos er } \\
\text { de méri } \\
\text { em cont } \\
\text { rtunidad } \\
\text { s de arr } \\
\text { ral da v } \\
\text { perigo } \\
\text { i ponto a }\end{array}$ & $\begin{array}{l}\text { pretensâ } \\
\text { sa ded } \\
\text { torte-am } \\
\text { m relaçâ } \\
\text { ta dívidc } \\
\text { em tese } \\
\text { fraquece } \\
\text { tivo. } \\
\text { produçâ } \\
\text { fl. } 969 / \\
\text { lo porqu } \\
\text { o à pret } \\
\text { ando po } \\
\text { re os bc } \\
\text { antia qu } \\
\text { ra, na } m\end{array}$ & $\begin{array}{l}\text { stituição do } \\
\text { embargos } \\
\text { hipótese em } \\
\text { e devedora, } \\
\text { ualmente, a } \\
\text { orrência do } \\
\text { bilidade das } \\
\text { a pleiteada } \\
\text { lão implica } \\
\text { as matérias } \\
\text { instituição } \\
\text { s elementos } \\
\text { éus, tantos } \\
\text { vante se diz } \\
\text { que não se } \\
\text { do eventual }\end{array}$ \\
\hline
\end{tabular}

${ }^{19}$ Trata-se de agravo de instrumento contra liminar que indeferiu pedido de arrresto de bens contra sociedade não financeira (em desfavor de instituição financeira). Este julgamento de segunda instância não entra no mérito da discussão, que deverá ser decidido em primeira instância (em sede de ação monitória), e apenas reitera o indeferimento da liminar referente ao arresto. 
É que não se pode afirmar, com base nos elementos carreados, seja pela situação de tentativa de reestruturação de passivos (fl. 16-TJ), seja pelas execuções ajuizadas em desfavor da primeira agravada Imcopa (fls. 1031/1033-TJ) que restará comprometida a eficácia do eventual provimento final favorável da ação monitória.

Ou seja, não há indícios para se deliberar sobre os ativos e passivos dos agravados e que desse cotejo nada sobrará para garantir o pagamento do crédito, ainda incerto, eventualmente possa ser reconhecido na ação monitória, o que afasta o segundo requisito da medida cautelar. 
Apêndice 59-PR ${ }^{20}$

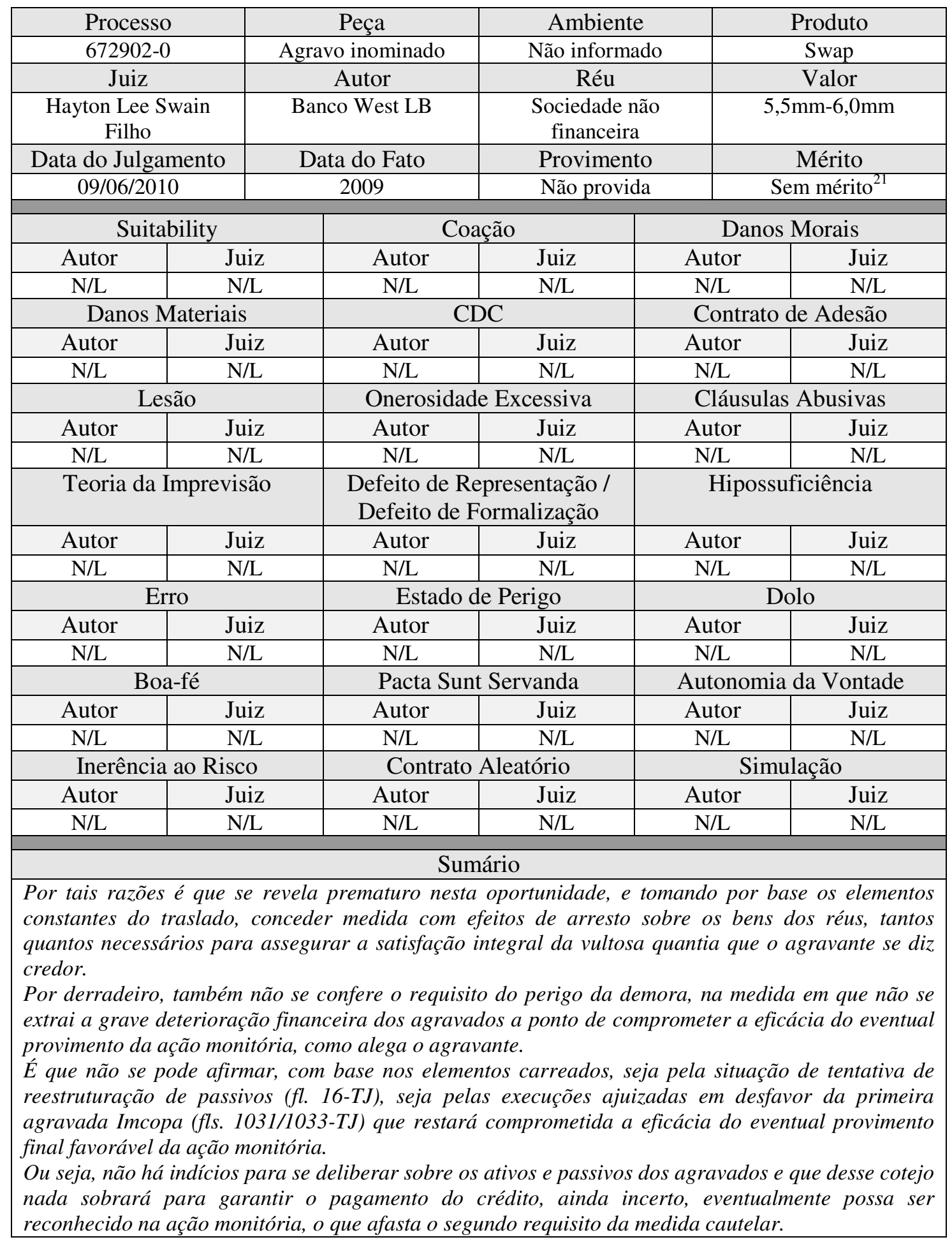

\footnotetext{
${ }^{20}$ Trata-se de agravo inominado contra agravo de instrumento descrito no Apêndice 58-PR.

${ }^{21}$ Novamente, tal como descrito no Apêndice 58-PR, decidiu-se que o mérito seria analisado em primeira instância, em sede de monitória.
} 
Apêndice 60-SC

\begin{tabular}{|c|c|c|c|c|c|}
\hline & Peça & \multicolumn{2}{|c|}{ Ambiente } & Produto \\
\hline \multicolumn{2}{|c|}{$2004.011416-8$} & Apelação & \multicolumn{2}{|c|}{ N/A - Fundo } & Fundo de investimento \\
\hline \multicolumn{2}{|c|}{ Juiz } & Autor & \multicolumn{2}{|c|}{ Réu } & Valor \\
\hline \multicolumn{2}{|c|}{$\begin{array}{l}\text { Wilson Augusto do } \\
\text { Nascimento }\end{array}$} & ssoa física & \multicolumn{2}{|c|}{ Banco Boavista S.A. } & Não informado \\
\hline \multicolumn{2}{|c|}{ Data do Julgamento } & \multirow{2}{*}{ ata do Fato } & \multicolumn{2}{|c|}{ Provimento } & Mérito \\
\hline \multicolumn{2}{|c|}{$17 / 10 / 2006$} & & \multicolumn{2}{|c|}{ Não provida } & Pró IF \\
\hline \multicolumn{2}{|c|}{ Suitability } & \multicolumn{2}{|c|}{ Coação } & \multicolumn{2}{|c|}{ Danos Morais } \\
\hline Autor & $\mathrm{Ju}$ & Autor & Juiz & Sim & Juiz \\
\hline $\mathrm{N} / \mathrm{L}$ & $\mathrm{N}$ & $\mathrm{N} / \mathrm{L}$ & $\mathrm{N} / \mathrm{L}$ & $\mathrm{N} / \mathrm{L}$ & $\mathrm{N} / \mathrm{L}$ \\
\hline \multicolumn{2}{|c|}{ Danos Materiais } & \multicolumn{2}{|c|}{$\mathrm{CDC}$} & \multicolumn{2}{|c|}{ Contrato de Adesão } \\
\hline Autor & $\mathrm{Ju}$ & Autor & Juiz & Autor & Juiz \\
\hline Sim & $\mathrm{N}$ & Sim & Sim & $\mathrm{N} / \mathrm{L}$ & $\mathrm{N} / \mathrm{L}$ \\
\hline \multicolumn{2}{|c|}{ Lesão } & \multicolumn{2}{|c|}{ Onerosidade Excessiva } & \multicolumn{2}{|c|}{ Cláusulas Abusivas } \\
\hline Autor & $\mathrm{Ju}$ & Autor & Juiz & Autor & Juiz \\
\hline $\mathrm{N} / \mathrm{L}$ & & $\mathrm{N} / \mathrm{L}$ & $\mathrm{N} / \mathrm{L}$ & $\mathrm{N} / \mathrm{L}$ & $\mathrm{N} / \mathrm{L}$ \\
\hline \multicolumn{2}{|c|}{ Teoria da Imprevisão } & $\begin{array}{c}\text { Defeito d } \\
\text { Defeito }\end{array}$ & $\begin{array}{l}\text { resentação } \\
\text { rmalização }\end{array}$ & Hip & ficiência \\
\hline Autor & & Autor & Juiz & Autor & Juiz \\
\hline $\mathrm{N} / \mathrm{L}$ & & $\mathrm{N} / \mathrm{L}$ & $\mathrm{N} / \mathrm{L}$ & $\mathrm{N} / \mathrm{L}$ & $\mathrm{N} / \mathrm{L}$ \\
\hline & & Esta & Perigo & & blo \\
\hline Autor & & Autor & Juiz & Autor & Juiz \\
\hline $\mathrm{N} / \mathrm{L}$ & & $\mathrm{N} / \mathrm{L}$ & $\mathrm{N} / \mathrm{L}$ & $\mathrm{N} / \mathrm{L}$ & $\mathrm{N} / \mathrm{L}$ \\
\hline & & Pacta & Servanda & Autono & da Vontade \\
\hline Autor & & Autor & Juiz & Autor & Juiz \\
\hline $\mathrm{N} / \mathrm{L}$ & & $\mathrm{N} / \mathrm{L}$ & $\mathrm{N} / \mathrm{L}$ & $\mathrm{N} / \mathrm{L}$ & $\mathrm{N} / \mathrm{L}$ \\
\hline Inerê & Risc & Cont & leatório & & lação \\
\hline Autor & & Autor & Juiz & Autor & Juiz \\
\hline $\mathrm{N} / \mathrm{L}$ & & $\mathrm{N} / \mathrm{L}$ & $\mathrm{N} / \mathrm{L}$ & $\mathrm{N} / \mathrm{L}$ & $\mathrm{N} / \mathrm{L}$ \\
\hline & & & & & \\
\hline $\begin{array}{l}\text { É cediço, e } \\
\text { oscilando e } \\
\text { ao investido } \\
\text { investimente } \\
\text { Nessa hipót } \\
\text { causal. } \\
\text { A conduta d } \\
\text { de ganho, o } \\
\text { consequênc } \\
\text { (...) } \\
\text { Ilógico seric } \\
\text { possibilidad } \\
\text { Por isso, in } \\
\text { falar em rep }\end{array}$ & $c ̧ a ̂$ & $\begin{array}{l}\text { Oos de inves } \\
\text { depender } \\
\text { decréscime } \\
\text { eira com a } \\
\text { a, torna-se } \\
\text { está em pr } \\
\text { perda dos } i \\
\text { rrelação da } \\
\text { alquer inves } \\
\text { na verdadei } \\
\text { duta enseja } \\
\text { imoniais en }\end{array}$ & $\begin{array}{l}\text { to, não obst } \\
\text { rcado finan } \\
\text { eu patrimôn } \\
\text { sa proposta } \\
\text { voca a pres } \\
\text { serviço de. } \\
\text { mentos aplic } \\
\text { uta ao dano. } \\
\text { to em fundos } \\
\text { pia de enriq } \\
\text { de responsal } \\
\text { ao autor. }\end{array}$ & $\begin{array}{l}\text { us result } \\
\text { promess } \\
\text { ido com } \\
\text { no positi } \\
\text { conduta } \\
\text { le investi } \\
\text { fundo de }\end{array}$ & $\begin{array}{l}\text { sejam incertos, } \\
\text { lusiva de ganho } \\
\text { o mesmo credite } \\
\text { dano e do nexo } \\
\text { o com promessa } \\
\text { estimento, e, por } \\
\text { de risco e sem a } \\
\text { o. } \\
\text { l, não há que se }\end{array}$ \\
\hline
\end{tabular}


Apêndice 61-SC

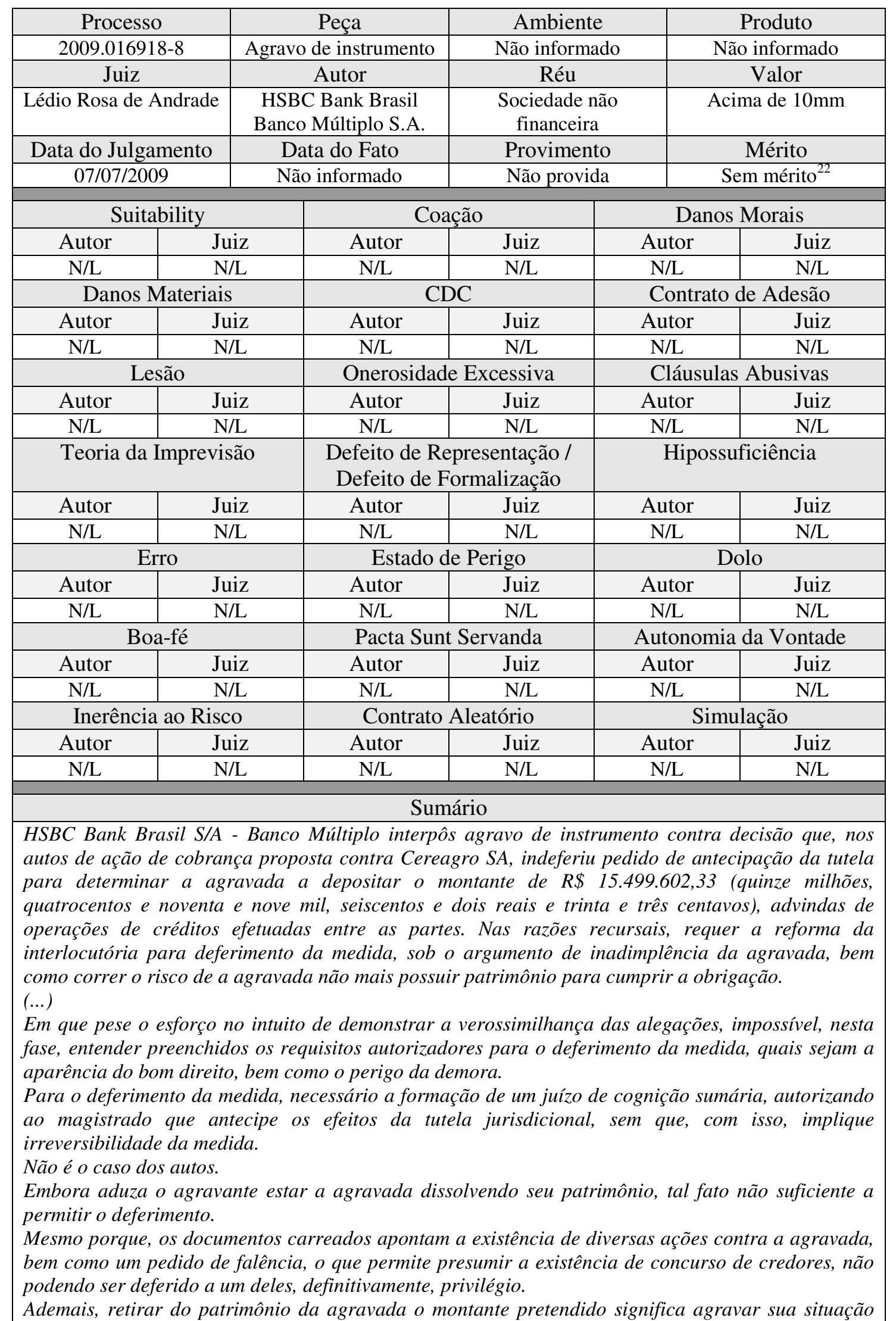

\footnotetext{
${ }^{22}$ Trata-se de agravo de instrumento contra decisão que indeferiu antecipação de tutela (depósito de valores) em desfavor de instituição financeira. Este julgamento de segunda instância não entra no mérito da discussão, que deverá ser decidido em primeira instância (em sede de ação de cobrança).
} 
financeira, tendo em vista a dificuldade de reaver montante que ultrapasse os quinze milhões de reais. Ainda, trata-se o agravante de instituição financeira multinacional, com capital social avantajado, motivo pelo qual não se verifica o perigo da demora.

A aparência do bom direito também não lhe é garantida, pois ausentes documentos que permitam concluir a finalização das operações, bem como do valor total da divida. 
Apêndice 62-SC

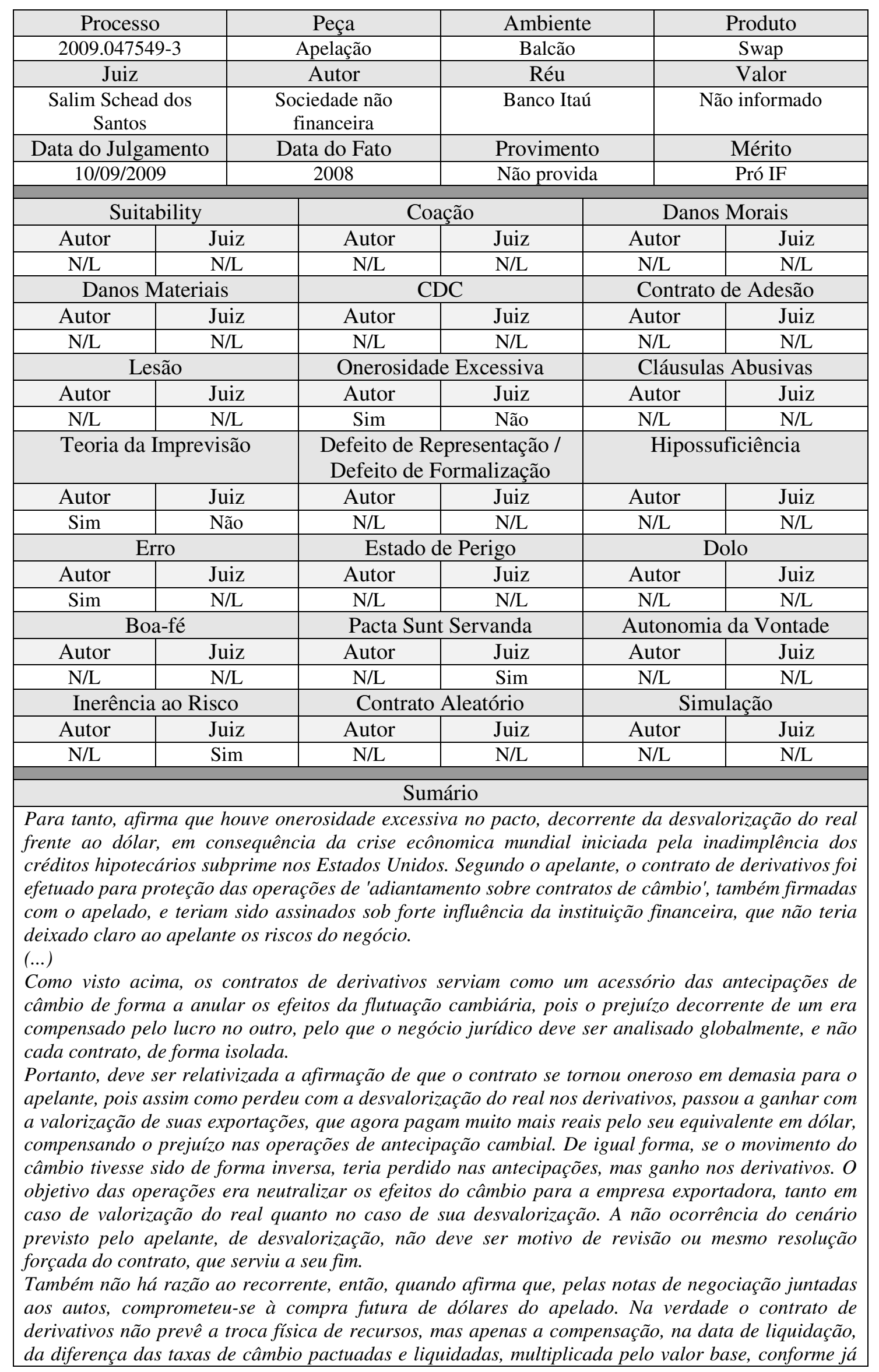


explicado.

E, ao contrário do que afirma o apelante, a teoria da imprevisão não é aplicável ao caso, pois a livre flutuação da moeda imposta pelo Banco Central há quase dez anos é de pleno conhecimento de todos, sendo que quem escolhe operar nesse mercado deve assumir os riscos que lhe são inerentes, tanto pelos diversos problemas aos quais estão sujeitas as exportações desde a saída do produto da empresa até o recebimento de seu valor, quanto pelas variações a que se submete a moeda.

Dessa forma, não cabe a resolução ou a revisão de um contrato quando o mesmo servia para garantir outro no qual a relação de prejuízo/lucro era inversa, constatando-se que a operação, quando analisada globalmente, pretendia garantir a neutralidade para o cliente bancário. A imprevisão do comportamento do mercado de câmbio também não é motivo para embasar a intenção do apelante, porquanto que os riscos são inerentes ao negócio pactuado, e devem ser assumidos pelos contratantes. 
Apêndice 63-SC

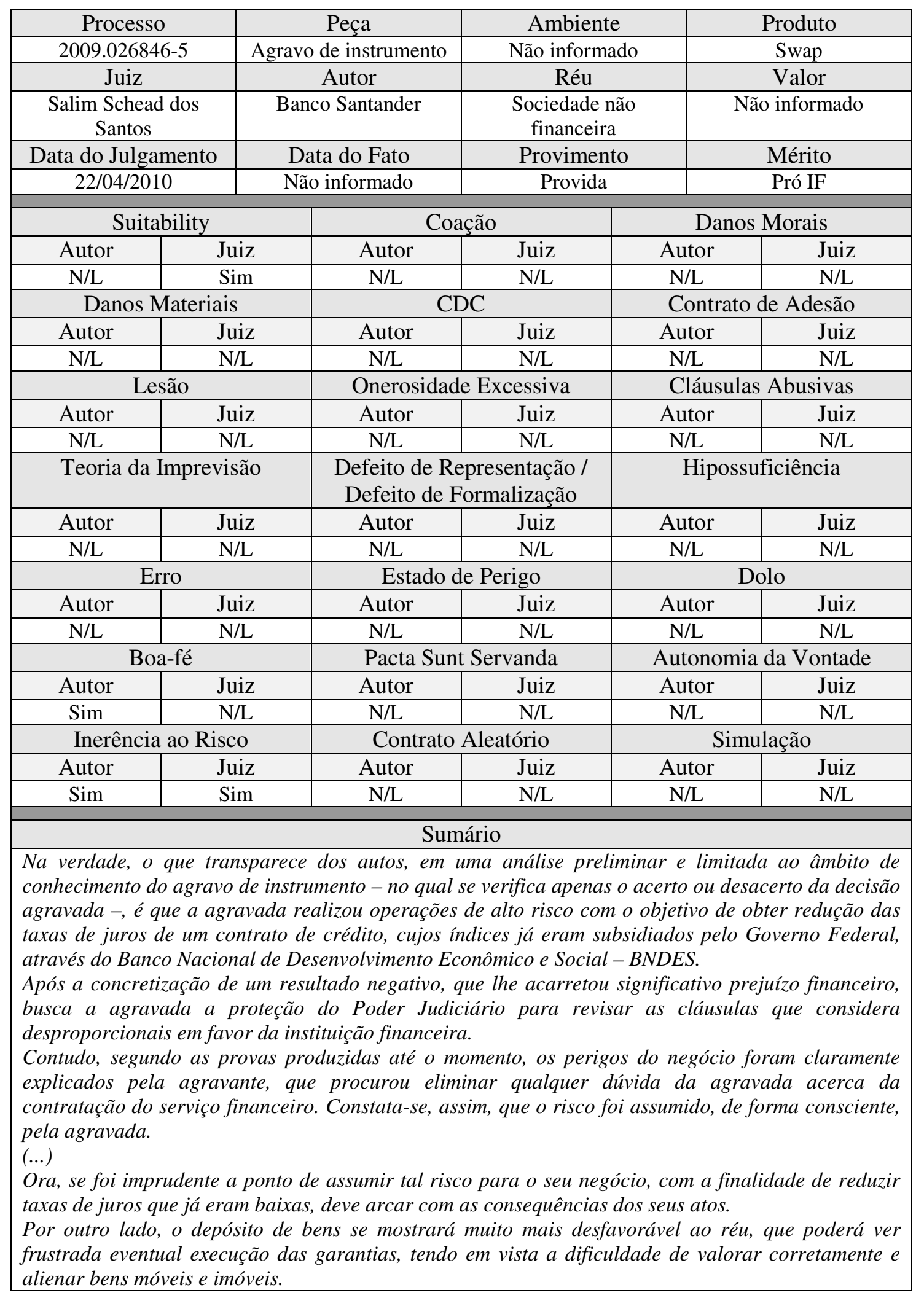


Apêndice 64-SC

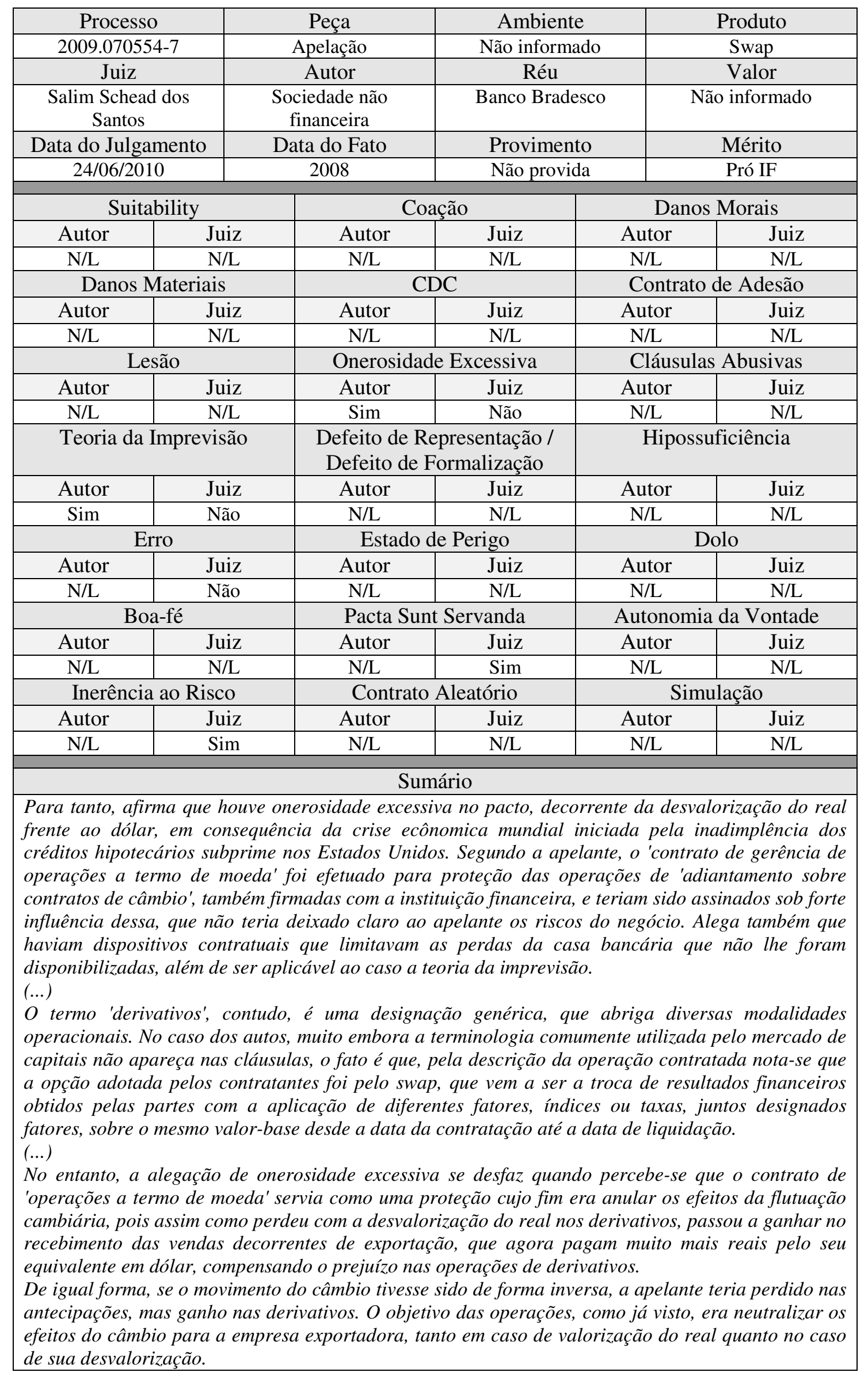


É certo também que a contratação de operações a termo não impede a ocorrência de prejuízos, eis que a complexidade da manobra financeira traz consigo a possibilidade de erros, tanto na avaliação de riscos por parte dos contratantes como na operacionalização por parte do banco.

Porém, no presente caso, não foi demonstrado qualquer erro de operação que fosse imputável à casa bancária, mas apenas a insatisfação da contratante com o resultado obtido com o contrato. A não ocorrência do cenário previsto pela apelante, entretanto, não deve ser motivo de revisão ou mesmo resolução forçada do contrato, que serviu a seu fim, mesmo que de modo inesperado pela parte.

(...)

E, ao contrário do que afirma a apelante, a teoria da imprevisão não é aplicável ao caso, pois a livre flutuação da moeda imposta pelo Banco Central há mais de dez anos é de pleno conhecimento de todos, sendo que quem escolhe operar nesse campo deve assumir os riscos que lhe são inerentes, tanto pelos diversos problemas aos quais estão sujeitas as exportações, desde a saída do produto da empresa até o recebimento de seu valor, quanto pelas variações diárias a que se submete a moeda, sempre suscetível de flutuações inesperadas de acordo com o sentimento do mercado em relação à economia mundial.

(...)

Assim, não cabe a resolução ou a revisão de um contrato quando o mesmo servia para garantir outro no qual a relação de prejuízo/lucro era inversa, constatando-se que a operação, quando analisada globalmente, pretendia garantir a neutralidade para o cliente bancário. A imprevisão do comportamento do mercado de câmbio também não é motivo para embasar a intenção do apelante, porquanto que os riscos são inerentes ao negócio pactuado, e devem ser assumidos pelos contratantes.

Last, but not least, não se pode olvidar que a apelante foi devidamente alertada dos riscos por ela assumidos com o contrato, conforme clara redação da cláusula 5.14 (fl. 33), "sem qualquer promessa de rentabilidade" por parte da instituição financeira.

Por tais motivos, deve ser mantida a decisão que julgou improcedentes os pedidos formulados nos autos da ação revisional e da ação cautelar inominada. 
Apêndice $65-\mathrm{SC}^{23}$

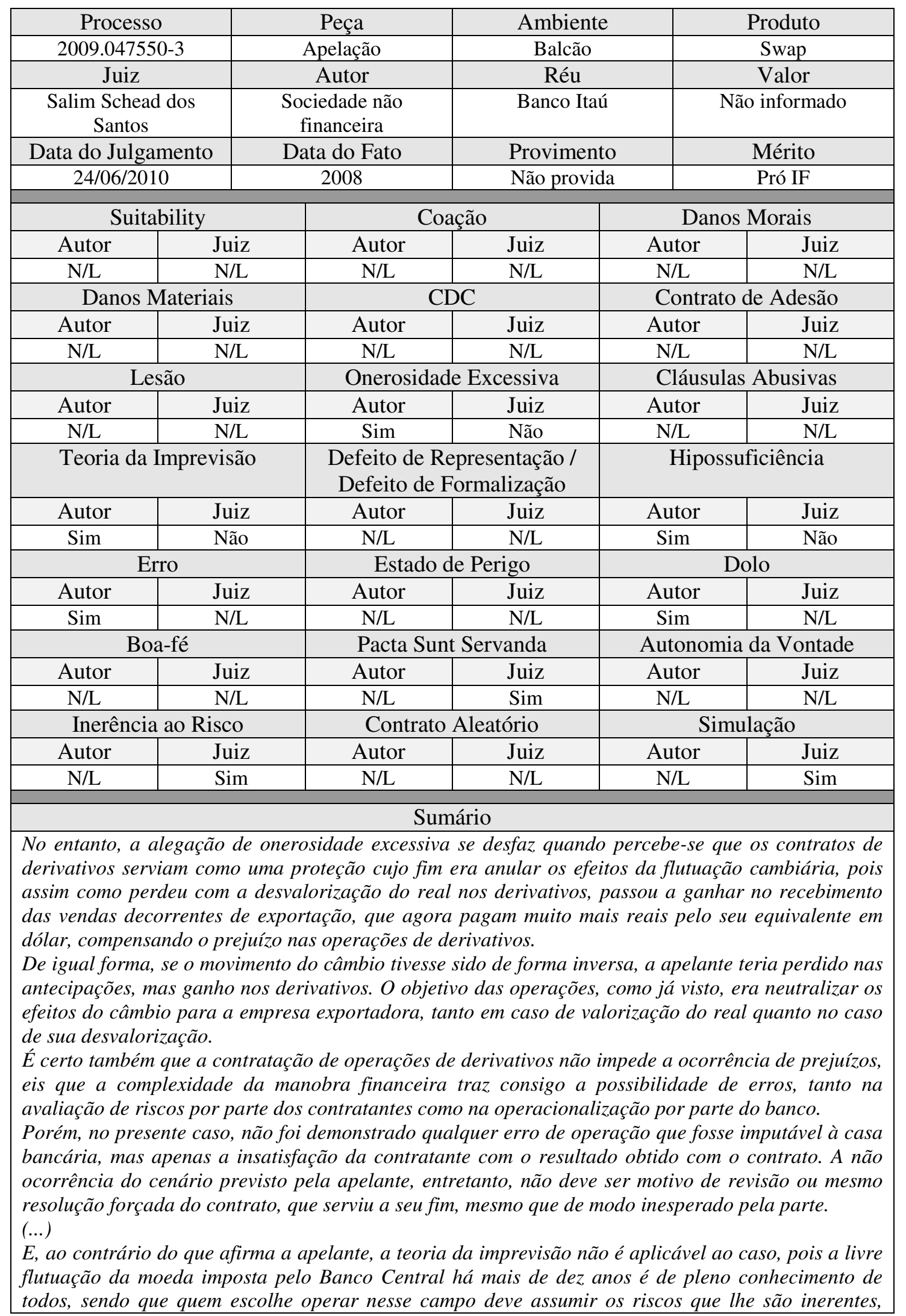

${ }^{23}$ Trata-se de recurso oriundo da mesma ação que originou o recurso descrito no Apêndice 62-SC. Após o retorno dos autos à origem, foi constatado equívoco na intimação dos advogados da empresa recorrente, ocasionando a nulidade do julgamento de primeira instância. Assim, houve nova apelação, mantendo-se exatamente a mesma decisão no mérito e os mesmos argumentos levantados e rebatidos. 
tanto pelos diversos problemas aos quais estão sujeitas as exportações, desde a saída do produto da empresa até o recebimento de seu valor, quanto pelas variações diárias a que se submete a moeda, sempre suscetível de flutuações inesperadas de acordo com o sentimento do mercado em relação à economia mundial. 
Apêndice 66-RS

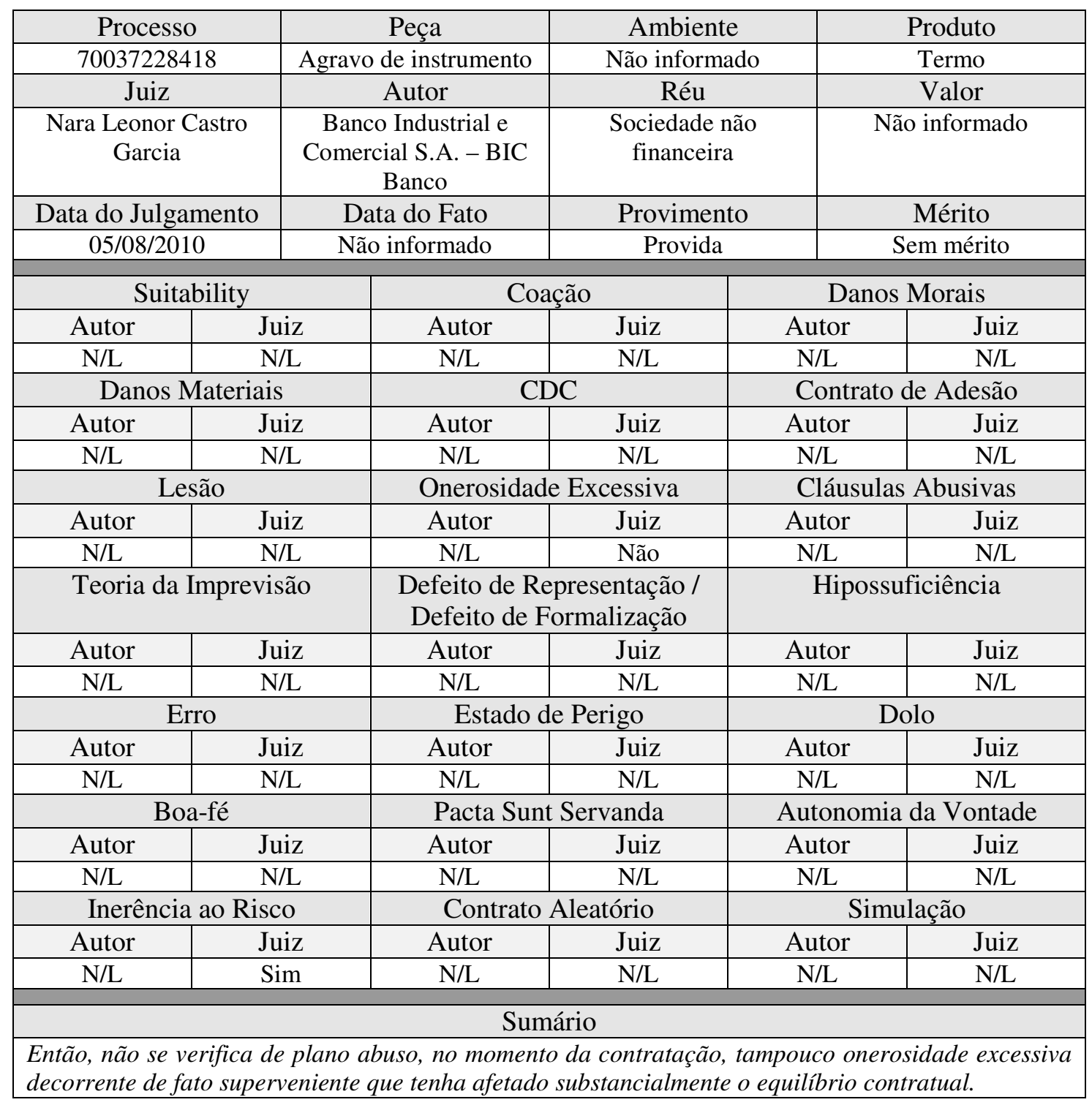


Apêndice 67-RS

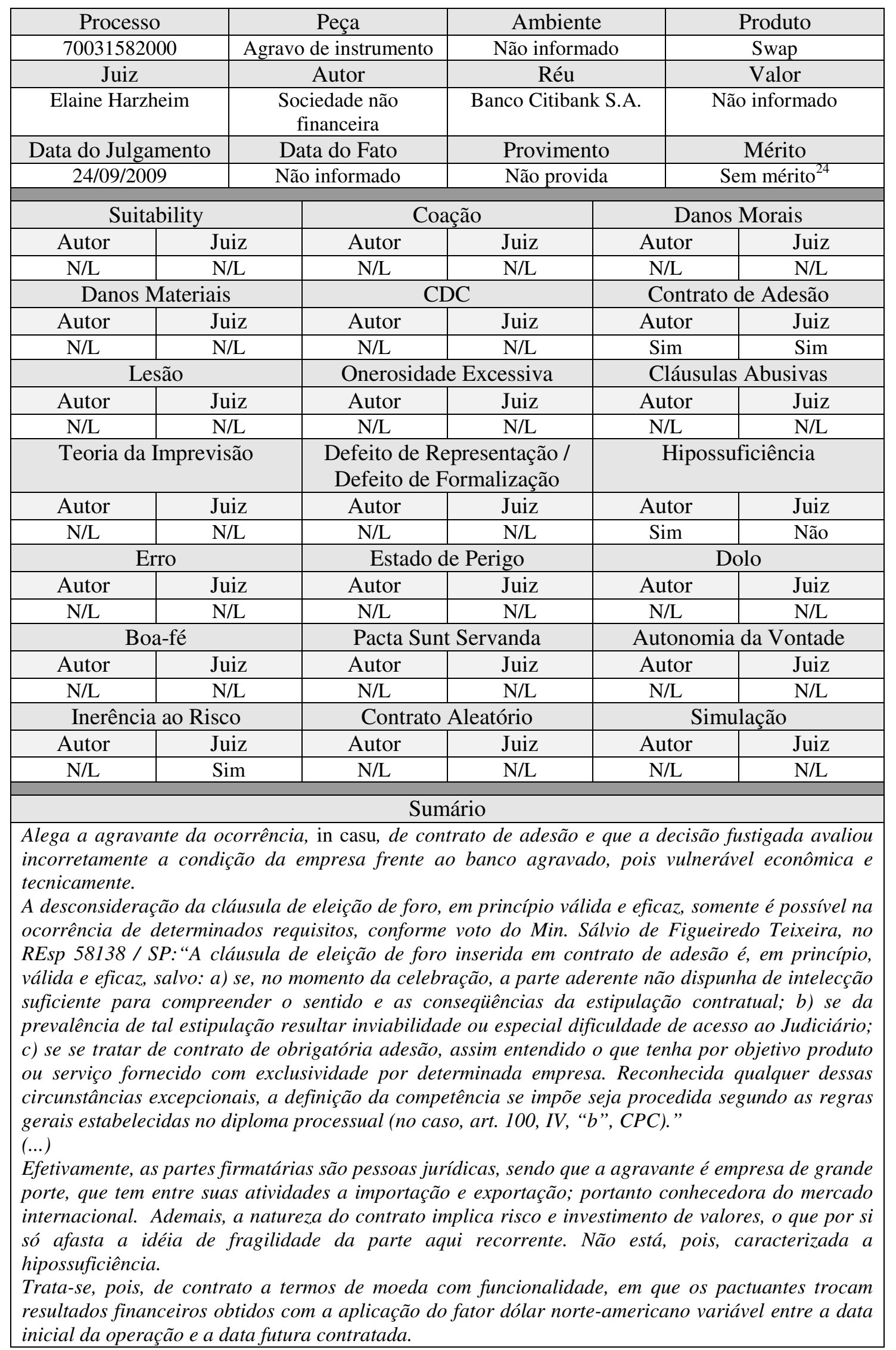

${ }^{24} \mathrm{~A}$ discussão gira em torno da cláusula de eleição de foro. De todo modo, vale o julgado pelos argumentos da magistrada referentes à hipossuficiência e à inerência ao risco dos derivativos. 
Assim, seja pela natureza do contrato e dos valores expressivos de cada negociação, não há que se falar em hipossuficiência. Aliás, a própria agravante, na inicial da ação revisional, informe ser "uma empresa dedicada à produção de calçados, com comercialização orientada para a exportação. Foi criada em 1962 e mantém 1.140 empregados diretos, em medida, gerando emprego, rendas $e$ tributos" (fl. 49). Portanto, estamos diante de empresa de grande porte.

Ainda no tocante à vulnerabilidade econômica ou técnica da agravante em relação à agravada, é elementar que diante de um contrato, as partes não sejam ou não tenham condições exatamente iguais, seja do ponto de vista econômico ou social. Mas nem por isso se estabelece uma condição jurídico-processual desigual, o que, aliás, não se vê no caso em tela, diante do competente trabalho desenvolvido pelos patronos de ambos os litigantes. Mas eventual desigualdade do ponto de vista econômico, por si só, não autoriza rasgar o que foi pactuado, do contrário estar-se-ia até mesmo a negar vigência aos dispositivos legais que tratam do foro de eleição. 
Apêndice 68-STJ

\begin{tabular}{|c|c|c|c|c|c|c|}
\hline & & Peça & \multicolumn{2}{|c|}{ Ambiente } & Produto \\
\hline \multicolumn{2}{|c|}{ 1003893RJ } & & rso Especial & \multicolumn{2}{|c|}{ N/A - Fundo } & Fundo de Investimento \\
\hline \multicolumn{2}{|c|}{ Juiz } & & Autor & \multicolumn{2}{|c|}{ Réu } & Valor \\
\hline \multicolumn{2}{|c|}{ Massami Uyeda } & & soa Física & \multicolumn{2}{|c|}{$\begin{array}{c}\text { Marka Nikko Asset } \\
\text { Management }\end{array}$} & Não informado \\
\hline \multicolumn{2}{|c|}{ Data do Julgamento } & & ta do Fato & \multicolumn{2}{|c|}{ Provimento } & Mérito \\
\hline \multicolumn{2}{|c|}{$10 / 08 / 2010$} & & Jan/99 & \multicolumn{2}{|c|}{ Não Provida } & Pró IF \\
\hline \multicolumn{2}{|c|}{ Suitability } & & \multicolumn{2}{|c|}{ Coação } & \multicolumn{2}{|c|}{ Danos Morais } \\
\hline Autor & & & Autor & Juiz & Autor & Juiz \\
\hline Não & & & $\mathrm{N} / \mathrm{L}$ & $\mathrm{N} / \mathrm{L}$ & $\mathrm{N} / \mathrm{L}$ & $\mathrm{N} / \mathrm{L}$ \\
\hline \multicolumn{2}{|c|}{ Danos Materiais } & & \multicolumn{2}{|c|}{$\mathrm{CDC}$} & \multicolumn{2}{|c|}{ Contrato de Adesão } \\
\hline Autor & $\mathrm{Ju}$ & & Autor & Juiz & Autor & Juiz \\
\hline $\mathrm{N} / \mathrm{L}$ & & & Sim & Sim & $\mathrm{N} / \mathrm{L}$ & $\mathrm{N} / \mathrm{L}$ \\
\hline \multicolumn{2}{|c|}{ Lesão } & & \multicolumn{2}{|c|}{ Onerosidade Excessiva } & \multicolumn{2}{|c|}{ Cláusulas Abusivas } \\
\hline Autor & & & Autor & Juiz & Autor & Juiz \\
\hline $\mathrm{N} / \mathrm{L}$ & & & $\mathrm{N} / \mathrm{L}$ & $\mathrm{N} / \mathrm{L}$ & $\mathrm{N} / \mathrm{L}$ & $\mathrm{N} / \mathrm{L}$ \\
\hline \multicolumn{2}{|c|}{ Teoria da Imprevisão } & & \multicolumn{2}{|c|}{$\begin{array}{c}\text { Defeito de Representação / } \\
\text { Defeito de Formalização }\end{array}$} & \multicolumn{2}{|c|}{ Hipossuficiência } \\
\hline Autor & & & Autor & Juiz & Autor & Juiz \\
\hline $\mathrm{N} / \mathrm{L}$ & & & $\mathrm{N} / \mathrm{L}$ & $\mathrm{N} / \mathrm{L}$ & $\mathrm{N} / \mathrm{L}$ & $\mathrm{N} / \mathrm{L}$ \\
\hline \multicolumn{2}{|c|}{ Erro } & & \multicolumn{2}{|c|}{ Estado de Perigo } & & olo \\
\hline Autor & & & Autor & Juiz & Autor & Juiz \\
\hline $\mathrm{N} / \mathrm{L}$ & & & $\mathrm{N} / \mathrm{L}$ & $\mathrm{N} / \mathrm{L}$ & $\mathrm{N} / \mathrm{L}$ & $\mathrm{N} / \mathrm{L}$ \\
\hline & & & Pacta $S$ & ervanda & Autono & da Vontade \\
\hline Autor & & & Autor & Juiz & Autor & Juiz \\
\hline $\mathrm{N} / \mathrm{L}$ & & & $\mathrm{N} / \mathrm{L}$ & $\mathrm{N} / \mathrm{L}$ & $\mathrm{N} / \mathrm{L}$ & $\mathrm{N} / \mathrm{L}$ \\
\hline Inerên & Risc & & Contr & leatório & & ulação \\
\hline Autor & & & Autor & Juiz & Autor & Juiz \\
\hline $\mathrm{N} / \mathrm{L}$ & & & $\mathrm{N} / \mathrm{L}$ & $\mathrm{N} / \mathrm{L}$ & $\mathrm{N} / \mathrm{L}$ & $\mathrm{N} / \mathrm{L}$ \\
\hline & & & & & & \\
\hline $\begin{array}{l}\text { O fornecedor } \\
\text { dar as inforn } \\
\text { serviços, cor } \\
\text { investimento } \\
\text { grau de risco } \\
\text { a investir em } \\
\text { (...) } \\
\text { Determina o } \\
\text { riscos, norm } \\
\text { adequadas a } \\
\text { tanto, o conh } \\
\text { derivativos, } \\
\text { para grande. } \\
\text { fundos arroj } \\
\text { investimentos } \\
\text { Não se pode } \\
\text { transformaçô } \\
\text { desse tipo de }\end{array}$ & $\begin{array}{l}\text { undos } \\
\text { to para } \\
\text { os arr } \\
\text { o } 8^{\circ} d \\
\text { previs } \\
\text { respei } \\
\text { ento do } \\
\text { ipalme } \\
\text { nhos, } \\
\text { estâo } \\
\text { s conse }\end{array}$ & & $\begin{array}{l}\text { em riscos, } n \\
\text { adequadas a } \\
\text { ito, o conhe } \\
\text { s, principalm } \\
\text { ganhos, come } \\
\text { äo cientes do } \\
\text { te Defesa do } \\
\text { consumidor } \\
\text { a, acerca da } \\
\text { nédio, consul } \\
\text { aculados ao } \\
\text { a perdas cor } \\
\text { os riscos do } \\
\text { como, por e. } \\
\text { nos idos de } \\
\text { ressalta o }\end{array}$ & $\begin{array}{l}\text { s e previsive } \\
\text { espeito, ou se } \\
\text { nto do hom } \\
\text { os vinculado } \\
\text { a perdas con } \\
\text { os do negóci } \\
\text { umidor que } \\
\text { mo dever d } \\
\text { reza e fruiç } \\
\text {-padrão. Des } \\
\text {-americano, } \\
\text { áveis. Aquel } \\
\text { cio, caso co } \\
\text { lo, na poupar } \\
9, \text { a econom }\end{array}$ & $\begin{array}{l}\text { ecedor de } \\
\text { as inform } \\
\text { serviços, } \\
\text { ma, no inv } \\
\text { to o alto } \\
\text { e se encor } \\
\text { o depositc }\end{array}$ & $\begin{array}{l}\text { s, tem o dever de } \\
\text { eza e fruição dos } \\
\text { idor-padrão. No } \\
\text { o, é ínsito o alto } \\
\text { que se encorajam } \\
\text { viços que causem } \\
\text { es necessárias e } \\
\text { nsiderando, para } \\
\text { imento em fundos } \\
\text { u de risco, tanto } \\
\text { im a investir em } \\
\text { Im suas reservas } \\
\text { a por profundas } \\
\text { dores dos riscos }\end{array}$ \\
\hline
\end{tabular}


$\underline{\text { Anexo SP }}$

\begin{tabular}{|l|l|l|l|l|l|l|}
\hline $\begin{array}{l}\text { Palavra- } \\
\text { Chave }\end{array}$ & Ano & $\begin{array}{l}\text { Retorno } \\
\text { Total }\end{array}$ & $\begin{array}{l}\text { Fora pelo } \\
\text { Escopo/Produto }\end{array}$ & $\begin{array}{l}\text { Fora pelo } \\
\text { Valor }\end{array}$ & Repetidos $^{25}$ & $\begin{array}{l}\text { Resultados } \\
\text { Válidos }\end{array}$ \\
\hline \multirow{5}{*}{ Derivativos } & 06 & 11 & 9 & 1 & 0 & 1 \\
\cline { 2 - 7 } & 07 & 9 & 3 & 0 & 0 & 6 \\
\cline { 2 - 7 } & 08 & 115 & $114^{26}$ & 0 & 0 & 1 \\
\cline { 2 - 7 } & 09 & 32 & 21 & 1 & 0 & 10 \\
\cline { 2 - 7 } & 10 & 17 & 14 & 1 & 0 & 2 \\
\hline \multirow{5}{*}{ Hedge } & 06 & 57 & $56^{27}$ & 0 & 1 & 0 \\
\cline { 2 - 7 } & 07 & 17 & 9 & 1 & 6 & 1 \\
\cline { 2 - 7 } & 08 & 22 & 22 & 0 & 0 & 0 \\
\cline { 2 - 7 } & 09 & 9 & 5 & 0 & 3 & 0 \\
\cline { 2 - 7 } & 10 & 9 & 9 & 1 & 0 & 0 \\
\hline Swap & 06 & 10 & 6 & 0 & 3 & 4 \\
\cline { 2 - 7 } & 07 & 9 & 2 & 0 & 0 & 1 \\
\cline { 2 - 7 } & 08 & 6 & 5 & 1 & 9 & 8 \\
\cline { 2 - 7 } & 09 & 21 & 5 & 0 & 1 & 5 \\
\cline { 2 - 7 } & 10 & 13 & 7 & & & \\
\hline
\end{tabular}

${ }^{25}$ Resultados repetidos são aqueles que já apareceram em anos anteriores com outras palavras chaves. Por exemplo, no ano de 2006, com a palavra-chave "hedge", tem-se a ocorrência de 1 resultado repetido, que, certamente, foi contabilizado no ano de 2006, quando do uso da palavra "derivativos".

${ }^{26}$ Dentre as 114 decisões, 58 são de um mesmo juiz que usa determinada citação com a palavra "derivativos" - não relacionada ao contexto da nossa pesquisa - e 48 de outro juiz que, ao discorrer sobre a inflação, nos casos do plano Verão, Collor e Bresser, usa outra citação que também traz a palavra "derivativos" como sinônimo de derivados. Nota-se que um mesmo juiz tende a usar o mesmo conteúdo em dezenas de sentenças que versam sobre a mesma matéria.

${ }^{27}$ Mais uma vez, um juiz usa o mesmo conteúdo de sentença para dezenas de deciões. Aqui, 54 decisões relacionadas aos casos de arrendamento mercantil (leasing) de 1999, que descrevem o "hedge" cambial realizado por instituições financeiras no contexto da maxi-desvalorização. Assim, usam a palavra "hedge" fora do contexto da nossa pesquisa.

${ }^{28}$ No contexto desta pesquisa, "dois mais dois" não é necessariamente "igual a quatro". Explica-se: para a palava-chave "swap", no ano de 2009, um único retorno deu origem a três resultados. Isso porque houve divergência entre os 3 desembargadores da câmara, o que ocasionou a contagem de 3 votos, como se fossem resultados diferentes. 
$\underline{\text { Anexo RJ }}$

\begin{tabular}{|c|c|c|c|c|c|c|}
\hline $\begin{array}{l}\text { Palavra- } \\
\text { Chave }\end{array}$ & Ano & $\begin{array}{l}\text { Retorno } \\
\text { Total }\end{array}$ & $\begin{array}{l}\text { Fora pelo } \\
\text { Escopo/Produto }\end{array}$ & $\begin{array}{ll}\text { Fora } & \text { pelo } \\
\text { Valor } & \end{array}$ & Repetidos & $\begin{array}{l}\text { Resultados } \\
\text { Válidos }\end{array}$ \\
\hline \multirow[t]{5}{*}{ Derivativos } & 06 & 1 & 0 & 0 & 0 & 1 \\
\hline & 07 & 1 & 0 & 1 & 0 & 0 \\
\hline & 08 & 3 & 1 & 0 & 0 & 2 \\
\hline & 09 & 2 & 0 & 1 & 0 & 1 \\
\hline & 10 & 1 & 0 & 1 & 0 & 0 \\
\hline \multirow[t]{5}{*}{ Hedge } & 06 & 2 & 0 & 0 & 1 & $2^{29}$ \\
\hline & 07 & 0 & 0 & 0 & 0 & 0 \\
\hline & 08 & 0 & 0 & 0 & 0 & 0 \\
\hline & 09 & 0 & 0 & 0 & 0 & 0 \\
\hline & 10 & 0 & 0 & 0 & 0 & 0 \\
\hline \multirow[t]{5}{*}{ Swap } & 06 & 0 & 0 & 0 & 0 & 0 \\
\hline & 07 & 0 & 0 & 0 & 0 & 0 \\
\hline & 08 & 0 & 0 & 0 & 0 & 0 \\
\hline & 09 & 0 & 0 & 0 & 0 & 0 \\
\hline & 10 & 0 & 0 & 0 & 0 & 0 \\
\hline \multicolumn{6}{|l|}{ TOTAL } & 6 \\
\hline
\end{tabular}

\footnotetext{
${ }^{29}$ Como dito, nesta pesquisa, "dois mais dois" não é necessariamente "igual a quatro". Assim como ocorrido em São Paulo no ano de 2009 para a palava-chave "swap", também no Estado do Rio de Janeiro, no ano de 2006 para a palavra-chave "hedge", um único retorno deu origem a dois resultados válidos. Isso porque houve divergência entre os desembargadores da câmara, o que ocasionou a contagem de 2 votos (voto vencido e voto vencedor), como se fossem resultados diferentes.
} 
$\underline{\text { Anexo MG }}$

\begin{tabular}{|c|c|c|c|c|c|c|}
\hline $\begin{array}{l}\text { Palavra- } \\
\text { Chave }\end{array}$ & Ano & \begin{tabular}{|l|} 
Retorno \\
Total
\end{tabular} & $\begin{array}{l}\text { Fora pelo } \\
\text { Escopo/Produto }\end{array}$ & $\begin{array}{l}\text { Fora pelo } \\
\text { Valor }\end{array}$ & Repetidos & $\begin{array}{l}\text { Resultados } \\
\text { Válidos }\end{array}$ \\
\hline \multirow[t]{5}{*}{ Derivativos } & 06 & 3 & 3 & 0 & 0 & 0 \\
\hline & 07 & 8 & 8 & 0 & 0 & 0 \\
\hline & 08 & 3 & 3 & 0 & 0 & 0 \\
\hline & 09 & 6 & 6 & 0 & 0 & 0 \\
\hline & 10 & 1 & 1 & 0 & 0 & 0 \\
\hline \multirow[t]{5}{*}{ Hedge } & 06 & 1 & 1 & 0 & 0 & 0 \\
\hline & 07 & 1 & 1 & 0 & 0 & 0 \\
\hline & 08 & 1 & 1 & 0 & 0 & 0 \\
\hline & 09 & 0 & 0 & 0 & 0 & 0 \\
\hline & 10 & 0 & 0 & 0 & 0 & 0 \\
\hline \multirow[t]{5}{*}{ Swap } & 06 & 0 & 0 & 0 & 0 & 0 \\
\hline & 07 & 0 & 0 & 0 & 0 & 0 \\
\hline & 08 & 1 & 0 & 1 & 0 & 0 \\
\hline & 09 & 0 & 0 & 0 & 0 & 0 \\
\hline & 10 & 0 & 0 & 0 & 0 & 0 \\
\hline \multicolumn{6}{|l|}{ TOTAL } & $\mathbf{0}$ \\
\hline
\end{tabular}


Anexo ES

\begin{tabular}{|l|l|l|l|l|l|l|}
\hline $\begin{array}{l}\text { Palavra- } \\
\text { Chave }\end{array}$ & Ano & $\begin{array}{l}\text { Retorno } \\
\text { Total }\end{array}$ & $\begin{array}{l}\text { Fora pelo } \\
\text { Escopo/Produto }\end{array}$ & $\begin{array}{l}\text { Fora pelo } \\
\text { Valor }\end{array}$ & Repetidos & $\begin{array}{l}\text { Resultados } \\
\text { Válidos }\end{array}$ \\
\hline \multirow{5}{*}{ Derivativos } & 06 & 0 & 0 & 0 & 0 & 0 \\
\cline { 2 - 7 } & 07 & 0 & 0 & 0 & 0 & 0 \\
\cline { 2 - 7 } & 08 & 0 & 0 & 0 & 0 & 0 \\
\cline { 2 - 7 } & 09 & 1 & 0 & 0 & 0 & 1 \\
\cline { 2 - 7 } & 10 & 0 & 0 & 0 & 0 & 0 \\
\hline \multirow{5}{*}{ Hedge } & 06 & 0 & 0 & 0 & 0 & 0 \\
\cline { 2 - 7 } & 07 & 0 & 0 & 0 & 0 & 0 \\
\cline { 2 - 7 } & 08 & 0 & 0 & 0 & 0 & 0 \\
\cline { 2 - 7 } & 09 & 1 & 0 & 0 & 1 & 0 \\
\cline { 2 - 7 } & 10 & 1 & 0 & 0 & 0 & 1 \\
\hline \multirow{5}{*}{ Swap } & 06 & 0 & 0 & 0 & 0 & 0 \\
\cline { 2 - 7 } & 07 & 0 & 0 & 0 & 0 & 0 \\
\cline { 2 - 7 } & 08 & 0 & 0 & 0 & 0 & 0 \\
\cline { 2 - 7 } & 09 & 0 & 0 & 0 & 0 & 0 \\
\cline { 2 - 7 } & 10 & 0 & 0 & & & 2 \\
\hline \multirow{5}{*}{ TOTAL } & & & 0 & 0 & 0 \\
\hline
\end{tabular}


$\underline{\text { Anexo PR }}$

\begin{tabular}{|c|c|c|c|c|c|c|}
\hline $\begin{array}{l}\text { Palavra- } \\
\text { Chave }\end{array}$ & Ano & $\begin{array}{l}\text { Retorno } \\
\text { Total }\end{array}$ & $\begin{array}{l}\text { Fora pelo } \\
\text { Escopo/Produto }\end{array}$ & $\begin{array}{l}\text { Fora pelo } \\
\text { Valor }\end{array}$ & Repetidos & $\begin{array}{l}\text { Resultados } \\
\text { Válidos } \\
\end{array}$ \\
\hline \multirow[t]{5}{*}{ Derivativos } & 06 & 4 & 4 & 0 & 0 & 0 \\
\hline & 07 & 0 & 0 & 0 & 0 & 0 \\
\hline & 08 & 1 & 0 & 1 & 0 & 0 \\
\hline & 09 & 7 & 4 & 0 & 0 & 3 \\
\hline & 10 & 9 & 8 & 1 & 0 & 0 \\
\hline \multirow[t]{5}{*}{ Hedge } & 06 & 3 & 2 & 1 & 0 & 0 \\
\hline & 07 & 3 & 3 & 0 & 0 & 0 \\
\hline & 08 & 6 & 5 & 0 & 0 & 1 \\
\hline & 09 & 4 & 4 & 0 & 0 & 0 \\
\hline & 10 & 1 & 1 & 0 & 0 & 0 \\
\hline \multirow[t]{5}{*}{ Swap } & 06 & 1 & 0 & 1 & 0 & 0 \\
\hline & 07 & 0 & 0 & 0 & 0 & 0 \\
\hline & 08 & 6 & 5 & 0 & 1 & 0 \\
\hline & 09 & 6 & 0 & 0 & 3 & 3 \\
\hline & 10 & 3 & 1 & 0 & 0 & 2 \\
\hline \multicolumn{6}{|l|}{ TOTAL } & 9 \\
\hline
\end{tabular}


Anexo SC

\begin{tabular}{|l|l|l|l|l|l|l|}
\hline $\begin{array}{l}\text { Palavra- } \\
\text { Chave }\end{array}$ & Ano & $\begin{array}{l}\text { Retorno } \\
\text { Total }\end{array}$ & $\begin{array}{l}\text { Fora pelo } \\
\text { Escopo/Produto }\end{array}$ & $\begin{array}{l}\text { Fora pelo } \\
\text { Valor }\end{array}$ & Repetidos & $\begin{array}{l}\text { Resultados } \\
\text { Válidos }\end{array}$ \\
\hline \multirow{5}{*}{ Derivativos } & 06 & 1 & 0 & 0 & 0 & 1 \\
\cline { 2 - 7 } & 07 & 0 & 0 & 0 & 0 & 0 \\
\cline { 2 - 7 } & 08 & 0 & 0 & 0 & 0 & 0 \\
\cline { 2 - 7 } & 09 & 3 & 0 & 0 & 1 & 2 \\
\cline { 2 - 7 } & 10 & 5 & 0 & 0 & 2 & 3 \\
\hline \multirow{5}{*}{ Hedge } & 06 & 1 & 0 & 0 & 1 & 0 \\
\cline { 2 - 7 } & 07 & 1 & 1 & 0 & 0 & 0 \\
\cline { 2 - 7 } & 08 & 0 & 0 & 0 & 0 & 0 \\
\cline { 2 - 7 } & 09 & 0 & 0 & 0 & 0 & 0 \\
\cline { 2 - 7 } & 10 & 0 & 0 & 0 & 0 & 0 \\
\hline \multirow{5}{*}{ Swap } & 06 & 0 & 0 & 0 & 0 & 0 \\
\cline { 2 - 7 } & 07 & 0 & 0 & 0 & 0 & 0 \\
\cline { 2 - 7 } & 08 & 0 & 0 & 0 & 0 & 0 \\
\cline { 2 - 7 } & 09 & 0 & 0 & 0 & 5 & 0 \\
\cline { 2 - 7 } & 10 & 5 & 0 & & & 0 \\
\hline \multirow{5}{*}{ TOTAL } & & & 0 & 0 & 0 \\
\hline
\end{tabular}


$\underline{\text { Anexo RS }}$

\begin{tabular}{|c|c|c|c|c|c|c|}
\hline $\begin{array}{l}\text { Palavra- } \\
\text { Chave }\end{array}$ & Ano & $\begin{array}{l}\text { Retorno } \\
\text { Total }\end{array}$ & $\begin{array}{l}\text { Fora pelo } \\
\text { Escopo/Produto }\end{array}$ & $\begin{array}{ll}\text { Fora } & \text { pelo } \\
\text { Valor } & \\
\end{array}$ & Repetidos & $\begin{array}{l}\text { Resultados } \\
\text { Válidos } \\
\end{array}$ \\
\hline \multirow[t]{5}{*}{ Derivativos } & 06 & 2 & 2 & 0 & 0 & 0 \\
\hline & 07 & 0 & 0 & 0 & 0 & 0 \\
\hline & 08 & 1 & 1 & 0 & 0 & 0 \\
\hline & 09 & 3 & 1 & 1 & 0 & 1 \\
\hline & 10 & 3 & 1 & 2 & 0 & 0 \\
\hline \multirow[t]{5}{*}{ Hedge } & 06 & 0 & 0 & 0 & 0 & 0 \\
\hline & 07 & 0 & 0 & 0 & 0 & 0 \\
\hline & 08 & 0 & 0 & 0 & 0 & 0 \\
\hline & 09 & 0 & 0 & 0 & 0 & 0 \\
\hline & 10 & 2 & 1 & 0 & 0 & 1 \\
\hline \multirow[t]{5}{*}{ Swap } & 06 & 0 & 0 & 0 & 0 & 0 \\
\hline & 07 & 0 & 0 & 0 & 0 & 0 \\
\hline & 08 & 0 & 0 & 0 & 0 & 0 \\
\hline & 09 & 1 & 0 & 0 & 1 & 0 \\
\hline & 10 & 2 & 0 & 2 & 0 & 0 \\
\hline \multicolumn{6}{|l|}{ TOTAL } & 2 \\
\hline
\end{tabular}


$\underline{\text { Anexo CE }}$

\begin{tabular}{|c|c|c|c|c|c|c|}
\hline $\begin{array}{l}\text { Palavra- } \\
\text { Chave }\end{array}$ & Ano & $\begin{array}{l}\text { Retorno } \\
\text { Total }\end{array}$ & $\begin{array}{l}\text { Fora pelo } \\
\text { Escopo/Produto }\end{array}$ & $\begin{array}{l}\text { Fora pelo } \\
\text { Valor }\end{array}$ & Repetidos & \begin{tabular}{|l} 
Resultados \\
Válidos \\
\end{tabular} \\
\hline \multirow[t]{5}{*}{ Derivativos } & 06 & 0 & 0 & 0 & 0 & 0 \\
\hline & 07 & 1 & 1 & 0 & 0 & $\mathbf{0}$ \\
\hline & 08 & 0 & 0 & 0 & 0 & 0 \\
\hline & 09 & 0 & 0 & 0 & 0 & 0 \\
\hline & 10 & 0 & 0 & 0 & 0 & 0 \\
\hline \multirow[t]{5}{*}{ Hedge } & 06 & 0 & 0 & 0 & 0 & $\mathbf{0}$ \\
\hline & 07 & 0 & 0 & 0 & 0 & 0 \\
\hline & 08 & 0 & 0 & 0 & 0 & $\mathbf{0}$ \\
\hline & 09 & 1 & 1 & 0 & 0 & $\mathbf{0}$ \\
\hline & 10 & 0 & 0 & 0 & 0 & 0 \\
\hline \multirow[t]{5}{*}{ Swap } & 06 & 0 & 0 & 0 & 0 & $\mathbf{0}$ \\
\hline & 07 & 0 & 0 & 0 & 0 & $\mathbf{0}$ \\
\hline & 08 & 0 & 0 & 0 & 0 & 0 \\
\hline & 09 & 1 & 1 & 0 & 0 & $\mathbf{0}$ \\
\hline & 10 & 1 & 1 & 0 & 0 & $\mathbf{0}$ \\
\hline \multicolumn{6}{|l|}{ TOTAL } & $\mathbf{0}$ \\
\hline
\end{tabular}


$\underline{\text { Anexo MA }}$

\begin{tabular}{|c|c|c|c|c|c|c|}
\hline $\begin{array}{l}\text { Palavra- } \\
\text { Chave }\end{array}$ & Ano & $\begin{array}{l}\text { Retorno } \\
\text { Total }\end{array}$ & $\begin{array}{l}\text { Fora pelo } \\
\text { Escopo/Produto }\end{array}$ & $\begin{array}{l}\text { Fora pelo } \\
\text { Valor }\end{array}$ & Repetidos & \begin{tabular}{|l} 
Resultados \\
Válidos
\end{tabular} \\
\hline \multirow[t]{5}{*}{ Derivativos } & 06 & 0 & 0 & 0 & 0 & 0 \\
\hline & 07 & 0 & 0 & 0 & 0 & 0 \\
\hline & 08 & 0 & 0 & 0 & 0 & 0 \\
\hline & 09 & 0 & 0 & 0 & 0 & 0 \\
\hline & 10 & 0 & 0 & 0 & 0 & 0 \\
\hline \multirow[t]{5}{*}{ Hedge } & 06 & 0 & 0 & 0 & 0 & 0 \\
\hline & 07 & 0 & 0 & 0 & 0 & 0 \\
\hline & 08 & 0 & 0 & 0 & 0 & 0 \\
\hline & 09 & 0 & 0 & 0 & 0 & 0 \\
\hline & 10 & 0 & 0 & 0 & 0 & $\mathbf{0}$ \\
\hline \multirow[t]{5}{*}{ Swap } & 06 & 0 & 0 & 0 & 0 & 0 \\
\hline & 07 & 0 & 0 & 0 & 0 & 0 \\
\hline & 08 & 0 & 0 & 0 & 0 & 0 \\
\hline & 09 & 0 & 0 & 0 & 0 & 0 \\
\hline & 10 & 0 & 0 & 0 & 0 & 0 \\
\hline \multicolumn{6}{|l|}{ TOTAL } & $\mathbf{0}$ \\
\hline
\end{tabular}


$\underline{\text { Anexo SE }}$

\begin{tabular}{|c|c|c|c|c|c|c|}
\hline $\begin{array}{l}\text { Palavra- } \\
\text { Chave }\end{array}$ & Ano & $\begin{array}{l}\text { Retorno } \\
\text { Total }\end{array}$ & $\begin{array}{l}\text { Fora pelo } \\
\text { Escopo/Produto }\end{array}$ & $\begin{array}{l}\text { Fora pelo } \\
\text { Valor }\end{array}$ & Repetidos & $\begin{array}{l}\text { Resultados } \\
\text { Válidos } \\
\end{array}$ \\
\hline \multirow[t]{5}{*}{ Derivativos } & 06 & 1 & 1 & 0 & 0 & 0 \\
\hline & 07 & 0 & 0 & 0 & 0 & $\mathbf{0}$ \\
\hline & 08 & 0 & 0 & 0 & 0 & 0 \\
\hline & 09 & 1 & 1 & 0 & 0 & 0 \\
\hline & 10 & 0 & 0 & 0 & 0 & $\mathbf{0}$ \\
\hline \multirow[t]{5}{*}{ Hedge } & 06 & 0 & 0 & 0 & 0 & $\mathbf{0}$ \\
\hline & 07 & 0 & 0 & 0 & 0 & $\mathbf{0}$ \\
\hline & 08 & 0 & 0 & 0 & 0 & $\mathbf{0}$ \\
\hline & 09 & 0 & 0 & 0 & 0 & $\mathbf{0}$ \\
\hline & 10 & 0 & 0 & 0 & 0 & 0 \\
\hline \multirow[t]{5}{*}{ Swap } & 06 & 35 & 35 & 0 & 0 & $\mathbf{0}$ \\
\hline & 07 & 7 & 7 & 0 & 0 & $\mathbf{0}$ \\
\hline & 08 & 1 & 1 & 0 & 0 & 0 \\
\hline & 09 & 0 & 0 & 0 & 0 & 0 \\
\hline & 10 & 0 & 0 & 0 & 0 & $\mathbf{0}$ \\
\hline \multicolumn{6}{|l|}{ TOTAL } & $\mathbf{0}$ \\
\hline
\end{tabular}


$\underline{\text { Anexo AL }}$

\begin{tabular}{|c|c|c|c|c|c|c|}
\hline $\begin{array}{l}\text { Palavra- } \\
\text { Chave }\end{array}$ & Ano & $\begin{array}{l}\text { Retorno } \\
\text { Total }\end{array}$ & $\begin{array}{l}\text { Fora pelo } \\
\text { Escopo/Produto }\end{array}$ & $\begin{array}{l}\text { Fora pelo } \\
\text { Valor }\end{array}$ & Repetidos & \begin{tabular}{|l} 
Resultados \\
Válidos \\
\end{tabular} \\
\hline \multirow[t]{5}{*}{ Derivativos } & 06 & 0 & 0 & 0 & 0 & 0 \\
\hline & 07 & 0 & 0 & 0 & 0 & 0 \\
\hline & 08 & 0 & 0 & 0 & 0 & 0 \\
\hline & 09 & 0 & 0 & 0 & 0 & 0 \\
\hline & 10 & 0 & 0 & 0 & 0 & 0 \\
\hline \multirow[t]{5}{*}{ Hedge } & 06 & 0 & 0 & 0 & 0 & $\mathbf{0}$ \\
\hline & 07 & 0 & 0 & 0 & 0 & 0 \\
\hline & 08 & 0 & 0 & 0 & 0 & $\mathbf{0}$ \\
\hline & 09 & 0 & 0 & 0 & 0 & $\mathbf{0}$ \\
\hline & 10 & 0 & 0 & 0 & 0 & $\mathbf{0}$ \\
\hline \multirow[t]{5}{*}{ Swap } & 06 & 0 & 0 & 0 & 0 & $\mathbf{0}$ \\
\hline & 07 & 0 & 0 & 0 & 0 & $\mathbf{0}$ \\
\hline & 08 & 0 & 0 & 0 & 0 & 0 \\
\hline & 09 & 0 & 0 & 0 & 0 & $\mathbf{0}$ \\
\hline & 10 & 0 & 0 & 0 & 0 & $\mathbf{0}$ \\
\hline \multicolumn{6}{|l|}{ TOTAL } & $\mathbf{0}$ \\
\hline
\end{tabular}


$\underline{\text { Anexo PI }}$

\begin{tabular}{|c|c|c|c|c|c|c|}
\hline $\begin{array}{l}\text { Palavra- } \\
\text { Chave }\end{array}$ & Ano & $\begin{array}{l}\text { Retorno } \\
\text { Total }\end{array}$ & $\begin{array}{l}\text { Fora pelo } \\
\text { Escopo/Produto }\end{array}$ & $\begin{array}{l}\text { Fora pelo } \\
\text { Valor }\end{array}$ & Repetidos & $\begin{array}{l}\text { Resultados } \\
\text { Válidos }\end{array}$ \\
\hline \multirow[t]{5}{*}{ Derivativos } & 06 & 0 & 0 & 0 & 0 & 0 \\
\hline & 07 & 0 & 0 & 0 & 0 & 0 \\
\hline & 08 & 0 & 0 & 0 & 0 & 0 \\
\hline & 09 & 0 & 0 & 0 & 0 & 0 \\
\hline & 10 & 0 & 0 & 0 & 0 & 0 \\
\hline \multirow[t]{5}{*}{ Hedge } & 06 & 0 & 0 & 0 & 0 & 0 \\
\hline & 07 & 0 & 0 & 0 & 0 & 0 \\
\hline & 08 & 0 & 0 & 0 & 0 & 0 \\
\hline & 09 & 0 & 0 & 0 & 0 & 0 \\
\hline & 10 & 0 & 0 & 0 & 0 & 0 \\
\hline \multirow[t]{5}{*}{ Swap } & 06 & 0 & 0 & 0 & 0 & 0 \\
\hline & 07 & 0 & 0 & 0 & 0 & 0 \\
\hline & 08 & 0 & 0 & 0 & 0 & 0 \\
\hline & 09 & 0 & 0 & 0 & 0 & 0 \\
\hline & 10 & 0 & 0 & 0 & 0 & 0 \\
\hline \multicolumn{6}{|l|}{ TOTAL } & 0 \\
\hline
\end{tabular}


Anexo RN

\begin{tabular}{|c|c|c|c|c|c|c|}
\hline $\begin{array}{l}\text { Palavra- } \\
\text { Chave }\end{array}$ & Ano & $\begin{array}{l}\text { Retorno } \\
\text { Total }\end{array}$ & $\begin{array}{l}\text { Fora pelo } \\
\text { Escopo/Produto }\end{array}$ & $\begin{array}{l}\text { Fora pelo } \\
\text { Valor }\end{array}$ & Repetidos & $\begin{array}{l}\text { Resultados } \\
\text { Válidos } \\
\end{array}$ \\
\hline \multirow[t]{5}{*}{ Derivativos } & 06 & 0 & 0 & 0 & 0 & 0 \\
\hline & 07 & 0 & 0 & 0 & 0 & $\mathbf{0}$ \\
\hline & 08 & 0 & 0 & 0 & 0 & 0 \\
\hline & 09 & 0 & 0 & 0 & 0 & $\mathbf{0}$ \\
\hline & 10 & 0 & 0 & 0 & 0 & 0 \\
\hline \multirow[t]{5}{*}{ Hedge } & 06 & 0 & 0 & 0 & 0 & $\mathbf{0}$ \\
\hline & 07 & 0 & 0 & 0 & 0 & $\mathbf{0}$ \\
\hline & 08 & 0 & 0 & 0 & 0 & $\mathbf{0}$ \\
\hline & 09 & 0 & 0 & 0 & 0 & $\mathbf{0}$ \\
\hline & 10 & 0 & 0 & 0 & 0 & 0 \\
\hline \multirow[t]{5}{*}{ Swap } & 06 & 0 & 0 & 0 & 0 & $\mathbf{0}$ \\
\hline & 07 & 0 & 0 & 0 & 0 & 0 \\
\hline & 08 & 0 & 0 & 0 & 0 & 0 \\
\hline & 09 & 0 & 0 & 0 & 0 & 0 \\
\hline & 10 & 0 & 0 & 0 & 0 & $\mathbf{0}$ \\
\hline \multicolumn{6}{|l|}{ TOTAL } & $\mathbf{0}$ \\
\hline
\end{tabular}


Anexo PB

\begin{tabular}{|c|c|c|c|c|c|c|}
\hline $\begin{array}{l}\text { Palavra- } \\
\text { Chave }\end{array}$ & Ano & $\begin{array}{l}\text { Retorno } \\
\text { Total }\end{array}$ & $\begin{array}{l}\text { Fora pelo } \\
\text { Escopo/Produto }\end{array}$ & $\begin{array}{l}\text { Fora pelo } \\
\text { Valor }\end{array}$ & Repetidos & $\begin{array}{l}\text { Resultados } \\
\text { Válidos }\end{array}$ \\
\hline \multirow[t]{5}{*}{ Derivativos } & 06 & 0 & 0 & 0 & 0 & 0 \\
\hline & 07 & 0 & 0 & 0 & 0 & $\mathbf{0}$ \\
\hline & 08 & 0 & 0 & 0 & 0 & 0 \\
\hline & 09 & 0 & 0 & 0 & 0 & 0 \\
\hline & 10 & 0 & 0 & 0 & 0 & 0 \\
\hline \multirow[t]{5}{*}{ Hedge } & 06 & 0 & 0 & 0 & 0 & $\mathbf{0}$ \\
\hline & 07 & 0 & 0 & 0 & 0 & 0 \\
\hline & 08 & 0 & 0 & 0 & 0 & 0 \\
\hline & 09 & 0 & 0 & 0 & 0 & 0 \\
\hline & 10 & 0 & 0 & 0 & 0 & 0 \\
\hline \multirow[t]{5}{*}{ Swap } & 06 & 0 & 0 & 0 & 0 & 0 \\
\hline & 07 & 0 & 0 & 0 & 0 & 0 \\
\hline & 08 & 0 & 0 & 0 & 0 & 0 \\
\hline & 09 & 0 & 0 & 0 & 0 & 0 \\
\hline & 10 & 0 & 0 & 0 & 0 & 0 \\
\hline \multicolumn{6}{|l|}{ TOTAL } & $\mathbf{0}$ \\
\hline
\end{tabular}


$\underline{\text { Anexo PE }}$

\begin{tabular}{|c|c|c|c|c|c|c|}
\hline $\begin{array}{l}\text { Palavra- } \\
\text { Chave }\end{array}$ & Ano & $\begin{array}{l}\text { Retorno } \\
\text { Total }\end{array}$ & $\begin{array}{l}\text { Fora pelo } \\
\text { Escopo/Produto }\end{array}$ & $\begin{array}{l}\text { Fora pelo } \\
\text { Valor }\end{array}$ & Repetidos & $\begin{array}{l}\text { Resultados } \\
\text { Válidos } \\
\end{array}$ \\
\hline \multirow[t]{5}{*}{ Derivativos } & 06 & 0 & 0 & 0 & 0 & 0 \\
\hline & 07 & 0 & 0 & 0 & 0 & $\mathbf{0}$ \\
\hline & 08 & 0 & 0 & 0 & 0 & 0 \\
\hline & 09 & 0 & 0 & 0 & 0 & $\mathbf{0}$ \\
\hline & 10 & 0 & 0 & 0 & 0 & 0 \\
\hline \multirow[t]{5}{*}{ Hedge } & 06 & 0 & 0 & 0 & 0 & $\mathbf{0}$ \\
\hline & 07 & 0 & 0 & 0 & 0 & $\mathbf{0}$ \\
\hline & 08 & 0 & 0 & 0 & 0 & $\mathbf{0}$ \\
\hline & 09 & 0 & 0 & 0 & 0 & $\mathbf{0}$ \\
\hline & 10 & 0 & 0 & 0 & 0 & 0 \\
\hline \multirow[t]{5}{*}{ Swap } & 06 & 0 & 0 & 0 & 0 & $\mathbf{0}$ \\
\hline & 07 & 0 & 0 & 0 & 0 & 0 \\
\hline & 08 & 0 & 0 & 0 & 0 & 0 \\
\hline & 09 & 0 & 0 & 0 & 0 & 0 \\
\hline & 10 & 0 & 0 & 0 & 0 & $\mathbf{0}$ \\
\hline \multicolumn{6}{|l|}{ TOTAL } & $\mathbf{0}$ \\
\hline
\end{tabular}


$\underline{\text { Anexo BA }}$

\begin{tabular}{|c|c|c|c|c|c|c|}
\hline $\begin{array}{l}\text { Palavra- } \\
\text { Chave }\end{array}$ & Ano & $\begin{array}{l}\begin{array}{l}\text { Retorno } \\
\text { Total }\end{array} \\
\end{array}$ & $\begin{array}{l}\text { Fora pelo } \\
\text { Escopo/Produto } \\
\end{array}$ & $\begin{array}{ll}\text { Fora } & \text { pelo } \\
\text { Valor } & \\
\end{array}$ & Repetidos & $\begin{array}{l}\text { Resultados } \\
\text { Válidos } \\
\end{array}$ \\
\hline \multirow[t]{5}{*}{ Derivativos } & 06 & 0 & 0 & 0 & 0 & 0 \\
\hline & 07 & 0 & 0 & 0 & 0 & 0 \\
\hline & 08 & 0 & 0 & 0 & 0 & 0 \\
\hline & 09 & 0 & 0 & 0 & 0 & 0 \\
\hline & 10 & 0 & 0 & 0 & 0 & 0 \\
\hline \multirow[t]{5}{*}{ Hedge } & 06 & 0 & 0 & 0 & 0 & 0 \\
\hline & 07 & 0 & 0 & 0 & 0 & 0 \\
\hline & 08 & 0 & 0 & 0 & 0 & $\mathbf{0}$ \\
\hline & 09 & 0 & 0 & 0 & 0 & 0 \\
\hline & 10 & 0 & 0 & 0 & 0 & 0 \\
\hline \multirow[t]{5}{*}{ Swap } & 06 & 0 & 0 & 0 & 0 & $\mathbf{0}$ \\
\hline & 07 & 0 & 0 & 0 & 0 & 0 \\
\hline & 08 & 0 & 0 & 0 & 0 & 0 \\
\hline & 09 & 0 & 0 & 0 & 0 & $\mathbf{0}$ \\
\hline & 10 & 0 & 0 & 0 & 0 & $\mathbf{0}$ \\
\hline TOTAL & & & & & & $\mathbf{0}$ \\
\hline
\end{tabular}


$\underline{\text { Anexo AM }}$

\begin{tabular}{|l|l|l|l|l|l|l|}
\hline $\begin{array}{l}\text { Palavra- } \\
\text { Chave }\end{array}$ & Ano & $\begin{array}{l}\text { Retorno } \\
\text { Total }\end{array}$ & $\begin{array}{l}\text { Fora pelo } \\
\text { Escopo/Produto }\end{array}$ & $\begin{array}{l}\text { Fora pelo } \\
\text { Valor }\end{array}$ & Repetidos & $\begin{array}{l}\text { Resultados } \\
\text { Válidos }\end{array}$ \\
\hline \multirow{5}{*}{ Derivativos } & 06 & 0 & 0 & 0 & 0 & $\mathbf{0}$ \\
\cline { 2 - 7 } & 07 & 0 & 0 & 0 & 0 & $\mathbf{0}$ \\
\cline { 2 - 7 } & 08 & 0 & 0 & 0 & 0 & $\mathbf{0}$ \\
\cline { 2 - 7 } & 09 & 0 & 0 & 0 & 0 & $\mathbf{0}$ \\
\cline { 2 - 7 } & 10 & 0 & 0 & 0 & 0 & $\mathbf{0}$ \\
\hline \multirow{5}{*}{ Hedge } & 06 & 0 & 0 & 0 & 0 & $\mathbf{0}$ \\
\cline { 2 - 7 } & 07 & 0 & 0 & 0 & 0 & $\mathbf{0}$ \\
\cline { 2 - 7 } & 08 & 0 & 0 & 0 & 0 & $\mathbf{0}$ \\
\cline { 2 - 7 } & 09 & 0 & 0 & 0 & 0 & $\mathbf{0}$ \\
\cline { 2 - 7 } & 10 & 0 & 0 & 0 & 0 & $\mathbf{0}$ \\
\hline \multirow{5}{*}{ Swap } & 06 & 0 & 0 & 0 & 0 & $\mathbf{0}$ \\
\cline { 2 - 7 } & 07 & 0 & 0 & 0 & 0 & $\mathbf{0}$ \\
\cline { 2 - 7 } & 08 & 0 & 0 & 0 & 0 & $\mathbf{0}$ \\
\cline { 2 - 7 } & 09 & 0 & 0 & 0 & 0 & $\mathbf{0}$ \\
\cline { 2 - 7 } & 10 & 0 & 0 & 0 & 0 & 0 \\
\hline \multirow{5}{*}{ TOTAL } & & 0 & 0 & 0 & 0 & 0 \\
\hline
\end{tabular}


$\underline{\text { Anexo PA }}$

Não há funcionalidade no sítio eletrônico do TJ-PA para busca de jurisprudência por palavras. 
$\underline{\text { Anexo AC }}$

\begin{tabular}{|c|c|c|c|c|c|c|}
\hline $\begin{array}{l}\text { Palavra- } \\
\text { Chave }\end{array}$ & Ano & $\begin{array}{l}\begin{array}{l}\text { Retorno } \\
\text { Total }\end{array} \\
\end{array}$ & $\begin{array}{l}\text { Fora pelo } \\
\text { Escopo/Produto } \\
\end{array}$ & $\begin{array}{ll}\text { Fora } & \text { pelo } \\
\text { Valor } & \\
\end{array}$ & Repetidos & $\begin{array}{l}\text { Resultados } \\
\text { Válidos } \\
\end{array}$ \\
\hline \multirow[t]{5}{*}{ Derivativos } & 06 & 0 & 0 & 0 & 0 & 0 \\
\hline & 07 & 0 & 0 & 0 & 0 & 0 \\
\hline & 08 & 0 & 0 & 0 & 0 & 0 \\
\hline & 09 & 0 & 0 & 0 & 0 & 0 \\
\hline & 10 & 0 & 0 & 0 & 0 & 0 \\
\hline \multirow[t]{5}{*}{ Hedge } & 06 & 0 & 0 & 0 & 0 & 0 \\
\hline & 07 & 0 & 0 & 0 & 0 & 0 \\
\hline & 08 & 0 & 0 & 0 & 0 & $\mathbf{0}$ \\
\hline & 09 & 0 & 0 & 0 & 0 & 0 \\
\hline & 10 & 0 & 0 & 0 & 0 & 0 \\
\hline \multirow[t]{5}{*}{ Swap } & 06 & 0 & 0 & 0 & 0 & $\mathbf{0}$ \\
\hline & 07 & 0 & 0 & 0 & 0 & 0 \\
\hline & 08 & 0 & 0 & 0 & 0 & 0 \\
\hline & 09 & 0 & 0 & 0 & 0 & $\mathbf{0}$ \\
\hline & 10 & 0 & 0 & 0 & 0 & $\mathbf{0}$ \\
\hline TOTAL & & & & & & $\mathbf{0}$ \\
\hline
\end{tabular}


$\underline{\text { Anexo RO }}$

\begin{tabular}{|c|c|c|c|c|c|c|}
\hline $\begin{array}{l}\text { Palavra- } \\
\text { Chave }\end{array}$ & Ano & $\begin{array}{l}\begin{array}{l}\text { Retorno } \\
\text { Total }\end{array} \\
\end{array}$ & $\begin{array}{l}\text { Fora pelo } \\
\text { Escopo/Produto } \\
\end{array}$ & $\begin{array}{ll}\text { Fora } & \text { pelo } \\
\text { Valor } & \\
\end{array}$ & Repetidos & $\begin{array}{l}\text { Resultados } \\
\text { Válidos } \\
\end{array}$ \\
\hline \multirow[t]{5}{*}{ Derivativos } & 06 & 0 & 0 & 0 & 0 & 0 \\
\hline & 07 & 0 & 0 & 0 & 0 & 0 \\
\hline & 08 & 0 & 0 & 0 & 0 & 0 \\
\hline & 09 & 0 & 0 & 0 & 0 & 0 \\
\hline & 10 & 0 & 0 & 0 & 0 & 0 \\
\hline \multirow[t]{5}{*}{ Hedge } & 06 & 0 & 0 & 0 & 0 & 0 \\
\hline & 07 & 0 & 0 & 0 & 0 & 0 \\
\hline & 08 & 0 & 0 & 0 & 0 & $\mathbf{0}$ \\
\hline & 09 & 0 & 0 & 0 & 0 & 0 \\
\hline & 10 & 0 & 0 & 0 & 0 & 0 \\
\hline \multirow[t]{5}{*}{ Swap } & 06 & 0 & 0 & 0 & 0 & $\mathbf{0}$ \\
\hline & 07 & 0 & 0 & 0 & 0 & 0 \\
\hline & 08 & 0 & 0 & 0 & 0 & 0 \\
\hline & 09 & 0 & 0 & 0 & 0 & $\mathbf{0}$ \\
\hline & 10 & 0 & 0 & 0 & 0 & $\mathbf{0}$ \\
\hline TOTAL & & & & & & $\mathbf{0}$ \\
\hline
\end{tabular}


$\underline{\text { Anexo RR }}$

\begin{tabular}{|c|c|c|c|c|c|c|}
\hline $\begin{array}{l}\text { Palavra- } \\
\text { Chave }\end{array}$ & Ano & $\begin{array}{l}\text { Retorno } \\
\text { Total }\end{array}$ & $\begin{array}{l}\text { Fora pelo } \\
\text { Escopo/Produto }\end{array}$ & $\begin{array}{l}\text { Fora pelo } \\
\text { Valor }\end{array}$ & Repetidos & \begin{tabular}{|l} 
Resultados \\
Válidos \\
\end{tabular} \\
\hline \multirow[t]{5}{*}{ Derivativos } & 06 & 0 & 0 & 0 & 0 & 0 \\
\hline & 07 & 0 & 0 & 0 & 0 & 0 \\
\hline & 08 & 0 & 0 & 0 & 0 & 0 \\
\hline & 09 & 0 & 0 & 0 & 0 & 0 \\
\hline & 10 & 0 & 0 & 0 & 0 & 0 \\
\hline \multirow[t]{5}{*}{ Hedge } & 06 & 0 & 0 & 0 & 0 & $\mathbf{0}$ \\
\hline & 07 & 0 & 0 & 0 & 0 & 0 \\
\hline & 08 & 0 & 0 & 0 & 0 & $\mathbf{0}$ \\
\hline & 09 & 0 & 0 & 0 & 0 & $\mathbf{0}$ \\
\hline & 10 & 0 & 0 & 0 & 0 & $\mathbf{0}$ \\
\hline \multirow[t]{5}{*}{ Swap } & 06 & 0 & 0 & 0 & 0 & $\mathbf{0}$ \\
\hline & 07 & 0 & 0 & 0 & 0 & $\mathbf{0}$ \\
\hline & 08 & 0 & 0 & 0 & 0 & 0 \\
\hline & 09 & 0 & 0 & 0 & 0 & $\mathbf{0}$ \\
\hline & 10 & 0 & 0 & 0 & 0 & $\mathbf{0}$ \\
\hline \multicolumn{6}{|l|}{ TOTAL } & $\mathbf{0}$ \\
\hline
\end{tabular}


$\underline{\text { Anexo AP }}$

\begin{tabular}{|c|c|c|c|c|c|c|}
\hline $\begin{array}{l}\text { Palavra- } \\
\text { Chave }\end{array}$ & Ano & $\begin{array}{l}\text { Retorno } \\
\text { Total }\end{array}$ & $\begin{array}{l}\text { Fora pelo } \\
\text { Escopo/Produto }\end{array}$ & $\begin{array}{l}\text { Fora pelo } \\
\text { Valor }\end{array}$ & Repetidos & $\begin{array}{l}\text { Resultados } \\
\text { Válidos } \\
\end{array}$ \\
\hline \multirow[t]{5}{*}{ Derivativos } & 06 & 0 & 0 & 0 & 0 & 0 \\
\hline & 07 & 0 & 0 & 0 & 0 & $\mathbf{0}$ \\
\hline & 08 & 0 & 0 & 0 & 0 & 0 \\
\hline & 09 & 0 & 0 & 0 & 0 & $\mathbf{0}$ \\
\hline & 10 & 1 & 0 & 1 & 0 & $\mathbf{0}$ \\
\hline \multirow[t]{5}{*}{ Hedge } & 06 & 0 & 0 & 0 & 0 & $\mathbf{0}$ \\
\hline & 07 & 0 & 0 & 0 & 0 & $\mathbf{0}$ \\
\hline & 08 & 0 & 0 & 0 & 0 & $\mathbf{0}$ \\
\hline & 09 & 0 & 0 & 0 & 0 & $\mathbf{0}$ \\
\hline & 10 & 0 & 0 & 0 & 0 & 0 \\
\hline \multirow[t]{5}{*}{ Swap } & 06 & 0 & 0 & 0 & 0 & $\mathbf{0}$ \\
\hline & 07 & 0 & 0 & 0 & 0 & 0 \\
\hline & 08 & 0 & 0 & 0 & 0 & 0 \\
\hline & 09 & 0 & 0 & 0 & 0 & 0 \\
\hline & 10 & 0 & 0 & 0 & 0 & $\mathbf{0}$ \\
\hline \multicolumn{6}{|l|}{ TOTAL } & $\mathbf{0}$ \\
\hline
\end{tabular}


$\underline{\text { Anexo TO }}$

\begin{tabular}{|c|c|c|c|c|c|c|}
\hline $\begin{array}{l}\text { Palavra- } \\
\text { Chave }\end{array}$ & Ano & $\begin{array}{l}\text { Retorno } \\
\text { Total }\end{array}$ & $\begin{array}{l}\text { Fora pelo } \\
\text { Escopo/Produto }\end{array}$ & $\begin{array}{l}\text { Fora pelo } \\
\text { Valor }\end{array}$ & Repetidos & \begin{tabular}{|l} 
Resultados \\
Válidos \\
\end{tabular} \\
\hline \multirow[t]{5}{*}{ Derivativos } & 06 & 0 & 0 & 0 & 0 & 0 \\
\hline & 07 & 0 & 0 & 0 & 0 & 0 \\
\hline & 08 & 0 & 0 & 0 & 0 & 0 \\
\hline & 09 & 0 & 0 & 0 & 0 & 0 \\
\hline & 10 & 0 & 0 & 0 & 0 & 0 \\
\hline \multirow[t]{5}{*}{ Hedge } & 06 & 0 & 0 & 0 & 0 & $\mathbf{0}$ \\
\hline & 07 & 0 & 0 & 0 & 0 & 0 \\
\hline & 08 & 0 & 0 & 0 & 0 & $\mathbf{0}$ \\
\hline & 09 & 0 & 0 & 0 & 0 & $\mathbf{0}$ \\
\hline & 10 & 0 & 0 & 0 & 0 & $\mathbf{0}$ \\
\hline \multirow[t]{5}{*}{ Swap } & 06 & 0 & 0 & 0 & 0 & $\mathbf{0}$ \\
\hline & 07 & 0 & 0 & 0 & 0 & $\mathbf{0}$ \\
\hline & 08 & 0 & 0 & 0 & 0 & 0 \\
\hline & 09 & 0 & 0 & 0 & 0 & $\mathbf{0}$ \\
\hline & 10 & 0 & 0 & 0 & 0 & $\mathbf{0}$ \\
\hline \multicolumn{6}{|l|}{ TOTAL } & $\mathbf{0}$ \\
\hline
\end{tabular}


$\underline{\text { Anexo DF }}$

\begin{tabular}{|c|c|c|c|c|c|c|}
\hline $\begin{array}{l}\text { Palavra- } \\
\text { Chave }\end{array}$ & Ano & $\begin{array}{l}\text { Retorno } \\
\text { Total }\end{array}$ & $\begin{array}{ll}\text { Fora } & \text { pelo } \\
\text { Escopo/Produto }\end{array}$ & $\begin{array}{ll}\text { Fora } & \text { pelo } \\
\text { Valor } & \\
\end{array}$ & Repetidos & $\begin{array}{l}\text { Resultados } \\
\text { Válidos } \\
\end{array}$ \\
\hline \multirow[t]{5}{*}{ Derivativos } & 06 & 0 & 0 & 0 & 0 & 0 \\
\hline & 07 & 0 & 0 & 0 & 0 & 0 \\
\hline & 08 & 0 & 0 & 0 & 0 & 0 \\
\hline & 09 & 0 & 0 & 0 & 0 & 0 \\
\hline & 10 & 0 & 0 & 0 & 0 & 0 \\
\hline \multirow[t]{5}{*}{ Hedge } & 06 & 0 & 0 & 0 & 0 & $\mathbf{0}$ \\
\hline & 07 & 0 & 0 & 0 & 0 & 0 \\
\hline & 08 & 0 & 0 & 0 & 0 & 0 \\
\hline & 09 & 0 & 0 & 0 & 0 & 0 \\
\hline & 10 & 0 & 0 & 0 & 0 & $\mathbf{0}$ \\
\hline \multirow[t]{5}{*}{ Swap } & 06 & 0 & 0 & 0 & 0 & $\mathbf{0}$ \\
\hline & 07 & 0 & 0 & 0 & 0 & $\mathbf{0}$ \\
\hline & 08 & 0 & 0 & 0 & 0 & 0 \\
\hline & 09 & 0 & 0 & 0 & 0 & $\mathbf{0}$ \\
\hline & 10 & 0 & 0 & 0 & 0 & $\mathbf{0}$ \\
\hline \multicolumn{6}{|l|}{ TOTAL } & $\mathbf{0}$ \\
\hline
\end{tabular}


$\underline{\text { Anexo MT }}$

\begin{tabular}{|c|c|c|c|c|c|c|}
\hline $\begin{array}{l}\text { Palavra- } \\
\text { Chave }\end{array}$ & Ano & $\begin{array}{l}\text { Retorno } \\
\text { Total }\end{array}$ & $\begin{array}{l}\text { Fora pelo } \\
\text { Escopo/Produto }\end{array}$ & $\begin{array}{l}\text { Fora pelo } \\
\text { Valor }\end{array}$ & Repetidos & \begin{tabular}{|l} 
Resultados \\
Válidos \\
\end{tabular} \\
\hline \multirow[t]{5}{*}{ Derivativos } & 06 & 1 & 1 & 0 & 0 & 0 \\
\hline & 07 & 0 & 0 & 0 & 0 & $\mathbf{0}$ \\
\hline & 08 & 1 & 1 & 0 & 0 & 0 \\
\hline & 09 & 3 & 3 & 0 & 0 & 0 \\
\hline & 10 & 1 & 1 & 0 & 0 & 0 \\
\hline \multirow[t]{5}{*}{ Hedge } & 06 & 0 & 0 & 0 & 0 & $\mathbf{0}$ \\
\hline & 07 & 0 & 0 & 0 & 0 & 0 \\
\hline & 08 & 0 & 0 & 0 & 0 & $\mathbf{0}$ \\
\hline & 09 & 0 & 0 & 0 & 0 & $\mathbf{0}$ \\
\hline & 10 & 3 & $3^{30}$ & 0 & 0 & 0 \\
\hline \multirow[t]{5}{*}{ Swap } & 06 & 0 & 0 & 0 & 0 & $\mathbf{0}$ \\
\hline & 07 & 0 & 0 & 0 & 0 & $\mathbf{0}$ \\
\hline & 08 & 1 & 1 & 0 & 0 & 0 \\
\hline & 09 & 0 & 0 & 0 & 0 & $\mathbf{0}$ \\
\hline & 10 & 0 & 0 & 0 & 0 & $\mathbf{0}$ \\
\hline
\end{tabular}

${ }^{30}$ Os 3 julgados encontrados tratam de Cédula de Produto Rural (CPR), instituída pela Lei 8.929/94. Embora este produto bancário possa ter efeito de "hedge", por representar antecipação de caixa para o agricultor com a expectativa de colheita futura, não se tem aqui um instrumento derivativo conforme explorado neste trabalho. 
$\underline{\text { Anexo MS }}$

\begin{tabular}{|c|c|c|c|c|c|c|}
\hline $\begin{array}{l}\text { Palavra- } \\
\text { Chave }\end{array}$ & Ano & $\begin{array}{l}\text { Retorno } \\
\text { Total }\end{array}$ & $\begin{array}{l}\text { Fora pelo } \\
\text { Escopo/Produto }\end{array}$ & $\begin{array}{l}\text { Fora pelo } \\
\text { Valor }\end{array}$ & Repetidos & \begin{tabular}{|l} 
Resultados \\
Válidos
\end{tabular} \\
\hline \multirow[t]{5}{*}{ Derivativos } & 06 & 0 & 0 & 0 & 0 & 0 \\
\hline & 07 & 0 & 0 & 0 & 0 & 0 \\
\hline & 08 & 0 & 0 & 0 & 0 & 0 \\
\hline & 09 & 0 & 0 & 0 & 0 & 0 \\
\hline & 10 & 1 & 1 & 0 & 0 & 0 \\
\hline \multirow[t]{5}{*}{ Hedge } & 06 & 1 & 1 & 0 & 0 & 0 \\
\hline & 07 & 2 & 2 & 0 & 0 & 0 \\
\hline & 08 & 1 & 1 & 0 & 0 & 0 \\
\hline & 09 & 3 & 3 & 0 & 0 & 0 \\
\hline & 10 & 1 & 1 & 0 & 0 & $\mathbf{0}$ \\
\hline \multirow[t]{5}{*}{ Swap } & 06 & 0 & 0 & 0 & 0 & 0 \\
\hline & 07 & 2 & 2 & 0 & 0 & 0 \\
\hline & 08 & 0 & 0 & 0 & 0 & 0 \\
\hline & 09 & 0 & 0 & 0 & 0 & 0 \\
\hline & 10 & 0 & 0 & 0 & 0 & 0 \\
\hline \multicolumn{6}{|l|}{ TOTAL } & $\mathbf{0}$ \\
\hline
\end{tabular}


$\underline{\text { Anexo GO }}$

\begin{tabular}{|c|c|c|c|c|c|c|}
\hline $\begin{array}{l}\text { Palavra- } \\
\text { Chave }\end{array}$ & Ano & $\begin{array}{l}\text { Retorno } \\
\text { Total }\end{array}$ & $\begin{array}{l}\text { Fora pelo } \\
\text { Escopo/Produto }\end{array}$ & $\begin{array}{l}\text { Fora pelo } \\
\text { Valor }\end{array}$ & Repetidos & $\begin{array}{l}\text { Resultados } \\
\text { Válidos }\end{array}$ \\
\hline \multirow[t]{5}{*}{ Derivativos } & 06 & 0 & 0 & 0 & 0 & 0 \\
\hline & 07 & 0 & 0 & 0 & 0 & 0 \\
\hline & 08 & 0 & 0 & 0 & 0 & 0 \\
\hline & 09 & 0 & 0 & 0 & 0 & 0 \\
\hline & 10 & 0 & 0 & 0 & 0 & 0 \\
\hline \multirow[t]{5}{*}{ Hedge } & 06 & 0 & 0 & 0 & 0 & 0 \\
\hline & 07 & 0 & 0 & 0 & 0 & 0 \\
\hline & 08 & 0 & 0 & 0 & 0 & 0 \\
\hline & 09 & 0 & 0 & 0 & 0 & 0 \\
\hline & 10 & 0 & 0 & 0 & 0 & 0 \\
\hline \multirow[t]{5}{*}{ Swap } & 06 & 0 & 0 & 0 & 0 & 0 \\
\hline & 07 & 0 & 0 & 0 & 0 & 0 \\
\hline & 08 & 0 & 0 & 0 & 0 & 0 \\
\hline & 09 & 0 & 0 & 0 & 0 & 0 \\
\hline & 10 & 0 & 0 & 0 & 0 & 0 \\
\hline \multicolumn{6}{|l|}{ TOTAL } & $\mathbf{0}$ \\
\hline
\end{tabular}


$\underline{\text { Anexo STJ }}$

\begin{tabular}{|c|c|c|c|c|c|c|}
\hline $\begin{array}{l}\text { Palavra- } \\
\text { Chave }\end{array}$ & Ano & $\begin{array}{l}\text { Retorno } \\
\text { Total }^{31} \\
\end{array}$ & $\begin{array}{l}\text { Fora pelo } \\
\text { Escopo/Produto }\end{array}$ & $\begin{array}{l}\text { Fora pelo } \\
\text { Valor }\end{array}$ & Repetidos & \begin{tabular}{|l} 
Resultados \\
Válidos \\
\end{tabular} \\
\hline \multirow[t]{5}{*}{ Derivativos } & 06 & 1 & 1 & 0 & 0 & 0 \\
\hline & 07 & 0 & 0 & 0 & 0 & 0 \\
\hline & 08 & 1 & 1 & 0 & 0 & 0 \\
\hline & 09 & 0 & 0 & 0 & 0 & 0 \\
\hline & 10 & 1 & 0 & 0 & 0 & 1 \\
\hline \multirow[t]{5}{*}{ Hedge } & 06 & 9 & 9 & 0 & 0 & $\mathbf{0}$ \\
\hline & 07 & 15 & 15 & 0 & 0 & 0 \\
\hline & 08 & 6 & 6 & 0 & 0 & $\mathbf{0}$ \\
\hline & 09 & 6 & 6 & 0 & 0 & $\mathbf{0}$ \\
\hline & 10 & 5 & 5 & 0 & 0 & $\mathbf{0}$ \\
\hline \multirow[t]{5}{*}{ Swap } & 06 & 9 & 9 & 0 & 0 & $\mathbf{0}$ \\
\hline & 07 & 14 & 14 & 0 & 0 & $\mathbf{0}$ \\
\hline & 08 & 6 & 6 & 0 & 0 & 0 \\
\hline & 09 & 6 & 6 & 0 & 0 & $\mathbf{0}$ \\
\hline & 10 & 3 & 3 & 0 & 0 & $\mathbf{0}$ \\
\hline \multicolumn{6}{|l|}{ TOTAL } & 1 \\
\hline
\end{tabular}

\footnotetext{
${ }^{31}$ A maioria dos 82 retornos relacionada à busca livre pela palavra-chave "hedge" e "swap" trata de uma discussão tributária acerca da incidência de tributos na fonte para as operações financeiras. Nesse sentido, foram contabilizadas como "fora pelo escopo / produto". Vide, por exemplo, a Ementa do Agravo Regimental no Agravo de Instrumento 2007/0274818-3 do STJ: A jurisprudência do Superior Tribunal de Justiça firmou-se no sentido que de incide o imposto de renda sobre os ganhos oriundos de operações de swap com cobertura hedge, uma vez que tais ganhos representam acréscimo patrimonial. Precedentes: AgRg no Ag 1.105.792/SP, Rel. Ministro Herman Benjamin, Segunda Turma, julgado em 12/5/2009, DJe 25/5/2009; AgRg no REsp 865.997/RJ, Rel. Ministro Luiz Fux, Primeira Turma, julgado em 17/2/2009, DJe 30/3/2009; AgRg no Ag 1.042.888/RJ, Rel. Ministro Mauro Campbell Marques, Segunda Turma, julgado em 2/9/2008, DJe 6/10/2008; AgRg no Ag 991.985/RJ, Rel. Ministro Hamilton Carvalhido, Primeira Turma, julgado em 7/8/2008, DJe 18/8/2008; entre outros.
} 